\title{
Studenti učitelství mezi tacitními a explicitními znalostmi
}

\author{
Vlastimil Švec \\ James Lawley \\ Jan Nehyba \\ Petr Svojanovský \\ Radim Šíp \\ Eva Minaříková \\ Blanka Pravdová \\ Barbora Šimůnková \\ Jan Slavík
}

Brno 2016 


\section{KATALOGIZACE V KNIZE - NÁRODNÍ KNIHOVNA ČR}

Švec, Vlastimil

Studenti učitelství mezi tacitními a explicitními znalostmi /

Vlastimil Švec, James Lawley, Jan Nehyba, Petr Svojanovský, Radim Šíp, Eva Minaříková, Blanka Pravdová, Barbora Šimůnková, Jan Slavík. -- 1. VYDÁNÍ. - Brno: Masarykova univerzita, 2016. -- doplnit strany

ISBN doplnit

$37 *$

- studenti učitelství

- učitelské vzdělávání

- učitelské praxe

- tacitní znalosti

- rozhovor z pozice druhé osoby

- kvalitativní výzkum -- Česko

- kolektivní monografie

37 - Výchova a vzdělávání [22]

Edice: Pedagogika v teorii a praxi

Svazek 3

Autoři kapitol:

Vlastimil Švec (kapitola 6, 10, 11, Závěr)

James Lawley (kapitola 2, 3)

Jan Nehyba (kapitola 4, 5, 7, 9)

Petr Svojanovský (kapitola 4, 5, 7)

Radim Šíp (Úvod, kapitola 1)

Eva Minaříková (kapitola 6, 8, Summary)

Blanka Pravdová (kapitola 8)

Barbora Šimůnková (kapitola 9)

Jan Slavík (Úvod)

Recenzenti:

doc. PhDr. Vladimír Chrz, Ph.D., Psychologický ústav Akademie věd ČR

prof. PhDr. Bronislava Kasáčová, Ph.D., Pedagogická fakulta Univerzity Mateja Bela v

Banskej Bystrici

(C) Masarykova univerzita 
(C) Vlastimil Švec, James Lawley, Jan Nehyba, Petr Svojanovský, Radim Šíp, Eva

Minaříková, Blanka Pravdová, Barbora Šimůnková, Jan Slavík

Publikace vznikla v rámci projektu Grantové agentury České republiky GA13-20049S s názvem Osvojování tacitních znalostí studenty učitelství v průběhu jejich pedagogické praxe řešeného na katedře pedagogiky Pedagogické fakulty Masarykovy univerzity. Autoři děkují za poskytnutou finanční podporu, díky níž se mohli tomuto tématu čtyři roky věnovat. 


\section{Obsah}

Úvod

Raná moderna a pozdní moderna: slohy myšlení a jednání

Pozice přechodových fází

Raná a pozdní moderna: metafory, které formují pochopení znalosti

Kontinuita mezi metaforickým vyjádřením a doslovným popisem

Nedostatky tradičního pojetí tacitních znalostí

Struktura publikace a obsahové zaměření jejích kapitol

1 Filozofická východiska výzkumu tacitní znalosti: znalost, figurativní jazyk a metafora

1.1 Metodologie teoretické kapitoly: ideální typ a slohy myšlení a jednání

1.2 Znalost a role figurativního jazyka v procesu její explikace

1.2.1 Znalost jako poznatek

1.2.2 Znalost jako poznatek dosažený intersubjektivním vyjednáváním a sdílením jeho struktury

1.2.3 Znalost jako sjednocení znalostního pole a tacitní znalost

1.2.4 Figurativní jazyk a metafora: jejich role při postupné explikaci tušeného

1.2.5 Metaforizace, fenomenologická analýza a rozvíjení metaforické krajiny

1.3 Coda první kapitoly

\section{Metafora, vtělenost a tacitní učení}

2.1 Co je myšleno pojmem vtělenost (vtělení)?

2.2 Co jsou to vtělené metafory?

2.3 Jazyk: metafory vtělují abstrakci do fyzického prostoru

2.4 Psychologie: mentální metafory mají formu

2.5 Fyziologie: tělo může být metaforou

2.6 Materiální rovina: metafory lze zhmotnit 
2.7 Proč je důležité, že jsou metafory vtělené?

2.7.1 Jazykové vtělení

2.7.2 Psychické vtělení

2.7.3 Fyziologické vtělení

2.7.4 Materiální vtělení

2.8 Vztah (vtělených) metafor a tacitního učení

3 Čisté dotazování: utvořme kvalitativní výzkum ověřitelným

3.1 Zkreslení na straně respondentů

3.2 Priming u tazatele

3.3 Proč tolik záleží na tazatelových metaforách?

3.4 Čistý jazyk

3.5 Potřeba škály „„̌istoty“

3.6 Další rysy rozhovorů vedených v čistém jazyce

3.6.1 Výzkum metafor a mentálních modelů

3.6.2 Sběr „hloubkových“ dat

3.7 Výzkum tacitních znalostí

\section{Metodologie výzkumu}

4.1 Základní definiční znaky tacitních znalostí

4.2 Účastníci výzkumu a kritéria jejich výběru

4.3 Proces získávání dat

4.4 Způsob získávání dat

\section{$5 \quad$ Evaluace čistého jazyka jako nástroje sběru dat}

5.1 Naše porozumění rozhovoru vedenému v čistém jazyce

5.2 Analýza vedení výzkumných rozhovorů

5.3 Fáze analýzy

5.4 Kvalitativní část analýzy 


\subsubsection{Kategorizace otázek}

5.4.2 Diskuze ke kategorizaci otázek

5.4.3 Kategorizace komentářů

5.4.4 Diskuze ke kategorizaci komentářů

5.5 Kvantitativní část analýzy

5.5.1 Diskuze ke kvantitativní části analýzy

\subsection{Závěr}

6 Tacitní znalosti studentů učitelství a učitelů z výzkumného pohledu: přehledová studie

6.1 Pokusy o vymezení pojmu tacitní znalosti

6.2 Cíle přehledové kapitoly a výběr výzkumných studií

6.3 Výsledky přehledové studie

6.3.1 Jak jsou tacitní znalosti a praktické znalosti konceptualizovány?

6.3.2 Jaké cíle, poprípadě jaké výzkumné otázky si kladou autoři těchto studií?

6.3.3 Jaké výzkumné metody autoři uplatnili a jaké výzkumné soubory (vzorky) použili?

6.3.4 Jaké závěry z těchto výzkumných studií vyplývají?

6.4 Diskuse a závěry

7 Metaforizace v procesu zexplicitnění tacitní znalosti

7.1 Příklad obsahu zexplicitněné tacitní znalosti

7.2 Tři důkazy zexplicitnění tacitní znalosti

7.3 Interakce metaforizace-zdoslovnění a zpětné metaforizace $v$ procesu zexplicitnění tacitní znalosti

\subsection{Závěr}

8 Pojetí výuky studentů učitelství: společná témata a individuální výzvy

8.1 Učitelovo/studentovo pojetí výuky

8.2 Zdroje a analýza dat

8.3 Výsledky analýzy
8.3.1 Pojetí žáka 


\subsubsection{Motivace jako společné téma}

\subsubsection{Individuální výzvy}

\subsection{Diskuse a závěry}

\section{Neočekávané situace $v$ průběhu praxe studentů učitelství}

9.1 Předběžné vymezení: od epizodické situace k neočekávané situaci

9.2 Co se děje v mysli při neočekávané situaci?

9.3 Metodologie

9.4 Typy neočekávaných situací

9.4.1 Nepříjemné neočekávané situace zasahující více osob

9.4.2 Nepř́ijemné neočekávané situace zasahující jen studenta

9.4.3 Př́ijemné neočekávané situace

9.5 Diskuse $k$ typologii neočekávaných situací

9.6 Řešení neočekávaných situací

9.7 Okolnosti vzniku neočekávané situace

9.8 Bezprostřední reakce na neočekávanou situaci

9.9 Strategie řešení neočekávané situace

9.10 Diskuze ke strategiím řešení neočekávaných situací

9.11 Závěr

10 Jak se utvářejí tacitní znalosti studentky učitelství Jaroslavy v průběhu její učitelské praxe?

10.1 Cíle a design výzkumu

10.2 Výsledky výzkumu

10.2.1 Pojetí výuky Jaroslavy v procesu utváření jejích TZ

10.2.2 Utváření TZ Jaroslavy řešením neočekávaných situací v komunikaci se žáky

10.2.3 Didaktické situace reflektované studentkou jako zdroj jejích TZ

10.2.4 Odkrývání prvků TZ prostřednictvím stimulovaného vybavování

10.3 Závěr 
11 Jak sdílí tacitní znalosti studentka učitelství Milada se svou cvičnou učitelkou

11.1 Učňovství jako způsob sdílení tacitních znalostí

11.2 Východiska výzkumu sdílení tacitních znalostí studentky s cvičnou učitelkou

11.3 Metodologie výzkumu

11.4 Výsledky výzkumu

11.5 Shrnutí výsledků a závěr

Závěr

Summary

Literatura

Věcný rejstřík

O autorech 


\section{Úvod \\ Radim Š́p, Jan Slavík}

\section{Raná moderna a pozdní moderna: slohy myšlení a jednání}

Na počátku našeho projektu ( $\mathrm{tj}$. v roce 2012, kdy jsme připravovali podklady pro grantovou žádost) jsme se rozhodli zabývat se výzkumem tacitních znalostí, které v profesní zkušenosti studentůํํㄹ pedagogických fakult vznikají, utvářejí se, formují, operují a jsou sdíleny během jejich praxe, prŕpadně během procesu reflexe této praxe. Netušili jsme ale, že nás toto téma donutí zcela nově promyslet mnoho dalších věcí. Včetně oné skutečnosti, která se podle nás velice nesprávně označuje „paradigma vědeckého výzkumu“. Při letmé analýze použití slova „paradigma“ - dnes tak nadužívaného, zjistíme, že má nejméně třináct významů. Některé z nich jsou ve vzájemném rozporu, jiné se částečně překrývají, další zahrnují na okrajích svých významových oblastí obsahy téměř obskurní. Dokonce ani vlastní kuhnovské užití nám př́liš nepomůže. Již v něm je zakódován základní problém - to, co bychom my chtěli nazývat paradigmatem, se nedotýká pouze jedné vědecké disciplíny (např. fyziky nebo sociologie), ani vědy jako jediného celku.

Věda se vyvijíi se svojí teorií vědy, epistemologií a metodologií v širokém kontextu dalších kulturních tradic a společně s celým tímto kontextem se pomalu, ale za to setrvale a kontinuálně proměňuje. $Z$ takového hlediska prohlášení jako: „Sociální vědy jsou na rozdíl od věd př́rodních multi-paradigmatické.“ nedávají žádný smysl. Sociální vědy jsou ze své podstaty stejně multi- či uni-paradigmatické jako vědy př́rodní. Jejich odlišnost spočívá pouze $\mathrm{v}$ tom, že je nelze tak snadno idealizovat (tzn. hned na počátku redukovat kvality jejich vstupních dat), jako to lze $\mathrm{v}$ některých př́rodních vědách. A proto se mohlo zdát, že na rozdíl od nich vědy prírodní tíhnou k uni-paradigmatičnosti. Důvod existence, zmnožení a proměn „paradigmat“ je však odlišný (viz níže). Jestliže odmítneme hledět na idealizovanou historii

\footnotetext{
${ }^{1} \mathrm{~V}$ textu monografie je uplatněn úzus běžný v českých textech - využití pouze maskulinních tvarů pojmů cvičný učitel, student učitelství, účastník výzkumu apod. Smyslem opomenutí femininních tvarů je snaha o zjednodušení a zpřehlednění textu. $V$ textu monografie je dále konzistentně používáno slovo student pro studenty učitelství (a tedy participanty našeho výzkumu) a slovo žák pro žáky základních škol.
} 
vědeckého výzkumu, jež je nám předkládána, a podíváme se do skutečné živé historie výzkumných tradic a jejich herezí, bude nám toto tvrzení mnohem zrejmější (srov. např. Feyerabend, 2001; Latour \& Woolgar, 1986).

Abychom se vyhnuli všem možným nedorozuměním, zavedli jsme nový pojem: sloh myšlení a jednání. Ten je v této monografii charakterizován $\mathrm{v}$ podkapitole $1.1{ }^{2}$ Není náhodou, že jsme zvolili pojem sloh. Inspirovali jsme se historií a teorií umění, v nichž pojem sloh odkazuje ke dvěma vlastnostem lidského jednání a jeho významové exprese. Na jedné straně pojmenovává tendenci k opakování určitých způsobů myšlení a jednání, jejichž vnitřní logika utváří jisté typy lidských artefaktů. Na druhé straně naznačuje neustálou kontinuální proměnu této logiky. Sloh myšlení a jednání je širším projevem toho samého principu principu opakování a proměny. Díky němu sloh mění dosavadní tradici, ale současně na ni navazuje. Tak se jeden umělecký sloh postupně prolamuje do druhého. Např́íklad renesance do baroka. Určit přesnou hranici předělu nelze, přesto jsme na základě tendencí $\mathrm{k}$ určitým podobám artefaktů schopni odlišit baroko 17. století od renesance století 15. a zároveň rozpoznávat, co mají společného. Současně s tím můžeme rozpoznávat, že některé rysy slohů (např. důraz na řád nebo na jeho porušování) se v dějinách opakují („opakování téhož“). To je obecná podmínka pro to, aby bylo možné prizmatem současnosti rozumět minulosti a kriticky se s ní vyrovnávat.

Proto musíme jak slohy myšlení a jednání, tak umělecké slohy definovat jako weberovské ideální typy (Weber, 2009, s. 7-63). Sloh myšlení a jednání, podobně jako umělecký sloh, nenajdeme $\mathrm{v}$ žádném konkrétním jasně vymezeném období od-do. Jedná se pouze o tendenci myšlení a jednání, která se po jistou dobu prosazuje, poté na nějakou dobu téměř ovládá většinu oblastí lidské činnosti, aby nakonec začala slábnout až ke svému nenápadnému vymizení. Sloh rané moderny se pomalu prosazoval od 15. a 16. století, v 17. století dosáhl zjevné odlišnosti od předešlých dob, aby v 18. a 19. století nabyl svého vrcholu a od té doby až do dnešních dnů slábl. Z tohoto vrcholného období také pochází většina předporozumění současné teorie vědy, která nejsou dosud dostatečně kriticky reflektována. Např. předporozumění, že lze jednoduše rozdělit vědu na „hard“ a „soft“ obory, že toto odlišení také charakterizuje „spolehlivé“ a „méně spolehlivé“ vědecké poznání a že s tím má souviset i rigidní odlišení na kvantitativní (spolehlivější) a kvalitativní (méně spolehlivou) metodologii.

\footnotetext{
${ }^{2}$ Detailnější, šedesátistránkovou charakteristiku čtenář najde v připravované monografii: Šíp, R. Pedagogika v době promény slohu myšlení a jednání: filozofická analýza. Předpokládaný rok vydání 2017.
} 
Důsledkem těchto dnes již anachronických myšlenek je také současná diskuse o multia uni-paradigmatických oborech. „Multi-“ a „uni-paradigmatičnost oborů“ není dána jejich podstatou, ale tím, na jakém místě historického přechodu od jednoho slohu ke druhému se nacházíme. V dobách, kdy jeden sloh ovládá kulturní představivost daných společností, máme větší tendenci jednotlivé vědecké disciplíny vnímat jako uni-paradigmatické. Ve chvíli, kdy se prochází dobou zintenzivňování a koncentrace důsledků postupných změn - v době sílícího vědomí přechodu - se uni-paradigmatičnost tříští. A to i ve vědách tzv. „tvrdých“. V současnosti to můžeme sledovat na proměnách biologických a kognitivních věd: vedle klasické ortodoxie se objevují konkurenční teorie, které mají tendenci zevnitř převracet logiku výkladu. Např. vedle neodarwinistické ortodoxie, jejíž původní jednota se navíc vnitřně roztřepila, se začínají prosazovat teorie, které se neodarwinistickému dohledu vymykají - viz např. teorie plasticity fenotypu, rozšířené syntézy či celkový přístup biosémantiky. Vedle kartezianismu kognitivních věd první generace reprezentované např. Fodorem či manželi Churchlandovými, se začíná prosazovat jejich tzv. „druhá generace“33, v níž se začínají naplno domýšlet antikarteziánská východiska, a vznikají tak teorie rozšířené mysli, vtělesněné mysli, zjednané mysli či teorie ekologického já atd. Toto třepení a tř́štění je projevem intenzity přechodu od slohu rané moderny ke slohu moderny pozdní.

Zmíněné proměny $\mathrm{v}$ běhu kontinuálního vývoje spatřujeme jak v pojetí znalosti, tak v pojetí dějin vědy. Projevují se také v dalších tradicích lidské činnosti (v umění, kultuře oblékání, způsobech trávení volného času atd.). Proměny v těchto dalších oblastech se odehrávají v souvislosti $\mathrm{s}$ proměnami v oblasti tradice vědy. Existuje mezi nimi vnitřní souvislost - proměna $\mathrm{v}$ jedné tradici (např. tradici vědy) existuje $\mathrm{v}$ korelaci $\mathrm{s}$ proměnami v dalších tradicích. Tato souvislost je dána skutečností, že tyto tradice objevují, rozvíjejí a nesou stejné bytosti - lidé daného období. Protože se tato monografie zabývá lidskou kognicí, především znalostí a tacitní znalostí, budeme se v souvislosti s přechodem z rané moderny do moderny pozdní soustředit především na tuto oblast.

Slohem myšlení a jednání máme na mysli historické a priori, které předem formuje jak styl našeho myšlení a jednání, tak způsoby, jakými legitimizujeme výsledky našeho poznání. A priori si můžeme představit jako předem danou mřížku, přes kterou jednotlivci

\footnotetext{
${ }^{3} \mathrm{~K}$ odlišení první a druhé generace kognitivních věd a $\mathrm{k}$ argumentaci, proč byla první generace omezována svými karteziánskými východisky, viz Lakoffovu a Johnsonovu knihu Filozofie oděná tělem (Philosophy in the flesh - 1999, především s. 71-74).
} 
prosívají svoji zkušenost, a tím dosahují strukturované zkušenosti - znalosti. „Historická“ jsou tato a priori proto, že se zmíněné charakteristiky kontinuálně proměňují a po určité době, kdy změny dosáhnou zjevné intenzity, se jedna epocha prolomí do druhé. Tato proměna může ve zpětném pohledu vypadat jako zlom, ale ve své podstatě má stejně kontinuitní charakter jako život člověka. Proměna slohu myšlení a jednání se podobá proměně člověka, který kontinuálně prožívá svůj životní příběh, nepřemýšlí příliš o změnách, stárnutí a případném konci, a přece se nad dvacet let starou fotografií zastaví a poprvé mu s hrůzou dojde, že zestárl a že za dalších dvacet let již pravděpodobně nebude mezi živými. Stejně tak i sloh rané moderny dnes kontinuálně a téměř neslyšně slábne a postupně se prolamuje do slohu moderny pozdní. A my se nacházíme v době přechodu mezi jedním a druhým slohem.

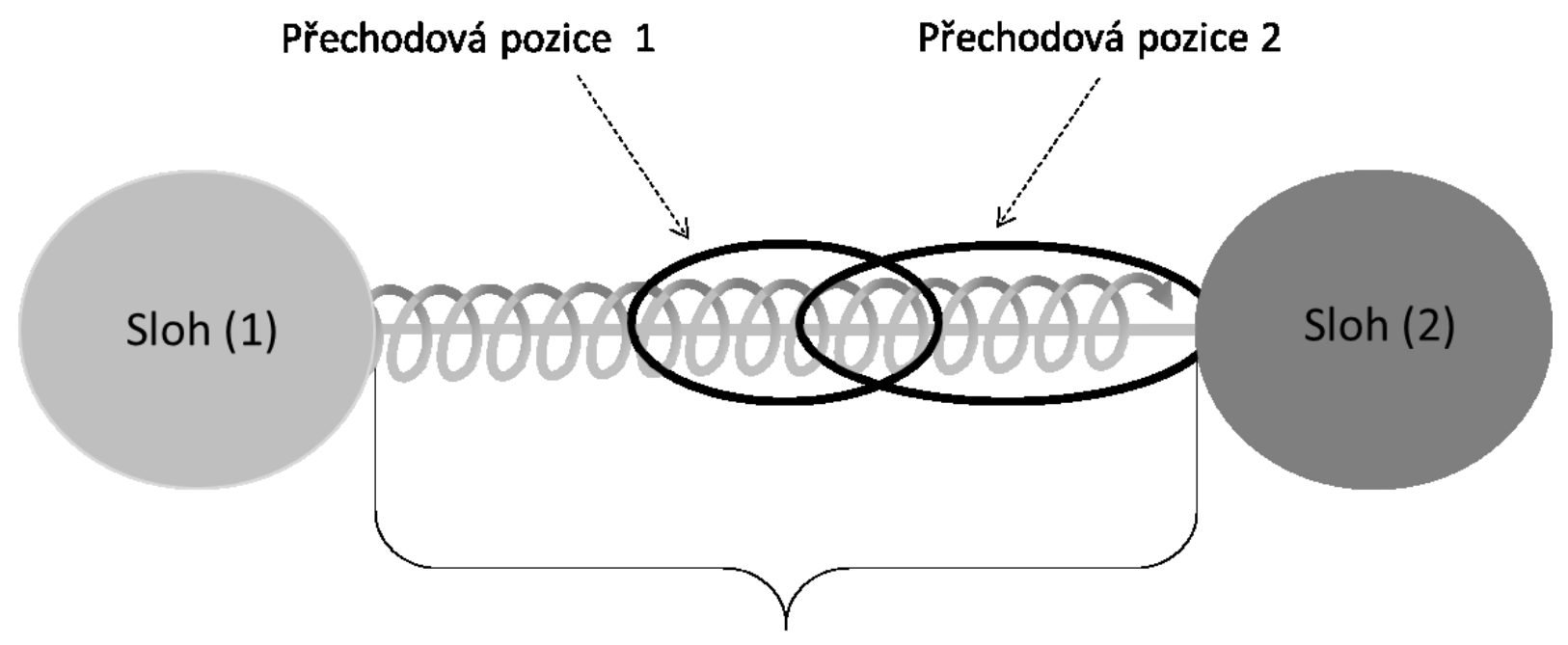

\section{Čára znázorňující kontinuitu proměny slohu myšlení a jednání od ideálního typu rané moderny $k$ ideálnímu typu pozdní moderny. Spirála naznačuje způsob proměny „opakování téhož“.}

Obrázek 1. Přechod od slohu rané moderny k moderně pozdní a přechodové pozice, o které se opírá tato monografie.

Tuto skutečnost jsme se pokusili vyjádřit obrázkem 1. Vidíme v něm dva krajní póly nalevo sloh rané moderny (1) a napravo sloh moderny pozdní (2). Mezi nimi se nacházejí dvě přechodové fáze. Přechodová fáze znamená, že jejich proponenti se odvracejí od myšlenkových a konativních habitů rané moderny, ale přesto jsou v některých idejích a v některých postupech s ranou modernou spjatí. V období přechodu jednoho uměleckého 
slohu do druhého je dílo vytvořené v tomto období rozkročeno mezi jedním a druhým uměleckým slohem. Dưmyslného rytíre dona Quichota de la Mancha můžeme jen stěží zařadit čistě do renesance, nebo čistě do baroka. Přesně v takovém smyslu mluvíme o přechodových fázích a přesně v takovém smyslu vykazují tyto fáze vnitřní napětí mezi starým a novým.

Přechodové fáze, které jsou $\mathrm{v}$ tomto obrázku vyčleněny, jsou pro tuto monografii významné. Obě fáze mají své pozice, z nichž jejich proponenti vycházejí při definici poznání, znalosti, tacitní znalosti a figurativního jazyka. Pozice 1 je ve schématu přesně uprostřed mezi slohy a je vprvní - teoretické - kapitole charakterizována prostřednictvím jedné z inspirativních monografií, která v českém vědeckém milieu v poslední době vyšla: Tvorba jako způsob poznávání (Slavík, J., Chrz, V., Štech, S., Nohavová, A., Klumparová, Š., Hník, O., ... \& Valenta, J., 2013; dále jen Tvorba). Hlavní úhelné kameny monografie - tedy důraz na strukturu obsahu zkušenosti, jeho intersubjektivní vyjednávání a pojetí metafory jako signatury (která ale paradoxně nenese význam), jsou postaveny především na myšlenkách postanalytických filozofu - zejména Donalda Davidsona, Willarda V. O. Quina, Jaroslava Peregrina, Nelsona Goodmana. ${ }^{4}$ Přechodová pozice 2 je pozicí naší. Odlišení obou fází a jejich pozic nám pomáhá artikulovat, v čem konkrétně při charakteristice znalosti, tacitní znalosti a figurativního jazyka jsme se museli odchýlit od pozice přechodové fáze 1 směrem blíže ke slohu pozdní moderny, abychom byli schopni učinit náš výzkum tacitních znalostí smysluplným. Aniž bychom zcela opustili hranice epistemologické a metodologické přijatelnosti, posunuli jsme tyto hranice dále směrem $\mathrm{k}$ ideálnímu typu pozdní moderny. Vnitřní napětí obou pozic způsobuje, že se tyto pozice navzájem mohou podpořit. Jestliže první pozice může prozatím lépe konstruovat společný profesní jazyk pedagogů, může naopak druhá pozice sledovat strukturaci zkušenosti - tzn. proces dosahování znalosti - v jejím povstávání a kontinuálním utváření.

\section{Pozice přechodových fází}

Naše myšlení a jemu odpovídající jednání prochází neustálou změnou. Podobně jako člověk. I když se zdá, že se jeho podoba a názory nemění, procházejí oba registry kontinuálním

\footnotetext{
${ }^{4}$ Protože Tvorba nemá anglickou mutaci, budeme se v anglické verzi této monografie odkazovat více na díla zmíněných filozofi̊, která jsou v angličtině dostupná.
} 
vývojem. Teprve ve vynuceném ohlédnutí si náhle uvědomujeme, že nám život prosvišščl před očima, že se naše názory významně proměnily. Taková ohlédnutí přinášejí největší kognitivní obsah. Porovnáváme dvě idealizované, „zastavené“ podoby. Tento přístup je běžný a účinný. Když však chceme zkoumat tacitní znalosti vznikající, utvářející se, operující a sdílené během praxe našich studentů, případně během procesu reflexe této praxe, pak potřebujeme najít nástroje, které posílí důraz na kontinuitu změny a naopak upozadí srovnávání dvou „zastavených“ podob tohoto proudu. Tacitní je tacitním právě proto, že jej zatím nelze sevřít do dočasně „,zastavené“ struktury, nebot' tato struktura je u tacitní znalosti neustále ve stavu zrodu. Pozice autorů Tvorby pracuje s dočasně zastavenými strukturami, jež následně porovnává, naše pozice klade důraz na neustálé rekonfigurace struktury. Tato opozice mezi jejich a naší pozicí je však čistě didaktická. Oba naše přístupy vnímáme jako komplementární pozice, které v době přechodu slohu myšlení a jednání potřebují vzájemné doplnění nebo snad inspirování uvědoměním vzájemné odlišnosti.

Pozice autorů Tvorby je utvářená snahou o modelování jazyka učitelské profese, prostřrednictvím kterého učitelé a jejich mentoři mohou na potřebnou dobu fixovat terminologii, jež je nutná k jejich vzájemnému dorozumění. Pozice našeho výzkumného týmu se soustřed’uje na kontinuitu. Budování profesního jazyka musí vycházet z idealizující práce, která začíná dočasným zastavením kontinuitního proudu a poté pokračuje porovnáváním dvou jeho podob a zjišt’ováním podobností a odlišností s vědomím „téhož v jiném“. Jako když na př́íklad porovnávám svoji tvář na dvou fotografiích, které od sebe dělí dvacet let - zjištěné podobnosti umožňují vytvářet vztah identity mezi mojí tváří dnešních dnů a tváŕí včerejší. $\mathrm{V}$ rámci této pozice vyrůstá identita $\mathrm{v}$ reflexi a ve vědomém uchopení částí utvářejících celek. Pozice autorů Tvorby tak poskytuje přístup, který umožňuje budovat kontextové rámce pro společnou terminologii.

Naše pozice na druhou stranu ještě více akcentuje trvání, umožňuje být př́itomen utváření zkušenosti. To vyžaduje prodlužování přitomnosti. Jelikož však tímto setrváváním unikáme idealizující a fragmentarizující podstatě doslovného jazyka, je možné identitu zachycovat pouze jako prožívanou kontinuitu. V rámci této pozice - obrazně řečeno - identitu stejné tváře, jejichž dvě podoby od sebe dělí dvacet let, neumožňuje zjišt'ovat zpětná reflexe dvou zastavených podob (jako bychom po ruce neměli ony dvě fotografie), nýbrž to, že prožívám kontinuitu „staré“ a „,nové“ tváře v proudu žití bez toho, abychom tematizovali, co 
se z minulého zachovává v přítomném okamžiku. To má ale své limity, nebot’ zatím chybí rigorózní jazyk, který by tuto kontinuitu náležitě uchopoval, byl přesný, ale zároveň nefixoval to, co vyjadřujeme, do více či méně uzavřených podob. Když se vrátíme k naší analogii s fotografiemi, pak by tento jazyk musel být schopen vyjádřit proces žité souvislosti, který propojuje starou tvář se svým o dvacet let mladším dvojníkem, aniž by je musel porovnávat. Takový jazyk ale stále neexistuje. Proto se obě pozice nutně doplňují. Naše pozice prodlužování př́tomnosti je doplňována zpřitomňováním minulého pozice autorů Tvorby a naopak. Autoři poskytují nástroje pro budování a sdílení profesního jazyka, my poskytujeme prostředky, jak zkoumat poznání v jeho pohybu.

V první kapitole ukazujeme, že znalost perspektivou slohu pozdní moderny chápeme jako komplexní dynamickou strukturu. S tímto pojetím znalosti se snažíme pracovat také v empirických kapitolách. Na práci s daty lze v jednotlivých výzkumných sondách sledovat jak aspekty, které se více blíží myšlení a jednání slohu rané moderny, tak aspekty blížící se více myšlení a jednání slohu pozdní moderny. Přeorientovávat se na myšlení a jednání slohu pozdní moderny nebylo pro výzkumníky snadným úkolem. Chápání znalosti jako komplexní dynamické struktury bylo při práci výzkumníků spíše než dokončeným dějem otevřeným procesem. Sami na sobě jsme pocítili, jak je proměna výchozích předpokladů velmi pozvolným (a dokonce i nyní stále neukončeným) procesem. Empirické kapitoly tak zachycují okamžik, ve kterém se každý z výzkumníků při práci s daty nacházel v určité fázi tohoto procesu. Tyto fáze jsou rozloženy na kontinuu proměny slohu myšlení a jednání $\mathrm{v}$ druhé přechodové pozici (viz obrázek 1).

Obecně lze říci, že ačkoli jsme si stále naléhavěji uvědomovali nezbytnost zaměřovat naši pozornost ve výzkumu nejen na kognitivní rovinu znalosti, v empirických kapitolách je znát, že další roviny znalosti (tělesné, interakční a vnějškové) jsme zohledňovali spíše doplňkově. Podobně také práce s metaforami při analýze a interpretaci dat nebyla nakonec natolik určující, jak bychom si přáli. ${ }^{5} \mathrm{Na}$ druhé straně se nám ale při práci s daty také dařilo přibližovat se ke slohu pozdní moderny. Dobře viditelné je to např. v kapitole sedm, kde byla pozornost při analýze věnována přímo snaze uchopit znalost jako komplexní dynamickou

\footnotetext{
${ }^{5} \mathrm{Na}$ druhou stranu důsledně přijímat striktní odlišení doslovného a figurativního jazyka by bylo projevem raně moderního myšlení, kterému se chceme vyhnout. Takový postup by opět potlačoval kontinuitu a pozvolnou proměnu jednoho $\mathrm{v}$ druhé a upřednostňoval ostré hranice a diskontinuitu. Blíže se této problematice budeme věnovat jak v části Kontinuita mezi metaforickým vyjádřením a doslovným popisem $\mathrm{v}$ tomto Úvodu, tak $\mathrm{v}$ části 1.2.4.
} 
strukturu, kde tacitní a explicitní znalost jsou interagující póly jednoho kontinua. Nebo v kapitole devět, ve které např. ukazujeme, že spouštěčem neočekávaných situací, ve kterých se projevují tacitní znalosti, je interakce vnějších podmínek (podmínky navázané na prostředí, ve kterém student učitelství vykonává svou praxi) a vnitřních podmínek (podmínky navázané na samotného studenta). Přehledně je struktura celé empirické části knihy vysvětlena v metodologické kapitole (kapitola 4).

\section{Raná a pozdní moderna: metafory, které formují pochopení znalosti}

Předcházející odstavce jsou plné jazykových figur, které tvarují výpověd’ takovým způsobem, abychom vyjádřili ty struktury smyslu, jež potřebujeme. Jazyková figurace nás provází od nepaměti - dobře známá je dávná karteziánská metafora těla-stroje či Komenského podobenství školy jako dílny lidskosti. I samotný př́stup k poznání a znalosti je utvářen metaforami. Právě ony ovlivňují to, co si pod pojmy poznání a znalost představujeme. Raně moderní sloh modeloval poznání kolem metafor zahlédnutí a uchopení. Poznání je tak vnímáno jako intelektuální zahlédnutí podstaty věcí. Výraz „teorie“ (theoria) má původ ve slovech thea - to, co lze zahlédnout (výhled) a horan - vidět. Antické pojetí teorie a s ním i pojetí poznání (at' už je nacházíme u Platóna, Aristotela či Démokrita) je založeno na vizuální metaforice. Raná moderna tuto metaforiku převzala, pouze proměnila racionální duši na mysl moderního člověka, uvnitř které jsou tyto formy nacházeny jako odrazy vnějšího světa ve vnitřním prostoru poznávajícího člověka (to je hlavní obraz, který utváří tradici kartezianismu).

Při porovnávání naší pozice s pojetím autorů Tvorby se ukazuje odlišnost v klíčové metafoře, která má vystihnout proces poznávání. V Tvorbě je užívána metafora konstruování či konfigurování, tj. uspořádání dílčích částí do celku. Metafora má vystihnout proces tvorby díla jakožto věcného artefaktu. Jeho ideový obsah lze při reflexi re-konstruovat a vykládat, protože dílo je výsledkem napětí mezi reprodukcí toho, co autor či interpret již z dřivějška zná a toho, co při tvưrčím procesu inovuje a překonává. Poznávání se tedy „ztělesňuje“ v artefaktech, které slouží jako nástroje pro intersubjektivní součinnost a pro dorozumění s cílem něčemu spolu porozumět. Tento př́stup volně navazuje na relativistickou pozici Goodmanovy „světatvorby“ a nepřímo se hlásí k tradici sociálního konstruktivismu. Vyžaduje do nutné míry omezit unikavost poznávacího procesu jeho dočasnou fixací: jeho 
zvěcněním v tvůrčích dílech, která dovolují na potřebný čas soustředit diskurz a na základě vzájemného porovnávání artefaktů udržovat dialog o různých variantách „téhož“.

Vznik artefaktu může být vyjádřen metaforou uchopení: v artefaktu (větě, obrazu, nebo třeba teploměru či GPS) je poznávací proces „nabízen k uchopení“. Akt poznání je tu vystižen na základě analogie: podobně jako se rukou chápu předmětu, podobně se svým intelektem chápu představ, hypotéz, teorií. Ale pozor: takto by mohla být pojímána i samotná znalost - jako pevné uchopení věci, jakožto jasně ohraničený mentální objekt, „substance“, kterou lze intelektem zahlédnout či uchopit. Na rozdíl od věcné podoby artefaktu však metafora uchopení pro př́stup ke znalosti dost dobře nevyhovuje.

Lidé, kteří se společně pokoušejí prostřednictvím artefaktů něčemu do hloubky porozumět, totiž velmi často zjišstují, že při snaze dorozumět se o ,uchopeném“ narážejí na více či méně nesmiřitelné intersubjektivní rozdíly. Tyto rozdíly je vyzývají k diskusi, k novému zkoumání, $\mathrm{k}$ opětovnému zdůvodňování, v němž se nezřídka ukáže, že doposud vyhovující poznatky musí být upravovány, měněny, nahrazovány. Tím se zjevně zpochybňuje setrvalost poznání.

Ještě mnohem nápadnější je tento moment při pohledu v rozsáhlejší historické perspektivě. $Z$ dějin vědy je dobře známo, že určité pojetí poznatků i poznávání bylo během let opouštěno a nahrazováno nebo alespoň doplněno a kriticky rozvíjeno jinými př́stupy. Pro tento fakt již nemůže dost dobře vyhovovat metafora znalosti založená na pevném „držení ideje“. Ukazuje se, že pro př́istup ke znalosti je třeba hledat další, přiléhavější metafory.

John Dewey byl jedním z autorů, který analýzou filozofických východisek moderní vědy došel k přesvědčení, že vizuální a taktilní metaforika neodpovídá skutečné podstatě vědeckého zkoumání. Pokoušel se proto zvrátit logiku důsledků těchto metafor. Aby se mu to povedlo, musel vymyslet jinou metaforu, kterou by rozvrátil metaforickou logiku původních metafor. Přišel s metaforou odemykání a otevírání dveří. Poznání je procesem, v němž naše myšlenky vstupují do vnějšího světa podobně jako klíč do zámku, a pakliže klíč zapadne do zámku, jsou odemčeny dveře, které otevírají další horizont. Znalostí pak není nějaký objekt mysli, ale zámek a klíč, které do sebe zapadají - respektive proces sjednocení, vyladění vnějšího a vnitřního prostředí, sjednocení a vyladění myšlenek a vnějšího světa, které ústí do 
jednání, jež dosahuje cíle. Znalost je sjednocení znalostního pole. A cíl, který je tím dosažen, je vždy dosažen relativně k našim potřebám.

Teprve tato metafora nám pomáhá artikulovat podstatu přechodu od rané moderny, která v teorii poznání zůstávala příliš pod vlivem středověké představy uchopování podstat poznávaného, k pozdně moderní podobě, jež se od této představy postupně osvobozuje. Znalost již není chápána jako jasné a vědomé uchopení objektu poznání, ale jako schopnost dosahovat cílů prostřednictvím cílesledného jednání, v němž hrají významnou roli nejen vědomá rozhodnutí, ale také tacitní dimenze jednání. Věda, která se formovala v novověku, vyšla z přirozenosti lidské kognitivní aktivity, přičemž posílila a systematizovala ty její prvky, které člověku umožňují dosahovat cíle. Tím se vymkla středověkému pojetí poznání jako uchopování podstat věcí, které bylo založeno již v antickém platonismu s jeho důrazem na vhled uchopující eidos. Přesto převládající teoretická reflexe vědy stále setrvávala na představě uchopování podstat - v současné terminologii: na představě uchopování objektivních struktur světa. Ovšem v moderní (a postmoderní) době se i v epistemologické reflexi posiluje potlačovaný princip, na kterém byla věda v novověku vystavěna - posiluje se vědomí, že cílem vědeckého poznání je inteligentní kontrola prostředí.

\section{Kontinuita mezi metaforickým vyjádřením a doslovným popisem}

Inteligentní kontrola prostředí není založena na objektivním zrcadlení reality, ale na účinné schematizaci. Právě s touto redukcí se pozdně moderní vědec musí naučit pracovat, nebot' on nemůže z principu fungování vědy samotné podávat objektivní obrázek toho, jak se to se světem má, ale poskytuje návody, jak dosahovat cílů. $Z$ toho důvodu věda nemůže být pojímána jako dosahování neochvějné jistoty, ale jako disciplinovaný nástroj, který nám pomáhá kontrolovat svět kolem nás. A snad by bylo dobré dodat: kontrolovat i sebe sama ve vztahu ke světu. Role vědce se mění. Přestává být malým bohem, zvěstovatelem neměnné pravdy a začíná být opatrným technologem, jehož návrhy musí být prosety etickými kritérii a vystaveny důsledné reflexi jejich dopadů. ${ }^{6}$

\footnotetext{
${ }^{6} \mathrm{~S}$ tímto pohybem souvisí odlišení objektivistického realismu od realismu experiencialistického (zkušenostního) (viz Lakoff, 2006, s. 11-16; Lakoff \& Johnson, 2002, s. 172 -201). Lakoff s Johnsonem chtějí zachránit realismus tím, že ho zbaví představy „objektivní pravdy“, která je důsledkem zděděné středověké představy poznání jako uchopování podstat poznávaných entit. Experiencialistický realismus je Lakoffův a Johnsonův
} 
Důsledky nekritické reprodukce metaforiky zahlédnutí a uchopení nás upozorn̆ují na roli, kterou v našem životě hrají metafory. Když se ze „živé“ stane metafora „mrtvác“7 , často nám uniká, že to, co jsme považovali za popis vyjádřený doslovným jazykem, je jednou z možných interpretací vycházející z metaforiky, která nás ovládla, a my si kvůli tomu již nejsme vědomi, že jsme pod nadvládou její figurace a že tato figurace by za odlišných historických okolností mohla být jiná. Proto nám chybí nástroj, který by takto figurativně zpracovanou realitu dokázal vidět ještě jinak.

A zde musíme hledat důvod, proč by čtenár mohl být jistými postupy a výsledky našeho výzkumu překvapený. Může se totiž ptát: proč se v první kapitole věnuje tolik prostoru problematice metafor, jejich vzniku, jejich schopnosti rozštěpit referenci a utvářet metaforické krajiny, když významná část výzkumů v empirické části je orientována na doslovný popis a využívá běžné techniky analýzy? Během výzkumu tacitní dimenze znalosti projevující se v jednání a myšlení našich studentů jsme postupně stále zřetelněji poznávali, že onen zdánlivě doslovný jazyk je ,jazykový habitus“, kterým studenti promýšlejí svoji zkušenost. Tento habitus spočívá $\mathrm{v}$ obrazech - jak jsme ostatně viděli na metaforách zahlédnutí a uchopení výše - které jsou metaforické skrz naskrz. Protože si však studenti této metaforičnosti nejsou vědomi, zaměňují určité porozumění světu za „objektivní“ obrázek toho, jak se to se světem má. A to i přesto, že tento „objektivní“ obrázek je pro ně často nepochopitelný.

Záměna původně metaforické interpretace za doslovný popis je činí neschopnými sledovat proces strukturace vlastní zkušenosti. A tak se teoreticky naučené znalosti nepropojí se znalostí, která se utváří v jejich jednání. Kvůli tomu nemůže docházet k dialogu mezi teorií a praxí. Když tedy zkoumáme zdánlivě doslovné popisy, pracujeme s těmito popisy jako s metaforickými krajinami, jejichž metaforičnosti si nejsou studenti vědomi. Mají na nose ony pověstné Wittgensteinovy brýle, které je nutí vidět jen jisté obrazy, přičemž tyto obrazy lze vyjádřit jen jistými zpo̊soby. Když s doslovným jazykem pracujeme jako s metaforickou figurací, vedeme naše studenty k tomu, aby viděli ,ještě jinak“, a tak se osvobodili od rutiny,

název pro ontologii a teorii poznání, které jsou v podstatné shodě s ontologií a teorií poznání, z nichž v této monografii vycházíme.

7 Ricoeurova kniha, ze které v této monografii vycházíme v úvodní teoretické kapitole, nesla původní francouzský název La métaphore vive - Živá metafora. Teprve v anglickém překladu dostala název The rule of metaphor - Zákon metafory. 
jež se na jednu stranu neopírá o teorii, protože ta je jen mechanicky osvojena, a zároveň se na straně druhé utápí v chaosu prožívaného.

\section{Nedostatky tradičního pojetí tacitních znalostí}

V posledních několika desetiletích dochází $\mathrm{k}$ vzestupu zájmu o výzkum tacitní dimenze poznávání a jednání. ${ }^{8}$ Bezpochyby jde o jeden z mnoha dalších projevů postupného přesunu od raně moderního k pozdně modernímu slohu myšlení a jednání. O tacitních znalostech (dále také pod zkratkou TZ) se poslední dobou mluví především ve vztahu k managementu, ale tato tematika pronikla i do lékařství či pedagogiky - tedy do profesí, v nichž spolu interagují a komunikují bytosti nadané reflektivním chováním, ve kterém se aktéři musejí vyrovnávat $\mathrm{s}$ vysokou mírou komplexity jevi̊ a s jejich dynamikou. Vysoká komplexita jevů a jejich proměnlivost je samozřejmě součástí jakékoli oblasti světa kolem nás. Ovšem oblasti, které nejsou pouze lidskou doménou, jsme se naučili snáze „idealizovat“. To znamená instrumentálně redukovat tak, abychom se získanými poznatky mohli jednoduše a účinně nakládat - ostatně právě redukce stála za obrovským úspěchem moderní vědy. Ovšem zmíněný utilitaristický moment moderní vědy klade na výzkumníky vysoké nároky, nebot' si musejí uvědomit, že nesprávně uplatněná „efektivita“ vědeckého výzkumu vede velmi často ke ztrátě podstaty zkoumaného fenoménu. ${ }^{9}$

Komplexita a dynamika zkoumaných situací vyžaduje, abychom jednali dříve, než je možné události vědomě uchopovat a reflektovat. Uvědomění a reflexe přicházejí až poté, co na úrovni nevědomého (předvědomého, př́ípadně již neuvědomovaného) proběhlo mnoho kognitivních procesů. V rámci raně moderního uvažování může být poznání, které není zcela uvědomované a explikovatelné, postaveno pouze na negativně definitoricky určených projevech TZ. Pokud jsou následně tyto projevy zaznamenány, pak se předpokládá, že

\footnotetext{
${ }^{8}$ Tomu se věnujeme v 6 . kapitole níže, částečně jsme tuto tematiku pojednali i v dř́ivějších studiích (viz Šíp \& Švec, 2013).

${ }^{9} \mathrm{~K}$ tomu viz např. Rockwellův myšlenkový experiment, kterým charakterizuje a ironizuje design reálně provedených výzkumů amygdaly u vyšších ne-lidských primátů, jenž byl prováděn na jedincích izolovaných v klecích. Primáti byli drženi v podmínkách, které z principu neumožňovaly zkoumat funkce amygdaly a to i přesto, že primátům do př́slušného místa $\mathrm{v}$ mozku byly chirurgicky zavedeny elektrody zaznamenávající jeho aktivitu. $Z$ pozice reduktivní raně moderní vědy bylo vše $\mathrm{v}$ pořádku: realita byla náležitě znormalizovaná tak, že se daly snadno kauzálně propojit iritace amygdaly s očekávanými, ale ještě zcela neprobádanými funkcemi. Jenže ony výzkumy nevedly k ničemu podstatnému. U vyšších primátu je totiž amygdala především „orgánem“ neuro-hormonální sociální koordinace, k níž z principu docházet nemohlo (srov. Rockwell, 2005, s. 107-109).
} 
v daných dějích TZ operují. Kruhovost výzkumu je zřejmá. Tento postup je na druhou stranu pochopitelný, protože $\mathrm{v}$ tomto rámci myšlení výzkumníci nemají $\mathrm{k}$ TZ jiný př́stup než prostřednictvím vědomí. Znalost je v tomto myšlenkovém rámci předem pochopena jako uvědomovaná a explikovatelná entita.

V jedné z posledních českých monografií, která se věnuje výzkumu našeho fenoménu (Matošková et al., 2014), autoři operacionalizují TZ následujícími projevy: „spontánní jednání bez vědomého přemýšleni““, „neschopnost popsat, jak člověk něco dělá“, „intuitivní pochopení, co v dané situaci dělat“, „patř̌ičná dovednost““ (srov. tamtéž, s. 54). Vyjmenované projevy následně slouží $\mathrm{k}$ detekování $\mathrm{TZ}$ ve výpovědích studentů a tyto výpovědi jsou považovány za doklad toho, že tacitní znalosti ovlivňují studijní úspěch studentů, a je navrhován způsob, jak tyto $\mathrm{TZ}$ rozvíjet (srov. s. 58-64). Ony čtyři projevy se v různých variantách zmiňují již od doby díla Michaela Polanyiho, tzn. od padesátých a šedesátých let 20. století (srov. 1959, 1983, 1998) ${ }^{10}$, a dále se pouze opakují. Ovšem vyjma kritiků výzkumu TZ se téměř nikdo neptá: jak si můžeme být jisti, že právě tyto projevy jsou projevy TZ? Proč je neschopnost popsat, co člověk dělá či udělal, projevem TZ? Jak zhodnotíme, zda intuitivní pochopení toho, co v danou situaci dělat, je či není projevem TZ? Jak zhodnotíme, že se jedná o skutečné pochopení? Co stanovuje patřičnost nějaké předvedené dovednosti? Tyto otázky se nekladou patrně proto, že v rámci raně moderního myšlení na ně není možné inteligentně odpovědět.

Výše jsme zmínili, že tyto projevy TZ jsou určeny negativně definitoricky. Jestliže je v rané moderně znalost definována jako uvědomovaná a explikovatelná (artikulovatelná), pak projevy TZ musejí být neuvědomované nebo jen zčásti uvědomované a jen těžko artikulovatelné či zcela neartikulovatelné. Proto v designech výzkumů, jež docela dobře reprezentuje výzkum vedený Matoškovou (2014), se pouze intuitivně předpokládá, že malá míra uvědomění, a z toho vyplývající nedostatečná artikulovatelnost, jsou projevem TZ.

I pro nás bude míra uvědomění a míra artikulovanosti hlavním znakem působení TZ, přesto nabízíme více. Nabizíme alternativní rámec pochopení toho, co je to znalost. Alternativní rámec vysvětluje, co zůstávalo v tradičním myšlení nevysvětleno - jak se ustavuje „patřičnost“ či „,náležitost““ jednání bez toho, aby si člověk zcela uvědomoval, kam a

\footnotetext{
${ }^{10}$ Roky vydání zmíněných knih se odkazují k pozdějším reedicím. Samotné knihy vznikaly ve zmíněném období.
} 
proč svým jednáním mírí, bez toho, aby byl schopen záměr a průběh svého jednání zcela artikulovat. Tento obrat k jednání je důležitý, protože cílesledné jednání, které je dosvědčeno dosažením cíle, je znakem toho, že člověk má nějakou znalost. Přičemž tuto znalost je možné při reflexi zkoušet zpětně z jednání vykládat a ve společném dialogu osvětlovat její souvislosti.

Přes genialitu Polanyiho zakládajících textů najdeme i v nich stopy raně moderního myšlení. Ve svých definicích se Polanyi př́liš opíral o přesvědčení, že tacitní znalost je osobní záležitostí (personal) - dokonce tak nazval svoji patrně nejznámější knihu Personal knowledge (1998). Pro Polanyiho sice není „osobní participace poznávajícího na všech aktech porozumění“ nic, co by rozumění činilo subjektivním (srov. 1998, s. iv). Přesto ale nevysvětluje dostatečně, jak se utváŕí cílesledné myšlení a jednání (skilful knowing and doing). To vedlo jeho následovníky $\mathrm{k}$ tomu, že sklouzli k subjektivizaci tacitní znalosti anglické personal začali číst jako subjektivní. Tím se ale vrátili opět do pozitivistického descartovského rámce, který je postaven na subjekt-objektové figuře myšlení. ${ }^{11}$

Polanyi nám poskytl obdivuhodné postřehy $\mathrm{k}$ tomu, jak se $\mathrm{v}$ aktu poznání prostupuje jednání poznávajícího člověka s lidskými nástroji (např. matematickými kalkuly či mikroskopem) a s „objektivním“ světem (srov. 1998, s. 2-68). Tím zvýraznil interaktivitu a neoddělitelnost poznávajícího organismu od prostředí. Akt poznání byl opět zakotven v jednání, a jednání se tak stalo kontinuitou, která překračuje jak jednotlivce, tak celé situace. Polanyi však své myšlenky nedovedl až k náležitým důsledkům, které z toho vyplývají - příliš zdůrazňoval osobitost (personal) poznávacího aktu a upozadil historickou a komunální dimenzi lidského myšlení a jednání. Tím se však zastírá zdroj racionality aktů, které nejsou plně uvědomované a které se tak nedají zcela artikulovat.

Podobně kritizují Polanyiho Gascoigne s Thortonem, když zdůrazňují kritéria, jež sedimentují skrze jednání a jež určují, zda je nebo není nějaké jednání šikovné, cílesledné, tedy skilful (srov. Gascoigne \& Thorton, 2003, s. 13-49). Výsledek sedimentace kritérií má charakter dynamické struktury - struktury, která každým okamžikem prochází změnami, ale díky svému kontinuitnímu charakteru si zachovává roli arbitra, jenž rozhoduje, zda je nějaký akt možné hodnotit jako náležitý či nikoli. Tuto dynamickou strukturu nikdo nevlastní, je součástí racionality sítě znalostí a je přenášena jak geneticky, tak kulturně.

\footnotetext{
${ }^{11} \mathrm{~K}$ tomu viz kritiku Šíp \& Švec (2013, s. 666-669).
} 
Právě role biologické a sociální historicity a komunality poznání a znalosti nás budou zajímat v první kapitole, nebot' vysvětlují, proč i neuvědomované jednání může být racionální, vysvětlují, jak dochází k sedimentaci struktury racionality a jak z ní vyplývá smysluplnost jednání, jež stanovuje jeho náležitost, cíleslednost.

To znamená, že námi očekávaný přínos, jímž bychom rádi obohatili dosavadní diskurz v pedagogických vědách, lze nejpř́hodněji vystihnout výše zmíněným poukazem na propojení biologické a sociální historicity s komunalitou poznávání a znalosti. Považujeme to za výzvu k diskusi nikoliv jen v rozmezí epistemologie nebo ontologie, ale též v oblasti etické. Protože zvláštní ohled k historicitě, právě tak jako ke komunalitě by měl být závazně spojován s obecným nárokem na zodpovědnost ke světu, jehož jsme součástí, nikoliv absolutními vládci.

\section{Struktura publikace a obsahové zaměření jejích kapitol}

Úvahy nastíněné v předcházející části Úvodu jsou podrobně rozvedeny a objasněny v první kapitole (R. Šíp). Tato kapitola byla východiskem pro promýšlení designů výzkumů charakterizovaných $\mathrm{v}$ empirických kapitolách. Zároveň představuje výsledek teoretického bádání autora.

Druhá kapitola (J. Lawley) se více zaměřuje na prozkoumání souvislostí metafor s fenoménem vtělenosti a vtěleným myšlením. V odkazu na Lakoffa, Johnsona a další autory této tradice jsou v kapitole představeny různé formy vtělených metafor. Následně pak autor podrobněji rozebírá důsledky těchto jednotlivých forem pro lidskou činnost, a to ve čtyřech rovinách: jazykové, psychické, fyziologické a materiální. V rámci každé z nich pak ukazuje, že metafory $v$ těchto rovinách pomáhají lépe porozumět tomu, jak ostatní lidé chápou a strukturují svět a sami sebe, a jak nám tyto vtělené metafory pomáhají lépe uchopit strukturální charakter zkušenosti. Kapitolu uzavírá úvahou nad tím, jak jsou metafory důležité pro tacitní učení člověka.

Třetí kapitola (J. Lawley) se podrobněji zaměřuje na téma čistého dotazování (clean language interview) v kvalitativním výzkumu. Autor poukazuje na důležitost záměrné reflexe způsobu, jakým výzkumník klade otázky při vedení výzkumného rozhovoru. Předkládá čtenáři metodu čistého dotazování jako jednu z forem systematického vedení kvalitativně orientovaného 
výzkumného rozhovoru a jako způsob, jak je možné se zcitlivovat k reflektovanému vedení výzkumného rozhovoru. Kromě toho nabízí i evaluační kritéria pro takovýto způsob kladení otázek. Z myšlenek těchto kritérií pak vychází pátá kapitola.

Metodologie celého výzkumu je přehledně představena ve čtvrté kapitole (P. Svojanovský a J. Nehyba). V kapitole jsou vysvětleny dva základní prvky, kterými jsou jednotlivé empirické kapitoly provázány. Prvním jsou definičními znaky tacitních znalostí, které jsou identifikovány jako míra uvědomovanosti a míra artikulovatelnosti znalosti, podle kterých lze rozlišovat, ve které části kontinua „tacitní - explicitni““ se ta která znalost nachází. Druhým prvkem jsou sdílená data, s nimiž výzkumníci pracovali a způsob jejich sběru.

Cílem páté kapitoly (J. Nehyba a P. Svojanovský) je vysvětlit a evaluovat způsob, jakým byla ve výzkumu implementována metoda sběru dat nazvaná „čistý jazyk“, která byla popsána ve třetí kapitole. V rámci pedagogického výzkumu se jedná se o nový způsob dotazování, který nám pomáhal získávat data, co nejvíce se blížící pozici první osoby, to znamená data získaná ze světa participantů výzkumu, tedy informace, které jsou během rozhovoru co nejméně ovlivněny perspektivou výzkumníka. Autoři vycházejí z předpokladu, že pokud jsou z definice tacitní znalosti méně uvědomované a obtížně artikulovatelné, je zapotřebí při vedení rozhovoru usilovat o to, aby strukturace takové znalosti vycházela přímo od informantů. Analýza výzkumů založená na použití čistého jazyka má kvalitativní a kvantitativní část. Na základě kódování autoři během analýzy identifikovali dvě základní kategorie, do kterých lze zařadit veškeré výroky, které výzkumníci při vedení rozhovorů se studenty použili - otázky a komentáře. Jak otázky, tak i komentáře rozdělili podle „míry čistoty“ do čtyř sub-kategorií. Jedním z důležitých zjištění studie je, že kvalita vedení rozhovoru (a tím také předpokládaná kvalita dat) se odvíjí od míry trénovanosti výzkumníka a jeho zkušeností s aplikací čistého jazyka.

Výzkumy tacitních znalostí studentů učitelství byly realizovány již dř́ve. Často šlo o výzkumy praktických znalostí budoucích učitelů, který lze považovat za určitý ekvivalent pojmu tacitní znalosti. Cílem šesté - přehledové - kapitoly (E. Minaříková a V. Švec) je odpovědět na otázku, jak se v rámci empirického výzkumu přistupuje $\mathrm{k}$ tacitním (resp. implicitním, praktickým) znalostem - jak je tento koncept definován, operacionalizován a zkoumán, a také jaké výsledky jejich výzkum přináší. Soubor textů tvořilo deset časopiseckých studií z let 2000 až 2015 psaných v anglickém jazyce a zařazených do databáze 
Web of Science. Vzhledem $\mathrm{k}$ daným kritériím se jednalo o úplný výběr v tomto časovém období. Analýza ukázala, že ačkoliv jsou tacitní (resp. praktické) znalosti předmětem empirického výzkumu, jejich definice a operacionalizace vjeho rámci nejsou vždy jednoznačné. Zkoumání tohoto konceptu vybízí k dalším výzkumům s využitím kvalitativního př́stupu. Výsledky výzkumů pak podávají informace o různých aspektech tacitních (resp. praktických) znalostí, jejich vývoji a faktorech, které jej mohou ovlivňovat. Jsou také inspirací pro vzdělavatele (budoucích) učitelů v jejich př́ípravném a dalším vzdělávání.

V sedmé kapitole autoři (P. Svojanovský a J. Nehyba) ukazují znalost jako komplexní dynamickou strukturu, kde tacitní znalost a explicitní znalost jsou interagující póly jednoho kontinua. Tato interakčnost je zachycena prostřednictvím analýzy a interpretace procesu zexplicitnění konkrétní tacitní znalosti a je ilustrována na vybraném empirickém materiálu. Identifikované fáze tohoto procesu jsou ukotveny v konceptech metaforizace-zdoslovnění a zpětné metaforizace, které tvoří základní stavební kameny filozofických východisek této knihy (kapitola 1).

Jednou z proměnných, která vstupuje do procesu utváření tacitních znalostí studentů učitelství je jejich pojetí výuky. Analýza pojetí výuky u studentů učitelství v prvním ročníku magisterského studia, kteří mají před sebou první učitelskou praxi, je obsahem osmé kapitoly (E. Minaříková a B. Pravdová). V analýze se autorky soustředily především na studentské pojetí žáků, cílů a učiva a na to, která témata jsou jim společná a kterým výzvám spojeným s pojetím výuky čelí. Analyzovány byly celkem čtyři rozhovory vedené čistým jazykem (se studenty Alenou, Beátou, Cyrilem a Karlem). Výsledky analýzy naznačují velkou rozdílnost v diferencovanosti pojetí žáků a jejich zohledňování při zprostředkování učiva. Společným tématem studentů je motivace, ale její pojetí se u jednotlivců liší v propracovanosti i podle toho, v čem studenti vidí zdroj motivace. Analýza jednotlivých výzev ukázala, že se tyto výzvy nacházejí na kontinuu od zaměření na žáka po zaměření na učivo a také na kontinuu tacitní - explicitní podle v závislosti na tom, jakým způsobem jsou studenti schopni o jednotlivých výzvách nejen hovořit, ale i přemýšlet.

Devátá kapitola (J. Nehyba a B. Šimůnková) přináší teoretický i empirický vhled do problematiky neočekávaných situací. Za neočekávané považují autoři situace, při nichž vznik1 nesoulad mezi očekávanou a skutečnou realitou, tedy to, co je pro jedince překvapující. Cílem empirického výzkumu bylo vytvořit typologii neočekávaných situací a zjistit, jakými 
strategiemi je studenti řešili. Přepsané rozhovory se studenty byly opakovaně pročítány a byla z nich vybrána témata, o nichž se studenti ve spojitosti s neočekávanými situacemi a jejich řešením vyjadřovali. Témata autoři analyzovali a hledali souvislosti napříč případy. Výsledkem je typologie neočekávaných situací sestavená na základě čtyř charakteristik: libosti, impaktu, závažnosti a náhlosti či postupnosti jejich vzniku. Při řešení neočekávaných situací uplatňovali studenti čtyři strategie: navrácení se k plynutí, útok, přetrpění a ústup. Studenti si svého pojetí neočekávaných situací a strategií jejich řešení nejsou zcela vědomi, což nasvědčuje tomu, že jsou (částečně) tacitní.

Odpověd’ na otázku, jak se utvářejí tacitní znalosti studentů učitelství a jak tyto znalosti sdílejí budoucí učitelé se svým cvičným učitelem, se pokoušejí dvě př́ípadové studie. V té první (kapitola desátá) si její autor (V. Švec) všímá, co všechno vstupuje do hry, když studentka učitelství Jaroslava získává zkušenosti z řešení různých situací ve vyučování chemii a př́rodopisu, a to $\mathrm{v}$ průběhu dvou učitelských praxí. Autor zvolil design kvalitativního výzkumu, založený na těchto metodách: pozorování jednání studentky Jaroslavy ve vyučovacích hodinách; hloubkové rozhovory se studentkou Jaroslavou; stimulované vybavování situací Jaroslavou s využitím videozáznamu její vyučovací hodiny.

Bylo zjištěno, že tacitní znalosti u Jaroslavy $\mathrm{v}$ průběhu učitelské praxe postupně krystalizovaly. Jejich zdrojem byly zejména neočekávané situace, které v reflexi Jaroslava uchopovala často intuitivně. Na základě reflexe situací ověřovala účinnost různých způsobů jejich řešení - pedagogických postupů a doporučení.

Předmětem druhé př́ípadové studie (jedenáctá kapitola, V. Švec) je sonda do komunikace mezi studentkou Miladou a její cvičnou učitelkou, jejímž těžištěm je sdílení tacitních i explicitních znalostí. Opět byl zvolen design kvalitativního výzkumu vycházející (a) z pozorování diskuse Milady s cvičnou učitelkou, přičemž tato diskuse navazovala na pozorování Miladiny vyučovací hodiny cvičnou učitelkou za prrítomnosti výzkumníka a (b) z hloubkového rozhovoru výzkumníka s Miladou. Ve společné diskusi Milady a cvičné učitelky (vycházející z pozorovaných hodin Milady) byly sdíleny zexplicitněné tacitní znalosti cvičné učitelky. Zexplicitnění vyvolaly (a) detekce problémových míst v pozorované Miladině vyučovací hodině cvičnou učitelkou; (b) dotazy Milady vyplývající z její výukové zkušenosti. 
Zexplicitněné tacitní znalosti cvičná učitelka vyjádřila formou metodických doporučení pro Miladinu další výuku.

\title{
$1 \quad$ Filozofická východiska výzkumu tacitní znalosti: znalost, figurativní jazyk a metafora ${ }^{12}$
}

\author{
Radim Šíp
}

\footnotetext{
12 Jedná se o text, který je komprimován (dokonce dvakrát) z daleko širšího analytického materiálu. Je výsledkem několikaletého rozboru problematiky poznání. Některé z hlubších analýz budou uveřejněny jinde. Zde předkládáme pouze takový souhrn, který by monografii nezatížil ještě větším rozsahem, než ji nyní zatěžuje, ale zároveň umožnil čtenářům, aby mohli alespoň ve zkráceném režimu projít proměnou rámce myšlení, která je nutná $\mathrm{k}$ tomu, abychom vůbec mohli tacitní znalosti zkoumat.
} 
Tato kapitola má komplikovanou strukturu a náročný argument i výklad. Museli jsme se v ní vyrovnat $\mathrm{s}$ epistemologickými předpoklady, které ještě stále utvářejí pozadí současného vědeckého výzkumu a jeho kritikou se propracovat $\mathrm{k}$ částečně odlišnému porozumění znalosti, povaze jazyka a metafory. Jak jsme se zmínili již v úvodu, přesouváme se tímto od východisek rané moderny $\mathrm{k}$ východiskům moderny pozdní. Abychom čtenářum usnadnili orientaci a zároveň zvýraznili vývoj argumentu, předkládáme v následujících odstavcích stručné shrnutí celé kapitoly. Teprve poté budou následovat jednotlivé podkapitoly a jejich části, kde poskytneme podrobné analýzy a argumentační sít' výkladu.

\subsection{Metodologie teoretické kapitoly}

Výklad teoretické kapitoly je přizpůsoben faktu, že přecházíme z rané moderny do moderny pozdní. Přechod se uskutečňuje přes tzv. prechodovou fázi. Ranou modernu, stejně jako pozdní modernu musíme chápat jako jisté ideální typy (Weber), protože před sebou máme pouze mnohé varianty myšlení rané moderny a mnohé varianty myšlení pozdně moderního období. V přechodové fázi můžeme zaznamenat mnoho přechodových prvků, které opouštějí sloh myšlení rané moderny, přičemž zachovávají některé její prvky. Přechodovou fázi v této kapitole představíme prostřednictvím analýzy monografie Tvorba jako způsob poznávání (Slavík, Chrz, Štech et al., 2013), kterou považujeme za propracovanou a dobře odůvodněnou snahu o překročení východisek rané moderny.

V přístupech přechodové fáze můžeme analyzovat mnoho dílčích otázek našeho výzkumného projektu, ale nikoli všechny. Při definici podstaty znalosti, tacitní znalosti, významu figurativního jazyka a metafory potřebujeme překročit přechodovou fázi důsledněji směrem k systémovému myšlení pozdní moderny. Proto budeme následující výklad o znalosti traktovat do třech částí - na raně moderní (1.2.1), na pojetí přechodové fáze (1.2.2) a pozdně moderní pojetí (1.2.3). Roli figurativního jazyka a metafory (1.2.4 a 1.2.5) nebudeme již nezkoumat odděleně z hlediska těchto dvou slohů myšlení a přechodové fáze mezi nimi, ale přesto se vymezíme vůči přechodové fázi, aby mohlo vyniknout relativně nové pojetí metafory jako hlavního nástroje zvýznamňování předem strukturované zkušenosti a zároveň jako exprese části této strukturované zkušenosti.

\subsection{Znalost a role figurativního jazyka v její explikaci}

\subsubsection{Znalost jako poznatek}


Tradiční pojetí znalosti je postaveno na přesvědčení, že znalost vzniká tak, že naše teorie a představy, které se utvářejí v lidských myslích, chápeme jako vnitřní reprezentace vnější reality. Tyto reprezentace poté porovnáme se světem. Pokud lze zjistit korespondenci reprezentace s př́slušnou částí reality, pak jsme dosáhli pravdivého poznatku (znalosti). Na několika prríkladech však ukážeme, že taková představa naráží na některé předpoklady, které jsou od počátku problematické. Nejdůležitější z těchto předpokladů je, že se svět stejně jako náš jazyk rozpadají na významové ,atomy“ (nejedná se o fyzikální atomy, ale o významové atomy - dalším rozkladem bychom již nedostali významově jasněji odlišené celky), přičemž se dále předpokládá, že mezi jazykovým atomem a částí tedy ,atomem“ světa existuje evidentní korespondenční souvislost. Dalším nesprávným předpokladem je, že z takových významových atomů lze utvořit komplexnější poznatek (znalost). Při analýze složitějších propozic však pochopíme, že takovému skládání se vzpírá:

a) problematika konceptualizace fenomenálně složitých událostí, protože s konceptualizací vždy souvisí sociální konstruktivismus (př́iklad propozice: „Země obíhá kolem Slunce.“);

b) problematika ontologické relativity, tzn. provázanosti faktů s posity, systémů empirických zjištění s teoretickými předpoklady (př́iklad propozice: „Příčinou uprchlické paniky v České republice v roce 2015 je skutečnost, že česká společnost je půl století nepřirozeně homogenizována a po tu dobu nemá hlubokou zkušenost s etnicky odlišným obyvatelstvem.").

\subsubsection{Znalost jako poznatek dosažený intersubjektivním vyjednáváním a sdílením struktury znalosti}

V této části doceníme, jak daleko autoři Tvorby postoupili $\mathrm{v}$ překročení hranic raně moderního myšlení. Pro náš další výklad je klíčové to, jak si všímají interaktivního charakteru znalosti - především její intersubjektivity. Znalost (poznatek) je pro ně intersubjektivní shoda na obsahu strukturované zkušenosti. Všimneme si jimi použitých termínů, které podporují tuto komunalitu znalosti - tradice, kulturní pole, konceptuální prostor - a termínů, které strukturují proces konstrukce znalosti a umožňují její intersubjektivní vyjednávání a sdílení - mentalizace, separovaný model, syntéza separovaných momentư, univerzální generický model. Univerzální modely naši autoři spojují s abstraktními objekty, pomocí kterých jsou intelektualizovány mentální objekty, což 
umožňuje, aby jednotlivé mentální subjektivní modely mohly být podřazeny pod společné pravidlo a dosáhnout tak „objektivity“ intersubjektivní shody.

Přestože oceňujeme otevření procesu poznání jeho interaktivní podstatě intersubjektivita je významná součást této podstaty - budeme dokládat, že přechodová fáze stále ještě vězí jednou nohou v rané moderně. Ukážeme to na jejich přístupu, který budeme na základě jejich odkazů na Peregrina, Quina, Davidsona a N. Goodmana nazývat postanalytickým strukturalismem. Postanalytický strukturalismus v podstatných momentech dosahování shody mezi jednotlivými subjektivními představami (či artefakty) nadřazuje strukturu obsahu nad proces strukturace (re/konfiguraci). Přechodová fáze pojímá poznávací proces jako jistý druh nahlížení - v jejich př́ípadě nahlížení shody mezi strukturami zkušenostního obsahu. Takový přistup vede naše autory k opětnému oživení epistemologického atomismu, nebot' struktura se pro ně musí skládat z částí, které musí být k sobě vztaženy „takovým a takovým“ způsobem. Abychom mohli náležitě pochopit TZ a analyzovat jejich nabývání, projevy, sdílení a zexplicitňování, musíme opustit východisko evidence či nazírání struktury a přijmout východisko systémově činnostní.

\subsubsection{Znalost jako sjednocení znalostního pole a tacitní znalost}

Na počátku této části dokončíme kritiku př́istupu přechodové fáze ke znalosti, všimneme si důvěry jejich představitelů $\mathrm{k}$,,bezprostř̌edně danému“, které se podle nich projevuje v jednoduchých odezvách. Budeme si všímat, jak se podle našich autorů tato bezprostřednost promítá do jednoduchých jazykových reakcí na úrovni pozorovacích vět („To je židle.“). Při té př́íležitosti poukážeme na skutečnost, že naše poznání komplexní reality není postaveno na skládání poznatků zachycených v pozorovacích větách a že jednoduché pozorovací věty nevedou $\mathrm{k}$ bezprostřednímu přechodu od stimulu (vidím židli) k náležité reakci (sednutí) nebo náležité pozorovací větě („To je židle.“). I v takových zdánlivě jednoduchých situacích se nám svět dává komplexně a „náležitý přechod“ je věcí konstrukce významu reakce či věty. Znalostní atomy jsou vždy již určitou epistemickou konstrukcí a význam těchto ,atomü“ se vždy mění na základě cíle, který směřuje celý proces poznávání. Právě tento epistemologický atomismus musíme překročit, pokud chceme pochopit fungování kontinuálního nabývání, projevu a sdílení tacitních znalostí, případně procesu jejich explikace.

Protože Dewey byl patrně první, kdo do moderní epistemologie a teorie poznání vnesl celostní pohled, využijeme jeho filozofii a teorii poznání jako východisko. Dewey důsledně 
vycházel $\mathrm{z}$ toho, že se nám svět dává v komplexech. Proto definoval termín situace jako existenční kvantum, v němž se objekty a vztahy mezi nimi nacházejí v kontextuálním celku. Tento celek (situace) je primární. Teprve v následném kroku komplexitu situace abstrahujeme do objektů a vztahů mezi nimi (do částí). Tato abstrakce je však vždy něčím motivovaná, proto objekty a vztahy nejsou znalostními atomy, které se přímo překrývají s prvky světa, a proto přesvědčení „,̌ásti se mají k sobě tak a tak“ nemůže zakládat naši „objektivní“ znalost dané situace. Motivace je vždy odvislá od toho, že potřebujeme vyř̌šit problém, který je $\mathrm{v}$ dané situaci vnořen.

Situace jako celek je prostoupena kvalitou, která ji vymezuje a kterou je určován charakter situace. Aby mohla být situace analyzována, aby mohly být abstrahovány objekty a jejich vztahy, musíme $k v a l i t u$ situace celostně uchopit intuicí. Na tomto místě našeho výkladu poprvé využijeme nejnovější výsledky neurofyziologických výzkumů a výzkumů v rámci současné kognitivní vědy, abychom ukázali, jaké procesy utvářejí to, co Dewey ve své době „intuicí“ nazýval. V rámci tohoto výkladu se obrátíme k výzkumům zrcadlových neuronů (ZN), k Damasiovu pojetí emocí, k senzomotorické koordinaci vnímání a jednání. Zde také upozorníme na konvergenci dřive odlišných teorií (teorie afordancí, teorie rozšǐrené mysli, teorie zjednané mysli, teorie vtělesněné mysli, teorie ekologického já), které dnes tvoří podklad pro nové pojetí kognice a znalosti. Tímto podkladem je bytostná souhra mezi organismem a prostředím (v originále organism-environment coupling). V souvislosti s tím upozorníme, jak se pozdní fenomenologie dopracovala $\mathrm{k}$ podobnému porozumění jako současné kognitivní vědy díky tomu, že důsledně dokončila původní Husserlovo dílo a překročila jej. Intuici tak ukotvíme jak ve výsledcích současné vědy, tak v rozvíjení významu tělesnosti v pozdní fenomenologii a následně ji definujeme jako jednotící vyjádření materiálně-fyziologicko-psychologického komplexu interakci organismu a jeho prostředí, $v$ němž je uchopena celistvost určité situace.

Díky tomuto novému východisku budeme poté moci definovat poznání jako proměnu neurčité situace $\mathrm{v}$ situaci určitou - v situaci, kterou zvládáme, umíme řešit. Poznání budeme prostřednictvím citace $\mathrm{z}$ Deweyho textu definovat jako kontrolovanou nebo směřvanou transformaci neurčité situace do určité podoby, v níż jsou prvky pưvodní situace určeny prostřednictvím konstituujicich rozdílů a vztahů takovým způsobem, že jsou proměněny ve sjednocený celek. Toto sjednocení nás uschopňuje zvládat situace a dosahovat dočasného 
ekvilibria mezi námi a prostředím. Produktem zvládání situace a dosažení rovnováhy je znalost.

Ještě než se dostaneme $\mathrm{k}$ naší definici znalosti, upozorníme na úzkou podobnost mezi neurčitou situaci (tj. situací, kterou podle Deweyho nezvládáme, pocit’ujeme ji jako problematickou a musíme ji nově artikulovat, a tak nově proměnit na situaci určitou) a neočekávanou situací. Neočekávanou situaci pojmeme jako typ neurčité situace. Tak budeme moci vztáhnout naši teorii poznávání $\mathrm{k}$ jedné ze základních kategorií našeho výzkumu a zároveň vysvětlit, proč se při řešení neočekávané situace začínají významně uplatňovat a projevovat TZ. TZ využívají svůj sít'ový charakter a mohou snáze uchopit změnu kvality neočekávané situace. Za tuto vlastnost ovšem platí tím, že jsou hưře uchopitelné vědomím a špatně artikulovatelné v propozici, která je jazykem organizována lineárně.

Důrazem na dosahování sjednoceného celku charakterizujeme znalost jako sjednocení znalostního pole do komplexní dynamické struktury, která teprve ve své jednotě utváři znalost. Znalostní pole poté rozčleníme $\mathrm{z}$ didaktických důvodů a z potřeby budoucí operacionalizace našeho výzkumu do čtyř rovin: (a) rovina interakci; (b) rovina tělesnosti; (c) rovina vnějšího světa; (d) rovina mysli (poznatková rovina).

Sjednocení znalostního pole budeme dokumentovat na ,paleolitickém př́́kladu“ objevu luku a šípu, prostřednictvím kterého ukážeme, že poznání je bytostně činnostní záležitost - začíná manipulací s objekty vnějšího světa a tělesným jednáním, prochází skrze rovinu mysli, kterou rekonstituuje, a končí v jednání, které dosahuje svého cíle. Všechny tyto děje mají interakční charakter a celý zmíněný proces sjednocuje všechny čtyři roviny tím, že je proměňuje, a tak uvádí do dočasného stavu vyrovnání. Poté upozorníme na skutečnost, že se celá raná moderna při definici znalosti soustředila pouze na rovinu mysli, a proto naše poznatky považovala za synonymum znalosti. My pojmy poznatek a znalost dưrazně odlišime a definujeme rovinu poznatků jako jednu ze čtyř rovin znalosti. Upozorníme, že přechodová fáze z interaktivní podstaty dosahování znalosti zvýznamnila především intersubjektivitu mezi mluvč́mi ve „společenství myslí“ a podcenila vnější část znalosti i znalost vtělesněnou do těl organismů. To s sebou nese dva důležité důsledky.

a) Přechodová fáze znalost pojímá jako dočasně uzavřenou strukturu, na které se shoduje společenství myslí ve své dominantně jazykové komunikaci. Tím znalost opět redukuje na poznatek, byt' se jedná o poznatek intersubjektivně vyjednaný. 
b) Privileguje jazyk a jednání odsouvá do pozadí, což představitele přechodové fáze vede k vytyčení hranice mezi „pojmovými““ a „bezpojmovými odezvami“. To má pak vážné důsledky pro jejich pojetí jazyka a metafory. Metaforizaci chápou jako „vtiskování signatury“" (k tomu viz 1.2.4).

Nová definice znalosti nám konečně umožní pochopit podstatu TZ. Budeme je definovat jako relativně úspěšné sjednocení znalostního pole iniciované a vedené možnostmi dostupných interakcí odvislých od stavu vnějšího prostředí a od možností tělesného jednání, jako relativně úspěšné sjednocení, které zatím není doprovázeno náležitou rekonstrukcí poznatkové roviny. Takto definovaná $\mathrm{TZ}$ není odkázána pouze na poznatky (na rovinu mysli), a tím lze vysvětlit, proč dosahujeme cílů, rozhodujeme se, ovládáme techniky, zvnitřňujeme dovednosti, aniž bychom tyto procesy dokázali uspokojivě artikulovat nebo si je plně uvědomit.

\subsubsection{Figurativní jazyk a metafora: jejich role při postupné explikaci tušeného}

$\mathrm{Na}$ počátku této části se opět vrátíme $\mathrm{k}$ autorům Tvorby, abychom upozornili na „přechodovost“ jejich fáze. Naši autoři, jako lidé mající velice blízko k umění, nepodceňují „bezpojmové odezvy“, ale přesto v podstatných místech své teorie privilegují jazyk. Zdůrazňují, že logické vyplývání je neseno „pojmovými odezvami“. Odkazem na autory, z nichž zde vycházíme (Dewey, Lakoff, Johnson, Galles, Nunez, Gibbs a další), ale doložíme, že rozlišení na odezvy bezpojmové a pojmové je podle současných výzkumů neudržitelné, nebot’ pojmy vznikají již na úrovni senzomotorické koordinace jednání. Tato skutečnost od nás vyžaduje, abychom předefinovali vztah mezi doslovným a figurativním jazykem. Protože autoři Tvorby kreslí tlustou čáru mezi pojmovými a bezpojmovými odezvami, musejí se v otázce figurativního jazyka inspirovat u Davidsona a spolu s ním tvrdit, že metafora nenese význam, pouze nás na něco upozorňuje. Kdyby metafora nesla význam, pak by byla zpochybněna hranice mezi těmito dvěma druhy odezev.

My naopak ukážeme, že metafora (která je v textu definována v širokém slova smyslu viz 1.2.4) vynáší význam z oblasti strukturované zkušenosti. Jedná se o ten význam, který jsme dosud neměli potřebu či nebyli schopni zvýznamnit v našem vědomí. Metaforu budeme definovat z jedné strany na základě Ricoeurova a Kohákova pojetí. Z druhé strany na základě neurofyziologických výzkumů a výzkumů kognitivních věd druhé generace. Podle Ricoeura jazyk vzniká v dění, které se do našeho vědomí dostává přes symbolickou strukturaci 
zkušenosti jako cosi neuchopitelného, a metafora je prostředkem, který dokáže z oblasti symbolického jednání vnést nový význam do jazykového řádu. Symbolické jednání je spojené s historií kosmu a života. Jak si tento vztah představit na více konkrétní a vědecky podložené rovině ukážeme na pozadí děl již zmíněných autorů (Johnson, Lakoff, Nunez, Galles, Gibbs). Ti na základě současných neurofyziologických výzkumů dokládají souběh nejzákladnějších úrovní jednání s hodnocením situace. Tato hodnocení utvářejí základní pojmovou bázi hluboko předtím, než může být ona báze na povrchu vyjádřena jazykem či nějakým jiným symbolickým řádem. Hodnocení je umožněno vtělesněnými strukturami, které utvářejí naše tělo. Opět na tomto místě poukazujeme na funkce zrcadlových neuronů, na emocionální zhodnocování a další procesy, které hluboko pod úrovní vědomí utvářejí rovinu smyslu. Vtělesněné (embodied), vnořené (embedded), rozšířené (extended), zjednané (enacted) dynamické struktury propojují jednotlivý organismus (člověka) s historií nejen vlastního druhu a s proměnami okolí, kterými tento druh ve své historii procházel, ale také s historií veškerého života. Tímto velice tělesným a materiálním způsobem vstupují dějiny kosmu do nejintimnějšího života jedinců.

Zmínění autoři dále dokládají, jak se od úrovně klastrů senzomotorických reakcí, jež utvářejí konkrétní pojmy, dostáváme prostřednictvím konceptuálních metafor a z nich kombinovaných metaforických forem ke stále abstraktnějším rovinám lidského života. Tyto skutečnosti ukazují několik podstatných věcí, které jsou zcela v protikladu k raně modernímu myšlení.

a) Doslovný jazyk není jazykem přímé ostenze či ostenze nepřímé (extenze). Doslovný jazyk je užitečným hřbitovem metaforické tvorby, jejímž úkolem není svět popsat, ale prostřednictvím náležité schematizace dosáhnout náležitého jednání.

b) Mezi doslovným a figurativním jazykem je hluboká kontinuita.

c) Prostřednictvím „mrtvých“ (zdoslovněných) a „živých“ (nekonvenčních) metafor jsme intimně propojeni s naší tělesností a skrze ni se životem obecně.

d) Abstraktní myšlenky a objekty nejsou ničím jiným než stopami kontinuity jednání organismu jako druhu.

e) I ty nejabstraktnější systémy, např. matematika, koření v tělesnosti a sedimentují do svých ideálních podob prostřednictvím metaforických zdvihů, které se ukáží být úspěšnými nástroji člověka. 
To má vážné důsledky pro náš výzkum. Nemáme přímý prrístup k tacitní znalosti, protože ta ze své podstaty operuje pod úrovní vědomí. Přesto jakákoli - i ta nejabstraktnější myšlenka je vkořeněna do řádu tělesnosti a je z ní vyzdvihována na vědomou a lingvistickou úroveň metaforickou strukturací. Z toho důvodu se tělesnost a metafora stávají centrem našeho výzkumu. Je ovšem nutné dodat, že i tzv. doslovný jazyk je nesen původní figurativní prací jazyka, a z toho důvodu je i ,doslovný“ jazyk vázán k tělesnosti a metaforám. Proto i v př́ípadě, kdy budeme zkoumat „doslovný“ jazyk, budeme zkoumat jeho metaforickou, strukturující povahu.

Díky této provázanosti metafory s tělesností a se symbolickým řádem kosmického života definujeme metaforu podstatně širším způsobem. Způsob, jakým jsou metafory pojímány v literárněvědných, lingvistických a tradičně filozofických textech, je dán tím, že v těchto oborech je metafora považována za primárně lingvistickou záležitost. Toto předporozumění zcela opustíme. Metaforu budeme spojovat s výše definovanou intuicí a považovat ji za komplexni prostředek vyzdvižení a vyjádření kvality situace, která má z principu kognitivni charakter, jenž spočivá v tom, že uvolňuje náš předcházející popis reality a vnáší do něho prvek, kterým definici reality mění (Ricoeurovo rozštěpení reference). Novým způsobem strukturuje naše porozuméní světu.

V posledních odstavcích této části ukážeme, jakým způsobem tohoto rozštěpení reference metafora dosahuje, a položíme důraz na komplexitu změn, které metafora způsobuje jak v řádu našeho porozumění světu, tak na úrovni jazyka.

\subsubsection{Metaforizace, fenomenologická analýza a rozvíjení metaforické krajiny}

V této poslední části druhé podkapitoly se budeme soustředit na proces metaforizace. Odlišíme dva typy: metaforizaci-zdoslovnění a zpětnou metaforizaci. První je procesem, v němž změnu způsobenou metaforickým posunem (rozštěpením reference) vyzdvihujeme na pole vědomí tím, že přes konceptuální metaforu zdoslovňujeme naše nové porozumění situaci, až jej ukotvíme v doslovných (ostrých) pojmech. Ty zdánlivě jasně a zřetelně popisují realitu kolem nás, ale ve skutečnosti tak činí díky tomu, že ztrácejí systémový charakter, a tím i kontakt s prožitou zkušeností a zařazují se do lingvistického řádu, v němž dominují syntagmatické (horizontální) vztahy jazyka.

Zpětná metaforizace je opačným procesem, kdy od ostrých pojmů, jdeme přes konceptuální metafory k souvislosti ukotvené ve strukturované tělesné zkušenosti. Na úrovni 
metafor a konceptuálních metafor se dostáváme do psychoaktivního stavu, v němž jsme vyslovované či psané schopni propojit s prožívaným a obohatit tak dříve od tělesnosti oddělené pojmy logickou souvislostí jednotlivých struktur dynamické zkušenosti. Tento postup je výhodný tehdy, když se člověk, který vypovídá, pohybuje na abstraktní, atomizované rovině. $\mathrm{V}$ našem př́padě se jedná o rovinu mechanicky osvojených odborných termínů a teorií, které studenti nejsou schopni propojit s jejich vlastní prožitou zkušeností, a proto nejsou schopni zahájit náležitý proces analýzy vlastního jednání, jeho silných a slabých stránek. Při zpětné metaforizaci často dochází k projasnění vlastní zkušenosti a k uchopení nastalé situace prostřednictvím intuice, jež se většinou dá vyjádřit především prostřednictvím metafor. Intuice, TZ a metafora jsou čepy, kolem kterých se otáčejí zkušenosti studentů na praxi - obecně zkušenosti lidí, jež se v daných situacích ještě neumí dostatečně jasně orientovat, a přesto relativně dosahují některých svých cílů. Metafora vyjadřuje intuici, jež následně pomáhá schematizovat situaci nikoli z pohledu pasivně osvojené terminologie a teorií, ale z perspektivy vlastních prožitků. Jestliže indukujeme a podporujeme metaforický proces, pomáháme tím studentům k prohloubení a zintenzivnění reflexe.

Metaforická vyjádření podporujeme zvláštní „,technikou“ čistého jazyka. V této části také upozorníme, že se v podstatě nejedná o techniku, ale celkový analytický přístup. Čistý jazyk považujeme za jednu z metod fenomenologické analýzy, její výhoda spočívá v tom, že dokáže elegantně a jednoduchým způsobem zabezpečit fenomenologickou redukci již ve fázi sběru dat. Tím umožňuje vstoupit snáze do prožitkového světa studenta, aniž bychom do jeho výpovědi vnášeli naše odborné teoretické předpoklady a očekávání (to je ideál, ke kterému se tázající snaží co nevíce přibližit). Právě tím, že se vzdáváme práva vstoupit do výpovědi, umožňujeme studentu, aby se co nejvěrněji přiblížil k logické struktuře vlastního prožitku. Toto přiblížení studentům následně umožňuje snáze analyzovat situaci a hledat alternativní řešení, která - aniž by opouštěla ontickou závaznost struktury zděděných významů - berou také v potaz jedinečnost situací a vlastní predispozice a předcházející zkušenosti studentů.

My, jako výzkumníci, kteří se snaží odhalit nabývání, operace a sdílení tacitních znalostí, sledujeme a musíme sledovat tento cíl pouze nepř́mo. Rozvíjíme metaforickou krajinu $(\mathrm{MK})$ našich respondentů. Zkušenostní významová struktura je zaprvé př́liš bohatá na to, abychom ji vcelku mohli uchopit vědomím a vyjádřit jazykem, a zadruhé je dynamická každým okamžikem prochází menšími či většími změnami. Proto musíme hledat nástroj, kterým zaprvé dokážeme tuto logiku dané struktury uchopit jiným způsobem než doslovným 
jazykem, a zadruhé to učinit takovým způsobem, aby jeho zachycení v řádu jazyka nebylo rigidní. MK je systémem metafor a jejich vzájemných vztahů. Tyto vztahy nejsou náhodné, mají svoji inherentní logiku, která vyvěrá z dynamické struktury zkušenosti. Právě díky této logice získáváme srovnávací objekt, který nám ukazuje, zda za jednáním studenta byl nebo nebyl blíže nespecifikovaný, vědomě neartikulovaný cíl, a pokud ano, pak zda se student k tomuto cíli blížil, či nikoli. Jestliže se blížil, pak v jednání studenta operovaly tacitní znalosti, které vedly studenta v jeho jednání náležitě, tzn. cílesledně. V další reflexi MK mohou být prvky zkušenosti lépe a přsněji artikulovány. Tak se dostáváme k uchopování a k zexplicitňování TZ.

\subsection{Metodologie teoretické kapitoly: ideální typ a slohy myšlení a jednání}

Modernou máme na mysli dlouhé období od počátku novověku až do současnosti. Přijímáme myšlenku, kterou pravděpodobně nezávisle na sobě zformulovali Dewey (dvacátá a třicátá léta 20. století) a Latour (osmdesátá léta toho samého století). Podle ní je moderní myšlení rozpolcené (Dewey; Latour), protože převzalo z předcházejícího dlouhého antickoscholastického období přesvědčení, že poznání je uchopováním podstaty věcí (Dewey). Oba autoři dokládají - Dewey (2012) analýzou filozofických předpokladů moderní vědy, Latour (2003; Latour \& Woolgar, 1986) analýzou reálných procesů vědeckých výzkumů - že nejsme zcela moderní, jelikož na teoretické úrovni reflexe vědy (teorie vědy, epistemologie) vyznáváme články víry, které jsou $\mathrm{v}$ rozporu s reálným provozem vědy, tedy $\mathrm{s}$ tím, co moderní vědu fakticky privileguje před jinými typy poznání. Tuto skutečnost zde promítáme do odlišení rané a pozdni moderny. Ranou míníme tu část moderny, která zůstává zatím „nedokončená“, nebot' v sobě nese prvky středověkého myšlení - prvky, jež nejsou kompatibilní s tím, co činí vědu moderní vědou. Pozdní moderna se reflexí vědy pokouší moderní obrat dokončit. Součástí této emancipace je osvobození od ideologie moderní vědy, jež je založena na objektivismu a korespondenční teorii pravdy a poznání. ${ }^{13}$

Raně moderní představa světa se dvě století (17. a 18.) ustalovala a konkretizovala a od 19. století se její hegemonie pomalu a postupně rozpadá. Proto můžeme v realitě kolem nás

\footnotetext{
${ }^{13} \mathrm{~K}$ odlišení objektivistického realismu od realismu experiencialistického (zkušenostního) viz Lakoff (2006, s. 11-16) a Lakoff \& Johnson (2002, s. 172-201). Viz též poznámku 6 výše.
} 
spatřit různá stadia či různé podoby raně moderního způsobu myšlení i různá stadia či různé podoby myšlení pozdně moderního. V žádném z těchto stadií nenalézáme čistou podobu. $\mathrm{S}$ paletou různých podob raně i pozdně modernistických př́stupů k poznání a znalosti budeme v následujících stranách pracovat tak, že stanovíme nejprve ideálně-typickou výchozí fázi raně moderního přístupu, poté fázi přechodovou a nakonec stejně ideálně-typickou fázi pozdně moderní.

S pojmem ideální typ se zde metodologicky odkazujeme na Maxe Webera, který vytyčil ideální typ jako nástroj sociálně vědního výzkumu. Podobně jako při zkoumání sociálních, politických či ekonomických procesů se i my při práci s přechody mezi jednotlivými rámci myšlení (mezi rámcem raně moderním a pozdně moderním), dostáváme do situace, kdy se nám v průběhu času ,realita“ zkoumaného jevu (tj. teorie poznání) proměňuje, a tím se proměňují i podmínky reference a definice toho, co je znalost, jazyk a metafora. Jestliže ještě v 18. století o korespondenci mezi reprezentací v lidské mysli a př́islušné části reality nebylo nutné přemýšlet ve vztahu k času a vývoji (bylo to období před hegelovským a darwinistickým obratem), v 19. století se situace radikálně proměňuje. Darwinismus se prosazoval postupně a váhavě. Teprve dnes můžeme říct, že se evoluční hledisko začíná důsledně uplatňovat např. i v kognitivních vědách. Stejně tak nedošlo k radikální změně pojetí teorie poznání a korespondenční teorie zůstala ještě další století nejvýznamnějším kandidátem na tu správnou teorii. Existovaly zde sice konkurenční teorie např. redundantní, minimalistická, koherenční, sémantická (srov. Kolář, 2002, s. 57-120). ${ }^{14}$ Každá však řešila některou ze slabin korespondenční teorie, ovšem žádná z nich nebyla ve svém celku dostatečně přesvědčivá. Mimo jiné i z toho důvodu korespondenční teorie vyhovovala nejlépe slohu myšlení rané moderny, v němž centrální pozici hrála reprezentace vnějšího (objektivního) světa uvnitř subjektu.

Proto se začaly vytvářet mnohé mezistupně a doplnění, které měly ideu korespondence mezi představou či teorií a př́íslušnou částí objektivního světa zachránit. Teprve další a další těžkosti, které se na této cestě objevovaly, přiměly některé filozofy, epistemology a vědce, aby začali uvažovat o celkově odlišném přístupu k pojetí poznání a znalosti. Občas nezávisle

\footnotetext{
${ }^{14} \mathrm{Z}$ přehledu konkurenčních teorií pravdy, které Kolář definuje, vyjímáme pragmatistickou teorii pravdy. Kolář ji př́iznačně nazývá ,pragmatická“ a definuje ji, na základě prvního období C. S. Peirce, aniž by reflektoval, že Peirce v pozdějším období zastával jiné, sofistikovanější pojetí ( $\mathrm{k}$ odlišnosti dvou definic pravdy u Peirce - viz Hroch, Šíp, Madzia, \& Funda (2010, s. 49-58) a na základě Jamesovy teorie pravdy (Koláŕ, 2002, s. 91-99). U obou se dopouští zjednodušení, která jsou typická pro české filozofické prostředí. Navíc se nezabývá Deweyho teorií, jež je mnohem komplexnější a je přesnějším projevem pozdně moderního myšlení. Proto se v části 1.2.3 stane hlavním východiskem našich úvah.
} 
na sobě (Dewey, Vygotskij, Piaget), někdy ve volné či těsnější závislosti (James, Husserl, Weber, Schütz, Berger a Luckmann) se začaly objevovat teorie, které narušovaly základní postuláty raně moderního pojetí poznání. Tak vzniká kontinuita alterujících podob, v níž se objevují varianty jednoho slohu myšlení, aby se v určité fází a s nejistou hranicí přechodu proměnily do jiného slohu myšlení (který se navíc také prosazuje v různých variantách), přičemž ty původně nepřijímané alternativy postupně sílí do pozice nadějného generátora konkurenčních teorií.

Je to velice podobné, jako když se prolamuje jeden umělecký sloh - např. renesance do jiného $-\mathrm{v}$ daném př́padě do baroka. Určit přesnou hranici předělu nelze. Někteří autoři budou Důmyslného rytíre dona Quichota de la Mancha považovat za předčasný projev baroka (Zdeněk Kalista), jiní za projev vrcholné renesance (Václav Černý). ${ }^{15}$ Přesto přechod od renesance $\mathrm{k}$ baroku a existence jednoho i druhého slohu jsou neoddiskutovatelné. Když však ke zmíněnému dílu přiložíme kritéria definovaná pojmem „renesance“ či pojmem „baroko“, vzpírá se zřejmému zařazení pod jeden nebo pod druhý pojem. Narážíme zde na velmi podstatný jev světa kolem nás. Nejen v sociálních vědách, jak se původně domníval Weber, ale ve vědě obecně dochází $\mathrm{k}$ proměnám teorií i celých slohů myšlení a $\mathrm{v}$ takové chvíli porozumění (Verstehen) předchází vysvětlení (Erklären). Ideálním typem Weber mínil konstrukci získanou „myšlenkovým stupňováním určitých prvků skutečnosti“, konstrukci, která „,není ,hypotézou“, ale chce tvorbě hypotéz ukazovat směr. Není zobrazením skutečnosti, ale chce pro zobrazení poskytovat jednoznačné výrazové prostředky“ (Weber, 2009, s. 43). Sloh myšlení a jednání rané moderny nenajdeme v žádném konkrétním období od-do. Jedná se pouze o tendenci myšlení, která se po jistou dobu prosazuje, poté na nějakou dobu téměř ovládá intelektuální pole daného období, aby nakonec začala slábnout až ke svému nenápadnému vymizení. Tak jako tomu bylo se zbytky tomistického (aristotelského) myšlení během 18. století, které reprezentovalo anticko-scholastický sloh a které bylo postupně překryto raně moderními teoriemi. Abychom o prolamování jednoho slohu do druhého mohli něco říci, musíme s definicí slohu pracovat ideálně-typicky, podobně jako historie a teorie umění pracuje ideálně-typicky s uměleckými slohy.

V následující podkapitole o znalosti a roli figurativního jazyka a metafory (1.2) budeme postupovat následujícím způsobem: nejdříve stanovíme ideální typ raně moderního pojetí znalosti, poté upozorníme na přechodovou fázi, kde se oba typy - raně i pozdně moderní -

\footnotetext{
${ }^{15}$ K tomu srov. pasáž z knihy Petra Vopěnky Podivuhodný květ českého baroka (2012, s. 52-59).
} 
prolínají, soupeří o pozici „náležitého výkladu“ a někdy i mísí (v takové době se dnes nacházíme), abychom následně vytvořili ideální typ pozdní moderny. Př́stupy ke znalosti, které se podle nás stávají při současném stavu věd neudržitelné, se nacházejí v oblasti mezi ideálním typem rané moderny a přechodovou fází. Přechodová fáze je důležitým momentem dějin vývoje myšlení, protože v sobě skrývá mnoho „epicyklů“ a „deferentů“, které vyrovnávají napětí mezi ranou a pozdní modernou takovým způsobem, že je tato fáze schopna uspokojit většinu našich současných potřeb, aniž by zatím musela přiznat, že korespondenční teorie pravdy a poznání a definice „objektivity“ se z epistemologického hlediska zcela vyprázdnily. ${ }^{16}$

Problém ale nastává ve chvíli, kdy se dostáváme k tématům, jež nemohou být plně rozvinuta $\mathrm{v}$ raně moderním slohu myšlení ani $\mathrm{v}$ přechodové fázi. Tato témata pak od nás vyžadují, abychom vykročili z přechodové fáze směrem $\mathrm{k}$ ideálnímu typu pozdní moderny. Tacitní znalost je jedním z takových témat. Právě v této oblasti mezi přechodovou fází a ideálním typem pozdní moderny se musí pohybovat náš výzkum tacitních znalostí. Tento rozptyl od přechodové fáze $\mathrm{k}$ horizontu ideálního typu pozdní moderny také vysvětluje, proč některá témata našeho výzkumu můžeme rozvíjet v kontextu přechodové fáze a jiná vkontextu, který přechodovou fázi překračuje. Ta první jsou bez větších problémů akceptovatelná většinovým názorem na metodologii a způsoby dokazování vědeckého „faktu“, protože grémia a recenzenti odborných časopisů si již zvykli na složitost přechodové fáze.

Ovšem rozvíjení dalších problémů nás nutí, abychom se v našich východiscích více přiblížili ideálnímu typu pozdně moderního slohu myšlení. U nich si musíme připustit (byt' je to kvůli většinovému názoru vědecké obce pro nás nepříjemné), že znalost není osobní znalost či poznatek (raná moderna), že dokonce není ani vymezitelná jako fakt posvěcený intersubjektivním uznáním a sdílením (přechodová fáze). Nacházíme se tak v situaci podobné situaci novověkých astronomů, kteři si v určité fázi vývoje museli připustit, že se planety

16 Odkazem na epicykly a deferenty míříme $\mathrm{k}$ podobnému procesu přechodové fáze, tentokrát mezi aristotelismem pozdní scholastiky a ranou modernou. Během tohoto období se astronomie 16. a 17. století držela kopernikánského systému pohybu planet se svými epicykly a deferenty, protože ještě dokázala odpovídat na nejožehavějši otázky dne a zároveň mohla tvrdit (či předstírat), že kopernikánské pojetí vesmíru je pouhým matematickým modelem, který neříká nic o tom, zda Slunce fakticky je, či není ve středu vesmíru. Ovšem již $\mathrm{v}$ tu dobu se chystal přechod ke zcela jinému pojetí vesmíru, který se stal realitou poté, co se objevil eliptický pohyb planet a klasická mechanika hmotných těles. $\mathrm{V}$ tomto kontextu přechodu mezi slohy myšlení bychom měli vnímat i Descartovy Meditace o první filosofii jako jistý druh „propagandy“, který podle Descartových vlastních slov v dopise Mersenovi měl ,čtenáře vést krok za krokem $\mathrm{k}$ přijetí jeho fyziky, aniž by si při tom uvědomovali, že se nakonec, až budou zcela přesvědčeni, zřeknou dominantního aristotelského obrazu světa a přijmou mechanický světový názor“" (parafrázováno in Chomsky, 1996, s. 18-19). 
nepohybují po ideálních kruhových drahách, a tím se jim s konečnou platností otevřela cesta k novému modelu vesmíru.

\subsection{Znalost a role figurativního jazyka v procesu její explikace}

\subsubsection{Znalost jako poznatek}

Ideálně-typické pojetí znalosti rané moderny je koncentrováno kolem představy, že se znalost vytváŕí a může vytvářet jedině v hlavě jednotlivce. Modelovým př́ikladem zde pro nás může být Descartes. Jako jeden z nejvýznamnějších učenců své doby byl Descartes provázán s největšími hlavami své doby, a tím prohluboval své poznání, byl v kontaktu s lidmi, kteří prováděli experimenty a výzkumy, a koreloval s nimi své názory, poměřoval své teorie s výsledky zmíněných experimentů, a tím stavěl své teorie na empirických zjištěních, která jsou generována společenstvím, ale přesto definoval poznání jako něco, co se odehrává ve vnitřním prostoru hlavy poznávajícího. Co se odehrává v mysli. Měl k tomu své důvody.

Chtěl se oddělit od tradice a autority, která na počátku 17. století ztrácela svoji vážnost. V té době byla narušena důvěra přetrvávající mnoho století. S postupně se prosazujícím heliocentrickým pojetím světa zesilovala také obava, že Země možná není středem vesmíru. Nacházíme se v době před hermeneutickým obratem čtení Bible, k němuž došlo v 19. století. Ztráta centrální pozice Země není jen astronomickou, ale také antropologickou a teologickou záležitostí. Symbolicky je zpochybněna základní jistota velikosti člověka, která byla do té doby garantována nejvyšší autoritou - církví. Navíc v Evropě právě skončila destabilizující třicetiletá válka, jež byla živena náboženskými spory. Zdálo se, že historicky znemožněná autorita musí být nahrazena něčím pevným, a jediný kandidát, který připadal tehdejším intelektuálům vhodný, byl lidský rozum. Obrat dovnitř je pohybem, který v 17. století můžeme vidět jak v obecně kulturním návratu do ,ráje srdce“, kde člověk potkává skutečného Boha (srov. Komenského Labyrint světa a ráj srdce), tak v novověké představě, že epistemickou jistotu může každý nalézt jedině uvnitř sebe. To je počátek paradoxu rané moderny, která z definice nachází informace o vnějším světě jedině uvnitř jedince.

Na počátku 17. století se tak utváŕí představa vnitřního prostoru (viz např. Descartes, 2003, především s. 27-35, 65-80), který byl později nazván bud’ tradičně „duše“ či nově „mysl“. Od té doby je vnější svět v podstatném smyslu produktem duše/mysli, protože prostřednictvím svých kognitivních schopností uvnitř sebe mysl reprodukuje vnější svět - 
utváří reprezentace. Omezením této představy byla pochyba, zda může poznatek vznikající v poznávajícím subjektu být objektivní. V 19. a 20. století se objevily snahy tento problém vyřešit: pozitivismus se soustředil na smyslově dané informace, pozitivně vykázané v naší evidenci. Tento přístup se př́liš nezabýval tím, co je to vlastně pozitivní fakt. Na to se pokusila odpovědět fenomenologie, která tento zamlčený problém pozitivismu kritizovala a snažila se nalézt transcendentální rovinu, jež teprve měla smyslově danému přiřadit vlastní význam. Husserl o fenomenologii prohlašoval, že klade základy skutečné vědy, protože na rozdíl od pozitivismu, psychologismu a fyzikalismu vychází z toho, co je nám jedině př́stupno, z naší zkušenosti. V jiných textech jsme ukazovali, jak Husserl nakonec př̌kročil východiska rané moderny a jak se fenomenologie podílí na proměně pozdně moderní teorie poznání (srov. Šíp, 2015, s. 684-692). ${ }^{17}$ Nyní se ale budeme soustředit na popis toho, jaké předpoklady a důsledky raně moderní sloh myšlení vnesl do pojetí znalosti.

Reálný svět je vně poznávajícího. Tento svět je světem objektů a objektivních struktur, které musí poznávající uchopit, aby měl znalost. Objektivní struktury ale není možné vyčíst pouze z materiálního povrchu, protože každý objekt má svoji podstatu a ta nemusí být vyjádřena jejím povrchem. Přesto jsou to vlastnosti povrchů, které zprostředkovávají informace. Slunce má svoji vnější podobu, vyzařuje paprsky, lidské oko zaznamenává tvar a světlo a zpracovává je na komplikované vizuální informace, které jsou do zpětného celku formovány $\mathrm{v}$ mysli. Tyto vizuální informace jsou doprovázeny informacemi dalšími, např́iklad z našich kožních receptorů, které nás zpravují o teple atd. V tomto vnitřním prostoru se skládají všechny přivedené informace do celku a utváŕí se mentální informační struktura, která může být podle jistých pravidel převedena do jazykové struktury: „Slunce svítí.“ Takto jsou však zpracovány pouze aktuální povrchové vlastnosti. To nás přivádí ke vsuvce o nesamozrejmosti pozorovaného.

Vzhledem ke komplexitě světa se ke zmíněným informacím okamžitě druží podle relativně pružných pravidel další zjištěné vlastnosti. Pozorujeme běh slunce po obloze od východu k západu a utváŕíme mentální obraz: „Slunce obíhá Zemi.“ „Slunce vychází na

\footnotetext{
${ }^{17}$ Ovšem i Husserl v první fázi svého působení propadal myšlení rané moderny, nebot' předem nadřazoval reflektivní jevení se věcí ve vědomí, a tak zdůrazňoval podstaty věcí jako invarianty a podceňoval dynamické aspekty fenomenologického utváření světa. Ve chvíli, kdy ve dvacátých letech vezme Husserl vážně intencionalitu jako primární dynamickou jednotu, která se teprve v reflexi sekundárně rozkládá na noema a noesis, $\mathrm{v}$ ten okamžik je osvobozen $\mathrm{z}$ raně moderního myšlení (k tomu srov. kritiku Husserla in Barbaras, 2005; Merleau-Ponty, 2010). Když tyto skutečnosti rozpracují jeho pokračovatelé, přestává být fenomenologie definičně závislá na subjekt-objektové figuře myšlení a objevuje se prostor pro „,asubjektivní“ myšlení a pro ideu, že samotná zkušenost je původně „,asubjektivní“, mimo kategorie subjektu a objektu (srov. Patočka, 2003; Kohák, 1993, s. 76-89).
} 
východě.“ „Slunce zapadá na západě“. Situace se nám výrazně komplikuje, když je potvrzena heliocentrická představa světa. Není to Slunce, které obíhá Zemi, ale naopak pohyb Země, který utváŕí dojem obíhání Slunce. Předcházející tvrzení: „Slunce obíhá..., vychází..., zapadá...“ se stávají pouhou „lidovou moudrostí“, skutečné popisy jsou odlišné. Již na této úrovni se nám utváření reprezentací významně komplikuje právě tím, že to, co poznávající subjekt pozoruje (zakouší), je povrch. V samotných aktech poznání je ale mnoho procesů, které určují, co, jak a proč bude subjekt pozorovat, a prostřednictvím pozorování tak dosahovat znalosti. Tyto procesy lze zvládat pouze jistou dovedností. Necvičené oko laika během prvního pohledu do mikroskopu nepozná nic. S každým dalším nástrojem poznání se zvětšuje prostor, v němž musí být člověk zacvičen. I to je důsledek skutečnosti, že člověk poznává pouze povrch pozorovaného, že poznání samotné je ve své podstatě nakládání a manipulace s věcmi a že člověk přitom využívá technologií, které postupně vydobývá z možností svého přirozeného prostředí tím, že jej proměňuje.

Co se děje v hlavě poznávajícího, když poznává? Co je to, když dosáhne znalosti o Slunci? Tradičně se soudí, že si poznávající utvoří představu, která odráží svojí strukturou strukturu poznávaného objektu. Že je mezi představou a vnějším objektem nalezena izomorfie. Při zprocesování shluku informací do představy dochází k modelování struktury, jež je izomorfická (strukturně stejná) s danou částí vnějšího světa. V naší představě je objektem Slunce, z něhož vychází záře - světlo. To umožňuje utvářet představu svítícího tělesa a artikulovat ji do propozice: „Slunce svítí‘“. V propozici byla představa ukotvena natolik, že dostala jasné hranice, a tím vykrojila jasný význam celé zkoumané situace. Tak byla situace poznána. V reálném světě se nachází objekt, který svítí, v představě máme mentální objekt, který je obklopen mentální září („,svítíc) a v propozici je zachycen objekt pojmy „Slunce“ a „,svíti“‘. Izomorfie je jasně doložitelná, a pokud Slunce skutečně na daném místě a v daném čase svítí, pak propozice koresponduje s vnějším stavem světa a propozice $\mathrm{i}$ představa jsou pravdivé. Dosáhli jsme znalosti o dané situaci.

Celé se nám to ale komplikuje ve chvíli, kdy si uvědomíme, že situace se svítícím objektem, který nazýváme Slunce, je prostě př́liš triviální. Do zjišt’ování, zda je tato představa a tato propozice pravdivá, se pustíme pouze tehdy, máme-li co dělat s psychotikem, který tvrdí, že Slunce nesvítí, i když my i ostatní máme za to, že svítí. Ale když se jen přesuneme ke skutečnosti, že Slunce je obíháno Zemí, pak se nám všechny děje výrazně komplikují (byt' se jedná o poznatek přírodních věd). Tuto skutečnost nevidíme. Nevyplývá 
př́mo z našeho fenomenálního prožitku. Jednoduché procesování informace do představy a artikulace propozice probíhá nepřímo přes zjištění astronomů a přes mnoho dalších faktických zapojení tohoto poznatku do sociálního života. Tato skutečnost je vlastně z velké části sociální konstrukt, a to i přesto, že podle našich nejlepších přírodovědných znalostí, je tomu přesně právě takto: Země skutečně svým pohybem vytváří dojem obíhání Slunce kolem Země.

Tento konstrukt není arbitrární, je založen na koherenci empirických zjištění, na našich potřebách a mentálních manipulacích s pojmy. Dohromady to vše dává alternativní představu, jež vysvětluje i mnoho jevi̊, které by nemohly být geocentrickou představou vysvětleny. Z tohoto celého procesu vychází i jistý systém užívání pojmů, kterého se musíme držet, máme-li si vytvořit náležitou představu a propozici: „Slunce je obíháno Zemí.“ Konceptualizace našeho poznání dokáže (a často musí dokázat) převrátit naše každodenní fenomenální vnímání stavu věcí, abychom se dostali k tomu, co pod tlakem tradice nazýváme „pravdivým faktem“. ${ }^{18} \mathrm{Z}$ toho plyne významné poučení, že sociální konstruktivismus nemá být a většinou není v nesouladu se světem kolem nás. Skutečný konstruktivismus je nástrojem náležité konceptualizace složité reality. ${ }^{19}$

Do ještě složitější situace se dostaneme u propozice pronášené např́íklad v politologickém diskurzu: „Příčinou uprchlické paniky v České republice v roce 2015 je skutečnost, že česká společnost je půl století nepřrirozeně homogenizována a po tu dobu nemá

\footnotetext{
${ }^{18} \mathrm{~K}$ tomu viz Slavík, Chrz, Štech et al. (2013, s. 39-40). Autoři monografie Tvorba jako způsob poznávání zmiňují jak př́ílad s geocentrickou soustavou, tak další zajímavý př́ílad. Jedná se o odkaz na Vygotského analýzu obsahu pojmu reflex u Pavlova. Na základě empirických dat Pavlov nemohl dojít ke dvěma základním podmínkám, kterými definoval reflex: reflex je tím, co negativně odděluje člověka od zviŕrete (člověk se neřídí jen svými reflexy), a tím, co není kontrolované, promýšlené, inteligentní. Nemohl k nim dojít proto, že tyto „podmínky“ definoval spolu s definicí reflexu. J. Friedrichová uvažovala nad tím, co by se stalo, kdyby Pavlov místo pojmu „reflex“ použil pojem „předreflektující intelekt“. To je pro nás velmi zajímavé. Ve vztahu $\mathrm{k}$ současné neurobiologii a neurofyziologii a také ve vztahu $\mathrm{k}$ tomu, co jsme psali výše, je oprávněné tvrdit, že by za takové situace rozvoj fyziologie nebyl brzděn celým konceptuálním komplexem, který nedovoloval až téměř do konce 20. století vidět v předreflektivních, nevědomých dějích kontinuitní potenciál intelektu. $\mathrm{S}$ velkou pravděpodobností by se urychlilo pochopení neurobiologických a neurofyziologických dějů jako podkladu vzniku racionální kontroly prostředí a inteligentního rozhodování. Ovšem Pavlovovo rozhodnutí nebylo arbitrární, jak by se snad dalo z textu Tvorby usuzovat. Bylo učiněno v naprostém souladu se slohem myšlení rané moderny, která vědomé a explikovatelné apriorně nadřazuje všemu předvědomému a předreflektivnímu a která na základě starší tradice a její v podstatě náboženské etiky kategoricky odděluje člověka od „pouhého“ zvířete.

${ }^{19}$ Aby L. Kvasz (2016) uchránil tento realistický prvek konstruktivismu, definoval šest principů konstruktivismu a pojmenoval takto charakterizovaný konstruktivismus „genetickým konstruktivismem“. Vychází totiž z poznatků kognitivních vědců a psychologů (Piaget, Vygotský, Lakoff, Johnson, Nunez), že lidé ve své re/konstrukci poznatků postupují rychleji a účinněji, následují-li proces, jakým ke konstrukci poznatků člověk docházel ve své fylogenezi či $\mathrm{v}$ historickém procesu rozvoje své kultury. Tímto našim čtenářùm vřele doporučujeme Kvaszův text, nebot' v něm také charakterizuje podstatu Hejného metody př́hodněji než sám prof. Hejný, a tím tuto metodu oddaluje od módního „zdivočelého“ konstruktivismu.
} 
hlubokou zkušenost s etnicky odlišným obyvatelstvem.“ Myšlenka, která je touto propozicí vyjadřována, je tak komplexní, že žádnou jednoduchou představu si již ani nemůžeme udělat. U předešlé věty: „Slunce je obíháno Zemí,“ si takovou představu zkonstruovat můžeme, a to doslova natruc naší fenomenální zkušenosti. Ovšem i kdybychom si představili řadu na sebe navazujících a vnitřně mezi sebou provázaných představ „homogenní společnost“”, „ČR v roce 2015“ „uprchlická panika“ atd., nemohli bychom dojít k ničemu, co bychom mohli jednoduše porovnávat se skutečností.

Zde se nám velmi výrazně relativizuje pojem korespondence. Běžná představa byla, že u takto složitých propozic ji rozložíme na její atomy: „uprchlická panika“, „panika v ČR“, „V ČR v roce 2015“ atd.; a tyto atomy nezávisle na sobě porovnáme se skutečností, a pokud všechny její části budou pravdivé, pak pravdivá bude i tato komplexní propozice. ${ }^{20}$ Ovšem zapomínáme na dvě podstatné skutečnosti.

a)Že atomy propozice se skládají ze slov a tato slova dostávají svůj význam pouze ve vztahu k desítkám a stovkám dalších vět, nebot’ jazyk je holistický nástroj.

b)A že pojmy „panika“, „С̆R“, „rok“, „2015“ v atomech propozice (např. ,,panika v ČR“ či ,zkušenost s obyvatelstvem“) budou mít mírně odlišné významy od těch samých pojmů ve chvíli, kdy je užijeme v celé komplexní propozici, nebot’ v širším kontextu nabývají i specifičtějších významů.

Rozkládání a skládání propozic se ukazuje být naprosto matoucí představou. Předpokládá totiž, že jazyk lze rozložit jako hodinový strojek na jednotlivá kolečka a separovat tak více či méně neměnný obsah pojmů ( $\mathrm{k}$ tomu se vrátíme $\mathrm{v}$ části 1.2 .4 pojednávající o jazyce a metafoře).

Sama analytická filozofie dospěla k tomu, že to možné není. Ve svých analýzách vztahu jazyka, jeho významů a pravdy Davidson dochází k přesvědčení, že nelze porovnávat či konfrontovat jednotlivý pojem či jednotlivé přesvědčení s př́slušnou částí reality, protože významy částí reality jsou nám dány v předchůdném významovém celku, který je určen tradicí našeho porozumění světu: „Představa podobné konfrontace [mezi pojmem a věcí] totiž nedává smysl, protože my se samožrejmě nemůžeme vysvléct z kůže a podívat se, co že to

\footnotetext{
${ }^{20}$ Špatné jméno sociálních věd pramenilo právě z toho, že taková atomizace byla v rámci jejich pole zkoumání vždy velmi podezřelá a často vedla $\mathrm{k}$ výsledkům výzkumu, které $\mathrm{v}$ realitě byly nepoužitelné. Později se ukázalo, že segmentace složitých jevů na atomární jevy a jejich separovaný výzkum je zjednodušením i pro př́rodní vědy samotné. Často nemůžeme oddělit fakta od positù teorie, proto významy pojmů jsou už předem určeny dílč́mi teoriemi, z nichž výzkumníci vycházejí. To se na vyšší úrovni zastřešujících teorií projevuje jejich ontologickou relativitou atd. K ontologické relativitě viz Quine (1998); a k důsledkủm, které lze z Quinovy relativity vyvodit, viz Rorty (2012, s. 184-200).
} 
působí na naše tělo a vyvolává v něm ony procesy a události, kterých jsme si vědomi.“ (Davidson, 2004a, s. 167) Podobně Quine ve svém textu Ontologická relativita dokládá, že reference sama (tedy jasný odkaz pojmu k př́slušené části světa) je „behaviorálně nevymezitelná“ (srov. Quine, 1998. s. 56). Propojení pojmu s věcí vně nás nám samo o sobě neřekne o významu věci nic nebo jenom velice málo. Dokonce ani pojmu „Slunce“ bychom neporozuměli tak, jak mu rozumíme, kdybychom nežili ve společnosti, která nám umožňuje ustálit význam pojmu, jejž spojujeme s daným objektem, což společnost činí tak, že mluví o komplexu reality kolem nás a v nás krystalizují komplexy významů na sobě vzájemně závislých pojmů. Významy bychom si tedy neměli představovat jako osamělé, oddělené, samy o sobě postačující atomy, ale jako uzly protínajících se významových funkcí jazyka, které jsou provázané a v nichž se význam ustaluje jen do té míry, abychom mohli náležitě kontrolovat své okolí.

Tyto skutečnosti výrazně narušují ideálně-typické základy raně moderního slohu myšlení. Všimněme si jedné podstatné věci. Naše reprezentace - at' už představy či propozice - vznikají ruku v ruce nejen s tím, jak se nám věci jeví v našem okolí, a nejen ruku v ruce s celou společností, v níž uchopujeme základní strukturu porozumění světu, ale také ruku $\mathrm{v}$ ruce s tím, jak experimentálně toto společenství manipuluje s koncepty. Bez konstrukce, která sice vzniká v závislosti na empirickém pozorování, ovšem nepřímo prostřednictvím práce s pojmy (tuto konstrukci nazýváme konceptualizací a rekonceptualizaci), bychom nemohli porozumět ničemu, co se nám našimi smysly dává odlišně. Dokonce ani tak banálnímu jevu, jakým je optické zakřivení hole, když ji ponoříme do vody.

Podstatným vkladem přechodové fáze je skutečnost, že různými způsoby zdůraznila komunalitu znalosti, její intersubjektivní sdílení a částečně také cirkularitu poznávacího aktu - tzn., že vycházíme z určitého předporozumění, docházíme k novým poznatkům a ty se následně stávají součástí našeho předporozumění. Tím je relativně jednoduchý obraz zrcadlení (reprezentace) a porovnání (korespondence) na jednu stranu uschopněn k tomu, aby vypovídal o složitějších věcech než o větách typu: „Slunce svítí“. Na druhou stranu se obraz komplikuje, protože se v této přechodové fázi stále držíme některých pojmů a představ, které jsou ovlivněny ranou modernou. Ale i tak dochází k významným posunům, jež nám umožňují odpoutat se od některých mýtů rané moderny a pružně pracovat s problémy, které potřebujeme vyřešit. 


\subsubsection{Znalost jako poznatek dosažený intersubjektivním vyjednáváním a sdílením jeho struktury}

Jak už jsme výše několikrát poznamenali, přechodovou fázi budeme rekonstruovat na př́kladu knihy Tvorba jako způsob poznávání (Slavík, Chrz, Štech et al., 2013). Tato monografie je v české epistemologické, didaktické a estetické oblasti výjimečná. Poznání je v ní chápáno jako „elementární akt tvorby“, v němž se vnímané stává stimulem k reakci, jež formuje subjektivní zkušenostní obsah pomocí exprese struktury výrazu (srov. tamtéž, s. 94110). Přes všechnu složitost celého procesu a jeho jemnosti (viz tamtéž a další níže zmíněné pasáže) jde o to, že se prostřednictvím tvorby „obsah externalizuje a zprostředkuje mezi lidmi“ (s. 97). Tak se poznání ukazuje být komunální, společenskou záležitostí, což následně umožňuje, aby bylo možné ,posuzovat a nacházet lep̌̌i alternativy artefaktu v určitém výběrovém poli možnosti“", a to je „společným jmenovatelem pro tvorbu i poznáni“ (tamtéž, kurzíva v originále).

Je zřjejmé, že se tento postoj k poznání významně vzdaluje ideálně-typickému pojetí poznání jako korespondence. Poznání není obkreslování objektivních rysů skutečnosti, ale smysluplnou reakcí, ${ }^{21}$ jež je cestou k expresi poznatku. Exprese může být komunálně posuzována, kriticky zhodnocena a př́ípadně navržena lepší alternativa. Poznání je zde již chápáno jako akt, jako jednání. Díky tomu může být poznání pojato jako napětí mezi pólem reprodukce - opakováním již poznaného - a pólem inovace - který vnáší do znalostní struktury nový prvek, přičemž cílem je, aby nový poznatek přispěl k větší přiměřenosti v porovnání se systémem předešlých poznatků (srov. tamtéž, 151-170).

Podstatné pro poznání je to, že je komunální. Komunalita je zárukou překročení subjektivního zkušenostního obsahu. Poznání tak již není vázáno na mimolidskou sféru mechanického porovnávání poznatku se svým předobrazem - př́íslušnou objektivní strukturou světa. Autoři se zde hlásí k tomu, co by ve slohu myšlení rané moderny bylo projevem epistemologické nedokonalosti. Poznání je významně určeno a formováno společenstvím mysli. ${ }^{22}$ Autor tohoto pojmu, Donald Davidson, je přesvědčen, že komunikace a poznání jiných myslí je základem našeho pojmu objektivity, která je definičně závislá na intersubjektivitě. To neznamená, že by struktury světa kolem nás byly závislé na našich dohodách. Společenství myslí může být společenstvím myslí jedině díky tomu, že se více či

\footnotetext{
${ }^{21}$ Nakolik je smysluplná, natolik vede v konečné fázi k přiměrenosti poznatku.

${ }^{22}$ Při čtení Tvorby čtenáŕ najde mnoho indicií, že tato komunalita je pro strukturu výkladu monografie stěžejní. Konkrétní odkaz na Davidsonovo společenství myslí (srov. Slavík, Chrz, Štech et al., 2013, s. 112) je pouhý vrcholek celého ledovce.
} 
méně koordinovaně řídí rysy světa. Kdyby tomu tak nebylo, lidé by neměli dostatečné možnosti určit významy vlastních slov, a tím by došlo ke zhroucení komunikace i společenství myslí. Odkaz na realitu kolem ukotvuje významy lidského jazyka (srov. Davidson, 2004c).

V procesu komunikace je prvek původní „objektivity“ skryt v nutnosti odkazovat se k vnějšímu světu a vytvářet koherentní vztah mezi slovy, významy a jednáním (jinak by došlo o onomu epistemologickému zhroucení). Vidíme proto, že pole komunikace zcela překresluje hranice slov „subjektivní“, „intersubjektivní“ a „objektivní“. Jejich významy se překrývají a jedno nelze určit bez druhého. Neexistuje prostor zcela „subjektivních“ událostí podobně jako neexistuje prostor pro zcela soukromý jazyk. Jestliže někomu alespoň částečně rozumíme třeba tak, že si uvědomíme, že nerozumíme, co přesně míní svými větami, pak s ním již mnohá přesvědčení musíme sdílet (srov. Davidson, 1998). Podobným způsobem neexistuje ani něco „objektivně“ zcela nezávislého na mluvčích, nebot' „objektivita“ může být nacházena a stvrzována jedině prostřednictvím intersubjektivního sdílení významu (představy), ke kterému dochází uvnitř společenství myslí. Ovšem intersubjektivně sdílená představa, která stvrzuje objektivitu, je vždy otevřena revizi, není „objektivní“ ve smyslu objektivistického realismu. ${ }^{23}$ Tato skutečnost bude pro nás podstatná i při definici pozdně moderního slohu myšlení.

Důraz na komunalitu společenství myslí se projevuje v přechodové fázi různými způsoby. Většinou tak, že se zdůrazňuje intersubjektivně vyjednaný obsah představy či propozice. Toto vyjednávání se ale odehrává na pozadí velkého množství přesvědčení, poznatků, o jejichž pravdivosti jsme zatím neměli důvod pochybovat a které poskytují společenství myslí společnou základnu, bez níž by vyjednávání vůbec nemohlo probíhat. Toto poznání je nazýváno různě, např. „tradice“, „kulturní pole“, „konceptuální prostor“, „mentální prostor“ či „schémata“ (srov. Slavík, Chrz, Štech et al., 2013, 68-69). Tyto „tradice“ či „konceptuální prostory“ atd. se stávají podstatou kontextu, který se utváŕí ve vztahu k danému obsahu. Komplex př́íslušných „kulturních poli““, „konceptuálních prostorů“ atd. vytváří dynamickou strukturu kontextu. Tvoří ji „sémantická provázanost“ a „logická inferenční struktura obsahových prvkư“, které se jako celek vyvíjejí, ale přesto poskytují

\footnotetext{
${ }^{23}$ Některé významné Davidsonovy texty bychom měli považovat za stejný typ reorientační (propagandistické) literatury, jakým byly Descartovy Meditace. Aniž si to možná Davidson přiznal, i on vede své čtenáře „krok za krokem k prrijetí [nové ontologie], aniž by si při tom uvědomovali, že se nakonec, až budou zcela přesvědčeni, zřeknou dominantního [raně moderního] obrazu světa a přijmou [nový] světový názor“. Viz poznámku 15 výše.
} 
„referenční rámec pro uspokojivý, resp. úspěšný výklad, pro argumentaci a zdůvodňování“ (srov. tamtéž, s. 117-118).

Podle autorů dochází v prostoru sociálně sdílených významů k vynucené konceptualizaci subjektivního mentálního prostoru, která vede ke konsenzuální analýze významu. Konsenzuální analýza zajišt’uje vztah schémat (tradic, kulturních polí atd.) k argumentační praxi. Právě v tomto ohledu je zmíněno společenství, které argumentační praxi zajišt'uje - jsou to „kompetentní debatéři“, kteří u vědomí své kompetence (tzn. u vědomí vzájemné obeznámenosti s problémem) mohou během své konverzace nakládat s empirický obsahem zpracovávaným v představě tak, aby dosáhli strukturovaného obsahu znalosti (srov. tamtéž, s. 70-71).

Proces, který v tomto prostoru probíhá, autoři Tvorby nazývají mentalizace, v níž jde mimo jiné především o to vyzdvihnout konkrétní zkušenostní výskyty na úroveň abstraktního objektu. Což probíhá výběrovou syntézou separovaných momentů zkušenosti. Např. pomocí pravítka rýsujeme přímky $a$ a $b$. Pro nás je zde důležité, že se jedná o činnost silně vázanou na kulturní pole geometrie - tedy už od počátku je zde přítomen formující faktor dynamické sociálně-kulturní tradice (kontext), která vede naši činnost. Podřazení těchto momentů pod abstraktní objekt $-\mathrm{v}$ tomto případě podřazení směřování jednotlivých př́mek pod abstraktní objekt směr - vede k tomu, že zkušenost je strukturována modelovým charakterem. Nejprve jako separovaný model pro př́pad konkrétních přímek $a$ a $b$, později jako univerzální generický model, který na abstraktní rovině strukturuje jakékoli směřování přímek (srov. tamtéž, s. 72-75).

Mentalizace vychází z rozpoznávání a rekonstruování struktur, na jejichž základě utváří zobecnění jednotlivých případů do podoby pravidel (k separovaným prrímkám $a, b$ jsou v generickém modelu potencionálně přiřazeny všechny další možné přímky). Pravidlo umožňuje utvoření systému konceptů - př́ímka, plocha, směřování, směr jsou propojeny do diskurzivně logického celku, v němž plocha obsahuje různě orientované př́ímky, které mají stejný nebo odlišný směr, abstraktní objekt „směr“ je však jen jeden. Tento proces přechází rekurzivně mezi subjektivní zkušeností a její uvědomělou vnější reprezentací. „Obsah a významy jsou určovány kombinací našich životních zkušeností a biologických předpokladů ve spojení v komunikaci v příslušném kulturním poli: pokud se mezi sebou liší dvě kulturní společenství, budou se lišit i jejich podmínky pro stanovení významů.“(tamtéž, s. 75) 
Autoři Tvorby přejímají tradiční rozlišení mezi mentálními objekty a abstraktními objekty. To jim umožňuje, aby se drželi přesvědčení, že ,představa, její vyjádření a intersubjektivní sdílení mohou mít společný obsah nebo význam“ (s. 86), jelikož toto sdílení je zajištěno právě tím, že sdílení probíhá jako sjednocení struktury subjektivní představy se strukturou abstraktní entity, s idejí, která odpovídá objektivně danému obsahu artefaktu / objektu. Tak abstraktní objekty vstupují do zkušenosti jednotlivce a vytvářejí kalibrační sít'. Přiřazují význam prožitým událostem. Pravidlo, díky kterému můžeme něco podřadit pod abstraktní objekt, vyžaduje systém, který určitým způsobem abstrahuje reálně zakoušené tak, aby bylo možné tyto prožitky zařadit pod příslušné pravidlo. U přímek je nutné, abychom je pochopili nezávisle na tom, zda jsou na papíre, na tabuli či fiktivně promítány do prostoru. U koní musíme odmyslet jejich konkrétní barvu, výšku atd. Tento moment, který by podle ideálního typu rané moderny měl být jednou provždy pevně daný a konečný, se přechodové fázi začíná rozpohybovávat. Odůvodnění principu abstrakčního zdvihu je vždy relativní vůči něčemu. Jednou můžeme zvíře před námi identifikovat jako koně, podruhé jako zvíře. Vždy ve vztahu k tomu, jaká intence je za naším procesem myšlení - očekáváme pohyb, útěk, př́jem potravy u toho tvora před námi, nebo se chceme na něm projet či jej chceme zapřáhnout do pluhu, anebo jsme zoologové a chceme jej zařadit do přesné klasifikační tabulky? Vytváŕíme řády významové nerozlišenosti, která závisí na funkci, tj. na tom, co od stanovení významu požadujeme (srov. tamtéž, s. 100-110).

Význam představy či poznatku se utvárí prostřednictvím mentalizace subjektivního prožitku do podoby intersubjektivně sdíleného obsahu. Adekvátnost obsahu je dána překrytím struktury subjektivní představy se strukturou intersubjektivně sdílenou společenstvím myslí. Mentalizace pracuje s podřazováním jednotlivých výskytů zkušenosti pod abstraktní objekty, které umožňují strukturaci významu - podřazením rovné čáry v sešitě pod abstraktní objekt „přímka“, přiřazujeme čáře charakteristiky, které pouze ze subjektivního pozorování nemusejí být zřejmé. Mentalizace osvobozuje partikulární zkušenost z jedinečnosti výskytu a přiřazuje jí význam.

Abstraktní objekty tak zajímavým způsobem oscilují mezi raně moderním pojetím, které je chápe jako vyjádření podstaty objektivních struktur světa kolem nás, a mezi pozdně moderním pojetím, které je chápe jako naše nástroje zvýznamňování zkušenosti. Pravdivost věty: „Přímka $b$ a přímka $a$ mají směr,“ nezjistíme prostřednictvím nacházení korespondence mezi ní a příslušnou částí reality - ostatně, která část to vlastně je, jak by se v tomto př́padě 
korespondence zjišt'ovala ${ }^{24}$ - ale tím, že této větě rozumíme v rámci specifického kulturněepistemologického kontextu a tento kontext je určován celkovým smyslem kulturního pole, v tomto př́padě kulturního pole geometrie, které zajišt’uje objektivitu v něm konstruovaných abstraktních entit. Kulturní pole má - přes svoji idealizující funkci - důležitý praktický význam pro lidský život. Přes veškerou objektivizaci jsou ony dvě čáry na tabuli prostřednictvím abstraktních entit významově otevřené, protože ve skutečnosti je mohla namalovat Maruška bez ohledu na geometrii, na přímky a směry. Tato významová otevřenost je tím, co utváŕí podstatu lidské adaptability na prostředí.

Ovšem $\mathrm{v}$ určitých partiích výzkumu tacitních znalostí si s přechodovou fází nevystačíme. Důvodem je míra, jakou i tato fáze přikládá uzavřeným tvarům, jazykovému vyjádření a logice, která je - podle nás mylně - přisuzována až propozičnímu charakteru vět. Více k tomu poznamenáme níže, zde jenom podtrhneme, jak tento důraz znejasňuje podstatu tacitní znalosti a vlastně i znalosti vůbec.

Autoři Tvorby zdůrazňují ve vztahu k významu exprese, že je nutné konstrukci či konfiguraci odlišit od struktury. Struktura je v jistém smyslu „nadčasová““. Struktura umožňuje opakování, konstrukce či konfigurace je pouze uskutečněním struktury (srov. tamtéž, s. 60-64). Nechceme zde zpochybňovat význam struktur pro lidské poznání - je-li čára na papíŕe pochopena jako konstrukce struktury „př́ímka“, pak to může mít pro další lidské jednání velký smysl. Např́iklad ten, že se projekce přímky do materiálního prostoru stane nástrojem, jak tento prostor popsat pomocí geometrické idealizace a prripravit jej tak $\mathrm{k}$ náležitému využití. To, co zde kritizujeme, je fakt, že naši autoři k celému problému přistupují ze strukturalistické pozice. Respektive z pozice těch, kteří už předem vědí, co je struktura a co je ne-struktura.

Dotýkáme se zde jednoho z posledních významných zbytků teorie poznání rané moderny. Ve strukturalistickém př́ístupu je podstatou poznání předchi̊dná znalost (znalost struktury). Je to velmi podobné korespondenční teorii, v níž bylo - vždy implicitně a vždy nezdůvodněně - předpokládáno, že objektivní struktury světa musíme předem znát, abychom mohli stvrdit či odmítnout korespondenci našich představ a teorií s daným výsekem objektivní struktury světa. V případě přechodové fáze zase víme, co je ona „nadčasová“ struktura. Důraz

\footnotetext{
${ }^{24}$ Právě potřeba nějakého světa abstraktních entit, s nímž by mohly naše pravdivé představy a teorie korespondovat, vedla Bolzana a později Fregeho k představě existence „světa vět o sobě“ (Bolzano) či „třetí říše“ - říše abstraktních entit (Frege).
} 
na strukturu v postanalytické literatuře zastiňuje samotný proces poznávání a to, co v něm postupně a kontinuálně vzniká.

Postanalytický strukturalismus nás tak vystavuje významné rozporuplnosti, k níž se autoři Tvorby nevyjadřují. Na jedné straně si je tato přechodová fáze vědoma, že poznání není nic pevného, je věčným rekonstruováním, ověřováním, vyjednáváním (tamtéž, s. 56). Ovšem na druhou stranu zároveň staví na přesvědčení, že ,význam je tím, co je dáno strukturou, zatímco chybné přesvědčení je tím, co v konkrétním př́ípadě vysvětluje odchylku od této struktury“ (tamtéž, s. 56; původně Peregrin, 1999, s. 168). ${ }^{25}$ Otázkou ale zůstává, jak poznáme, že se jedná o náležitou strukturu, od níž můžeme odečítat „odchylky“, které definují „chybná přesvědčení“. Nemůžeme zároveň tvrdit, že se význam či struktura, který tento význam nese, vyjednává, konstruuje, v rámci exprese utváří, a zároveň mít za to, že je tato struktura již hotová. Tím bychom se vrátili k předpokladům rané moderny. Pouze diskurz o objektivně daných strukturách světa bychom nahradili diskurzem o strukturách. Přes veškeré obdivuhodné přechodové úsilí se tato fáze nezbavila základní praskliny, která prostupuje celou moderní teorii poznání. Mohli bychom ji zformulovat do otázky: jak je možné, že praxe procesu poznání v moderní vědě je hledáním nového prvku vysvětlení dějů kolem nás, ale teorie vědy je stále postavena na odhalování ukončené, předem dané struktury?

Možná nejsme daleko od pravdy, když na základě Deweyho analýzy západního myšlení (srov. Dewey, 1992, lw.1: 69-131) ${ }^{26}$ máme za to, že jsme instinkt privilegovat již hotové před teprve se utvářejícím zdědili z platónsko-aristotelské tradice. Nepopíráme zde skutečnost, že projektovat dosud známé do právě probíhajícího, je základním kamenem epistemické orientace člověka. Pouze tvrdíme, že to, zda je předem známá struktura vhodná pro řešení současného problému, zjistíme teprve tehdy, až nám aplikace této znalosti pomůže dosáhnout cílů, kterých dosáhnout potřebujeme. Jak ale tuto skutečnost náležitě promítnout do teorie poznání? V následující části se o to v náznaku pokusíme tím, že pojetí znalosti posuneme ještě o kus dál za přechodovou fázi.

\footnotetext{
${ }^{25}$ Je př́źznačné, že Peregrinova kniha, na kterou se autoři Tvorby v tomto klíčovém místě odkazují, se jmenuje Význam a struktura (1999). Význam pojmů je zde pochopen jako dočasně zastavená struktura. Alternativní pojetí významu (viz 1.2.3 a 1.2.4 níže) se musí s tímto předpokladem vyrovnat kriticky.

${ }^{26}$ Jedná se o standardizovaný způsob odkazu na The collected works of John Dewey, kde „ew“ či „,mw“ nebo „lw“ znamená dílo raného či středního nebo pozdního období, číslo po tečce označuje svazek a prípadné číselné rozmezí za dvojtečkou detekují strany od-do. V následujících odkazech, již nebudeme uvádět Deweyho jméno a rok vydání.
} 


\subsubsection{Znalost jako sjednocení znalostního pole a tacitní znalost}

V textu Proposition, warranted assertability, and truth (lw.14: 168-188) Dewey reagoval na Russellovu kritiku jeho nejvýznamnější knihy zabývající se poznáním Logic: The theory of inquiry (Logika: teorie zkoumání - lw.12). Pro nás je to zajímavý text, nebot' v něm Dewey na velice krátkém prostoru vysvětluje svoji teorii poznání. Právě zde používá metaforu, jež bude $\mathrm{v}$ dalších partiích této kapitoly stěžejní. Používá ji v kontextu situace, jíž jsme se implicitně zabývali v části 1.2.2 ve vztahu $\mathrm{k}$ Tvorbě. Naši autoři totiž sdílejí východisko s Russellem, který předpokládal, že zde existuje jakési bezprostřední poznání (knowledge by acquaintance), které je natolik přesvědčivé, že na jeho základě epistemicky zcela bezpochybně utváŕíme propozici. Jestliže vidíme červený kruh, utvoří se nám představa červeň-kruh, která se př́mo promítá do bezrozporné propozice „Zde je červený kruh.“ Tyto základní jednoduché vjemy přecházejí do epistemicky bezrozporných propozic, které se stávají základem, od něhož se prostřednictvím logických inferencí deskriptivního poznání (knowledge by description) odvozují další - zprostředkované - propozice.

Dewey zde kritizuje pozitivistické snahy spatřovat ve shlucích atomů smyslově daného (např. červeň, kruh) jednoduché strukturované propozice, jejichž pravdivost je bezprostředně zřejmá. I přechodová fáze postanalytického strukturalismu předpokládá, ,že všechny složky jsou provázány vzájemným vyplýváním (inferenci) od úrovně tzv. pozorovacích vět, které nejúžeji korespondují se smyslovým obrazem světa“ (srov. Slavík, Chrz, Štech, 2013, s. 57, zvýraznění $\mathrm{v}$ originále). ${ }^{27}$ Supervenience a izomorfismus zajišt'ují propojení od úrovně pozorovacích vět až po komplexnější úrovně. Na úrovni jednoduchých pozorovacích vět ${ }^{28}$ „dochází ke shodě v přesvědčení mezi různými subjekty ve vztahu k témuž jevu či situaci“ (tamtéž). „Mezi jednotlivými subjektivními přístupy je mnoho dílčích rozdílností, ale to nic nemění na přijaté významové shodě prokázané určitou společnou odezvou; nejprůkazněji shodou v pojmenování (,toto je stůl’...)“(tamtéž).

\footnotetext{
${ }^{27}$ Naši autoři se v této souvislosti odkazují na Peregrina, Brandoma a Quina. Přestože se Quine občas odkazoval na Deweyho a sám do analytické filozofie zavedl myšlenku ontologického relativismu (viz poznámku 7 výše), nikdy se nevzdal přesvědčení, že lidské poznání je konstruováno z jednotlivých pozorovacích vět, o jejichž pravdivosti budou rozhodovat kompetentní mluvčí stejně, budou-li vystavěni stejnému stimulu. (Jeho poslední kniha se jmenuje od Stimulu $k$ vědě - 2002.) Dominance pozorovacích vět jako východiska je zřejmá i u našich autorů.

${ }^{28}$ Někdy je používáno také pojmenování „atomární věty“, což zcela př́ihodně pojmenovává východiska pozitivismu, který je založen na epistemologickém atomismu - vychází z pozorovacích vět, jež mají údajně zachycovat ,atomy“ bezprostředních poznatkü.
} 
Další partie Tvorby (srov. např. tamtéž, s. 162-185) naznačují, že zde neexistují jasně daná pravidla, jak sestupovat z komplexní úrovně naší zkušenosti na jednoduchou úroveň a naopak. Přesto je celá argumentace v konečném součtu postavena na přesvědčení, že na nejnižší úrovni existuje bezprostřední přechod od stimulu k náležité reakci a že náležitost reakce na komplexní stimul je zajištěn logickým vyplýváním z pozorovacích vět. To by ale vedlo k absurdní představě, že jestliže se na nejjednodušší úrovni shodneme prostřednictvím jednání či propozic na tom, že např. předmět vedle nás je židle, že uvnitř nás existuje cosi jako kostra, že existuje časová jednotka, která pokrývá sto let atd., a tímto způsobem uchopíme strukturu pojmů ,židle“, „kostra“, „století“ atd., pak se prostřednictvím logického vyplývání můžeme chopit také náležité struktury např. propozice: „Vzhledem k tomu, jak se bude proměňovat lidská kostra, budou mít ve 28. století židle zcela odlišnou podobu.“

Celý problém ale nespočívá $\mathrm{v}$ představě logické inference, která prochází od úrovně pozorovacích vět ke komplexním úrovním a skládá komplexní představy. Zavádějící je už popis nejnižší úrovně. Tato úroveň nám poskytuje epistemicky triviální situace, v nichž nemusíme vynakládat sebemenší epistemickou námahu. Proto se zdá, že se percepce automaticky a bezrozporně proměňuje ve strukturovanou představu, která je hned následována stejně strukturovanou propozicí - prrítomnost židle vede bezprostředně $\mathrm{k}$ sednutí na židli či k výroku „to je židle“. Ovšem i tyto banální každodenní představy a propozice byly během ontogeneze jedince konstruovány a konstrukce rekonstituovány $\mathrm{v}$ komunikaci s účastníky společenství myslí. To, že se nám zdá, že se nám strukturovaný smyslový obsah perceptů bezprostředně „dává“ ve struktuře smyslových vjemů a že tyto obsahy jsou společně s logickou inferencí poslední a první zárukou náležitého poznání, je zapřričiněno skutečností, že jsme již zapomněli na dávné procesy konstrukce a rekonstrukce.

Přes veškerý důraz na procesualitu poznání autoři Tvorby vycházejí z několika jednoduchých přesvědčení, které si přechodová fáze přenesla z ideálního typu rané moderny:

a) Pozorovaci věty jsou základními východisky poznání - epistemickými atomy. Pro představitele přechodové fáze sice nejsou pozorovací věty jednoduše po ruce, nebot' jsou dosahovány $\mathrm{v}$ intersubjektivní shodě společenství myslí, ale jakmile projdou k bodu intersubjektivní shody, stávají se pevnými atomy, utvářejí strukturu, od níž můžeme odečítat odchylky (viz výše 1.2.2). 
b) Z těchto atomů můžeme vystavět komplexnější poznatky prostřednictvím inferenčních zákonů. Tyto zákony jsou zákony myšlení a jsou paralelní k naší zkušenosti - jsou tím, co zvnějšku (z rozumu) přistupuje ke zkušenosti a pořádá ji.

c) Jsme schopni dosáhnout komplexních znalostí v její náležité struktuře. Náležitá struktura znalosti je dána tím, že existují její neměnné atomy a předem dané inference. V přechodové fázi je tato raně moderní argumentace zakryta skutečností, že každý stupeň (a až c) je vystaven dohledu intersubjektivního vyjednávání. V tomto vyjednávání je zachycena procesualita poznání. Přesto i zde se předpokládá, že epistemicky nejbezpečnější jsou atomární stavy, které jsme bezprostředně obdrželi ve zkušenosti a ty se nám okamžitě proměňují ve strukturovanou atomární znalost vyjádřitelnou propozicí - např. „to je židle“. Právě tato bezprostřednost umožňuje intersubjektivní shodu. Zde však vězí další prasklina rané moderny, nebot' se nám svět „nedává“ v atomárních datech, ale prostřednictvím zkušenostních komplexů, které rozkládáme vždy ve vztahu k nějaké potřebě. Proto atomární fakta nejsou nikdy stejná, jejich obsah je s každou potřebou odlišný - jednou je židle něčím k sezení, podruhé je vybavením nového bytu, potřetí zbraní, jíž se bráníme útočníkovi. Pokud budeme po vzoru fenomenologů hledat invariantní jádro tohoto předmětu (židle), pak zjistíme, že toto jádro je utvářeno sítí relací, kterou je významově vpleten do žitého světa. V takovém prŕípadě je ale analogie mezi komplexní znalostí a stavbou utvořenou ze znalostních atomů nepoužitelná. A s tím se také rozpadá i představa, že je možné odlišit struktury od procesu jejich konstrukce a že je možné privilegovat strukturu před konfigurací (viz výše 1.2.2).

Pokud chceme představit skutečně alternativní pojetí poznání, které nepotřebuje znalostní atomy a znalostní struktury, pak se musíme vzdát metafyzické pozice toho, kdo zná náležitou strukturu, protože vychází ze znalostních atomů a z inferenčních zákonů. Musíme vyjít z komplexity našich životů, pojímat proces rozkladu na atomy za pouhý nástroj, jenž je vždy relativní k potřebě, která se v danou chvíli a na daném místě objeví jako vpletená do komplexity situace. A právě tyto požadavky nás vedou k Deweyho teorii poznání.

Dewey se nevzdává myšlenky korespondence, ovšem chápe ji v „operacionalistickém smyslu“. Korespondence není „údajný vztah mezi ,subjektem‘ a ,objektem‘29 , nýbrž jsou jím

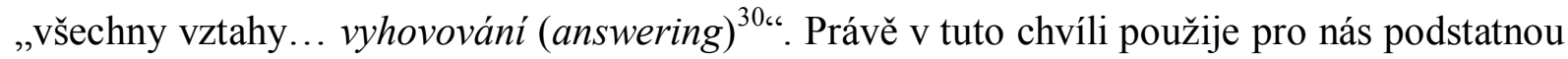

\footnotetext{
${ }^{29}$ Upozorňujeme, že slova „subjekt“ a „objekt“ Dewey dává do uvozovek.

${ }^{30}$ Nejedná se nám pouze o náležitou odpověd’ na otázku, ale skutečně o obecné vyhovování podmínkám. Jestliže náležitě odpovím na otázku, je to pouze jeden z mnoha projevů vyhovování něčeho něčemu. Abychom udrželi
} 
metaforu klíče a zámku. Odpovídání/vyhovování bychom měli pochopit podobně, jako když „klíč odpovídá/vyhovuje podmínkám vynuceným zámkem“. Nakonec toto pojetí „vyhovování/odpovídání“ zobecňuje do formulace, která nás přivádí k jádru pragmatistické teorie poznání: proces poznání je hledání „řešení, jež odpovídá požadavkům (requirements) problému“ (srov. lw.14: 179). Pojem, „řešení“ vyjadřuje klíčovou roli, jakou pro pragmatismus v procesu poznání hraje jednání. Poznání není pouhým nacházením náležité struktury, ale jednáním, které konstruuje takovou znalost, že tím řeší problém. V tomto pojetí je také převrácen vztah mezi re/konstrukcí (konfigurací) a strukturou. Pokud je v tomto procesu něco „nadčasového“, pak je to proces věčně se proměňující konfigurace. Struktura je sekundární, je pouhým nástrojem naší reflexe.

V monografii Logic: The theory of inquiry najdeme nejpodrobnější a nejucelenější představení Deweyho pragmatistické teorie poznání. Zde autor opět vysvětluje termín, který do svého pojetí zavedl již dř́ve - situace. Tento zdánlivě obyčejný pojem Dewey předefinoval tak, aby se mohl stát jedním z nejdůležitějších termínů pragmatistické ontologie a teorie poznání. Situací míní existenční kvantum ${ }^{31}$, v němž se objekty a vztahy mezi objekty nacházejí v jejich kontextuálním celku (in a contextual whole). Objekty a jejich vztahy mají až druhotný charakter - jsou výsledkem kategorizace a symbolizace. Existenčním kvantem máme na mysli, že náš život proživáme $\mathrm{v}$ časově a prostorově omezených kontextuálních celcích, které kontinuálně navazují jeden na druhý. Tyto celky jsou primární. Žádný objekt, ani událost, ani vztah se nikde neobjevují izolovaně, jsou zakoušeny v systému obklopujícího světa a tento systém se podílí na charakteristice daných objektů a událostí. ${ }^{32}$ Situace je touto sití vztahů, která je omezena určitým místem a určitým časovým rozsahem navazujících zkušeností, přičemž ona omezení zajištuje kvalita, jež je inherentní součástí situace. (Srov. lw.12: 72-73.)

tuto významovou rozkročenost originálního answering, budeme v následujících pasážích originál překládat jak „odpovídání“", tak „,vyhovování““.

${ }^{31}$ Jedná se o naše pojmenování - v Deweyho textech jej, pokud je nám známo, nenajdeme.

${ }^{32}$ Ontologický charakter situace je stále více rozeznáván i v moderní metodologii. V situační analýze se situace stala centrem výzkumu. Kolem ní se utváři množina výzkumných analytických nástrojů, které popisují její dynamický charakter. Právě detailní popis situace se stává cílem. Cílem totiž už není popis myšlení a jednání aktérů působících v situaci, nebot' ti jsou utvářeni situací, podílejí se na proměně situace a ovlivňují budoucí vliv situace na ně samotné - jsou tedy pouze jednou ze součástí situace. Situace se stává základní analytickou jednotkou (srov. Clarke, 2005). Situační analýza vznikla tím, že proměnila zakotvenou teorii důslednějším př́klonem k Chicagské sociologické škole, v níž byla situace charakterizována na základě vlastních důsledků tzn. situace je tím, jaké důsledky přináší (Thomasův teorém, in Clarke, 2005, s. 7). Chicagská škola vycházela z chicagského pragmatismu, jehož hlavní postavou byl G. H. Mead. Mead byl hlavním spolupracovníkem Deweyho před Deweyho odchodem z Chicaga. V té době Dewey i pod vlivem Meada vypracovával základy své budoucí teorie poznání - viz např. jeho pět kapitol v knize Studies in logical theory (mw.2: s. 294-384). 
Pojem kvalita je dalším významným Deweyho termínem. Situace je určena a ohraničena kvalitou, která prostupuje celou situací (odtud v originále pervasive quality prostupující kvalita). Kvalita vyjadřuje jednotu a vlastní jedinečnou charakteristiku dané situace. ${ }^{33}$ Situaci je tedy nutné odlišit od objektů, vlastností či vztahů. Dewey proto zavádí pojem téma (subject-matter), ${ }^{34}$ kterým pokrývá 1) jednotící prvek situace, který je 2) nadán možností různých způsobů specifikací podle okolností a proměn dané situace. Téma určuje situaci svojí jednotící kvalitou, obsahuje tak v sobě jednotící princip, ale zároveň může být artikulováno mnoha způsoby. Zradí-li artikulace vnitřní princip jednoty tématu, artikuluje se téma jiné, a nejedná se tak o artikulaci původní situace. A jestliže je situace artikulována nesprávně, vede to $\mathrm{k}$ existenčnímu neúspěchu - např. $\mathrm{k}$ selhání $\mathrm{v}$ řešení problému, $\mathrm{k}$ tomu, že není dosaženo cíle.

„Pojmem situace je míněn fakt, že téma, $\mathrm{k}$ němuž je odkazováno v existenčních propozicích ${ }^{35}$, je komplexem existence, která přes svoji vnitřní složitost drží pohromadě díky tomu, že je zcela ovládána a charakterizována jednou kvalitou. „Objektem“ je míněn nějaký element onoho kontextuálního celku, který je definován tím, že je abstrahován z daného celku na základě nějaké jeho výrazné vlastnosti. Je zde nutné zmínit následující: selektivní výběr objektů a vztahů mezi nimi, k němuž dochází v procesu myšlení, je kontrolován odkazem na situaci, na to, co je v ní konstituováno prostupující a vnitřně integrující kvalitou. Jestliže nejsme schopni situaci náležitě ohodnotit, pak nakonec necháváme logickou sílu objektů a jejich vztahů nevysvětlenou.“

(lw.5: 246)

Zmínka o logické síle objektů a jejich vztahů je zde klíčová. Náležité ohodnocení situace, vede ke skutečnosti, že její téma je artikulováno v souladu s vnitřním pořádajícím principem. Náležité ohodnocení kvality, která svojí jednotou integruje komplexní situaci, a činí tak situaci rozumem uchopitelnou, je zdrojem veškeré epistemické závaznosti. Logická inference nepřistupuje k objektům zvenčí, není formálním, od existence odděleným nástrojem „ř́ádného“ myšlení. Je součástí situace a podílí se na vyčleňování objektů a jejich vztahů z kontextuálního celku. Vyčleňování objektů a vztahů a logické inference jsou jedním

\footnotetext{
33 Dewey pojmu prostupující kvality věnoval mnoho textů, z nichž patrně nejvýznamnější jsou Qualitative thought (lw.5: 243-262) a Theory of valuation (lw.13: 189-251).

${ }^{34}$ Je velice složité překládat Deweyho odborný termín „subject-matter“. Doslovný překlad by zněl „podstata“ a mohla by tím být míněna podstata nějakého problému či události nebo věci. U Deweyho však znamená existenční substrát zkušenosti, který je nadán proměnou ve strukturovanou znalost. Tento substrát má ovšem již předem sobě vlastni kvalitu, která zevnitř ř́dí náležitost své proměny ve znalost. Volíme proto český termín téma. Pojem „téma“ v sobě zahrnuje jak ideu jednotícího principu, tak i skutečnost, že téma může být vyjádřeno mnoha způsoby, tak jak je tomu např́klad v tématu hudební skladby či tématu románu atp.

${ }^{35}$ Existenčními propozicemi má Dewey na mysli ta tvrzení, která vypovídají o prožívané zkušenosti, vyjadřují kvalitu situace a mají rozhodující vliv na podobu života, řešení problémů. Vztah ke zkušenosti, k existenci, která se odhaluje ve zkušenosti, je u nich podstatný.
} 
kontinuem artikulace situace, které vychází z ohodnocení kvality. Jestliže jsme situaci (její kvalitu) neohodnotili náležitě, pak selháváme, jak ve vyčleňování náležitých objektů, tak v aplikaci logických vztahů. Ohodnocení je proto prvním stadiem jakéhokoli kognitivního aktu.

Kvalita je prožívána prostřednictvím intuice (pocitu či tušení). Je zde ale třeba okamžitě zdůraznit, že zdrojem této intuice není poznávající osoba, nýbrž situace ve svém kontextuálním celku, jehož je poznávající pouze jednou z mnoha součástí. Konzistentnost či nekonzistentnost dosavadního jednání s charakterem situace je tím, co se promítá do intuice, která se projevuje v jedinci a skrze jedince - jedinec ale není zdrojem intuice. Dewey proto souhlasí s Bergsonem, že „intuice předchází pochopení (conception) a jde hlouběji“, a dodává, že „reflexe a racionální rozvinutí vychází z intuice a činí intuici explicitní“ (lw.5: 249).

Na mnoha místech svých textů napsaných v první polovině 20. století Dewey píše, že zatím neznáme „fyziologické procesy“, které rozhodují o uchopování kvality situace pocitem či intuicí, natolik, abychom věděli, jak fungují. Dnešní výzkumy v neurobiologii a fyziologii, stejně tak jako v kognitivních vědách nám dávají nahlédnout, jak se komplexita takové intuice utváŕí v tisíci a tisíci neuronálních a fyziologických procesech, které probíhají a musí probíhat na nevědomé úrovni a do vědomí se dostávají jako převládající pocit, který uchopuje situaci vcelku a vede člověka v jeho jednání. Abychom náležitě pochopili, že deweyovské pojmy téma a kvalita nejsou projevem pseudofilozofického, „nevědeckého“ diskurzu, musíme si nyní přiblížit mechanismy, které utvářejí kvalitu a její téma (intuitivní uchopení). Toto přiblížení je centrální nejen pro pragmatistické pojetí poznání a znalosti, ale také pro pochopení role figurativního jazyka a především metafory (chápanou v širokém slova smyslu - k tomu viz níže), jež toto intuitivní uchopení celku „překládá“ do lidského diskurzu a umožňuje nejen nastartování poznávacího procesu, ale také mezilidské sdílení jak intuice, tak procesu poznání.

Na komplexitu lidského poznání narazila i klasická fenomenologie, když hodnotila pozitivistická východiska. Husserl začal svoji kritiku pozitivismu tím, že se pokoušel být „rigoróznější než sami pozitivisté“. Uvědomil si, že svět je nám dán pouze prostřednictvím našeho vědomí. Proto zavádí přístup, který později nazývá princip principů: V našem poznání musíme vycházet pouze z toho, jak se nám věci dávají „,originárně“ - tedy v našem vědomí (srov. Husserl, 2006a, § 24, s. 56 / 1983, § 24, s. 44). Aby tento obrat metodologicky ošetřil, 
zavádí fenomenologickou redukci. Fenomenologickou redukcí se metodologicky „odstřiháváme“ od světa kolem nás a necháváme „promlouvat“ věci pouze tak, jak se nám dávají ve vědomí. Husserl tím naráží na téma, které nakonec fenomenologii přivede zcela mimo rámec raně moderní epistemologie. To, co se nám po fenomenologické redukci takto dává, nemá ani fyzickou, ani psychickou podstatu (srov. Bernet, Kern, \& Marbach, 2004, s. 69-72). Postupně se nám před očima boří představa, na níž byla vystavena epistemologie rané moderny - východiskem nám již nemohou být zjednodušující dichotomie: vně x uvnitř, fyzické x psychické, tělo x mysl. Věci se nám ve vědomí dávají takovým způsobem, že teprve v reflexi a vždy jen v určitém kontextu jsme schopni odlišit vnitřní a vnější prostor, fyzické a psychické děje, tělo a mysl. Fenomenologická redukce boří naše nejvlastnější jistoty, a tato dekonstrukce nás přivádí k nepř́jemným otázkám. Cožpak není zcela zjevné, že něco je uvnitř a něco mimo nás? Že předmět před námi má fyzikální vlastnosti, zatímco jeho představa v naší hlavě je psychický komplex?

Současné kognitivní vědy se od kognitivních věd padesátých až osmdesátých let 20. století liší ve svých východiscích natolik, že byly obdařeny př́ídomkem „druhá generace“. Vědy první generace modelovaly lidské poznání na karteziánských východiscích a měly za to, že lidský mozek je možné chápat jako hardware a mysl jako software počítače. Z toho mimo jiné vyplývala představa, že myšlení je procesováním informací (srov. Johnson, 2008, s. 120). Takto v podstatě jen zmodernizovaly descartovskou představu existence vnitřního prostoru poznávajícího subjektu a vnějšího prostoru, kde se nacházejí a působí objekty poznání. Druhá generace však začala ve svých výzkumech narážet na skutečnosti, které je donutily zcela proměnit tento zakládající obrázek. Objev a výzkum zrcadlových neuronů (viz Rizzolatti \& Sinigaglia, 2008; Iacoboni, 2008) či současný výzkum fyziologie, funkce a důsledků emocí (Damasio, 1996, 1994, 2010) nebo koordinace senzomotorického jednání v jednotlivých oblastech mozku, které vedou k plasticitě mozkové aktivity a ke vzniku komplexních vzorů koordinovaného jednání vyšších organismů (srov. Johnson, 2008, s. 117-134) dokládají, že odlišení toho, co je vně a uvnitř těla poznávajícího, je zcela matoucí.

Například zrcadlové neurony $(\mathrm{ZN})$, nacházející se v našem mozku ve specifických oblastech, interpretují jednání druhého člověka již ve chvíli, kdy si ani my, ani onen druhý neuvědomujeme, že něco vnímáme, natož interpretujeme. Jestliže se objeví vědomá interpretace, pak s velmi podstatným zpožděním a pouze díky tomu, že vědomí má již ,,po ruce“ výsledky interpretací, které předpřipravily zrcadlové neurony a další předvědomé 
kognitivní procesy. Komplex funkcí zrcadlových neuronů v nás dokonce dokáže simulovat prožívání druhého způsobem, jako by onen druhý byl skutečně v nás. To, co nás od něho odděluje, jsou pouze informace z receptorů na naší kůži (srov. Ramachandran, 2013, 0:05:000:06:30). To, že jsme schopni koordinovat naše gestické jednání tak, aby došlo ke komunikaci, že jsme schopni komunikaci dovést až k jazykovému vyjádření, že jsme schopni se vcítit do komplexní situace druhého, je dáno tím, že v nás druzí v jistém smyslu sídlí (Iacoboni, 2008, s. 47-157).

Nejedná se o žádnou mystickou poučku. Druzí sídlí v nás díky specifickým funkcím našich neuronů (v obecné rovině: díky specifickým funkcím našeho těla-mysli ${ }^{36}$ ), které se do své specifické podoby strukturovaly během fylogenetického vývoje života obecně a člověka jako druhu zvlášt'. Reakce druhých lidí jsou v nás komprimovány a uloženy ve funkcích naší neuronální sítě (na obecné rovině: ve funkcích našeho těla-mysli).

K podobnému nás vede výzkum primárních a sekundárních emocí. Damasio odlišuje emoce od pocitů. Pocity jsou zpětnou vazbou emociální reakce - jsou tím, co cítíme, co si uvědomujeme. Emoce samotné jsou evolucí předpřipravené moduly jednání, které proběhnou okamžitě, jakmile př́ślušné mozkové oblasti vyhodnotí situaci (srov. Damasio, 2006, s. 131134). Napřr. uskočíme, zpětná vazba tohoto pohybu je nepříjemný pocit, který nás vede k průzkumu situace, díky němuž zjistíme, že se před námi klikatí had. Tento příklad se týká primárních emocí, emocí řízených limbickým systémem. Už na této úrovni jsou odlišení vně vs. uvnitř či fyzické vs. psychické znejistěno. Díky evoluci jsou ve funkcích našeho mozku svinuty výsledky úspěšných interakcí mezi vnitřním a vnějším prostředím organismu jako druhu. Tak tyto interakce do nás vtělesnily stavy situací, v nichž organismus ve své evoluční historii interagoval.

Na základě těchto výsledků se postupně formovaly emoce - tedy ona předpřipravená nevědomá a předvědomá jednání. Odlišení psychického od fyzického dění je pouze schematickým zjednodušením. Obě dění přecházejí jedno v druhé na mnoha úrovních fyzické vzruchy se proměňují na fyziologické reakce, které vyvolávají specifické psychické

\footnotetext{
${ }^{36}$ Současné kognitivní vědy vycházejí z toho, že entity „mysl“ a „tělo“ je vhodné vnímat jako jeden komplex, který byl $\mathrm{v}$ 17. století $\mathrm{z}$ historických důvodů rozštěpen ( $\mathrm{k}$ některým $\mathrm{z}$ důvodů viz začátek části 1.2.1 výše). Komplex reaguje $\mathrm{s}$ vnějším okolím a změny, jež se v něm šiří zasahují jak fyzickou, tak psychickou stránku současně. Žádná změna není pouze psychická či pouze fyzická. V moderní době najdeme úvahy o bytostném propojení mezi tělem a myslí v díle Johna Deweyho, který komplexitu nazývá body-mind (srov. lw.1: 199-225). Dewey byl inspirován výsledky vývojové psychologie a fyziologie dvacátých a třicátých let 20. století. Současná filozofická reflexe nejnovějších výsledků kognitivních věd přejímá tuto komplexitu jako podstatnou odpověd’ na kartezianismus předešlé fáze kognitivní vědy, tzv. první generace. K první a druhé generaci kognitivních věd viz poznámku 3.
} 
stavy, které se následně opět proměňují v neurofyziologické vzruchy, jež jsou koordinovány mimo jiné i postupným vznikem vědomého prožívání. Jedno prostupuje v druhé v organickém okruhu zakoušení a jednání. Jednoduché odlišení jednoho a druhého je simplifikace a schematizace faktického fungování organismu.

Ještě složitější je to se sekundárními emocemi, které vznikají tím, že na emoce primární nasedají komplikovanější struktury předpřipraveného jednání. Jedná se o emoce vyvolané kombinací přirozených reakcí a sociálního, institucionálního působení. Tyto emoce vznikají sice v limbickém systému, ale procházejí mozkem až k předním lalokům, kde se vyhodnocují minulé zkušenosti, jejich dopady a takto vyhodnocené situace se promítají do zautomatizování jistých reakcí. Donucovací prostředky státu, disciplinace uvnitř nějaké organizace, způsob edukace ve škole atd. vstupují prostřednictvím sekundárních emocí přímo do hlav jedinců a i tímto způsobem je opět znejistěna hranice mezi vnějším a vnitřním prostorem. ${ }^{37}$ Respektive je to proces, který fakticky nikdy takovou hranici neumožnil ustálit. Tato hranice se ukazuje být epistemologickou fikcí moderny, kterou si zjednodušila přechod od scholastického aristotelismu k mechanicismu moderní vědy.

Ve výčtu neuro-fyziologicko-hormonálních procesů můžeme jít ještě dále. Na př́íklad můžeme mluvit o tom, jak je organismus bytostně svázán s vnějšími situacemi, jimiž procházel a jež řešil v průběhu svého fylogenetického vývoje, a jak se výsledky tohoto procesu zapisovaly a zapisují do evolučního kódu, prostřednictvím kterého můžeme současné situace smysluplně prožívat a smysluplně v nich jednat, odhalovat v nich somatizované, vtělesněné významy (srov. Johnson, 2008, s. 66-68). K podrobnostem týkajícím se neurobiologie a lidské kognice se vrátíme níže, až budeme charakterizovat metaforu jako nástroj prosazování života (1.2.4).

Soudobá literatura o mysli, poznání a jejich založení v tělesnosti poznávajícího organismu, jejichž část jsme právě představili, v podstatě vysvětluje, jak je jednající a poznávající organismus skrze své tělo existenčně propojen se svým okolím, a jak proto s tímto okolím tvoří nedělitelnou jednotu. Všechny výše zmíněné procesy (zrcadlení neuronů, emoce, koordinace a formování senzomotorických informací ve smysluplné jednání atp.) jsou procesy, které se vtělesněňuji do fyzické konstituce organismu, které se do organismu zapisují. Nejvýznamnější z těchto zápisů se přenášejí prostřednictvím DNA či kultury (v

\footnotetext{
${ }^{37}$ Mimochodem tak můžeme vysvětlit ztrátu nebo nabývání vnitřní motivace žáků a studentů a také to, jak změna režimu výuky i samotného uspořádání tř́́dy může výrazně proměnit charakter motivace a nabývání znalostí.
} 
rámci procesů socializace a edukace). Tím specifickým způsobem vztahují organismus $k$ jeho prostředí a naopak prostředi $k$ organismu. Toto vztažení se promítá do specifických forem poznávání: ${ }^{38}$ Člověk má ruku, aby uchopoval věci, přinášel si je k ústům či je vrhal, vytvářel si prostřednictvím ní nástroje a artefakty, vyjadřoval svoje poznatky a emoce gesty, objímal atd. Člověk má ústa, aby přijímal potravu, artikuloval zvuky, vyjadřoval myšlenky a emoce, líbal partnera. Člověk má mozek, aby skenoval vnitřní a vnější prostředí, koordinoval nevědomé reakce, utvářel ekvilibrium mezi vnějším a vnitřním prostředím, spouštěl a vypínal hormonální systém, dosahoval vědomí. Neplatí zde ale jednoduchá jednosměrná kauzalita, mohli bychom také říct, že aby člověk mohl uchopovat, vrhat, vyrábět, hladit, vytvořila se mu v průběhu fylogeneze ruka, aby mohl jíst, mluvit, zpívat, líbat, utvořila se mu ústa, aby mohl koordinovat miliony vzruchů a informací, dosahovat přiměřených re/akcí, být si vědom a vědomě myslet, utvořil se mu mozek. Ještě přesněji vyjádřeno: ruka a její funkce (ústa a jejich funkce, mozek a jeho funkce) se ve fylogenetickém vývoji utvářely postupně a recipročně a vždy ještě v napětí a ve vztazích k dalším částem lidského těla a vnějšího prostředí.

S uvědoměním této sítové kauzality a vzájemné prostupnosti a ovlivňování se postupně prosazuje teorie dynamických systémů (srov. např. Thelen \& Smith, 1994; Rockwell, 2005; Clark, 2001, s. 120-139), která pochází z kybernetiky a v teorii poznání byla původně brána jako jedna $\mathrm{z}$ alternativních teorií. V kontextu kognitivních věd druhé generace ji však můžeme v oboru kognice živých organismů považovat za zastřešující teorii. Ta integruje několik původně velmi odvážných, dnes stále více přijímaných dílčích teorií - affordance theory (teorie afordancí), extended mind theory (teorie rozširřené mysli), embodied mind theory (teorie vtělesněné mysli), enacted mind theory (teorii enaktivní či zjednané mysli), ecological self theory (teorie ekologického já) atd. Jejich společným jmenovatelem je bytostné neoddělitelné fylogenetické a kulturní propojení organismu a prostředí - v anglické literatuře nazývané organism-environement coupling (srov. Johnson, 2008, s. 50-51, 117, 276). ${ }^{39}$ Bytostná jednota je založena na hloubkové interakci všech vstupů, které do ní vcházejí jak ze strany organismu, tak ze strany prostředí. Jednotlivé procesy, na kterých zmíněné dílčí teorie

\footnotetext{
${ }^{38}$ Zde je nutné dodat, že v pozdně moderním pojetí poznání centrem veškeré kognitivní aktivity je jednání organismu (člověka) - proto mluvíme o kognitivních aktivitách. Když tedy budeme následně psát o ruce a jejích funkcích, o ústech a jejich funkcích atd., pak proto, že právě tyto funkce utvářejí formy, skrze které člověk může poznávat. To úzce souvisí s teorií afordancí, jež je však jen jedním z projevů bytostného provázání organismu a prostředí ( $\mathrm{k}$ tomu viz také následující poznámku).

${ }^{39} \mathrm{~V}$ dosud nepublikovaném textu jsme organism-environment coupling překládali jako bytostná souhra organismu a prostředí. V této tradici zde budeme pokračovat. Slovem „bytostná“ jsme chtěli podpořit existenciální podklad tohoto vztahu, který se váže na komplexní charakter situací a jejich témat a který nelze $\mathrm{v}$ českém kontextu jednoduše vyjádřit.
} 
vystavěly svoji teoretickou bázi a přesvědčivost: vtělesnění (embodying), rozšiřrení (extention), vnoření (embedding), zjednání či ustavení (enacting) - vnímáme pouze jako různá vyjádření hlubšiho společného jmenovatele, jako perspektivní nahližení dynamické jednoty mezi organismem a prostředím.

Pro tuto chvíli si shrňme podstatné. Striktní odlišení mezi vnitřním a vnějším prostorem, mezi fyzickými a psychickými ději a mezi poznávajícím subjektem a poznávaným objektem není nic přirozeného a samozřejmého. Jedná se o myšlenkovou konstrukci rané moderny. Tato představa se složitě utvářela v přechodové fázi od pozdního středověku do ustálení raně moderního řádu myšlení a $\mathrm{v}$ této relativně nahodilé př̀edstavě jsme byli socializováni $\mathrm{a}$ vychováváni. Ona představa se dvě stě let formovala (16. až 18. století) a stejně tak se od počátku 19. století postupně proměňuje a rozpadá. ${ }^{40}$

Sám Husserl ke konci svého života stále více docházel k tomu, že i transcendentální rovina má svoje dějiny (srov. Husserl, 1968, s. 75). Tyto dějiny jsme právě spojili s vtělesněním, rozšířením a ustavením (viz výše předešlé odstavce). Transcendentální rovina měla původně přesahovat jakoukoli empirickou zkušenost a předem (transcendentálně) ji formovat tím, že jim měla přikládat význam. Transcendentální rovina měla být korekcí naivity, jež se projevovala $\mathrm{v}$ pozitivistické víře ve významovou samodanost smyslových vjemů. Dějinnost a materialita této transcendentální roviny však nakonec překročily původní Husserlova descartovsko-kantovská východiska (srov. např. Patočka, 2003, s. 53-101). Husserl však neučinil onen krok, ke kterému se uchýlila pozdní fenomenologie, jež nakonec opustila primát vědomí, aniž by opustila projekt zjevování významu. Již nepotřebovala, aby její pozici ve vztahu k pozitivismu metodologicky chránila fenomenologická redukce, protože si všimla role, jakou hraje tělo pro zprostř̌edkovávání „transcendentálních“ významů (srov. Merleau-Ponty, 2004, 2013). ${ }^{41}$

Barbaras, který přímo navazuje na Merleau-Pontyho, mluví o „fenomenologickém poli“, v němž se předměty okolního světa jeví, přičemž vnímající subjekt ${ }^{42}$ není absolutním,

\footnotetext{
${ }^{40}$ Srov. naše poznámky k metodologii této kapitoly v části 1.1 výše.

${ }^{41} \mathrm{~K}$ tomu, jak Merleau-Ponty navázal na Husserla a jak se zároveň vymezil vưči vědomí jako východisku, viz 2010. Někteří autoři mluví o radikalizaci transcendentální redukce tím, že ji začínají důsledně hledat v těle a v tělesném jednání, což vede $\mathrm{k}$ tomu, že se transcendentální rovina prochází kontinuální proměnou, aniž by ztratila svoji roli předem dané struktury smyslu (srov. např. Barbaras, 2005, s. 30-83).

42 Přestože se odůvodněně snažíme v této kapitole vyhnout slovu ,subjekt“, zde jej zachováváme, protože je součástí fenomenologické tradice. Nicméně i samotné dílo Barbarase, stejně jako Patočky je snahou vymknout se subjekt-objektovému způsobu myšlení. Následující výklad, v němž je vnímající subjekt rozpoznán jako výsledek konstituce fenomenologického pole a zároveň jako přesažený a určený dějinami vlastního druhu a
} 
karteziánským - od světa odděleným - subjektem, ale konstitutivní komponentou fenomenality, tedy jevení se světa (srov. 2005, s. 109-111). Při průzkumu toho, jak jsou subjekt a vnímaný svět konstituovány ve vztahu ke konstituci fenomenálního pole, Barbaras překračuje Merleau-Pontyho a nechává se inspirovat Patočkou. Všímá si role, jakou v konstituci perceptivního aktu, jenž je spolupodmínkou jevení, hraje tělo a jeho motorický moment. Motorika má však své dějiny - dějiny živoucího pohybu. Patočka mluvil o „fundamentálním pohybu“, který je souhrnem modalit všech pohybů subjektu. Tento fundamentální pohyb Barbaras nazývá touha a spojuje jej se životem jako obecným projevem živých bytostí (srov. Barbaras, 2005, s. 143-146). Obrací se ke genetické fenomenologii, která zkoumá to, jak se utváří transcendentální rovina - zkoumá její výše zmíněné dějiny, a dospívá k přesvědčení, že „sám smysl transcendentálna implikuje jeho vepsání do empiričnosti v podobě života“ (srov. tamtéž, s. 150-151). Není proto překvapením, že Barbaras následně rozebírá texty „gestaltových“ neurologů (K. Goldstein, V. von Weizsäcker, E. Straus), jež se z hlediska výzkumu stavby a funkcí organismu věnují té samé sounáležitosti mezi organismem a prostředím, která se z perspektivy fenomenologie jeví jako fenomenální pole konstituované životem jednajícím ve světě. Zmínění neurologové si všímají zvláštního vztahu mezi organismem jako individuem a prostředím: „... ono oddělení [živého organismu] od původní totality, v níž spočívá jeho nejhlubší bytí, je ve skutečnosti korelátem jeho individuality, tj. jeho existence jako živé bytosti, a $\mathrm{z}$ toho důvodu je principiálně nepřekročitelné“ (tamtéž, s. 158). Barbaras při promýšlení pohybu života dochází až ke kosmologii, v níž ,původní pohyb, jímž svět vystupuje ze sebe sama, se uskutečňuje jako život“" (tamtéž, s. 174), který se na úrovni života jedince odehrává v neustálém hledání formy rovnováhy s vnějším prostředím. Rovnováhy však nemůže být nikdy dosaženo dlouhodobě, protože oddělení je principem života organismů.

Shrňme si některé právě naznačené rysy pozdní fenomenologie. Jevení a intencionální vztah je projevem původnější dynamické jednoty, která překračuje jedince jak ve směru historie jeho druhu (např. člověka jako druhu), tak překračuje jakýkoli druh ve směru k celku života. Zmíněná jednota je utvářena také ve vztahu ke světu, v němž jedinec jedná a jejž poznává. Princip jevení je postaven na tělesném jednání. To, že máme tělo a to tělo je v prostř̌edí nějak situované a nějak se v něm může pohybovat, je podmínkou skutečnosti, že vnímáme a jakým způsobem vnímáme. Vědomí je umožňováno nevědomými procesy našeho

dějinami života obecně, ukazuje, že slovo „subjekt“ hraje v pozdní fenomenologii zcela odlišnou roli od té, jakou hraje v rané moderně. 
těla. Vědomí je vrcholem individuace, ale zároveň něčím, co každého jedince odděluje od totality světa. Osudem jak člověka, tak každé bytosti je, že jeho život je neustálým hledáním rovnováhy, která je okamžitě po jejím dosažení narušována. Tento princip se umocňuje vědomím, jež na jednu stranu poskytuje sobě vlastní prostředky hledání rovnováhy, na stranu druhou ale tíhne k fixaci životního pohybu do neměnných forem, skrze které myslí. Proto je vědomí neustále rozvracováno životem, nevědomím. Hledáním rovnováhy organismus dosahuje poznání. Organismus je záznam života, vepisují se do něho dějiny dosahování rovnováhy jeho druhu i života obecně, vepisuje se do něho historie dosažených znalostí. Do těla organismu se vtělesňují ona dosažení a stávají se specifickými funkcemi těla, pomocí kterých organismus ve světě jedná a díky specifickému jednání vnímá svět. Díky jednání a vnímání organismus prodlužuje život. Dějiny dosahování rovnováhy jsou transcendentální rovinou, která orientuje organismus, přikládá smysl jeho jednání. Transcendentální rovina sídlí v těle organismu a je ve svém původu empirická. Z pohledu jednotlivého organismu je však transcendentální - umožňuje organismu se orientovat v empirickém světě tím, že ho v jeho jednání vede tak, aby jednal smysluplně. Ovšem z hlediska celku života a z hlediska druhu spočívá původ této roviny v empirických dějinách dosahování rovnováhy.

Když tyto myšlenky vysvlékneme ze specifického fenomenologického jazyka, zjistíme, že se pozdní fenomenologie překvapivě potkává s výsledky výzkumů v neurobiologii, fyziologii a v kognitivních vědách. Kognitivní nevědomé (cognitive unconscious) ${ }^{43}$ nám umožňuje racionálně jednat již na nevědomé úrovni. Jednotlivé funkce vtělesněné do podoby těla-mysli a do způsobů, jak tělo-mysl daného druhu může reagovat $\mathrm{v}$ daných prostředích, je přesně onou transcendentální/empirickou rovinou. Zde si pohled zevnitř organismu (fenomenologie) a pohled zvnějšku na fungování organismu (neurobiologie, neurofyziologie, kognitivní vědy) podávají ruku. (K neurobiologii a kognitivním vědám se v našem výkladu ještě vrátíme, protože její současné výsledky nám poskytují možnost rozvinout pragmatistické pojetí znalosti - a tacitní znalosti - a protože nám pomohou doložit, že jazyk i metafora vyvěrají z této roviny vtělesněných funkcí.) Na pozdní fenomenologii můžeme také pozorovat výrazné sblížení fenomenologie s pragmatismem a jeho teorií poznání. Ve fenomenologii i v jeho pojetí fenomenologického pole se setkáváme s důrazem na bytostnou propojenost jedince

\footnotetext{
${ }^{43}$ Lakoff a Johnson (1999) na základě metaanalýzy výzkumů odhadují, že poměr mezi „kognitivním nevědomým" (cognitive unconscious) a kognitivním vědomím by mohlo být až $95 \%: 5$ \% (srov. 1999, 21-26). Nejde nám zde o přesné číslo poměru, ale pouze o upozornění na množství nevědomých, ale již racionálních procesů a na s tím související význam, který jim musíme v pozdně moderním pojetí poznání přisoudit.
} 
a prostředí a s kontinuitou života jedince s dějinami života obecně. Jestliže budeme níže definovat znalost jako sjednocení znalostního pole, pak jen na všeobecnější úrovni pragmatistické teorie poznání opakujeme to, co pozdní fenomenologie nalezla při analýze intencionality a fenomenologického pole. Jestliže jsme $v$ jiném textu ve vztahu k fenomenologické kritice pozitivismu mluvili o vyjevující se struktuře smyslu, která je zdrojem dosahování znalosti, ${ }^{44}$ pak jsme jen jiným jazykem vyjadřovali to, co měl na mysli Dewey, když poznání charakterizoval jako primárně určené kvalitou situace. Tato kvalita je jednotící strukturou smyslu, kterou poznávající organismus uchopuje a komunikuje skrze své tělo a jeho funkce. ${ }^{45}$

Celé naše předešlé snažení můžeme nyní poučeně zakončit charakteristikou tohoto, čím je intuice a jaké místo v kognitivním jednání sehrává. Intuice je jednotícím vyjádřením materiálně-fyziologicko-psychologického komplexu interakci organismu a jeho prostředí, $v$ němž je uchopena celistvost situace. Toto uchopení je první fází kognitivní aktivity, díky které se všechny její následující fáze mohou teprve následně rozvinout.

Zde se nacházíme v samotném centru alternativní teorie poznání. V pragmatismu se vychází z komplexity prožívání. Tato komplexnost ale není nediferencovaná jednota všeho bytí (jako v některých verzích idealismu), ale je tvořena na sebe navazujícími situacemi. Situace přecházejí jedna $\mathrm{v}$ druhou, jedna situace se stává následně poznatkovou bází pro artikulaci situací př́ístích (organismus se nachází v nějaké situaci, do ní se dostal z jiné situace a její vyřešení či selhání jej posune do další situace). Každé další zpřesňování situace prostřednictvím myšlenkového procesu, $v$ němž ji rozčleníme na objekty a na vztahy mezi těmito objekty, je vždy abstrakcí, která zohledňuje určité rysy situace podle potřeby. Potřeba ale není subjektivní, nevychází z poznávajícího, byt' se v první fázi projevuje jako intuice či pocit uvnitř jedince. Intuice je projevem určující kvality, nejedná se primárně o psychický či psychologický fakt (srov. lw.5: 248). Kvalita situace sjednocuje statisíce fyziologickopsychických procesů, jejichž úkolem je utvářet rovnováhu mezi organismem a jeho prostředím a jež jsou nevědomým či předvědomým racionálním podložím jakéhokoli vědomého stavu či aktu.

\footnotetext{
${ }^{44}$ Srov. Šíp, 2015, s. 684-692.

${ }^{45}$ Naši verzi sblížení a kombinace pragmatismu a fenomenologie jsme rozvinuli nezávisle na podobných cestách, které byly s jinými důrazy učiněny dříve a zastř̌ešeny pojmem postfenomenologie (srov. Ihde, 2012; Selinger, 2006). Tuto tradici jsme poznali až poté, co byla napsána základní verze této kapitoly. Že však jdeme správnou cestou, nám již v té době naznačovaly texty Rockwella (2005) či Dreyfuse a Wrathalla (2006, především s. 289-599).
} 
Na rozdíl od teorií ovlivněné více či méně ranou modernou, které mají tendenci pojímat poznání jako skládání atomárních poznatků do větších celků, a tak se dostávat ke komplexním znalostem, pragmatismus vychází z komplexity situace a všechny své schematizace, abstrakce a artikulace měří daným tématem situace. Pracuje sice s objekty poznání, ale vnímá je přesně tak, jak by je měla vnímat moderní věda - jako naše nástroje $\mathrm{k}$ dosahování jistých cílů. Poznatky uspořádané do propozičních inferencí nejsou samy o sobě znalostí, nebot' jsou vždy jistou schematizací. Znalostí je komplexní dynamická struktura (o tom níže).

Jestliže přijmeme komplexitu zkušenosti jako epistemické i epistemologické východisko, pak nás tato pozice osvobozuje od tendence raně moderního poznání, kterou bychom s trochou nadsázky mohli nazvat ,ppankognitivismem“. Smyslem poznání není poznat vše, vše prostoupit naším vědomím a kognitivním uchopením. Smyslem poznání je prodlužovat a zkvalitňovat život. Proto v tomto pragmatisticko-fenomenologickém rámci myšlení nejde o to, abychom vše vědomě uchopili v poznatku. Uvědomění a artikulace je nutná teprve tam, kde narážíme na nějakou nesnáz. Pokud procházíme situací bez problémů, pak ji máme natolik zvnitřněnou a natolik ji ovládáme našimi mentálními modely, že ji nemusíme blíže reflektovat. Pokud ovšem v určité situaci pocit’ujeme nesnáz, v ten okamžik začneme situaci prožívat jako neurčitou, nejasnou a ohrožující. Cítíme nesnáz, ale zpočátku nevíme, jak se jí zbavit. Pocit’ování nesnáze je součástí intuice, která vyjadřuje kvalitu situace. Nesnáz nás vyzývá k řešení a poznání je jednáním, jež na tuto nesnáz odpovídá - zda úspěšně či neúspěšně bude zhodnoceno podle toho, jestli problém, který vězel v srdci situace, byl vyřešen. „Poznání je kontrolovaná nebo směřovaná transformace neurčité situace do určité podoby, v níž jsou prvky původní situace určeny prostřednictvím konstituujících rozdílů a vztahů takovým způsobem, že jsou proměněny ve sjednocený celek“ (lw.12: 108, zvýraznění přidáno). Dosahování znalosti tak vede od komplexity situace, přes její artikulaci do podoby, $v$ níž jsme $\mathrm{s}$ to řešit nastalý problém. Toto řešení však vede $\mathrm{k}$ opětnému sjednocení - ke komplexitě s novou kvalitou. O tom, co fakticky znamená ono sjednocení, se zmíníme o několik odstavců níže. Zde učiníme ještě další poznámku k charakteristice situace a jejímu využití ve výzkumu v prostředí pedagogiky.

Definice situace a důsledky, které z ní vyplývají, jsou významné i pro naše pojetí tzv. neočekávaných situací. To jsou totiž přesně ony situace, v níž se přirozený průchod zastaví, situace se ukáže být nedostatečně ovládnutá našimi mentálními modely a naše dosavadní zkušenost se stř̌etává s realitou. Kvalita prostupující a ohraničující situaci nás mate. Cítíme, že 
se nemůžeme „pohnout“ dále. Objevil se epistemický střet, který vzniká s tím, jak se prostupující kvalita situace proměnila v kvalitu jinou. Jedna situace se specifickou kvalitou se prolomila do situace následující. Změna kvality vede ke změně pocitu, jenž náhle není v souladu s tím, jak jsme si situaci artikulovali před okamžikem a s plány, který jsme s tím vědomě či podvědomě spojovali. Často nejsme s potřebnou hbitostí schopni analyzovat změnu, proto se původní pocit a z něho vycházející artikulace dostává do rozporu s pocitem, který je nyní ve hře. Narážíme na neočekávanou situaci.

V těchto chvílích musíme akcelerovat proměnu našich mentálních modelů, které nám slouží k orientaci v našem jednání. K tomu ale potřebujeme situaci analyzovat, schematizovat a pochopit ty vztahy, jež jsme $\mathrm{v}$ předcházejících modelech nereflektovali. Právě tento epistemický střet je místem, kde se tacitní znalosti začínají významně projevovat, a jsou proto $\mathrm{v}$ této fázi snáze detekovatelné. Je tomu tak z toho důvodu, že TZ jsou založeny na sítové kauzalitě. Tento sítový charakter na jednu stranu činí TZ hůře uvědomitelné a artikulovatelné. Tím jak jsou TZ vnořeny do mnoha vztahů, není jednoduché je vědomě uchopit a snadno artikulovat. Jakékoli uchopení je vždy určitým schématem, zjednodušením. Na straně druhé dokáží lépe reagovat na komplexitu situace, na pocitové hodnocení dané situace, jež je počátkem poznávacího procesu. To je důvodem, proč se začnou v neočekávané situaci projevovat více a jsou zjevnější. Proces uplatnění TZ a nové artikulace dané situace většinou nakonec vede $\mathrm{k}$ takové transformaci a souhře našich mentálních modelů, které nám umožní reagovat přiměřeněji, a tak nastolit (opět dočasně) rovnováhu v našem vnitřním a vnějším prostř̌edí. Vytvoří se komplexní znalost. ${ }^{46}$

Nyní si tento abstraktní model neočekávaných situací pokusíme dokumentovat na reálné situaci jedné z našich studentek. ${ }^{47}$ Studentka vchází se svým cvičným učitelem do třídy. Ocitá se v „,novém světě“ - v nové situaci. Okamžitě na ni dýchne atmosféra, má nějaký pocit. Pocit kopíruje změnu situace - kopíruje př̀echod z jedné situace do druhé. Přechod ze sborovny přes chodbu do třídy. Žádná situace (vyjma extrémních příkladů) není zcela neznámá, předcházející podobné situace dávají studentce vodítko, jak situaci alespoň zhruba artikulovat, proto se studentce kontextuální celek nové situace okamžitě rozpadá na objekty a jejich vztahy: třída, žáci, lavice, stupínek, tabule, vztah učitel a žáci, vztah učitel-praktikant a cvičný učitel, očekávání spojená s výukovým procesem atd. Přesto je v dané situaci mnoho

\footnotetext{
${ }^{46}$ Ke komplexitě znalosti viz níže v této části. K výzkumu neočekávaných situací viz 8 . kapitolu níže.

${ }^{47}$ Následující př́íklad byl inspirován zkušeností jedné z participantek výzkumu - Aleny, o níž se ještě dozvíme níže při výkladu podstaty procesu metaforizace.
} 
neznámého. Studentka nezná charakteristiky jednotlivých žáků, neví, jaké jsou poměry v jejich rodinách, neví, jaký je jejich temperament, jaké jsou jejich kognitivní schopnosti, jaký jej jejich současný psychický stav, neví tisíce další věcí, které se do situace okamžitě začínají promítat a ovlivňovat kvalitu situace. I kdyby cvičný učitel chtěl a byl schopen tyto informace podat, neměl by dostatek času je studentce sdělit. Pro samotného cvičného učitele navíc mnoho z těchto detailů je ukryto $\mathrm{v}$ jeho podvědomí a sám si je již dávno neartikuluje $-\mathrm{k}$ jejich artikulaci dochází až poté, co zaznamená nějaký nesoulad mezi jednáním studentky a intuicí, prostřednictvím které hodnotí situaci. K tomu všemu některé informace nezná ani on. Studentka proto začíná jednat, učí.

Komplexita situace je natolik velká, že studentce nezbývá, než se soustředit na postupy a strukturu hodiny, které si prripravila, a postupovat podle skriptů, které si o podobných situacích udělala na vysoké škole či na základě své vlastní zkušenosti atd. Postupuje podle plánu. Žáci si vypisují slovíčka. Poté chce praktikantka pustit vánoční píseň, kterou si den předtím vybrala na internetu. Spouští internetový prohlížeč. Internetové spojení však nefunguje. Objeví se zmatek. Studentka manipuluje dál a dál s počítačem. Žáci zaregistrují, že je něco v nepořádku. Začíná narůstat ruch - internetové připojení, zneklidnění žáků, zpytavé pohledy cvičného učitele. Praktikantka propadá panice. Celková atmosféra se náhle proměnila. Zdá se, jakoby se studentka náhle ocitla $v$ jiné třídě, $v$ jiném př́iběhu. Kvalita situace se z ničeho nic prolomila do jiné kvality a studentka vstoupila do nové situace. Zmatení narůstá, studentce se zdá, že „Zamrzla“, nemůže se pohnout, nemůže přemýšlet. Mechanicky opakuje snahy o zapojení internetu a zároveň utišuje žáky. Nakonec - jako by zásahem shůry - opustí tento cyklící se plán. Zadá úkol, žáci se pouští do jeho naplnění, ona začne procházet mezi lavicemi a kontrolovat postup jednotlivých žáků. Napětí klesá. Studentka se uklidňuje. Těší se sice na konec hodiny, až bude moci utéct ze třídy, ale výuka se rozbíhá. Situace byla relativně vyřešena, kvalita situace se proměňuje a studentka společně s žáky a cvičným učitelem vstoupila do další navazující situace.

Vrat'me se nyní k pojmu sjednocený celek. Sjednocený celek je kladný závěr epistemického jednání $\mathrm{v}$ dané situaci. Známkou adekvátnosti jednání (známkou odpovídání/vyhovování) a tedy známkou dosažení znalosti a jejího uplatnění je skutečnost, že situace byla uvedena ve sjednocený celek. Problém byl relativně vyřešen. Ovšem toto řešení bylo podmíněno celou situací, nebylo výsledkem subjektivního hodnocení a ani dosažený výsledek nebyl subjektivní záležitostí. Tak jako v našem př́kladu skutečnost, že se studentka 
ze ,zamrzlé“ situace pohnula dále a hodina opět dostala svůj rytmus a průběh, nebylo dáno jejím pocitem, jejím rozhodnutím, ale tím, že její jednání zapadlo do dané situace náležitě. Podmínky pro určení toho, zda poznávající jedinec situaci analyzoval prostřednictvím observačních, konceptualizačních, komunikačních a behaviorálních operací náležitě, bylo předem dáno $\mathrm{v}$ dané situaci a projevilo se tím, že závěrečné jednání vyřešilo problém - že bylo dosaženo toho, co nastolilo relativní rovnováhu (lw.14: 181-185). Fakt, že situace mohla být vyřešena elegantněji, plnohodnotněji, je věc druhá - větší elegance a větší plnohodnotnost jednání jsou známkou expertnosti zkušeného učitele. V každém případě bylo dosaženo takového cíle, který umožnil zvrátit ,zamrzlost“ situace a proměnit ji v situaci př́ijatelnější. Pokud by relativní rovnováha nastolena nebyla, byly by analýzy a z nich vycházející jednání nenáležité.

Situace je zámkem, který si vynucuje podmínky, dosažená osobní znalost (poznatek) je klíčem, který zapadl do zámku, dveře byly odemčeny, a tím byla situace vyřešena. Nejistota, jež se projevila ve chvíli pochyb, nebyla pochybami subjektu. Pochyba spočívala v charakteru celé situace a projevila se $\mathrm{v}$ jedinci, jeho reakce byla reakcí na komplexní problematičnost dané situace. „Zvyk, považovat nejistotu za něco, co patří pouze $\mathrm{k}$ nám a nikoli $\mathrm{k}$ nějaké životní situaci, v níž jsme chyceni a zapleteni, je dědictvím subjektivistické psychologie.“ (lw.12: 110) Pro Deweyho je odlišení subjektu a objektu příliš pohodlnou a nic neříkající abstrakcí primární epistemické situace, v níž hlavní roli hraje asubjektivní zkušenost. Zkušenost je dynamická struktura, která se utváři v situaci a která je utvářena vzájemnými jednáními (interactivities) organismu (člověka) a jeho prostředí. Jejich energie na sebe navzájem narážejí, proplétají se a vzájemně proměňují. Proto tato struktura prostupuje jak jedincem, tak prostředím. Právě tyto inter-aktivity určují hranice a kvalitu situace, př́ípadný problém i podmínky jeho náležitého řešení (lw.14: 185).

Jaký má dopad pragmatistická teorie poznání a její celkové zakotvení v současných výsledcích neurobiologie, fyziologie a kognitivních věd na vnímání znalosti? Jestliže je východiskem jakéhokoli poznávacího aktu pole, v němž operuje poznávající i poznávané, organismus i prostředí, jestliže je kladným výsledkem poznání to, že dosáhneme nějakého cíle (klíč zapadne do zámku a dveře jsou otevřeny), pak samotná znalost nemůže být definována pouze tím, co je uzavřeno $\mathrm{v}$ hlavě poznávajícího, ani tím, co je uzavřeno $\mathrm{v}$ hlavách společenství myslí. Součástí znalosti musí být - obrazně řečeno - zámek, tedy podmínky stanovené celkovou situací, i možnosti, které jsou dány procesem zasouvání klíče do zámku, 
jeho zapadnutím a aktem, které vedou k otevření dveří. Jinými slovy, znalostí je celostní struktura, která vzniká sjednocením znalostního pole, přičemž toto pole:

a) je tvořeno poznatky, které se utvářejí v myslích jedinců,

b) je tvořeno inter-aktivní směnou mezi poznávajícími a jejich okolím intersubjektivní vyjednávání uvnitř společenství mysli je sice významnou, ale presto jednou z mnoha dalšich interakcí,

c) je tvořeno těly, která nám všechny interakce zprostředkovávají a mnohé z nich i hodnoti, a

d) je tvořeno vnějším okolím.

Směr, kterým šli představitelé přechodové fáze, zde neměníme, pouze posouváme porozumění znalosti v logice jejich myšlení ještě dále. Ještě více zdůrazňujeme interaktivitu a komunalitu poznání. Jestliže společenství myslí potřebuje jednotlivá těla a vnější svět proto, aby mohlo intersubjektivně sdílet své poznatky a dokázalo utvářet porozumění jeden druhému (srov. 1.2.2 výše), pak těla i vnější svět musejí být součástí znalostní sítě. Těla a vnější svět nemohou být vnější „objektivní strukturou“, s níž má být naše představa konformní. Je čímsi, co můžeme do určité míry proměnit podobným způsobem, jako mohou být proměněny naše představy či poznatky $\mathrm{v}$ přesnější představy a přesnější poznatky. Změny $\mathrm{v}$ mysli, $\mathrm{v}$ těle, ve vnějším prostředí jsou součástí procesu dosahování znalosti. I z tohoto důvodu metafora korespondence mezi poznatkem a objektivními strukturami světa je pro popis procesu poznávání nepoužitelná. V ideálním typu pozdní moderny je znalost chápána jako sjednocení všech čtyř dimenzí - mysli, těla, interakce a světa.

Abychom tuto netradiční myšlenku mohli ještě lépe vysvětlit, představme si následující „paleolitickou“ situaci: jsme kmenem pravěkých lovců, který umí lovit velká zviŕata několika způsoby. Jedním z nich je vedle koordinovaného zahánění zvířat ke srázům či zaháněním zvířat do omezeného prostoru, kde jsou pak ubita, také zabíjení pomocí vrhu oštěpem. Každá situace, v níž lovíme, je svým způsobem aplikováním již dosažených poznatků. Zdánlivě máme předem danou strukturu znalosti. Ovšem v každé reálné situaci lovu vždy dochází $\mathrm{k}$ větším či menším úpravám této struktury. To však není tak zajímavé.

To, co bývá zajímavé, jsou průlomové události. Jeden z nás náhodou odhalí sílu pružnosti určitých dřevin. Při experimentaci na ni natáhne šlachu mrtvého zviŕřete a vidí, jak se dřevo napíná, když za šlachu zatáhne. Fyzicky cítí sílu, se kterou se po uvolnění tahu šlacha vrací zpět pod snahou dřeviny dosáhnout svého původního tvaru. Cítí potenciál toho, 
co právě vyzkoušel. Neví, jak jej využít, prostě je to pro něho zatím pouze vzrušující. Při lovu dojde k neštěstí. Jeden z lovců se snaží zasáhnout oštěpem medvěda a jde prŕliš blízko. Medvěd zahnán do pasti mezi skalami instinktivně zaútočí a lovce roztrhá dřív, než je ubit ostatními. Náš experimentátor je touto situací rozrušen, ptá se sám sebe, jak to udělat, aby lovec nemusel $\mathrm{k}$ mědvědovi tak přibližovat. $\mathrm{V}$ jeho hlavě právě startuje proces, který dnes nazýváme konceptová integrace (srov. Slavík, Chrz, Štech et al., 2013, s. 188-199).

Konceptová integrace, jak bude zřejmé z tohoto příkladu, není nějaký lingvistický jev, může se dotýkat těch nejhmatatelnějších věcí kolem nás. Je jednou z nejvýznamnějších komponent poznání. Během tohoto procesu, který připomíná zásah blesku, náš lovec připadne na myšlenku, která ho irituje, ale nedokáže ji náležitě uchopit. To, co mu brání, jsou dosavadní představy o tom, jak funguje lov a jaké jsou „náležité“ prostředky lovu: koordinované štvaní zvěře, sráz hory, past ze skal, vrhání kamenů, vrhání oštěpu, zahánění zvěře do bažiny. Náhle se mu v hlavě propojí představa dřeviny s nataženou šlachou, zvláštní fyzický pocit, když šlachu po tahu uvolní a zvuk, kterou šlacha vydá při prudkém návratu dřeviny ke svému původní tvaru... a také oštěp, který letí. Druhý den nasadí menší oštěp tak, aby mu šlacha mohla „předat sílu“. Ostatní se mu smějí, byl neúspěšný. Vypadal směšně. Oštěp uletěl zoufale krátkou vzdálenost, téměř spadl před lovce. Jeden vážný, přemýšlivý starší muž mu ale řekne, že šlacha nemůže ,předat“ svoji „sílu“ tak velkému předmětu. Náš lovec se dívá na velikost dřeviny se šlachou, na velikost oštěpu. Nepoměr ho překvapí, jak to, že si toho nevšiml dříve? Experimentuje - raději o samotě, přesto blízkost onoho vážného starce vyhledává. Konzultuje s ním. Nakonec „upraveným oštěpem“ na velkou vzdálenost zabije medvěda a poté jelena. Stává se hrdinou.

Samozřejmě, že zde vyprávíme o objevu luku a šípu. Mýtus „O lovci kmene“ se ve skutečnosti mohl odehrát mnoha odlišnými způsoby. Přesto naše „vyprávění“ nese významnou informaci o tom, co je to znalost. Dokumentovalo nám dynamický proces dosahování znalosti. Abychom byly schopni náležitě pochopit tento proces, využijeme rozčlenění na čtyři roviny a z důvodu, které záhy vysvětlíme, si dovolíme přeskládat jejich pořadí.

1. Rovina interakcí. Na této rovině proběhly všechny zásadní události: předcházející zkušenost s lovem a stechnologiemi, které jsou k lovu používány, manipulace se dřevem a šlachou, posměch okolí, komunikace se starším mužem, manipulace s větším a menším oštěpem, zabití medvěda, konečné uznání kmene - to vše jsou 
interakce, které proměňují celé znalostní pole. Posměch, komunikace, uznání vytvářejí specificky lidský typ interakce v takzvaném společenství myslí. Tento typ interakce dynamizuje proces sjednocování, protože prohlubuje a urychluje symbolizaci a konceptualizaci. Přesto se jedná o jeden typ interakcí mezi mnohými dalšími a o úspěšnosti sjednocení rozhoduje soulad všech interakcí. ${ }^{48} \mathrm{Na}$ rovině interakce je také docíleno sjednocení znalostního pole, toto sjednocení vede k dosažení výsledku a k jeho zobecnění - medvěd je zabit střelou z luku, další zabitá zvířata potvrzují účinnost nové technologie lovu.

2. Rovina tělesnosti. Všechny předešlé zkušenosti s lovem a s jednotlivými technologiemi lovu musely být dosaženy ve vztahu k možnostem lidského těla - $\mathrm{k}$ jeho způsobům pohybu, ke zpo̊sobu získávání informací z vnějšího prostředí, ke způsobu jejich zpracování uvnitř těla, ke způsobům reakcí, které tělo na základě získaných informací spouští atd. S každým dalším novým způsobem lovu musejí lovci upravovat používání svých těl a fixovat a zdokonalovat způsoby použití - jiné pohyby vyžaduje stopování, jiné štvaní zvěře, jiné vrhání kamenů, jiné vrhání oštěpu, jiné střelba z luku. Bylo to tělo, které umožňovalo komunikaci jak prostřednictvím gest, tak prostřednictvím zvuků, které tvořilo pomocí dechu, fonace a artikulace. Bylo to tělo, které poskytovalo základní ohodnocení situací, v nichž se lovci nacházeli. Jinými pocity hodnocení lovci procházeli při lovu, jinými při zabití kořisti, jinými při odpočinku, jiným procházel náš lovec během manipulace se dřevem a šlachou, jiným, když byl vystaven posměchu, a zase jiným, když dosáhl uznání po zabití medvěda. Každý pocit vedl lovce k jinému typu jednání a přemýšlení. Pocity byly nahlédnutím prostupující kvality dané situace.

3. Rovina vnějšiho světa. Svět, v němž naši lovci žili, měl jasné kontury. Kopce, údolí, lesy, jeskyně, bažiny. Jeho součástí byla zviŕrata s určitými vlastnostmi. Zvírata se mohla stát jejich potravou. Každý typ zvírat mohl být loven jiným způsobem. Bylo $\mathrm{k}$ tomu nutné jistými způsoby využívat krajinu. Zvířata musela být v krajině stopována, štvána, zabíjena. Díky existenci ohně mohli členové kmene mrtvá zvíratata zpracovávat. Všechny tyto vlastnosti světa se musejí stát součástí struktury znalosti,

\footnotetext{
${ }^{48}$ Kdyby tomu tak nebylo, pak by intersubjektivní vyjednávání vedlo k radikální relativizaci pravdy. Znalost by byla konstruována $\mathrm{v}$ komunikaci nezávisle na vnějším světě. Takový stav, ale není dlouhodobě udržitelný a ohled na praktické výsledky a důsledky nás dříve nebo později přivede bliže $\mathrm{k}$ realitě. To je skutečná podstata pragmatismu a jeho pojetí sociální konstrukce, které jsou v naprostém souladu jak s Lakoffovým a Johnosonovým experiencialistickým realismem (k tomu viz poznámku 6 výše), tak s principy Kvaszova genetického konstruktivismu ( $\mathrm{k}$ tomu viz poznámku 19 výše).
} 
jinak lidé daného kmene nebudou moci dosahovat svých cílů. Svět se z tohoto pohledu zdá inertní. Zdá se, že se lovci musejí přizpůsobovat vnějšímu světu. Nemohou si například myslet, že zviŕre přijde a nechá se zabít, protože to není charakteristické pro svět kolem nich. Nicméně ani svět není neměnný. Nejen v tom smyslu, že podstupuje neustálé geologické, ekologické a evoluční proměny, ale také v tom smyslu, že lidé, ve větší míře než zvěř či rostliny, ale přesto společně s nimi, svět proměňují svými technologiemi - získáváním ohně, uchováváním ohně, výrobou nástrojů, výrobou zbraní. S každou technologickou inovací, se svět stává ,jiným“ - s objevením luku a šípu se svět stává jiným světem. I svět je plastický a na jeho plastičnosti se významně podílí člověk. Člověk i další bytosti neodpovídají tupě na podmínky stanovené světem, ale sami tyto podmínky vnějšího světa aktivně proměňují. Nepracují tedy jenom na podobě klíče (4. rovina), ale také na podobě zámku, který stanovuje podmínky.

4. Rovina poznatkư (rovina mysli). Právě tato rovina je tradičně spojována se znalostí, přesto ji zde uvádíme jako poslední, abychom zdůraznili význam všech ostatních rovin. $\mathrm{V}$ našem př́běhu tuto rovinu tvořily všechny informace, které lovci potřebovali $\mathrm{k}$ lovu. Museli mít poznatky o materiálech, které využívali $\mathrm{k}$ vytváření nástrojů a zbraní, o charakteristikách krajiny, o jednotlivých lovených zvíratech, o technologiích lovu s těmi či oněmi zbraněmi. Na př́kladu našeho lovce inovátora jsme mohli sledovat zajímavý proces, který proměňoval staré poznatky na poznatky nové. Nikde ve svém inovátorství nezačínal od nuly. Staré poznatky obohacoval, proměňoval, rekonstruoval. Poznatky o dřevě a šlaše obohatil o vlastnosti, kterých si dříve nikdo nevšiml nebo je nedokázal využít, poznatky o oštěpu obohatil o konstrukci „malého oštěpu“. Myšlenky o ,předávání sil““, které můžeme považovat za animistické, a naivně je proto podceňovat, náš lovec obohatil, když velice prakticky propojil sílu šlachy napjaté na dřevě s možností vystř̌elení „malého oštěpu“. Celý tento komplex rekonstruovaných vlastností propojil s představou zabití zvířete. Je docela pravděpodobné, že ve chvíli prvního úspěšného výstřelu ještě neměl jasnou představu, co to znamená „luk a šíp“, teprve s dalším používáním se představa vyjasňovala, dostávala zřetelné kontury. Nakonec se promítla i do jazyka - „malý oštěp“ byl vyvázán ze souvislosti s oštěpem a byl pro něj zaveden nový termín - „šíp“. 
Traktování celé události do čtyř rovin (interakce, tělo, svět, mysl) je didakticky vhodným prostředkem jak náležitě vysvětlit, co znamená znalostní pole a jeho sjednocení. Znalost není stav mysli či v ní uchovávaný objekt, ale sjednocením znalostního pole. Znalostní pole se sjednocuje napříč všemi čtyřmi rovinami: interakce jsou podmíněny stavy ostatních třech rovin, ale zároveň jsou to interakce, které umožňují změny na těchto rovinách. Zpětně změny na rovinách těl, světa a mysli utvářejí a podmiňují další možné interakce. Tak se vytváŕí dynamická struktura znalosti. Znalost, jak ulovit zvíře pomocí luku a šípu, je dosažena, když možnosti světa a do něho vnesených artefaktů (luk a šíp) se propojí s možnostmi těla a do něho zapsaných procesů, instinktů a zvyků a také s poznatky, které chápou, proč byl luk a šíp konstruován právě tak a ne onak, a chápou, jak se s nimi zachází, že jejich užití souvisí se zabitím zviŕrete atd. Dynamická je tato struktura proto, že je v neustálém pohybu - mění se chování zvěře (zvěř po určité době od objevení luku a šípu začne reagovat na člověka z větší dálky), zdokonaluje se výroba luku a šípu i technologie jejich využití, mění se způsob, jak plnohodnotně a elegantně tělo využívá tuto technologii, mění se poznatky o chování zvěře, o výrobě, o uživání technologie a o cviku těla, aby užití bylo co nejefektivnější.

Přesto je rozlišení znalostního pole do čtyř rovin znalosti hrubé a v určitém smyslu zavádějící. Neadekvátnost je dána tím, že mezi všemi čtyřmi rovinami probíhá neustálá směna. Každá rovina systémově ovlivňuje všechny tři ostatní. Potřeba potravy, což bychom mohli zjednodušeně spojit s rovinou těl, ovlivňuje a proměňuje mapování vnějšího světa, způsobuje modulaci interakce a re/formuluje poznatky. Všechny proměny zpětně ovlivňují těla. Přesto nám toto didaktické odlišení umožňuje lépe pochopit podstatu tacitních znalostí.

Představa sjednocení znalostního pole do dynamické struktury již není vázána na nějaký konkrétní mentální stav, na konkrétní strukturu obsahu zkušenosti. Sjednocení se projevuje dosažením cíle. Za určitých okolností můžeme relativně úspěšně (i když ne vždy zcela elegantně a plnohodnotně) dosáhnout cíle, aniž bychom měli jasné poznatky o dané situaci a její proměně - a vzhledem ke kapacitě lidského vědomí jsou tyto okolnosti častější než opačné případy. Když náš lovec poprvé úspěšně vystřelil z luku, nevěděl ještě zcela přesně, co je to luk a šíp, jak přesně jej lze využívat, např. na jakou vzdálenost lze zvíŕe zasáhnout a zabít. Přesto bylo dosaženo sjednocení - po řadě neúspěchů „malý oštěp“ vyletěl s nevídanou razancí. Teprve další manipulace s lukem a šípem, další střelba, další zkušenosti a jejich reflexe povedou ke zpřesnění poznatkové roviny. Dochází k výraznějším 
sjednocením. Podobně tomu bylo s naší studentkou na praxi: po „zamrznutí““ se nakonec výuka přece jenom rozběhla, dostala svůj rytmus, bylo dosaženo cíle - výuka pokračovala určitým smysluplným směrem. Bylo dosaženo sjednocení. Teprve další podobné zkušenosti a následné reflexe vyladí poznatkovou rovinu. Dojde k novému - dokonalejšímu - sjednocení.

Protože je znalost dynamickou strukturou, kterou tvoří prvky všech čtyř rovin, stává se často, že je poznávající veden vnějšími podmínkami (žáci, třída, výuka), že je veden tělesnými signály, které předcházejí racionálnímu rozvinutí situace (pocit něčeho nepř́ijemného, potřeba to překonat, možnosti, které tělo v danou chvíli poskytuje) a že je veden možnými interakcemi, které vnější podmínky a těla poskytují (odpoutání se od počítače, zadání úlohy, procházení mezi žáky). Tacitní znalost tak lze definovat jako relativně úspěšné sjednoceni znalostního pole iniciované a vedené možnostmi dostupných interakcí odvislých od stavu vnějšího prostředí a od možností tělesného jednání, relativně úspěšné sjednocení, které zatím není doprovázeno náležitou rekonstrukcí poznatkové roviny.

Z pohledu jedince se tacitní znalost projevuje jako zvláštní tušení, které člověka vede, aniž by věděl kam a proč. Někdy dokonce jedná zdánlivě zcela nemotivovaně, a přesto se ukáže, že jeho jednání mělo logiku, směřování a že relativně naplnilo cíl. Definice znalosti jako komplexní struktury sjednoceného pole, nám umožňuje odpoutat se od podmínky plného uvědomění a plné artikulovatelnosti, kterou byla znalost zcela vědomě (raná moderna) či ve svých důsledcích (přechodová fáze) definována. A díky tomu i jednání jedince, který není schopen vyjádřit, jaká znalost jeho jednání vedla, jsme za určitých okolností schopni považovat za projev znalosti - za projev tacitní znalosti. Člověk má tuto znalost, protože smysluplně reaguje na externí část znalosti rozptýlenou v prostředí mimo něj, přičemž je ve svém jednání veden možnostmi svého těla-mysli, jehož struktura byla tvarována vtělesněním a částečně také i zatím ještě nedokonale restrukturovanou poznatkovou rovinou. Tacitní znalost si tak můžeme představit jako negativní formu, která člověka vede. Podobně jako umělce vede skutečná negativní forma $\mathrm{k}$ tomu, aby ji náležitě naplnil, a tím vytvořil dílo, které bude mít pozitivní tvar. Pozitivně tvarované dílo je metaforou náležité rekonstrukce poznatkové roviny.

Abychom dokreslili stav, kdy je pozitivní forma poznatkové roviny dosažena, i stav, kdy není, vrátíme se na okamžik $\mathrm{k}$ našemu lovci. V případě, že dokáže pomocí luku a šípu zabít zviřre, ale nedokáže ještě vysvětlit, proč není úspěšný s „,velkým oštěpem“, ale je úspěšný s „malým oštěpem“, popř. nedokáže vysvětlit, kde se bere ona síla, která vrhá malý 
oštěp větší rychlostí, než dokáže lidská ruka s velkým oštěpem, anebo zatím mu pro tato vysvětlení chybějí náležitá slova, či dokonce pojmy, prostřednictvím kterých on i ostatní mohou procesu střelby porozumět, jeho poznatková rovina nedosáhla náležité pozitivní formy. V prípadě, že toto všechno dokáže vysvětlit (samozřejmě vždy pouze relativně), pak náležité pozitivní formy dosáhl.

Abychom neupadli do dichotomií rané moderny, musíme mít ale na paměti, že nedosažení a dosažení pozitivní formy jsou opět jen didaktická zjednodušení. Vždy dokážeme něco vysvětlit, v každém velice špatně artikulovaném poznatku je již zárodek budoucí pozitivní znalosti. A stejně tak nikdy nedochází k naprostému dosažení pozitivní formy poznatku a ke konečnému sjednocení znalostního pole. Kdyby tomu tak mohlo být, pak by se svět, naše těla a interakce nesměly proměňovat. Ovšem kdyby se neproměňovaly, nepoznávali bychom, protože změny na všech čtyřech rovinách jsou důsledky dosažení předešlých relativních znalostí. Absolutní neznalost i absolutní znalost jsou pouze extrapolacemi reálných procesů poznání, které ve skutečnosti neexistují.

\subsubsection{Figurativní jazyk a metafora: jejich role při postupné explikaci tušeného ${ }^{49}$}

Již v předcházejících třech částech předešlé podkapitoly jsme viděli, že 1) získávání znalosti je úzce vázáno na diskurz, na jazykové vyjádření, že těžkosti s nabýváním znalosti se promítají do jazyka a naopak, a že 2) jazyk není nástrojem, který lze rozkládat na atomární jednotky, jimi pak bezrozporně pojmenovat znalostní atomy a poté pomocí jazykových atomů složit komplexní jazykové vyjádření celistvé znalosti. Stejně jako zkušenost a stejně jako znalost i jazykové vyjádření je nám dáno jako komplex. Každé jeho slovo je původně komprimací nesmírně mnoha událostí, jedná se o sémanticky pokrytý uzel vztahů, jehož význam je neustále otevřený změnám. Dokonce i význam tak banálního a každodenního slova „židle“ je vždy otevřen obměnám - jednou je věcí k sezení, podruhé výbavou nového bytu, potřetí nástrojem sebeobrany (viz výše 1.2.3).

Každý pojem je otevřen všem permutacím, které umožňují vztahy jím pojmenovávaného objektu k ostatním objektům, přičemž se význam pojmu může kvalitativně

\footnotetext{
${ }^{49} \mathrm{~V}$ předcházejících částech jsme úvahy o pojetí poznání a znalosti a tacitní znalosti traktovali do částí o ideálním typu rané moderny, o přechodové fázi a o ideálním typu pozdní moderny. V komprimované verzi této podkapitoly však již na tento postup nemáme prostor. Problematice jazyka a metafory se proto budeme věnovat pouze ve vztahu $\mathrm{k}$ ideálnímu typu pozdní moderny a budeme odůvodňovat, proč nám již přechodová fáze nemůže dostačovat.
} 
proměnit s každou permutací. Některé permutace nevratně promění pojem. Ve chvíli, kdy se v procesu konceptualizace změní „oštěp“ “ přes „malý oštěp“ v „šíp“, je svět obohacen o novou významovou jednotku, jak na úrovni materiálního artefaktu a s ním spojených habituálních a mentálních změn, tak na úrovni jazyka, jehož alterace vyvěrá z těchto změn. Celý proces šírící se alterace má komplexní charakter. Jakákoli změna na úrovni pojmů, prostupuje sítí pojmů a jejich sémantických a syntaktických vztahů. Pragmatický zásah do podoby jazyka, jímž je vznik nového pojmu v procesu vynalézání (tvorby), více či méně postupně zasahuje sémantiku i syntax. Tyto změny mají samožrejmě hluboký vliv na porozumění a poznání a promítají se do podmínek, které určují další sjednocení znalostního pole.

V mnoha pasážích Tvorby nalezneme důraz na jazyk a na jeho primát v dosahování porozumění. Někdy se zdá, že pro naše autory - v souladu s postanalytickým strukturalismem - je to jedině jazyk, díky kterému můžeme náležitého porozumění dosáhnout. Vše ostatní jsou pouhé, často velice nejednoznačné „odezvy“. ${ }^{50}$ Proto odlišují „pojmový“ a „bezpojmový“ obsah, kde pojmový obsah je opřen o zkušenosti s objekty, jež ,lze jmenovitě vymezovat jako ,jednotku“ obsahu“, což se v logice nazývá extenze (Slavík, Chrz, Štech et al., 2013, s. 8687). ${ }^{51}$ U bezpojmového obsahu schází „inferenční sdílená pravidla“, nelze je „vědomě uplatňovat, protože není k dispozici nástroj pro jejich srozumitelnou explicitní reprezentaci jazyk. Oproti [pojmovému obsahu] není žádný porovnatelný důvod, abychom stejným právem

\footnotetext{
${ }^{50}$ Srov.: „,... Významy se sice nejzřetelněji prokazují v pojmenování a predikaci prostřednictvím jazyka, ale lze je také odvozovat na základě jiných typů odezev, které nejsou zdaleka tak jednoznačné..." (Slavík, Chrz, Štech et al., 2013, s. 148, zvýraznění přidáno).

${ }^{51} \mathrm{~S}$ pojmem extenze je spojen také pojem intenze. Jedná se o dva způsoby, kterými se významy slov váží ke skutečnosti. Extenze je chápána jako rozsah pojmu, který tvoří všechny věci, jež jsou tímto pojmem pojmenovány: pod pojem ,pes“ řadíme všechny psy na světě. Inherentní součástí tohoto podřazení je nepřímý ostenzivní vztah. Ostenze znamená, že identifikujeme objekt, o kterém mluvíme tímto způsobem: ukážeme na psa a řekneme: „pes“, a tak naznačíme, že objekt před námi pod daný pojem spadá. „Neprímost“ je dána tím, že přímá ostenzivní identifikace je schována za abstraktní funkci: „spadat pod pojem“, nicméně ostenze zde stále působí. Intenzi je míněna konstrukce smyslu, která také identifikuje věci ve světě, ale tento vztah není založen na nepř́mé ostenzi. Denotaci psa pomocí intenze můžeme konstruovat vyjádřením: „nejstarší domestikované zviŕre“". Jak je na tomto př́ikladu zřejmé, vztah k realitě je podstatně volnější, protože se může ukázat, že nejstarším domestikovaným zviřetem byl tur, a tím by tento výraz odkazoval na tura a vyjadřoval by neprímo význam slova „tur“. K tomu srov. také pasáž Tvorby o vztahu extenzionality a intenzionality, v níž se autoři přiklánějí $\mathrm{k}$ praxi analytické filozofie, že $\mathrm{v}$ případě každého nového systému významů musí přetrvávat význam zakotvený extenzí (srov. tamtéž, s. 173). Pragmatisté, experiencialističtí realisté, konstruktivisté postupují ještě o něco dále. Všímají si, že ostenze, která působí v extenzionálním vztahu mezi významem a věcí, je vlastně jen jedním ze způsobů jednání. Proto zdůrazňují fakt, že náš jazyk se ve světě ukotvuje jednáním, nikoli připisováním významu věcem. Důsledky manipulace s věcmi, které jsou součástí komplexity jednání, vytvářejí naše porozumění a formují význam pojmenovávaných věcí. Důrazem na jednání nás pragmatisté zbavují nedomyšlené závislosti na extenzionálním ukotvení jazyka, které je i přes svoji zdánlivou samožrejmost vždy vystaveno ontologické relativitě. K ontologické relativitě viz Quine (1998); a k důsledkům, které lze z Quinovy relativity vyvodit, viz Rorty (2012, s. 184-200).
} 
mohli tvrdit, že takové logické vyvozování lze uplatnit na obsah vnímání nebo představ, nejsou-li uchopeny v pojmech“"(tamtéž, s. 87).

V následujících pasážích nám nejde o to popírat, že ve většině případů se jazykem domluvíme snáze než jinými typy „odezev“. Jde nám o to, aby nám tato banalita nezakryla skutečnost, že jazyk je jen dalším, byt' v jistém smyslu geniálním typem „odezvy“, že je ve své podstatě jedním ze způsobů dovršení komplexního jednání. Pokud si toto připustíme, pak je pro nás samožrejmé, že logické inference nevstupují do lidského jednání až s použitím jazyka. Na to jsme upozorňovali v předcházející části (1.2.3), když jsme ve vztahu k pojmům situace a kvalita zdůrazňovali, že logická inference je ukotvena v situaci a je nesena jednáním. Výsledkem „bezpojmových odezev“ je skutečnost, že jazyk je předem již určitým způsobem tvarován (nap̌r. že má subjekt-predikátovou strukturu, která umožňuje přisuzovat vlastnosti předmětům, že existují určité syntaktické vazby - slučovací, vylučovací, př́ičinné, důsledkové, že existují určité sémantické vazby - syntetičnost a analytičnost atd.). Tyto „odezvy“ - nikoli jako jednotlivosti, ale jako smysluplný celek, který se ustavuje prostřrednictvím jednání organismů - jsou tím, skrze co se projevuje dynamická struktura smyslu a co tuto strukturu utváŕí. Tato dynamická struktura smyslu je také zdrojem logických vztahů.

To, co naši autoři nazývají „bezpojmovým“ obsahem, není ve své podstatě bezpojmové (srov. Johnson, 2008; Lakoff \& Johnson, 1999; Lakoff \& Núnez, 2000; Lakoff, 2006/1987). Právě toto zjednodušení jim umožňuje, aby charakterizovali metaforu jako „vtiskování [sic] signatury“, nebot’ strukturu signatury lze nakonec plně vyjádřit jazykem a lze ji zpětně reflektovat jako pojmově uzavřenou strukturu (srov. Slavík, Chrz, Štech et al., 2013, s. 201-202). ${ }^{52} \mathrm{Na}$ tom není nic špatného, pokud si autoři Tvorby uvědomují, že tímto postupem proces poznání významně zjednodušují, nebot' nadřazují již ukončené nad vznikající.

At' už je to s jejich uvědoměním jakkoli, naši autoři vzhledem k záměrům našeho výzkumu příliš radikálně vyčleňují jazyk z komplexních procesů lidského jednání, a tím se vracejí k privilegování vědomí a oddělených stavů - tzn. mimo jiné i k privilegování završených struktur. Vyčlenění jazyka pak vyžaduje, že musejí provádět kroky,

\footnotetext{
${ }^{52} \mathrm{~V}$ souvislosti s následujícím výkladem o tom, jak použité metafory preformují naše myšlení (viz dále v hlavním textu), musíme vzít mnohem vážněji než naši autoři skutečnost, že metafora vtištěni je metaforou, na které byla vybudována představa raně moderní reprezentace. Pomocí této metafory se vytvořily podmínky pro to, aby mentální kognitivní procesy mohly být pochopeny jako otisky vnějších objektů do mysli, aby se tyto otisky staly mentálními objekty, které naše vědomí nazírá (srov. Yolton, 1991).
} 
prostřednictvím kterých udržují jasnou hranici mezi „pojmovým“ a „bezpojmovým“. Proto pracují s jazykem, a především s metaforou, delimitujícím způsobem. Metafora totiž přichází z oblasti, která je podle jejich rozčlenění „bezpojmová“. A proto i metafora musí zůstat „bezpojmová“, jinak by se narušila radikalita odlišnosti mezi jazykem a ne-jazykem, mezi pojmovou a bezpojmovou „odezvou“. Významnou roli při takové tvořivé práci s metaforou sehrál opět Donald Davidson.

Jeho texty o metafoře patří v postanalytické literatuře $\mathrm{k}$ těm nejzajímavějším. $\mathrm{V}$ textu What metaphors mean (2006) Davidson metaforu metaforicky charakterizoval jako snění jazyka, jehož interpretace je věcí jak interpreta, tak původce metafory (srov. tamtéž, s. 209). To je sympatické, nebot' tato dikce jakoby naznačovala, že naše přesvědčení je správné: jestliže si původce metafory při reakcích a odpovědích př́ijemce metafory může myslet, že interpret pochopil, co metaforou chtěl vyjádřit, pak zde musí existovat nějaká skrytá logika, která řídí jak produkci, tak přijetí a interpretaci metafory. A jestliže je zde nějaká logika, pak metafora musí mít význam. Ovšem cíl Davidsonovy eseje je mnohem prozaičtější a vede spíše opačným směrem. Nebere v úvahu smysl vlastního tvrzení, že aby mohla být metafora považována za metaforu, musejí původce a interpret sdílet význam svého jazykového snění. Pokouší se naopak ukázat, že metafora nemá k dispozici žádný jiný smysl, než mají použitá slova v jejich doslovném významu, a že proto z hlediska jazyka metafora „není ničím jiným“ (srov. tamtéž, s. 209).

Již v tomto předpokladu je imanentní důsledek, který Davidson explikuje v pozdějších pasážích textu: ,Jestliže je ale věta, která je použita metaforicky, pravdivá nebo nepravdivá ve svém obvyklém smyslu [tj. na základě pravdivostních podmínek daných doslovným významem ve větě obsažených slov], pak je zřejmé, že je zpravidla nepravdivá.“ (tamtéž, s. 218) Metafora podobně jako vtip či sen nebo obraz či úder do hlavy nás podle Davidsona může přimět docenit určitý specifický rys skutečnosti - ovšem ne proto, že něco znamená nebo že vyjadřuje nějaký fakt (srov. tamtéž, s. 222-223). Metafora je zde podle Davidsona od toho, aby nás na něco upozornila, nikoli od toho, aby něco vyjadřovala či znamenala. ${ }^{53}$ Abychom porozuměli tomu zvláštnímu postoji, musíme vzít v potaz, že Davidson je součástí

\footnotetext{
${ }^{53}$ Richard Rorty se u Davidsona inspiroval, když koncipoval svoji verzi filozofie jazyka. Aniž jsme v té době znali texty kognitivních vědců druhé generace, kritizovali jsme Rortyho postanalytický prŕstup k jazyku a došli jsme $\mathrm{v} \mathrm{k}$ závěrům velmi podobným těm, které dnes se znalostí Lakoffovy a Johnosonovy kritiky prezentujeme (srov. Šíp, 2008, s. 111-116, 175-179).
} 
analytické tradice a sdílí $\mathrm{s}$ ní to zajímavé $\mathrm{i}$ to, co onu tradici omezuje a uzavírá v rané moderně.

Ve finále textu Davidson přichází s př́íkladem někoho, kdo „zmíní krásu a eleganci (deftness) linie na Picassově leptu“, a poté čtenářům pokládá rétorickou otázku, „ke kolika věcem je obrácena vaše pozornost“. Sám si odpovídá: můžeme vypočítat dlouhý seznam, který nebude končit, protože pojem ukončení zde nemá žádné jasné použití. „To, čeho si povšimneme či co uvidíme, nemá v podstatě propoziční povahu.“ (srov. tamtéž, s. 223)

Podle Davidsona metafora nemá propoziční charakter, protože jí chybí vázanost na pravdivostní podmínky. Pravdivostní podmínky poskytují pouze propozice, jejíž části nesou doslovné významy. Význam je proto striktně vázán na jazyk v jeho synchronní podobě, kde jsou významy předem fixovány. Jestliže je ve větě nějaké slovo použito figurativně, význam metaforické věty nezapadá do pravdivostních podmínek a je nepravdivá, přesněji nemá smysl pravdivost zjištovat. Jestliže známe pravdivostní podmínky např. doslovně míněných slov Slunce a září, pak rozumíme větě: Slunce září, a jsme schopni toto tvrzení v dané situaci bud' potvrdit, nebo odmítnout. Naproti tomu metaforická věta: Jeho hlava zářila, je nepravdivá, přesněji nemá smysl pátrat po tom, zda pravdivá je či nikoli, protože doslovné významy slov hlava a září určené pravdivostními podmínkami nejsou slučitelné, hlava zářit nemůže. Přesto nás podle Davidsonovy teorie může upozornit na zajímavý rys našeho vztahu k dotyčnému člověku, kterého jsme si nebyli vědomi - např́klad na náš pocit obdivu. ${ }^{54}$

Ovšem představa jazyka, v němž je sémantika oddělena od pragmatiky, je idealizací, která neodpovídá skutečnému fungování jazyka. Díky této idealizaci je možné chápat sémantiku jazyka jako katalog neměnných entit. Tak jsou významy zmrazeny, jsou neměnné, proto mohou poskytovat doslovné významy a z nich vyplývající pravdivostní podmínky. Pokud se nějaké použití slova vzpírá své v sémantice zmrazené podobě, jedná se o figuraci, která neposkytuje pravdivostní podmínky. Taková idealizace sice neodpovídá reálnému fungování jazyka, ale pro člověka socializovaného v mentálním obzoru rané moderny je uspokojivá. Umožňuje mu totiž chápat pravdu nezávisle na jednání a pojímat ji jako

\footnotetext{
${ }^{54} \mathrm{O}$ něco níže ve vztahu k Aristotelově př́ikladu: Slunce rozsévá světlo, ukážeme, že davidsonovský přístup k jazyku je fakticky neudržitelný, stejně jako byl neudržitelný př́stup Aristotela. Oba totiž vycházejí z přesvědčení, že existuje př́sná hranice mezi doslovným jazykem a figurativním jazykem. Výsledky výzkumů evoluční a kognitivní lingvistiky dokazují, že žádná taková hranice nemůže existovat, protože (paradoxně $\mathrm{k}$ představám aristotelismu a rané moderny) by nemohlo existovat samotné lidské poznání. Uvidíme, že za určitých okolností, které jsou reálné a odůvodnitelné, slunce může rozsévat světlo stejně, jako něčí hlava může záritit. Ke kritice Davidsona i Rortyho za to, že nezakládají svá přesvědčení na nejnovějších výsledcích výzkumů, viz např. Johnson (2008, s. 196-200).
} 
v podstatě sémantickou záležitost, kdy význam věty zapadá do pravdivostních podmínek konstruovaných doslovnými významy slov, z nichž je věta složena. Takové pojetí disciplinovaně obchází fakt, že naše zkušenost je strukturována vtělesněním interakcí mezi organismem a jeho prostředím, a proto je utvářena dynamickou strukturou smyslu. Strukturou, která na rovině významu prochází neustálou změnou. Zmíněné obcházení se projevuje tím, že je metafoře předem upřena možnost mít význam a může nás pouze na něco upozorňovat, popř. pouze $\mathrm{k}$ něčemu obracet naši pozornost. $\mathrm{K}$ tomuto tvrzení se hlásí i naši autoři v mnoha pasážích Tvorby, kde se píše o podstatě a funkci metafory (viz Slavík, Chrz, Štech et al., 2013, s. 109-110, 181-182, 194).

Metafora pro ně tak „,nevyjadřuje objektivni stav věcí“, není to ,„propozice vztažená jen k externím relacím“, je „především projevem subjektivní organizace mezi mentálními prostory“ (tamtéž, s. 181). „Subjektivní uchopení metafory předchází jejímu pomovému [sic patrně míněno: pojmovému] uchopení“ (tamtéž, s. 182 - zvýraznění přidáno). ${ }^{55}$ Určující je zde ona neustále zpř́ítomňovaná dichotomie „subjektivní“ versus „objektivní“. Již výšse (viz 1.2.3 - pasáž o tom, co na neurofyziologické rovině tvoří intuici) jsme uvedli, že taková dichotomie $\mathrm{v}$ podstatě neexistuje a je pouze sekundárním zjednodušením, kterým si raná moderna budovala své sebevědomí v boji proti aristotelsko-scholastickému myšlení. I ty nejintimnější prožitky se dějí na základě dynamické významové struktury, která je nesena jak biologickým historickým a priori organismu jako druhu, tak kulturně-sociálním historickým $a$ priori společenství, v němž byl jedinec socializován a vychován. ${ }^{56}$ Je vztažená $\mathrm{k}$ „externím relacím“ mnohem hlouběji a závazněji, než bychom to dokázali pomocí ostenze či pomocí extenzivního určení pojmu. Tedy nejedná se o něco zcela „subjektivního“. Stejně tak když vyjadřujeme „objektivní stav věcí“ a společenství myslí se shodne na základě svého časově a místně omezeného intersubjektivního porozumění, že se skutečně jedná o „objektivní stav věcí“, tento stav věcí není nikdy absolutně ,objektivni'“. Metafora není ani „subjektivní“, ani „objektivní“ - ostatně jako jakékoli jazykové vyjádření. V tomto smyslu metafora sice není „objektivní“, ale je ontologicky závazná, nevzniká arbitrárně. Na druhou stranu není ani

\footnotetext{
${ }^{55}$ Všechny tyto pasáže se odkazují k textu J. Máchy (2009), v němž jeho autor představuje českému publiku Davidsonovo pojetí metafory, přičemž poslední citát je př́mo Máchova věta (Mácha, 2009, s. 144).

${ }^{56}$ Pojem „historické a priori“ si vypůjčujeme od Foucaulta, který jej použival pro charakteristiku svých epistém (srov. Foucault 2000, s. 12-14; 2002, s. 193-201 / 1994, xix-xxi; 1972, s. 142-148). Souslovím chtěl vyjádřit, že zde existují předem formované struktury smyslu (apriorní část), které však procházejí neustálou proměnou, mají svoji kulturní historii, v níž k této proměně dochází. My jsme jeho pojem rozšíríli i na biologickou vrstvu našich životů. Stejně jako socio-kuturní vrstva i biologická má svá historicky proměnlivá a priori. Obě a priori spolu souvisejí a ovlivňují navzájem své proměny.
} 
„subjektivní“, má tolik „objektivních“ rysů, že druzí lidé jsou většinou schopni zařadit ji do svého rámce porozumění a někteří z nich ji dokonce začnou používat jako popis reality, který je př́íhodnější než popisy předcházející. Právě tuto skutečnost musíme neustále zdůrazňovat, pokud chceme zkoumat reálné funkce metafory a její podíl na artikulaci tušeného, na artikulaci tacitních znalostí.

$\mathrm{Na}$ tomto místě musíme zodpovědět otázky, které zcela překračují horizont rané moderny a jsou reflektovány v přechodové fázi jen částečně: Proč metafora vzniká? Co tvoři její motivaci a generuje její energii, s niž vstupuje do jazykového ř́du a narušuje jej? Č́m metafora vlastně je? Charakter metafory, který následně představíme, nás vede $\mathrm{k}$ tomu, že ji pojímáme mnohem širreji než je běžné v literárně vědných a lingvistických textech či v textech tradiční filozofie jazyka. Metafora neni primárně lingvistickou záležitostí - k tomu podrobněji viz níže.

$\mathrm{Na}$ jedné straně stavíme své porozumění metafoře na pojetí Ricoeura, který těsně vztahuje metaforu k symbolu. Jeho pojetí z druhé strany propojujeme s pojetím neurobiologů, kognitivních vědců a filozofů, kteří dokáží vysvětlit, jak provázání se symbolickou předjazykovou vrstvou jednání funguje na úrovni materiálně-fyziologicko-psychických procesů. Díky tomuto propojení jsme schopni propojit dějiny života s projevy života jednotlivých organismů. Již z tohoto krátkého úvodu je zřejmé, že metafora je projevem života, je způsobem, jakým se vyšší organismy adaptují na proměny prostředí.

Ricoeur metaforu definuje ve vztahu $\mathrm{k}$ přebytku významů a nevyčerpatelnosti symbolu (srov. Ricoeur 1976). Symbol je u něho chápán jiným způsobem než v teoriích objektivistického realismu. Objektivisté mají pod slovem symbol na mysli reprezentaci předmětu reálného světa (objekt, stav, vztah atp.) v řádu nějakého symbolického kalkulu. U Ricoeura je symbol chápán v tradici fenomenologické hermeneutiky jako projev života (bios), který není zařaditelný do řádu jazyka (logos), nebot' obsah symbolu či symbolického jednání vždy předchází porozumění dosažené prostřednictvím řádu jazyka.

Zde je pro další výklad nutné odlišit systém pojmů od systému jazyka, který pojmy vyjadřuje prostřednictvím svého řádu. Jak uvidíme níže, pojmy i se svými významy vznikají již v senzomotorické oblasti. Jazyk je řádem systémů sémantické, syntaktické a pragmatické roviny, který slouží ke snazší manipulaci se sdílenými znaky, čímž umožňuje včlenit předjazykové dění do komunikačního kódu. Prostřednictvím tohoto kódu lidé (organismy obecně) intenzifikují koordinaci sociálního jednání. Jazyk ze své podstaty není schopen 
vyjádřit bohatost předjazykového dění. Jazyk za svoji schopnost dosahovat svého účelu, tedy koordinovat sociální jednání, jehož podstatou je redukce významů na únosnou míru (k tomu viz níže 1.2.5), platí tím, že vyjadřuje předjazykové dění pouze přibližně a reduktivně, a vždy se zpožděním. Tj. vyjadřuje to, co je již v dění předem strukturováno. $\mathrm{V}$ tomto smyslu je dění jazykem neuchopitelné - symbolické. Dění se strukturuje prostřednictvím ricoeurovsky pojatých symbolů. Tato strukturace teprve umožňuje - vždy „,nedokonalé“ - jazykové uchopení a vyzdvižení jen jisté části významů.

Př́kladem neuchopitelnosti symbolu je prrímý náboženský symbol (svaté prrijímání), popř́ípadě symbol od toho religiózního odvozený (úcta ke královně). At’ je překládáme do jazyka jakkoli zdatně či vytrvale, jeho podstatu nejsme v jazyce s to zpř́itomnit pro jedince, který se s námi neoddává symbolickému jednání. Například ve chvíli, kdy jedinci, který je chladným pozorovatelem úkonů při mši, vysvětlujeme, že lidé přicházející ke svatému přijímání, přijímají tělo Kristovo. Nebo ve chvíli, kdy na příklad punkerovi vysvětlujeme, že by měl prokázat úctu prricházející královně. Teprve symbolická účast na svatém přijímání či na úctě $\mathrm{k}$ nějaké společenské roli dává možnost porozumět jazykovému vyjádření. Symbolické jednání strukturuje náš svět - je to symbolické jednání, které teprve utváří prostor, v němž se může zrodit a operovat sdílení významů prostřednictvím jazyka. A právě proto není jazykem zcela vyjádřitelné. ${ }^{57}$

Metafora si zachovává přebytek významů, polysémičnost symbolu. Je ale zároveň „lingvistickou rovinou symbolu“. Je schopna pročistit neuchopitelnou bohatost symbolu a vnést do jazyka jeho implicitní sémantiku, v níž ovšem tuto bohatost a propojenost nahlíží pouze v určité perspektivě, pouze s určitým záměrem (srov. tamtéž, 1976, s. 68-69). Metafora tak vnáší symbolickou sílu do jazykového řádu. Tím je schopna vnést do jazyka zcela odlišné podmínky chápání a způsobit to, co budeme níže nazývat rozštěpením reference. Zmínka o symbolické síle, která vstupuje do řádu jazyka, nám naznačuje i to, v čem tato síla spočívá. Její podstatou je komplexita, která propojuje celý život jedince či společenství s kosmem v jeho vývoji. Takovou komplexitu nejsme schopni včlenit do jazykového vyjádření, ani

\footnotetext{
57 „Od samotného počátku jsme varováni [v Ottově textu Posvátno], že zde překračujeme práh zkušenosti, která nedovoluje, aby byla zcela vepsána do kategorií logu... Tato síla jako účinnost par excellence je tím, co nepřechází zcela do artikulace významu. Je pravda, že pojem hierofanie, kterým Eliade nahrazuje př́liš zatěžkaný termín numinózní, naznačuje, že manifestace Posvátného má formu nebo strukturu, ale že i přesto nebylo řeči přiznáno žádné privilegium... Předverbální charakter takové zkušenosti je potvrzován samotnými proměnami prostoru a času v posvátný prostor a posvátný čas, které na rovině estetické zkušenosti míŕi a je vepsán do oblasti pod jazykem...." (citováno dle anglického originálu, Ricoeur, 1976, s. 60-61, slovenský překlad viz 1997, s. 85-86).
} 
vědomě uchopit, přesto souvislosti - často vzdálené a většinou předem neuvědomované mohou vstoupit díky metafoře do našeho vědomého pole a proměnit nejen jazyk, kterým o světě vypovídáme, ale i naše porozumění světu.

Ricoeurovy představy by mohly ve čtenáři vyvolat dojem, že se nyní dotýkáme nějaké mystické, iracionální záležitosti. Č́stečně tomu tak může být i proto, že si neuvědomujeme, jakým způsobem jsme prostř̌ednictvím našich těl-myslí propojeni s celkem života a $\mathrm{s}$ jeho historií. Můžeme si to dokumentovat na následujícím příkladu, v němž Derrida (1993, s. 230232) rozebírá jednu z klíčových pasáží textu, v kterém Aristotelés definoval své pojetí metafory (Aristotelés, $1457 \mathrm{~b}^{58}-1999$, s. 59-60). Derrida zde podrobuje kritice tradiční Aristotelovu definici metafory jako přenášení jména ( $\mathrm{v}$ pozdějším vývoji této tradice: přenášení vlastností) jedné věci na druhou. ${ }^{59}$ Od Aristotela až po dnešní dny je metafora chápána jako přenášení vlastností z jedné věci na druhou. ${ }^{60}$

Derrida se ve své kritice obrací k pasáži, kde si Aristotelés všímá zvláštní moci, jakou má mezi metaforami jeden její druh - analogie (v českém kanonickém překladu - „obdoba“). Tuto moc Aristotelés vysvětluje na prríkladu metafory: Slunce rozsévá světlo. ${ }^{61} \mathrm{Je} \mathrm{v}$ ní naznačen vztah mezi setím (zrna) a rozsévačem na jedné straně a mezi svitem slunečních paprsků a Sluncem na straně druhé. Aristotelské pojetí metafory vychází z předpokladu, že mezi různými objekty nacházíme podobnosti, které nám posléze umožní přenášet jména (vlastnosti). Ovšem kdyby metaforické přeznačení naší metafory rozsévajícího slunce mělo

\footnotetext{
${ }^{58}$ Jedná se o mezinárodně standardizovaný odkaz na Aristotelovo dílo.

59 „Metafora je přenesení jména jedné věci na druhou, bud’ z rodu na druh nebo z druhu na rod nebo z jednoho rodu na jiný nebo podle obdoby [analogie - podle anglického překladu doplnil RŠ]“(1999, 1457 b 6-9, s. 370).

${ }^{60}$ Stopy tohoto pojetí nalezneme ještě $\mathrm{v}$ přechodové fázi našich autorů, kdy zachovávají důraz na přenos vlastností prostřednictvím ztvárnění jednoho jako druhého. Podle našeho výkladu však dostatečně nedoceňují důraz na existenciální transformaci porozumění zkušenosti: „Jakým způsobem metafora vypovídá smysluplně o skutečnosti? Odpověd' může znít: Tím, že ji ,ztvárňuje jako '... Zde je možné se opř́í o Lakoffovo a Johnosonovo vymezení metafory jako ,chápání a prožívání jednoho druhu věcí z hlediska jiného druhu věcí‘. Tuto definici lze mírně odpsychologizovat a ř́ci, že metafora ,ztvárňuje jedno z hlediska druhého', či ,ztvánnuje jedno jako druhé “" (Slavík, Chrz, Štech et al., 2013, s. 201). Ovšem tím, že autoři Lakoffovu a Johnsonovu dikci „odpsychologizovali“, se vrátili tam, odkud Lakoff a Johnson vědomě odešli. Ve chvíli, kdy použijeme metaforu nikoli jako ornament diskurzu, ale skutečně jako prostředek rozštěpení reference a nového popisu zkušenosti, pak nejenže ztvárn̆ujeme, ale hlavně nově chápeme a prožíváme. Nejedná se o žádný psychologismus, ale o existenciální krok. Pokud se soustředíme na ztvárnění, pak zůstáváme pouze u toho, že vlastnosti jedné věci přenášíme na věc druhou. Zůstáváme pouze na rovině exprese, ale nesestoupili jsme na existenciální rovinu chápání a proživání, která expresi zakládá a obdařuje ji smyslem. Holan jednu ze svých nejlepších básní Jeskyni slov primárně neztvánňoval, on skrze ní rozuměl životu básníka, a tak tento život také prožíval. Ztvárnění přicházelo až po transformaci jeho vědomí a způsobu života jako důsledek změny chápání a proživání.

${ }^{61} \mathrm{~V}$ přesném znění: [slunce] rozsévaje bohem daný žár (Aristotelés, 1999, 1457 b 33-34, s. 60) Stejně jako Derrida dáváme stranou božský element a soustředíme se na „rozsévání světla“ či „rozsévání žáru“ s tím ovšem, že božský element by pouze náš výklad hlubinných souvislostí a symbolického pozadí každého jazykového vyjádření ještě prohloubil.
} 
být dáno skutečně pouze tím, že si původce metaforického přesunu všiml nějaké podobnosti mezi jedním (rozsévačem) a druhým (sluncem) a poté provedl metaforické přestrukturování smyslu, pak by metafora o rozsévání světla nikdy nemohla vzniknout. Mezi rozsévačem a sluncem není žádný vztah, který bychom předem mohli vidět. Obecně zde neexistuje žádný vztah, který by byl smyslově uchopitelný. Slunce a rozsévač mají odlišné fyzikálně-chemické charakteristiky, jejich odlišnost lze zaznamenat pouhým okem.

I když si připustíme, že zde hledání vztahu mezi sluncem a rozsévačem přece jen existuje, dostáváme se k druhé zarážející vlastnosti metafory. Aby slunce mohlo rozsévat, musí se učinit mnoho významových posunů. Musíme pozměnit naše chápání slunce i rozsévače zrna. Jelikož je ale slunce spoludefinováno světlem a dalšími s tím spojenými věcmi a vztahy a rozsévač zase zrnem a dalšími s tím spojenými věcmi a vztahy, pak po vstupu metafory do jazyka musí posuny zasáhnout celé široké oblasti smyslu. Pakliže tato metafora vznikla, nejedná se zde o jednoduché „přenášeni““, ale komplexní systémové proměny porozumění. Metafora při své aplikaci alteruje nejen smysl pưvodního objektu $i$ objektu, na které byly vlastnosti přeneseny, nýbrž všech věcí, které se vzájemně podílejí na spoludefinici významových oblastí „slunce a jeho záreni" a ,zemědělská činnost“. Jak ale k takovým komplexním proměnám může dojít bez zjevné fyzikální změny slunce i rozsévače? Byla tato komplexní proměna nějakým zpo̊sobem již dříve přítomna v člověku, který jako první tuto metaforu použil? Ale jak by v něm přítomna mohla být, když zde není zjevná odlišnost od fyzikálních podmínek před a po její aplikaci, které by umožnily změnu pravdivostních podmínek? Slunce zjevně není rozsévačem zrna a naopak.

Jak jsme již podotkli, podle aristotelské definice zde musí existovat nějaká podobnost mezi jednou a druhou věcí. Moderně bychom řekli, že zde musí operovat teorie identity, která by ř́́dila proces, v němž uchopujeme podobný obsah v jednom i v druhém (v rozsévači i ve slunci). A díky této částečné identitě jednoho a druhého se teprve ustavuje možnost přenosu. Podle této definice teprve na základě zjištěné podobnosti může metafora přenést jména (vlastnosti) z jedné věci na druhou. Ovšem takovou teorii identity (v podstatě se jedná o to, co autoři Tvorby nazývají ,spadat pod společné pravidlo“) zde nelze použít. Ve skutečnosti tato teorie může být využita pouze minimálně a pouze ve velice jednoduchých metaforických posunech. Už metafora Slunce rozsévá světlo, se tomuto analytickému př́istupu vymyká. 
Derrida si dále všímá jiných prvků této pasáže, kde Aristotelés píše o možnosti označit na základě analogie „něco“ jménem něčeho ,jiného“, prričemž předmětu, který je v centru metaforického posunu, upřeme některou z významných vlastností identifikující původní věc: Číše se má k Dionýsovi stejně jako štít k Aréovi. Jsou to jejich atributy. V tomto způsobu metaforického užití nazve původce metafory štít „číší Aréovou“. Ovšem v následném metaforickém přesunu se rozhodne odebrat zástupnému jménu ( $\mathrm{v}$ našem případě číši) právě tuto přemost'ující vlastnost. Štít již nenazve „č́iší Aréovou“, ale „čćíśi bez vína“. Derrida připomíná, že tento proces přesouvání jmen (vlastností) může probíhat do nekonečna, mluví o „metaforizaci metafory“, o „bezedném zvrstvování určení [metafory]“, aby nakonec upozornil, že „, analogii jsou všechny termíny zapuštěny v metaforickém vztahu“ (1993, s. 231).

Tato komplikace charakterizuje podstatu metafory obecně - možnost metaforizace metafory je tím, co utváří podstatu metafory. Tradiční kánon, který chápe metaforu jako přenášení, se domnívá, že abychom se neztratili v nekonečnu variací metaforických posunů, musí být užití metafory $\mathrm{v}$ něčem ukotveno. Toto ukotvení hledá v odlišení doslovného a figurativního jazyka. Doslovný jazyk je jazykem kognice, figurativní je pouhé ozvláštnění, popř. nám umožňuje všimnout si něčeho, čeho jsme si dř́́ve nevšimli. ${ }^{62}$ Zde je ale nutné zdůraznit, že jsme to my, kdo činí metaforu nebezpečnou. Jestliže metaforu pochopíme jako pouhou lingvistickou záležitost (raná moderna) nebo jako sen či úder do hlavy, který nás má na něco upozornit, ale nenese význam (přechodová fáze), pak vyvazujeme metaforu z jejího ukotvení v těle-mysli, a tím ji vyvazujeme i z dlouhé tradice našeho druhového i kosmického života a obrovskou tvořivou sílu symbolu uvolňujeme z obvodu zpětnovazebné kontroly. Za takové situace nám skutečně nezbývá nic jiného než vymýšlet, jak metaforu omezit a učinit ji pro kognici marginální. Metafora je však něčím, co je ukotveno v řádu existence (bios), který omezuje pole a hloubku metaforizace metafory. Můžeme si to dokumentovat na př́kladu slunce, které rozsévá světlo.

Mezi sluncem a tím, kdo seje zrno, musel být vztah již před tím, než si toho první původce metafory všiml. Tato mnohočetná tvořivá více-vztahovost, ono „bezedné zmnožení vrstev určení“, které překračuje pevné formy bytí (středověk) či pevné a relativně neměnné podstaty věcí (raná moderna), je v ontologii středověku i rané moderny nevysvětlitelná a přirozeně vyvolává strach. Jestliže ale přijmeme ontologii vzájemně se ovlivňujících sítí, jak

\footnotetext{
${ }^{62} \mathrm{~K}$ tomu srov. podkapitolu Strach z metafor v Lakoffově a Johnsonově knize Metafory, kterými žijeme (2002, s. 206-209).
} 
nám jí předkládá pozdní moderna, je nám tato skutečnost mnohem bližší. Vztah mezi sluncem a rozsévačem zrna se rozhodujícím způsobem utvářel v dlouhé historii vývoje zemědělství, v koloběhu ročních období a síly slunečního záření, přičemž to vše mělo vliv na formování významové struktury procesu setí. V lidské zkušenosti se proto vytvářelo specifické porozumění (kulturně historické a priori), které bylo samo zakotveno $\mathrm{v}$ sedimentaci zkušenosti na úrovni fylogenetického zápisu do DNA a jí podporované biologické paměti (biologické historické a priori) - jistá podoba lidského těla, která se po generace opakuje, umožňuje takové jednání, které souhrnně nazýváme zemědělská činnost, jejíž součástí je mimo mnohých dalších operací i setí semen. Tato historická a priori umožnila, aby ve struktuře vtělesněné významové struktury byly k sobě vztaženy slunce a jeho působení v systému ročních období na jedné straně a celá oblast zemědělských prací na straně druhé. Toto vztažení jednoho $\mathrm{k}$ druhému existuje bez toho, aby mezi sluncem a rozsévačem bylo nutné shledávat nějaké podobnosti. Vztah byl již přítomen ve struktuře vtělesněné bud' do DNA a biologické paměti, anebo do kulturní paměti nesené lidskými institucemi a čekal, až nastane jistá potřeba na tento vztah upozornit.

Pro ranou modernu je tento způsob nahlížení „vrstev určeni““ nepochopitelný, protože je vnitřně svázána $s$ představou lineární kauzality. Představitelé rané moderny netuší (či si ještě stále nepřipouštějí), že kauzalita je pragmatickou př́činností, že se jedná o metodickou trivializaci komplexní sítě vztahů na jednoduše ovladatelné schéma „př́íčina - následek“. Jelikož lineárně kauzální vztahy považuje za podstatu ontologické danosti, ${ }^{63}$ musí hledat mezi sluncem a rozsévačem nějaké podobnosti - v podobě, ve funkcích atp. Jelikož takové př́mé podobnosti neexistují, jsou pro Aristotela i představitele rané moderny metafory podobné té o slunci rozsévajícím světlo záhadou. Pro Ricoeura tato skutečnost není nevysvětlitelná. Symbol jako projev symbolického jednání je důsledkem našeho smysluplného existenciálního vnoření do reality kolem nás. Metafora si propůjčuje sílu z oblasti symbolu a vstupuje do jazykového plánu, aby pozměnila naše chápání a prožívání.

Zpětnovazebná kontrola, která symbol a metaforické přenosy udržuje v řádu života, je dána hlubokou souvislostí mezi tělesným prožíáním života a jeho smyslem. Aniž by tato souvislost spočívala pouze v hmotné a tělesné stránce samotné, je osudově vázána na svoji hmotnou a tělesnou podstatu, nebot' je to souhra všech relací života v kosmu, která činí život

\footnotetext{
${ }^{63}$ K odlišení komplexni přičiny od př́čciny pragmatické viz Rockwell (2005, s. 51-52). Neschopnost za lineárními kauzálními řetězci vidět účelovou schematizaci skutečnosti je znakem, který odlišuje lineárně kauzální myšlení rané moderny od systémového myšlení moderny pozdní.
} 
posvátným a smysluplným. Na tuto skutečnost s půvabnou přesvědčivostí upozorňuje ve své knize The embers and the stars (1984) Erazim Kohák. Poukazuje zde na skutečnost, že jestliže se chceme dostat za „fakta“, k jejich smyslu, pak nutně musíme použit metaforického vyjádření (srov. tamtéž, s. 55-56). Dokládá to na příkladu lunárního cyklu (prrírodní zákonitosti), který se stává prostředkem pochopení proměňující se jednoty života jedince i společenství (srov. tamtéž, s. 56-57).

Tento fenomenologicko-hermeneutický přistup, který Kohák s Ricoeurem sdílí, Axelsenová porovnává s přístupem současné kognitivní vědy, když jej vztahuje k dílu Lakoffa a Johnsona ${ }^{64}$ a dokládá jejich vnitřní souvislost (srov. Axelsenová, 2012, s. 344-348). Souběh je pro náš argument centrální, nebot' ukazuje, jak se symbolický svět strukturuje a přenáší z generace na generaci skrze tělesnost. Skrze tuto tělesnost se také můžeme dostat ze symbolické roviny metaforického smyslu k tělesným procesům, s jejichž pomocí se tento smysl artikuluje $v$ životě a v jazyce jednotlivců i celých společenství. To, jak jsme propojeni $\mathrm{s}$ onou nepřehlédnutelnou sítí života a jakou roli v tom hraje metafora a tělo-mysl, se pokusíme vysvětlit v následujících odstavcích.

Naše pojetí metafory vystavěné na Ricoeurově a Kohákově smysluplnosti života promítaného do jazyka se propojuje s pojetím, které ve svých textech předkládají kognitivní vědci druhé generace, pragmatističtí filozofové či evoluční lingvisté - Johnson (2008), Lakoff a Johnson (1999, 2002), Lakoff (1987), Lakoff a Nunez (2000), Galles a Lakoff (2005), Gibbs (2005) a další. Již v předcházejících kapitolách jsme věnovali velkou pozornost tělesněpsychickým procesům, jelikož jsme si uvědomili, jakou roli hrají těla-mysli organismů v prosazování a zkvalitňování jejich života. Skrze tělo-mysl je organismus propojen se svým prostředím. Historie organismu jako druhu i jako toho, kdo nebo co participuje na celku života obecně, vztahuje interakce mezi organismem a prostředím k celým dějinám života na Zemi. Těla-mysli jsou fakticky záznamy výsledků interakcí, jsou katalogem dějinných událostí daného druhu v kontextu kosmického vývoje. Jestliže jsme si výše mohli ve vztahu k Ricoeurovi klást otázku, jak je člověk, který vnáší metaforu do jazykového řádu, propojen se symboly, v nichž se odráží komplexita kosmu, pak právě zde nacházíme odpověd'. Prostřednictvím těla-mysli je každý organismus vpleten do komplexity života. Všichni výše zmínění autoři vztahují figurativní myšlení a především metaforu k tělesným kognitivním

\footnotetext{
${ }^{64}$ Metafory, kterými žijeme (2002) a Philosophy in the flesh (1999).
} 
aktům. Proces metaforizace ${ }^{65}$ je vkořeněn již v představových schématech (viz níže) a prorůstá skrze celé lidské kognitivně-estetické chování až k těm úkonům, jejichž nejzazšími výtvory mohou být objekty světa umění. Ukázkovým př́kladem je kniha Marka Johnsona The meaning of the body (Význam těla - 2008).

Metafora je pro něj prostředkem zvýznamňování naší zkušenosti. Prostřednictvím metafory jsme schopni pochopit vyjevující se a proměňující se zkušenost díky tomu, že je vkořeněna do vtělesněné dynamické struktury významů. Jistým jednáním vyzvedáváme určitý význam či trs významů a metafora reaguje na ono vyzvednutí tím, že obrazově uchopuje komplex této významové struktury a včleňuje jej do jazykového vyjádření. Metaforizace je zapuštěna již $\mathrm{v}$ představových schématech (image schemes), která mapují senzomotorické procesy. Představová schémata jsou utvářena percepcí, jež proniká různými oblastmi (crossmodal perception), a tak dochází $\mathrm{k}$ překrývání různých neurálně-fyziologických procesů. Překrývání těchto procesů umožňuje jejich postupnou koordinaci, a tím i nárůst jejich rozrůzněné celistvosti (srov. tamtéž, s. 135-154).

Nejdříve tímto způsobem vznikají bazální predstavová schémata, která poskytují organismu základní orientaci. Některá z významných schémat jsou: schéma nádoby (v originálu container), schéma zdroje-cesty-cíle, schéma vertikality (nahoře-dole), schéma centra-periferie atd. (srov. Johnson, 2008, s 136-145). Schémata poskytují základní orientační mapy, které prostupují našimi životy od narození až po smrt. Napřr. schéma nádoby strukturuje naši zkušenost prostřednictvím kognitivně zkušenostního gestaltu, který nás informuje o tom, zda my (nebo nějaký námi sledovaný předmět) jsme (nebo je) v něčem, nebo mimo něco. Už zde kognitivní vědci nacházejí základy logických inferencí: entita je bud' uvnitř, anebo vně „nádoby“ (množiny), ale nemůže být uvnitř i vně. Tento existenční vztah má své další důsledky, které z ní vyplývají přímo a tvoří základ logiky. Jestliže je entita $\mathrm{E}$ $\mathrm{v}$ nádobě $\mathrm{N}$ a tato nádoba je dána do nádoby $\mathrm{O}$, pak entita $\mathrm{E}$ musí být v nádobě $\mathrm{O}$ atd. (srov. tamtéž, s. 179-180). Když jsme na několika místech výše psali o tom, že logické inference jsou nedílnou součástí situace, když jsme citovali Deweyho tvrzení, že nesprávná artikulace situace vede k tomu, že z ní abstrahované objekty a vztahy postrádají „logickou sílu“, měli jsme na mysli právě tuto existenční závislost logického kalkulu na nejelementárnějších

\footnotetext{
${ }^{65}$ Tímto termínem máme na mysli proces, v němž zvýznamňujeme naši zkušenost prostřednictvím nějaké metafory či klastru metafor, a tak ji činíme vyjádřitelnou v jazyce. Vstupem metafor se jazyk stává figurativním, nedoslovným. To je vobjektivistickém myšlení chápáno jako něco negativního, my stejně jako experiencialističtí realisté naopak nedoslovnost chápeme jako nutný kognitivní prostředek k vyjádření nové kvality.
} 
procesech jednání, kterým je organismus inherentně provázán se situací a s jejím vnitřním uspořádáním.

Představová schémata jsou počáteční orientačními prvky, $\mathrm{v}$ nichž se ukotvuje porozumění. Prostřednictvím nich dochází k uchopení základních vtělesněných významů dané struktury zkušenosti. Percepce je multimodální, je zároveň jak uchopením prostorové či pohybové interakce, tak tím, co vybírá možnosti následných reakcí. Jinými slovy percepce a jednání, stejně jako percepce a pojmy nejsou primárně odlišenými oblastmi, ale povstávají během výkonu života organismu $\mathrm{v}$ interakcích $\mathrm{s}$ prostředím. Představová schémata se kombinují, a podílejí se tak na složitější syntaktické struktuře naší zkušenosti. Každá takto vzniklá vrstva významů je zároveň vtělena do automatických procesů, které probíhají na podvědomé úrovni organismu. Jestliže si např. uvědomujeme, že jsme uvnitř nějaké místnosti, pak naše tělo již tuto základní situaci vyhodnotilo a připravilo portfolio možných jednání. Soujedinost percepce, jednání a myšlení umožňuje, aby organismus porozuměl situaci prostřednictvím simulace jednání (srov. tamtéž, s. 157-162).

Jak si takovou simulaci můžeme představit i na nevědomé úrovni, dokládají funkce zrcadlových neuronů $(\mathrm{ZN})$, o nichž jsme psali výše (1.2.3). ZN umožňují hodnotit situaci ještě předtím, než jsme si jí vědomi. Aktivují se například v mozku pokusné osoby, když ona pouze sleduje, že experimentátor uchopí něco do rukou. ZN v mozku zkoumané osoby na neuronální úrovni simulují to, co se děje v mozku experimentátora - protože se aktivuje stejné centrum velmi podobným způsobem, naše neuronální aktivita hodnotí situaci podobně, jako bychom předmět uchopovali my (srov. Iacoboni, 2009, s. 9-11). Zmíněná hodnocení, která ZN zkoumané osoby provádějí na nevědomé úrovni, mohou mít i velice složitou strukturu, strukturu přibližně odpovídající sémantice a syntaxi jazykového hodnocení. Jestliže je předmět uchopen tímto způsobem, bude následovat taková množina dalšího jednání. Jestliže je předmět uchopen tamtím způsobem a zároveň je přítomna deska stolu, na který lze předmět odložit, aktér s největší pravděpodobností předmět odloží na tuto desku. (Srov. tamtéž, s. 3135.)^{66}$

\footnotetext{
${ }^{66}$ Je zde samozřejmě kontinuita simulací. Jestliže se učíme nápodobou, využíváme zrcadlové neurony našeho mozku. Když pozorujeme lovce před námi, jak vrhá oštěp, způsob úchopu oštěpu a série následujících pohybů vyvolá $\mathrm{v}$ př́slušných zrcadlových neuronech reakci, která nám napovídá, jak máme brát do rukou oštěp a jaké pohyby máme napodobovat. Pak následují další fáze simulace. Tělesné pocity vyvolané nápodobou koordinujeme se změnami ve vnějším prostředím. Na jednu stranu tyto změny dávají význam našemu jednání (jsme schopni zasáhnout cíl), na stranu druhou tělesné pocity propojují tyto významy s novou činností a se strukturou naší předešlé habituace ve světě - tím se vytváŕí další spirála senzomotorického okruhu, která restrukturuje významovou rovinu.
} 
Podle Lakoffa, Johnsona, Galleseho a dalších se senzomotorickými procesy strukturují inter-aktivity organismu a prostředí, a formuje se tak repertoár možného jednání. Vzájemná souvislost těchto procesů je zdrojem smysluplnosti života. Smysl je na té nejbazálnější úrovni dán tím, že vybrané jednání zapadá do celkové senzomotorické situace. Smysluplnost jednání na té nejabstraktnější úrovni - například volba nejracionálnějšího řešení „uprchlické krize“ je utvářen a zakotven $\mathrm{v}$ lidské tělesnosti. Tato souvislost vede $\mathrm{k}$ utváření schémat, která umožňují organismu komplexně hodnotit podobné události a podobně na ně reagovat. ${ }^{67}$ Strukturují zkušenost na obecnější úrovni. Schémata jsou významy konkrétních pojmů, nebot' se utvářejí „neurálně jako senzomotorická schémata, která organizují funkcionální, neuronální klastry do významuplných, integrovaných gestaltư“ (Johnson, 2008, s. 162). Význam těchto gestaltů moduluje procesované informace do škály budoucích možných aktivit. Tímto na neuronální úrovni krystalizují konkrétni pojmy: např. nazírání, uchopování, manipulování, přesouvání atd. Podstatné zde je, že se touto koncepcí jednoty mezi senzomotorickými aktivitami a konkrétními pojmy ruší tradiční raně moderní předpoklad „dvou paralelních systémů, jeden z nich je tvořen senzomotorickými procesy, druhý zase pojmy, které pokrývají zmíněné procesy“ (tamtéž, s. 164). Strukturované a koordinované neuronální procesy jsou pojmy, jež se primárně projevují ve způsobu jednání a jeho di̊sledcích a teprve sekundárně mohou být vyjádřeny jazykem prostřednictvím jeho znaků, sémantiky, syntaxe a pragmatiky.

Abstraktní pojmy jsou podle zmíněných autorů utvářeny metaforickým přenosem významů senzomotorické aktivity na aktivity, které jsou ř́zeny jinými oblastmi mozku. K tomuto abstrakčnímu zdvihu napomáhají tzv. konceptuální metafory (conceptual metaphors), které řídí přenesení vlastností konkrétních pojmů na ony jiné oblasti, jež zajišstují abstraktní myšlení (srov. tamtéž, s. 176-179).

„...Hypotéza konceptuální metafory nahlížená z perspektivy neurálních procesů tvrdí, že neurální mapování (neural mapping) je základem pro konceptuální mapování (conceptual mapping), jež konstituuje konceptuální metaforu. Metaforické mapování je fyzicky uskutečňováno ve stabilní neurální soustavě oběhů (neural circuitry), která propojuje senzomotorický systém s ostatními oblastmi mozku. Vyjádřeno ještě jinak, jestliže zde působí konceptuální metafory, musejí zde existovat propojení senzomotorických oblastí mozku s ostatními oblastmi, které jsou zapojeny do procesu myšlení...“

(Johnson, 2008, s. 167)

\footnotetext{
$67 \mathrm{~S}$ těmito schématy pracují i zmíněné zrcadlové neurony. ZN jsou jen částí neuronálních aktivit, které se podílejí na senzomotorickém okruhu jednání. Na jejich funkci si však můžeme přehledně dokumentovat výše zmíněnou multimodálnost: Nejenže tento typ neuronů vykazuje aktivitu, když zkoumaná osoba sleduje nějakou činnost (senzorický aspekt), ale zároveň situaci hodnotí a připravuje následnou reakci (motorický aspekt). Jestliže je předmět např. uchopen přesným úchopem (the presicion grip), jsou předpřipraveny jiné typy jednání než v prrípadě, kdy se člověk před námi zmocňuje předmětu úchopem celé ruky (the whole-hand grip) (srov. Iacoboni, 2009, s. 22-24).
} 
Přestože Johnson připouští, že se jedná o hypotézu, v celé knize dokládá, že tato hypotéza je stále zřetelněji podporována kognitivní vědou a neurovědou a zároveň daleko koherentněji řeší problematiku poznání. Metafora je v tomto pojetí základním generátorem významů. $\mathrm{Na}$ rozdíl od objektivistické teorie v experiencialistickém pojetí nejsou metafory primárně lingvistickou záležitostí, ale záležitostí myšlení a činnosti. Jazykové jsou až odvozeně (srov. Lakoff \& Johnson, 2002, s. 170).

Jak jsou konstruovány abstraktní pojmy z pojmů konkrétních, si můžeme dokumentovat na př́kladu formace významu abstraktního pojmu pochopeni bud' prostřednictvím senzomotorické aktivity, která je podkladem konkrétního pojmu nazírání, anebo prostř̌ednictvím jiné senzomotorické aktivity, která je podkladem konkrétního pojmu uchopení. Jestliže procesu pochopení budeme rozumět na základě metafory nazírání, pak pro nás pochopení bude pohledem svého druhu. A díky tomuto přenosu může být 1) idea, které někdo porozuměl, chápána jako zahlédnutý předmět, 2) porozumění významu ideje může být chápáno jako zahlédnutí předmětu jasným způsobem, 3) člověk, který rozumí, může být chápán jako člověk, který jasně zahlédl předmět atd. (srov. Johnson, 2008, s. 165). Jestliže naopak pochopení budeme strukturovat na základě metafory uchopování, pak tomuto pojmu budeme rozumět jako zvláštnímu typu uchopení něčeho. Díky tomu zase budeme 1) pochopení něčeho nahlížet jako uchopení nějakého předmětu, 2) hloubku pochopení nahlížet jako sílu, s níž předmět držíme, 3) neschopnost něco pochopit budeme nahlížet jako stav, kdy předmět nedržíme a nejsme s to jej uchopit atd. (srov. tamtéž, s. 165). Tak přenosem vlastností z konkrétních pojmů na abstraktnější aktivity vzniká struktura významu abstraktních pojmů a jejich vzájemných vztahů. Ty se na vyšší rovině mohou podobným způsobem kř́žit, prohlubovat, rozrůzňovat (k tomu viz především Lakoff \& Johnson, 2002, s. 113-130).

Základní představová schémata poskytují nejen základní prostorovou a časovou orientaci, ale jsou to již ony, které podkládají ty nejabstraktnější typy jednání (byt' jsou v následných metaforických zdvizích obohacovány a rozrůzňovány dalšími metaforickými kombinacemi). V podstatě umožňují otevřít život přesahu, který je podle našeho pyšného přesvědčení typický pouze pro lidské bytosti. Axelsenová při analýze Lakoffova a Johnsonova pojetí metafory a při jeho propojení s pojetím Kohákovým ukazuje, jak se představová schémata stávají možností spirituálního ukotvení života. Schéma nádoby a jeho metaforický zdvih do oblasti celkového životního osudu umožňuje strukturovat myšlenku 
domova (domov je nádoba) jako zdroje citové a duševní opory, jako zdroje smyslu života (domov-nádoba je obklopena smysluplným okolním celkem), přičemž takové pojetí domova může člověku pomoci „pochopit místo člověka v kosmu“ (srov. Axelsonová, 2012, s. 346$347)$.

Proto není překvapení, že i ty nejabstraktnější oblasti lidské kognitivní aktivity jsou v nezanedbatelné míře ukotveny v tělesnosti, které jsou následně prostřednictvím metafor vyzdviženy do dalších abstraktních rovin. Lakoff a Nunez v monografii Where mathematics comes from (2000) považují současnou podobu matematiky za kombinaci dvou aspektů lidské zkušenosti. První z nich jsou vrozené schopnosti používat nejelementárnější procedury orientace $\mathrm{v}$ geometrickém prostoru a nejelementárnější aritmetické procedury (např. rozlišení malého počtu čísel, jednotné uchopení malého počtu čísel - tzv. subitace). V porovnání s rozvinutými prostory současné matematiky jsou tyto vrozené schopnosti velice skromné. Druhým aspektem je schopnost uplatňovat na ně konceptuální metafory. Jejich kombinací se formují nové prostory (či prostředi) matematického myšleni. ${ }^{68}$ Tato kombinace vytvořila možnost existence takových průlomů, jakým je např. infinitezimální počet nebo teorie množin (srov. tamtéž, s. 15-103).

Hejného metoda výuky matematiky je vedle dalších zákonitostí založena především na objevování matematických prostorů prostřednictvím tělesně ukotvených zkušeností a na vzájemné sociální kooperaci mezi žáky i mezi žáky a učitelem. Sociální kooperace není pouze prostředkem „dorozuměni““, ale také opětovným formováním abstrakčního zdvihu, původně způsobeného určitou konceptuální metaforou (či metaforami). Toto opětovné formování pomáhá žákům zevnitř pochopit pravidla daného matematického prostoru (představitelé metody zde používají slovo „prostředí“). Výsledky naznačují, že na Lakoffově a Nunezově hypotéze je pravděpodobně více pravdivého, než si byli matematici ještě nedávno ochotni přiznat. Žáci se dostávají $\mathrm{k}$ logice komplexních matematických prostorů prostřednictvím faktu, že rozvíjejí vrozené matematické a geometrické základy pomocí senzomotorického osvojování navazujících zákonitostí. Takto nabytý a senzomotoricky ukotvený komplex je $\mathrm{v}$ žácích dále rozvíjen tím, že se učí přecházet $\mathrm{z}$ jednoho prostoru (prostředí) do druhého.

\footnotetext{
${ }^{68}$ „Vezměme například v úvahu metaforu: Čísla jsou body na úsečce. Čísla nemají být konceptualizována jako body na úsečce, protože nejsou geometrickými pojmy. Ale číselná osa je jedním z centrálních pojmů v celé matematice. Analytická geometrie by bez ní neexistovala a stejně tak trigonometrie. Nebo pohlédněme na metaforu: Č́sla jsou množiny... Neměli bychom přeci konceptualizovat čísla jako množiny. Aritmetika existovala více jak dvě milénia bez této metafory... Ale jestliže přijmeme tuto metaforu, pak stvoř́íme takový způsob uvažovaní, který může aplikovat množiny také na čísla.“ (Lakoff \& Nunez, 2000, s. 6).
} 
Když fixují prostupnost prostorů, učí se chápat jejich vzájemnou souvislost - zevnitř tak pronikají do zákonitostí matematického a geometrického systému. Ve své podstatě následují trajektorii historického vývoje matematického myšlení od jednoduchého, vtělesněného momentu k momentům komplexním a vysoce abstraktním.

Podstatné je, že veškeré činnosti - od konkrétnich až po ty nejabstraktnější - jsou prímo nebo neprímo ukotveny v našem těle-mysli a jsou tělem-myslí koordinovány. Tato skutečnost je pro náš výzkum klíčová. Když budeme níže mluvit o tom, jak zpětným metaforizačním posunem v reflexi nepřímo vedeme naše studenty $\mathrm{k}$ tělesné zkušenosti, pak využíváme zakotvení abstraktního myšlení v těle-mysli, vracíme studenty ke konceptuální metafoře a přivádíme je k logice jejich jednání.

Metafory si zachovávají vlastnost gestaltu. V tom spočívá jejich podmanivost a tvořivá síla. At’ je účinná metafora jakkoli složitě strukturovaná, vždy se dá pochopit „naráz“, „jedním přehlédnutím“. Proto některé metafory dokáží preformovat způsob myšlení lidí po mnoho staletí - jsou podložím, z něhož povstávají a udržují se slohy myšlení a jednání (k tomu viz 1.1 výše). Na obou variantách strukturace abstraktního pojmu pochopení si můžeme dokumentovat, jak takové strukturace mohou významně ovlivnit naše chápání světa, přestože se tento svět „reálně“ nezměnil. Jestliže pochopení budeme strukturovat pomocí metafory pohledu (nazíráni), pak to má vážné důsledky pro naši teorii poznání. Převládající stř̌edověká teorie poznání (jednalo se o tomistickou variaci na aristotelské sejímání tvaru pohledem duše) a novověká teorie poznání (poznání jako evidence reprezentací vnějších předmětů ve vnitřním prostoru mysli) sdílejí - přes všechny své odlišnosti - celou množinu vizuálních metafor, které jsou řízeny základní metaforou nazírání a které nakonec zapř́íčiňují, že poznání rozumíme jako ději, jenž se odehrává výhradně v našich hlavách - at' už v hlavách jedinců, nebo $\mathrm{v}$ hlavách společenství myslí. V nadvládě takové vizuální metaforiky chápeme velice snadno výsledek poznání jako poznatek, tedy jako to, co se odehrává v mysli a tam se uchovává v podobě mentálního objektu. ${ }^{69}$

Ani v zakládající metafoře pochopení je nazírání, ani v metafoře pochopení je uchopení nejsme schopni dát jakýkoli smysl představě, že znalost je sjednocení znalostního pole,

\footnotetext{
${ }^{69}$ A i když budeme bojovat proti nebezpečí psychologismu mentálních objektů podobně jako Bolzano, Frege (viz poznámku 24 výše) či raný Husserl (viz poznámku 17 výše), pak musíme vymýšlet nějaký další svět - „,řetí ř́ı̌si“ či „transcendentální rovinu významu“, v níž existují „,věty o sobě“, významy, abstraktní objekty, invarianty, k nimž se mentální objekty vztahují, aby mohly být pravdivé. Avšak tím neni logika vizuálni metaforiky prekročena. Do této říše zase nahližime - bud' zrakem svého rozumu (Bolzano, Frege), anebo přes plátno našeho vědomí (Husserl).
} 
kterého je dosahováno jak v hlavě jedince, tak ve vnějším světě. Obě metafory - pochopeni je nazírání / pochopení je uchopování - totiž předem formují znalost jako předmět, který je v prvním prrípadě nahližen myslí a ve druhém uchopován myslí. Abychom byli schopni vymknout se této metaforické dlouhé tradici, kterou obě metafory podsouvaly, museli jsme se obrátit k Deweyho metafoře pochopení je zapadnutí kliče do zámku a otevření dveři. ${ }^{70}$

Shrňme si předešlé odstavce. Mark Johnson v The meaning of the body (2008, s. 113206) ukazuje, jak proces metaforizace stoupá od multimodálních představových schémat, v nichž se křiží svazky senzorických a motorických okruhů, které strukturují zkušenost do významových gestaltů, čímž se ustavují konkrétní pojmy; ukazuje, jak jsou tyto pojmy zdrojem dalšího metaforického zdvihu prostřednictvím tzv. konceptuálních metafor (conceptual metaphors). Tyto metaforické zdvihy generují abstraktní pojmy a abstraktní vztahy mezi nimi. Tímto způsobem metafory a shluky metafor strukturují naše celkové porozumění světu. $^{71}$

Náš jazyk je něžným hřbitovem metaforické strukturace. Metafory v něm potkáváme všude, byt' si jich většinou nevšímáme, protože již ztratily svoji nekonvenčnost. Konvenční metafory jsou takovými metaforami, které utvářejí naši strukturaci světa, aniž bychom si většinou uvědomovali, že se původně jednalo o metafory. Většinou jim již nerozumíme jako metaforám a jejich jazykové figury bereme za doslovné pojmenování světa kolem nás. Touto neviditelností hluboce ovlivňují naše porozumění světu. Mimo jiné i tím, že vytvářejí představu, že pravdivostní podmínky jsou dány doslovným jazykem. Ve své podstatě jsou to ale metafory, jež řídí jak systém utváření pravdivostních podmínek, tak systém distribuce podobností, na základě kterých můžeme dosahovat metaforických přenosů. Metafory jsou zakotveny pod úrovní jazyka, v oblasti jednání.

Vstup nekonvenční metafory do jazykového řádu je vynucen tím, že je zaveden nový systém podobností, který umožňuje novou metaforizaci. Tím se ruší systém původních pravdivostních podmínek a formují se nové pravdivostní podmínky. Jestliže je figurativní jazykové pojmenování zaznamenáno, značí to, že do zdánlivě doslovně popsaného světa vstoupila nekonvenční metafora a rozehrála redistribuci podobností a umožnila nové významové posuny. Většina důležitých nekonvenčních metafor časem „zevšední“ a stane se

\footnotetext{
${ }^{70}$ Lakoffova a Johnsonova kniha Philosophy in the flesh (1999) je věnována právě tomu, jak byly euroamerická filozofie a věda, odvozeny z těchto filozofických východisek, chyceny v nadvládě několika základních metafor, které nám dosud bránily dokončit moderní obrat, dosáhnout stadia pozdní moderny.

${ }^{71}$ Podrobnou charakteristiku strukturace světa prostřednictvím procesu neustálé metaforizace čtenári mohou najít i v českém překladu Lakoffovy a Johnsonovy knihy Metafory, kterými žijeme (2002).
} 
součástí konvenčního metaforického arzenálu, skrze který rozumíme světu (Lakoff \& Johnson, 2002, s. 164-172). Tak metafora prochází procesem zdoslovnění, proměňuje se ze „živé metafory“ v „mrtvou“ (Ricoeur). V každém případě naše porozumění světu je skrz na skrz metaforické. Mrtvé metafory doslovného jazyka vytvářejí bojové pole, do něhož může vstoupit nekonvenční metafora, která v sobě nese energii symbolu a proměňuje naše porozumění světu.

Ve třetí, poslední část The meaning of the body (2008, s. 207-283) Johnson dokládá, jak se na jedné straně abstraktní myšlení nesené a strukturované složitým systémem metafor podílí na estetickém uchopování světa, ale na straně druhé, jak je toto uchopování skrze metaforu a její závislost na tělesném dění vázáno k našemu světu. Proces metaforizace je procesem nacházení náležitých významů, které vedou naše životy. Komplexní estetické formy, jaké můžeme najít ve vrcholných estetických dílech poezie, románu, malířství, hudby - těmito tématy Johnson graduje svůj výklad (srov. tamtéž, s. 209-262) - jsou vnořeny do tělesného dění a skrze tělesné dění je určeno jejich téma (subject-matter), které je pak rozváděno do konkrétní formy. Umění je jen rafinovanější, komplexnější a zkušenější podobou každodenní kognitivní aktivity. Jestliže Masaryk kdysi tvrdil, že charakter národa pozná prostřednictvím jeho umění (měl na mysli především romány), pak přistupoval k poznání tak složitého a dynamického jevu, jakým je národ, přesně tímto pragmatistickofenomenologickým způsobem.

Zmínka o tématu a jeho rozvádění do konkrétní formy nás přivádí ke vztahu metafory (figurativního myšlení) a kognitivní aktivity. Metafora je mimo jiné komplexním prostředkem vyzdvižení a vyjádření kvality situace a má z principu kognitivní charakter, který spočívá v tom, že uvolñuje náš predcházejicí popis reality a vnáši do něho prvek, kterým definici reality mění (k tomu viz níže pasáž o rozštěpení reference). Metafora je vyjádřením intuice, jež uchopuje kvalitu situace a startuje kognitivní proces (k odborným termínům situace, kvalita, intuice viz 1.2.3 výše). Hlavním úkolem metafory je napomoci novému porozumění světa kolem nás. Proto pod pojem metafora řadíme všechny ty jazykové figury, které vnášejí do pojmenování reality prvek polysémičnosti: katechrezi, synestezii, personifikaci, analogii, synekdochu, antonomázii, hyperbolu, litotes, perifrázi atd. Jak níže uvidíme, polysémie je nutnou vlastností pro jazykovou experimentaci, která je neodlučitelnou součástí začleňování nových poznatků do systému již přijaté znalosti. Stejně jako konceptuální integrace, metafora i polysémičnost nejsou primárně jazykovou záležitostí. Když náš paleolitický vynálezce luku 
a šípu začal užívat sousloví „malý oštěp“, začal narušovat sémantickou stabilitu oštěpu, začal zároveň prakticky manipulovat $\mathrm{s}$ charakteristikami svého okolí. Návrat k polysémičnosti znaků je návratem $\mathrm{k}$ bytostnému vztahu $\mathrm{k}$ tělesnosti, kde se systém významové struktury utvárí.

Metafora je pro nás vyzdvižením a zaměrením určité části zkušenosti, která před jejím uvedením do jazykového systému nebyla „vzata na vědomi “ či nebyla ,zahrnuta do védomého pole“, ovšem situace, v níz se nyní nacházíme, si tento proces vyzdvižení a zaměrení vyžaduje. Proto pro nás nemůže být metafora charakterizována jako „vtiskávání signatury“, kterým se předává určitá struktura (srov. Slavík, Chrz, Štech et al., 2013, s. 226-230). Když metafora vstupuje do jazykového vyjádření, má svoji motivaci - ta je dána její návazností na průběh života a jeho potřeby $\mathrm{v}$ dané situaci. Ovšem tato motivace neznamená předem danou strukturu, kterou by vtiskávala. Metafora vynáší téma situace a konkrétní naplňování tématu je věcí s otevřeným koncem. Metafoře bychom mohli porozumět jako vtiskávání signatury jedině ze zpětného pohledu. Zpětný pohled se na metaforu jako uzavřenou strukturu dívá tehdy, když je mise metafory již ukončena. Např́iklad když se metafora již v jazykovém vyjádření zdoslovnila a proces její konfigurace je uzavřen. Nebo když reflektivně hodnotíme roli určité metafory $\mathrm{v}$ rozvíjení nějakého uměleckého žánru (např́iklad tragické narativní struktury - srov. tamtéž, s. 229-230). Podle autorů Tvorby je proces užití metafory podřízen společnému pravidlu, protože porozumění metaforickému vyjádření „vždy vyžaduje určitý postup obrazotvornosti vyhmatávající zmíněné ,společné pravidlo““ (srov. tamtéž, s. 231). Ovšem takové společné pravidlo je pravidlem zpětného pohledu. Ve chvíli vstupu metafory do jazykového vyjádření se mění pravidla jak pro určení významu předmětu, jehož vlastnosti jsou v procesu metaforizace přenášeny, tak toho předmětu, na který jsou tyto vlastnosti přenášeny, a společné pravidlo se ustanovuje až poté, co je proces dané metaforizace ukončen.

Proto navrhujeme jinou metaforu, na základě které bychom měli rozumět metaforickému porozumění. Jedná se o metaforu posunu kuželu světla v potemnělém prostoru. $V$ této metafoře je podstatný strukturovaný prostor, $v$ němž dochází $k$ posunu jasného bodového reflektoru z jedné jeho části do druhé, přičemž tento posun vede $k$ novému porozumění prostoru. Toto nové porozumění je tvořeno posunem světelného kuželu a překrýváním postupně slábnouci vzpomínky na pưvodně osvícenou část s nově osvětlenou částí, na niž se kužel světla dočasně ustálil. 
Přechodovou fázi překračujeme jen malým krůčkem, jen malou změnou důrazu, kde se přesouváme od struktury jazyka, metafory, poznávání, porozumění k jejich funkci. Tento krůček má však za následek koncentraci důsledků, která vede k efektu, jenž se v teorii dynamických systémů nazývá „pákový“. Výrazně mění naše pojetí poznání i naše pochopení toho, jak jsme zapuštěni do světa kolem nás. Tímto krokem jsme donuceni pochopit jazyk jako pohybujici se kontinuitu mezi doslovným a poetickým modem. Spojitost jazyka, jeho kontinua, je utvářena tím, že významy vyvstávaji z tělesného jednání a tělesných dějů a tyto děje mají svoji dynamickou pravidelnost. Pravidelnost, která sice procházi neustálou zmènou, ale samotný průběh této proměny vytvárí identifikující spojitost.

Co je tedy to, s čím metafora vstupuje do jazyka? Jinými slovy, ptáme se po funkci metafory. Co metafora dělá s jazykem, co dělá s naším porozuměním, co dělá s naším pojetím světa? Ricoeur na otázky odpovídá tak, že inspirován Jakobsonem pojmenovává tuto funkci rozštěpování reference, tedy reference splittting (srov. Ricouer, 1977, s. 259-260). Využívá př́kladů poezie, aby poukázal na vlastnost jazyka, který pomocí metafory (ve výše charakterizovaném širokém smyslu) dokáže pozměnit pozadí, na základě něhož se nám na podvědomé úrovni utváří řád porozumění světu. Tento řád ovlivňuje naše vědomé uchopení světa. Pozadí určuje oblast denotace, podmiňuje vytyčování entit a jejich vztahů. Modelováním nových či rekonstruováním starých entit a vztahů proměňuje komplexní zkušenost na propoziční charakter vět a na vědomé úrovni zavádí možnost nové fixace významů pomocí jazykem sdílených pravdivostních podmínek.

Slovem ,pozadí“ zde máme na mysli to, co vystupuje z významové bohatosti obsahu, která v daném čase a za daných okolností privileguje pouze některé z jeho potencionálních významů. Již jsme se zmínili o Ricoeurově definici metafory ve vztahu k symbolu. Jak pro symbol, tak pro metaforu je podstatná skutečnost, že jsou neseny nadbytkem významu, který z principu nemůže být zcela uchopen ani jazykovými prostředky, ani naším vědomím. Oba procesy (využití jazykových prostředků k lingvistické expresi, využití mentálních prostředků vědomí $\mathrm{k}$ představové expresi) jsou způsobem, jakým člověk z nadbytku významu selektivně vybírá jen určitý obsah (srov. Ricoeur 1997). Je tomu tak proto, že vědomí je př́liš křehký nástroj a není schopno pojmout takové množství informačních souvislostí. Výše jsme již zmínili kvalifikovaný odhad Lakoffa a Johnsona, že kognitivní nevědomé procesy (cognitive unconscious) tvoří až 95 \% kognitivních dějů (srov. Lakoff \& Johnson, 1999, s. 21-26). 
Proto se dynamické struktury významů dostávají do našeho pole vědomí pouze výběrově a vždy vzhledem k našim potřebám.

Děje se tomu tak, že je rozrušena synchronnost sémantického řádu jazyka. Při procesu rozštěpení není reference úplně zrušena. Reference vždy denotuje, ale svět, k němuž se po rozštěpení referuje, má částečně odlišné pozadí, a proto je částečně jiným světem. Vytvárí se denotace druhého řádu, která suspendovala řád denotace první. Jinými slovy metaforická výpověd' je hybatelem, jenž umožňuje potlačit referenci prvního řádu, je schopností pochopit strukturu dané situace ,ještě jinak", než bylo možné za podmínek reference prvního řádu (srov. s. Ricoeur, 1977, s. 261).

Celá Ricoeurova kniha o metaforách přibližuje myšlenku, která je dnes mezi odborníky na metaforu (srov. Kövecses 2010, 2015; Lakoff \& Johnson, 2002) vcelku běžně přijímána, ovšem v době prvního vydání knihy (francouzsky 1975) byla avantgardní: jazykové vyjádření a její interpretace jsou umožněny tím, že spolu působí jak jazykový řád, který je utvářen znaky a který je nahlížen $\mathrm{v}$ synchronním pohledu, tak diskurzivní akt, který využívá prostředků tohoto řádu, ale zároveň do něj zavádí diachronní pohyb, a proto může měnit podmínky reference - může referenci „rozštěpit" (srov. Ricoeur, 1977, s. 255-261). Současní představitelé kognitivní lingvistiky „rozštěpení reference“ popisují jinými slovy jako procesy konceptuální integrace, jehož podstatou je proces konceptuálního mísení (blending) atp. (srov. Kövecses, 2010, 269-283; 2015, s. 16-30). Změněné podmínky reference jsou utvářeny použitím metafory, která vnáší do diskurzu prvek neurčitosti a polysémie (srov. Zanotto \& Palma, 2008, s. 13-15). Prvek polysémie obrací naši pozornost k základní vlastnosti strukturované zkušenosti - knadbytku významů, který je ve svém celku ve vědomí neuchopitelný. Tento pro vědomí naddimenzovaný obsah musíme redukovat, abychom byli schopni danou situaci vědomě popsat, porozumět jí a následně v ní náležitě jednat. Jestliže jsme se prostřednictvím metafory a její polysémie vymkli doslovnému popisu, máme náhle prostor svět pochopit a následně popsat jiným zpơsobem. Jedná se o existenciální transformaci, lingvistický oděv metafory je pouhým prostředkem této transformace.

Ricoeur ukazuje, jak metafora predstírá, že přesouvá význam pouze v paradigmatickém smyslu (tedy, že zaměňuje jednu hodnotu $\mathrm{v}$ predikátu za hodnotu druhou, systémově souměrnou). Toto předstírání metafoře umožňuje, aby mohla vstoupit do jazykového řádu. Po svém vstupu však metafora ve skutečnosti rozruší pozadí výpovědi a nastoluje polysémii či utváŕí prostor pro rozštěpení reference (srov. 1977, s. 76-87). Například námi 
zkoumaná studentka Alena započala svou výpověd' o jedné náročné neočekávané situaci takto: „Žáci byli...“72 Taková věta primárně naznačuje, že následující přesun významu bude učiněn pouze na paradigmatické rovině, kdy se hodnota v predikátu nahradí nějakou jinou, sémioticky souměřitelnou hodnotou. Například věta: žáci byli hodní, bude nahrazena větou: žáci byli nepozorní nebo větou: žáci byli rozjívení. Ovšem, když byla tato věta poté dokončena spojením: ,jak opičáci“, pak se zcela mění situace. Komplexní nekonvenční metafora: žáci jsou opičáci, nastoluje změnu na syntagmatické úrovni. Tedy na úrovni, která mění podmínky denotování, vytváří prostor pro rozštěpení reference. Tím, že byl člověk v jistém smyslu ztotožněn se zvířetem, se náhle mění pozadí, na základě kterého můžeme výpověd' interpretovat. Interpretace samozřejmě mohou být různé podle toho, zda do centra naší pozornosti zařadíme význam „rozjívení” , „nepozorní”, „neposlušní”, „poskakující" , „,nedisciplinovaní" atd. Metafora ale naznačuje zcela novou a mnohem bohatší a komplexnější zkušenost, kterou bychom nemohli vyčíst z věty: žáci byli nepozorní nebo z věty: žáci poskakovali po tř́dě. Hledání interpretace se nespokojuje s jednosměrným přesunem ze zdrojové oblasti metaforizačního procesu do oblasti cílové tohoto procesu (k tomu viz níže). Žák (člověk) zjevně není opičák (zvíře), proto je nutné přebíhat ze zdrojové oblasti do oblasti cílové tam a zpět a $\mathrm{v}$ neustálém poměřování vlastností v jedné a $\mathrm{v}$ druhé oblasti nakonec dojít $\mathrm{k}$ výběru souhrnu vlastností, na základě kterých dojde $\mathrm{k}$ celkové konceptuální integraci.

Ve svém pověstném př́kladu Kövecses popisuje podobně složitý proces na metaforickém posunu ve větě ,ten chirurg je řezník“ (srov. 2010, s. 305-322; 2013). My jeho výklad přizpůsobíme naší metafoře: žáci jsou opičáci. Kövecses inspirován texty Fauconniera a Turnera (2008) o konceptuální integraci a mentálních prostorech přidává $\mathrm{k}$ Lakoffovu a Johnsonovu přesunu významu mezi zdrojovou (source domain) a cílovou oblastí (target domain) ještě oblast smíšenou (blended domain) a poukazuje na její zvláštní význam. Než se však dostaneme ke zvláštnímu procesu mísení významu, které probíhá ve všech třech oblastech, musíme se zmínit ještě o takzvaném generickém prostoru (generic space) - o zastřešujícím prostoru, v němž hledáme počáteční podobnosti, jejichž identifikace umožní odstartovat proces metaforizace.

\footnotetext{
${ }^{72} \mathrm{Na}$ tomto konkrétním př́kladu představujeme metaforickou práci našich studentů ve chvíli zexplicitňování tacitní znalosti. Alena je anonymizované jméno, které zastupuje jednu studentku, jež nepř́jemnou situaci nepořádku ve třídě vyřešila tím, že zašla pro ředitele školy. Zásah zvenčí se v dané situaci zdál na podvědomé úrovni jediným možným řešení. Jednání studentky vedlo k obnovení režimu výuky. K celému procesu viz kapitolu 9.
} 
I naši autoři správně poukazují na skutečnost, že „k porozumění... metafoře je nutné zacházet s komplexnějšími významovými trsy“ (Slavík, Chrz, Štech et al., 2013, s. 192). Otázkou ale zůstává, co utváří vnitřní propojení „významových trsů“. Výše jsme mluvili o tom, že konvenční metafory řídí stanovování pravdivostních podmínek, ale také distribuci podobností a odlišností. Podobnosti pak umožňují metaforické posuny. V př́padě konvenčních metafor nás metaforické posuny nepřekvapí. Na příklad v básni, jejímž hlavním tématem je proměna lásky ve vztahu ke stáří, byla poslední strofa uvedena verši: podruhé ji potkal jsem / když má hlava byla pokryta již sněhem. Běloba sněhu a šediny stáří jsou často metaforicky propojovány, jedná se o velice konvenční metaforický posun, a proto můžeme tuto metaforu číst s jistou lehkostí - snadno jí rozumíme. Ovšem čím větší je míra lehkosti porozumění, tím více podléháme povrchnímu čtení metafory. $\mathrm{V}$ takových př́ípadech se soustředíme na „prostřední člen“ a na podoby, které tento prostřední člen zastupují. V tomto případě je to bělost - sněhu a vlasu.

Metaforu vlasy pokryté sněhem analyzujeme - pokud ji ještě vůbec analyzujeme - jako přenesení vlastnosti ročního období na člověka, prostřednictvím podoby mezi bělobou sněhu a bělobou šedivých vlasů. Když se však soustředíme pouze na „prostřední člen“ - bělobu, pak se takovou analýzou zcela míjíme s podstatou vstupu této metafory do řádu jazyka, nechápeme hloubku rozštěpení reference a zůstáváme zcela na povrchu. Metaforu jsme si ochočili poukazem na jednu z ,podobností“. Ovšem v metaforickém posunu nejde o jednotlivé podobnosti a rozdílnosti, ale o celkový systém, který podobnosti a odlišnosti utvářejí. Vztahovost systému navíc umožňuje, aby se systém proměňoval. Jde tedy opět o velice komplexní záležitost, kterou netvoří jedna či deset vlastností, ale kontinuum souvislostí, jež umožňuje vyčlenit určité vlastnosti, a jež se tak stanou v metaforickém posunu nejviditelnější. Za těmito nejviditelnějšími vlastnostmi však operuje celý zmíněný komplex významových vztahů, který nelze redukovat na ony nejviditelnější vlastnosti. To, že kdysi dávno první původce této metafory použil smísení běloby sněhu a šedin vlasu, mělo daleko hlubší a celostní motivace. Ve své podstatě se jednalo o promísení celého komplexu vlastností zimního období s procesem stárnutí a se stářím jako výsledkem tohoto procesu.

Ve výše analyzované metafoře: slunce rozsévá světlo, byla tato komplexita viditelnější, protože nás nemohla omezit zjevná podobnost - mezi sluncem a rozsévačem není nic podobného, na rozdíl od sněhu a šedivých vlasů, kde komplexitu zastupuje bílá barva. Proto jsme si na metafoře: slunce rozsévá světlo, mohli dokumentovat, jak metafora vytryskla 
z provázání významových oblastí „slunce a jeho záření“ a ,zemědělské činnosti“ a vynesla na pole vědomí bytostný vztah mezi těmito oblastmi. Ale stejně tak je to ve skutečnosti i v našem př́padě vlasů pokrytých sněhem. Podstatou této metafory je fáze života, v němž ubývá sil a tento úbytek se promítá i do fyzické charakteristiky výživy lidského vlasu. Fyzická stránka koresponduje s psychickými vlastnostmi, kdy člověku nakonec nezbývá než se s úbytkem sil smířit, smírit se s blížící se smrtí a se skutečností, že mnohé z možností, před kterými jsme stáli v mladším věku, nenávratně zmizely. Zmizely jako ona možnost, která byla tématem básně - její hrdina již nikdy neprožije onen žhoucí milostný vztah, jenž v mládí vzklíčil k určité ženě. Zároveň ale zima života poskytuje jiné perspektivy - vyrovnanost, nadhled, smíření, které nejsou a nemohou být $\mathrm{k}$ dispozici zdravému mladému člověku, stejně jako nemohou být vlastní přírodě $\mathrm{v}$ plném rozpuku jejích živoucích sil na jaře a v létě.

Generický prostor, ve kterém se utvářejí podobnosti a souvislosti, je mnohem a mnohem širší než ten, který máme $\mathrm{k}$ dispozici, když se soustředíme pouze na povrchové, dobře čitelné podobnosti a odlišnosti. Generický prostor je utvářen komplexitou vývoje kosmu a jeho příslušných částí - v našem př́ípadě je dána hlubokým souladem mezi zimním obdobím a stáŕím. V dalších výše zmíněných případech mezi porážkou zvířat a jejich porcováním a charakterem chirurgické práce a $\mathrm{v}$ další metafoře mezi lidmi a jinými vyššími primáty. Nekonvenční metafora je pro nás vždy větší výzvou a nutí nás, abychom se ponořili do komplexity generického prostoru mnohem hlouběji a proměnili naše dosavadní porozumění. Konvenční metafora nás uklidňuje a strhává pozornost k ostrým pojmům ${ }^{73}$ doslovného jazyka a k jeho striktně ohraničeným významům, pomocí kterých (ovšem jen zdánlivě) snadno určujeme systém podobností a odlišností.

Nyní se vrátíme k výkladu, jak metafora metaforizuje v případě věty: Žáci jsou opičáci. Žák (člověk) zjevně není opičákem (primátem), a přesto zde existuje velká biologická a kulturní souvislost mezi lidskými a ne-lidskými vyššími primáty. V komplexitě těchto vlastností dochází k posunům. Identita žáků a identita opic je výběrově redukována takovým způsobem, že může vzniknout překryv ve smíšené oblasti. Pro nás je ale podstatné, že tento překryv či zúžení na některé z vlastností není odečítán ze „skutečných“ vlastností, protože vzniká v tvorivém procesu metaforizace. Zjevnou sférou podobnosti budou znaky, které člověk jako vyšší primát sdílí s jinými vyššími primáty, například se šimpanzi: vzpřímená postava, chůze po dvou, speciální způsob uchopování předmětů rukama, ústa, která dokážou

\footnotetext{
${ }^{73} \mathrm{~K}$ ostrým pojmům viz níže.
} 
artikulovat zvuky a prostřednictvím nich komunikovat. Na základě těchto podobností bylo možné člověka a opici vztáhnout $\mathrm{k}$ sobě dávno předtím, než byla moderní prŕírodovědou potvrzena těsná evoluční souvislost mezi člověkem a vyššími primáty.

$\mathrm{V}$ následném kroku metaforizace, ale musela být nalezena nějaká odlišnost, jinak by kategorie žák a opičák splývaly a chyběla by př́ležitost $\mathrm{k}$ metaforickému přesunu. Tato odlišnost se odhaluje porovnáváním vlastností, k němuž dochází ve smíšené oblasti. Nakonec jsou identifikovány vedle dalších odlišností ty, které nejvíce odpovídají ohnisku dynamické struktury Aleniny zkušenosti. Z Aleniny výpovědi ${ }^{74}$ vyplývá, že základním ohniskem celého metaforického posunu byly tři skutečnosti: nekontrolovaný pohyb po třídě (skákání), řev a kontrast zviŕre vs. člověk (který je ale charakterizován jako bezbranný člověk, kterého celá situace prevyšuje - „človíček"). Poznamenejme, že v tomto př́ípadě je metafora: žáci jsou opičáci, strukturována další metaforou: žáci jsou stádem divokých zvírat. Jedná se o komplexní, zdvojenou metaforu. Ona druhá metafora (stádo divokých zvírat) naznačuje, jaké negativní rozdíly mezi žáky a opičáky jsou metaforicky vyzdvihovány. Využívá se zde předem zažitých a kulturně silně sdílených představ, jež strukturují opozice: zvíre versus člověk, príroda versus kultura, pudy versus sebekontrola. A dále s tělesně ukotvenou zkušeností (získanou např́klad při návštěvě zoologické zahrady nebo při sledování filmového dokumentu o šimpanzích), kdy jsme prožívali opičí komunikaci prostřednictvím artikulovaných zvuků a pohybů jako řev a skřeky a jejich pohyb jako nekontrolované poskakování.

Podstatné zde je, že podobnosti a odlišnosti byly v Alenině zkušenosti uloženy již před započetím metaforizace. K jejich zúžení a identifikaci však došlo až během procesu metaforizace. Předem daná struktura zkušenosti se náhle propojila s Aleninou potřebou vyjádřit novou zkušenost, kterou nabyla během praxe, a toto propojení a nedostatečné jazykové možnosti, jež jí poskytoval doslovný jazyk (,žáci pobíhali po třídě“, „žáci poskakovali“, „žáci křičeli“) byl důvodem zahájení procesu metaforizace. Díky prosáknutí zažitých kulturních vzorců a předvědění do procesu metaforizace je v následném kroku identifikován rozdíl mezi námi (lidmi) a jimi (opičáky) jako neschopnost sebekontroly a racionální (tj. kultivované, spořádané, disciplinované) řeči - viz obrázek 1 níže. A právě tato neschopnost je momentem, který určuje metaforický posun významů zdrojové oblasti. Opice

${ }^{74}$... Oni [žáci] už byli tak jako rozjetí a úplně jak opičáci skákali nahoru dolů a prostě řvali a ted' prostě já jsem tam byla takovej malej človíček mezi nima, mezi tím stádem prostě těch divokých zvírat... (z přepisu 4. rozhovoru s Alenou). 
jsou nedisciplinované, neschopné řeči, nesmyslně a nekoordinovaně poskakují. Ve skutečnosti to není pravda - jejich komunikace má podstatnou míru artikulovanosti, jejich pohyby vyjadřují potřeby a myšlenky. Neschopnost proměňuje i metaforický posun významů v cílové oblasti. Skuteční žáci jsou disciplinovaní, drží se ve vymezeném prostoru, bez příkazu se nepohybují po třídě a dokáží odpovídat, když jsou tázáni anebo komunikovat se spolužáky, když jsou k tomu vyzváni. Ovšem i toto porozumění není zcela pravdivé, takový popis se blíží spíše herbartovskému ideálu než tomu, co tvoří moderní výukový proces. Nicméně je to právě toto zaměření a vyzdvižení, které umožňuje Aleně artikulovat svoji zkušenost, vyrovnat se svým částečným selháním a navrhnout budoucí alterace jednání.



Obrázek 2. Komplexita přenosu mezi všemi oblastmi metaforizace.

Při těchto krocích (identifikace podobnosti, identifikace rozdílnosti, kulturně podmíněná interpretace podobností a odlišností, zpětné úpravy významu jak cílové, tak zdrojové oblasti) $^{75}$ jsme neustále „přebíhali““ od cílové do smíšené oblasti a zpět, od zdrojové do

\footnotetext{
${ }^{75}$ Ve skutečnosti jde o zjednodušení v tom smyslu, že se nejedná o „kroky“, ale o paralelní a velice rychlé procesy, jež tvoří skelet metaforizace.
} 
smíšené oblasti a zpět a toto „přebíháni““ utvářelo základní pohyby tam a zpět od zdrojové oblasti do cílové. V těchto ,přebíháních“ docházelo k identifikaci podobností a rozdílů a k ,překrývání“ významů a jejich porovnávání.

Mnohem více než autoři Tvorby (srov. Slavík, Chrz, Štech et al., 2013, s. 192-194) zde zdůrazňujeme dynamiku a procesuálnost, protože proces metaforizace není nikdy fakticky ukončen, každá struktura se každou setinu sekundy prolamuje do struktury více či méně odlišné, respektive nikdy tento proces v nějaké ukončené struktuře nezamrzne. Struktura se objevuje až ex post v reflektivním vědomém ohlédnutí. Je tedy zřejmé, že již nemůžeme jednoduše nazvat jednotlivé oblasti jako „cílová" či „zdrojová" nebo „smíšená" (to je pouze naše instrumentální lešení, kterým si v řeči pomáháme), protože jejich význam se uskutečňuje a ustaluje ve vzájemném vztahu a napětí. Ve chvíli, kdy dochází k metaforizaci, dochází také $\mathrm{k}$ tomu, co Ricoeur nazval „suspendací reference prvního řádu“ . V našem př́ípadě je prvním řádem: toto jsou lidé/žáci a toto jsou opice, a objevuje se „druhý řád reference" : lidé/žáci jsou kultivovaní, disciplinovaní, sedí na svých místech a mluví způsobně a „racionálně"; opice jsou nekultivované, nedisciplinované, nesmyslně se pohybují a řvou. Interpretace světa kolem nás probíhá právě v kaskádách takových suspendací a proměn reference. Nemáme proto před sebou nějaký nám předem přístupný svět s jasnou a neměnnou strukturou, který byl nutnou existenční podmínkou objektivistického realismu v jeho ideálně-typické podobě.

\subsubsection{Metaforizace, fenomenologická analýza a rozvíjení metaforické krajiny}

Proces, který umožňuje komplexní proměny porozumění naznačené výše, nazýváme procesem metaforizace. Pro naše teoretické potřeby pracovně rozlišujeme dva typy: metaforizace-zdoslovnění a zpětná metaforizace.

Metaforizace-zdoslovnění nazýváme naši schopnost si na nevědomé úrovni zvolit ohniska obsahu naši zkušenosti právě ve vztahu k cílưm a prostřednictvím takto zaměrené části ji učinit viditelnějším tak, že ohnisko je vyzdviženo do pole našeho vědomí. Přesně tento moment měl na mysli Dewey, když definoval situaci jako ohraničenou komplexnost, která má svoji kvalitu. Tato kvalita vede kognitivní proces schematizace. Schematizace situace je počátkem zachycování naší komplexní zkušenosti a její kvalita situace je tím, co určuje, jakým způsobem máme proces schematizování vést (viz výše 1.2.3). Konceptuální metafora dokáže vtěsnat fokusovanou část obsahu do slova či fráze slov, a tím ji vyzdvihnou na úroveň, 
na níž lze aktualizovanou část obsahu začlenit do jazykového vyjádření (1.2.4). Další redukcí nadbytku významu lze konceptuální metaforu dovést až k úplnému zdoslovnění, v němž významy slov nabydou zcela určité, lehce definovatelné a artikulovatelné podoby a ztratí přímý kontakt $\mathrm{s}$ bohatým, tělesně ukotveným obsahem zkušenosti. V této monografii budeme tyto zdoslovněné jazykové jednotky nazývat ostrými pojmy. Ostré pojmy jsou „ostré“, protože mají jasně definované hranice významu - Descartes by je nazval „čistými a zřetelnými“. Tím naznačujeme jejich radikální separovanost. Čím je pojem jasněji definovaný, tím více je obsah zúžen a zaostř̌en a tím více ztrácí kontakt s komplexitou svého vtělesnění.

Ze stejného obsahu jsme schopni aktualizovat pouze některé z potencionálních významů. To se snažíme naznačit obrázkem 3.

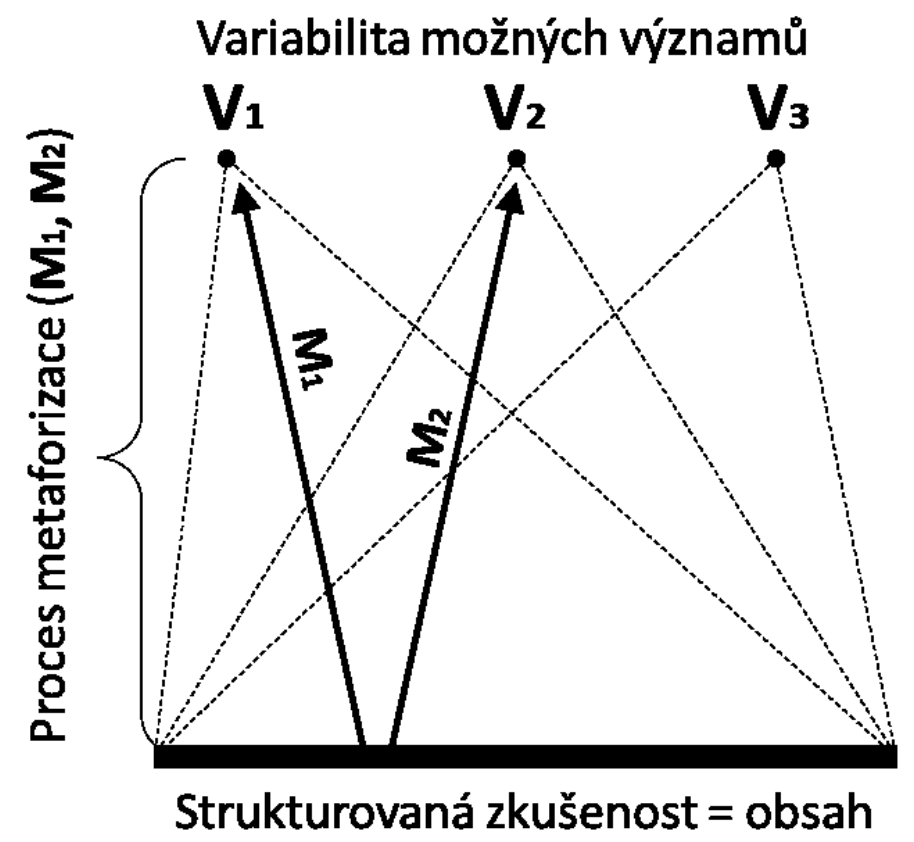

Obrázek 3. Proces metaforizace-zdoslovnění.

Obsah strukturované zkušenosti vyjadřuje společná základna všech trojúhelníků. Trojúhelníky jsou schematickým vyjádřením různých aktualizací tématu situace, které daná strukturovaná zkušenost umožňuje. Trojúhelníkový tvar znázorňuje redukci obsahu od základny (plný obsah), přes konceptuální metafory (cca prostřední část trojúhelníků), až po vrcholy (V1-V2), které zde symbolizují doslovné významy ostrých pojmů. Doslovné významy již na rozdíl od svých předchůdců - konceptuálních metafor - nejsou propojeny s dalšími možnými významy skrze tělesně ukotvené souvislosti. Vrcholy trojúhelníků se po dokončení procesu 
metaforizace-zdoslovnění zdají být zcela odlišné a jen volně spolu související. To naznačujeme vrcholy V1 a V2, které původně povstaly ze stejného obsahu zkušenosti, ale nyní po procesech metaforizace M1 a M2 se zdají být na sobě zcela nezávislé.

Tato zdánlivá absolutní odlišnost či jen volná souvislost doslovných významů nás vede k představě, že jazyk je systém pojmenování, který označuje diskrétní a pozitivně vykazatelné rysy skutečnosti. Proto pojmy vnímáme jako snadno odlišitelné jednotky a předpokládáme, že ze stejně snadno odlišitelných jednotek se skládá svět kolem nás. Proto máme tendence přeceňovat různé projevy neopozitivismu a tíhnout $\mathrm{k}$ atomistickému stylu myšlení. Tak nám „mizí před očima komplexnost a kontinuita významů, jejich vztah k tělesné zkušenosti i možné alternativy, které nám nabízejí neaktualizované významy zkušenostního obsahu.

Protože hledáme významy v syntagmatických (horizontálních) vztazích jazyka či symbolických kalkulů a potlačujeme vertikální dimenzi, v níž významy vyvstávají ze žité zkušenosti, máme tendenci vnímat figurativní popis skutečnosti jako nedokonalý popis, který v dalším kroku musí být nahrazen rigorózním popisem. Přeceňování horizontálních vztahů také vysvětluje, proč byl strukturalismus v mnoha svých lingvistických, literárněvědných, antropologických či filozofických podobách ${ }^{76}$ dominantním intelektuálním hnutím od poloviny 19. století až do konce druhé třetiny století 20. Tento systémový př́klon ke strukturalismu byl poslední významnější odpovědí rané moderny na objevení významu času v 19. století, např́klad v hegelianismu a evolucionismu (k tomu srov. Foucault, 2000; kde autor ukazuje, jak se objevení časovosti promítlo do rozpadu představy reprezentace jako pořádajícího principu vědy). ${ }^{77}$ Postupně se ale v rámci samotného strukturalismu začaly prosazovat osobnosti, které důraz na strukturu doplnily o dějiny proměn struktur (Jacobson, Vygotský, Piaget, Bachtin, Lacan, Foucault, Derrida, Barthez). Současný důraz na tělesnost a funkci je další kapitolou, kdy se uzavřená struktura prolamuje do silokřivky, ${ }^{78}$ do dynamické struktury a neustálé re/konfigurace života.

Ke znovu objevení horizontální roviny můžeme zpětně využít návrat ke konceptuálním metaforám, protože ty přivádějí určitý výsek tělesné, strukturované zkušenosti do pole jazykového vyjádření. Jsou vyjádřitelné znaky (slovy či frází několika slov), ale jsou ještě

\footnotetext{
${ }^{76}$ Od strukturalismu Saussurova přes strukturalismus ruského formalismu a Pražského lingvistického kroužku až po antropologický, religionistický a filozofický strukturalismus Léviho-Strausse a Dumézila či po důraz lingvistů na strukturální př́ístup ve výuce cizích jazyků.

$77 \mathrm{~V}$ tomto kontextu bychom mohli rozumět vzniku postanalytického strukturalismu jako pokusu zachovat nadvládu stálého nad proměnlivým.

${ }^{78}$ Jedná se o termín Erazima Koháka, kterým se snažil vyjádřit dynamičnost a proměnlivost struktury.
} 
stále definičně otevřené natolik, aby jejich tělesné - tacitní - pozadí zcela nezmizelo. Díky propojení s tacitním tělesným pozadím se uživatelé konceptuálních metafor udržují v psychoaktivním stavu, v němž dokážou přidružovat významy pojmů s prožitkovým pozadím, s obsahem zkušenosti a to i s jeho neaktualizovanými částmi. V prožitkovém pozadí se ukrývá logika struktury zkušenosti. Protože nejsme schopni na vědomé úrovni uchopit celé zkušenostní pozadí, musíme se zaměrit jen na její určitou část, která je v danou chvili, pro danou situaci aktuální. Právě na úrovni konceptuálních metafor se nacházíme v oblasti, kdy lze zkušenost vědomě uchopit a mluvit o ní, ale nejsme ještě odkázáni na uzavřené a rigidní ostré pojmy doslovného jazykového vyjádření. Na úrovni konceptuálních metafor se kř́žží jazykový řád, jehož uspořádání je dáno synchronním uspořádáním znaků s relativně stálou sémantikou, s diskurzivním aktem, který do synchronní struktury jazyka a jeho sémantiky zavádí diachronní událost, jež způsobuje rozštěpení reference (viz výše pasáže o Ricoeurově pojetí metafory - 1.2.4).

Tyto vlastnosti konceptuálních metafor využíváme při procesu tzv. zpětné metaforizace. Proces spočívá $\mathrm{v}$ tom, že pomocí různých technik - $\mathrm{v}$ našem př́ípadě nejčastěji prostřednictvím čistého jazyka - bud' pouze podporujeme, nebo př́mo generujeme metaforická vyjádření zkoumaných studentů. Je zde nutné podotknout, že se nemůžeme soustředit pouze na nekonvenční metafory, které jsou zarážející a patrné - například zaplátovat (výukovou hodinu něčím) nebo nacpat (do hlav žáků). Musíme si všímat i „mrtvých metafor“ - tedy jen zdánlivě doslovných pojmů, protože i ty nám poskytují stopy a indicie $\mathrm{k}$ tomu, jakým zpo̊sobem byla zkušenost strukturována původně metaforickým posunem, který se proměnil $\mathrm{v}$ - jen zdánlivě - doslovný popis. Zpětná metaforizace nám umožňuje opustit dogma hranice doslovného a figurativního jazyka, protože nás vede k metaforickému podloží strukturace zkušenosti.

Navíc zpětná metaforizace je výhodná především ve chvíli, kdy je zjevné, že se studenti při reflexi vlastní činnosti a výukové situace pohybují po povrchu. Dost často $\mathrm{k}$ tomuto neproduktivnímu popisu používají profesní slovník, který sice načerpali na přednáškách z obecné či oborové didaktiky, ovšem jeho pojmy jsou zcela odpojené od jejich profesní i osobní zkušenosti. To jim brání, aby byli schopni pochopit, co se v danou chvíli a v dané výukové situaci dělo. Nepochopení zabraňuje následné analýze situace a bez analýzy studenti nejsou schopni hledat alternativní jednání jinak než metodou pokus omyl. Podporou či př́ímo generováním metaforického vyjádření jsou studenti vedeni račím postupem (od neúčinných 
doslovných pojmů přes jejich významové zřetězení v konceptuální metafoře) proti proudu původní metaforizace-zdoslovnění. Metaforizace-zdoslovnění dospěla k doslovnému jazyku, v němž jim byly při výuce podávány instrukce a předávána odborná terminologie. Přri procesu zpětné metaforizace se vracejí (či jsou vedeni k návratu) od ostrých pojmů ke konceptuálním metaforám.

Tento návrat umožňuje, aby svoji reflexi propojili s obsahem zkušenosti, který čeká připravený $\mathrm{k}$ vytěženi ${ }^{79}$ a je zatím neuchopitelný doslovným jazykem. Zpětnou metaforizací se dostávají od ostrého pojmu ke konceptuální metafoře. Většina konceptuálních metafor, které byly pro náš výzkum stěžejní, jsou navázány na nějaké tělesné či tělesně zakoušené děje zamrznout, proudění (energie). Tato tělesná podstata dějů je $\mathrm{v}$ úzkém vztahu $\mathrm{k}$ tělesným prožitkům, jež v danou výukovou situaci probíhaly.



Obrázek 4. Proces zpětné metaforizace.

Obrázek 4 opět pracuje se základnou trojúhelníků, která symbolizuje obsah zkušenosti a potenciál jejích významů. Vrcholy trojúhelníků zastupují možné ostré pojmy s doslovnými významy. V obrázku 3 byly aktualizovány významy pojmů V1 a V2. V obrázku 4 jsme

\footnotetext{
${ }^{79}$ Metaforu vytěžení použila v pozdějších rozhovorech Alena, když se pokoušela specifikovat, proč mohou být neočekávané situace př́nosné. Vytěžení této zkušenosti pro ni znamenalo nabytí schopnosti využít nastalou situaci k jednání, jež nebylo plánováno, a také znamenalo nabytí schopnosti, jak se v podobných okamžicích zachovat př́ště. O vytěžení mluvila v pozdější fázi výzkumu, kdy se dostala (i díky reflektivním rozhovorům) do vysokého stupně sebereflexe, $\mathrm{s}$ níž přicházela také aktivita a sebedůvěra, a proto neočekávané situace přestaly být jen zdrojem stresu a nebezpečí, a staly se také přiležitostí $k$ vytěžení ( $\mathrm{k}$ tomu viz kapitolu 8).
} 
konfrontováni se situací, kdy význam V1 je součástí povrchního popisu, jenž studentovi neumožňuje analyzovat proběhlou situaci. Procesem zpětné metaforizace je veden od doslovného významu ke konceptuální metafoře a hlouběji (šedá šipka M1). V tomto prostředí tělesné zkušenosti se trojúhelníky možných aktualizací překrývají. To je symbolické vyjádření faktu, že obsah zkušenosti je kontinuálním dynamickým polem, kde významy - aktuální a potencionální - spolu inherentně souvisejí, mají určitou zkušenostní strukturu a z ní vyplývající logiku. Na této úrovni, kterou konceptuální metafora zviditelnila, zažívají studenti logiku zkušenostního obsahu a jsou schopni provést refokusaci - změnit ohnisko zkušenostního obsahu a aktualizovat jiný význam (černá šipka M3 vedoucí k V3). Současně s aktualizací nového významu si studenti začínají uvědomovat vztah mezi V1 a V3.

Ale ne jen to. Zakoušejí (byt' ne zcela vědomě) vztah mezi mnoha dalšími aktuálními a potencionálními významy, nebot' čím jsou blíže základně - tělesně ukotvenému prožitkovému pozadí, v němž zakoušejí obsah zkušenosti - tím více se dotýkají dynamické struktury zkušenosti. Obsah zkušenosti tvoří část tohoto řádu, a je proto na zcela vědomé úrovni neuchopitelný. Oč zřetelněji studenti uchopují význam V3 a vedou jej tak důsledněji k významové doslovnosti, čímž se pojem s významem V3 stává více odlišitelným od jiných významů, tím více se jiné části obsahu jejich zkušenosti svinují a mizejí z pole vědomí. Děje se tak proto, že na vědomé úrovni není možné udržet takové množství informací a vztahů. Proto se pojmy osamostatňují a zdají se být pouze body (atomy), které zastupují zdánlivě stejně oddělené části a vztahy (také atomy) reality kolem nás. Jestliže tuto fázi vezmeme za podstatu poznání, pak zcela míjíme dynamickou strukturu našich životů, která nás předchází a umožňuje naše jednání a myšlení.

Metafora metaforizuje komplexně. Nemůžeme ji tedy rozkládat na atomy a poté ji opět skládat a tak z jejích částí vyčítat význam celé metaforické struktury. To je další moment, který je v protikladu s našimi raně moderními instinkty. Dynamická struktura může být pochopena jako ukončená struktura s jasně daným „společným pravidlem“ jedině, když má nějaké jasně rozlišené části a tyto části se k sobě mají zcela určitým způsobem (srov. např. Slavík, Chrz, Štech et al., 2013, s. 49-50 či 100). Ovšem tak může být dynamická struktura pojímána jedině zpětně v reflexi. Představa „zdrojových“ a „cílových“ oblastí, které údajně poskytují nějaké struktury, jsou pouze experimentálním a didaktickým zjednodušením. Komplexnost vztahů mezi oblastmi nám nedovoluje chápat metaforu jen jako další rétorickou figuru, popř́padě jako vtiskávání signatury již předem dané struktury, nebot' prostupuje celým 
diskurzem a proměňuje více či méně pozadí, na základě kterého definujeme pravdivostní hodnoty nejen v oblastech metaforického přesunu, ale také v dalších částech diskurzu - mění řády reference.

Kvůli této komplexitě nemůžeme pracovat s metaforou atomistickým způsobem. Tedy tak, že ji budeme rozkládat na méně komplexní metafory (např. primární) a poté z významů méně komplexních metafor skládat celkový popis struktury zkušenosti. Jestliže se jednotlivé prvky procesu metaforizace (žáci, opičáci) stávají součástí metafory komplexní: žáci jsou opičáci, pak celkový význam metafory štěpí referenci, mění pravidla denotace a vytváří ,jiný svět, k němuž referujeme". Celkový význam tak zpětně redefinuje významové pozadí původních prvků. V našem př́íkladu ,druhý řád reference“ způsobuje, že žáci jsou pochopeni jako a priori kultivovaní a odchylka od této kultivovanosti se stává odchylkou od definice pojmu žák. Z této redefinice také vyplývají závazky. Být žákem znamená být kultivovaným či být veden ke kultivovanosti, být učitelem zase znamená vyvádět žáky z nedisciplinovanosti zviŕrecího (opičáckého) stavu.

Jinak řečeno po zapojení metaforických prvků do komplexní metafory není cesty zpět k původním významům těchto prvků. Zní to paradoxně, ale vysvětluje to zcela běžné životní situace. Poté, co byl člověk poprvé podveden, je svět jiný, než předtím - a to dokonce i přesto, že se extenze drtivé většiny pojmů nemění. Ovšem mění se intenze pojmů: svět je světem, ve kterém můžu být podveden. Člověk A, je člověkem, který mě podvedl a může podvést opět; ostatní lidé mě mohou podvést jako člověk A. Obdobně je to i v dalších situacích - v situaci, kdy člověk prožije iniciaci prvního sexuálního spojení, v situaci, kdy se člověk potká poprvé $\mathrm{s}$ alkoholem, nebo $\mathrm{v}$ situaci, $\mathrm{v}$ níž pohyb přestaneme definovat prostřednictvím aristotelského pojmu entelecheia (tedy jako spění k aktualizaci potenciality, jež je danému objektu z jeho podstaty vlastní) a začneme jej pojímat jako vztah různě velikých materiálních těles. ${ }^{80}$ Tyto obrovské posuny v porozumění jsou tak běžné, že si jejich dopad neuvědomujeme, a proto nejsou v raně moderní teorii poznání brány za rozhodující a v teorii poznání přechodové fáze jsou omezovány představou „zařazování pod společné pravidlo“ či „skládáním částí do celku struktury pomocí společného pravidla“.

\footnotetext{
${ }^{80} \mathrm{~V}$ tomto posledním př́ípadě charakterizujeme podmínku vzniku newtonovského vesmíru. Ta byla umožněna nejen prostřednictvím intezionálních změn, ale i změn v extenzi. Byla totiž omezena množina věcí, které se mohou pohybovat - zrání květiny již nebylo považováno za pohyb, ale změnu kvality. Ale např. u dalš́ho podobného př́padu - porozumění procesu hoření - šlo o změnu čistě extenzionální. Když tento proces začal být vysvětlován pomocí oxidace a nikoli pomocí předpokladu existence látky nazývané „flogiston“, pak se jednalo o změnu čistě intezionální. Fakt hořících těles zůstal extenzionálně stejný.
} 
S ohledem na právě artikulovanou problematiku komplexnosti metaforické strukturace, by se mohlo zdát, že cesta k dynamické struktuře zkušenosti je s konečnou platností uzavřena. $\mathrm{Na}$ jednu stranu nemůžeme pochopit metaforizaci pomocí rozkládání na metaforické atomy, na stranu druhou nemůžeme tuto dynamickou strukturu smyslu nahlédnout vcelku, nebot' komplexita obsahu mnohonásobně přesahuje možnosti lidského vědomí a reflexe. To, že ji bez ztráty smyslu nemůžeme rozložit na menší části, také znamená, že ji nemůžeme uchopit jako završenou a dokončenou strukturu. Proces metaforizace nám však pomáhá najít stabilnější logické vztahy, které se zrcadlí v jednotlivých prvcích tzv. metaforické krajiny (MK). Metaforickou krajinou budeme v této monografii mínit logiku výseku komplexní dynamické struktury, která se zobrazuje vorganizaci vzájemně propojených metafor. Metaforickou krajinu si můžeme představit jako dynamickou (proměnlivou) mapu zachycující strukturaci zkušenosti.

V této mapě se však neopíráme o doslovný jazyk ostrých pojmů, ale o sítě vztahů mezi metaforami, které dokáží zachytit dynamicky se rozvíjející strukturu zkušenosti. Protože se neopíráme o ostré pojmy, ale o vztahy mezi jednotlivými metaforami, poskytujeme dostatečný prostor pro dynamiku strukturace, přitom ale tento postup dokáže zachytit dlouhodobě se projevující gestalty prožitků a jednání, které nám jako výzkumníkům i studentům mohou pomoci zorientovat se ve zkoumané zkušenosti. Během našeho výzkumu jsme studentům pomáhali rozvíjet MK stimulovaným tázáním pomocí techniky čistého jazyka (clean language). K čistému jazyku jsme se uchýlili především proto, že se nejedná pouze o jakousi „techniku“ tázání, jak je občas prezentována. Za touto technikou tázání se totiž skrývá celkový analytický přístup, který má fenomenologický charakter.

Jak jsme již upozornili výše, k dynamické struktuře zkušenosti a tedy i k projevům tacitních znalostí se nemůžeme dostat přes tradiční postupy postpozitivistické metodologie: 1) rozkládáním komplexity zkušenosti na atomy a 2) jejich idealizací, jimiž proměňujeme tyto atomy na „pozitivní“ fakta naší znalosti. Tato skutečnost souvisí i s tím, že všechny čtyři roviny znalostního pole - interakční, tělesná, externí a poznatková - jsou v neustálém stavu proměny a jakákoli změna $\mathrm{v}$ jedné $\mathrm{z}$ nich proměňuje jak tuto rovinu, tak všechny tři ostatní. To má za následek, že korespondenční teorie pravdy a poznání je nepoužitelná.

O metodě čistého jazyka budeme psát v kapitole 3 níže. Zde pouze poznamenáme několik důležitých poznámek o filozoficko-teoretických východiscích metody, abychom ji mohli spojit s předcházejícím výkladem o znalosti, figurativním jazyku a metaforách. Čistý 
jazyk dotazování je elegantním a přitom nečekaně účinným způsobem, jak během výzkumného šetření provést základní krok fenomenologického výzkumu: fenomenologickou redukci. V jiných fenomenologických metodách lze tuto redukci učinit jen nedokonale prostřednictvím opakovaného čtení a reflexe vlastní zkušenosti s tématem - např. v Interpretative Phenomenological Analysis (IPA - interpretativní fenomenologické analýze srov. Eatough \& Smith, 2009). Nebo ji lze v rámci metody Meaning Constitution Analysis (MCA - analýza konstituce významů) dosáhnout pomocí relativně složité práce s textem prostřednictví softwaru Minerva (srov. Sages, 2003). Na rozdíl od ostatních analytických fenomenologických př́stupů, které fenomenologickou redukci zařazují až na počátek práce se sebranými daty, je zde redukce zahrnuta již do procesu sběru dat. V této metodě se fenomenologické redukce dosahuje způsobem kladení otázek. Podstatou této metody je kladení tzv. čistých či kontextově čistých otázek. Cílem takového dotazování je, aby tázající používal slova, konstrukce vět a metafory dotazovaného a aby to byl dotazovaný, kdo vytváří slovy či metaforami vztahy, které uchopují logickou strukturu jeho prožitku (srov. Tosey, Lawley, \& Meese, 2014).

Fenomenologická redukce obecně odstraňuje nános tradiční interpretace a nechává, aby se vyjevily struktury smyslu jednání. ${ }^{81}$ Počáteční potlačení tradiční interpretace umožňuje zohlednit proces metaforizace zkušenosti, jižž byla zkušenost strukturována. Jestliže se nám podaří fenomenologicky čistě či kontextově čistě indukovat proces zpětné metaforizace u studentů, dosahujeme toho, že tázaný odpovídá způsobem, který není tazatelem vynucen běžným typem otázek, a tak umožňujeme tázanému rozvinout logickou strukturu jeho metaforické krajiny. Rozvíjením MK reaktivujeme základní prvky zkušenostní struktury a zvýrazňujeme v ní její vztahy.

V obrázku 5 se pokoušíme vizuálně znázornit tento celostní proces zvýznamňování událostí a neustále probíhající sktrukturaci zkušenosti. Předem však upozorňujeme, že se jedná o významné zjednodušení, protože ve skutečnosti neexistuje dolní plán (zkušenost) a horní plán (metaforická krajina a její rozvíjení). Rozvíjení MK a její explikace se odehrává v té samé zkušenosti, ve které prožíváme svět a utváŕíme své znalosti. Proto mezi

\footnotetext{
${ }^{81}$ Nejde jen o struktury vnímání, ale skutečně o struktury smyslu jednání. Struktury vnímání jsou samozřejmě propojeny s jednáním skrze mechanismy kognitivního nevědomého (cognitive unconscious) - vnímání se utvářelo v bytostném vztahu $\mathrm{k}$ jednání ( $\mathrm{k}$ tomu viz 1.2.4 výše). Výsledek jednání je však arbitrem toho, zda je nějaké vnímání náležité a zda bylo dosaženo cíle - zda bylo dosaženo znalosti. Jednání má proto komplexnější strukturu a je podmínkou pro dosahování znalosti ( $\mathrm{k}$ tomu viz 1.2.3 výše). S naším fenomenologickým př́stupem jsme symbolicky pokročili od Husserla k Merleau-Pontymu a Barbarasovi.
} 
strukturovanou asubjektivní zkušenostî ${ }^{82}$ a logikou MK dochází $\mathrm{k}$ neustálému hermeneutickému kruhovému pohybu interpretace. ${ }^{83}$

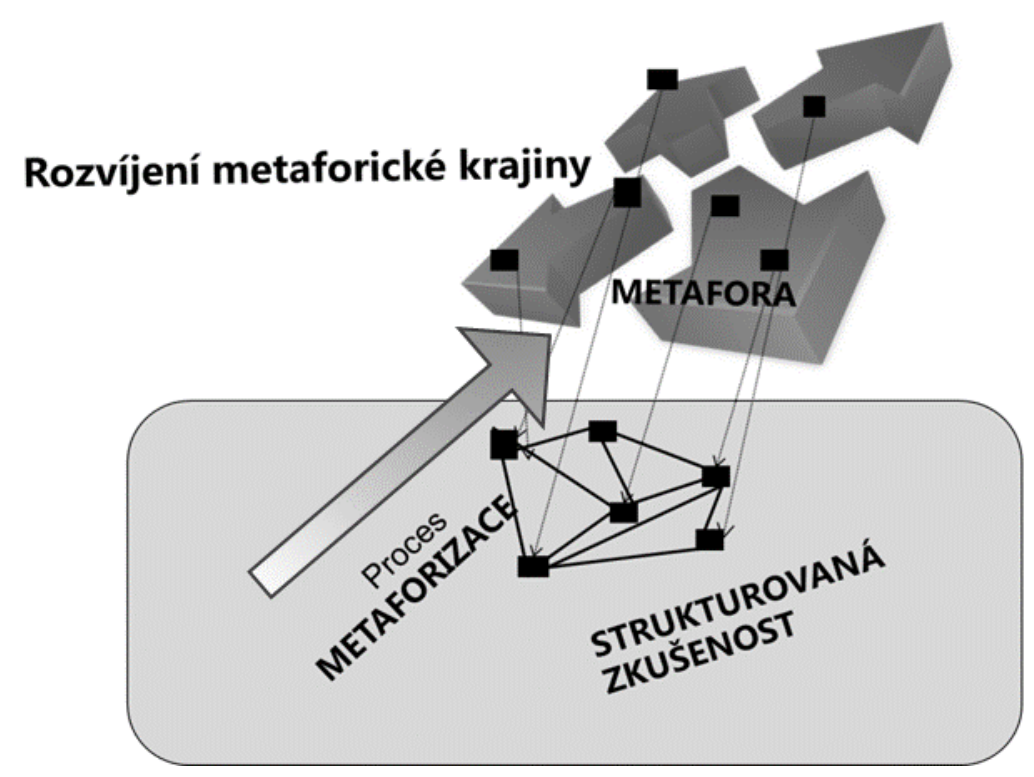

Obrázek 5. Rozvíjení MK a její inherentní logické struktury zkušenosti.

Obrázek 5 lze popsat následovně: proces metaforizace znovu zaměří zkušenostní obsah novým způsobem a vyzdvihne její jiné ohnisko, a tak nasvití zkušenost jistým způsobem podle převládajícího emocionálního mapování př́ílušného úseku strukturované zkušenosti $\mathrm{v}$ dané situaci. Tak je vybráno ohnisko, které určuje proces redukce významů situace a vede $\mathrm{k}$ určité metafoře či systému metafor. Ona metafora (systém metafor) však vzniká na širším pozadí, a proto v sobě ukrývá logiku podstatně širší části zkušenosti, než je ta v ohnisku naší metaforické práce. Při rozvíjením MK dochází k rozvíjení - k explikaci - logických struktur zkušenosti s přihlédnutím k dané perspektivě vybraného ohniska. Objekty (černé obdélníčky) v horní části obrázku (v části rozvíjení MK), jsou zachycením podstatných uzlů zkušenosti, mezi nimiž se zviditelňují logické vztahy v metaforické krajině. Přestože jsou ony uzly povětšinou také vyjádřeny metaforicky, jejich vztahy nejsou náhodné, a proto nás mohou

\footnotetext{
${ }^{82} \mathrm{~K}$ asubjektivní podstatě zkušenosti viz poznámku 17 výše.

${ }^{83} \mathrm{Na}$ tomto místě musíme odlišit dva významy, v nichž bylo slovo ,interpretace“ použito. Výše jsme mluvili o „potlačení tradiční interpretace“. Měli jsme na mysli interpretace, které by do procesu výzkumu mohl vkládat výzkumník ovlivněný tradičními představami, a tak by mohl umrtvit význam rozvíjené logické struktury MK tradičními výklady, které jsou spojeny s pozitivismem a postpozitivismem. Zde mluvíme o interpretaci, která neustále probíhá v procesu strukturace vlastní zkušenosti mezi metaforicky se vyjevující logikou a samotnou dynamickou zkušeností.
} 
informovat o tom, jak je prozatímně strukturována příslušná část zkušenosti a jak se s ní dotyčný student na tacitní úrovni setkává a jak ji poznává. Obrázek se to pokouší naznačit šipkami, které vedou zpět do oblasti strukturované zkušenosti, kam se promitají tyto uzly společně se svými logickými vztahy. Právě zde můžeme vidět důsledek didaktického zjednodušení obrázku, protože rozvíjení MK i promítání její logické struktury do zkušenosti se cele odehrává ve zkušenosti samotné. To má velmi důležité důsledky, nebot' vyjasnění logiky metaforické krajiny ovlivňuje další strukturaci. To jsme mohli vidět na některých našich studentech, protože ve chvíli, kdy jim systém metafor pomohl popsat proběhlou situaci, byli náhle schopni o této situaci přemýšlet strukturovaněji, prŕípadně - pokud byli v sebereflexi zdatnější - byli schopni dosáhnout samotného počátku analýzy situace.

Logické vztahy jsou znázorněny tlustými čarami mezi promítnutými uzly (mezi černými obdélníčky v dolní oblasti). Tyto čáry symbolizují hledanou strukturu. Přestože (nebo spíše právě proto, že) se nejedná o klasickou reprezentaci, nás tato struktura informuje o situaci a tedy o možnosti následného jednání. Nalezená struktura významu situace je dynamická, podle okolností se více či méně mění. Nepracujeme zde s ostrými pojmy, ale s otevřenými pojmy (to znamená pojmy blížící se konceptuální metafoře), poprrípadě s konceptuálními metaforami samotnými. Díky tomu můžeme snáze reagovat na významové posuny, přeskupování ohniska a přestrukturovávání zkušenosti. Ta je na druhou stranu v principu kontinuální, a proto se základní vztahy nemění, a jestliže ano, pak pouze za výjimečných okolností.

Zvýrazněné vztahy MK nejsou náhodné, mají svoji inherentní logiku, která vyvěrá ze struktury. Právě díky této logice získáváme srovnávací objekt, který nám ukazuje, zda za jednáním studenta byl nebo nebyl blíže nespecifikovaný, vědomě neartikulovaný cíl. Pokud tam takový cíl byl, pak se můžeme ptát, zda se student $\mathrm{k}$ tomuto cíli více méně blížil, či nikoli. Jestliže ano, pak v jednání studenta operovaly tacitní znalosti, které vedly studenta $\mathrm{v}$ jeho jednání náležitě, tzn. cílesledně. $\mathrm{V}$ další diskusi kolem $\mathrm{MK}$ a př́ípadných jen nejasně uvědomovaných motivačních prvků mohou být tyto prvky lépe a přsesněji artikulovány. Tak se dostáváme $\mathrm{k}$ uchopení a k zexplicitňování TZ. V ideálním případě jsme mohli na TZ upozornit ještě jiným způsobem, než že jsme na základě negativní definice projevů TZ - tzn., žádné nebo malé uvědomění situace a neschopnost situaci jasně artikulovat - detekovali operaci TZ a jejich př́ípadné nabývání a sdílení. Mohli jsme TZ detekovat na základě porovnání inherentní logiky vyjevující se v rozvinuté MK s výsledky a důsledky jednání studentů v dané situaci. 


\subsection{Coda první kapitoly}

Abychom učinili výzkum TZ smysluplnějším, museli jsme se na poli teorie vydat dlouhou oklikou. Na ní jsme sami prodělali velice hlubokou proměnu. Kdybychom dnes s nově nabytými znalostmi mohli formulovat cíle výzkumu alternativním způsobem, pak bychom jistě nekladli znalost a tacitní znalost do dichotomického vztahu. Mezi znalostí a tacitní znalostí je kontinuita, jejíž krajní póly - zcela explicitní a zcela tacitní znalost - ve skutečnosti neexistují. Neexistuje zcela explicitní znalost, protože znalostní pole je neustále v pohybu, stejně jako neexistuje zcela tacitní (tzn. zcela se neprojevující) znalost, protože znalost už tím, že je znalostí, za sebou nechává stopy. Jednáním k něčemu směřujeme a každé dosažení cíle nebo selhání zanechává stopy. Tyto stopy se stávají informací pro další pokračování procesu poznání.

Podobně neexistuje zcela doslovný pojem, nebot'v sobě skrývá historii figurace pomocí dřive nekonvenční, dnes již „mrtvé“ metafory, a stejně neexistuje metafora, která by nevyužívala systém doslovných pojmů. Všechny čtyři extrémy - absolutně explicitní znalost, absolutně tacitní znalost, absolutně doslovný pojem, absolutně nedoslovná metafora - jsou v podstatě pouhými extrapolacemi kontinuitních přechodových variant, které fakticky neexistují. K těmto extrapolacím nás nutí náš jazyk, který byl dlouho pod vlivem rané moderny, pod vlivem jeho tendence $\mathrm{k}$ epistemologickému atomismu.

Tato skutečnost nás dostala do nekomfortní pozice. Když jsme formulovali grantový projekt, netušili jsme, jak daleko se budeme muset vzdálit našim původním představám o povaze znalosti a tacitní znalosti. Jestliže se dnes pokoušíme vyhovět výzkumným otázkám, které jsme kladli na počátku projektu, a které jsou proto závaznou součástí našeho projektu, často zjišt’ujeme, že ve svém výzkumu nemůžeme být dostatečně důslední. Proto se naše monografie pohybuje na škále od přechodové fáze $\mathrm{k}$ ideálnímu typu pozdní moderny. Přesto naši práci chápeme jako průlomovou. Jako bránu, kterou se bude nadále vstupovat do oblastí, jež se pro pedagogiku a didaktiku stanou stále více klíčové.

Poslední poznámka této kapitoly musí být věnována autorům Tvorby, jejichž práci jsme kontrastovali s prací naší, abychom byli schopni jasněji vytyčit důsledky pozdně moderního myšlení. Naše cesty se však potkávají v zájmu o studenty a učitele. Autoři Tvorby je mohou 
vést $\mathrm{k}$ profesně více účinnému jazyku, v němž budou schopni pracovat sofistikovaněji $\mathrm{s}$ důležitými teoriemi. My naopak umožňujeme, aby studenti rozvinuli svoji profesní zkušenost takovým způsobem, že ji budou schopni účinně propojit s profesním jazykem a zmíněnými teoriemi. Naše setkání je dáno jejich i naším povoláním ke společnému profesnímu úkolu vychovat skvělé kantory. To nás spojuje a zavazuje, protože názory bez sdílených struktur nejsou komunální a struktury bez zkušenostního pohybu jsou mrtvé. 


\section{Metafora, vtělenost a tacitní učení}

\section{James Lawley}

Tato kapitola se zabývá dílčí částí oblasti vtělené kognice - vtělenou metaforou - a zkoumá řadu způsobů, jimiž se metafory vtělují, stejně jako jejich spojitost s tacitním učením.

\subsection{Co je myšleno pojmem vtělenost (vtělení)?}

Pojem vtělenost (popř. vtěleni) je možno vysvětlovat různě. Lze jej chápat v obecném smyslu, tak jak to uvádí teorie poznání založená na konceptu autopoesis ve své odvážné tezi: „Veškeré vědění je i konání,“ (Maturana \& Varela, 1992, s. 26) nebo naopak velmi konkrétně, jako myšlenku, že lidský konceptuální systém pracuje se senzomotorickými simulacemi v mozkových centrech pro konkrétní modality (Barsalou, 1999).

At' už je definice jakákoli, základem vtělenosti je myšlenka, že mozek, tělo a prostředí jsou dynamicky provázané a vzájemně se ovlivňují. Jinými slovy, strukturují samy sebe, přičemž na mnohých úrovních této struktury se vyskytují emergentní procesy, prríčinné jak směrem nahoru, tak i dolů (Thompson \& Varela, 2001). Toto poznání vedlo k systematickému studiu provázanosti jazyka, mysli, těla a prostředí, konkrétně pak k hledání způsobu, jakým je abstraktní myšlení zakořeněno ve vtělené zkušenosti. Nikdo nezastává názor, že by vtělení bylo jedinou základnou pro veškeré myšlení a jazyk. Spíše se - na základě výsledků experimentálních studií - usuzuje, že opakovaná vtělená zkušenost se často zapojuje do tacitního utváření chápání světa člověka (Wilson \& Gibbs, 2007).

\subsection{Co jsou to vtělené metafory?}

V roce 1980 George Lakoff a Mark Johnson přišli na tehdejší dobu s radikální myšlenkou, že značná část našeho jazyka a mnohé naše koncepce jsou v základě metafory, které ovlivňují způsob, jakým vnímáme, myslíme a jednáme. I samotná realita je zčásti definována metaforou. Dále tvrdili, že „myšlení v metaforách je nevyhnutelné, všudypř́itomné a většinou nevědomé“ (Lakoff \& Johnson, 2003, s. 272). 
Přestože důkazy se poněkud různí, řada studií z oblasti neurozobrazování nalezla spojitost mezi somatotopickou motorickou aktivitou a metaforami a idiomy. V fMRI studiích, v nichž byli účastníci požádáni, aby četli věty s hmatovými metaforami (např. byl to drsný den) nebo s nehmatovými, kontrolními větami (např. byl to náročný den), a s chut'ovými metaforami (např. sladce se na něj usmála) či parafrázemi bez chut’ových výrazů (např. mile se na něj usmála), bylo zjištěno, že metafory s hmatovými a chut'ovými metaforami vyvolaly zvýšenou aktivitu v oblastech mozku, jež jsou aktivní při hmatových a chut'ových vjemech (Casasanto \& Gijssels, 2015, s. 333).

Ve svém shrnutí poznatků z oblasti neurologie činí Daniel Casasanto a Tom Gijssel (tamtéž) následující závěr: Existují silné důkazy pro to, že lidé myslí v mentálních metaforách a že naše myšleni je zčásti vtělené. Není však prokázáno, že by mentálni metafory byly vtělené v simulacích prostřednictvím smyslových modalit, [jako se domnívá Barsalou].

Je možné, že neurověda zatím nedisponuje dostatečně přesnými rozlišovacími prostředky anebo se „objevuje stále více důkazů pro velice těsnou provázanost a interakci mezi smyslovými centry mozku, a tím i pro obtížnost určení, zda se vjem pohybuje v čistě zrakové, čistě sluchové nebo v čistě jakékoli rovině“ (Sacks, 2010, s. 237-238).

Poznatky z oblasti neurologie lze považovat za přední důkazy o vtělení, avšak pouze pokud je neurologie považována za nadřazenou ostatním výzkumným formám rozebíraným v této kapitole. Z praktického hlediska a z hlediska kvalitativního výzkumu, poznávání lze v obecném smyslu a metaforu ve smyslu konkrétním chápat jako vtělené nejen z pohledu neurologie, ale i z jiných úhlů pohledu. Následující podkapitoly se zaměřují na čtyři hlediska, skrze něž lze metafory vnímat jako vtělené: hledisko (a) jazykové, (b) psychologické, (c) fyziologické a (d) materiální.

\subsection{Jazyk: metafory vtělují abstrakci do fyzického prostoru}

Lakoff a Johnson se ve své klíčové definici podstatou metafory je chápání a proživání jedné věci v rámci druhé (1980, s. 5) straní upřesnění mechanismu, jehož prostřednictvím jsou metafory vyjadřovány. Zmíněná ,jedna věc“ bývá relativně více abstraktní než ta „druhá“ (tedy metafora). Většina metafor používá pro popsání a vysvětlení abstraktnějších myšlenek slova z fyziologicko-materiálního prostoru. Zoltan Kövecses (2002) vypsal prostory používané jako základ každodenních metafor uvedených ve slovnících metafor a v odborné 
literatuře. Zjistil, že nejčastěji se vyskytují tyto: (a) lidské tělo, včetně zdravotního stavu a nemocí; (b) živá přiroda, např. zviŕata, rostliny; (c) lidmi stvořené věci, např. stavby, stroje, nástroje; (d) lidské činnosti, např. hry, sport, válka, finance, vaření, jídlo; (e) prostředí, např. teplo, chlad, světlo, tma; (f) fyzika, např. prostor, síly, pohyb, směr.

Relativně abstraktní a komplexní myšlenky tak bývají pomocí metafor vtěleny v názvech zkušeností, jež jsou nám nejznámější, tedy v lidských a zvířecích tělech, v předmětech, v prostředí a v jejich fungování.

Výzkumy vycházející z různého zdrojového materiálu (z psychoterapeutických rozhovorů, z esejí a televizních debat) udávají, že lidé zpravidla používají kolem šesti metafor za minutu (Tosey, Sullivan, \& Meyer, 2013). Zatímco mluvčí, posluchači, pisatelé a čtenáři si jsou užitých slov vědomi, značná část jejich metaforické povahy zůstává mimo povědomí všech.

\subsection{Psychologie: mentální metafory mají formu}

Ačkoli jsou metaforické obsahy jazyka evidentní, nemusí to znamenat, že „metafory, jako jazyková vyjádření jsou možné ryze proto, že jsou metaforami v rámci konceptuálního systému jedince“ (Lakoff \& Johnson, 1980, s. 6). I když v interpretaci výsledků vždy existuje jistá nejednotnost, zdá se, že se závěry empirických výzkumů z oblasti kognitivní vědy na tento problém zaměřují. Uved'me několik př́kladů.

O čase premýšlíme v prostorových, lineárních a trojrozměrných reprezentacích, které jsou naznačeny vjazykových metaforách. (Ramscar, Matlock, \& Boroditsky, 2009)

Když lidé vidí slova napsaná blizko u sebe, považuji je za „bližši“ i významově. (Casasanto, 2008)

Experimenty založené na metaforách pocitu ,vřelosti“ a „,chladu“ vůči druhé osobě poukazuji na vzájemnou systémovou závislost mezi jazykem, vnímáním a sociální blizkostí. (IJzerman \& Semin, 2009)

V současné literatuře jsou často zmiňovány důkazy o tom, že lidé přemýšlejí v mentálních metaforách a že metafory utvářejí strukturu našich myšlenek, citů a rozhodování (Carpenter, 2010; Casasanto \& Gijssels, 2015; Gibbs, Lima, \& Francozo, 2004). 
Metafory většinou pocházejí z našeho chápání lidského a zvířecího těla, věcí, prostř̌edí a způsobů, jakými fungují. Když pak toto chápání reprezentujeme ve svých myslích, mají symboly, z nichž se metafory skládají, svou velikost, tvar, barvu, texturu, teplotu, pocitový vjem, chování, rytmus, tón atd. (Gordon, 1978). Poradenský psycholog David Grove v průběhu 25 let své klinické praxe prokázal, že pokud se terapeut pomocí čistého jazyka (viz kapitolu 3) zbaví svých metafor, lidé mu nabídnou bohatý a osobitý popis své vnitřní zkušenosti prostřednictvím zrakových, sluchových, dotykových a proprioceptivních metafor (Grove \& Panzer, 1986; Lawley \& Tompkins, 2000).

\subsection{Fyziologie: tělo může být metaforou}

Z výzkumných šetření vyplývá, že naše schopnost vnímat věci a události je těsně spjata s našimi tacitními pohyby (Gibbs \& de Macedo, 2010). Jak se domnívá Mark Johnson (1987), realita každého z nás je utvářena pohybovými vzorci našeho těla, nebot' naše mysl používá tělo pro pochopení abstraktních a komplexních konceptů, a činí tak hlavně prostřednictvím metaforického promítání „obrazových schémat“, jako jsou obsažnost (containment), zdrojcesta-cíl (source-path-goal), překážka (blockage), pohnutka (compulsion), rovnováha (balance) atd.

David McNeill je toho názoru, že gesto - zvláště pak metaforické gesto - je nenahraditelnou součástí řeči, a že gesta mají svůj vlastní, na slovech nezávislý význam: „V metaforickém gestu se prezentuje abstraktní význam jako projev určité formy a/nebo prostoru ... Gesta propůjčují obraz nezobrazitelnému.“ (2008, s. 45) Tělo samotné lze tedy použít jako prostředek metaforického vyjádření prostřednictvím gest, postoje a propriocepce. Neverbální metafory se často vyskytují zároveň s verbálními, avšak narozdíl od slov, jsou schopny vyjádřit několik věcí najednou, někdy v očividném konfliktu s řečovým obsahem (Lawley \& Tompkins, 2000).

Siri Carpenterová (2010) si klade otázku: „Jestliže tělesné stavy infiltrují tak často do kognice, proč jsme si tohoto jevu tak zř́idka vědomi?“ A odpovídá na ni: „Naše tělesné vjemy a pohyby jsou nejspíše př́liš pomíjivé nebo triviální, abychom si všimli jejich vlivu na naše psychické žití“. „Příliš pomíjivé“ snad, ale „př́iliš triviální“? Lze si odpovědět jednodušeji, tedy, že tyto jevy nepotřebujeme vnímat vědomě. Ve většině případů postačuje jejich tacitní uvědomění. To, že nejsou patrné ve vědomé mysli, neznamená, že jsou triviální. Až na př́pady extrémních okolností, evoluce nám zanechala téměř nulové povědomí např́iklad o 
takřka nepřetržitém pohybu hladkého střevního svalstva, jejž lze jen sotva označit za triviální záležitost. Naše pozornost je omezená, a tudíž musí být selektivní. Jak podotýká James Geary (2012), kdyby byla naše těla rozdílná, lišily by se i naše metafory.

\subsection{Materiální rovina: metafory lze zhmotnit}

Metafory lze kreslit, malovat, psát, sochat, stavět $\mathrm{z}$ lega a nahrávat, ale i jinak vědomě vtělovat do materiálního světa. Jakmile je materiální metafora vytvořena, nastupuje existenci oddělenou od toho, kdo ji stvořil. Jako jednu z nejběžnějších materiálních metafor (natolik běžnou, že snadno zapomínáme, že metaforou je) uved'me pracovní plochu počítače se soubory, složkami, košem atd.

Když jsou lidé požádáni o fyzickou reprezentaci abstraktních pojmů, uchylují se často $\mathrm{k}$ použití metafor, nebot' abstrakce jsou netělesné a bez formy, a tedy těžko zobrazitelné. Když jsou vnitřní reprezentace externalizovány, vytvoření materiální metafory navazuje zpětnou vazbu, která pak může být užitečná pro sebereflexi a porozumění (Lawley \& Tompkins, 2000).

Leung, Kim, Polman, Ong, Qiu, Goncalo, \& Sanchez-Burks (2012) realizovali pět studií, jejichž účelem bylo zjistit, zda vtělování kreativních metafor jak fyzické, tak v chování může podporovat tvořivé myšlení a schopnost řešit problémy. Jeden $\mathrm{z}$ experimentů pracoval s bednou (vyrobenou z PVC a kartonu, dost velkou na to, aby se do ní vešel člověk), jejíž pomocí se zkoušelo, zda se ,thinking outside the box “84 významně projeví. Jiný experiment zjišt’oval, zda zvažování problému „na jedné straně a pak na straně druhé“ zvyšuje plynulost, flexibilitu a originálnost nápadů. Dospěli pak k závěru, že „,vtělení může aktivovat kognitivní procesy, které přispívají k nacházení nových nápadů a souvislostí“‘ (tamtéž, s. 502).

Práce s vtělenými metaforami není novinkou. Carl Jung, zakladatel analytické psychologie, strávil 35 let výstavbou a přestavbou svého domu na základě externalizace vývoje svého vnitřně symbolického světa: Musel jsem své nejvnitřnějši myšlenky a své vlastní vědění nějak zpodobnit v kameni ... To byl počátek věže, kterou jsem si postavil v Bollingenu, [a ze které se stal] symbol psychické celosti (Jung, 1983, s. 250). Tyto myšlenky byly prověřovány ve výzkumných podmínkách až v nedávné době.

\footnotetext{
${ }^{84}$ Anglický výraz pro tvořivé, nebo v dané situaci neobvyklé myšlení, zpravidla užívané v prŕípadech, kdy jde o nalezení nového řešení. Doslova přeloženo: přemýšlet mimo krabici.
} 


\subsection{Proč je důležité, že jsou metafory vtělené?}

Metafora může napomáhat učení, objevovat nové způsoby popisu věcí a zlepšit kreativitu. Je proto pravděpodobné, že procesy užívající metafor jsou spojeny s určitými změnami v synaptických vahách a propojeních, stejně jako s regenerací (Seung, 2012). Důkazů však zatím není dostatek. Následující části této kapitoly se proto zaměří na některé důsledky ostatních forem výše popsaného vtělení.

\subsubsection{Jazykové vtělení}

Protože zdroje většiny metafor dosud zkoumaných jazyků pocházejí ze společné zkušenosti prostoru a sil (Pinker, 1998), pomáhají metafory v komunikaci, v chápání a v učení se relativně abstraktním pojmům a komplexním významům. Vtělená povaha metafor navíc napomáhá nejen porozumění, jak ostatní lidé chápou svět, ale i porozumění sobě samému.

Implicitní metafory jsou v běžné konverzaci zpravidla přecházeny bez povšimnutí. Podávají však cenné informace o způsobu, jak si člověk organizuje své zkušenosti. Když někdo řekne: Zažil jsem zklamání, ale zvedl jsem se, slovo zklamání nejspíše přiláká nejvíce pozornosti. Mezitím však význam vtělený v akční metafoře zvedl jsem se, daleko lépe vystihuje postoj mluvčího ke zkušenosti, kterou vnímá jako zklamání. Př́nos vtělené metafory může být patrnější, když si uvedeme alternativní vyjádření situace mluvčího a sledujeme, jak se náš pocit mění.

Zažil jsem zklamání, ale zotavuji se.

Zažil jsem zklamání, ale musím to překlenout.

Zažil jsem zklamání, ale vyrovnám se s tím.

Zažil jsem zklamání, ale nenechám se tím zviklat.

Zažil jsem zklamání, ale zvládám to.

Zažil jsem zklamání, ale prosekám se tím.

Každá z těchto metafor představuje jinou činnost spojovanou s vizuálně-kinestetickým zpodobením. Každá metafora s sebou navíc nese svá vyplývání, např. ze spojení „,nemrhej časem“ vyplývá, že čas je omezený a také vzácný (Lakoff \& Johnson, 1980). Mezi hmotným zdrojem metafory a metaforou samotnou panuje do jisté míry shoda $\mathrm{v}$ tom smyslu, že část 
logiky a struktury z materiální roviny se promítne i do metafory. I když metafory kombinujeme a slučujeme, zachováváme přitom jejich logiku (Fauconnier \& Turner, 2008).

\subsubsection{Psychické vtělení}

Abstraktní pojmy nemají formu, zatímco mentální metafory ano. Pojem učení nemá formu a nenachází se nikde v prostoru nebo v čase, avšak „nasává vědomosti jako houba“ - může mít velikost, tvar, barvu, texturu. Představa houby je u každého člověka odlišná, ale vyplývají z ní jisté společné rysy. Na rozdíl od nevtělených pojmů, houby mohou reagovat na prostředí a časem se měnit.

Vtělená metafora obsahuje strukturní charakter zkušenosti mluvčího. Během terapie a koučinku se mění respondentovo pojetí tématu spolu se změnami a s vývojem metafor. Př́kladem může být práce $\mathrm{s}$ jedním žákem, který popsal své problémy s učením se matematice slovy: mám v hlavě zauzlované špagety. Poté, co žák odpověděl na několik otázek $\mathrm{v}$ čistém jazyce ohledně této metafory - Jak jsou zauzlované? Kde v hlavě ty zauzlované špagety jsou? Ještě něco ohledně špaget? - měl dobře vyvinuté, vtělené chápání těchto symbolů. Žákovi byla po té položena otázka: A co ty špagety chtějí, aby se s nimi stalo? Po chvíli odpověděl: Chtějí, aby je někdo namočil, aby se rozmotaly a pak uschnuly na slunci. Žák poté ještě chvíli odpovídal na otázky v čistém jazyce, až najednou zvolal: A hele, ty špagety se smrskly do jednoho kusu. Jako jeden kus papíru, kam můžu psát čísla. Žák takto získal povědomí o pozadí, na kterém byl schopen operovat s čísly a jeho schopnost učit se matematice se během následujících měsíců zlepšila (Tompkins, Sullivan, \& Lawley, 2005).

\subsubsection{Fyziologické vtělení}

Mark Johnson nazval svoji knihu Tělo uvnitř mysli, ale mohl ji pojmenovat i Mysl uvnitř těla, nebot’ mezi oběma názvy je systémová spojitost. Výsledky výzkumných šetření podporují názor, že „přiměřená tělesná činnost nebo i představa činnosti posiluje vtělený, metaforický výklad abstraktních pojmů, o kterých se hovoří v obrazných výrazech“ (Wilson \& Gibbs, 2007, s. 721).

Neverbální chování, jako např́klad gestikulace, výrazy obličeje a tělesný postoj, se často interpretuje jako komunikace mezi lidmi, avšak často se jedná o komunikaci se sebou samým. Užívání tělesných metafor nám pomáhá myslet, uvažovat a činit rozhodnutí týkající se abstraktních a komplexních životních zkušeností. Když člověk používá své tělo k utřídění pocitů, srovnání myšlenek a zvážení situací, nevědomě tak komunikuje sám se sebou. Díky 
těmto situacím je pak mluvčí schopen utřídit si myšlenky během řečového projevu, a tím si uvolnit krátkodobou pamět' pro jiné úkoly (Carpenter, 2010).

I lidé z různých kultur běžně používají tělo v metaforické rovině. Všechny jazyky např́íklad používají metafory času, přičemž slovní vyjádření bývají často doplněna gesty, která identifikují pořadí událostí v duševním a fyzickém prostoru. Identifikace času se vyskytuje ve všech kulturách, i když její způsob se může lišit (Casasanto \& Bottini, 2014; Lakoff \& Johnson, 1999).

\subsubsection{Materiální vtělení}

Vytváření metaforických reprezentací nám umožňuje získat nad věcmi nadhled, vidět je z různých úhli̊, obracet je. Aplikaci této myšlenky dokládají následující př́iklady.

Loizos Heracleous a Claus Jacobs (2008) dali vedoucím podniků za úkol, aby sestavili hmotný objekt z kostek pro lepší utřídění komplexních aspektů vedení firem jako například návrh strategie.

Robert Barner (2008) vyzýval skupiny manažerů, aby pomocí metafor „dodali slov“ svým emočním reakcím na probíhající změny v organizaci.

Heather Cairns-Leeová (2015) využila rozhovory a kresby pro zmapování subjektivní a symbolické reality třiceti vedoucích pracovníků. Toto mapování posloužilo ke zjištění toho, co se mohou naučit o (a) vlastní schopnosti vést ostatní, o (b) možnosti tuto schopnost rozvíjet od základního povědomí až k vlastním mentálním modelům.

Alke Gröpel-Wegenerová (2015) provedla studii se 165 studenty umění a designu, kteří měli za úkol nakreslit a prodiskutovat osobní vizuální metafory analýzy sekundárních zdrojů.

Sarah Nixonová a Caitlin Walkerová (2009) napomohly zaměstnancům jedné vysokoškolské katedry, aby namodelovali kurikulum pomocí verbálních a vizuálních metafor prostřednictvím procesu zvaného metaphors at work (pracující metafory).

Sabine Harrerová (2014) se ve svém doktorském projektu na Rakouské akademii věd zaměřila na způsob, jakým lze zprostředkovat osobní ztrátu a žal pomocí návrhu digitálních her. Použila přitom zkušenosti s konstrukcí materiálních metafor truchlících matek. 
Takovéto př́stupy mají své výhody, protože hmotných konstrukcí se lze dotýkat, lze jimi pohybovat a zkoumat je z různých úhlů, stejně jako je předvádět druhým. Tím se stávají alternativním způsobem zprostředkování chápání, diskuse a rozhodování. Zhmotňování metafor má oboustranný efekt. Metafory dovolují externalizaci vnitřní zkušenosti a současně mají fyzické metaforické reprezentace vliv na duševní procesy.

David Grove si uvědomil, že s tímto vzájemným působením psychického a hmotného prostoru lze pracovat. Vytvořil léčebné centrum, v němž se nacházely hmatatelné simulace metafor jeho klientů. Pokud klientovy metafory hovořily o lese, jeskyni, kopci nebo vodní ploše, sezení se prováděla na skutečném místě, které se shodovalo se smyšleným prostředím klienta (Lawley, 2006).

\subsection{Vztah (vtělených) metafor a tacitního učení}

Tacitní znalost se často chápe jako výsledek tacitního učení - učení, které probíhá, aniž by si jej člověk uvědomoval. Zatímco naše pozornost je zaměřena na explicitní rovinu, tacitní učení probíhá v pozadí, v rovině implicitní.

Metafory jsou dobrou ilustrací této skutečnosti, nebot' jejich sdělení je obsažnější než jejich samotná forma. Mají emergentní vlastnosti - pohled na formu jejich vyjádření nestačí k předpovědi jejich významu. Tacitně je získávána informace „navíc“, aniž bychom si toho byli vědomi. Toto platí pro všechny metafory, i pro ty neverbálně vyjádřené. Např́íklad gesta, pohled a otočení hlavy často poukazují na pozici symbolů v mentálním prostoru mluvčího. Metafora „plánování do budoucna si žádá otevřenost“ může být často provázena gestem značícím otevřenost a přimhouřením očí, jakoby se mluvčí díval do dálky před sebou. Tato mimojazyková informace je užitečná pro posluchačovo porozumění metafoře, avšak není př́iliš pravděpodobné, že si jí bude vědom.

Fyzické reprezentace našich metafor nám mohou poskytnout překvapivé př́ležitosti si mnohé uvědomit a získat vhled do věcí. Einstein jednou řekl: „Moje tužka je chytřejší než já.“ (Popper, 1994, s. 109) Jeden z mých klientů řekl něco podobného: Po naší schůzce jsem nakreslil sám sebe jen s jednou rukou. Moje fyzické tělo na to zareagovalo a já ucítil bolest v pravé paži. Po večeři jsem se k tomu obrázku vrátil, začal jsem znovu kreslit a prostě se vyloupla levá ruka a ta fontána zesílila. A mně došlo, že nemám jen jednu, ale dvě paže „,moji “ velikosti a že na věci dosáhnu a nemusím se natahovat. 
Tato výpověd' nabízí několik stop k jevưm, které probíhají, aniž by si jich byl klient vědom: „moje tělo na to zareagovalo“, „vyloupla se levá ruka“a „ta fontána zesílila“. Kombinovaným účinkem těchto výrazů bylo navození podmínek pro náhlé uvědomění. Klient by měl možná potíže s vysvětlováním, odkud se tyto vizuální a kinestetické symboly berou nebo proč se mění. Značná část učení - v tomto př́ípadě o sobě samém - poukazuje na tacitní znalosti a tacitní myšlení.

Rostoucí povědomí o významu vtělené metafory pro učení a vzdělávání je prezentováno ve dvou nových knihách. Jedna z nich „se zabývá vtělenými a analogickými přístupy“ k učení dospělých (Taylor \& Marienau, 2016) a druhá se soustřed'uje na aplikaci těchto př́istupů ve vzdělávání dětí (McCracken, 2016).

Vytváření mentálních modelů je primárně tacitní operací. Lidé jsou si vědomi svých myšlenek, pocitů a způsobů chápání světa, ale často nemají ponětí o tom, jak je organizují do jednoho uceleného svazku. (Lakoff \& Johnson, 1999) Způsoby, kterými člověk využívá prostor, čas, formu a hierarchii k trrídění svých zkušeností, však mohou po hluboké úvaze vstoupit do jeho vědomí. Často je k tomu však třeba obratné pomoci (Depraz, Varela, \& Vermesch, 2003; viz kapitolu 3 o čistém jazyce). Člověk používá vtělené metafory pro popis této tacitní znalosti. 


\title{
3 Čisté dotazování: utvořme kvalitativní výzkum ověřitelným
}

\author{
James Lawley \\ Výzkum pomocí rozhovoru je ve společenských vědách zatižen obecně utvrzenou představou, \\ že rozhovor otevírá př́mou cestu do respondentových zkušeností, názorů, přesvědčení, identit \\ a postojů k celé řadě sociálních a kulturních jevi̛, což vedlo k rozšírení nekritického použití \\ rozhovorů v různých empirických studiich, kde výzkumníci přiliš spoléhali na poněkud \\ zjednodušenou představu: „položím otázku, oni odpovědí a vy pak budete vědět".
}

(Cho, 2014, s. 42-43)

Právě volba slov při dotazování hraje roli, která se těsně dotýká výše uvedené kritiky, jejíž autorkou je Yoonjoo Choová. Mnohé literární zdroje prezentují četné důkazy o potenciálu neúmyslného ovlivnění tazatelovými otázkami (viz níže), méně však bylo napsáno o možném vlivu metafor, které je výzkumník zvyklý používat (Tosey, 2015), nebo o ovlivnění ze strany presupozic a rámování (framing). Je to překvapující, nebot' otázky jsou pro rozhovory condicio sine qua non, a navíc rozhovory jsou dost možná nejrozširřenější metodou sběru dat v kvalitativním výzkumu (King, 2004).

Tato kapitola zkoumá, jak tazatelovy jazykové struktury (jako metafory, presupozice a rámcování), mohou neúmyslně ovlivnit obsahy odpovědí respondenta, a jak může tento jev narušit autenticitu a důvěryhodnost nasbíraných dat (Lincoln \& Guba, 1985). Tyto záležitosti jsou rozebírány v následujícím popisu metody čistého jazyka a metody pro kontrolu validity výzkumných rozhovorů. $\mathrm{V}$ závěru je diskutován př́nos čistého dotazování pro výzkum tacitních znalostí.

\subsection{Zkreslení na straně respondentů}

Mnohé prekoncepty respondentů, které mohou mít vliv na proces otázka-odpověd, zdokumentovali Podsakoff, MacKenzie, Lee, \& Podsakoff (2003). Např́klad tzv. consistency effect znamená tendenci odpovídat způsoby, které se shodují s otázkou; acquiesence bias je tendence přijímat domněnky implicitně obsažené v otázce; a friendliness effect je sklon 
odpovídat tak, jak se participant domnívá, že výzkumník očekává. Ve všech třech případech může participant (nevědomě) v tazatelovi hledat signály, na jejichž základě odpovídá. Participant i výzkumník tak mohou nevědomě zvýšit riziko primingu, kdy vystavení se jednomu podnětu ovlivňuje pozdější jednání. Nevědomé důsledky primingu se pak mohou projevit ve volbě slov i dlouho poté, co vědomá mysl na podnět zapomněla (Tulving, Schacter, \& Stark, 1982).

\subsection{Priming u tazatele}

Př́ručky zabývající se technikou rozhovorů zmiňují potřebu minimálního tazatelova zkreslení participantovy výpovědi. Mimo rozbor metod otevřených a uzavřených otázek je však málo pozornosti věnováno potenciálnímu vlivu jazykových struktur. Ještě více alarmující je však skutečnost, že některé přední publikace použivají př́klady rozhovorů, které jsou protkány metaforami ze strany tazatele a sugestivními otázkami. Autoři na ně ale neupozorňují, ani je nijak nekomentují. Uved’me dva z desítek sesbíraných prríkladů. První ukázka je z publikovaného článku o technice vedení rozhovoru (Englander, 2012, s. 31-33; metafory jsou podtrženy).

Výzkumník: Jak ovlivnila tato vzpomínka váš život? Jaký dopad měla na váš život?

Participant: Byt tátovy přitelkyně, nebo moje babička? Obojí?

Výzkumník: Ta první. Jak vás to zasáhlo, jaký to na vás mělo dopad?

Participant: ...značný dopad to rozhodně má. ...

Autor ve svém článku prezentuje několik zajímavých poznatků o deskriptivních fenomenologických výzkumných rozhovorech, ale nezmiňuje se, že použití tazatelovy metafory dopad/zasáhnout třikrát rychle za sebou může navodit priming. Pokud existuje možnost, že participantova výpověd' „značný dopad to rozhodně má“ je výsledek vlivu výzkumníkovy metafory třikrát užité $\mathrm{v}$ předcházejících otázkách, může dojít $\mathrm{k}$ narušení věrohodnosti následných analýz nebo vyvozených závěrů.

Další článek vydaný National Institute for Health Research ve Spojeném království Velké Británie a Severního Irska (Lacey \& Luff, 2009, s. 45) předkládá úryvky z přepisu rozhovorů pro budoucí analýzu. Jeden z transkriptů zachycuje rozhovor s učitelkou střední školy, která 
hovoří o svém návratu do práce 14 měsíců poté, co prodělala srdeční prříhodu. Jsou v něm následující tř̌i otázky položené v rychlém sledu (metafory podtrženy):

\section{Takže bylo těžké se vrátit?}

Myslíte, že to změnilo váš výhled do budoucna?

Takže váš výhled se změnil?

Aby tyto otázky pochopila, musí respondentka porozumět metaforám těžké se vrátit a změnilo vášs výhled, z nichž ani jedna nebyla dř́ve v přepisu zmíněna. Pokud nejsou tyto otázky hned zpočátku zavrženy, jejich slovosled ponese presupozici, že vracení se je těžké a že její výhled se změnil. Ačkoli článek vysvětluje způsoby analýzy takového transkriptu a poukazuje na riziko zkreslení na straně tazatele během interpretace, nikde se nepozastavuje nad zpochybněním autenticity výpovědí respondentky. Obava o autenticitu výpovědí je oprávněná vzhledem ke sklonům ke zkreslení v důsledku primingu i ostatních zkreslujících vlivů (viz podkapitola 3.1), jimž respondentka podléhá při své snaze odpovědět na otázku, která již sama o sobě definuje rámec pro odpověd'. Zůstane záhadou, zda by tato konkrétní respondentka skutečně odpověděla jinak na otázky bez těchto rámců, jistá pochybnost však přetrvává.

Paul Tosey (2011) uvádí jiný příklad z článku, který se zabývá charakterem osobních transformací dospělých studentů. Metafora pokraje/hranice (nap̌r. „hranice vědění) je v článku zmíněna sto čtyřikrát, ale $\mathrm{v}$ citacích respondentových výpovědí se nenachází ani jednou. Po velmi pozorném přečtení článku lze dojít k závěru, že hranice je pravděpodobně metafora, kterou použíá autor a nikoli respondent.

\subsection{Proč tolik záleží na tazatelových metaforách?}

Elizabeth Loftusová a John Palmer (1974, s. 586-588) zjistili, že konkrétní znění otázek pozměnilo u respondentů vzpomínky na události, které na vlastní oči viděli. Jeden experiment ukázal, že záměna jediného slova v otázce dokázala změnit výši odhadu rychlosti u diváků videonahrávky nehody až o 27 \%. Na otázku: „V jaké rychlosti do sebe ta auta narazila?“ odpověděli respondenti v průměru 31,8 mil v hodině. Jiná skupina reagovala na otázku: „,V jaké rychlosti do sebe ta auta tř́skla?" Tato skupina odhadovala rychlost o devět mil v hodině vyšší, tedy 40,8. Zcela jinou metodu použili Paul Thibodeau a Lera Boroditsky (2011) ve 
svém nedávném výzkumu, když zkoumali změnu jedné metafory o trestném činu: zločin jako virus nebo zločin jako bestie; přičemž zjistili, že tato záměna byla dost zásadní na to, aby systémově změnila způsob, jakým lidé uvažovali o zločinu. Došli k závěru, že „i ta nejprchavější přítomnost metafory (zastoupená jedním slovem) může mít silný vliv, který je navíc skrytý: lidé metaforám nepřipisují takový význam.“V kontextu této kapitoly se „lidmi“ rozumí tazatel i participant.

Loftusová (1975) také zjistila, že otázky, které nesly nepravdivou domněnku, že se nějaký předmět nebo událost objevily ve filmovém záznamu (např́íklad: Přešla ta žena s kočárkem přes cestu?) zdvojnásobily pravděpodobnost odpovědi, v níž participant tvrdil, že se tato událost stala, než kdyby otázka zněla: Viděl/viděla jste ženu s kočárkem? Tato pravděpodobnost byla dokonce třikrát vyšši v porovnání s kontrolní skupinou, jíž žádná z těchto - domněnkami obtěžkaných - otázek nebyla kladena.

\subsection{1 Čistý jazyk}

Pokud je vmísení metafor a domnělých způsobů myšlení neúmyslné a převážně nevědomé (Lakoff \& Johnson, 1999), je možné zmírnit riziko „kontaminace“ dat jazykovými strukturami výzkumníka? Poradenský psycholog David Grove (1989) nalezl způsob, jak své terapeutické rozhovory se silně traumatizovanými pacienty oprostit od metafor. Nazval tento př́stup čistý jazyk (clean language). Za posledních dvacet let se čistý jazyk rozšíril z terapie do obchodní sféry (Doyle, Tosey, \& Walker, 2010; Martin 1999; Martin \& Sullivan, 2007), vzdělávání (Gröppel-Wegener, 2015; McCracken, 2016; Nixon \& Walker, 2009; Nixon, 2013) a kvalitativního výzkumu (podrobněji níže).

Tím, že si výzkumníci dávají dobrý pozor na jazyk, který používají, dokáží minimalizovat nechtěné vlivy a neúmyslné zkreslení v průběhu všech stadií výzkumu: návrhu, sběru dat, analýzy a prezentace (Van Helsdingen \& Lawley, 2012). Čistý jazyk dokáže zdokonalit rozhovor konkrétně tím, že minimalizuje vnášení metafor a konstruktů ze strany výzkumníka (Tosey et al., 2014). Tím se nemyslí, že je výzkumník, který používá čistý jazyk, zcela bez vlivu. Cílem čistého jazyka je minimalizovat spolukonstrukci obsahi̊, ale zároveň brát ohled na fakt, že tazatel hraje důležitou roli ve společné konstrukci procesu prostřednictvím přivádění respondentovy pozornosti k jistým aspektům jeho zkušenosti (Tosey, 2015). 
Owen (1996) si jako první uvědomil význam osvojení si Groveových otázek v rámci fenomenologického výzkumu a od té doby se tato technika aplikuje ve výzkumných šetřeních věnovaných např́iklad těmto tématům:

- metafory o učitelích vytvářené íránskými studenty (Akbari, 2013);

- narativy o životě osob s diagnózou demence (Calderwood, 2011);

- nizozemská prŕípadová studie o roli znalostí $\mathrm{v}$ oblasti protipovodňové ochrany (Janssen, Mol, van Tatenhove, \& Otter, 2014);

- jak starší pracovníci požárních a záchranných sborů nacházejí rovnováhu mezi prací a osobním životem, když plánují a řeší odchod do důchodu a přizpůsobují se životu v penzi (Pickerden, 2013);

- zkušenosti členů Ulsterského obranného pluku (Ulster Defence Regiment) ve městě Belfast v Severním Irsku (Snoddon, 2005).

\subsection{Potřeba škály ,čistoty“}

Výzkumníci musejí predvést kvalitu své práce způsoby, které jsou úměrné jejich domněnkám o tom, jak použivají rozhovory. (Roulston, 2010, s. 199)

I když má výzkumník v plánu držet se protokolu čistého jazyka, řeší tak jen polovinu problému. Jestliže dotazovatelovy metafory a konstrukty vstupují do rozhovoru neplánovaně, jak poznáme, k čemu ve skutečnosti dochází? Současná literatura o kvalitativním výzkumu popisuje opatření, jež se starají o robustnost analýzy dat z rozhovoru; málo se však diskutuje o aplikaci kriterií validity samotného procesu rozhovoru.

Pro ověření, nakolik se dotazovatelé drží zásad metody čistého jazyka, byla sestavena „škála čistoty“ (Lawley, 2010; Lawley \& Linder-Pelz, 2016). Každá otázka nebo každé tvrzení ze strany dotazovatele spadá do jedné z pěti kategorií:

klasicky čisté - spadají do standardního souboru otázek čistého jazyka (Lawley \& Tompkins, 2000) nebo se jedná jen o opakování respondentových slov; ${ }^{85}$

\footnotetext{
$8585 \%$ otázek ze šesti rozhovorů o rovnováze mezi prací a osobním životem byly následujícího, klasicky čistého formátu (Tosey, Lawley, \& Meese, 2014):

A co to bylo za......?

A kde (asi) je......?

A ještě něco k......?

A odkud znáte......?
} 
kontextově čisté - vnášejí pouze „neutrální“ slova založená na kontextu výzkumu nebo logiky vyplývající z participantovy výpovědi;

mírně navádějicí - vnášejí slova, která mohou odvádět, ale bez znatelného efektu na respondentovy odpovědi;

silně navádějicí - vnášejí slova, obzvláště metafory, domněnky, rámce nebo názory, které mohou nastolit pochybnosti o autorství respondentových odpovědí;

ostatni - komentáře mimo obsah rozhovoru, napřr. o průběhu rozhovoru nebo odpověd' na participantovu praktickou otázku.

Výsledky analýzy jednotlivých otázek a sdělení jsou shrnuty do tabulky a je z nich vyhodnocena celková „čistota“ každého rozhovoru. Cílem je samozřejmě dosáhnout 100\% „,̌istoty“ rozhovoru, avšak je zde několik faktorů, které to takřka znemožňují. Pro praktickou ilustraci byly přesto zkombinovány výsledky kategorizace 15 rozhovorů (875 otázek/sdělení tazatelů). Tyto byly provedeny třemi výzkumníky se zkušenostmi s čistým jazykem v rámci tří různých publikovaných projektů. Z tabulky 1 je patrné, že v průměru pět (z 58) otázek nebo komentářů spadalo do kategorie „mírné navádějící“ a pouze jedna do „silně navádějící“.

Tabulka 1

Průměrné hodnoty ,,čistoty “ patnácti rozhovorů vedených s využitím čistého jazyka

\begin{tabular}{|l|l|l|}
\hline $\begin{array}{l}\text { Kategorie tazatelovy } \\
\text { otázky/sdělení }\end{array}$ & $\begin{array}{l}\text { Průměrný počet otázek/sdělenív } \\
\text { průběhu rozhovoru }\end{array}$ & $60 \%$ \\
\hline Klasicky čisté & 35 & $25 \%$ \\
\hline Kontextově čisté & 15 & $9 \%$ \\
\hline Mírně navádějící & 5 & \\
\hline
\end{tabular}

A tedy ...... kupř́ḱkladu jak?

A když .......co se stane s.....?

A existuje nějaký vztah mezi ...... a .....?

A ...... je totéž, nebo se liší od......?

A dál?

A co se děje pak?

A odkud se ....... vzalo?

A co se děje těsně před......?

Poznámka: ,....." značí participantova slova. 


\begin{tabular}{|l|l|l|}
\hline Silně navádějící & 1 & $2 \%$ \\
\hline Ostatní & 2 & $4 \%$ \\
\hline Celkem & $\mathbf{5 8}$ & $\mathbf{1 0 0} \%$ \\
\hline
\end{tabular}

Pokud jsou v rozhovoru pouze dvě silně navádějící otázky, je možné vyřadit tuto část respondentových odpovědí z analýzy a stále zachovat většinu dat. Se zvyšujícím se počtem navádějících otázek a sdělení se však zvyšuje i zpochybnitelnost věrohodnosti a integrity dat.

Na systematické studii čistoty rozhovorů vedených v čistém jazyce ve srovnání s tradičními rozhovory se zatím pracuje a bude publikována později. Prozatím i letmé zhodnocení vzorků „modelových“" rozhovorů (v knihách a odborných článcích z oboru kvalitativního výzkumu) podává důkazy potvrzující hypotézu, že tradiční rozhovory jsou vystaveny většímu riziku vnášení obsahů a jsou zranitelnější vůči navádějícím domněnkám. Vzhledem k tomu, že „cílem každého rozhovoru v kvalitativním výzkumu je ... nahlížet na dané téma z pohledu participanta a pochopit jak a proč zaujímá tuto konkrétní perspektivu“ (King, 2004), rozšíření neúmyslných navádějících otázek a vnucování obsahu zpochybňuje validitu výsledků získaných z těchto rozhovorů.

\subsection{Další rysy rozhovorů vedených v čistém jazyce}

Mimo mechanismus minimalizace vnášení metafor a domněnek ze strany dotazovatele, rozeznávají zastánci metody čistého jazyka ještě další dva její rysy: (a) ideálně se hodí pro zkoumání metafor a mentálních modelů participantů a (b) dokáže sbírat hloubková data daleko účinněji než tradiční metody.

\subsubsection{Výzkum metafor a mentálních modelů}

Mnozí autoři se shodují na tvrzení, že čistý jazyk je obzvláště užitečný pro výzkum autogenních metafor a mentálních modelů, což potvrzuje řada studií (Cairns-Lee, 2015; Linder-Pelz \& Lawley, 2015; Tosey et al., 2014).

Toseyho (2015, s. 205) zaujal „potenciál [čistého jazyka] pro výzkumnou práci díky systematickému a preciznímu způsobu zkoumání bez narušování participantova vnitřního světa“. Vzhledem k tomu, že dodržování techniky čistého jazyka zabraňuje tazatelům, aby do 
rozhovoru vnášeli své metafory, datový analytik, a nakonec i čtenář mohou mít jistotu, že všechny citované metafory pocházejí od respondenta.

\subsubsection{Sběr „hloubkových“ dat}

Protože rozhovor vedený čistým jazykem se v plné míře odvíjí jen od respondentových popisů za použití jeho vlastní slovní zásoby, má participant větší tendenci k sebereflexi a pátrání po mechanismech své subjektivní zkušenosti. Studie metafor vedoucích pracovníků o jejich vnímání rovnováhy mezi pracovním a osobním životem odhalila daleko barvitější popisy jejich zkušenosti, než může nabídnout tradiční metafora „rovnováhy“ (Tosey et al., 2014): $d v e ̌$ poloviny kruhu; vezu se na vrcholu vlny; šplhám po skalní stěně a uskakuji balvanům; fyzické a duševní věci jsou oddělené; rozpolcení a prohození; oboustranně pružná situace; jako když žongluju a roztáčím káču.

Tyto metafory byly provázeny osobitými a detailními popisy jak slovními, tak vizuálními (kresbou). Je zajímavé, že čtyři z celkových šesti manažerů si dokázali vzpomenout na své metafory při neformálním setkání o tři roky později (W. Sullivan, osobní komunikace, 2. 7. 2013).

V jiné studii srovnával Jonathan Lloyd (2011) počet „významových jednotek“ získaných od participantů během rozhovorů za použití čistého jazyka a rozhovorů řízených pomocí tradiční techniky. Lloyd zjistil, že průměrný počet významových jednotek získaných otázkami v čistém jazyce se blížil pěti, zatímco srovnatelný rozhovor v tradičním stylu přinesl méně než dvě jednotky na otázku. Přestože přiznává několik možných nedostatků v analýze dat, jeho zjištění otevírá zajímavé téma pro budoucí výzkum.

\subsection{Výzkum tacitních znalostí}

Sám název napovídá, že tacitní znalosti jsou těžko př́stupné a obtížně sdělitelné, což činí z jejich výzkumu nesnadný úkol. Čistý jazyk však může napomoci několika způsoby. Zaprvé, tacitní znalosti nejsou participantovi snadno přístupné ani za ideálních podmínek a situace by se jen zkomplikovala, pokud by do ní výzkumník vnášel své neúmyslné konstrukty. Zadruhé, téměř každý pokus participanta o vyjádření tacitní znalosti bude vyžadovat užití metafory (viz kapitolu 2 o vtělených metaforách). Zatřetí, participanti se mohou ve snaze uchopit a sdělit své zkušenosti nevědomě obracet na výzkumníka pro náznaky a pobídky, které však naruší autenticitu výpovědi, pokud je výzkumník poskytne. $Z$ těchto důvodů má technika rozhovoru 
vedeného v čistém jazyce kapacitu poskytnout kvalitní a ověřitelná data pro kvalitativní výzkum, jakým je kupříkladu výzkum tacitních znalostí. 


\section{Metodologie výzkumu}

\section{Petr Svojanovský, Jan Nehyba}

Empirickou část knihy tvoří kapitoly 4 až 11, tedy sedm kapitol. Jádro empirické části tvoří pět kapitol (kapitoly 7-11), které skrze různé výzkumné otázky a různé výzkumné postupy nahlížejí stejný fenomén: „tacitně-explicitní“ kontinuum znalostí studentů učitelství. Výzkumný design jednotlivých sond je vždy autory podrobně popsán a vysvětlen. Všechny dílčí výzkumy jsou však mezi sebou provázány (1) sdílenými základními definičními znaky tacitních znalostí a (2) sdílenými daty i metodami jejich sběru. Právě tyto dva prvky prolínající se napříč zmiňovanými empirickými kapitolami zde, ve čtvrté kapitole věnované metodologii, vysvětlíme.

Pátá kapitola rozšiřuje metodologii jako takovou. Jejím cílem je evaluovat způsob, jakým jsme ve výzkumu implementovali metodu sběru dat označovanou jako „,čistý jazyk“. Využití této metody nám při výzkumu tacitních znalostí poskytlo několik důležitých benefitů (viz kapitolu 4.4). Je proto důležité rozumět tomu, jak jsme s touto metodou pracovali. V kapitole jsou kvalitativním i kvantitativním způsobem analyzovány vybrané výzkumné rozhovory.

Šestá kapitola je přehledovou studií, která doplňuje a svým způsobem rozšiřuje teoretickou část. Jejím cílem je odpovědět na otázku, jak se v rámci empirického výzkumu přistupuje k tacitním (resp. implicitním, praktickým) znalostem. Jak je tento koncept definován, operacionalizován a zkoumán a také jaké výsledky jejich výzkum přináší. Soubor analyzovaných textů tvořilo deset časopiseckých studií z let 2000 až 2015 psaných v anglickém jazyce a zařazených do databáze Web of Science. Vzhledem k daným kritériím v tomto časovém období se jednalo o úplný výběr.

\subsection{Základní definiční znaky tacitních znalostí}

Haron a Alias (2005) v přehledové studii sumarizovali charakteristiky tacitních znalostí, ke kterým se mnoho autorů odvolává. Tacitní znalosti jsou např́klad považovány za osobní, kontextově vázané, zkušenostně osvojované, individuální či kolektivní či orientované na akci. 
Abychom však byli schopni tacitní znalosti výzkumně uchopit, je potřeba se při jejich operacionalizaci omezit pouze na ty jejich vlastnosti, pomocí kterých lze rozlišovat, zda se jedná o znalost tacitní či explicitní. Přesněji řečeno, s jakou mírou určitosti můžeme hovořit o tom, zda se jedná o znalost tacitní či explicitní. Tacitní a explicitní znalost totiž podobně jako Nonaka a Krogh (2009, s. 636) považujeme za dva póly jednoho kontinua. Dva konkrétní atributy znalosti nám mohou pomoci rozlišovat míru, do jaké lze označit určitou znalost za tacitní či explicitní - uvědomovanost a artikulovatelnost znalosti (srov. Reber, 1989; Eraut, 2000; Polanyi, 2009). V této perspektivě pak můžeme mluvit o míře uvědomovanosti a míře artikulovatelnosti jako o kritériích (definičních znacích), podle kterých lze rozlišovat, ve které části kontinua „tacitní - explicitní“ se ta která znalost nachází. Čím méně uvědomovaná a čím obtížněji artikulovatelná znalost je, tím více se blíží tacitnímu pólu kontinua a naopak. V tabulce 2 ukazujeme, jak vymezení typů znalosti podle vybraných autorů (první sloupec) koresponduje s různou podobou zvolených atributů znalosti (druhý a třetí sloupec). Tyto typy znalostí přitom považujeme za ideální typy (Weber, 2009). Ideální typy nám sice pomáhají znalost diferencovat, a tím lépe konceptualizovat, na druhé straně ale jejich kategorizací dochází ke vzniku umělých (ostrých) hranic mezi jednotlivými typy navzájem, což nezohledňuje komplexní a dynamickou strukturu znalosti (viz kapitolu 1). Proto znalost uchopujeme skrze konstrukt kontinua (čtvrtý sloupec), který určitou míru komplexnosti umožňuje zachovávat (upraveno podle Nehyba a Svojanovský, 2016, s. 60).

Tabulka 2

Od ideálních typů znalosti ke znalostnímu kontinuu „,tacitní-explicitni““

\begin{tabular}{|c|c|c|c|}
\hline $\begin{array}{c}\text { Ideální typy znalostí } \\
\text { podle vybraných } \\
\text { autorů }\end{array}$ & $\begin{array}{c}\text { Míra } \\
\text { artikulovatelnost } \\
\text { i }\end{array}$ & $\begin{array}{c}\text { Míra } \\
\text { uvědomovanost } \\
\text { i }\end{array}$ & $\begin{array}{c}\text { Znalost jako } \\
\text { kontinuum }\end{array}$ \\
\hline $\begin{array}{l}\text { Explicit skills } \\
\text { (Ambrosini \& Bowman, } \\
\text { 2001); Embrained } \\
\text { knowledge (Lam, 2000) }\end{array}$ & $\begin{array}{c}\text { zcela } \\
\text { artikulovatelná }\end{array}$ & $\begin{array}{c}\text { zcela } \\
\text { uvědomovaná }\end{array}$ & \\
\hline $\begin{array}{l}\text { Tacit knowledge- } \\
\text { cognitive element } \\
\text { (Nonaka, 1994); } \\
\text { Imperfortly articulatod } \\
\text { tacit skills (Ambrosini \& } \\
\text { Bowman, 2001); }\end{array}$ & $\begin{array}{c}\text { obtížně } \\
\text { artikuılnvatelná }\end{array}$ & $\begin{array}{c}\text { méně } \\
\text { uvědomovaná }\end{array}$ & $\begin{array}{l}\text { Kontinuum znalosti } \\
\text { „tacitní - explicitni““ }\end{array}$ \\
\hline
\end{tabular}




\begin{tabular}{|l|c|c|}
\hline $\begin{array}{l}\text { Sagacious tacit } \\
\text { knowledge (Castillo, }\end{array}$ & \\
2002) & & \\
\hline $\begin{array}{l}\text { Deeply ingrained tacit } \\
\text { skills (Ambrosini \& }\end{array}$ & zcela & zcela \\
Bowman, 2001); & neartikulovatelná & neuvědomovaná \\
Nonepistle tacit & & \\
knowledge (Castillo, & & \\
2002); Tacit knowledge & & \\
(Reber, 1989) & & \\
\hline
\end{tabular}

Předložený kategoriální rámec slouží jako nástroj, který nám pomáhá operacionalizovat znalost tak, abychom s ní mohli pracovat ve výzkumu, a zároveň nám umožňuje nebýt svázáni ideálními typy. Kontinuum „tacitní - explicitní“ je ve své podstatě založeno na předpokladu, že žádnou znalost nelze jednoznačně označit za tacitní či naopak za explicitní. Přesnější by patrně bylo mluvit o dimenzích znalosti (Šíp \& Švec, 2013). Exaktní určení hranice mezi tím, co je a co není tacitní, v této perspektivě není ani považováno za účelné. To však (zdánlivě paradoxně) neznamená, že bychom ve výzkumu rezignovali na snahu rozlišovat mezi tacitním a explicitním. Spíše než na hledání dělicí čáry je snaha výzkumníků orientována na provázanost obou znalostních dimenzí. Autoři výzkumných sond vysvětlují to, co bylo participanty relativně explicitně řečeno a současně také zaměřují pozornost na to, co v kontextu vysloveného zůstává nepojmenované. To rozpoznávají právě pomocí atributů uvědomovanosti a artikulovatelnosti, které jsou integrální součástí jejich definic tacitních znalostí.

Přestože se uchopením znalosti skrze kontinuum ,tacitní - explicitni““ přibližujeme její komplexnosti patrně více než skrze ideální typy, jsme si vědomi toho, že se jedná o jednu z mnoha perspektiv, jak lze komplexitu znalosti nahlížet. V této knize nabízíme ještě další perspektivu jak komplexitu a dynamičnost znalosti uchopovat, a to skrze čtyři roviny - rovinu interakcí, rovinu tělesnosti, rovinu vnějšího světa a rovinu mysli (viz kapitolu 1.2.3). Přestože v první kapitole ukazujeme, že pro důsledné pochopení znalosti je třeba ji uchopovat skrze všechny zmíněné roviny, omezujeme se při práci s daty především na rovinu mysli z pozice jedince, tedy z pozice participanta výzkumu. Toto epistemologické zaměření nám sloužilo jako sdílený rámec výzkumu. Teprve se sílícím ukotvením postupně zrajících filozofických východisek a díky flexibilní povaze (cirkularitě) kvalitativního výzkumu (srov. Flick, 2009) jsme postupně objevovali význam dalších konceptuálních rovin znalosti a snažili jsme se je do 
analýzy organicky včleňovat. Jejich důkladné empirické vytěžení však zůstává výzvou pro další výzkum.

\section{9 Účastníci výzkumu a kritéria jejich výběru}

Výzkumný vzorek ve výzkumných sondách tvořilo devět studentů učitelství a jedna cvičná učitelka. Všichni studenti v době výzkumu studovali navazujícího magisterské studium učitelství pro základní nebo střední školy. Celkem šlo o sedm studentek (ve výzkumných sondách vystupují pod pseudonymy Alena, Beáta, Dana, Ema, Františka, Jaroslava, Milada) a dva studenty (s pseudonymy Cyril a Karel). Cvičná učitelka provázela studentku Miladu během její učitelské praxe na základní škole.

Před zahájením výzkumu byli studenti osloveni v rámci povinné výuky. Jednalo se o semináře, jejichž cílem bylo podněcovat studenty k reflexi jejich učitelské praxe. Výzkumníci si (zde v roli vzdělavatelů) všímali, jak studenti reflektují svou výuku realizovanou v rámci praxí. Hlavním kritériem výběru studentů pro výzkum byla jejich schopnosti verbální (sebe)reflexe. Vybraní studenti se vyznačovali vysokou měrou rozvinutosti schopnosti reflektovat svoje aktivity v průběhu učitelské praxe. Tím se lišili od ostatních studentů v semináři. Hovoříme o výběru extrémního případu (Maxwell, 2013, s. 98). Důvodem pro stanovení tohoto kritéria byl předpoklad, že práce se studenty, kteří mají rozvinutou schopnost reflektivního uvažování - v kombinaci s použitým způsobem dotazování - povede ke znásobení potenciálu elicitovat tacitní znalosti během výzkumných rozhovorů.

U informantů jsme přitom rozlišovali dvě základní tendence, kterými se při verbální (sebe)reflexi projevovali: (a) tendence reflektovat analyticky a (b) tendence reflektovat „obrazově“. Korthagen (1993) v této souvislosti píše o dvou modech reflexe. V prvním (analytickém) modu je reflexe zrcadlem racionálních procesů (zkušenost je uchopována diferencovaně), v druhém př́ípadě slouží jako zrcadlo neracionálních procesů (zkušenost je uchopována celostně, v gestaltech). Můžeme říci, že analytický modus reflexe je vázaný na doslovný jazyk kdežto „obrazový“ modus naopak na figurativní jazyk, především pak na metafory (blíže k tomu viz první kapitolu). V literatuře (Nonaka, 1991, 1994; Tobin \& Tippins, 1996; Moser, 2000), ale také ve vlastní empirické studii (Nehyba a Svojanovský, 2016) jsme identifikovali návaznost tacitních znalostí na metaforický jazyk. Přestože studenti přirozeně tendovali více či méně $\mathrm{k}$ jednomu $\mathrm{z}$ modů reflexe, díky používané metodě dotazování (viz dále) se nám dařilo ve výpovědích studentů „,nenásilně“ generovat a rozvíjet 
metaforická vyjádření. Metafory se tak staly integrální součástí získávaných dat, což pro výzkumníky představovalo další potenciál k uchopování tacitních znalostí v průběhu analýzy dat.

Homogenitu výzkumného vzorku jsme vyvažovali druhým (doplňujícím) kritériem, na základě něhož jsme oslovovali studenty - potenciální účastníky výzkumu - s pestrou škálou studijních aprobací. Participanti výzkumu byli studenty humanitních (český jazyk, základy společenských věd), př́rodovědných (matematika, chemie, fyzika, přírodopis), výchovných (tělesná výchova, výchova k občanství, výchova ke zdraví, hudební výchova) i jazykových oborů (anglický jazyk, německý jazyk).

\subsection{Proces získávání dat}

Hlavním zdrojem dat bylo celkem 44 nestrukturovaných hloubkových rozhovorů získaných ve výzkumných sondách. Jeden rozhovor trval přibližně 60-90 minut a byl zaznamenáván na video. Výzkumníci tak měli při analýze dat $\mathrm{k}$ dispozici nejen verbální, ale také neverbální projevy studentů. Se sedmi informanty jsme vedli sérii pěti výzkumných rozhovorů realizovaných od záŕí 2013 do ledna 2016.

Každý rozhovor měl své specifické tematické zaměření. Ema a Jaroslava předčasně ukončily studium, a rozhovor o změně studentova pojetí výuky (viz níže) u nich neproběhl. Celkově tedy proběhlo u těchto informantů 33 rozhovorů. Zbývajících 11 rozhovorů proběhlo s Alenou (5 rozhovorů) a Miladou (6 rozhovorů). U prŕípadové studie Aleny (empiricky zpracované v textu Nehyby a Svojanovského, 2016) a př́padové studie Milady (podrobně viz kapitolu 11) proběhla s ohledem na položené výzkumné otázky série rozhovorů, která byla zčásti tematicky orientovaná jinak než u ostatních informantů (viz tabulku 3).

\section{Tabulka 3}

Přehled tematického zaměrení rozhovorů a informantů, s nimiž byly rozhovory uskutečněny

\begin{tabular}{|l|c|c|c|c|c|}
\hline \multicolumn{1}{|c|}{ Informanti } & \multicolumn{4}{|c|}{ Témata jednotlivých rozhovorů (chronologicky seřazeno) } \\
\hline $\begin{array}{l}\text { Ema, Beáta, } \\
\text { Karel, Cyril, } \\
\begin{array}{l}\text { Dana, Františka, } \\
\text { Jaroslava }\end{array}\end{array}$ & $\begin{array}{c}\text { Subjektivní } \\
\text { pojetí výuky } \\
\text { (SPV) }\end{array}$ & $\begin{array}{c}\text { Neočekávané } \\
\text { situace (NS) }\end{array}$ & $\begin{array}{c}\text { Didaktická } \\
\text { transformace } \\
\text { obsahu }\end{array}$ & $\begin{array}{c}\text { Stimulované } \\
\text { vybavování o NS } \\
\text { po výuce }\end{array}$ & Změna v SPV \\
\hline & Subjektivní & Neočekávané & Neočekávané & Metafory & Metafory \\
\hline
\end{tabular}




\begin{tabular}{|l|c|c|c|c|c|}
\hline Alena & pojetí výuky & situace & situace & $\begin{array}{c}\text { v předchozích } \\
\text { rozhovorech }\end{array}$ & $\begin{array}{c}\text { v předchozích } \\
\text { rozhovorech }\end{array}$ \\
\hline Milada, cvičná & $\begin{array}{c}\text { Problematické } \\
\text { situace ve výuce } \\
\text { učitelka }\end{array}$ & $\begin{array}{c}\text { Subjektivní } \\
\text { pojetí výuky } \\
\text { siladentky }\end{array}$ & $\begin{array}{c}\text { Problematické } \\
\text { situace ve výuce } \\
\text { studentky }\end{array}$ & $\begin{array}{c}\text { Problematické } \\
\text { situace ve výuce } \\
\text { studentky }\end{array}$ & $\begin{array}{c}\text { Vybraná místa } \\
\text { z predchozích } \\
\text { rozhovorů }\end{array}$ \\
\hline
\end{tabular}

Doplňujícím zdrojem dat bylo zúčastněné pozorování (nejméně dvakrát u každého studenta) a videozáznam z výuky (jeden u každého ze sedmi studentů, u kterých probíhalo stimulované vybavování). V jednotlivých kapitolách výzkumníci využívali ty datové materiály, které korespondovaly s výzkumnými otázkami ${ }^{86}$.

Veškerá data, s nimiž jsme v rámci výzkumu pracovali, byla získávána výhradně $\mathrm{s}$ (písemným) souhlasem participantů. Účastníci výzkumu byli seznámeni s výzkumným záměrem a se svou rolí v rámci výzkumu. Písemný souhlas s účastí na výzkumu byl získáván i od rodičủ žáků, kteří se zúčastnili pořizování videozáznamu vyučovací hodiny praktikujícího studenta učitelství.

Každý rozhovor začal velmi obecnou úvodní otázkou, která orientovala pozornost studenta na dílčí výzkumné téma (viz tabulku 3). Dále byl rozhovor většinou veden pomocí metody čistého dotazování (viz dále). Stručně nyní vysvětlíme způsob provedení pěti tematických rozhovorů, které tvoří jádro sesbíraných dat.

Tématem prvního rozhovoru bylo subjektivní pojetí výuky studenta (Mareš, 2013; Pravdová, 2014). Jednalo se o téma vhodné pro první rozhovor, nebot' poskytovalo zastřešující rámec pro studentovo uvažování o výuce. Úvodní otázka tohoto rozhovoru zněla: „Když řeknu vy a výuka, co to ve vás vyvolává, co vás k tomu napadá?“ Tématem druhého rozhovoru byly neočekávané situace, se kterými se student učitelství během své výuky setkal. Právě v neočekávaných situacích se totiž mohou aktivovat a projevovat tacitní znalosti (Evans \& Kersh, 2004). Úvodní otázka tohoto rozhovoru zněla: „Setkal/a jste se během výuky s nějakou situací, která vás překvapila, kterou jste nečekal/a?“ Ve třetím rozhovoru jsme pozornost studentů zaměřovali na didaktickou transformaci obsahu (Janík et al., 2007), kterou chápeme jako stěžejní element při snaze studenta (učitele) dosahovat ve výuce vytyčených edukačních cílů. Rozhovor začínal otázkou: „O co vám v dnešní výuce šlo?“ Před čtvrtým

\footnotetext{
${ }^{86}$ Současně výzkumníci v průběhu analýzy dat mezi sebou sdíleli svá zjištění a vzájemně se upozorňovali na relevantní datové úryvky. Pokud např́klad výzkumník analyzující rozhovory o neočekávaných situacích $\mathrm{v}$ datech narazil na potenciálně důležité informace o subjektivním pojetí výuky, předal je kolegovi, který toto téma řešil ve své výzkumné části.
} 
rozhovorem proběhlo pozorování studenta při výuce na základní škole. Tato výuka byla zaznamenána na videokameru. Čtvrtý rozhovor byl realizován na základě stimulovaného vybavování nad tímto videozáznamem. Student byl vyzván, aby si pustil záznam a zaměřoval svoji pozornost na situace, které ho překvapily (tedy na neočekávané situace) a hovořil o nich. Úvodní otázka tedy byla přítomna v této instrukci a podobně jako druhý rozhovor byl dialog studenta a výzkumníka rámován tématem neočekávaných situací. Cílem pátého rozhovoru bylo podobně jako v prvním rozhovoru podnítit studenta k uvažování o vlastním pojetí výuky. Úvahy studenta byly tentokrát směrovány $\mathrm{k}$ uchopení potenciální změny v subjektivním pojetí výuky od doby, kdy byl realizován první rozhovor. Úvodní otázka zněla: „Když řeknu vy a výuka po všech vámi absolvovaných praxích - co je ted’ jinak?“

\subsection{Zpưsob získávání dat}

Na základě postupně zrajících epistemologických východisek (viz kapitolu 1) a po ne zcela uspokojivých výsledcích pilotní fáze ${ }^{87}$ sběru dat výzkumný tým začal při vedení hloubkových nestrukturovaných rozhovorů používat specifický způsob dotazování, tzv. čistý jazyk či čisté dotazování $^{88}$ (clean language interviewing, viz kapitolu 3). Využití čistého dotazování nám při výzkumu tacitních znalostí poskytlo tři klíčové benefity.

1. Umožnilo v rozhovorech získávat data, která se co nejvíce blížila perspektivě první osoby (Varela \& Shear, 1999). Takový přístup „,nezajišt'uje neomylnost dotazovaných, ale umožňuje jim tematizovat důležité a jinak tacitní aspekty jejich zkušenosti“ (Lutz \& Thompson, 2003, s. 39). Právě taková data považujeme při výzkumu tacitních znalostí za relevantní (blíže viz kapitolu 5).

2. Nenásilně podněcovalo respondenta $\mathrm{k}$ vyjadřování se $\mathrm{v}$ metaforickém jazyce (Lawley \& Tompkins, 2000). Právě u metafor byl identifikován potenciál pro výzkumné uchopení tacitních znalostí (např. Tobin \& Tippins, 1996; Nehyba \& Svojanovský, 2016).

\footnotetext{
${ }^{87}$ Data z pilotní fáze výzkumu nebyla zahrnuta do analýz, jež jsou předloženy $\mathrm{v}$ jednotlivých empirických kapitolách. Jednalo se o několik (konvenčním způsobem vedených) rozhovorů, jejichž obsah výzkumný tým analyzoval pouze pro účely vytyčení dalšího postupu při sběru dat. Můžeme říci, že šlo o ,zkušební“ rozhovory.

88 Čistý jazyk a čisté dotazování použiváme v textu jako synonyma. Termín čisté dotazování (clean language interviewing) se používá spíše v souvislosti využití čistého jazyka ve výzkumu (srov. Lawley \& Linder-Pelz, 2016).
} 
3. Orientovalo participanta na prozkoumávání mikrodynamiky a mikrostruktury vlastní zkušenosti. Právě analýzou detailních aspektů zkušenosti se zvyšuje potenciál pro uchopování pre-reflektivní („,tacitní“) dimenze této zkušenosti (Petitmengin, 2006, s. 231-234; Lutz \& Thompson, 2003, s. 37).

Kvalitní data se ukázala být důležitým východiskem při zkoumání tacitních znalostí. Do jaké míry se výzkumníkům dařilo vyžívat potenciál metody čistého dotazování, ukazuje pátá kapitola.

Čistý jazyk má svými východisky blízko k rozhovorovým metodám, které jsou využívány $\mathrm{v}$ naturalizované fenomenologii a v kognitivních vědách - metody takzvané asistované introspekce. Provázení druhého člověka během tohoto procesu umožňuje minimalizovat ,introspektivní iluzi“, tedy zkreslování interpretace vlastní zkušenosti (srovnej Nisbett \& Wilson, 1977; Tvrdý, 2016). Jedná se např́klad o elicitační rozhovory (elicitation interview, Petitmengin, 1999), které jsou konstruovány s odkazem na neurofenomenologii F. Varely nebo o expoziční rozhovory (expositional interview), které jsou důležitou součástí metody popisného vzorkování zkušenosti (Descriptive experience sampling method, Hurlburt, 2009, 2011). Všechny tyto metody se zaměřují na zkoumání toho, jak se naše zkušenost jeví ve vědomí. „Na gramatiku zacílená“ metoda vedení rozhovoru, jež je s čistým jazykem taktéž porovnatelná, se využívá přímo pro výzkum tacitních znalostí (Grammar-targeted interview method - GIM, Zappavigna, 2013). Přestože GIM kategorizuje otázky jiným způsobem než čistý jazyk (používá kategorie jako je nominalizace, generalizace aj.), ve výsledku mají kladené otázky velmi podobnou podobu. Podrobně je metoda čistého dotazování popsána $\mathrm{V}$ kapitole 3. 


\section{$5 \quad$ Evaluace čistého jazyka jako nástroje sběru dat}

\section{Jan Nehyba, Petr Svojanovský}

Cílem této kapitoly je vysvětlit a evaluovat způsob, jakým jsme ve výzkumu implementovali metodu sběru dat označovanou jako čistý jazyk, která byla podrobněji popsána ve třetí kapitole. V kontextu pedagogických věd se jedná o nový způsob dotazování, který nám pomáhá získávat data co nejvíce se blížící pozici první osoby (Searle, 1992; Varela, 1999). V kontextu našeho výzkumu prritom vycházíme z předpokladu, že čím více jsou data získávána z pozice první osoby, tím kvalitnější data to jsou. Kvalitní data chápeme jako informace skutečně získané ze světa participantů výzkumu, tedy informace, které jsou během rozhovoru co nejméně ovlivněné perspektivou výzkumníka. Domníváme se, že pokud jsou - jak z definice vyplývá - tacitní znalosti méně uvědomované a obtižně artikulovatelné, je zapotřebí při vedení rozhovoru usilovat o to, aby strukturace takové znalosti vycházela přímo od informantů. Jinými slovy: čím méně výzkumník do rozhovoru zasahuje, tím větší předpokládáme potenciál pro elicitaci tacitních znalostí. Čistý jazyk umožňuje informantovi prozkoumávat to, co Petitmengin (2014) označuje jako mikrostrukturu své zkušenosti, a tím napomáhá $\mathrm{k}$ uchopování toho, co je pro něj méně uvědomované a obtížně artikulovatelné. Intervence do obsahu rozhovoru ze strany výzkumníka (parafráze či interpretace řečeného či uvádění zcela nových témat) může naopak odpoutávat pozornost dotazovaného od podstatných detailů vlastní zkušenosti, které přispívají $\mathrm{k}$ uvědomění a pojmenování méně zjevných aspektů vlastní zkušenosti.

V textu nejdříve vysvětlíme, jak rozumíme termínu čistý jazyk a jak jej a interpretujeme. Po té přejdeme $\mathrm{k}$ samotné analýze způsobu, jakým jsme tuto metodu používali v praxi, tedy při vedení výzkumných rozhovorů. 


\subsection{Naše porozumění rozhovoru vedenému v čistém jazyce}

Přestože metoda čistého dotazování je založena na několika jasných myšlenkách (např. opakování verbálních a neverbálních projevů participanta, použivání čistých otázek aj.), můžeme $u$ různých představitelů této metody rozlišovat důraz na její odlišné aspekty. Např́klad zda je důraz kladen na přirozenost formulací otázek kladených v rozhovoru, nebo zda je důraz kladen více na používání striktně čistých otázek. Tyto odlišnosti se mohou jevit jako jemné nuance, zároveň však mají velký vliv na způsob, jak je rozhovor veden. Je totiž rozdíl, zda se při vedení rozhovoru striktně držíme seznamu čistých otázek, nebo klademe důraz na to, kde je pozornost informanta na základě jeho předchozí odpovědi (což neznamená, že se musí tyto pozice vylučovat). Proto považujeme za důležité představit to, jak si myslíme, že náš výzkumný tým pochopil a aplikoval metodu čistého dotazování. V následujících odstavcích tak představíme aspekty čistého dotazování, které jsou pro nás důležité.

V našem pojetí se vymezujeme vůči extrémnímu pólu, který lze chápat jako objektivistické pojetí čistoty v rozhovoru, jehož podstata spočívá v technicistní aplikaci otázek uvedených na některém ze seznamu čistých otázek ${ }^{89}$ bez hlubšího smyslu a bez empatie pro dotazovaného. Předpokladem tohoto modelu je přesvědčení, že nám tyto specifické otázky pomáhají systematicky odstraňovat vlastní předpoklady ve vedení rozhovoru tak, aby nás neovlivňovaly pri jeho vedení. V našem pojetí pracujeme spíše s tím, že čistý jazyk nám díky používání čistých otázek pomáhá „minimalizovat“ předpoklady otázek samotných. Každá otázka má určité předpoklady a čisté otázky jsou konstruovány tak, aby měly těchto předpokladů v sobě co nejméně. Např́iklad otázka: „Co za X je to X?” předpokládá jen nějakou formu existence X, oproti otázce: „Co si myslíš o X?”, která předpokládá, že informant si musí o X něco myslet a nikoliv třeba cítit apod. Přesto je jasné, že i čisté otázky svou konstrukcí také formují to, jak informant uchopuje svou zkušenost. Nicméně mnohem méně než běžné otevřené otázky v rozhovoru (srov. kapitola 3 ). To nás ve výsledku zcitlivuje k používání našeho jazyka při vedení výzkumného rozhovoru. Toto zcitlivování vnímáme jako nejdůležitější př́ínos čistého dotazování.

\footnotetext{
${ }^{89}$ Přičemž seznamy otázek se od sebe více či méně liší, a to jak v počtu, tak i kvalitativně (zařazení jiného typu otázek do seznamu) v závislosti kontextu a praxe jednotlivých autorů. Seznamy čistých otázek viz např́. Lawley a Tompkins (2000); Harland (2012a); Way (2013); Tosey, Lawley, \& Meese (2014); McCracken (2016).
} 
Dále nám čistý jazyk pomáhá uvědomovat si a minimalizovat vlastní předpoklady (nikoli mít tendenci je odstranit) ve vztahu k participantovi (vztahová rovina komunikace) a dále minimalizovat předpoklady kladené na vedení rozhovoru (srov. Hulburt, 2011, kapitola 20). To nás přivádí $\mathrm{k}$ více kontextuálnímu a vztahovému pojetí čistoty v rozhovoru. Jedná se tak o určitý návrat $\mathrm{k}$ myšlence tvůrců čistého jazyka Grova a Panzara (1989, s. 23): „Nemůžeme předem definovat gramatiku, syntaxi nebo slovní zásobu čisté otázky. Čistá otázka je jedinečná pro každého člověka. Můžeme dát obecná pravidla k definování čistých otázek. Nicméně musíme zjistit, jaké otázky se hodí pro konkrétního člověka.”

V tomto kontextuálním modelu čistoty je tedy důležité téma raportu (vztahová rovina rozhovoru). Raport považujeme za stěžejní pro to, abychom se dostali ke kvalitnímu obsahu, kterým jsou pro nás data bliźící se co nejvíce perspektivě první osoby. V rámci našeho výzkumu byla podpora raportu uskutečňována především specifickými verbálními komentáři. Samo úspěšné kladení výhradně zcela čistých otázek předpokládá „určitý” raport mezi informantem a výzkumníkem, díky němuž se vytváří bezpečné prostředí, ve kterém se informant může soustředit na vlastní vnitřní svět. Čisté dotazování se tak v našem pojetí snaží udržet raport mezi informantem a jeho vnitřním světem zkušenosti, $\mathrm{k}$ čemuž je však nezbytné udržet určitý druh raportu výzkumník-informant ${ }^{90}$.

Dalším důležitým aspektem našeho pojetí čistého dotazování je, že čisté otázky předně ovlivňují proces vedení rozhovoru a snaži se minimalizovat obsahové ovlivnění informantovy zkušenosti. Nelze říci, že čistý jazyk neovlivňuje dotazovaného. To z pohledu sociálního konstrukcionismu (Gergen, 1999), rozšsiřrené teorie mysli (Rowlands, 2010) a v odkazu na neopragmatismus (Rorty, 1991) není ani možné. Rozdíl je však v tom, jakým způsobem čisté dotazování informanta ovlivňuje. Záměrně dotazovaného ovlivňuje tak, že udržuje jeho pozornost v jeho vlastním zkušenostním poli ${ }^{91}$, aby se na zkoumaný fenomén díval co nejvíce ze své pozice $^{92}$. Neovlivňujeme obsah jeho pozornosti přidáváním nových témat, ale

\footnotetext{
${ }^{90} \mathrm{Z}$ osobní zkušenosti nicméně víme, že experti v čistém jazyce dokáží vytvářet raport pouze používáním čistých otázek a neverbálními projevy (zrcadlení apod.).

${ }^{91}$ Srovnej Urban (2015, s. 44): „Výraz pole Husserl ... zavádí s vědomým poukazem na analogii k běžným zkušenostním polím, jakými jsou např. zrakové pole, hmatové pole atd.“

${ }^{92}$ To předpokládá rozdělení mezi vlastní a cizí zkušeností, což je náš osobní konstrukt. Vlastní zkušenost odkazuje $\mathrm{k}$ tomu, jak já proživám to, když pišu tyto řádky a cizí zkušenost $\mathrm{k}$ tomu, jak prožívá někdo jiný, když píše jinou kapitolu této knihy. Snažím se tak proniknout do cizí zkušenosti, jak vypadá tato cizí zkušenost. Pokud bych se chtěl vrátit k vlastní zkušenosti, tak by to znamenalo, že se musím vrátit k tomu, jak já prožívám zaměřování se na cizí zkušenost.
} 
ovlivňujeme to, o jaké části svého zkušenostního pole informant bude mluvit. Proto můžeme tuto metodu označit jako dotazování z perspektivy druhé osoby (second person interview), která podporuje dotazovaného přiblížit se co možná nejvíce k sobě (z naší perspektivy však nikdy v rozhovoru nemůžeme tuto hranici překročit). Jde tak o to, do jaké míry se "bližíme" $v$ rozhovoru $k$ tomu, kde je pozornost dotazovaného. Dále vnímáme jako čisté i to, pokud se přiblížíme $\mathrm{k}$ tomu, kde je pozornost dotazovaného (užitím syntaxu čistého jazyka ${ }^{93}$ ) a pak jeho pozornost nasměřujeme k „okraji” jeho vnímání osobní zkušenosti (pomocí čisté otázky). Například informant řekne větu: „Vidím sebe prripojeného, jak ke mně proudí všechna ta energie žáků." Pozornost dotazovaného podržíme u celého popisu jeho zkušenosti zopakováním jeho slov a následně ji nasměřujeme na to, co je to za „připojení”, i když jeho pozornost by původně například směřovala dál k rozvíjení tématu žáka. Pokud se „strefíme“ otázkou do toho, kde je nebo kam směřuje pozornost informanta, může ho to ještě více „ponořit” do proudu vlastního prožívání. To ve výsledku může informantovi umožnit dostat se $\mathrm{i}$ k obsahům, které pro něj nejsou zjevné ${ }^{94}$. Cílem výzkumného rozhovoru však není jen „ponoření”, ale právě „vyvážení” tohoto ponoření a zjišt’ování informací ve vztahu k výzkumné otázce.

Ve vztahu k tématu čistoty v rozhovoru je důležité upozornit na to, že samotný pojem „čistota” je metaforou, a někteří autoři ji dokonce v kontextu experimentálního výzkumu považují za vtělenou metaforu, která ovlivňuje naše morální hodnocení (Zhong \& Liljenquist, 2006; Schnall, Benton, \& Harvey, 2008). To je pak reprezentováno konceptuálními metaforami: ČISTÉ JE DOBRÉ a ŠPINAVÉ JE ŠPATNÉ. Této tendence jsme si vědomi a rozumíme slovu „čistý” jinak. Vést rozhovor v čistém jazyce neznamená vést dobrý rozhovor, ale přibližovat se co nejvíce perspektivě první osoby informanta. Toto pojetí se tak snaží zdůraznit, že rozhovor, který je veden v čistém jazyce, je jiný, nikoliv lepší. Přináší nám jiný typ dat než rozhovory vedené konvenčním způsobem (srovnej s hermeneutickým pojetím rozumění jako ,jiného”, ne „lepšího”, Grondin, 2007, s. 174).

\footnotetext{
${ }^{93}$ Syntax je způsob, jak výzkumník skládá otázku pro informanta. Ve formalizované podobě se skládá ze třech částí: 1) A [klientova slova]. 2) A když/jakmile [klientova slova], 3) [čistá otázka]? Ne vždy však výzkumníci přesně dodržovali tři části, někdy použili jen čistou otázku.

${ }^{94}$ Srovnej využití tranzu jako elicitace zkušenosti (Lifshitz et al., 2013).
} 


\subsection{Analýza vedení výzkumných rozhovorů}

Nejdř́ve zdůvodníme výběr rozhovorů, které jsme podrobili analýze a popíšeme jednotlivé fáze analýzy. Po té přejdeme k zjištěním a nakonec $\mathrm{k}$ diskusi výsledků.

V celkovém součtu realizoval výzkumný tým v období září 2013 až leden 201644 hloubkových nestrukturovaných rozhovorů. Rozhovory vedlo 7 proškolených výzkumníků. Všichni výzkumníci prošli školením, jak vést rozhovor v čistém jazyce a konzultovali s experty ve vedení čistého rozhovoru (s James Lawleym, Penny Tompkinsovou nebo Caitlin Walkerovou). Tř́i výzkumníci měli s vedením rozhovoru s pomocí čistých otázek větší praktickou zkušenost (výzkumník 1, 2, a 7), protože prošli jedním z oficiálních workshopů zaměřených na čisté dotazování a delším praktickým nácvikem. Čtyři výzkumníci prošli pouze několikahodinovým školením (výzkumník 3, 4, 5, 6). Výzkumníci (1,2,3) přitom vedli každý přibližně jednu čtvrtinu celkového počtu rozhovorů. Tito tři výzkumníci tedy zajistili přibližně tři čtvrtiny sesbíraných dat. Za účelem evaluace způsobu implementace čistého jazyka při vedení výzkumných rozhovorů jsme od každého z těchto výzkumníků náhodně (losováním) vybrali jeden rozhovor, který jsme následně podrobili analýze (tedy celkem 3 rozhovory). Poslední (čtvrtý) rozhovor, který analyzujeme, byl náhodně vybrán ze zbývající čtvrtiny rozhovorů, vedené jedním ze čtyř dalších výzkumníků (tabulka 4).

Tabulka 4

Základní údaje o výzkumných rozhovorech a jejich analýze.

\begin{tabular}{|l|l|l|l|l|l|}
\hline & \multicolumn{2}{|c|}{$\begin{array}{c}\text { Počet } \\
\text { výzkumných } \\
\text { rozhovorů }\end{array}$} & $\begin{array}{c}\text { Počet } \\
\text { analyzovaných } \\
\text { rozhovorů }\end{array}$ & $\begin{array}{l}\text { Téma analyzovaného } \\
\text { rozhovoru }\end{array}$ & $\begin{array}{l}\text { Informant v } \\
\text { analyzované } \\
\text { m rozhovoru }\end{array}$ \\
\hline Výzkumník 1 & 10 & $23 \%$ & 1 & $\begin{array}{l}\text { subjektivní pojetí } \\
\text { výuky }\end{array}$ & Karel \\
\hline Výzkumník 2 & 12 & $27 \%$ & 1 & $\begin{array}{l}\text { subjektivní pojetí } \\
\text { výuky }\end{array}$ & Ema \\
\hline Výzkumník 3 & 10 & $23 \%$ & 1 & didaktická & Františka \\
\hline
\end{tabular}




\begin{tabular}{|l|l|l|l|l|l|}
\hline & & & & transformace obsahu & \\
\hline $\begin{array}{l}\text { Výzkumník 4, } \\
\mathbf{5 , 6 , 7}\end{array}$ & 12 & $27 \%$ & 1 & $\begin{array}{l}\text { didaktická } \\
\text { transformace obsahu }\end{array}$ & Ema \\
\hline Celkový počet & $\mathbf{4 4}$ & $\mathbf{1 0 0} \%$ & $\mathbf{4}$ & & \\
\hline
\end{tabular}

\subsection{Fáze analýzy}

Pro analýzu rozhovorů jsme vyšli z protokolu pro validizaci „čistoty“ při vedení výzkumného rozhovoru (kapitola 3.5), ve kterém jsou stanoveny čtyři základní kategorie hodnotící míru, s níž výzkumník v otázkách ovlivňuje obsah výpovědí informanta: 1) klasicky čisté (classically clean); 2) kontextuálně čisté (contextually clean); 3) mírně/potenciálně navádějící (mildly/potentially leading); 4) silně navádějící (strongly leading).

Proškolili jsme výzkumníci, která začala podle těchto kategorií (deduktivně) analyzovat otázky v rozhovorech. Všechny ostatní výroky (tzv. komentáře) v rozhovoru kategorizovala a vytvářela tak postupně (induktivně) typologii komentářru. Jednalo se o první čtení dat, prováděné proškolenou výzkumnicí.

Kategorizace otázek a komentářủ byla podrobena opětovné analýze dvěma jinými výzkumníky (autory kapitoly), jednalo se tedy o druhé čtení. Ukázalo se, že teoreticky konstruované kategorie pro hodnocení otázek jsou příliš vágně definované - nebyli jsme schopni spolehlivě rozlišit, do které kategorie ta která otázka patří, a začali jsme k analýze přistupovat induktivně. Co se komentářù týče, ukázalo se, že také skrze ně výzkumník ovlivňuje různou měrou výpovědi participanta. A proto také jednotlivé jsme začali kategorizovat jednotlivé komentáře podle míry vlivu na informanta.

Původně kategorizované otázky prošly revizí (třetí čtení, prováděné opět výzkumnicí na základě instrukce) a vznikla tak nová typologie otázek a nové definice kategorií, do kterých jednotlivé typy otázek spadají. Zároveň byly podle míry vlivu na výpovědi participantů kategorizovány také jednotlivé komentáře. 
Poslední fází bylo čtvrté, finální čtení (prováděné autory kapitoly), na základě něhož jsme sledovali, do jaké míry se $\mathrm{v}$ zařazování jednotlivých typů otázek a komentár̆ù ke kategoriím „čistoty“ shodujeme s výzkumnicí. Zkorigovali jsme kategorizaci a finalizovali její dílčí definice.

Na základě popsaného iterativního procesu jsme si přizpůsobili původní kategorie Lawleyho (kapitola 3.5) pro kontext našeho výzkumu. Předně v přizpůsobení došlo k tomu, že chápeme jinak rozsah jednotlivých kategorií. Rozsahem míníme to, co se standardně v logice chápe jako rozsah pojmu, tedy souhrn objektů, které „spadají” pod danou kategorii (např. objekty spadající do námi definované kategorie 1). Náš rozsah kategorií je mnohem větší než u Lawleyho. Lawley do kategorie „klasicky čisté” otázky zařazuje striktně jen předepsané čisté otázky, zatímco my jsme do kategorie 1 zahrnuli i některé konverzační způsoby užití čistého jazyka. Na jedné straně je to způsobeno tím, že nejsme tak zkušení ve vedení rozhovoru $\mathrm{v}$ čistém jazyce, na druhou stranu pro nás byla důležitá i jiná kritéria než jen objektivisticky definovaná čistota (tedy čisté je jen to, co spadá do kategorií čistých otázek).

Výsledky analýzy v následujících odstavcích sumarizujeme nejdříve v části, která popisuje kvalitativní analýzu otázek a komentár̆ů (typy a rozdíly mezi nimi) a pak se zaměřujeme na kvantitativní část analýzy rozhovorů (procentuální zastoupení jednotlivých kategorií otázek a komentář u analyzovaných rozhovorů).

\subsection{Kvalitativní část analýzy}

V této kapitole popisujeme jednotlivé kategorie, které vznikly během analýzy. Otázky jsou seřazené podle míry vlivu na participanta - od kategorie 1 , kam jsou zařazeny nejméně ovlivňující otázky či komentáře až po kategorii 4, kam patří nejvíce ovlivňující otázky. Způsob kategorizace ilustrujeme na konkrétních př́kladech.

\subsubsection{Kategorizace otázek}

Kategorie 1: čisté otázky - varianty ${ }^{95}$

\footnotetext{
${ }^{95}$ U jednotlivých kategorií otázek nebo komentářo̊, kde jsou prezentovány různé varianty (jde o kategorie 1 a 2 u otázek i komentářu), uvádíme ty varianty, které se v rozhovorech vyskytovaly opakovaně. Ty, které se vyskytovaly jen výjimečně, jsme do výčtu nezařadili.
} 
a) Jedná se o otázky, které obsahují pouze slova informanta doplněné o některou z čistých otázek uvedených na seznamu Lawelyho a Tompkinse (2000, s. 282-283).

Př́klad

Participant: Tak bylo to zklamání, že se nenaplnil ten plán, co jsem předpokládal.

Výzkumnik: Co za zklamání? (otázka: What kind of? v seznamu Lawelyho a Tompkinse)

b) Jedná se o otázky, které jsou variací na základní otázku „Co za X to je?”, protože neobsahují žádná témata, názory, představy, přesvědčení atp., které by skrze ně výzkumník do rozhovoru vnášel. Jde pouze o variaci formulace otázky.

Př́klad 1

Výzkumník: Co vás k tomu napadá?

Př́klad 2

Výzkumník: O čem to pro vás je?

Př́klad 3

Výzkumník: Jak bys to pojmenoval?

c) Jedná se o otázky obsahující slova, jež obsahově nijak (na rovině vnější řeči informanta) nekontaminují jeho výpověd'. V podstatě jde o určité parafráze čistých otázek, při kterých však nedochází k jejich významovému posunu. Jde o čistou otázku řečenou vlastními slovy, kde jsou tato slova obecně sdílenými výrazy běžné komunikace.

Př́klad

Výzkumnik: A když to takhle proběhne všechno, tak co se stane dál? (parafráze otázky: What happen next? v seznamu Lawelyho a Tompkinse).

\section{Kategorie 2: kontextově čisté otázky - varianty}

a) Ověrující otázky, kterými se výzkumník ujišt’uje, zda správně rozumí tomu, co informant sděluje. Jde de facto o parafrázi, jejímž cílem je vyjasnění si konkrétní informace, jež ve 
výpovědi informanta zazněla. Nejde o snahu parafrázovat význam výpovědi (tak jako je tomu u kategorie středně ovlivňujících otázek).

Př́klad 1

Výzkumnik: Takže pani učitelka vám řekne, co máte udělat za téma, a na vás je, kolik těch textů, autorů, tam?

Př́klad 2

Výzkumník: A ted'ka přesně mluvíš o matematice, nebo mluvíš o...?

b) Úvodní otázky, kterými výzkumník zahajuje rozhovor s informantem.

Př́klad

Výzkumník: Když řeknu , vy a výuka“, co to s váma dělá, co byste k tomu mohla říct?

c) Otázky směrující ke zpưsobu vyjádření, jejichž smyslem je vyzvat informanty k tomu, aby se vyjadřovali prostřednictvím zvolené instrukce či techniky.

Př́klad 1

Výzkumnik: Když se na to ted'ka podíváte z odstupu a podíváte se na to, o čem to bylo, co vzniklo, tak co se ve vás děje?

Př́klad 2

Výzkumník: A jde to tam zakreslit?

\section{Kategorie 3: středně ovlivňující otázky}

Jedná se otázky, které obsahují i slova, která informant neřekl a která vnášejí do rozhovoru potenciálně nové téma nebo souvislost, resp. významový posun. Jedná se o otázky, které v sobě obsahují parafrázi studentova výroku.

\section{Př́klad 1}

Participant: No já si myslím, že tam hodně třeba u některých hraje vliv to, že když maj třeba ty tři pětky za sebou, tak pak už přijde takové to: „No, tak to stejně dostanu zase pètku. “ 
Výzkumník: Takže to špatné hodnocení, ty tři pětky na ně působí jako, že se jim potom nechce, že si řikají, že už je to jedno?

V uvedeném úryvku se jedná o parafrázi vnášející potenciálně nové téma, že žákům je to jedno. Přestože se tato parafráze může jevit jako významově odpovídající výroku studentky, nelze toto říci $\mathrm{s}$ určitostí. Informant mohl $\mathrm{v}$ pozadí svého výroku implicitně vnímat jiný význam (jiné téma), např́iklad to, že učitelka hodnotí nespravedlivě.

Parafráze je ze své podstaty vždy interpretací, protože totéž řečeno jinými slovy znamená, že v těchto jiných slovech může nastat potenciálně významový posun. Proto je těžké odlišit v tomto ohledu parafrázi (středně ovlivňující otázky) od interpretace (silně ovlivňující otázky), tedy do jaké míry byl či nebyl význam slov informanta posunut, do jaké míry byl informant výzkumníkem ovlivněn. Zařazení otázky do té které kategorie tak záleží na citlivosti výzkumníka v rozlišování míry, do jaké byl v otázce význam informantových výpovědí posunut. Sporné př́pady (tam kde se výzkumníci na zařazení otázky do konkrétní kategorie neshodovali) byly mezi výzkumníky znovu vyjednávány.

$\mathrm{V}$ následujícím úryvku $\mathrm{z}$ dat podtrhaná slova značí př́íklady potencialit pro významový posun v otázce výzkumníka. Formulace studentky všechno, co si připravím, byla výzkumníkem parafrázována na jako učivo. Tím došlo $\mathrm{k}$ významové redukci a tedy významovém posunu výpovědi - všechno co si studentka do výuky připraví, se obsahově nemusí týkat pouze učiva. Formulace studentky uchytí tak ta čtvrtka je výzkumníkem parafrázována jako uchytí, aspoň ta čtvrtina. Parafráze v sobě nese implicitní předpoklad, že pokud by se $\mathrm{v}$ žácích uchytila méně než čtvrtina, pak nelze v další hodině navazovat na hodinu předchozí. Tím vnáší výzkumník do rozhovoru potenciálně novou souvislost, totiž předpoklad o kauzalitě ,jestliže-pak“.

Př́klad 2

Participant: Já už teda jsem upustila od toho, že jim předám v té hodině všechno, co si připravím, protože to většinou nikdy mi nevyšlo. Takže spíš tak jako doufám, že třeba se $v$ nich uchytí tak ta čtvrtka toho, co jim řeknu ... že třeba dalši hodinu mi dokážou zopakovat třeba nebo zodpovědět pár otázek, kterými navážu jako by na to další... 
Výzkumník: Takže když se to uchytí, aspon̆ ta čtvrtina, tak to znamená, že máte na co navázat v té dalši hodině, že vám zareagují na vaše otázky, že se rozpomenou vlastně na to učivo, na to, co jste dělali?

\section{Kategorie 4: silně ovlivňující otázky}

Jedná se otázky, které obsahují i slova, která informant neřekl a která vnášejí do rozhovoru explicitně zcela nové téma nebo souvislost. Jedná se o otázky, které v sobě obsahují interpretaci studentova výroku.

V prvním příkladu informantka popisuje zkušenost z vlastní výuky, kdy žáci nejsou schopni vypočítat příklad, aniž by je svoji fyzikou přítomností a neverbálními signály nepovzbuzovala. Reakce výzkumníka vybízí informanta, aby uvažoval nad tím, zda se takové jednání žáků snaží nějak měnit, odbourávat. Takové úvahy však nebyly ve výpovědích informantky přítomny. Vnesením zcela nového tématu tak výzkumník silně ovlivnil obsah, o kterém studentka mluví.

Př́klad 1

Participant:... nejsou schopni ten př́klad vypočitat bez toho, aniž bych já u nich seděla a kejvala, že jako dobrý ... právě spousta děcek jako má s tím problém, mně pripadá.

Výzkumnik: A odbouráváš to tam nějak...?

Obdobnou situaci ilustruje také druhý př́klad. Výzkumník zde vnáší do rozhovoru explicitně nové téma - zohlednění toho jaký ty děcka jsou v přípravě na výuku.

Př́klad 2

Participant: ...já si myslím, že si toho všímám, jaký ty děcka jsou a co mě tam třeba v té hodině dělají. Samožrejmě nevšimnu si úplně v tu hodinu jako všech... ale prostě měla jsem vytipovanejch pár lidí [žáki̊], na který jsem se potom radši doptávala [ostatnich učitelu]...

Výzkumník: A když potom už teda víš, nebos asi už asi věděla, tak co potom - jako nějak jsi to zohlednila v prípravě, nebo jaks s tím šla dál? 


\subsubsection{Diskuze ke kategorizaci otázek}

Variace na čisté otázky a kategorie 1a, 1c a 2a odkazují k tomu, co Lawley a Tompkins (2005) popisují jako konverzační pojetí čistého jazyka. Čistá konverzace (dialog) se liší od použití čistého jazyka v tom, že:

1) tazatel při ní má v úmyslu něčeho (pro sebe) dosáhnout; v kontextu výzkumu je úmyslem výzkumníka prozkoumat zkušenost informanta v rámci určitého „rámce”, který vytváŕí výzkumná otázka rozhovoru;

2) se děje $v$ reálném světě, a proto je možné, aby tazatel předpokládal více než $v$ metaforické krajině; například v čisté konverzaci v běžném světě předpokládáme, že zákony fyziky platí, kdežto v metaforické krajině dotazovaného tomu tak být nemusí (srov. law of cartoon physics, Harland, 2012a, s. 56);

Tyto subkategorie $(1 \mathrm{~b}, 1 \mathrm{c}, 2 \mathrm{a})$ odkazují k tomu, co se v rámci zkoumání zkušenosti při expozičních rozhovorech (spadajících do metod zkoumání zkušenosti co nejvíce se blížící perspektivě první osoby) nazývá „záměrná nekonzistence otázky” (Hurlburt \& Schwitzgebel, 2007, s. 15). Tato myšlenka jde však částečně proti filozofii čistého jazyka. Uvedení autoři tvrdí, že pokud je určitý zkušenostní fenomén dostatečně „robustní”, tak díky tomu, že otázka je kladena opakovaně a jinak (nekonzistentně), dojde k „zostření významu” zkušenosti (Hurlburt, 2011, s. 161). Z pohledu čistého jazyka s ním můžeme souhlasit jen ve vztahu k opakování otázky (srov. Harland, 2012b). Protože jak sám Hulburt (2011) uvádí, každá z takovýchto otázek má svou výhodu a nevýhodu a právě z pohledu čistého jazyka - čím je větší jednotnost otázky, tím se tyto nevýhody minimalizují.

Hurlburt tak předpokládá to, že naše zkušenost může být „robustní” a můžeme obměňovat otázky, abychom se dostali $\mathrm{k}$ popisu zkušenosti, klademe důraz na to, aby $\mathrm{v}$ otázkách docházelo k „hravé” fenomenologické variaci (srov. Ihde, 2012). To znamená nabízet více možných otázek, které umožňují proniknout ke zkušenosti z různých úhlů pohledu, zatímco čistý jazyk předpokládá „křehkost a fluidnost” některých momentů vnitřní zkušenosti, která se může po sebemenším obsahovém ovlivnění rozpadnout. 


\subsubsection{Kategorizace komentářů}

\section{Kategorie 1: pozitivně ovlivňující komentáře}

Jedná se o komentáře, které upevňují vztah se studentem a povzbuzují ho k otevřenému a detailními prozkoumávání struktury vlastní zkušenosti. Přestože tyto komentáře obvykle obsahují i slova, která informant neřekl, orientují se na proces rozhovoru, nikoliv na obsah rozhovoru.

a) Dávání najevo porozuméní a osobní účasti

V analýze jsme kategorizovali pouze výraznější projevy aktivního naslouchání. Jednoslovné či dvouslovné výrazy, jako např. $h m m$ nebo $a h a$, dobře, jsme jako komentáře nekódovali a neovlivňují tak celkovou četnost komentářů v této kategorii.

Př́klad 1

Výzkumník: Jasný, jasný, jasný. Jasný, žárovka. Jo, jo, jo. (Slovo žárovka použil participant, výzkumník je pouze opakuje.)

Př́klad 2

Výzkumnik: Hm, hm, hm, oukej, dobře.

b) Stabilizování pozornosti skrze doslovnou repliku

Př́klad

Participant: Jo, př́mo $v$ té fyzice, jako ten vztah mezi tím pochopením a učením si fakt myslím, že je jednoduchý - pokud není pochopení, není učení, podle mě.

Výzkumník: Není pochopení, není učení \{kývá hlavou\}.

c) Ubezpečení vedoucí k otevřenosti

Př́klad

Výzkumník: ...nemusí to třeba dávat úplnou logiku ... když vám to nebude nějak sedět, tak se třeba opravite nebo neopravíte \{gestikuluje\} ... prostě, když to nebude přesně odpovídat třeba tomu, jak to máte, tak prostě to nevadí. 


\section{Kategorie 2: kontextově vázané komentáře - neutrální}

a) Předrámování rozhovoru - vysvětlení, o čem je výzkum, jak bude rozhovor probíhat apod.

Př́klad

Výzkumnik: ... já se budu na něco ptát, vy se budete snažit odpovídat, jenom upozorním na to, že některý ty otázky budou znit trošku divně... co vás bude napadat, at' už to bude nějaká myšlenka, pocit, nějaké cokoliv, tak to semka patří, kvůli tomu jsme tady...

b) Upřesňování instrukcí - tyto komentáře vycházejí ze snahy výzkumníka směřovat pozornost participanta výzkumu tak, aby to korespondovalo s výzkumnou otázkou. Nedochází však k vnášení nového obsahu, pouze k rozvíjení obsahu již řečeného.

Př́klad 1

Výzkumník: Já bych se ještě vrátila k tomu, že jim to vysvětlujete polopaticky.

Př́klad 2

Výzkumník: Ještě nějak to vysvětlete trošku.

c) Komentár̆ spojenýs instrukcí/technikou

Př́klad

Výzkumník: ...zkusili bysme automatický psaní, což znamená to, že na téma, který vám dám ... vy budete tři minuty psát, aniž byste měl jako cokoliv na př́pravu a dưležitý na tom je, aby se vám nezastavila ruka...

\section{Kategorie 3: ovlivňující komentáře}

Jedná se komentáře, které obsahují i slova, která informant neřekl a která vnášejí do rozhovoru potenciálně nové téma nebo souvislost, resp. významový posun. Jedná se o komentáře, které v sobě typicky obsahují parafrázi studentova výroku.

Př́klad 
Participant: Ale vím, že když odejdu, tak někteří to dopočitají, a já se vrátím a řeknu, jo, super, dobře, jedeme dál, anebo [řeknu] myslím si, že bysme to mohli udělat trošku jinak, jako trošku líp nebo takhle to nemá být.

Výzkumník: Jo, jo, takže vlastně to řekneš tak nějak jako, neřekneš, jo, tohle je špatně, ale zkusime to jako...

V tomto př́ikladu výzkumník svou parafrází vnáší do rozhovoru potenciálně nové téma, když ve výroku studenta zdůrazňuje rovinu zpětné vazby. Jak vyplývá i z předchozích výpovědí, studentka tematizuje především vliv její fyzické přítomnosti vedle žáků, když mají plnit nějaký početní úkol: jako nenápadně se du třeba napit jo, nebo řeknu, že si du pro kapesník a tak podobně a zkouším jako odejít, aby oni si to zkusili sami... nikoliv způsob, jakým dává žákům zpětnou vazbu.

\section{Kategorie 4: silně ovlivňující komentáře}

Jedná se komentáře, které obsahují i slova, která informant neřekl a která vnášejí do rozhovoru explicitně zcela nové téma nebo souvislost. Jedná se o komentáře, které v sobě obsahují interpretaci studentova výroku. V prvním příkladu jde v první části výroku o shrnutí obsahu dosavadních výpovědí informanta, které ze své povahy nebylo ovlivňující, protože obsahovalo slova a významové souvislosti uvedené samotným informantem. V druhé části výroku však výzkumník už výpovědi studentky interpretoval. Vytvořil tak novou významovou souvislost, konkrétně souvislost $\mathrm{s}$ neočekávanou situací a utvrzením v roli učitele.

Př́klad 1

Výzkumnik: Mluvili jsme o nečekaných situacích, o situacích, které vás vykolejily z role učitele a vrátily vás spišs do té jiné. Ted’ vlastně naopak zase nečekaná situace, která vás v té roli utvrdila.

V druhém př́kladu jde o formu hodnocení výroku studenta a o předložení vlastního názoru. Jak hodnocení, tak vlastní názor vnášejí do rozhovoru novou významovou perspektivu, nové souvislosti.

Př́klad 2 
Participant: ...lepši, když se přiznaji, že to nechápou a to třeba v těch sedmičckách se príznaj ... to jsem se jim to jako snažila dál vysvětlit, nebo podat nějak jinak. Což si myslím, že je takový asi lepší, ale to už je sedmička, to už není ta šestka, no.

Výzkumnik: Hmm, tak to nevadí, tak to je obecně že, já si myslím, že i v té šestce asi, i když by $k$ tomu došlo, tak to bude mít asi stejný průběh.

\subsubsection{Diskuze ke kategorizaci komentářů}

V komentárích se nejvíce projevil náš odklon od tradičního pojetí čistého dotazování ve výzkumu, které záměrně s komentáři nepracuje. Kategorie 1a a 1c by se mohly jevit z pohledu tradičního čistého dotazování jako nežádoucí, ale $1 \mathrm{~b}$ odpovídá nejvíce filozofii čistého dotazování. To proto, že se v př́ípadě této kategorie jedná pouze o naplnění prvních dvou fází syntaxe čistého dotazování a není použita tretéi část (podrobněji k syntaxi viz kapitolu 5.1 Naše porozumění rozhovoru vedenému v čistém jazyce). Tím, že zopakujeme jen dvě fáze syntaxe, chybí otázka a zopakování je jen oznamovací větou, tedy komentářem. Přitom v komentáři není obsaženo nic, co by kontaminovalo výrok respondenta, ale naopak (z naší zkušenosti) toto zopakování posiluje „ponořeni““ informanta do jeho vlastní zkušenosti. V jiných metodách dotazování přibližujícího se pozici první osoby se tato technika běžně používá (srov. Gendlin, 2004 nebo Petitmengin \& Bitbol, 2009). Většina ostatních komentářů v kategorii 1 a 2 slouží bud' $\mathrm{k}$ podpoře vztahu mezi informantem a výzkumníkem, nebo $\mathrm{k}$ orámování či $\mathrm{k}$ předrámování prostoru výzkumného rozhovoru. To přispívá $\mathrm{k}$ vytvoření atmosféry důvěry a bezpečného prostředí, ve kterém se rozhovor odehrává. Zajisté můžeme uvažovat o tom, že tyto komentáře mohou mít sugestivní podobu, ale jsou sugestivní ve vztahu k procesu, nikoliv k obsahu rozhovoru. Kategorie 3 a 4 jsou pak komentáře, které bychom označili v rámci rozhovoru jako nežádoucí, nebot' zbytečně zanášejí témata, která přináší informant.

Souhrnně lze říci, že pozitivně ovlivňující komentáře přispívají k získávání dat z pozice blízké první osoby. Neutrální komentáre pomáhají udržovat proces výzkumného rozhovoru v žádoucí dynamice. Ovlivňující a silně ovlivňující komentáře jsou v rozhovoru nežádoucí, protože mají potenciál měnit či přímo mění obsahové zaměření rozhovoru tak, že není v přirozeném souladu s předchozí výpovědí informanta. 


\subsection{Kvantitativní část analýzy}

Díky výše definovaným kategoriím jsme mohli přistoupit ke kvantifikaci analyzovaných dat. Dva výzkumníci (výzkumník 1 a 2), kteří vedli polovinu výzkumných rozhovorů (22 ze 44), pokládali v náhodně vybraném rozhovoru průměrně $82 \%$ zcela čistých otázek (kategorie 1). Výzkumník 3, který vedl taktéž přibližně čtvrtinu rozhovorů, používal otázky spadající do kategorie 1 pouze z $24 \%$ všech otázek položených v analyzovaném rozhovoru. Zástupce výzkumníků, kteří vedli dohromady přibližně čtvrtinu výzkumných rozhovorů (výzkumník 4) používal otázky spadající do kategorie 1 z 57 \% procent (tabulka 5, obrázek 6). S určitou mírou zkreslení lze dedukovat, že uvedená čísla reprezentují úroveň čistoty i v ostatních výzkumných rozhovorech, které analýze podrobeny nebyly.

Tabulka 5

Četnost otázek $v$ jednotlivých kategoriích čistoty $v$ analyzovaných rozhovorech (v absolutních čislech)

\begin{tabular}{|c|c|c|c|c|}
\hline \multicolumn{5}{|c|}{ Čistota otázek u rozhovorů } \\
\hline & $\begin{array}{l}\text { Rozhovor: } \\
\text { výzkumní } \\
\text { k } 1+ \\
\text { Karel }\end{array}$ & $\begin{array}{l}\text { Rozhovor: } \\
\text { výzkumní } \\
\text { k2+Ema }\end{array}$ & $\begin{array}{l}\text { Rozhovor: } \\
\text { výzkumní } \\
\text { k } 3+ \\
\text { Františka }\end{array}$ & $\begin{array}{l}\text { Rozhovor: } \\
\text { výzkumník } \\
4+\text { Ema }\end{array}$ \\
\hline Kategorie 1 & 57 & 65 & 20 & 66 \\
\hline Kategorie 2 & 11 & 9 & 8 & 8 \\
\hline Kategorie 3 & 1 & 5 & 22 & 32 \\
\hline Kategorie 4 & 0 & 1 & 32 & 10 \\
\hline Celkem & 69 & 80 & 82 & 116 \\
\hline $\begin{array}{l}\text { Délka } \\
\text { rozhovoru }\end{array}$ & 80 minut & 95 minut & 85 minut & 77 minut \\
\hline
\end{tabular}






Obrázek 6. Četnost otázek v jednotlivých kategoriích čistoty v analyzovaných rozhovorech (v procentech).

Co se analyzovaných komentářu týče, z tabulky 6 a z obrázku 7 je patrné, že výzkumník 3 a výzkumník 4 měli výrazně vyšší počet komentářủ v kategorii 3 a 4 než první dva výzkumníci, kteří jsou zkušenější ve vedení čistého dotazování. 
Tabulka 6

Četnost komentárư $v$ jednotlivých kategoriích čistoty vanalyzovaných rozhovorech (v absolutních čislech)

\begin{tabular}{|c|c|c|c|c|}
\hline \multicolumn{5}{|c|}{ Čistota otázek u komentářů } \\
\hline & $\begin{array}{l}\text { Rozhovor: } \\
\text { výzkumní } \\
\text { k } 1+ \\
\text { Karel }\end{array}$ & $\begin{array}{l}\text { Rozhovor: } \\
\text { výzkumní } \\
\text { k2 + Ema }\end{array}$ & $\begin{array}{l}\text { Rozhovor: } \\
\text { výzkumník } \\
3+ \\
\text { Františka }\end{array}$ & $\begin{array}{l}\text { Rozhovor: } \\
\text { výzkumník } \\
4 \text { + Ema }\end{array}$ \\
\hline Kategorie 1 & 18 & 38 & 26 & 34 \\
\hline Kategorie 2 & 12 & 15 & 8 & 22 \\
\hline Kategorie 3 & 2 & 0 & 15 & 15 \\
\hline Kategorie 4 & 0 & 0 & 26 & 15 \\
\hline Celkem & 32 & 53 & 75 & 86 \\
\hline $\begin{array}{l}\text { Délka } \\
\text { rozhovoru }\end{array}$ & 80 minut & 95 minut & 85 minut & 77 minut \\
\hline
\end{tabular}




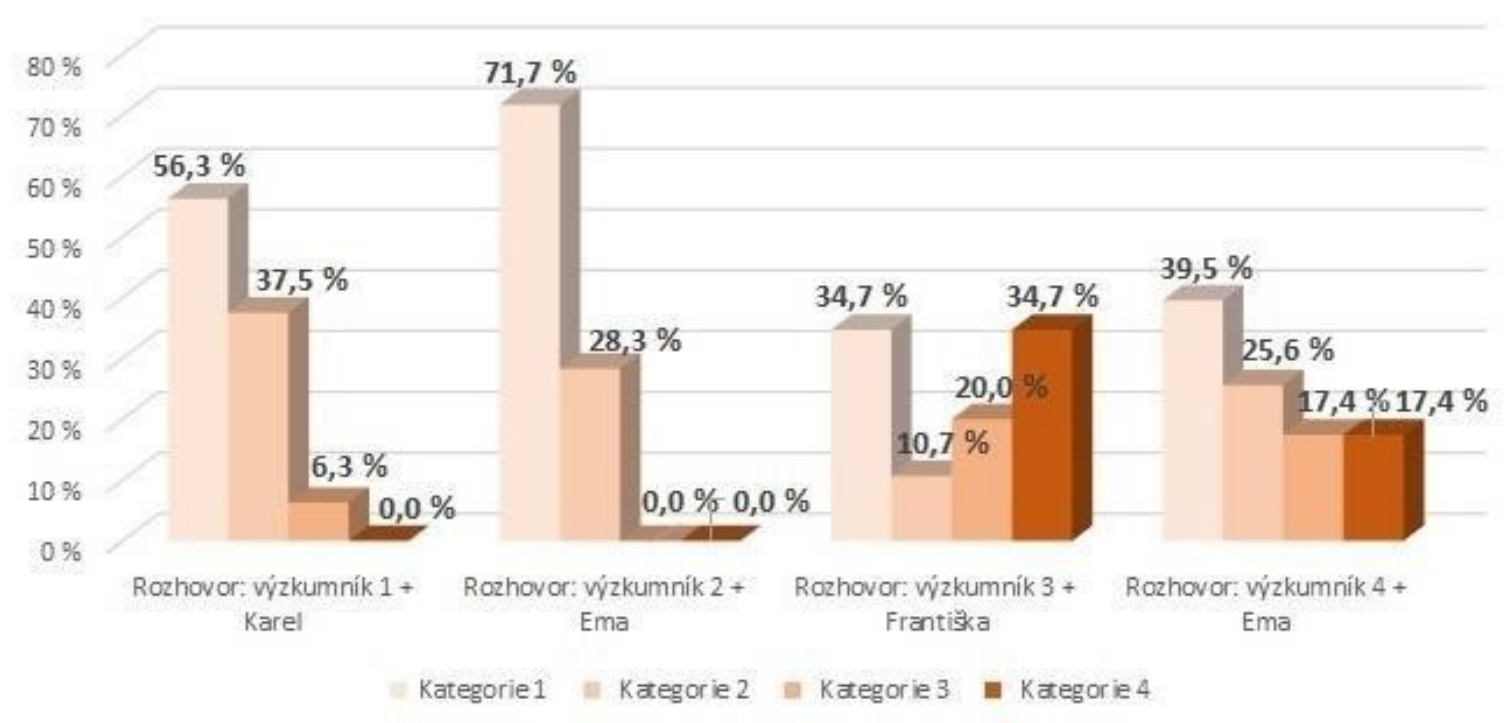

Obrázek 7. Četnost komentárů v jednotlivých kategoriích čistoty v analyzovaných rozhovorech (v procentech).

\subsubsection{Diskuze ke kvantitativní části analýzy}

Souhrnně lze říci, že výzkumníci 1 a 2 používali více nejen otázky spadající do kategorie 1 , ale také používali daleko méně komentářù v oblasti kategorie 3 a 4. Naopak výzkumníci 3 a 4 používali čisté otázky méně a komentářů $\mathrm{v}$ kategoriích 3 a 4 použivali významně více. Tyto výsledky interpretujeme ve vztahu $\mathrm{k}$ míre zkušenosti jednotlivých výzkumníků s aplikací čistého jazyka do rozhovoru. Výzkumníci 1 a 2 mají intenzivnější zkušenost s používáním čistého jazyka, a to nejen $\mathrm{v}$ rámci výzkumných rozhovorů, ale také v rámci koučovacích a terapeutických rozhovorů, rozhovorů zaměřených na reflektivní praxi. To nás vede $\mathrm{k}$ závěru, že ke zvládnutí aplikace čistého jazyka do výzkumného rozhovoru je zapotřebí intenzivní trénink výzkumníků. Ten nespočívá jen v porozumění tomu, jak metoda funguje, ale především $\mathrm{v}$ opakovaném tréninku kladení otázek podporovaného zpětnou vazbou zkušenějšśho praktika. Lze předpokládat, že intenzivnější trénink povede také $\mathrm{k}$ redukci komentářů v kategoriích 3 a 4. Pokud výzkumník není s metodou dostatečně „sžitý“, musí se během vedení rozhovoru soustředit na samotné kladení otázek. To může výzkumníka odvádět od žité zkušenosti dotazovaného, a současně pozornost samotného informanta tímto může být odkláněna od reflektovaného tématu.

Př́klad 1

A jak to teda ... já nevím, jak to formulovat, ale jak to vypadá teda? 
Př́klad 2

Tak - ehm - co by to teda bylo za - ehm, nevím jak to nazvat, nechci to nazvat nějaký odrážky a podobně, prostě co je, čeho bys ty chtěla dosáhnout, takhle?

\subsection{Závěr}

Celkově můžeme shrnout několik závěrů, ke kterým jsme v rámci evaluace čistého dotazování $\mathrm{v}$ rámci sběru dat pro náš výzkum dospěli.

- Definovali jsme jednotlivé kategorie a subkategorie čistoty (1 až 4) u položených otázek. Bylo by zapotřebí dalších výzkumů, které by postupovali taktéž induktivně a mohli by dospět nezávisle na sobě k dalším kategoriím. Takové kategorie by šlo následně navzájem komparovat, což může vést $\mathrm{k}$ zpřesnění kategorií. Zpřesněné kategorie by pak mohli sloužit $\mathrm{k}$ deduktivnímu kódování rozhovorů za účelem evaluace vedených rozhovorů.

- Definovali jsme jednotlivé kategorie a subkategorie čistoty (1 až 4) u použitých komentářů.

- Diskutovali jsme povahu jednotlivých kategorií otázek a komentářu ve vztahu $\mathrm{k}$ ostatním metodám dotazování, které se taktéž v praxi přibližují perspektivě první osoby.

- Provedli jsme kvantifikaci jednotlivých kategorií otázek a komentářù u čtyř rozhovorů, abychom dostali přehled o tom, do jaké míry se nám dařilo dodržovat čistotu při sběru dat. Výzkumníci méně zkušení v dotazování prostřednictvím čistého jazyka měli nejen menší počet čistých otázek spadajících do kategorie 1, ale měli také znatelně vyšší počet komentářů ve 3. a 4. kategorii, než tomu bylo u výzkumníků, kteří absolvovali déletrvající trénink.

- Za zdánlivě banální - z našeho úhlu pohledu však důležitý - poznatek vyjevující se z kvantitativní části analýzy lze považovat to, že kvalita vedení rozhovoru (a tím také předpokládaná kvalita dat) se odvíjí od míry „trénovanosti“ výzkumníka.

Užitečné rozšîŕení výsledků evaluace by mohlo zajistit využití konverzační analýzy. Díky tomu bychom se mohli dozvědět, jakým způsobem otázky a komentáře ovlivňují výpovědi informantů. Z našeho subjektivního pozorování usuzujeme, že během dotazování 
dochází např. k edukaci informanta. Výzkumníci měli opakovaně zkušenost s tím, že informanti po určité době realizace rozhovorů předvídali, na jakou otázku se výzkumník zeptá. Často si otázku dokonce sami sobě položili a odpovídali na ni.

Předpokládáme, že tato zkušenost jde ruku v ruce se zcitlivováním se vůči popisům a reflexi vlastní zkušenosti. To by se dalo vnímat jako přirozený efekt dlouhodobějšího používání čistého dotazování. V rámci zkoumání zkušenosti v lidském vědomí se v některých metodách, jako je tomu např́klad u metody popisného vzorkování zkušenosti (descriptive experience sampling, Hulburt, 2011) informanti záměrně zacvičují, aby dokázali zachytit svou vnitřní zkušenost. To je inspirativní myšlenka, nebot' nejde jen o edukaci výzkumníka, ale také participanta $\mathrm{v}$ tom, jak má ke zkušenosti přistupovat. Zdá se, že čistý jazyk toto způsobuje skrytě.

Z naší zkušenosti vyplývá, že čisté otázky jsou informanty na začátku rozhovoru někdy vnímány jako nepřirozené (informanti se podivují nad tím, co je to za divnou otázku). Informanti pak nemají tendenci soustředit se na obsah své zkušenosti, ale komentují samotnou otázku (často se to stávalo u otázky: „Co za X je to X?”). V našem pojetí čistého dotazování však neztotožňujeme čistotu s přirozeností otázky. Pokud bychom totiž ztotožnili čistotu a přirozenost otázek, informant by pak některé otázky na začátku rozhovoru mohl považovat za čisté, i když v sobě obsahují mnoho předpokladů, kterých si sám není v počáteční fázi rozhovoru vědom. Pro výzkumníka není důležité, aby informantovi vysvětloval, která otázka je čistá a která ne, v rámci procesu si totiž informant postupně skrytě osvojuje logiku dotazování a zcitlivuje se sám ke své zkušenosti. To nás také více přivádí ke vztahovému a kontextuálnímu pojetí čistoty v rozhovoru (viz výše).

\section{$6 \quad$ Tacitní znalosti studentů učitelství a učitelů z výzkumného pohledu: přehledová studie}

\section{Eva Minaříková, Vlastimil Švec}

V současnosti je zřejmé, že profesionál využivá při řešení praktických problémů nejenom literaturu, ale také své skryté poznání, které vychází z jeho zkušeností i ze spolupráce s kolegy a dalšími odborníky a které či často ani neuvědomuje. Toto poznání je označováno jako 
tacitní vědění, jehož základem jsou tacitní znalosti. V této kapitole se zaměříme na přístupy ke zkoumání tacitních znalostí studentů učitelství a učitelů. Nejdříve upozorníme na samotný pojem tacitní znalosti a zmíníme některé pokusy o jeho vymezení.

\subsection{Pokusy o vymezení pojmu tacitní znalosti}

Vznik termínu tacitní znalosti je obvykle spojován se jménem Michaela Polanyiho (18911976), který tvrdil, že víme více, než můžeme vyslovit. Např́́klad poznáme určitého člověka mezi mnoha lidmi, ale nemůžeme obvykle říci, jak jsme ho poznali, nedovedeme to vyjádřit slovy (Polanyi, 1983, s. 4). ${ }^{96}$ Bohm (1992, s. 24) připomíná, že bez tacitní znalosti by neměla žádná jiná znalost smysl:

Když mluvíme, je většina významů implicitní nebo tacitní. Dokonce i při myšlení (ačkoli myšlení může být explicitní, tvoří-li obrazy) je skutečná aktivita myšlení tacitní. Nemůžeme říci, jak to děláme. Když chceme přejít místnost, nemůžeme také říci, jak k tomu dochází. Rozvíjí se to tacitně.

(Bohm, 1992, s. 24)

Podle Schöna často nemůžeme říci, co to znamená, že víme. Když se to snažíme popsat, ocitáme se v nesnázích nebo produkujeme nepřesném popisy (podle Kinsella, 2007, s. 407).

Pojem tacitní znalosti je velmi obtížné jednoznačně vymezit. Sternberg, Grigorenko, Gil, \& Hedlund (2000, s. 313) konstatují, že pojem tacitní znalost je přirozený pojem, který se liší od pojmů nominálních. Proto jej vymezili výčtem jeho charakteristických rysů (Sternberg, Grigorenko, Gil, \& Hedlund, 2000, s. 314-316):

- tacitní znalosti jsou osvojovány bez podpory prostředí;

- jsou procedurální;

- jsou prakticky užitečné;

- zahrnují koherentní vztahy mezi jeho předcházejícími rysy.

Sternberg, který se spolupracovníky dlouhodobě zkoumal tacitní znalosti, dospěl k řadě poznatků, z nich některé - pro naše uvažování zajímavé - uvádíme (Sternberg, 1999, s. 231234):

- tacitní znalosti jsou obtížně přístupné introspekci;

\footnotetext{
${ }^{96}$ Idea tacitního (skrytého) poznání založeného na zkušenostech je však staršího data. Připomeňme Aristotelovo rozlišení teoretického (epistémé), praktického (phronésis) a produktivního (techné) vědění, které lze považovat za první klasifikaci tacitní a explicitní formy znalostí (Adloff, Gerund, \& Kaldewey, 2015, s. 8).
} 
- jsou osvojovány ze zkušeností, a to nejlépe v prostředí, kde budou později využívány;

- nejvhodnější je prostředí, které podporuje zkoumání a povzbuzuje kritické posuzování idejí a zároveň respektuje lidi, kteří tyto ideje navrhli;

- vhodnou příležitostí pro osvojování tacitních znalostí jsou neobvyklé, ale reálné situace.

Tacitní znalosti lze považovat za zdroj individuálních rozdílů mezi jedinci. Jakmile se tyto znalosti stanou explicitními a kodifikovanými, přestanou jako zdroj individuálních rozdílů fungovat (Sternberg, 1999, s. 232).

Jestliže uvažujeme o tacitních znalostech a jejich výzkumu, je třeba vzít v úvahu také jejich komplementární „protipól““ - explicitní znalosti. Z tohoto pohledu můžeme explicitní znalosti charakterizovat těmito znaky:

- jsou osvojovány s podporou prostředí, např. pomocí učebnic, odborných knih, instrukcí učitele;

- mohou být také procedurální, na rozdíl od tacitních znalostí, si jedinec postup uvědomuje;

- mohou být užitečné, a tvořit tak účelné spojení s tacitními znalostmi;

- jedinec si je osvojuje většinou ve standardních situacích.

V literatuře nalezneme mnoho prací, které srovnávají znaky, vlastnosti a projevy tacitních a explicitních znalostí. Např. Panahiu, Watson a Partridge (2012) porovnávají znaky obou těchto druhů znalostí (viz tabulku 7).

Tabulka 7

Znaky tacitnich a explicitnich znalostí (Panahiu, Watson, \& Partridge, 2012, s. 1096)

\begin{tabular}{|c|c|}
\hline Tacitní znalosti & Explicitní znalosti \\
\hline $\begin{array}{l}\text { - vysoce individualizované a osobní } \\
\text { - osvojované prostřednictvím } \\
\text { zkušeností, dovedností, pozorování, } \\
\text { intuitivního cítění, mentálních modů, } \\
\text { přesvědčení a hodnot } \\
\text { - nestrukturované, obtižně se } \\
\text { zviditelňuií, hodnotí, formalizuií, }\end{array}$ & $\begin{array}{l}\text { - } \begin{array}{l}\text { artikulované, strukturované, } \\
\text { dokumentované }\end{array} \\
\text { - } \begin{array}{l}\text { osvojované } \\
\text { instrukce, výkladu nebo opakování }\end{array} \\
\text { - jednoduše se zkoumají, kodifikují, } \\
\text { formalizují, shromažd'ují, sdílejí, } \\
\text { komunikuií a užívaií }\end{array}$ \\
\hline
\end{tabular}




\begin{tabular}{|c|c|}
\hline $\begin{array}{l}\text { zkoumají, zachycují a komunikují } \\
\text { - neuvědomované znalosti } \\
\text { - pracovně a kontextově specifické } \\
\text { - přenositelné prostřednictvím } \\
\text { konverzace a narace (vyprávění } \\
\text { př́běhů, diskuse atd.) } \\
\text { - znalosti typu ,jak“ } \\
\text { - expertní znalosti }\end{array}$ & $\begin{array}{l}\text { - mohou být uloženy v knihách, } \\
\text { časopisech, databázích atd. } \\
\text { - uvědomované } \\
\text { - znalosti typu „,co“a ,„že“ } \\
\text { - akademické znalosti }\end{array}$ \\
\hline
\end{tabular}

Sternberg (1999, s. 232) upozorňuje na vzájemnou interakci tacitních a explicitních znalostí při řešení praktických situací a problémů. Např. rozhodnutí, zda určité explicitní pravidlo aplikovat $\mathrm{v}$ dané situaci vyžaduje tacitní znalost, která se opírá o zkušenosti z řešení profesních situací. Tacitní znalosti se mohou měnit v explicitní znalosti, a to v závislosti na tom, do jaké míry si je (např. při sebereflexi) jedinec uvědomuje. V tomto smyslu lze vztah tacitních a explicitních znalostí chápat jako kontinuum mezi tacitní a explicitní dimenzí znalosti (srov. Connell, Klein, \& Powell, 2003; Švec, 2011).

Vybrané př́stupy k vymezování pojmu tacitní znalosti, které jsme uvedli, byly v našem výzkumném týmu podrobeny kritické analýze. Kritika směřovala k tradičnímu paradigmatu, podle kterého se znalost utváŕí uvnitř těla člověka, resp. v jeho mozku. Nové poznatky z kognitivní psychologie, neurověd i filozofie mysli však ukazují na alternativní paradigma, které - zjednodušeně řečeno - chápe znalosti jako kognitivní, dynamickou strukturu, která se vytváŕí v interakci jedince s prostředím, a není tedy omezena na jeho hlavu a tělo (Šíp \& Švec, 2013; podrobně je toto paradigma objasňováno v kapitole 1 této monografie).

V další části kapitoly podáme přehled vybraných výzkumů orientovaných na tacitní znalosti studentů učitelství a učitelů. Řada autorů výzkumných studií však nepoužívá pojem tacitní znalosti, ale pojem praktické znalosti (studenta učitelství a učitele). Pojem praktické znalosti se poměrně často objevuje ve studiích z oblasti učitelského vzdělávání. Na základě analýzy četných studií upozornili na obsah pojmu praktické znalosti učitele Meijer, Zanting, \& Verloop (2002, s. 407). Praktické znalosti učitele jsou:

- osobní;

- situační (uplatňované v situacích); 
- založeny na reflexi zkušeností;

- převážně tacitní;

- spojovány s určitým obsahem.

Z uvedeného výčtu lze usuzovat, že praktické znalosti učitele mají tacitní charakter.

\subsection{Cíle přehledové kapitoly a výběr výzkumných studií}

Cílem této přehledové kapitoly je podat přehled zahraničních výzkumů tacitních a praktických znalostí studentů učitelství a učitelů. Zaměŕíme se na tyto otázky:

a) Jak jsou ve výzkumných studiích konceptualizovány tacitní znalosti a praktické znalosti učitelů / studentů učitelství?

b) Jaké cíle, popř. výzkumné otázky si kladou autoři těchto studií?

c) Jaké výzkumné metody autoři uplatnili a jaké výzkumné soubory (vzorky) použili?

d) Jaké závěry z těchto výzkumných studií vyplývají?

Výzkumné studie byly vyhledávány v databázi Web of Science, která zahrnuje prestižní mezinárodní odborné časopisy. Vyhledávání proběhlo v únoru 2016 a bylo omezeno na roky 2000-2015 tak, aby bylo možné postihnout nejnovější trendy v námi sledované oblasti. Klíčová slova zahrnovala tacitní/implicitní/praktické znalosti (resp. vědění) v kombinaci se slovy „učitel“ a „výzkum“ ${ }^{97}$ Výsledkem vyhledávání bylo 288 záznamů. Ty byly dále tř́iěny ručně. Do našeho přehledu byly zahrnuty pouze studie splňující následující kritéria:

- časopisecká studie;

- psána v anglickém jazyce;

- reportující empirický výzkum;

- výzkum se explicitně týkal tacitních/implicitních/praktických znalostí;

- jednalo se o tacitní/implicitní/praktické znalosti učitelů nebo studentů učitelství.

Třídění proběhlo ve dvou krocích - nejprve na základě formálních kritérií (zdroj, jazyk studie) a abstraktu (do užšího výběru bylo zahrnuto 27 studií), poté na základě pročítání

\footnotetext{
${ }^{97}$ Přesné zadání bylo následující: TS=("tacit knowledge" OR "tacit knowing" OR "implicit knowledge" OR "implicit knowing" OR "practical knowledge" OR "practical knowing") AND TS=(research) AND $\mathrm{TS}=($ teacher*). TS odpovídá kategorii Topic, která ve Web of Science znamená prohledávání názvu, abstraktu a klíčových slov.
} 
plných textů studií. Do finální analýzy bylo zařazeno pouze 10 studií, které splňovaly výše uvedená kritéria. Jejich přehled je uveden v př́loze.

\subsection{Výsledky přehledové studie}

\subsubsection{Jak jsou tacitní znalosti a praktické znalosti konceptualizovány?}

Autoři sedmi studií se opírají o pojem praktické znalosti. Všechny studie považují za důležitý rys učitelských praktických znalostí osobní angažovanost jedince. Feryok \& Fryde (2012) a Sun (2012) dokonce tento rys uvádějí i v názvu samotného konceptu - osobní praktické znalosti.

Praktické znalosti představují složitější kognitivní struktury, které se obtížně definují. Ve studii, jejímiž autory jsou Clemente a Ramírez (2008) nejsou praktické znalosti vymezeny vůbec. Autoři uvažují o úrovních reprezentace těchto znalostí - pravidla uplatňovaná ve výuce, praktická pravidla a principy. Další autoři vymezují tento koncept poměrně široce. V jejich charakteristikách jsou praktické znalosti chápány jako:

- všechny učitelovy kognice (např. přesvědčení, hodnoty, motivy), které řídí jeho činnosti (Gholami \& Husu, 2010, s. 1520);

- dva druhy poznání - 1) znalosti a přesvědčení, 2) interaktivní kognice (Schepens, Aelterman, \& Keer, 2007, s. 459);

- znalosti, které jsou zkušeností, zakotvenou a rekonstruovanou z narativů života učitelů; zahrnují např. pravidla, principy, obrazy, metafory apod. (Sun, 2012, s. 761). Obrazný (narativní) charakter mají praktické znalosti také v pojetí Feryoka \& Prydeho (2012). Pouze ve dvou studiích je patrný pokus o operacionalizaci pojmu praktické znalosti prostřednictvím jejich znaků nebo zdrojů:

- znaky: na činnost orientované, kontextuální, tacitní, integrované, filtr, na jehož základě fungují přesvědčení studenta učitelství (Melville, Campbell, Fazio, Stefanie, \& Tkaczyk, 2014, s. 754),

- zdroje: situační, osobní, sociální, zkušenostní, teoretické (Levin \& He, 2008, s. 55).

Zbývající tři studie se zabývají výzkumem tacitních znalostí učitelů. Dvě z nich vycházejí z Polanyiho metafory tacitních znalostí: víme více, než můžeme říci (Brevik, 2014; Rämä \& Kontu, 2012). Elliott, Stemler, Sternberg, Grigorenko, \& Hoffman (2011, s. 85) se opírají o 
Sternberga a vymezují tři klíčové vlastnosti tacitních znalostí: 1) jsou osvojovány bez instrukcí druhých, b) mají procedurální charakter, 3) jejich užití je vázáno na cíle jedince.

V analyzovaných výzkumných studiích je vymezení konceptů „tacitní znalosti“ a ,praktické znalosti“ poplatné tradičnímu paradigmatu. Autoři těchto studií se shodují v tom, že tacitní i praktické znalosti učitelů (studentů učitelství) jsou individuální, založené na jejich zkušenostech a že představují složitější kognitivní struktury.

\subsubsection{Jaké cíle, popř́padě jaké výzkumné otázky si kladou autoři těchto studií?}

Námi analyzované studie se často zaměřují na vyjádření, obsah nebo charakter tacitních znalostí. Zkoumá se např́iklad, jak učitelé vyjadřují svoje tacitní znalosti (Clemente \& Ramirez, 2008) nebo to, jaké klíčové obrazy vyjadřují učitelovy osobní praktické znalosti (Feryok \& Pryde, 2012; Sun, 2012). Na projevy tacitních znalostí v jednání se zaměřuje studie učitele autistických dětí (Rämä \& Kontu, 2012).

Další skupinu studií tvoří ty, které se zabývají faktory ovlivňujícími tacitní znalosti (budoucích) učitelů, prŕpadně jejich zdroji (např. Levin \& He, 2008; Melville et al., 2014; Sun, 2012). Na změny tacitních znalostí v rámci určité intervence se zaměřují čtyři studie - tři v rámci přípravného vzdělávání (Elliott et al., 2011; Melville et al., 2014; Schepens et al., 2007), jedna v rámci programu dalšího vzdělávání (Brevik, 2014). Další studie se věnují tématům, jako jsou aktivizování tacitních znalostí (Brevik, 2014) nebo zdůvodňování praktických znalostí (Gholami \& Husu, 2010).

Co se týče cílové skupiny jednotlivých studií, většina se zaměřuje na učitele (šest prrípadů), méně pak na studenty učitelství (tř̆i studie). Pouze jedna se zaměřila na porovnání obou těchto skupin (Elliott et al., 2011).

\subsubsection{Jaké výzkumné metody autoři uplatnili a jaké výzkumné soubory (vzorky) použili?}

Při výběru výzkumného př́stupu studií volí kvalitativní př́ístup (osm studií), jedna kvantitativní prŕístup a jedna přístup smíšený. Vzorek se zpravidla pohybuje v jednotkách respondentů (tři studie pracují s jedním učitelem, dvě studie se dvěma; jedna studie pracuje s 10 a jedna s 21 účastníky). Výjimku tvoří dvě studie s velký počtem respondentů (94, resp. 
664 účastníků). V jednom př́padě není zmíněn počet učitelů, jelikož př́ípadem a tedy i jednotkou byla škola (výzkumu se jich zúčastnilo sedm).

Pro sběr dat jsou využívány různé metody v souladu se zaměřením studie. Nejčastěji se soustředí na učitelovy znalosti a myšlení (kognice), využívají proto rozhovory (v šesti př́padech) a stimulované vybavování (trři př́ípady; pro vybavení se používá bud' videozáznam, nebo audiozáznam výuky doplněný o terénní poznámky výzkumníka), př́padně psaná vyjádření učitelů na zadané téma. Zajímavý př́ístup zvolili Elliott et al. (2011), kteří využili viněty výukových situací, ke kterým byly $\mathrm{k}$ dispozici různé typy řešení. Respondenti měli za úkol jednotlivá řešení ohodnotit na Likertově škále. Výsledky byly poté vyhodnocovány kvantitativně.

\subsubsection{Jaké závěry z těchto výzkumných studií vyplývají?}

Námi analyzované studie zaměřené na tacitní (implicitní), resp. praktické znalosti učitelů přinášejí zajímavé výsledky. Ukazuje se, že projevy tacitních znalostí v jednání učitele (konkrétně v komunikaci s autistickými studenty) jsou obtížně identifikovatelné - lze na ně částečně usuzovat z neverbálních projevů (Rämä \& Kontu, 2012). Naproti tomu v projevech učitelů lze tacitní znalosti učitelů zexplicitnit, a to i za účelem profesního rozvoje (Brevik, 2014). Za povšimnutí stojí, že praktické znalosti učitelů jsou zpravidla reprezentovány na třech úrovních (které ale tvoří kontinuum). Jedná se o vyjádření praktických znalostí konkrétními př́íklady (pravidel, aktivit, materiálů apod.), méně konkrétními praktickými pravidly nebo víceméně dekontextualizovanými principy (Clemente \& Ramírez, 2008). Feryok a Pryde (2012) postavili svůj výzkum na předpokladu, že osobní praktické znalosti učitele jsou tvořeny obrazy, které vedou jednání. Na konkrétním př́íkladu učitele angličtiny jako cizího jazyka identifikovali tři ilustrace takových obrazů: (1) učitel jako průvodce studentů, (2) studenti hledající své já a (3) angličtina v každodenním použití. Další studie (Gholami \& Husu, 2010) naznačuje, že učitelé své praktické znalosti zdůvodňují dvěma typy argumentů - etickým étosem (zejména ideou péče) a tím, co funguje (what works).

Co se týče faktorů ovlivňujících tacitní a praktické znalosti učitelů, studie zmiňují především profesní biografii a oborové vzdělání (Melville et al., 2014), identitu a kulturu jedince (Sun, 2012) nebo zkušenosti před vstupem do prrípravného vzdělávání (školní i mimoškolní; Levin \& He, 2008). Důležitá je i délka praxe, jak naznačuje výzkum Elliotta a kolegů (2011). Ti porovnávali přístup zkušených učitelů a studentů učitelství k hodnocení modelových řešení 
situací popsaných ve vinětách. Ukázalo se, že v hodnocení dobrých řešení se skupiny neliší. Výrazně se ale lišily v hodnocení špatných řešení - ty byly pro studenty učitelství hưře identifikovatelné, a proto je hodnotili lépe (tedy jako dobrá řešení).

Výzkumy zaměřující se na studenty učitelství a jejich praktickou zkušenost v rámci př́pravného vzdělávání potvrzují, že u nich dochází ke změnám v tacitních a praktických znalostech (např. Elliott et al., 2011). Na vliv přípravného vzdělávání obecně na praktické osobní teorie studentů učitelství (a tedy potažmo na jejich praktické znalosti) usuzuje studie Levina a He (2008). Ukazuje se ale, že pouze étos pracoviště, na kterém se vzdělávají a kde konají praxi, nestačí. Studie Melvilla a kolegů (2014) naznačuje, že kontext vzdělávání a praktika, který kladl důraz na badatelsky orientovanou výuku př́rodních věd, neovlivnil studenty tak, aby se prvky takovéto výuky projevily v jejich hodinách. Stejně jako v dalších studiích (Schepens et al., 2007) i zde autoři poukazují na to, že praxe musí být doprovázena reflexí a že podpora od mentora je stěžejní.

\subsection{Diskuse a závěry}

V analyzovaných výzkumných studiích se nejčastěji vyskytuje pojem praktické znalosti. Jsou to znalosti spojené s individualitou (budoucího) učitele. Proto zřejmě někteří autoři (Feryok \& Pryde, 2012; Sun, 2012) tento rys zdůrazňují již v samotném názvu pojmu - mluví o osobních praktických znalostech.

Autoři studií však praktické znalosti vymezují nejednoznačně. Podobně nejednoznačné je definování pojmu tacitní znalosti. Autoři se př́liš drží Polanyiho nebo Sternbergovy charakteristiky tohoto druhu znalostí. Nejasné vymezení obou pojmů může znesnadňovat výzkum tacitních/praktických znalostí studentů učitelství a učitelů. Řada analyzovaných výzkumných studií předpokládá existenci tacitních/praktických znalostí, aniž tyto pojmy definuje v operacionalizované podobě. Většina studií zjišt’uje projevy tacitních/praktických znalostí, ojediněle se úroveň těchto znalostí měří (Elliott et al., 2011).

Většina studií se opírá o kvalitativní výzkumný design, pouze jedna studie je orientována kvantitativně s využitím inventáře tacitních znalostí (Elliott et al., 2011) a jedna studie má smíšený charakter (Melville et al., 2014), kombinující videozáznamy výuky analyzované pomocí kategoriálního systému a hloubkové rozhovory. Volba kvalitativního designu je 
oprávněná, zejména pokud připustíme, že tacitní/praktické znalosti jsou zakotveny ve zkušenostech (budoucích) učitelů. Výpovědi o těchto zkušenostech umožňují usuzovat na projevy tacitních/praktických znalostí. Analyzované kvalitativní výzkumné studie se opírají především o rozhovory a stimulované vybavování. Jde o rozhovory individuální (polostrukturované a hloubkové) a v jednom př́padě o skupinový rozhovor (Brevik, 2014). Za perspektivní je možné považovat př́ípadové studie, které mohou odhalit skryté zdroje tacitních/praktických znalostí. Z analyzovaných výzkumů př́padovou studii využívají tři práce (Clemente \& Ramírez, 2008; Feryok \& Pryde, 2012; Sun, 2012).

Z výzkumných studií je zřejmé, že utváření a rozvíjení tacitních/praktických znalostí učitelů ovlivňuje řada faktorů, počínaje identitou a kulturou učitele (a tedy i kulturou prostředí, ve kterém učitelé žijí a pracují), přes profesní biografii a vzdělání, až po délku pedagogické praxe. Přes proměnlivost těchto faktorů se domníváme, že tacitní/praktické znalosti učitelů jsou stabilnější než tytéž znalosti u studentů učitelství. Nepřekvapují proto výzkumná zjištění ukazující na rozdíly v úrovni tacitních/praktických znalostí studentů učitelství a zkušenějších učitelů. Z analyzovaných výzkumů jedna studie (Elliott et al., 2011) na tyto rozdíly upozorňuje. Přináší zajímavé zjištění: studenti učitelství a zkušení učitelé se nelišili v tacitních znalostech, které potřebovali k identifikaci správných (dobrých) řešení pedagogických situací, ale lišili se videntifikaci řešení nesprávných. Tyto výsledky mohou být interpretovány ve světle konstruktu negativního vědění (např. Gartmeier et al., 2008), které odkazuje k vědění o tom, co nedělat, a tvoří součást efektivního jednání expertů v různých doménách tím, že jim umožňuje vyhnout se slepým uličkám a nevhodným postupům.

Tacitní/praktické znalosti studentů učitelství se v jejich prrípravném vzdělávání teprve utvářejí, metaforicky řečeno krystalizují. K tomu potřebují příznivé podmínky. Dvě z analyzovaných studií ukázaly, že k těmto podmínkám patří podpora jednání studentů ve vyučovacích hodinách mentorem (sdílení znalostí) a průběžné studentské sebereflexe (Schepens et al., 2007; Melville et al., 2014). Do procesu utváření tacitních/praktických znalostí u studentů učitelství vstupují i jejich osobní teorie, jak to výzkumnými výsledky doložila jedna studie (Levin \& He, 2008).

Z analyzovaných studií vyplynulo, že pojem praktické znalosti (budoucích) učitelů je běžně používán (byt' není stále ještě jednoznačně vymezen), zatímco pojem tacitní znalosti se v pedeutologii teprve etabluje, na rozdíl naprríklad od oblasti znalostního managementu. Tato 
skutečnost pravděpodobně ovlivňuje i menší počet výzkumů tacitních znalostí učitelů, a zejména studentů učitelství. V ČR jsou zatím takovéto výzkumy, ale i teoretické studie spíše ojedinělé (např. Švec, 2005). Za jednu z prríčin naznačeného stavu považuje Šíp (2016, viz 1. kapitolu v této monografii) nevyjasněnost samotného pojmu tacitní znalosti. Situace se však pomalu začíná měnit k lepšímu. Na tacitní charakter znalostí učitele - experta poukazuje rozsáhlá výzkumná publikace kolektivu autorů (Píšová et al., 2013). Na nové přístupy (opřené o tzv. čistý jazyk) k výzkumu tacitních znalostí studentů učitelství je zaměřena studie Nehyby a Svojanovského (2016), stejně jako empirické kapitoly této publikace (zejména kap. 7, 8 a 9). 

Tabulka 8

Přehled výzkumů tacitnich a praktických znalostí studentů učitelství a učitelů

\begin{tabular}{|c|c|c|c|c|}
\hline Autoři & $\begin{array}{l}\text { Koncep } \\
\mathrm{t}\end{array}$ & $\begin{array}{l}\text { Cíle studie/výzkumné } \\
\text { otázky }\end{array}$ & Metody výzkumu; výzkumný vzorek & Vybrané výsledky, závěry \\
\hline $\begin{array}{l}\text { Gholami \& } \\
\text { Husu } \\
(2010)\end{array}$ & $\begin{array}{l}\text { Praktické } \\
\text { znalosti }\end{array}$ & $\begin{array}{l}\text { Prozkoumat, jak učitelé } \\
\text { zdůvodňují svoje praktické } \\
\text { znalosti }\end{array}$ & $\begin{array}{l}\text { Kvalitativní výzkum; polostrukturované rozhovory, } \\
\text { stimulované vybavování založené na poznámkách } \\
\text { výzkumníka a audiozáznamech hodin; } 2 \text { zkušení } \\
\text { učitelé prvního stupně ZŠ }\end{array}$ & $\begin{array}{l}\text { Učitelé zdůvodňují své praktické znalosti dvěma } \\
\text { typy argumentů - etickým étosem a tím, co funguje } \\
(\text {,what works“). }\end{array}$ \\
\hline $\begin{array}{l}\text { Schepens, } \\
\text { Aelterman, } \\
\text { \& Keer } \\
(2007)\end{array}$ & $\begin{array}{l}\text { Praktické } \\
\text { znalosti }\end{array}$ & $\begin{array}{l}\text { Prozkoumat změny interaktivní } \\
\text { kognice (jako součásti } \\
\text { praktických znalostí) v průběhu } \\
\text { pedagogické praxe studentů }\end{array}$ & $\begin{array}{l}\text { Kvalitativní výzkum; stimulované vybavování } \\
\text { založené na záznamu hodiny - třikrát v průběhu } \\
\text { praxe studentů učitelství; } 10 \text { studentů učitelství }\end{array}$ & $\begin{array}{l}\text { Změny jsou závislé na studentově individualitě, } \\
\text { studenti potřebují podporu mentora a průběžnou } \\
\text { reflexi jejich činnosti. Obecná tendence byly změny } \\
\text { na úkor promýšlení učiva a ve prospěch přemýšlení o } \\
\text { žácích, jejich potřebách, učení a porozumění. }\end{array}$ \\
\hline $\begin{array}{l}\text { Brevik } \\
(2014)\end{array}$ & $\begin{array}{l}\text { Tacitní } \\
\text { znalosti }\end{array}$ & $\begin{array}{l}\text { Prozkoumat, zda a jak se aktivují } \\
\text { (zexplicitňují) tacitní znalostí } \\
\text { učitelů o jejich výuce } \\
\text { podporující žákovo porozumění } \\
\text { čtenému textu v průběhu } \\
\text { programu dalšího vzdělávání }\end{array}$ & $\begin{array}{l}\text { Kvalitativní výzkum; psané narace týkající se } \\
\text { úspěšné výuky porozumění čtenému textu, } \\
\text { skupinová interview na stejné téma; } 21 \text { učitelů } \\
\text { střední školy, kteří se zúčastnili programu dalšího } \\
\text { vzdělávání zaměřeného na výuku porozumění } \\
\text { čtenému textu }\end{array}$ & $\begin{array}{l}\text { Tacitní znalosti učitelů byly zexplicitňovány } \\
\text { prostřednictvím narativù a s využitím rostoucího } \\
\text { metakognitivního uvědomování si jejich vlastních } \\
\text { znalostí. }\end{array}$ \\
\hline $\begin{array}{l}\text { Clemente } \\
\text { \& Ramírez } \\
(2008)\end{array}$ & $\begin{array}{l}\text { Praktické } \\
\text { znalosti }\end{array}$ & $\begin{array}{l}\text { Prozkoumat, jak učitelé vyjadřují } \\
\text { své praktické znalosti }\end{array}$ & $\begin{array}{l}\text { Kvalitativní výzkum - vícepř́ípadová studie; } \\
\text { hloubkový skupinový rozhovor na téma ,jak } \\
\text { vyučujete čtení“; } 7 \text { škol (1 škola = } 1 \text { prŕípad) }\end{array}$ & $\begin{array}{l}\text { Narativy učitelů vyjadřují tři úrovně reprezentace } \\
\text { jejich praktických znalostí, které tvoří kontinuum } \\
\text { podle míry konkrétnosti a dekontextualizace: } \\
\text { 1. příklady pravidel uplatňovaných ve výuce, } \\
\text { materiálů a aktivit, 2. praktická pravidla, } \\
\text { 3. principy. }\end{array}$ \\
\hline $\begin{array}{l}\text { Elliott, } \\
\text { Stemler, } \\
\text { Sternberg, } \\
\text { Grigorenko }\end{array}$ & $\begin{array}{l}\text { Tacitní } \\
\text { znalosti }\end{array}$ & $\begin{array}{l}\text { Porovnat tacitní znalosti studentů } \\
\text { učitelství a zkušených učitelů a } \\
\text { vliv ročního tréninku učitelských } \\
\text { dovedností na úroveň tacitních }\end{array}$ & $\begin{array}{l}\text { Kvantitativní výzkum; inventář tacitních znalostí: } \\
\text { respondenti posuzovali pedagogické situace a } \\
\text { návrhy jejich řešení na Likertově škále (dobrá } \\
\text { řešení - špatná řešení); } 501 \text { studentů učitelství a }\end{array}$ & $\begin{array}{l}\text { Studenti učitelství a zkušení učitelé se liší v tacitních } \\
\text { znalostech, které jim umožňuji identifikovat špatná } \\
\text { řešení situací. Neukázaly se rozdíly při identifikaci } \\
\text { dobrých řešení. Jeden rok profesního vzdělávání, }\end{array}$ \\
\hline
\end{tabular}




\begin{tabular}{|c|c|c|c|c|}
\hline $\begin{array}{l}, \& \\
\text { Hoffman } \\
(2011)\end{array}$ & & znalostí & 163 zkušených učitelů & $\begin{array}{l}\text { kteří studenti učitelství absolvovali, snížil rozdíly } \\
\text { mezi novici a zkušenými učiteli v identifikaci } \\
\text { špatných řešení situací. }\end{array}$ \\
\hline $\begin{array}{l}\text { Rämä \& } \\
\text { Kontu } \\
(2012)\end{array}$ & $\begin{array}{l}\text { Tacitní } \\
\text { znalosti }\end{array}$ & $\begin{array}{l}\text { Prozkoumat, jak se učitelovy } \\
\text { pedagogické tacitní znalosti } \\
\text { projevují v jeho komunikaci } \\
\text { s autistickými žáky }\end{array}$ & $\begin{array}{l}\text { Kvalitativní výzkum; etnometodologický přístup - } \\
\text { videozáznam učitelovy komunikace se šesti autisty } \\
\text { v autentických situacích, doplněno rozhovory } \\
\text { s učitelem; } 1 \text { učitel }\end{array}$ & $\begin{array}{l}\text { Tacitní znalosti učitelů v komunikaci s autistickými } \\
\text { dětmi se velmi obtížně odhalují. Lze na ně usuzovat } \\
\text { z neverbálních tělových projevi̊ učitele. }\end{array}$ \\
\hline $\begin{array}{l}\text { Feryok \& } \\
\text { Pryde } \\
(2012)\end{array}$ & $\begin{array}{l}\text { Osobní } \\
\text { praktické } \\
\text { znalosti }\end{array}$ & $\begin{array}{l}\text { Prozkoumat, jaké klíčové obrazy } \\
\text { tvoří součást učitelových } \\
\text { osobních praktických znalostí }\end{array}$ & $\begin{array}{l}\text { Kvalitativní výzkum - př́ípadová studie jednoho } \\
\text { z autorů; pozorování, neformální rozhovory } \\
\text { s učitelem, stimulované vybavování, třídní blog, } \\
\text { sběr dat probíhal po celý jeden školní rok; } 1 \text { učitel } \\
\text { angličtiny jako cizího jazyka }\end{array}$ & $\begin{array}{l}\text { V osobních praktických znalostech učitele nalezeny } \\
\text { tři hlavní obrazy: } 1 \text {. učitel jako průvodce studentů, } 2 . \\
\text { jeho studenti hledající své já (v cizím výukovém } \\
\text { prostředí), 3. angličtina v každodenním použití. Pro } \\
\text { rozvíjení osobních praktických znalostí mají zásadní } \\
\text { význam praktické zkušenosti učitele. Avšak při } \\
\text { poznávání a uplatňování nových principů a způsobů } \\
\text { výuky učitel využívá také teorii. }\end{array}$ \\
\hline $\begin{array}{l}\text { Melville, } \\
\text { Campbell, } \\
\text { Fazio, } \\
\text { Stefanile, } \\
\& \text { Tkaczyk } \\
(2014)\end{array}$ & $\begin{array}{l}\text { Praktické } \\
\text { znalosti }\end{array}$ & $\begin{array}{l}\text { Prozkoumat vliv pedagogického } \\
\text { praktika na praktické znalosti } \\
\text { studentů učitelství } \\
\text { př́rodovědných předmětů a to, } \\
\text { jaké faktory ovlivňují integraci } \\
\text { jejich praktických znalostí }\end{array}$ & $\begin{array}{l}\text { Smíšený design; videozáznamy výuky analyzované } \\
\text { pomocí kategoriálního systému, hloubkové } \\
\text { rozhovory; dva studenti učitelství přírodovědných } \\
\text { předmětů v průběhu praxe }\end{array}$ & $\begin{array}{l}\text { Integraci praktických znalostí ovlivňují: kontext } \\
\text { praktika (reforma výuky přírodovědných předmětů - } \\
\text { důraz na výzkumné aktivity žáků), reflexe a } \\
\text { spolupráce s mentorem, studentova profesní } \\
\text { biografie, jeho přírodovědné vzdělání. }\end{array}$ \\
\hline Sun (2012) & $\begin{array}{l}\text { Osobní } \\
\text { praktické } \\
\text { znalosti }\end{array}$ & $\begin{array}{l}\text { Porozumět významu učitelových } \\
\text { zkušeností, které vypovídají o } \\
\text { utváření jeho osobních } \\
\text { praktických znalostí }\end{array}$ & $\begin{array}{l}\text { Kvalitativní výzkum - př́ípadová studie; } \\
\text { rozhovory, videozáznam výuky, terénní poznámky, } \\
\text { další dokumenty (plány hodin, práce studentů, ...); } \\
\text { učitelka čínštiny - imigrantka z Č́́ny, rodilá } \\
\text { mluvčího čínského jazyka }\end{array}$ & $\begin{array}{l}\text { Utváření osobních praktických znalostí učitele - } \\
\text { imigranta je výrazně ovlivněno jeho identitou a } \\
\text { kulturou jeho původní země (Čína). Učitelovy } \\
\text { osobní praktické znalosti jsou mnohovrstevné a } \\
\text { cílevědomé, řízené jedním dominantním obrazem. }\end{array}$ \\
\hline $\begin{array}{l}\text { Levin \& He } \\
(2008)\end{array}$ & $\begin{array}{l}\text { Praktické } \\
\text { znalosti, } \\
\text { praktická } \\
\text { osobní }\end{array}$ & $\begin{array}{l}\text { Předpoklad: praktické osobní } \\
\text { teorie kandidátů učitelství } \\
\text { ovlivňují utváření jejich } \\
\text { praktických znalostí. }\end{array}$ & $\begin{array}{l}\text { Kvalitativní výzkum; písemné vyjádření týkající se } \\
\text { praktických osobních teorií (popis vlastních } \\
\text { přesvědčení o výuce, příklady ilustrující tato } \\
\text { přesvědčení, identifikace zdrojů těchto }\end{array}$ & $\begin{array}{l}\text { Vzdělávání budoucích učitelů ovlivňuje přesvědčení } \\
\text { kandidátů učitelství, zejména jejich uvažování o } \\
\text { výuce. Toto vzdělávání považují autoři za hlavní } \\
\text { zdroj praktických osobních teorií budoucích učitelů. }\end{array}$ \\
\hline
\end{tabular}




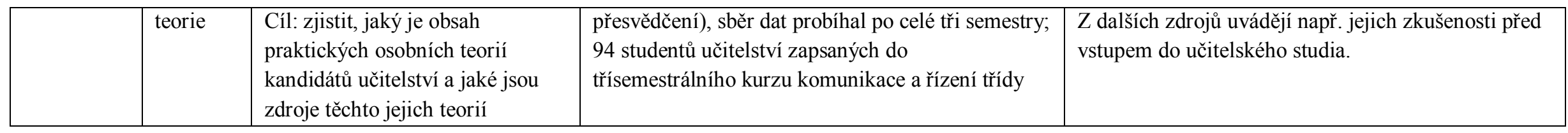





\title{
$7 \quad$ Metaforizace $\mathbf{v}$ procesu zexplicitnění tacitní znalosti
}

\author{
Petr Svojanovský, Jan Nehyba
}

Cílem této kapitoly je ukázat znalost jako komplexní dynamickou strukturu (viz kapitolu 1), kde tacitní znalost a explicitní znalost jsou interagující póly jednoho kontinua. Tato interakčnost je zachycena prostřednictvím analýzy a interpretace procesu zexplicitnění konkrétní tacitní znalosti, který je ilustrován na vybraném empirickém materiálu. Identifikované fáze tohoto procesu ukotvíme v konceptech metaforizace-zdoslovnění a zpětné metaforizace, které tvoří základní stavební kameny filozofických východisek této knihy (kapitola 1).

V textu nejdříve ukážeme konkrétní zexplicitněný obsah původně tacitní znalosti (1), dále vysvětlíme několik indikátorů prokazujících validitu tohoto zjištění (2), po té pomocí tří fází popíšeme samotný proces zexplicitnění (3). Nakonec ukážeme, jakým způsobem se odehrává interakce metaforizace-zdoslovnění a zpětné metaforizace v procesu zexplicitnění TZ (4). Data, na kterých naše zjištění ilustrujeme, pocházejí z třetího rozhovoru s participantem Karlem, který byl tematicky zaměřený na didaktickou transformaci obsahu (viz kapitolu 4).

\subsection{Př́klad obsahu zexplicitněné tacitní znalosti}

Tacitní znalost chápeme jako méně uvědomovaný a/nebo obtížně artikulovatelný aspekt zkušenosti, který se může projevovat v myšlení, jednání a prožívání člověka (Nehyba \& Svojanovský, 2016). Zexplicitnit tacitní znalost v následně popsaném případě znamená, že student Karel pojmenoval dílčí prvek znalosti, jehož obsahu si nebyl zcela vědom a nedokázal jej zprvu artikulovat. Konkrétně se jedná o dílčí část (procedurální) znalosti toho, jak Karel zprostředkovává učivo svým žákům.

Karel během výzkumného rozhovoru vysvětluje své myšlenky o tom, jak zprostředkovává učivo svým žákům a schematicky to zapisuje na tabuli. Pojmenovává dílčí prvky jeho znalosti: vyjdeme od toho, že má žák nějakou představu (dílčí prvek Karlovy znalosti 1), na tabuli napsal slovo představa. Karel tak artikuluje předpoklad, na kterém jeho znalost stojí, 
předpoklad, že žák má představu o učivu. Ve své výuce si podobu této představy žáků Karel ověřuje zjištovaci otázkou ... otázka, kterou jsem zjistil, jestli umí, neumí (prvek znalosti 2). Následují dvě možnosti - bud’ je představa žáků správná (prvek znalosti 3), nebo nikoliv (prvek znalosti 4). V prvním př́padě pak následuje ze strany Karla rozšírení či prohlubování znalostí (prvek znalosti 5), které žáci už mají. V př́ípadě druhém je žákovská představa mylná. To je podle Karla ideální stav, protože pokud učitel pravdivost této představy popře, žáci jsou překvapeni (prvek znalosti 6), a díky tomu zaujatí, tedy motivováni k dalšímu průběhu výuky, mají lepši pozornost, víc je to bude bavit (prvek znalosti 7). Díky tomu může lépe fungovat krok $d v a$, tedy Karlovo vysvětlení (prvek znalosti 8), kdy představu o daném učivu uvede na pravou míru. Vysvětlení Karlova modelu v této úrovni konkrétnosti stačí k tomu, abychom mohli ukázat obsah zexplicitněné TZ a vysvětlit tento proces jako takový.

Pojmenovávání dílčích prvků znalosti o tom, jak zprostředkovává učivo svým žákům, je pro Karla obtížný úkol, který ho znejišt'uje a někdy také uvádí do rozpaků. Přesto je pro Karla toto uvědomění si své vlastní představy důležitým poznáním, ke kterému se během celého rozhovoru na různých místech vrací. Svoji nejistotu vyjadřuje vícekrát během rozhovoru, např́klad: těžký jako udělat nějakej prostě logickej smysluplnej model takhle z fleku ... eh, já půjdu ještě od začátku ... \{drži se za hlavu\} já úplně nevím, kam to zařadit, tu pozornost. Výzkumník proto Karla ubezpečuje, že je v pořádku nevědět, aby jeho nejistota nebránila $\mathrm{v}$ nesnadném procesu jasnější atrikulace znalosti. V této fázi upozad'uje důsledné dodržování techniky čistého jazyka a upřednostňuje raport (viz kapitolu 5), např́klad: „to úplně chápu...možná za deset minut zjistíš, že ti tam něco chybí nebo že to úplně nemá logiku a to je jako úplně v pohodě“. Karel nakonec zexplicitňuje (artikuluje) původně tacitní, tedy méně uvědomovanou znalost (resp. její dílčí prvek), že totiž předpoklad o existenci žákovské představy je ve skutečnosti jeho vlastní představa o tom, jaká je představa žáků: $E h$, abych asi si sám udělal pořádek, co v tom grafu je ted’ka, protože tohle je \{4 sekundy ticho, pak se zasměje a gestikuluje\} moje představa o tom, jakou oni mají představu, v podstatě. (3. rozhovor)

Jedná se o dílčí prvek Karlovy (procedurální) znalosti o tom, jak zprostř̌edkovává učivo žákům (obrázek 8). 




Karel

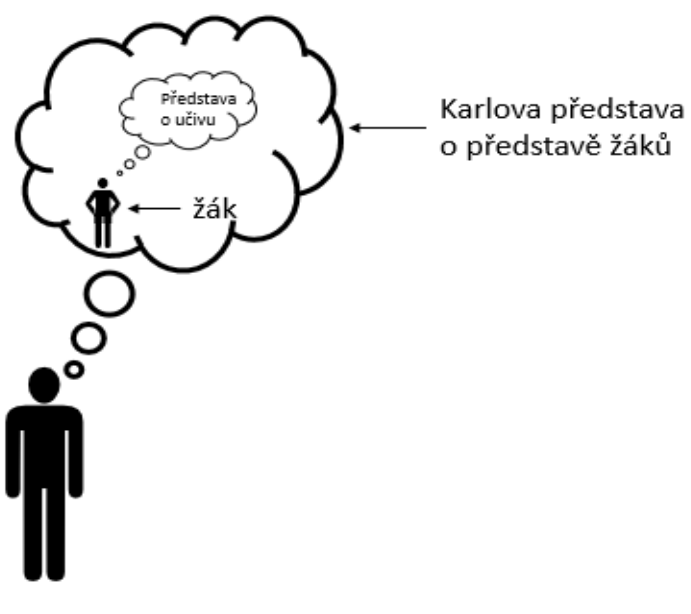

Karel

Obrázek 8. Zexplicitnění dílčího prvku Karlovy původně tacitní znalosti toho, jak zprostředkovává učivo žákům (tj. jak didakticky transformovat obsah).

Stav, kdy nebyl Karlův prvek znalosti 1 zcela uvědomovaný (byl tacitní), reprezentuje v obrázku postava vlevo. Zpočátku byl tento prvek znalosti uvědomovaný a artikulovaný jen částečně - jako žákovská představa o učivu. Později si však Karel uvědomil, že takto vymezený prvek znalosti není odpovídající a původní definici tohoto prvku rozšíriil, čímž zexplicitnil (pojmenoval) tacitní znalost. Výsledek tohoto uvědomění reprezentuje v obrázku postava vpravo. Na první pohled ne tolik významný výsledek Karlovy reflexe má poměrně velké důsledky pro jeho úspěšnost v učitelské profesi. Nejenže žáci mohou mít o učivu náležité a nenáležité představy, ale také učitel sám může správně či nesprávně pochopit, jaká je vlastně výchozí představa žáků. Tím se množí potenciální možnosti selhání v edukačním procesu. Dokonce jako učitel může Karel selhat i tehdy, když mají žáci náležitou představu, ale on ji diagnostikuje jako nesprávnou představu. Podobně jako kultivace TZ (Nehyba \& Svojanovský, 2016) také zexplicitnění TZ vede k větším distinkcím v pochopení samotného procesu výuky, a tím i k přesnějšímu porozumění toho, co je pro práci učitele důležité.

\subsection{Tř́i důkazy zexplicitnění tacitní znalosti}

Lze pojmenovat několik indikátorů, které poukazují na to, že Karel skutečně zexplicitnil tacitní znalost: 1) Karel opakovaně dával najevo, že se ve svém mentálním modelu ztrácí (k tomu používá metaforu zamotáni). To poukazuje na skutečnost, že si plně neuvědomoval přesný obsah své znalosti, konkrétně dílčího prvku znalosti 1 (žákovská představa), který 
nakonec upřesnil na vlastní představu o představě žáků. 2) Samotné zexplicitnění znalosti bezprostředně předcházely verbální (smích) a neverbální (ticho, výrazy těla) projevy „aha“ momentu, tedy uvědomění si něčeho doposud neuvědomovaného - viz datový fragment uvedený výše. 3) Na výzvu výzkumníka k meta-komentování proběhlé konverzace Karel zpětně popsal samotný proces zexplicitňování své tacitní znalosti:

\section{Výzkumník: Dokázal byste o tom něco říct, co se ted'ka ve vás dělo, když jste to psal?}

Karel: ... já mám nějakou představu o tom, co vlastně oni můžou mít $\mathrm{v}$ hlavách, a tím pádem tam dochází, tam dochází ke dvoum potvrzení nebo ke dvoum vyvrácení ... to bylo vlastně to, v čem já jsem se tam tak nějak zamotal, jak jsem nevěděl, jaká představa to tam vlastně je. Ale jo, už asi vím... (3. rozhovor)

Výzkumník: $O$ čem vlastně bylo to zamotání?

Karel: ... zamotání spočívalo v tom, že jsem si uvědomil, že vlas[tně], že nevím, co píšu ... asi jsem neměl jakoby dostatečný prostředky na to, abych vyjádřil to, co jsem opravdu vyjádřit chtěl. Proto se tam objevilo na tabuli slovo představa a já, když jsem se $\mathrm{k}$ němu potom vracel, $\mathrm{k}$ té představě, tak jako v tom ne stresu, ale prostě, že jo, chci něco udělat, a ted' jako vidím něco jiného před sebou tak jako [ř́íám si], jaká je to vlastně představa? Moje? Jejich? Kde to, kde se to tam vzalo na té tabuli, z toho vyšlo to zamotání. (3. rozhovor)

Karel nejdříve poukazuje na to, že si nebyl zcela vědom obsahu znalosti, který chtěl vyjádřit (nevím, co pišs...), nebyl schopen tuto znalost zprvu artikulovat (jsem neměl jakoby dostatečné prostředky na to), což se mu nakonec podařilo (jo, už asi vím).

\section{Proces zexplicitnění tacitní znalosti}

U Karlovy zpětné rekonstrukce procesu zexplicitnění tacitní znalosti se na chvíli zastavíme. Ještě před tím, než proces zexplicitňování začal, se projevila tacitnost Karlovy znalosti v jeho jednání (před-fáze procesu zexplicitnění). Karel napsal na tabuli slovo představa, ale nebyl si plně vědom významu, který tomuto slovu přikládá - nevím, co píšu ... se tam objevilo na tabuli slovo představa. Samotný proces zexplicitnění pak začal v okamžiku (první fáze), kdy Karel začal reflektovat vizualizaci dílčího prvku znalosti 1 (tj. žákovskou představu). Jinými slovy v momentě, kdy začal reflektovat slovo predstava, které na tabuli napsal - když jsem se k němu [slovu] potom vracel, $k$ té představě. Právě v tento okamžik došlo k vnímání nesouladu mezi významem, který slovu představa Karel původně přisoudil a mezi významem, který „za“ tímto slovem řekněme intuitivně vnímal - vidím něco jiného před sebou, tj. uvedené slovo nese jiný význam, než jaký by mělo nést.

Další (druhou) fází procesu zexplicitnění je zamotání, což je metafora, jíž Karel označuje své prožívání situace nesouladu. Karel se v této fázi snaží přijít na to, jaký význam 
slovo představa pro něj skutečně nese - tam docházi ke dvoum potvrzení nebo ke dvoum vyvráceni ... to bylo vlastně to, v čem já jsem se tam tak nějak zamotal. Nakonec (třetí fáze) Karel dochází k uvědomění, čímž zakoušený nesoulad rozpustí.

Karel: ...to bylo jako náraz $[\mathrm{kdy}] \mathrm{z}$ jejich představy se stala moje představa ... uvědomění, že vlastně já mám taky nějakou představu o tom, jaké oni mají představy, to co oni mají v hlavě o té dané látce...

Výzkumník: Vypadá to nějak, to uvědomění?

Karel: (pauza osm sekund) Tak nějak mlhavě ... nebylo to nic ostrého, co bych hledal, nebo nic takového, za čím bych si šel (čtyři sekundy). Já jsem to nehledal, tu věc, která ke mně přišla ... jsem chtěl vyjádřit to, že to přišlo tak nějak samovolně. (3. rozhovor)

Uvědomění Karel spojuje s metaforou nárazu. Pomáhá si tak při vysvětlování tím, co Lakoff a Johnson (1980, s. 26) označují jako orientační metaforu, která dává „pojmu prostorovou orientaci“ (tamtéž). Slovo představa, které bylo napsáno na tabuli, „šlo“ od tabule ke Karlovi. $\mathrm{V}$ momentě, kdy k němu došlo, tak nastal „náraz“. Jedná se tak o fyzikalizaci procesu uvědomování, kdy je uvědomování vnímáno jako prostorový vektor, který vrcholí v momentu uvědomění. Je zajímavé, že Karel si o slově „představa“, které stálo na počátku tohoto procesu myslí, že je to: „takový termín, nevědecký \{kroutí hlavou\}, nefyzikální”. Karlova reflexe odhaluje jeden ze způsobů, jak dochází k zexplicitnění tacitních znalostí, kdy proces uvědomění je vnímán jako entita, která má určitou sílu a směr, jenž způsobuje náraz. Kövecec (2003) a Lakoff (1992) upozorňují na to, že příčina určité události může být vnímána jako síla, která směřuje odněkud někam (causes for forces). To odpovídá i př́ípadu popisovaného vektoru, který je příčinou uvědomění.

\subsection{Interakce metaforizace-zdoslovnění a zpětné metaforizace v procesu zexplicitnění tacitní znalosti}

Před-fáze procesu zexplicitnění tacitní znalosti je ilustrací jednání bez myšlení, kdy Karel napsal na tabuli slovo představa a teprve po té zjišt’oval, zda nese význam, který odpovídá jeho pre-reflektivní zkušenosti (Merleu-Ponty, 1962), v kapitole 1 označované jako strukturovaná zkušenost. Karel v této fázi nevědomě zvolil ohnisko obsahu, na který se dále zaměřovala jeho pozornost. V první fázi procesu zexplicitnění pak toto ohnisko vyzdvihl do vědomí. Před-fáze a první fáze tak odpovídá tomu, co je v kapitole 1 definováno jako proces metaforizace-zdoslovnění. Výsledkem tohoto procesu je uchopení významu vynořovaného z pre-reflektivní roviny zkušenosti v doslovné rovině zkušenosti. Karlem je tento význam 
pojmenován jako představa žáků o učivu, což zaznamenal na tabuli ve zkratce slovem predstava. V obrázku 9 je proto význam označen zkratkou V1 - představa.



Obrázek 9. Interakce metaforizace-zdoslovnění a zpětné metaforizace v procesu zexplicitnění TZ

Jakmile začal Karel zpětně analyzovat význam, který zkušenosti přisoudil, zjistil, že zdoslovněný pojem ,představa“ neodpovídá jeho pre-reflektivní zkušenosti. V obrázku 9 je tento nesoulad znázorněn přerušovanou čarou. Jedná se o okamžik, kdy Karel přechází z první fáze procesu zexplicitnění $\mathrm{TZ}$ do fáze druhé, tedy od nereflektovaného vyzdvižení obsahu znalosti do vědomí $\mathrm{k}$ jeho záměrné reflexi. Tento přechod je současně přechodem $\mathrm{z}$ procesu metaforizace-zdoslovnění do procesu zpětné metaforizace. Zpětná metaforizace slouží Karlovi k tomu, aby se svojí pozorností vrátil z doslovné roviny zkušenosti ke zvolenému ohnisku obsahu v pre-reflektivní rovině zkušenosti. K záměrnému znovu-ponoření se do prereflektivní zkušenosti dochází prostřednictvím roviny figurativní, kdy Karel uchopuje obtížně artikulovatelnou zkušenost pomocí metafor.

Tuto část procesu zexplictnění Karel označuje metaforou zamotání a odpovídá fázi 2 v obrázku 9. Smyslem této fáze je snaha Karla identifkovat význam, který by lépe odpovídal jeho pre-reflektivní zkušenosti. Druhá fáze procesu zexplicitnění vrcholí nárazem (Karlova metafora pro uvědomění), který označuje přechod do poslední (třetí) fáze tohoto procesu. Tento přechod je zároveň také návratem od zpětné metaforizace k metaforizaci-zdoslovnění, kdy Karel vyzdvihuje revidovaný obsah do vědomí. Výsledkem poslední fáze procesu 
zexplicitnění je tak uchopení revidovaného významu v doslovné rovině, že totiž představa žáků o učivu je ve skutečnosti Karlovou představou o představě žáků - v obrázku 9 V2 představa o představě (viz také obrázek 8). Takto doslovně pojmenovaný (revidovaný) význam je již v souladu s Karlovou pre-reflektivní zkušeností, což je v obrázku 9 znázorněno čarou vedoucí od vrcholu V2. Ta propojuje zkušenost uchopenou doslovně a pre-reflektivně.

\subsection{Závěr}

Rozložením procesu zexplicitnění $\mathrm{TZ}$ na jednotlivé fáze jsme se pokusili zachytit dynamiku interakce mezi tacitní a explicitní znalostí. Přechody mezi jednotlivými fázemi procesu zexplictnění a přechody mezi jednotlivými rovinami zkušenosti během tohoto procesu naznačují, že znalost je komplexní dynamická struktura. Právě v interakci doslovného jazyka (pojmů) a před-reflektivní roviny zkušenosti povstává význam: Význam je utvářen v interakci proživání a něčeho, co funguje jako symbol. Cítěni bez symbolizace je slepé, symbolizace bez cítěni je prázdná (Gendlin, 1962, s. 5). Právě to se ukazuje v analýze dat použitých v této kapitole, když Karel neodpovídajícím způsobem provázal pojem představa se svou prereflektivní zkušeností (výsledek metaforizace-zdoslovnění). Pojem představa se stal slovy Gendlina „prázdný“، Až při asistované reflexi procesem zpětné metaforizace došlo pomocí figurativního uchopení zkušenosti $\mathrm{k}$ intenzivnější (resp. komplexnější) interakci mezi doslovnou a pre-reflektivní rovinou zkušenosti, která vedla k souladu tacitní a explicitní dimenze znalosti.

Z této perspektivy tak explikace tacitní znalosti neznamená převádění obsahu tacitní znalosti do vědeckých pojmů (do doslovné roviny jazyka), ale setkávání se (interakci) pre-reflektivní roviny zkušenosti s doslovnou rovinou zkušenosti: Prožívání a pojmy (nebo symboly) nejsou dvě oddělené věci, které je potřeba spojit. Každý z nich je vždy implicitně př́tomen v tom druhém. Neexistuje „,nesymbolické proživáni““ stejně jako není „čistá logika“. Dokonce bez explicitních slov nebo pojmů je prožívání symbolizováno přinejmenším interakcí a situací, v které se toto prožívání děje." (Gendlin, 1962, s. xii)

Pokud chceme, aby si studenti učitelství opravdově osvojovali pedagogické koncepty a teorie, je nezbytné, aby docházelo k interakcím jejich pre-reflektivní roviny zkušenosti a doslovného jazyka. 


\section{$8 \quad$ Pojetí výuky studentů učitelství: společná témata a individuální výzvy}

\section{Eva Minař́ḱková, Blanka Pravdová}

Jednání učitele ve výuce je ovlivněno mnoha proměnnými - jedná se o faktory externí (širší sociální kontext, klima a kultura školy, konkrétní třídy a žáci), ale především o faktory vlastní samotnému učiteli. Často se hovoří o znalostech nebo vědění učitele (viz teoretická část této knihy), o profesním vidění (Minaříková \& Janík, 2012), o profesních kompetencích (pro diskusi tohoto pojmu viz např. Píšová, 2005, s. 37 a dále). Jednou z oblastí, která je v rámci výzkumu učitele často tematizována, je oblast jeho pedagogických názorů, postojů, hodnotové orientace nebo víry (belief - nejedná se o víru náboženskou, ale profesní; viz Píšová, 2005, s. 26). Ačkoliv je terminologie v této oblasti neujasněná a nepřehledná (pro diskusi souvisejících pojmů viz Mareš, Slavík, Svatoš, \& Švec 1996, s. 10-11), existuje konsensus na tom, že má velký vliv na jednání učitele. V českém prostředí se v této souvislosti vžil pojem učitelovo pojetí výuky (Mareš, 2013, s. 455). Mluvíme-li o studentech učitelství, zpravidla se užívá termínu studentovo pojetí výuky (Švec, 1999, s. 39). Tato kapitola si klade za cíl prozkoumat pojetí výuky u studentů učitelství na začátku jejich učitelské praxe, tedy na počátku navazujícího magisterského studia, a to především ve vztahu k jejich pojetí cílů, učiva a žáků (srov. Pravdová, 2014, s. 158-166) Soustředíme se na to, jaká témata jsou studentům společná a jakým individuálním výzvám, díky nimž si zpřesňují a vyjasňují své pojetí výuky, aktuálně čelí. Důležitým aspektem našeho bádání bude jasnost a artikulovanost pojetí výuky a na druhé straně jeho tacitní dimenze.

V následujícím textu nejprve definujeme koncept učitelova/studentova pojetí výuky a pokusíme se zdůvodnit naše zaměření na pojetí cílů, učiva a žáků. Poté představíme zdroje dat a analytický postup. Na základě výsledků analýzy se pokusíme odpovědět na stanovené výzkumné otázky. 


\subsection{Učitelovo/studentovo pojetí výuky}

„Učitelovým pojetím výuky rozumíme komplex pedagogických názorů, pedagogických postojů a učitelových argumentů, které jej zdůvodňují. Tento komplex vytváří kognitivní i emoční základnu pro učitelovo uvažování o edukaci, pro hodnocení edukace a učitelova jednání se všemi aktéry edukačního procesu.“(Mareš, 2013, s. 455).

Jak uvádí Mareš (Mareš et al., 1996, s. 12; Mareš, 2013, s. 456), učitelovo pojetí výuky má mnoho funkcí - podílí se na tom, co a jak chce učitel dělat, co pokládá za důležité, jak se reálně rozhoduje atd. Vyznačuje se například svou relativní stabilitou, orientovaností (pozitivní, negativní nebo neutrální postoje, hodnocení) a subjektivitou (liší se u jednotlivých učitelů). Z hlediska našeho výzkumu je stěžejní to, že se jedná o konstrukt implicitní, resp. tacitní a relativně neuvědomovaný - zpravidla se nejedná o soubor explicitních a vědomě promýšlených pravidel (Mareš, 2013, s. 456). Míra vyhraněnosti se ale pro různé učitele liší od nejasně formulovaných a volně seskupených zásad až po pevná a artikulovaná pravidla (Mareš, 2013, s. 459).

Pojetí výuky se utváŕí již v období před započetím učitelovy kariéry, dokonce ještě před začátkem př́ípravného vzdělávání. Silným vlivem jsou zkušenosti studenta učitelství v roli žáka (Borg, 2003, s. 82; Pravdová, 2014, s. 158-164) a takzvané učňovství pozorováním (apprenticeship of observation; Lortie, 1975). Pro vzdělavatele učitelů tato skutečnost představuje velkou výzvu. Studentovo pojetí výuky, s kterým do programu přípravného vzdělávání přichází, tvoří silný kontext pro jeho další učení. Výzkumy naznačují, že přípravné vzdělávání (Debreli, 2016) a výuková praxe (Borg, 2003) mají na pojetí výuky vliv, ale další autoři upozorn̆ují, že je třeba toto pojetí $\mathrm{v}$ počátcích diagnostikovat a dále s ním cíleně pracovat (např. Joram \& Gabriele, 1998; Švec, 1999, s. 45). To ale může být v současném kontextu, kdy je na pedagogických fakultách připravován velký počet studentů, náročné. Tento př́spěvek si proto klade za cíl ilustrovat různorodost pojetí výuky u studentů ve stejné fázi profesního rozvoje (z hlediska objektivních externích měřítek fáze studia učitelství), ale také postihnout témata, která jsou jim společná.

Učitelovo pojetí výuky se skládá z dílčích složek (Mareš, 2013, s. 457). Jedná se o: pojetí cílů, pojetí učiva, pojetí organizačních forem, pojetí vyučovacích metod a prostředků, pojetí žáka a jeho učení, pojetí třídy, pojetí učitelské role, pojetí role vedení školy a pojetí role rodičů. Všechny tyto dílčí složky svým způsobem ovlivňují učitelovo pedagogické působení. V různých etapách profesního rozvoje přikládají ale učitelé různým aspektům různou váhu. 
Podle Fullera a Bowna (1975) lze rozlišit tři fáze zaměření - nejprve jsou (začínající) učitelé zaměřeni na sebe a přežití, poté na pedagogickou situaci a teprve v poslední fázi se zaměřují na žáka. Podle Berlinera (1995) se koncentrace učitele přesouvá postupně od obsahu k žákovi.

Pravdová (2014, s. 158) ve svém kvalitativním výzkumu u studentů pedagogické fakulty (bakalářského stupně studia) identifikovala jako dominantní kategorie studentova pojetí výuky: pojetí role učitele, pojetí žaka a jeho hodnoceni, pojetí vyučovací hodiny a pojetí vyučovacího předmětu. Méně zastoupenými kategoriemi byly následující: pojetí role rodičù žaka, pojetí třidy, pojeti cílů a pojetí učiva.

V naší analýze (viz níže) jsme se proto soustředili především na studentovo pojetí učiva (a cíli̊) a žáka a jejich vzájemnou provázanost, jakožto oblasti, které mohou být problematické a teprve emergující. Věnování pozornosti žákům, orientace výuky na žáky a také obsahová zaměřenost jsou přitom stěžejní pro kvalitu výuky (Janík et al., 2013).

V rámci předkládané analýzy jsme si proto kladly následující otázky: Jaké je současné pojetí žáků u jednotlivých studentů? Která témata jsou studentům v oblasti pojetí žáků, učiva a cílů společná? Jak je jednotliví studenti řeši? Na čem si studenti v aktuálni fázi profesního vývoje vyjasn̆uji své emergujicí pojetí výuky (resp. žákỉ, učiva a cílü) a do jaké míry je jejich pojetí tacitní?

\subsection{Zdroje a analýza dat}

Jako zdroj dat pro tuto kapitolu sloužily rozhovory, které byly s účastníky výzkumu vedeny hned na počátku série učitelských praxí a které byly zaměřeny na subjektivní pojetí výuky studentů učitelství. Tyto první rozhovory začínaly otázkou: „Když řeknu vy a výuka, co to ve vás vyvolává, co vás $\mathrm{k}$ tomu napadá?““ (podrobněji viz kapitolu 4). Data analyzovaná v této kapitole se vztahují k rozhovorům se čtyřmi participanty (s Alenou, Beátou, Cyrilem a Karlem). Je nutné konstatovat, že tyto rozhovory byly vedeny výzkumníky, kteří disponovali největší zkušeností s dotazováním prostřednictvím čistého jazyka (clean language interviewing, viz kapitolu 3), a jednotlivé rozhovory tak generovaly vzájemně srovnatelná data.

Realizované rozhovory byly doslovně přepsány v programu Videograph (Rimmele, 2002). Součástí přepisu byl i záznam neverbálních projevů participantů, jejichž sledování je důležité pro zachycení tacitní dimenze. Získaná data byla opakovaně pročítána dvěma výzkumníky. V prvním kroku byla identifikována místa, kde participanti hovoří o žácích, o cílech výuky 
nebo o učivu. V dalším kroku byla identifikována související místa, která naznačují, že se studenti dostali na hranici pro ně aktuálně artikulovatelného a/nebo uvědomovaného a postupně odkrývají tacitní dimenzi svých znalostí a svého pojetí výuky. Jednalo se o místa, kde (srov. Nehyba \& Svojanovský, 2016, s. 75):

- participant uvádí, že neví, jak své myšlenky artikulovat;

- participant oproti předchozím promluvám využívá nápadně více „výplňových slov“ (takový, tento, ...);

- participant se oproti předchozím promluvám častěji a na delší dobu odmlčuje, častěji používá citoslovce jako hmmm nebo ehm;

- participant používá metakomentáře, které naznačují, že si dané téma ujasňuje nebo poprvé formuluje do slov (,takto jsem nad tím nikdy nepřemýšlel“").

Následovalo další intenzivní a rekursivní čtení (jedním výzkumníkem) identifikovaných úryvků, ve kterých se studenti zaměřili na žáka, cíle nebo učivo, a hledání stěžejních témat v rámci jednotlivých rozhovorů. Úryvky v rámci jednoho rozhovoru byly studovány ve vzájemné souvislosti, ačkoliv se mohly vyskytovat časově vzdáleně. Rozhovory a identifikovaná témata byly mezi sebou kontrastovány, aby bylo možné odpovědět na dané výzkumné otázky. Výsledky analýzy budou představeny $v$ následující části $v$ logice výzkumných otázek.

\subsection{Výsledky analýzy}

Analýzy rozhovorů přinesly zajímavé výsledky. Z vnějšího pohledu jsou naši účastníci výzkumu v podobné fázi profesního rozvoje - právě začínají učitelskou praxi v rámci prvního semestru magisterského studia na stejné pedagogické fakultě, kde jsou praxe organizovány podobně pro všechny učitelské obory studia. Jejich biografie osobní i profesní se však liší někteří z nich se věnují volnočasové a vzdělávací práci s dětmi i s dospělými (turistický kroužek, výuka plavání, výuka v jazykové škole), někteří z nich mají v rodině učitele nebo učitelku, každý z nich prošel různými školami, setkal se s různými učiteli i s různými tř́́dními kolektivy. Je proto nasnadě, že se ve svých pojetích výuky liší, ačkoliv řeší některá společná témata. My se nejdříve budeme věnovat tématu, které bylo pro naši analýzu centrální: pojetí žáka. 


\subsubsection{Pojetí žáka}

Každý z našich participantů tematizoval ve svých vyjádřeních žáky. Jelikož byly rozhovory vedeny metodou čistého jazyka, nebylo toto téma do hry vneseno výzkumníkem, ale samotným studentem. Jejich přemýšlení o žácích se ale značně lišilo. V našem (ač limitovaném) vzorku lze identifikovat určité kontinuum pojetí žáka. Na jednom konci kontinua je pojetí nespecifické, skupinové (blížící se pojetí třídy), téměř bez vyjádřeného vztahu k výuce, ke zprostředkování učiva či motivaci. Na druhé straně kontinua je pojetí žáka jako jednotlivce, jehož individuální charakteristiky mají vliv jak na utváření vztahu mezi učitelem a žákem, tak na motivování učitelem, zprostředkování učiva apod.

Studentka učitelství Beáta je se svým pojetím žáka, jak jej demonstrovala ve výzkumném rozhovoru, blíže prvnímu, nespecifickému, konci spektra. Ve svých vyjádřeních mluví o žácích jako o skupině. Zmiňuje je především ve vztahu k cíli výuky („chci je něco naučit“, „ucelená struktura, co si děcka odnesou z té školy“, „s čím se můžou v životě setkat“) a k realizaci hodiny (,nebude plná věcí, které je baví, ale přitom je úplně nezhnusí“). Latentně je v těchto výrocích obsaženo to, že žáci mají život mimo školu (,s čím se můžou v životě setkat") a že je něco baví, ale Beáta zůstává na úrovni žáků jako nediferencované skupiny a nepřemýšlí dále o tom, jak zohlednit to, že každého baví něco jiného a každý má (a do budoucna bude mít) jinou životní zkušenost. V závěru rozhovoru však mluví o vztazích učitele a žáka:

Výzkumník: Co je pro vás to nejpodstatnější v kontextu vaší výuky? Co je pro vás důležité?

Beáta: (přemýšlí) Asi porozumět si s těmi žáky. (pauza) Aby tam nebyla nějaká napjatá atmosféra na začátku. Aby nedocházelo ke zbytečným nedorozuměním. Někdy, hm, ten učitel třeba něco řekne a nemyslí to tak. A nedomyslí, že ty děti to nějak zraní, že jsou na to citlivé. Vlastně nechce způsobit a ani je nechce zranit, ani zdeptat. Prostě nic špatného. Jenom tak něco pronese, třeba i v nějakém skrytém smyslu. A pro ně to má vlastně jiný význam, a dojde $\mathrm{k}$ nedorozumění, a ty děcka potom už se $\mathrm{k}$ němu staví odmítavě. (1. rozhovor)

Vyjadřuje obavy z toho, aby nezranila žáky, byt' neúmyslně. Nadále ale žáky pojímá jako skupinu, která jako skupina reaguje. Ani v oblasti emocí a práce s nimi se nedostává na úroveň jednotlivce. Náznakem rozlišuje žáky na základě věku (,je to trošku jiné, komunikovat s těmi šestiletými dětmi a s těmi pubertačkami“), ale jen obecně v oblasti komunikace, a opět zůstává na povrchu. To může být ovlivněno její omezenou pedagogickou praxí (výuka klavíru, výuka plavání), která jí prozatím neposkytla dostatek př́ležitostí přemýšlet o žácích jako jednotlivcích. Aktuální výzva, kterou řeší a o které pojednáme dále, je na obecnější úrovni a týká se pojetí předmětu (viz kapitolu 7.3.3). Dá se tedy předpokládat, že 
její pojetí žáků se bude v budoucnu měnit (viz posun $\mathrm{k}$ zaměření na žáka $\mathrm{v}$ rámci profesního rozvoje učitele; Fuller \& Bown, 1975).

Dále se ve svých úvahách dostává Karel, jenž v rozhovoru mluví především o výuce fyziky. Tematizuje, jak propojit reálnou zkušenost žáků a jejich svět s učivem a abstraktními pojmy a jak je využít pro učení žáků (podrobněji kap. 7.3.3). V jeho přemýšlení je patrný př́íklon k žákům, k uvědomění si návaznosti zprostředkování učiva na zkušenosti žáků. Při vysvětlování důležitosti propojení fyziky a reálného světa uvádí Karel jako příklad jednotlivé žáky:

Když budete vysvětlovat třeba přenos tepla, tak kdo spravuje auta, vzpomene si na výfuk, pochopí přenos tepla. A kdo zas rád plave, tak když skočí do studené vody, tak to rychle chápe přenos tepla. Protože ví, že se mu ochladí tělo a je mu kosa. (1. rozhovor)

Z rozhovoru ale není patrné, zda se jedná o konkrétní žáky, které zná z učitelské praxe, nebo o imaginární žáky, které by mohl mít ve třídě a kteří by hypoteticky takovou zkušenost mohli mít. Další úryvky týkající se jeho praxe ve výuce fyziky na základní škole naznačují, že žáky a jejich zkušenost pojímá obecně. Je si vědom možných rozdílů mezi žáky. Řešením této různorodosti pro učitele (resp. pro Karla samotného) se zdá být spíše repertoár př́íkladů a propojení se životem než znalost jednotlivých žáků a jejich kontextu.

Jenže já v tom nehledám specifickou... nějakou tu realitu nebo zkušenost, kterou má ten daný specifický žák, ale já si vezmu nějakou..., kterou si myslím, že oni znají... (1. rozhovor)

Toto pojetí je ale v rozporu stím, jak Karel mluví o individuální výuce angličtiny (s konkrétním dospělým studentem).

Já dělám to, že musím nejprve přijít na to, co to je [zkušenost studenta nebo jeho zájmy]. A když to zjistím, tak ten svi̊j poznatek vezmu a na tom postavím tu výuku. (v úryvku se vyskytuji dlouhé pauzy a váhání; 1. rozhovor)

Zde se promítá rozdílná zkušenost s výukou početné třídy a jednotlivého žáka (dospělého studenta). Karel svou výuku přizpůsobuje situaci - a individuální výuka mu poskytuje prostor vycházet z reálné zkušenosti jediného studenta. Tímto tématem se budeme zabývat dále při popisu aktuální výzvy, kterou Karel v rámci vývoje svého pojetí výuky řeší.

Alena naproti tomu uvažuje o žácích jako o jednotlivcích s určitým sociálním a rodinným zázemím a určitou kulturou, na kterou je nutné brát ohled a která má velký vliv především na vztah učitele a žáka.

Co bych asi dál vypíchla, tak třeba konkrétně na té základce mají docela reálnou představu o prostředí, ze kterého ty děcka pochází, z té dané rodiny, protože jsou s nimi v kontaktu, řeší to, takže ví, jak to vypadá. Ví, jaké problémy se řeší v té rodině a co řeší př́ípadně ten žák. A to je zase o tom, to... jakoby nechci říct úplně zohledňovat v té výuce, ale mít to na mysli. [...] Zohledňovat nejenom momentální situace, ale i to prostředí, 
ze kterého pochází, protože je samozřejmě prostředí, které je méně podnětné. Třeba si uvědomit, že je potřeba dát více podnětů $\mathrm{k}$ tomu, aby to děcko třeba vůbec škola bavila, aby školu vnímalo jako pozitivní instituci. (Alena, 1. rozhovor)

Alena akcentuje především mimovýukovou a vztahovou rovinu, ve které by se měl kontext jednotlivého žáka zohledňovat, ale její pojetí žáka se promítá i do jejího uvažování do výuce.

To dokládá i následující citace z rozhovoru:

Alena: Orientace na toho člověka, na tu bytost, na jeho potřeby. To je asi ted'ka jakoby směr, kterým se ta škola nebo školství ubírá. Vlastně uvědomovat si ty odlišnosti, že to není nebo nemusí být špatný, ale v podstatě to je jen o tom umět prrizpưsobit ty věci tak, aby to ten žák byl schopen zpracovat na té svojí úrovni v porovnání s jeho potřebami [...]

Výzkumník: A když tohle je ten směr, jak to ted’ vnímáš ve vztahu k sobě?

Alena: Ve vztahu ke mně? No, tak opět to klade vy̌ší nároky na učitele, protože si musí dát větší práci nejenom s tím, jak zpracovat látku, ale jak ji zpracovat zábavným způsobem, pochopitelným a zároveň jak ji interpretovat zvlášt' pro skupiny třeba nadaných jedinců, naopak pro část, která je pomalejší, která méně zvládá. A prostě ideál je mít na jednu hodinu víc př́íprav, které by byly ovlivněné těmi žáky, kteří se nachází $\mathrm{v}$ té škole. (1. rozhovor)

Tento poslední výrok naznačuje diferenciaci výuky vzhledem k charakteristikám jednotlivých žáků. O žácích se však stále hovoří na skupinové úrovni (ta část, která zvládá). Poslední věta úryvku naznačuje, že Alena možná vnímá spíše specifika na úrovni školy než na úrovni jednotlivých tříd a žáků. To je pravděpodobně ovlivněno daným kontextem její učitelské praxe, která se odehrává ve škole s výrazným zastoupením romských žáků (podrobněji viz níže), což podle Aleny ovlivňuje celý chod, klima i kulturu školy.

Konkrétní zaměření na žáky jako skupinu i jako jednotlivce ve vztahu k učiteli, učivu a zprostředkování učiva tematizuje Cyril - a to hned od prvního dne učitelské praxe.

Když jsem přišel na praxi, tak jsem tu výuku vnímal hlavně ze strany učitele. Všímal jsem si, co on dělá. A po prvním dnu jsem se jakoby zamyslel i nad tím, co dělá ten žák. Že musí nosit hromadu sešitů, pomůcek, pravítka (úsměv). [...] Takže jsem se snažil pojmout, co vlastně má splnit ten žák a co má splnit ten učitel. A když jsem ted'ka už učil asi pět hodin, tak jsem snažil, i když jsem tvořil tu př́ípravu nebo se zamýšlel, co budu dělat, aby to navazovalo i z mého pohledu. Jakoby když já něco přednesu, tak si uvědomím, že oni si zapisují, kam si to zapisují a podobně. (Cyril, 1. rozhovor)

Zohledňování žáků v konkrétních výukových situacích dokladuje Cyril i na zkušenosti s rýsováním.

No, když jsem třeba jakoby přemýšlel nad časem, jak mi to vyjde, tak jsem si musel uvědomit, že já když na tabuli nakreslím čtverec, tak těm dětem to bude trvat dvakrát tak dlouho. Někdo si na to vezme pravítko, takže než to sestrojí celý, tak to trvá strašně dlouho. A nemůžu je nutit, aby si ho udělali škaredě, takže musím počítat s tím, že oni pracují jinou rychlostí než já třeba. Takže jsem, kdybych já přeskočil třeba deset př́kladů, tak vím, že oni zvládnou jenom tři. Takže jsem se musel přizpůsobit i tomu. [...] namaloval jsem čtverec a už jsem přecházel $\mathrm{k}$ obdélníku, tak jsem se kouknul, že slečny v první lavici mají problém pochopit, co je čtverec a jak se to vlastně kreslí. I když to mají umět někdy z třetí třídy. Takže jsem musel zvolnit a dál jsem to dělal jakoby pomaleji všechno. [...] zastavil jsem, řekl, že si to dopišou. Takže si jakoby dokreslily ten čtverec a znovu jsem probral s nimi ten obsah a objem, nebo obsah a obvod [...] aby ony to slyšely znova. A pak už jsem vždycky počkal, až ony si to vždycky jakoby nakreslí, a pak se všema, až poslouchali, 
jsem teprve dělal to důležité, což znamená ten obsah a povrch a podobně. Podle toho co, to bylo. (Cyril, 1. rozhovor)

Z této ukázky je patrné, jak se Cyril učí ze zkušenosti a jak je schopen (dle svých slov) flexibilně reagovat na potřeby jednotlivých žáků. Z jeho projevů (v nichž popisuje, jak se učí ze zkušenosti) se dá usuzovat, že podobné úvahy si ponese i do další praxe a bude svůj pohled na žáky diferencovat a dále provazovat s dalšími aspekty výuky a vztahovat i ke způsobu zprostředkování učiva. Tomuto náš úsudek lze podpořit i dalšími úryvky z jeho rozhovoru. V následující ukázce mluví o výuce Thaletovy kružnice a o tom, jak zajistit, aby se do opakování zapojili i ti, kteří v matematice nevynikají a nepamatují si dané učivo z dř́ivěšša. $\mathrm{Na}$ základě zkušenosti s konkrétní třídou a s konkrétní výukovou situací ale dochází k následující interpretaci, která dokladuje jeho přemýšlení o žácích:

[...] Muselo by se jim říct dopředu, že se to bude probírat, tak at' se na to podívají. Ale u tady těch dětí konkrétně by se to asi minulo účinkem, už jenom s tím, že ty sešity nemají. (Cyril, 1. rozhovor)

Se znalostí žáků souvisí i Cyrilova snaha sledovat žáky přímo v rámci výukové situace podle jeho slov si všímá, zda dávají pozor. Konkrétně popisuje, jak projevy žáků sleduje a jak z nich vyvozuje závěry ohledně jejich (ne)pozornosti, (ne)pochopení a jak v návaznosti na to adaptuje výuku. Tyto jeho výroky naznačují, že se aktivně snaží rozvíjet své profesní vidění a vnímání výukových situací, v nichž hrají žáci stěžejní roli.

V této kapitole popsaná analýza naznačuje, že téma žáků je všem našim participantům společné, ačkoliv jej pojímají jinak - pravděpodobně v závislosti na svých zkušenostech, osobních charakteristikách a (profesní) biografii (viz diskuse v kapitole 7.1). Nyní se podíváme na konkrétnější témata, která se ve výpovědích účastníků výzkumu objevují a která představují propojení mezi několika dílčími složkami jejich pojetí výuky.

\subsubsection{Motivace jako společné téma}

Druhá výzkumná otázka se vztahovala $\mathrm{k}$ tomu, jaká témata jsou participantům společná. Analýza ukázala, že kromě témat nejobecnější úrovně (žáci, učivo, role učitele apod.) se všichni studenti učitelství zabývají motivaci žáků a jejich pozitivním přístupem $\mathrm{k}$ výuce. Pro každého z účastníků výzkumu má toto téma různou důležitost a přistupuje $\mathrm{k}$ němu z odlišným způsobem.

Pro Beátu je otázka motivace v aktuální fázi spojena s otázkami po cílech a smyslu výuky předmětu hudební výchova. Doslova uvádí, že „kolikrát přemýšlela nad tím, co jim odpovím, 
když se mě zeptají, proč se to mám učit, co ten a ten napsal““. V současné chvíli tedy neřeší motivaci jednotlivých žáků ani jejich pozitivní přístup k výuce. Vše se pro ni odvíjí od pojetí předmětu a jeho legitimity v rámci kurikula základní školy (o tom více níže). Ani Alena neřeší motivaci k učení jako takovou, ale spíše pozitivní přístup žáků - přála by si, aby je to „nadchlo“, „pohltilo“ a „zabavilo“. Z jejího rozhovoru je patrné - spíše jen v náznacích a v celkovém vyznění - že zábava a pohlcení není cíl sám o sobě, ale spíše prostředek, jak dosáhnout pozitivního př́stupu žáků $\mathrm{k}$ učení a naplnit vzdělávací i výchovné cíle. Toto propojení bylo identifikováno spíše jako vágní a pojetí motivace ne zcela ujasněné (a jak uvidíme v následující podkapitole, není ani Aleninou aktuální výzvou). V tomto ohledu je o něco dále Karel, který ve svých vyjádřeních klade důraz na to, „aby to ty děcka bavilo“. Inspiraci čerpá u svého cvičného učitele a v jeho výuce. Zábavná forma pro něj však není samoúčelná - vidí její jasný vliv na učení žáků:

Pro mě ty elementy, o kterých jsem mluvil, že je to ten učitel naučí zábavnou formou a naučí je toho dost, jsou docela... nechci tvrdit nejdůležitější nebo nejsignifikantnější, protože tam je určitě plno dalších věcí musí tam probíhat nějaká morální výchova a nějaké jako dobré vztahy s tím učitelem. Ale po té stránce... po té stránce... (mne si čelo) nevím, po jaké stránce, ale... je to pro mě důležité, že se ty dětí naučí, že se ty děti naučí, co mají, a naučí se to takovou formou, že je to baví (pokyvuje hlavou). Nebo možná je to právě proto, že je to baví, tak jsou schopny se toho naučit víc. To asi spíš. Protože kdyby je to nebavilo, tak se to nebudou učit tolik. (Karel, 1. rozhovor)

V uvedené ukázce lze postřehnout, že Karel toto pojetí spojení zábavné formy a učení se nemá předem jasně vydefinované. Své myšlenky postupně formuluje, precizuje a artikuluje můžeme se tedy domnívat, že tato část jeho pojetí je tacitní a v rámci výzkumného rozhovoru se postupně zexplicitňuje. To dokládá i jeho postup v rámci rozhovoru. O pár minut dříve v rozhovoru jasně a bez přemýšlení formuluje následující:

[o cvičném učiteli] $\mathrm{Z}$ mého pohledu je naučí hodně a většinu trríd naučí tak, že je to baví. To jsou pro mě dvě... dva elementy (zamyslí se), které bych chtěl... které jsou důležité, jo? Taky bych chtěl, když já učím, aby to ty děcka bavilo... a předal jim, co si myslím, že je důležité. (Karel, 1. rozhovor)

Karel se tedy tímto pojetím - spojením zábavy a učení se - do jisté míry rrídil i dříve, ale výzkumný rozhovor mu poskytl př́ležitost si tyto svoje pozice uvědomit, ujasnit a přesněji formulovat.

Z výše uvedených citací je jasně patrný rozdíl v pojetí motivace žáka k učení u Karla a Aleny, pro niž je spojení „baví je to“ a „naučí se“ stále spíše vágní. Zajímavé je, že v rozhovoru s Cyrilem se reference k zábavě nebo zábavné formě učení nevyskytují. Motivace je pro něj tématem, ale není navázána na zábavnou formu. Jako motivační prvek ve výuce vidí prožitek úspěchu. 
[o tom, jak se devátáci učili rovnice] Protože tam mají nějaká písmenka a něco počítají a nevidí vůbec žádný výsledek. Mají výsledek, ale on jim nic neř́íá. A pak se přijde na nějaké slovní úlohy a najednou vidí, že to, co se naučili, tak si umí dát nějak dohromady. A už mají ten výsledek, už mají jakoby lepší motivaci pro to vypočítat nebo naučit se tu rovnici. (Cyril, 1. rozhovor)

Zdroj Cyrilova přístupu (využívá pozitivní motivaci skrze zprostředkování prožitku úspěchu) lze vysledovat v jeho zkušenosti jako trenéra plavání.

Učím třeba i plavat. A to jsme byli... chtěl jsem je pořád dotlačit na závody. Akorát jednou si to zkusili, to jsem je ještě nevedl já, a moc dobře nedopadli. A ted’ jsme chtěli jet na stejný závody... od kterých jsem nakonec upustil. A jeli jsme jakoby na lehké závody. Takže oni si vyzkoušeli lehký, vyhráli hodně umístění a tak z toho měli radost. A viděl jsem, že se snažili. Tak to byl jakoby ten postup. Že jsem upustil od těch těžkých závodů, kde by sice měli asi větší... u někoho větší třeba motivaci se zlepšit. Protože někdo je o mnoho lepší. Ale nad tím, že si většina zkusila někde horší úroveň, ale mají z toho, že něco dokázali. Takže to pak může být i ve tř́́dě, když jim dám třeba nějaký těžký př́iklad, tak když to většina nevypočítá, tak to bude mít spiše špatný výsledek, protože ten zbytek se bude cítit, že to neumí. (Cyril, 1. rozhovor)

Cyril tuto zkušenost z trenérství přenesl i do výuky matematiky. Zajímavé je i to, že je Cyril schopen, ačkoliv je jeho praxe s výukou na základní škole zatím omezená, toto pojetí motivace propojit se znalostí žáků a zohlednit přitom i jejich pocity. To potvrzuje naše závěry z předchozí podkapitoly ohledně jeho rozvoje pojetí žáků.

Naše analýza naznačuje, že motivace a její propojení s učením se žáků je pro studenty učitelství důležitým tématem. U studentky Emy (která ale nebyla zahrnuta do této konkrétní analýzy) je zmíněné téma natolik důležité, že tvoří osu celého výzkumného rozhovoru.

$\mathrm{Na}$ to, která témata jsme $\mathrm{v}$ jednotlivých výzkumných rozhovorech identifikovaly jako dominantní a jaké individuální výzvy tedy účastníci výzkumu řeší, se podíváme v následující kapitole.

\subsubsection{Individuální výzvy}

Jedním z přínosů dotazování prostřednictvím čistého jazyka, které bylo využito při získávání dat, je skutečnost, že minimalizuje obsahový vklad výzkumníka do rozhovoru. Lze proto předpokládat, že témata, která participanti v rozhovoru otevírají a ke kterým se vracejí, jsou pro ně tématy skutečně aktuálními. U každého z účastníků výzkumu bylo možné identifikovat jedno až dvě témata, která lze označit v daném rozhovoru za stěžejní. V návaznosti na naše zaměření - žák, cíl a učivo - se u studentů (podobně jako v kapitole 7.3.1) ukazuje určité kontinuum, a to od většího zaměření na žáka (Alena) po větší zaměření na cíle a učivo (Beáta). Tato témata můžeme podle našeho názoru označit jako výzvy, s nimiž se studenti v aktuální fázi svého profesního rozvoje vypořádávají a v nichž upřesňují své pojetí výuky. $\mathrm{K}$ tomu nás vede $\mathrm{i}$ fakt, že některé aspekty těchto témat jsou pro studenty obtížně 
artikulovatelné, případně méně uvědomované, a tedy tacitní. Nyní se zaměříme na jednotlivé studenty, na jejich aktuální výzvy i na tacitní dimenzi témat, která řeší.

Začneme s Alenou, jejíž aktuální výzva je podle našeho názoru definována konkrétním prostředím školy, na níž praktikovala. Alena studovala německý jazyk a výchovu ke zdraví a praxi absolvovala ve škole, v níž je většina romských žáků. Alena ve svém rozhovoru načíná různá témata, například: návaznost učiva a praktičnost informací nebo stanovování cílů s využitím Bloomovy taxonomie. Celým rozhovorem ale rezonuje její zaměření na žáky a vztah s nimi. Alena komentuje přístup k žákům v konkrétní škole, který zohledňuje specifika dětí, které ji navštěvují. Přístup učitelů této školy je - podle Aleny - otevřený, přátelský, starostlivý a individuální s ohledem na kontext jednotlivých žáků. Z rozhovoru je zřejmé, že ji tento př́stup ovlivňuje a poskytuje jí náměty k zamýšlení. Často tematizuje vztah mezi učitelem a žákem. Její přístup je také ovlivněn negativními zkušenostmi z dřivějška. $Z$ těchto zkušeností vychází podoba jejího nechtěného učitelského já (srov. Pravdová, 2014, s. 119135), tedy jak se (ne)chce $\mathrm{v}$ roli učitele chovat: neponižovat, nedokazovat si moc, nenadržovat, neukazovat, kdo je „boss“. Naproti tomu vyzdvihuje aspekty, jako jsou férovost, práva a povinnosti na straně žáka i učitele, empatii, láskyplnost a lidský přístup (vlastní slova Aleny na různých místech rozhovoru). Její pojetí vztahu učitele a žáka není ovlivněno jen předchozí zkušeností, ale i teorií:

Já trochu nat'ukávám tu pozitivní psychologii, takže určitě uvědomovat si silné stránky děcek a umět je $\mathrm{v}$ nich př́padně rozvinout nebo probudit tak, aby byli schopni kompenzovat ty slabé stránky. A zároveň $\mathrm{k}$ tomu opravdu přistupovat kladně. (Alena, 1. rozhovor)

Alena v průběhu rozhovoru působila, jako by si většinu diskutovaných věcí uvědomovala a promýšlela již dříve. Ačkoliv jsou pro ni aktuální výzvou, jedná se o výzvu, kterou sama explicitně promýšlí. Na kontinuu mezi tacitním a explicitním se tedy většinou pohybuje spíše blíže explicitnímu pólu. Výzvou, o které takto mluví, je vědomé definování vztahu k žákům. Cítí potřebu se rozhodnout, zda $\mathrm{k}$ nim prristupovat spíše z pozice autority, nebo zvolit partnerský př́stup, jak je to na ,jeji“‘ škole obvyklé.

\footnotetext{
Alena: Já jsem si vždycky myslela, že nejlepší je, když ten učitel tam nastoupí spíš jako autorita do té trrídy, a tudíž tam panuje určitý distanc mezi tím žákem. A ted' mě ta praxe přesvědčuje o tom, že je i jiný způsob. Otázkou je, který je lepší, popřípadě vhodný, a jestli se to potom neodvíjí od typu těch žákủ. Že vlastně tam se pracuje s těmi žáky spiś na základě vztahu učitel - žák. Máme tady spolu nějaký vztah, máme tady spolu nějaký úkol a jedeme na férovku [...]
}

Výzkumník: Takže v jiných školách je to tak, nebo tak, jak sis to ty představovala?

Alena: No, to je takový ten i zastaralý asi trochu způsob. Ten učitel tam naklape $\mathrm{v}$ tom bílém plášti, popř́ípadě představuje tam nějakou tu roli a něco povídá ze své pozice $\mathrm{k}$ těm žákům, kteř́ jsou tam někde dole. A tady to vlastně funguje tak... ne teda vždycky, samozřejmě každý učitel je jiný, ale není to tak, že: já 
vám tady jdu něco předat. Ale to neznamená, že vy mně nic předat nemůžete nebo nemáte mi co předat. A to je jako o tom, vlastně lidským.

Výzkumník: A jak to máš teda ty, když takhle vnímáš ty dvě věci?

Alena: Já ted’ka jsem někde na půli cesty. Já právě zjišt’uji, že to jde jinak. Jak to mám já? Já upř́ímně sama nevím, já jsem se ještě nerozhodla, co je ten lepší prístup nebo co mně bude víc vyhovovat. Určitě bych se nebránila tomu fungovat i na té bázi toho partnerského př́ístupu, ale já nevím. Já asi tou praxí teprve si zkouším, co a jak a co už ne. (1. rozhovor)

Z ukázky je zřejmé, že se jedná o téma, které Alenu v současné chvíli zajímá a potřebuje jej řešit. Na druhou stranu je rovněž patrné, že jej řeší i mimo výzkumný rozhovor a věnuje mu pravděpodobně vědomou pozornost, nebot’ - i když má svoje stanoviska sice neujasněná argumenty pro i proti dokáže explicitně pojmenovat. Výrok ,ještě jsem se nerozhodla“ odkazuje k vědomému př́ístupu k této její individuální výzvě.

Karel se na výše zmíněném kontinuu pohybuje blíže k pólu učiva. V době získávání dat Karel studoval učitelství angličtiny a fyziky a současně učil na jazykové škole. Učitelská praxe, kterou tematizoval v rozhovorech, se vztahovala především k výuce fyziky. U Karla vystupují do popředí dvě témata, která spolu úzce souvisejí. Obě rozebírá do hloubky, u obou se dostává na hranici snadné artikulace myšlenek, do oblasti tacitní, a v obou si ujasňuje a zexplicitňuje svoje pojetí výuky. Zaprvé se jedná o propojení reality a reálné zkušenosti žáků s učivem (resp. s oborovými obsahy), zadruhé se snaží si vyjasnit, co znamená „naučit se“.

Když Karel mluví o výuce fyziky, opakovaně tematizuje reálnou zkušenost žáků s fyzikálními jevy (viz také př́iklady v kap. 7.3.1). Současně naráží na vybavenost učitele různými př́klady, kterými lze žákům fyzikální jevy přiblížit.

[...] musí mít ten učitel nějakou širokou škálu těch... ehm... (gestikuluje) těch... př́kladů z toho reálného života. Jo? Jako... ten koncept nebo ten... ten pokus nebo ten... nějaký ten fenomén fyzikální, tak... když on ho podpoří něčím... něčím, co ty dětí znají, tak právě dojde tady k tomu propojení potom [...] té vlastní zkušenosti s nějakým tím fyzikálním. (Karel, 1. rozhovor)

Z uvedené ukázky je patrné, že Karel (ačkoliv podobné téma dříve v rozhovoru již zmínil) jde do hloubky a snaží se jasně formulovat, co znamená propojení žákovy zkušenosti s „tím fyzikálním“. Jeho verbální i neverbální projevy (pauzy, gestikulace) naznačují, že se dostává do oblasti tacitních znalostí, resp. tacitní dimenze svého pojetí výuky a částečně některé aspekty skrze rozhovor zexplicitňuje. Zajímavé je, že svými vlastními slovy vlastně pojmenovává didaktické znalosti obsahu, které učitel fyziky potřebuje (srov. např. Janík, 2009). Karel se k propojení vrací i v další části rozhovoru:

Výzkumník: Hmm. Takže to propojení znalostí se zkušeností.

Karel: Třeba, ano. 
Výzkumník: A vy jste mluvil o nějaké vzdálenosti. A co za vzdálenost to je?

Karel: (asi 20 sekund pauza, pohledem těká po místnosti) Asi... asi... nevím. Vzdálenost mezi, mezi zkušeností... jejich vlastní... (gestikulace), tím, co žijí, a mezi tím, co bych já je měl naučit. [...] Mně pořád vyvstane na mysli, že to je ta fyzika tak, že to je nějaké to pochopení. A... v tom učení je to, je to spíš nějaké... nějaké přiblížení možná ... něčeho. (1. rozhovor)

Zde se Karel dotýká významového kanálu mezi žákovskou a expertní zkušeností (srov. Slavík \& Janík, 2007, s. 272). Zároveň si pro sebe definuje pojetí fyziky, resp. učení se fyzice. $\mathrm{Z}$ analyzovaných dat je patrné, že si právě toto pojetí v rámci rozhovoru zpřesnil a zvědomil, což dokládá i následující úryvek:

Ale to, že je to, že je to asi opravdu to nejdůležitější v té fyzice [...] ale pro to fyzikální... (přivře oči) pro naučení toho fyzikálního je to pochopení nejdůležitější. (gestikuluje) K tomu jsem ted' během nějakých, já nevím, jak dlouho spolu mluvíme, ale došel, že to je tak. [...] že jsem si to nikdy tak konkrétně neuvědomoval [...] spíš jsem nad tím tak nějak nepřemýšlel. Jako já vím, že je to důležité, a používám to, ale nikdy jsem si prostě neřekl... tak to je to nejdůležitější. (1. rozhovor)

Karel není jen budoucím učitelem fyziky, ale i angličtiny (kterou vyučuje v jazykové škole).

$\mathrm{V}$ průběhu rozhovoru postupně přichází na rozdíly mezi oběma předměty a na to, co je v nich důležité, resp. jak v nich funguje proces učení se.

V té angličtině si myslím, že je to trochu něco jiného, protože tam málokdy je potřeba - ne něco pochopit jo, je potřeba tam něco chápat, ale... ale... vědět, že takový časy používám v takových situacích, tak... jako... to se bud' naučím, nebo nenaučím. Tam není moc co pochopit. A tam si myslím, že to propojení s tím reálnem [...] spíš nějaký vztah, který bude... který... který bude... který bude podporovat to moje učení. Tu moji výuku. (Karel, 1. rozhovor)

Zde je vidět, že v angličtině si nachází zcela jiné pojetí výuky a učení se než ve fyzice, více založené na pamětovém učení. Ani zde se mu však nevytrácí nutnost propojení s reálným světem, ale toto propojení získává jinou funkci. Už není (minimálně podle jeho vyjádření $\mathrm{v}$ tomto rozhovoru) prostředkem pochopení, ale prostředkem motivace, „který podporuje to učení“.

[o studentovi z jazykové školy, kterého začal učit] Dobrý, tak jsem zjistil, že opravuje stará auta. Jo? A tak... Nemluví vůbec anglicky, ale když se začne bavit o starých autech a proč je vlastně spravuje, tak vlastně dojdeme $\mathrm{k}$ tomu, že se bavíme a že se bavíme $\mathrm{v}$ angličtině. Takže já bych viděl... tady tohleto... nějaké to reálno... jako... prostředek $\mathrm{k}$ tomu, abych... něco naučil. (Karel, 1. rozhovor)

Výzkumný rozhovor tak pravděpodobně pomohl Karlovi částečně se vypořádat s výzvou vyjasnění pojetí učení se v různých předmětech a využití žákovské zkušenosti. V průběhu rozhovoru Karel postupně precizuje svá vyjádření a potvrzuje více vědomý pohled na vyučování a učení se. Zároveň je velmi zajímavé sledovat, jak postupně přichází na rozdíly mezi oběma předměty a začíná je explicitně reflektovat. Lze se domnívat, že to bude mít další vliv na jeho pojetí výuky v obou předmětech, a tudíž i na jeho učitelskou praxi. 
Tématům propojujícím pojetí žáka a učiva se věnuje i Cyril (student učitelství matematiky), ale na kontinuu žák - učivo se pohybuje spíše směrem k učivu. Výrazně tematizuje systematičnost učiva, provázanost a určení důležitosti jednotlivých obsahů. Návaznost a systematičnost nevnímá jen ve smyslu obsahu, tedy aby dobře navazoval na to, co se žáci dříve učili, ale i procesuálně - tedy ,aby to měli tak, jak jsou zvyklí“. Zároveň nevidí systematičnost a návaznost jen vzhledem k minulému učivu (co už se učili), ale i $\mathrm{k}$ budoucímu. Důležitost, jakou návaznosti přikládá, je patrná i v jeho popisu prŕpravy na výuku: používá nejen učebnici a pracovní sešit, ale má půjčený i sešit jedné z žákyň, aby „se pokud možno držel stejných postupů‘“.

Pro Cyrila je důležité, aby si žáci na „to“ přišli sami. Snaží se pomáhat jim „vidět“ různá řešení (např. při probírání zlomků) a k tomuto účelu často využívá otázky, které jsou tématem po značnou část výzkumného rozhovoru. Tyto otázky se pro něj zdají být přirozené, v jejich kladení a vymýšlení nevidí problém. Když má ale vysvětlit, z čeho otázky plynou a jak je klade, naráží zde na své hranice a má problém nejen své myšlenky artikulovat, ale zdá se, že je pro něj obtížné tento proces vůbec zvědomit:

Většinou ty otázky nepromýšlím, co bude, předem. Jako improvizace. [...] Nebo mně přijde, že se tady samy nabízí. [...] Nebo aspoň já to tak cítím. [...] Já si třeba řeknu, co vlastně já bych s tím dělal. [...] Ehm, nevím, to je takový intuitivní pro mě asi. [...] To je možná taková zkušenost už jako. Že já vím, o čem mluvím, vím, jak to na sebe navazuje. Umím se jakoby zeptat tak, abych je dovedl k tomu, co oni chtějí. Když budu učit třeba zeměpis [není jeho aprobací], tak bych se tak nezeptal. Prostě bych nevěděl. [...] Pokud je ten prríklad těžší, tak by ta otázka měla být specifičtější. Nebo bych měl vědět, co ten dotyčný umí i neumí. (Cyril, 1. rozhovor)

Tento úryvek je průřezem více než patnácti minut rozhovoru, kdy se Cyril snaží proniknout $\mathrm{k}$ podstatě toho, jak klade otázky. Z ukázky je patrná náročnost tohoto procesu. Část postupu i zdrojů rozhodování si Cyril v průběhu rozhovoru zvědomuje. Za nejdůležitější lze asi považovat poslední výrok týkající se přizpůsobení se otázek žákům a tomu, co umějí i neumějí. Zde je nutné připomenout Cyrilův postoj k pozitivní motivaci a snahu zprostřredkovat žákům pocit úspěchu. Cílem otázek tedy není jen, aby „si na to přišli sami a lépe se to naučili“, ale aby mohli správně odpovědět, a zažít tak úspěch.

Podíváme-li se na rozhovor s Beátou (aprobace hudební výchova - občanská výchova), je zřejmé, že její výzva se na našem kontinuu pohybuje zcela v oblasti cílů a učiva. Jak jsme naznačili výše, její pojetí žáků a motivace je spíše nediferencované. Stěžejním tématem, s nímž se vypořádává, je pojetí předmětu hudební výchova, jeho cíle a legitimita jeho zařazení do kurikula základní školy. To plyne i z dříve uvedené ukázky, v níž Beáta vyjadřuje obavu 
z toho, že se jí žáci zeptají, proč by se vlastně hudební výchovu měli učit. Když v rozhovoru dojde na to, co je v hudební výchově podstatné, Beáta naráží na obtíže a dochází k závěru, že důležité je to, „s čím se můžou v životě setkat““ a „co prakticky využiji““ a také „,Všeobecný kulturní přehled“. Zde však participantka neví jak dál. Velká část navazujícího rozhovoru se soustředí na kulturu, kulturní přehled a člověka jako kulturní bytost. Z Beátiných reakcí vyplývá, že její pojetí je neujasněné. Ani v průběhu rozhovoru se nezexplicitňuje a neposouvá.

Beátino vágní pojetí toho, proč vlastně hudební výchovu učit a „,co je to důležité“, je v ostrém rozporu s její jasnou představou o „nahuštěnosti“ kurikula. Když mluví o učivu, osnovách a tempu, používá spojení jako: „lijeme hodně informací“, učivo je „nutné osekat“, „hustit“, „přeskočit“, „ošulit“, „doprobrat“, „,nestihnout“, „dohnat“”, „mezera“, „chybí“ apod. Její pojetí současného nastavení učiva a kurikula je výrazně negativní. Ačkoliv tedy neformuluje zcela jasně pojetí předmětu hudební výchova, její postoj k obsahu a jeho rozsahu je záporný. To může být pravděpodobně ovlivněno především její zkušeností získanou v roli žákyně, nebot' s praxí na základní škole teprve začíná.

V této podkapitole jsme se snažily tematizovat individuální a aktuální výzvy, kterým čelí jednotliví účastníci výzkumu. Implikace těchto zjištění se pokusíme interpretovat v následující kapitole.

\subsection{Diskuse a závěry}

V této kapitole jsme se zabývali pojetím výuky u studentů učitelství (především ve vztahu $\mathrm{k}$ žákům, $\mathrm{k}$ cílům a $\mathrm{k}$ učivu) a jeho tacitní a explicitní dimenzí. Naše sonda upozornila na některé aspekty, které mohou být zajímavé pro vzdělavatele učitelů, př́ípadně i pro studenty učitelství samotné. Ukázalo se, že ačkoliv studenti byli v době, kdy vznikaly analyzované rozhovory, ve stejné fázi profesní př́ípravy ( $\mathrm{v}$ prvním semestru navazujícího magisterského studia učitelství, na začátku průběžné učitelské praxe), jejich pojetí výuky se od sebe výrazně lišilo, a to jak z hlediska obsahu, tak v míře tacitnosti/explicitnosti jednotlivých složek.

U všech studentů učitelství byly shledány výroky vztahující se $\mathrm{k}$ pojetí žáka. Všichni participanti o žácích hovoří, ale někteří je pojímají jako skupinu a nediferencují jednotlivce. U některých participantů také není zřejmé propojení uvažování o žácích s uvažováním o učivu a jeho zprostředkování, což je pro práci učitele stěžejní. Toto zjištění však koresponduje 
s výzkumem profesního rozvoje učitelů, který upozorňuje, že začínající učitelé jsou spíše soustředění na sebe a své přežití a až v pozdějších fázích se více soustředí na žáky a jejich učení (Fuller \& Bown, 1975).

Skutečnost, že všichni účastníci výzkumu tematizují žáky, není překvapením. Studentům učitelství jsou však společná i jiná témata. Př́kladem může být motivace $k$ učení a její pojetí. I zde však nalezneme u jednotlivých účastníků výzkumu odlišnosti. U některých je pojetí motivace vágní a vztahuje se pouze k zábavné formě výuky, u jiných je propracovanější a má vztah k reálné zkušenosti žáků a k jejich emocím.

Stěžejní část kapitoly tvořily výzvy, které byly dle naší analýzy pro studenty učitelství participující na našem výzkumu (v době počínající učitelské praxe) aktuální a kterým věnovali pozornost. Ukazuje se, že u každého ze studentů lze nalézt specifické téma, jehož prostřednictvím si ujasňuje vlastní pojetí výuky. Z analyzovaných dat vyvstala i dvě kontinua, na nichž se tyto výzvy nacházejí. Prvním z nich je kontinuum zaměření na žáka a zaměření na učivo. Ačkoliv z podstaty věci vyplývá, že jedno nejde oddělit od druhého, to, že studenti našeho výzkumného vzorku inklinují k jednomu či druhému pólu kontinuta, je v analyzovovaných rozhovorech patrné.

Druhým kontinuem je tacitnost versus explicitnost ve vztahu k promýšlení těchto výzev. Zatímco z rozhovoru s Alenou se zdá, že výzvu, které čelí, vědomě promýšlí a snaží se s ní vypořádat, rozhovory s Karlem a Cyrilem naznačují, že si v jejich rámci respondenti postupně zvědomovali některé aspekty svých výzev. Naproti tomu u Beáty je její pojetí předmětu a jeho cílů natolik neujasněné a obtížně artikulovatelné, že k velkému posunu nedošlo ani v průběhu hloubkového rozhovoru. Tyto výsledky potvrzují i postřehy Mareše (2013, s. 459), který hovoří o různé vyhraněnosti pojetí u jednotlivých učitelů. Důležité je ale i to, že míra vyhraněnosti a ujasněnosti (resp. tacitnosti) se neliší jen mezi učiteli (resp. studenty učitelství), ale i u jednotlivých učitelů (studentů učitelství) ve vztahu k různým tématům.

Uvědomujeme si limity naší výzkumné sondy. Byla provedena na malém vzorku účastníků výzkumu a od každého z nich byl analyzován pouze jeden rozhovor, který se odehrával $\mathrm{v}$ jednom časovém úseku. Tento náš výběr je objasněn v úvodu kapitoly.

Vedení rozhovoru s využitím čistého jazyka (a) umožnilo rozhovor prohloubit, (b) přivedlo studenty k nahlédnutí vlastního myšlení a (c) poskytlo relevantní a zajímavá data ve vztahu $\mathrm{k}$ tacitní dimenzi studentova pojetí výuky. Ačkoliv tématu pojetí výuky (resp. beliefs a 
podobných konceptů) bylo věnováno již mnoho empirických studií, naše analýza do hloubky prozkoumala a porovnala pojetí výuky u čtyř studentů ze stejného, a přeci velmi rozdílného kontextu. Pokud naše kapitola přispěla k otevření tématu rozdílnosti studentů pedagogických fakult (na stejném stupni pregraduální př́ípravy), pokud čtenáře přivedla k zamyšlení nad rozmanitostí výzev, jimž studenti učitelství v průběhu svého studia (a především učitelské praxe) čelí a které se vztahují k utváření a zvědomování jejich (mnohdy dosud tacitního) pojetí výuky, pak splnila svůj cíl.

\section{Neočekávané situace v průběhu praxe studentů učitelství}

\section{Jan Nehyba, Barbora Šimůnková}

Třídu můžeme považovat za otevřený a nelineární sociální systém (Trygestad, 1997; Wang, Zhou, Chen, \& Zhan, 2009), v kterém se odehrává vyučovací proces jako velmi komplexní a dynamický jev. Tento proces vyučování je plný neočekávaných situací (unexpected situations) nebo událostí (event). ${ }^{98}$ Zvládání těchto neočekávaných situací je velmi důležité pro proces vyučování. Pokud jsou tyto neočekávané situace reflektovány, jsou velmi důležitým zdrojem poznání o procesech výuky pro samotného učitele (Flavell, 1979). V této kapitole se proto nejdříve budeme zabývat teoretickými předpoklady ohledně neočekávaných situací ve vyučování, abychom posléze mohli na empirických datech ukázat jednotlivé typy neočekávaných situací a řešení těchto situací studenty učitelství.

V literatuře můžeme najít několik poznámek o problematice neočekávaných situací ve vyučování, ale bez hlubšího a systematického vhledu do dané problematiky (výjimkou je např́iklad zmapování neočekávaných situací v matematické tř̌́dě, Foster, 2015). Můžeme najít obecná prohlášení podobná tomu Brookfieldovu (2006, s. xii), že vyučování je „plné

\footnotetext{
${ }^{98}$ Dále budeme používat pojem situace.
} 
neočekávaných událostí, nenadálých překvapení a nečekaných zvratư“. Tvrdí, že jen jednu věc mohou učitelé očekávat s jistotou, a tou je nejistota (tamtéž).

Neočekávané situace jsou často propojeny s tacitními znalostmi (Evans \& Kersh, 2004; Wilton, 2010), a to proto, že v těchto situacích často selhávají naučené vzorce chování a myšlení a situace jsou následně řešeny na základě předchozích znalostí a zkušeností, které jsou v danou chvíli méně uvědomované a obtížně artikulované (jde tak o specifický typ tacitních znalostí, srovnej Polanyi, 2009; Reber, 1989; Nonaka \& Krogh, 2009; Eraut, 2000). Podobným termínem je nepředvídatelná situace, který je často spojen s neočekávanými a neplánovanými reakcemi učitelů, jež jsou spuštěny na základě reakcí studentů Rowland \& Zazkis (2013, s. 138-139).

Př́buzným pojmem je i to, co se nazývá zlomová událost ${ }^{99}$ (critical incidents). Pojem pochází od Flanagana (1954), který napsal klasický článek o technice zlomových událostí (critical incident technique).

Zlomové události jsou definovány jako extrémní chování, a to bud' jako mimořádně účinné, nebo jako neúčinné ve vztahu k dosažení obecných cílů nějaké činnosti. Tento postup je značně účinný díky tomu, že se zaměruje na extrémní chování. Je dobře známo, že extrémní př́pady mohou být identifikovány přesněji než chování průměrné. (Flanagan, 1954, s. 338)

Během uplynulých 40 let se technika zlomových událostí stala široce používanou kvalitativní výzkumnou metodou a jedním z nejcitovanějších témat v psychologii organizace (viz Butterfield, Borgen, Amundson, \& Malio, 2005, s. 475). V edukačním kontextu je významná práce Trippa (1993), který uvádí, že:

„zlomové události nejsou věci, které existují nezávisle na pozorovateli a čekají na objevení, ale jsou vytvářeny. Incidenty se stanou, ale zda jsou kritické, nebo ne, závisí na tom, jak interpretujeme význam této události. Je to založené na hodnoticím soudu, který přisuzujeme významu incidentu.“ (Tripp, 1993, s. 8)

V českém kontextu např́iklad definuje zlomové události z pohledu narativního výzkumu Švaříček (2011, s. 251) jako: ,samostatné vložky (digrese), krátké př́iběhy, které odbočují od hlavního děje, ve kterém se líčí profesní vývoj učitele experta“. Nabízené definice pro edukační kontext jsou velmi vágní, proto Angelides (2001) navrhuje kritérium, které pomůže upřesnit, zda se jedná o zlomovou událost, nebo nikoliv. Na základě myšlenek Schöna (1995) a Scheina (1985) uvádí, že důležitým kritériem pro rozlišení, kdy jde o zlomový incident, je

\footnotetext{
${ }^{99}$ Jiným pojmenováním by mohlo být označení kritické incidenty či události, ale držíme se zavedeného termínu „zlomová událost“ (viz Švaříček, 2011).
} 
fenomén „překvapení“. Jde tak o překvapující nebo problematickou situaci, která stimuluje reflexi nebo řešení situace (Angelides, 2001, s. 431). Tím se pojetí zlomových incidentů blíží neočekávaným situacím.

Předchozí poznámky k neočekávaným situacím a podobným konceptům naznačují nesystematičnost, s níž je tento fenomén zkoumán. To je důvod, proč je zapotřebí podívat se na téma neočekávaných situací detailněji a pokusit se (a) najít jasnější definici neočekávaných situací a (b) následně na základě empirických dat ukázat typologii neočekávaných situací při vyučování a dále také možnosti jejich řešení. 


\subsection{Př̀edběžné vymezení: od epizodické situace $k$ neočekávané situaci}

Z pohledu fenomenologické kognitivní vědy je situace nejzákladnější smysluplným segmentem žité zkušenosti (Havel, 1999), proto ji nazývá epizodickou situací či zkušeností. Pro Havla (2009) je důležitý pohled na epizodickou situaci z pozice první osoby, ${ }^{100}$ proto důležitou charakteristikou těchto situací je, 1) že je lze vyprávět (mají určitý obsah) a 2) že je vázána na místo a má časové ohraničení (srov. 1.2). Např́iklad Gerstner \& Goldberg (1994) nebo Nagy (2011) taktéž tvrdí, že naše žitá zkušenost je rozdělena do segmentů (př́padně na rytmy), jež jsou strukturovány jako tř́sekundové celky. Naproti tomu psychobiolog Trevarthen (2011) uvádí, že existují i jiné segmenty, které selektují lidské prožívání do různě dlouhých časových cyklů.

Na základě takto ukotvené teorie epizodické situace můžeme dojít k pojmu neočekávaná situace, kterou lze definovat jako pro první osobu překvapující smysluplným segmentem lidské zkušenosti, pro nějž je typické, že její obsah lze z principu vyprávět (je o čem mluvit) a má své místo a časové ohraničení. Přičemž překvapení je znamená, že tato situace neodpovídá ničemu podobnému, co dotyčný vědomě zažil v minulosti (Haider \& Frensch, 2005, s. 401) ${ }^{101}$. Další charakteristiku přidává Gallagher (2015, s. 117), který říká, že údiv (wonder) je zdánlivě „způsoben“ nedostatkem rozpoznání příčiny, která způsobila situaci, ale to zase může způsobit další emoce, jako jsou zděšení, hrůza a podobně.

Soulad mezi očekávanou realitou na základě své zkušenosti a skutečnou realitou je tak pro neočekávané situace velmi podstatný. Nesloud Jarvis (2010, s. 83) definuje jako „složitý fenomén, který je nejlépe popsatelný jako rozdíl (mezera) mezitím, co očekáváme, že budeme vnímat, díky předchozí získané zkušenosti a toho s čím jsme aktuálně [ve vnímání] konfrontováni“. Nesoulad nastává, pokud lidé nemohou na situaci (osobu, já, věc,...) zareagovat takovým způsobem, který doposud používali, který měli uložený ve své zkušenosti, vztah se tak přeruší. Jednoduše řečeno nesoulad je, když nedochází ke shodě

\footnotetext{
${ }^{100}$ Perspektiva první osoby je ve výzkumu spojena se snahou získat data z pozice první osoby, například ve formě vyjádření samotného subjektu o jeho prožívání. Takováto povaha dat je dle některých výzkumníků (např́iklad Varela \& Shear, 1999b) neredukovatelná na objektivní perspektivu nezávislého subjektu (třetí osoby).

${ }^{101}$ Událost je neočekávaná, když to není v souladu s tím, co jsem zakoušel v této konkrétní situaci v minulosti.
} 
„minulé lidské zkušeností a současné situace“ (Jarvis, 2004, s. 92). To je velmi podobné tomu, jak na "situaci” pohlíží Dewey (srovnej kapitola 1.2 Znalost a role figurativního jazyka v procesu její explikace). Jarvis (1992) explicitně ř́ká, že paradoxně tam kde existuje harmonie, neexistuje situace, která vede k učení. Uvádí k tomu, že děti přichází se situací nesouladu velmi brzo do kontaktu (Jarvis, 2009). Graficky lze koncept nesouladu znázornit následujícím způsobem. ${ }^{102}$



Obrázek 10. Nesoulad očekávání a reality - převzato z Jarvis (2010, s. 84).

Spodní šipka grafu znázorňuje očekávané vnímání. To je takové vnímání, které je založeno na předešlých, získaných zkušenostech, ty tvoří podle Jarvise tzv. totální zkušenost (jde o souhrn všech zkušeností, které do určité doby člověk ve svém životě získal). Horní šipka v grafu pak znázorňuje aktuální vnímání reality. $\mathrm{Na}$ začátku grafu toto vnímání reality odpovídá nasbíraným zkušenostem, to Jarvis nazývá „shoda“ (aktuálně vnímané reality a minulé zkušenosti). „Rozdílnost““ je nepatrná odchylka mezi těmito dvěma stavy, v ní však můžeme přizpůsobit své chování situaci bez změny našeho porozumění světu, většinou to děláme, aniž bychom si toho byli vědomi. „Oddělení“ nastává, když je mezera mezi těmito dvěma postoji větší a my se začínáme ptát: co se děje? Toto stadium je dle Jarvise počátek vědomého učení. V tomto bodě začíná nesoulad, a to v oblasti kognitivní, emoční i praktické. „Odlišnost““ nastává, když je mezera tak velká, že tuto distinkci musíme vyřešit větším úsilím, např́íklad studiem. Jarvis (2010) uvádí, že někdy se může stát, že mezera bude tak velká, že ji nedokážeme učením překonat. Jednou z možností, jak takovou nastalou situaci ještě řešit, je -

102 Částečně převzato z Nehyba (2012, s. 39). 
jak by pravděpodobně uvedl Mezirow (1990) - změna „,ýznamových schémat a perspektiv“, tedy nutnost redefinovat, jak dochází $\mathrm{k}$ samotnému procesu vnímání reality. 


\subsection{Co se děje v mysli při neočekávané situaci?}

V kontextu motorického učení, konkrétně pro sekvenční učení (učení se libovolnému sériovému vzoru nebo seznamu čísel, písmen apod.) existuje takzvaná hypotéza neočekávaných situací (Frensch, Haider, Rünger, Neugebauer, Voigt, \& Werg, 2003). Pokud jedinci hledají prŕíčinu odchylky od toho, co zakoušejí, s tím, co očekávali, pak ve výše zmíněném kontextu dochází k produkci správné znalosti o příčinách těchto odchylek. Tato hypotéza je podpořena několika empirickými výzkumy (Runger \& Frensch, 2008; Haider \& Frensch, 2005, 2009). Tento typ učení „vytváří v nedeklarativní paměti pamět’ové stopy, které přímo řídí chování člověka; přičemž pozorování vlastního chování následně spouští učení v deklarativní paměti“ (Haider \& Frensch, 2005, s. 401). Přestože nelze vnímat jednání začínajícího učitele jako jednoduché sekvenční učení, dá se říct, že se snaží naučit jednat rutinním způsobem na jednotlivé situace, aby se jeho jednání stalo automatickým. Ale jeho jednání je daleko komplexnější. Přesto můžeme tvrdit, že pozorování, či dokonce reflexe, tedy záměrné přemýšlení o automatických komplexních procesech jako je proces vyučování (a automatismy jsou spojené s nedeklarativní pamětí), následně vedou k vytváření znalostí o těchto procesech a k jejich možnému zlepšení, což ostatně dokládá silný proud reflektivní praxe v př́ípravě pedagogů (Korthagen, 2001; Dieker \& Monda-Amaya, 1997; Henry, 1999; Parkay, 2000; Yost \& Sentner, 2000).

Co se však děje v mysli učitele, který se dostane do neočekávané situace? Na základě čeho volí další jednání v neočekávané situaci či na základě čeho dojde k vytvoření nějaké znalosti o možném řešení neočekávané situace? Jeden výkladovým rámcem, který je empiricky ověřen, můžeme nalézt v tom, co se označuje jako prediktivní mysl.

Ústř̌ední myšlenkou je, že pojmovou, percepční, poznávací úroveň, a dokonce i úroveň jednání je možné uchopit skrze jeden princip, kterým je predikce minimalizace chyby (prediction error minimalization) (srov. Hohwy, 2013).

Přičemž prediktivní chyba je ,,v̌̌dy větší než překvapení, což znamená, že prediktivní chyba = překvapení + percepční divergence. Je vždy větší než překvapení, protože percepční divergence je nezáporná“ (Hohwy, 2013, s. 52). V naše pojetí můžeme mluvit o Jarvisově nesouladu, který může být také jedině nezáporný, jak plyne z grafu č. 1 . 
Tomu odpovídá empiricky prokázaná hypotéza, že si náš mozek vytváří hierarchicky uspořádané generativní modely (generative model), které generují předpovědi o smyslových vstupech a jejich skrytých příčinách (tyto utvořené modely vycházejí z předchozích senzorických dat, které už člověk zpracovával ve vztahu k již existujícím modelům). Když $\mathrm{k}$ nám $\mathrm{v}$ situaci tady a ted' dorazí smyslové signály, jejich př́ípadná odlišnost od našich předpovědí založených na obecném modelu musí být dále zpracována na vyšší úrovni modelu.

Lidský mozek tak průběžně generuje předpovědi o prostředí založené na naučených pravidelnostech ve světě. Tyto predikce aktivně a efektivně usnadňují interpretaci příchozích smyslových informací (srov. Damasio, 2010, s. 93-121). Původně bylo prediktivní kódování navrženo jako model vizuální percepce (Barlow, 1961). V současné době hraje důležitou roli ve snaze najít jednotnou teorii mozku (Friston, 2010). Ústřední myšlenkou je, že odezvy některých neuronových okruhů neobsahují informace o aktuálně vnímaném stimulu, ale o rozdílu mezi stimulem a očekávanou reakcí na stimul (Fiorillo, Tobler, \& Schultz, 2003; Schultz, Dayan, \& Montague 1997; Schultz, 2010). Důležitou funkcí je tak minimalizace překvapení, se kterým se člověk potkává. Ukazuje se tedy, že mozek se - v rámci určitého jednání - v neočekávané situaci snaží minimalizovat moment překvapení na základě předchozích zkušeností (Blakemore, Goodbody, \& Wolpert, 1998; Bestmann, Harrison, Blankenburg, Mars, Haggard, Friston, \& Rothwell, 2008; Franklin \& Wolpert, 2011). Zužitkováváme naše znalosti z předchozích zkušeností a vytváříme předpovědi, jež minimalizují moment překvapení (Friston, Kilner, \& Harrison, 2006).

Z tohoto pohledu pak můžeme mluvit o tom, že tacitní znalosti, které nám pomáhají při jednání v neočekávaných situacích, můžeme vnímat jako určitý druh predikcí, jež jsou založeny na předchozích zkušenostech (prior experience), které se projevují při snaze minimalizovat prediktivní chybu, tedy minimalizovat chybu plynoucí z překvapení a percepční divergence. Tacitní spočívá $\mathrm{v}$ tom, že tyto predikce jsou méně uvědomované ${ }^{103} \mathrm{a}$ obtížně atrikulovatelné nebo zcela neuvědomované a neartikulovatelné (viz to, co Helmholtz, 1866/1962, označuje jako nevědomé vyvození - unconscious inference). Přesto se nám zdá, že tacitní znalosti jsou často zatíženy nejasností tohoto pojmu a různými výkladovými rámci,

\footnotetext{
103 „Kromě toho termín predikce má neutrální konotaci a může odkazovat na implictiní (nevědomé) predikce nebo explicitní (intelektuální) predikce.“ (Van de Cruys \& Wagemans, 2011, s. 336).
} 
které na ně kladou určité požadavky a přinášejí očekávání, proto raději v rámci osmé kapitoly používání tohoto pojmu minimalizujeme.

Přestože máme určitou mlhavou představu o tom, jaké procesy mohou fungovat $\mathrm{v}$ hlavě člověka prožívajícího neočekávanou situaci (viz popis uvedených souvislostí výše), chybí systematičtější pohled na to, jak vypadá neočekávaná situace z pohledu zkušenosti první osoby studenta učitelství, z pohledu jeho prožívání.

V následující kapitole popíšeme nejdřive metodologii takovéhoto výzkumu a dále předložíme výsledky výzkumu, který odpovídá na dvě výzkumné otázky: (a) jaké typy neočekávaných situací se vyskytují u studentů učitelství a (b) jak studenti učitelství proživají neočekávané situace?

\subsection{Metodologie}

Při analýze jsme se zabývali především rozhovory, které byly zaměřeny na neočekávané situace. (Iniciační otázka těchto rozhovorů zněla: Když se řekne neočekávaná situace, tak co tě napadne?) Dále jsme zohlednili i rozhovory zaměřené na subjektivní pojetí výuky, při nichž někteři informanti referovali o neočekávaných situacích. Díky metodě sběru dat jsme získali velmi detailní popis jednotlivých neočekávaných situací a procesu jejich řešení či neřešení. Data jsme analyzovali tak, že jsme po přepsání rozhovorů hledali témata, která se dotýkala neočekávaných situací. Zabývali jsme se tedy především těmi pasážemi, ve kterých studenti reflektovali situace, které je překvapily či které přímo nazývali jako neočekávané, př́padně se s nimi nikdy předtím nesetkali. Díky tomu jsme jednak dostali typologii neočekávaných situací, jednak jsme dále mohli detailně prozkoumat asynchronní a diachronní aspekt těchto těchto situací (Petitmengin, 2006). Tímto způsobem bylo možné z textu sestavit detailní popisy neočekávaných situací a jejich př́ípadného řešení. Řešení jsme sestavili tak, že jsme vytvořili diagramy jednotlivých situací. Blížíme se tak diagramům vycházejících ze systémové dynamiky (Šusta \& Kostroň, 2004). Jako př́iklad můžeme uvést mapu Karla a jeho procesu řešení jedné neočekávané situace (viz obrázek 11). 


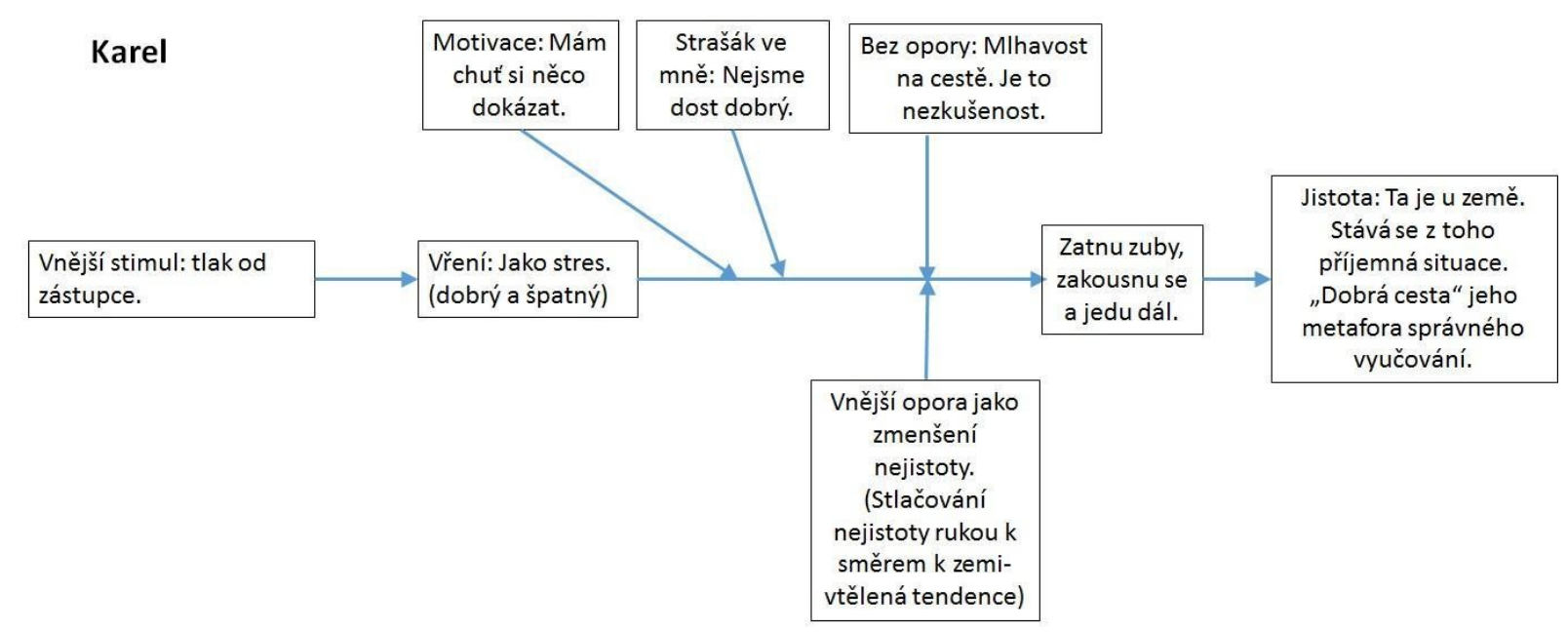

Obrázek 11. Př́iklad osobního diagramu.

Metoda sběru dat nám pomáhala nahlédnout na mikrostrukturu a mikrodynamiku procesu neočekávaných situací, který se mnohdy odehraje během několika sekund. To je v myšlenkové shodě například s tím, jak o takové analýze uvažuje Kimmel (2016) nebo Gardner (2009, 2011), kteří se soustřed’ují právě na analýzu vzniku mikrodynamiky jednání (micro-genetic analyses of interaction).

Následně jsme abstrahovali rysy jednotlivých procesů řešení neočekávaných situací, abychom dospěli k obecnému modelu řešení (viz podkapitolu 8.7). Celý proces probíhal interaktivně: vykreslovali jsme mapy situací a znovu se nořili do dat, znovu mapy upravovali a následně abstrahovali rysy obecného modelu, které jsme znovu porovnávali s daty a jednotlivými mapami situací a opět je abstrahovali, než jsme kategorie považovali za dostatečně usazené a jasné ve vztahu $\mathrm{k}$ datům. $\mathrm{Z}$ pohledu designu můžeme říci, že se jednalo o detailní deskriptivně fenomenologicky orientovanou analýzu konkrétní situace, spíše v odkazu na psychofenomenologii (Tosey \& Mathison, 2010) než na deskriptivně orientovanou fenomenologii (Giorgi, 2009). Jde nám tak předně o ,popis podstatných struktur prožitkové zkušenosti“(Urban, 2015, s. 39). 


\subsection{Typy neočekávaných situací}

$\mathrm{V}$ rámci práce $\mathrm{s}$ daty se nám $\mathrm{v}$ datech začaly ukazovat různé typy neočekávaných situací. Tyto typy jsme podrobněji analyzovali a identifikovali jsme v datech jejich charakteristiky (kritéria členění, srovn. Marradi, 1990), díky kterým jsme mohli neočekávané situace lépe oddělit. Jako nejdůležitější se ukázaly být charakteristiky situace týkající se vnímání situace, impaktu (dopadu situace na okolí) a závažnosti situace. Tyto tři charakteristiky byly jednak hojně reflektované, jednak spolu u nejvíce zastoupených neočekávaných situací vzájemně souvisely. Pro přehlednost uvádíme výsledné charakteristiky neočekávaných situací s vysvětlením v tabulce 9 .

Tabulka 9

Vysvětlení charakteristik neočekávaných situací

\begin{tabular}{|l|l|}
\hline Libost situace & $\begin{array}{l}\text { Student vnímá neočekávanou situaci bud' jako př́ijemnou, } \\
\text { nebo jako nepŕ́jemnou. Jedná se tak o míru libosti situace } \\
\text { pro informanta. }\end{array}$ \\
\hline Impakt situace & $\begin{array}{l}\text { Kategorie určená dle toho, kolik osob je danou neočekávanou } \\
\text { situaci zasaženo. }\end{array}$ \\
\hline Závažnost situace & $\begin{array}{l}\text { Kategorie, která je určena podle míry narušení plynutí hodiny } \\
\text { (bude vysvětleno níže). }\end{array}$ \\
\hline váhlost versus postupnost & $\begin{array}{l}\text { Některé neočekávané situace se objevují náhle, zatímco jiné } \\
\text { se postupně vyvíjejí čase a student jejich postupný vývoj } \\
\text { může pozorovat. Náhlost či postupnost tak představují další } \\
\text { kategorii neočekávaných situací, které se vempirických } \\
\text { datech objevily. }\end{array}$ \\
\hline
\end{tabular}

Základní třídění neočekávaných situací proběhlo dle toho, zda byla situace vnímána studentem jako př́jemná, či jako nepř́iemná (vnímání libosti). Následně jsme se zabývali tím, zda je neočekávanou situaci zasaženo více osob, či pouze praktikující student (impakt). Tak vzniklo základní schéma, podle nějž budeme neočekávané situace postupně charakterizovat. Nejprve se budeme věnovat nepřijemným neočekávaným situacím zasahujícím více osob (1). Těchto neočekávaných situací byla v empirických datech většina. Následně se budeme 
zabývat nepř́ijemnými neočekávanými situacemi, které zasáhly (jen) praktikujícího studenta (2), a nakonec pojednáme o př́jemných neočekávaných situacích (3).

\subsubsection{Nepř́ijemné neočekávané situace zasahující více osob}

Jako klíčová kategorie pro typologii nepř́ijemných neočekávaných situací zasahujících více osob se ukazuje závažnost narušení plynutí vyučovací hodiny, která je provázána $\mathrm{s}$ jejich impaktem (počtem zasažených osob). Závažnost těchto nepř́ijemných neočekávaných situací je z empirických dat poměrně dobře čitelná, pracujeme přitom s pojmem plynutí, který je in vivo kódem. Jedná se o metaforické vyjádření, které účastníci výzkumu sami užívají ve svých reflexích. Pokud se jejich pedagogické působení vyvíjelo podle jejich očekávání (plánu), mluví o „hezkém, prř́jemném či nerušeném” plynutí, my pro tento stav budeme používat termín ideální plynutí.

Dana: ...že se tam nestalo nic, co bych, ehm, že bych třeba nějak zmatkovala nebo najednou nevěděla, nebo tak, to to právě, to právě vůbec, tak nějak to, ehm, hezky plynulo.

Výzkumník: Takže hodina tak hezky plynula... Všechno se zadařilo, napsali diktát, dělali to cvičení. Co je to to plynutí?

Dana: Jako že to, že to, že se nestalo nic, nic zvláštního, nic, žádnej jako, nevím incident... (2. rozhovor)

Výzkumník: Když to plyne vlastně, tak co je to za plynutí?

Cyril: Hm, že pokračuju v tý výuce tak, jak jsem ji měl, že vlastně mě tam nic jako nerozhodilo.

(2. rozhovor)

Pro ideální plynutí hodiny jsou důležité dva atributy: přiměrená rychlost a vzájemnost. Pokud jsou rychlost a vzájemnost plynutí něčím či někým narušeny, dochází k nepříjemným neočekávaným situacím. V empirických datech se takových situací objevilo několik typů, o nichž pojednáme níže. Rychlost a vzájemnost plynutí jsou spolu provázány (pokud je narušena rychlost, je narušena i vzájemnost). Studenti však reflektovali převážně narušení rychlosti plynutí, méně se vyjadřovali o narušení vzájemnosti. Pro bližší zkoumání nepř́ijemných neočekávaných situací se přidržíme tohoto schématu, a ačkoli spolu obě charakteristiky souvisejí, pojednáme nejprve o narušení rychlosti plynutí a následně o narušení jeho vzájemnosti.

\section{Rychlost plynutí}


Studenti nejčastěji reflektovali takové nepř́ijemné neočekávané situace, při kterých je plynutí zpomaleno až zastaveno. Jedná se o situace, kdy praktikující student nemůže realizovat hodinu podle svých představ, zpravidla je těmito situacemi zasažen větší počet osob (student a alespoň někteří ze žáků). Při následné reflexi studenti hovoří o zaseknutí, zadrhnutí či používají jiné výrazy evokující znemožnění fyzického pohybu.

Cyril: ...když udělám chybu doma nebo něco, tak to není takovej jakoby problém, ale když prostě, at' je to na tom tréninku nebo když jsem učil, tak ten - hm - jakoby první záměr, aby to prostě pokračovalo nějak dál, aby nebylo vidět, že já jsem se zastavil, že něco je špatně nebo podobně. Tak - hm - většinou jde hrozně dobře vidět, že se ten člověk nějak zasek. (2. rozhovor).

Na této ukázce vidíme, že student považuje zpomalení pohybu za negativní jev a snaží se jednat tak, aby toto zpomalení mělo co nejmenší impakt. Zajímavý je rovněž respondentův přechod do vyprávění ve třetí osobě, což může být projevem toho, že je mu situace natolik nepř́ijemná, že se z ní snaží vyloučit vlastní osobu či ji zevšeobecnit na všechny lidi. Na základě empirických dat můžeme stanovit závažnost nepř́ijemných neočekávaných situací podle míry narušení plynutí vyučovací hodiny: (a) mírné zpomalení plynutí; (b) zpomalení plynutí; (c) zastaveni plynutí.

Stupeň závažnosti těchto situací souvisí s jejich impaktem: čím výrazněji je plynutí zpomaleno, tím vyšší počet osob je situací zasažen. Co se týče náhlosti či postupnosti vzniku takové situace, pojednáme o ní podrobněji níže.

\section{a) mírné zpomalení}

Neočekávaná situace je studentovi sice nepř́ijemná, ale student na ni zatím výrazněji nereaguje a vyčkává, co bude následovat (,ještě to půjde, počkám”). V následné reflexi studenti hovoří o zpomalení fyzického pohybu a vyjadřují se o mezi či hranici oddělující, co je pro ně ještě akceptovatelné a co už ne. Můžeme použít termín mez akceptovatelnosti. Situace s mírným zpomalením plynutí je vnímána jako ještě akceptovatelná, protože mez akceptovatelnosti není překročena. Pro studenty je velmi obtížné svou mez akceptovatelnosti blíže specifikovat. Na základě dat můžeme konstatovat, že její nastavení je velmi individuální pro každého studenta, a navíc je pohyblivé (např́iklad situaci, kterou je student schopen akceptovat v hodině výtvarné výchovy, by neakceptoval při hodině českého jazyka). Ve zkoumaných situacích byla nejvíce reflektována souvislost mezi mezí akceptovatelnosti 
a naplněním cílů hodiny (dokud hodina dle studenta plnila svůj účel, situaci považoval za ještě akceptovatelnou).

Dana: Jestli je teda napomenout, nebo ne. Tak jsem si napřed musela zhodnotit jakoby, jako, ehm, jestli je to, to, jak se třeba baví nebo mluví jako, ehm, jako na hranici toho, že bych je teda měla napomenout. Tak jsem je pak teda bud' nenapomenula, nebo to ještě nechala být.

Výzkumník: Takže, ty jsi vlastně předtím cítila, pokládala sis otázku, jestli je máš napomenout, nebo ne. Jestli je to až zas tak na hranici mezi tím napomenout, nebo to nechat být. Tak co je to za tu hranici?

Dana: (pauza pět sekund) Že někdo se třeba ... mluví docela potichu a zároveň u toho i pracuje, dělá to, co má tak toho třeba nenapomenu, ale když, když třeba ... mluví, ale nepracuje u toho, tak jde třeba na chodbu nebo ... před tou hranicí, že to ... je pro ně ješšě jako, ehm, ... užitečný a ... prostě něco mít z té hodiny. (2. rozhovor)

Cyril: ... před tou hranicí, že to je pro ně ještě jako, ehm, ... užitečný, a ... prostě něco mít z té hodiny. (2. rozhovor)

Situace s mírným zpomalením pohybu, které se v empirických datech objevily, se nejčastěji postupně vyvijely $v$ čase (žáci, kteří například pracovali na nějakém cvičení, postupně přestávali být pozorní, začali se mezi sebou bavit, zatímco student se svou reakcí vyčkával). Méně často došlo k takové situaci náhle (napřs. nefungovala nějaká drobnější pomůcka, což však významně nenarušilo plnění cílů hodiny).

\section{b) zpomalení plynutí}

Nepř́ijemná neočekávaná situace již přesahuje mez akceptovatelnosti. Plynutí hodiny je výrazněji zpomaleno (už není možné bez modifikace realizovat plán, cíl hodiny přestává být realizován). Student vnímá nechtěnost takové situace natolik, že se rozhodne jednat. V empirických datech se taková situace vždy postupně vyvinula tím, že narostl impakt (počet zasažených osob).

Cyril: No, a v pondělí jsem jim prostě dal menší části, cokoliv měli plavat míň, ale byl tam jeden slabší, co třeba plavat nebyl. Jedna holka, bolela ji hlava nebo jí nebylo úplně dobře ... takže takový různý druhy připomínky a hned se toho chytne celá skupina, tak se najednou nechce nikomu. Takže, ... jsou tam prostě někteř́, kteří si jako to uvědomí, že to je dobrý, že to uplavou a ten zbytek, co se tak jako chytne. ... Tak bylo to zklamání, že se nenaplnil ten plán, co jsem ... co jsem předpokládal, že jim to půjde třeba. (2. rozhovor).

Impakt výše citované situace postupně vzrůstal, až došlo k přesažení studentovy meze akceptovatelnosti (zamýšlený cíl přestal být plněn). Student se rozhodl jednat a pozměnil své původní plány. 
Nejzávažnější nepříjemné neočekávané situace zcela zastaví plynutí hodiny, studentovi již nestačí pozměnit plány, musí řešit nové (zcela jiné) skutečnosti. Taková situace, jež je velmi intenzivně vnímaná jako nechtěná a jejíž impakt je vysoký, zpravidla zahrnuje nejen studenta a žáky, ale i další osoby (rodiče, pracovníky školy, diváky závodů atd.). Situace, které jsme zaznamenali, nejčastěji vznikly náhle a obvykle bylo nad studentovy možnosti je vyřešit: „Běhali jsme sprinty a uprostřed jednoho prostě se chlapeček skácel, protože dostal křeč do stehna. Takže jsem ani nic moc dělat nemohla, tak to byla neočekávaná, neznámá situace. (Beáta, 2. rozhovor).

Pouze jednou se v empirických datech objevila situace typu 3, která se vyvinula z předchozích dvou typů nepř́jemných neočekávaných situací. Jednalo o situaci, která nebyla v předchozím stadiu vhodně řešena, až došlo $\mathrm{k}$ jejímu vystupňování a praktické neřešitelnosti. Studentka byla $\mathrm{v}$ tomto př́padě pouze pozorovatelem (situace se přihodila během jejího náslechu $\mathrm{v}$ zájmovém kroužku).

Jaroslava: Tak jsem si začala všímat jedné skupinky chlapců, kde začal vznikat nějaký konflikt. Ten chlapec, on nechtěl dělat tu roli, která mu byla přidělena. Ten lektor to vyř̌šil v tu chvíli tak, že mu řekl, že prostě to bude dělat, a víc se s ním o tom nebavil. No, ... pokračovalo to tak, že ten chlapec, teda, prostě to musel přijmout, ale přiliš nepracoval a začal být, jakoby čím dál více agresivnějšíi. A místo toho, aby dělal to, co měl zadané, tak začal zlobit i spolužáky, začal je bít, začal jim nadávat. Ten lektor se věnoval jiným dětem a toto jako kdyby přehlížel celou dobu. A on potom, on tam registroval, že tam prostě probíhá něco, protože ten druhý chlapec, ehm $\mathrm{k}$ té, ... k té ten, ten náš objekt, o kterém mluvím, tak ten vlastně jakoby nadával a bil tam toho kamaráda. Ten si začal stěžovat, ten lektor řekl: „Prostě, kluci, přestaňte, ty dělej toto, ty dělej tamto.“ Ale nic to neřešilo a zase se věnoval těm jiným skupinkám. No, v podstatě to pokračovalo, že ten chlapec, jak kdyby ho najednou popadl amok, ehm, ... on začal být teda velmi, ale velmi vulgární, ehm, ... začal bít ještě více ty všechny okolo sebe, de facto, až ta situace vyústila, lektor zakročil tak, jak kdyby to schytal ten lektor od toho žáka. Ten žák na něj vlastně vyjel s tím, že ehm, že ho zabije, že, začal mu sprostě nadávat a řekl mu, že ho dá k soudu, že ho bude soudit za to, že ho nějakým způsobem napadl a ten lektor se ho už snažil uklidnit, ale to už bylo pozdě. Ten chlapec už byl prostě, jak kdyby mimo sebe a už prostě útočil. Ten lektor, ehm, vrhnul takový ten pohled na mě, jakože pomoz mi ... A já jsem byla v takovém šoku, že já jsem prostě nevěděla jako, co mám v tu chvíli dělat. (2. rozhovor). 


\section{Vzájemnost plynutí}

Kromě rychlosti má plynutí hodiny ještě určitý směr. Pokud žáci spolupracují očekávaným způsobem se studentem, má student nad směrem (i rychlostí) plynutí kontrolu. Plynutí je vnímáno jako vzájemné. Vzájemností plynutí tedy rozumíme stav, kdy obě strany (student a žáci) mají společné cíle a spolupracují na jejich realizaci. Může však dojít k situaci, kdy je směr plynutí změněn, plynutí přestává být vzájemné a vzniká neočekávaná situace:

Alena: Tady prostě snahu neměli, více méně. Podle toho to tak možná hnedka už se nedařilo od začátku hodiny. Tady to spíś byla souhra okolností, nějakých jako holt - prostě se to stává, ale toto to byla taková ta jako nechut' vưči jakékoliv té osobě, která tam prostě přijde, to už je fakt rozdíl.

Výzkumník: A ta situace byla pro tebe jako co?

Alena: Nepř́ijemná? Nó, tak jako já jsem prostě nevěrila vlastním očím, proto jsem doufala, že to teda potom jako přjeje, že se rychle uklidní a půjdeme dál, ale neé, no.

$(\ldots)$

Alena: Nó, jasně, bud' se člověk přenese a jede se dál, nebo v podstatě se nic moc neděje nebo prostě fakt jako člověk už zjistí, že se to, že to prostě půjde úplně jiným SMĚREM ... (5. rozhovor)

Ztráta kontroly nad směrem plynutí může být také způsobena špatnou organizací práce či nejasnou domluvou se cvičným učitelem. Studenti učitelství například až přímo v hodině zjistí, že si připravili učivo, které již žáci probírali, či učivo, na které mají žáci zadány referáty. Studenti často reflektují problém s přebytkem času, s nímž se $\mathrm{v}$ takové situaci potýkali.

Františka: Tak jsem nevěděla, jestli to s nima mám projít, nebo nemám to s nima procházet nebo co a jak na to mám reagovat, protože jsem to vážně měla připravený, tak plus mínus na těch pětačtyřicet minut, aby mně to vyšlo. No, a ted' já jsem měla takovej pocit, ted' si ř́íám, ježišmarja, pětačtyřicet minut. (2. rozhovor)

Vzájemnost plynutí může být rovněž narušena, pokud je plynutí zrychleno natolik, že student už nestíhá mít kontakt se žáky. Žáci mohou být např́iklad př́liš aktivní a student práci s nimi z oborového či oborově-didaktického hlediska nezvládá.

Jaroslava: Potom jakoby co se mi děje pořád. Tak jsou takové ty neočekávané dotazy, kdy, kdy já nevím. Já se třeba jako přistihnu, že, ehm, prostě nevím jakoby nějakou tu teoretickou informaci, že ta teorie je určitě taky potřeba, ale když se mě to dítě zeptá, já dám ted'ka prostě př́iklad, na který zrovna odpověd' vím, ale je to lepší uvést to na příkladě, že se mě třeba dítě zeptá, proč mi ta vodoměrka skáče po té vodě, jak je to možné, že ona prostě se neutopí? Já prostě reaguji tak, že jsem zaskočená a že nevím najednou a, ježišs, co to vlastně je? A já jsem se úplně na těch prvních hodinách, jsem zamluvila, že jsem jakoby odvedla řeč od toho úplně někam jinam 
a ještě jsem řekla tomu dítěti: hele, ty tady máš dělat tohleto a neděláš to. Radši místo otázek si dělej tady to, co máš. (2. rozhovor)

V empirických datech se neočekávaných situací s narušenou vzájemností plynutí objevilo pouze malé množství, a tak je nelze blíže charakterizovat, jako jsme to udělali u situací s narušenou rychlostí plynutí. Mezi vzájemností a rychlostí plynutí však existuje provázanost, kterou můžeme vyjádřit graficky.



Obrázek 12. Provázanost rychlosti a vzájemnosti plynutí.

Tučně je znázorněno plynutí hodiny, které má dvě provázané charakteristiky: vzájemnost a rychlost. V levé části grafu jsou znázorněny situace, při kterých byla rychlost plynutí hodiny sice kontrolována studentem, ale docházelo k jejímu zpomalování. Zároveň s rychlostí klesala i vzájemnost plynutí. Takových neočekávaných situací studenti reflektovali nejvíce a výše jsme rozlišili jejich tři stupně (od mírného zpomalení až po faktické zastavení plynutí). Studenti rovněž reflektovali mez akceptovatelnosti oddělující méně závažný typ těchto situací od závažnějších. Uprostřed grafu je stav nazvaný ideální plynutí, kdy je míra vzájemnosti a rychlost taková, jakou student očekával a hodina probíhá bez problémů. V pravé části grafu jsou neprŕijemné neočekávané situace, při nichž bylo plynutí zrychlené a/nebo se jeho směr dostával mimo kontrolu studenta. Desynchronizace rychlosti a směru plynutí mezi studentem a jeho žáky vedla ke ztrátě vzájemnosti plynutí. 
Z empirických dat vyplynulo, že jednotliví informanti mají povědomí jen o určité části celého tohoto vzorce plynutí, někteří jen vnímají důležitost „zpomalení” či „zaseknutî”, jiní ztrátu vzájemnosti nebo odkazují na tyto fenomény odděleně. Studenti učitelství nedokáží na tento fenomén nahlédnout celistvě, jak je zde prezentován např́íklad v grafu. To nás vede $\mathrm{k}$ úvaze, že jsou jim známy jen některé aspekty tohoto procesu, ale celý „,vzorec” plynutí je pro ně spíše tacitní.

\subsubsection{Nepř́jemné neočekávané situace zasahující jen studenta}

Zvláštní skupinu tvořily $\mathrm{v}$ empirických datech neočekávané situace, které zasahovaly pouze praktikujícího studenta, žáci ani další osoby je nevnímali. K takovým situacím došlo mimo hlavní pedagogické působení studenta (mimo samotnou vyučovací hodinu), nejčastěji před vyučovací hodinou. Student například musel učit vyšší počet hodin či jiné učivo, než bylo původně plánováno. Je obtížné najít u těchto situací charakteristiky, které by mohly určit míru jejich závažnosti. Nelze hovořit o rychlosti či vzájemnosti plynutí, jelikož situace zasahuje pouze studenta. Intenzita (i polarita) jejího vnímání takové situace studentem se ukazuje být proměnlivá:

Karel: ... že přijdu ráno do školy, mám učit jednu hodinu, nebudu učit jednu hodinu, ale čtyři. Prostě ten moment, že vím, že nejsem připravený a stejně to musím jít nějak odučit. Nebo tam něco jít dělat do té tř́́dy, tak to bych řekl, že to pro mě osobně začalo, ta nepř́ijemná situace ... A končilo to, končilo to tím, že se z té nepř́íjemné situace vlastně stala př́ijemná, protože jsem to nějakým způsobem zvládl. (2. rozhovor)

Situace tohoto typu se objevovaly v empirických datech výjimečně a všechny vznikly náhle.

\subsubsection{Př́jemné neočekávané situace}

Některé neočekávané situace hodnotili studenti jako př́ijemné. Nevyjadřovali se o nich však př́liš podrobně, a tak je obtížné takové situace blíže charakterizovat. Situace, které byly reflektovány, vznikly pokaždé prrímo v hodině. Praktikující student byl překvapen průběhem plynutí, jehož rychlost byla ještě ideálnější a vzájemnost ještě vyšší, než původně očekával. Není však zřejmě, zda takovou situaci vnímaly jako neočekávanou i ostatní zúčastněné osoby, tedy žáci.

Výzkumník: Dneska mě zajímá, jestli jste se setkala na vaší praxi s něčím neočekávaným pro vás.

Beáta: Oni byli strašně hodní. Ony, vlastně to byly skoro samé dívky, a jsem to ani nečekala, že budou tak strašně hodný, jakože celou dobu dávaly pozor, dokonce se vyptávaly a tak. (2. rozhovor) 
Reflektované př́ijemné neočekávané situace se mírně vyvíjely v čase (podle toho, jak se vyvíjela spolupráce mezi studentem a žáky v hodině).

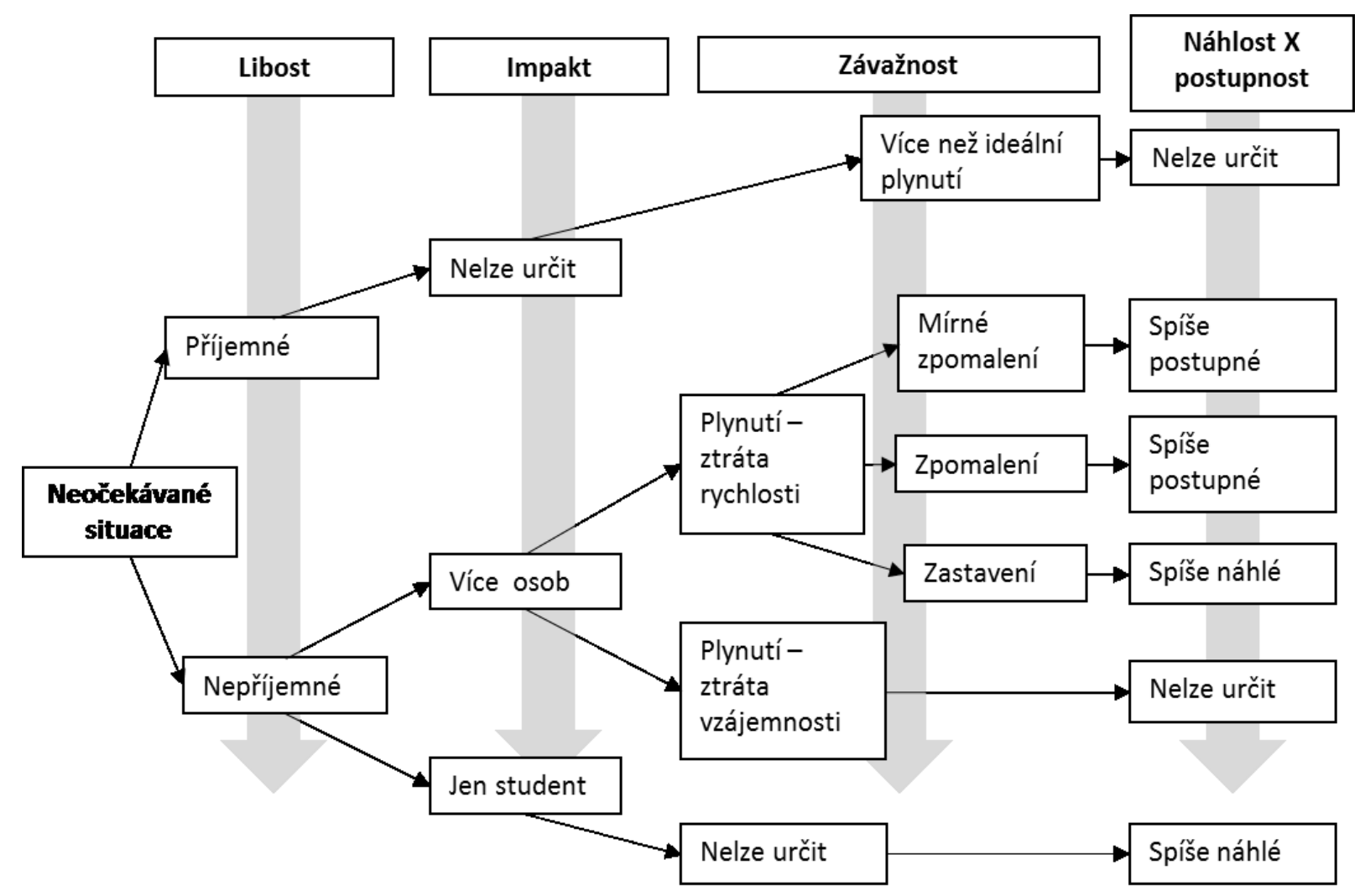

Obrázek 13. Znázornění klasifikace neočekávaných situací.

Libost, impakt a závažnost neočekávané situace jsou vzájemně provázány. Studenti nejdetailněji reflektovali situace nepř́ijemné, které zasáhly více osob a při kterých došlo ke zpomalení rychlosti plynutí. Těchto neočekávaných situací bylo vempirických datech nejvíce, což nám umožnilo určit jejich závažnost podle míry zpomalení (mírné zpomalení, zpomalení, zastavení plynutí). Pro tyto situace platí, že pokud vzrostl jejich impakt, vzrostla rovněž jejich závažnost. Zpomalení, zrychlení či ztráta kontroly nad směrem plynutí hodiny souvisely se ztrátou vzájemnosti plynutí. Studenti však ztrátu vzájemnosti nereflektovali tolik jako ztrátu rychlosti, proto je obtížné vzájemnost plynutí blíže charakterizovat. Podobně nebyly př́liš často reflektovány nepř́ijemné neočekávané situace, které zasáhly pouze studenta, nebyly př́liš početné. Nejméně pak můžeme na základě sesbíraných dat charakterizovat př́ijemné neočekávané situace, ke kterým docházelo zřídka (anebo studenti neměli potřebu se $\mathrm{k}$ nim vyjadřovat). 
Jako poslední z charakteristik neočekávaných situací jsme na začátku své typologie uvedli náhlost versus postupnost jejich vzniku. U reflektovaných situací nebyla zjištěna větší provázanost jejich náhlosti či postupnosti se třemi výše zmíněnými charakteristikami. Můžeme pouze konstatovat, že nepř́ijemné neočekávané situace zasahující více osob, při nichž dochází ke zpomalení plynutí, se vyvíjejí zpravidla postupně, zatímco situace, při nichž je plynutí zcela zastaveno, se objevují spíše náhle. Nepříjemné neočekávané situace zasahující pouze studenta jsou většinou také náhlé. Naopak př́ijemné neočekávané situace, které byly reflektovány, vykazovaly určitý postupný vývoje v čase, bylo jich však málo na to, abychom z nich mohli činit závěry.

\subsection{Diskuse k typologii neočekávaných situací}

Každodenní život je rozdělen na oblasti, k nimž jedinec přistupuje mechanicky, a na oblasti, v nichž se setkává s určitým typem problémů. Oblasti, ve kterých má jedinec hluboké znalosti, jsou pro něj rutinní záležitostí. Okolnosti však jedince nutí vstupovat do oblastí nových či problematických (Berger \& Luckmann, 1999, s. 29-30). Situace, se kterými se student učitelství setkává během své pedagogické praxe, pro něj právě takovou novou a neprobádanou oblastí jsou. Student se poprvé setkává $\mathrm{v}$ roli učitele $\mathrm{s}$ realitou školy a musí čelit skutečnostem, se kterými většinou neměl předchozí zkušenost. Na základě reflexí studentů jsme sestavili typologii neočekávaných situací, přričemž nám nešlo o nalezení „objektivní pravdy”, ale o interpretaci jejich „tady a ted” zkušenosti.

Jako nejvýznamnější charakteristiky neočekávaných situací se ukazují být jejich libost, impakt a závažnost. U nepř́ijemných neočekávaných situací zasahujících více osob rostla závažnost zároveň s rostoucím impaktem, přičemž míru závažnosti jsme určovali na základě míry narušení rychlosti a vzájemnosti plynutí, kterou studenti reflektovali. Metafora plynutí může být dána do souvislosti s termínem pacing (Janík et al., 2013, s. 110-115).

Termín pacing je překládán jako přiměřené tempo, tj. „,[frekvence] s níž během výuky dochází ke střridání učebních činností žáků a výukových aktivit učitele” (Janík et al., 2013, s. 113). Spolu s využitím času a strukturovaností je pacing považován za jednu z důležitých komponent pro určení kvality organizace a řízení třídy (Janík et al., 2013, s. 110). Studenti důležitost této komponenty „cíti”” či ji určitým způsobem vnímají, nedokáží ji však přesně vyjádřit ani ji oddělit od ostatních komponent organizace a řízení třídy. Zřejmě proto uživají 
metaforu plynutí, která v sobě však zahrnuje i využití času, strukturovanost a zřejmě i jiné komponenty v závislosti na povaze konkrétní neočekávané situace.

Zajímavá je rovněž existence meze akceptovatelnosti, na základě které studenti rozlišují závažnost nepř́ijemných neočekávaných situací (kdy jsou rychlost a vzájemnost plynutí ještě akceptovatelné, a kdy už ne). Mez akceptovatelnosti studenti obtížně charakterizují, v jejich výpovědích se objevují pauzy, definice kruhem či metaforická vyjádření, což nasvědčuje tomu, že mez (a její nastavení) je výrazně tacitní.

Sporadicky se vyskytující nepř́ijemné neočekávané situace zasahující pouze studenta nevykazují provázanost mezi impaktem a závažností, jako tomu bylo u situací zasahující více osob. Impakt situací zasahujících pouze studenta je samozřejmě nízký, ale vnímání situace studentem se ukázalo být proměnlivé - student např́íklad nejprve situaci vnímal intenzivně negativně, poté se s ní smíril, a nakonec reflektoval, že situace se stala př́ijemnou. Mưžeme tedy usuzovat, že student se s neočekávanou situací relativně dobře vyrovnává, pokud je její impakt malý - situace nezasahuje další osoby a veškeré vypořádání se s ní je závislé pouze na studentovi, nikoli na dalších osobách.

Velmi málo byly reflektovány př́ijemné neočekávané situace. Nemusí to nutně znamenat, že by $\mathrm{k}$ př́ijemným neočekávaným situacím během praxe studentů nedocházelo. Domníváme se, že studenti spíše neměli potřebu takové situace reflektovat - jejich hodina plynula více než ideálně, vzájemnost byla vyšší, než očekávali, a rychlost přiměřenější. O skutečnosti, že studenti neměli potřebu př́ijemné situace reflektovat, svědčí i kvalita dat, která je v porovnání s daty o nepř́ijemných neočekávaných situacích nižší (co do hloubky úvah, použitých metafor atd.).

Minimální souvislost byla nalezena mezi typem neočekávané situace a další poslední charakteristikou (náhlostí versus postupností). Je sice pravda, že všechny reflektované př́jemné neočekávané situace vznikly na základě velmi dobře se vyvíjející spolupráce žáků, při dlouhodobějším zkoumání a dlouhodobější praxi studentů ve škole, bychom však jistě objevili prř́jemné neočekávané situace vzniklé náhle (a jejich další podtypy). Zajímavé může být i zjištění, že nejvíce závažné nepř́ijemné neočekávané situace vznikaly především náhle (zdravotní kolaps žáka, odchod žáka z kroužku bez vědomí studenta atd.) Ukazuje to, že 
většina nepř́ijemných neočekávaných situací byla vyřešena dřive, než došlo k úplnému zastavení plynutí hodiny. O řešení neočekávaných situací pojednáme následně. 


\subsection{3 Řešení neočekávaných situací}

Setkání s neočekávanou situací a její řešení je proces, který se často odehrává velmi rychle, aniž by si participanti uvědomovali všechny jejich části. Při vedení našich retrospektivních hloubkových rozhovorů založených na čistém jazyce jsme tak postupně rozkrývali jednotlivé fáze celé sekvence „,o se děje, když se setkávám s neočekávanou situací“. Ve většině případů díky tomu u účastníků výzkumu docházelo $\mathrm{k}$ zvědomování některých dílčích částí (fází) řešení neočekávaných situací, které měli předtím skryté. Ve výsledku se před námi vykresluje „barvitý” systém nejrůznějších stimulů, reakcí a strategií, které toto řešení ovlivňují. Přri určité míře redukce můžeme tento systém znázornit obrázkem 14 . V dalších podkapitolách postupně rozebereme jednotlivé fáze diagramu.

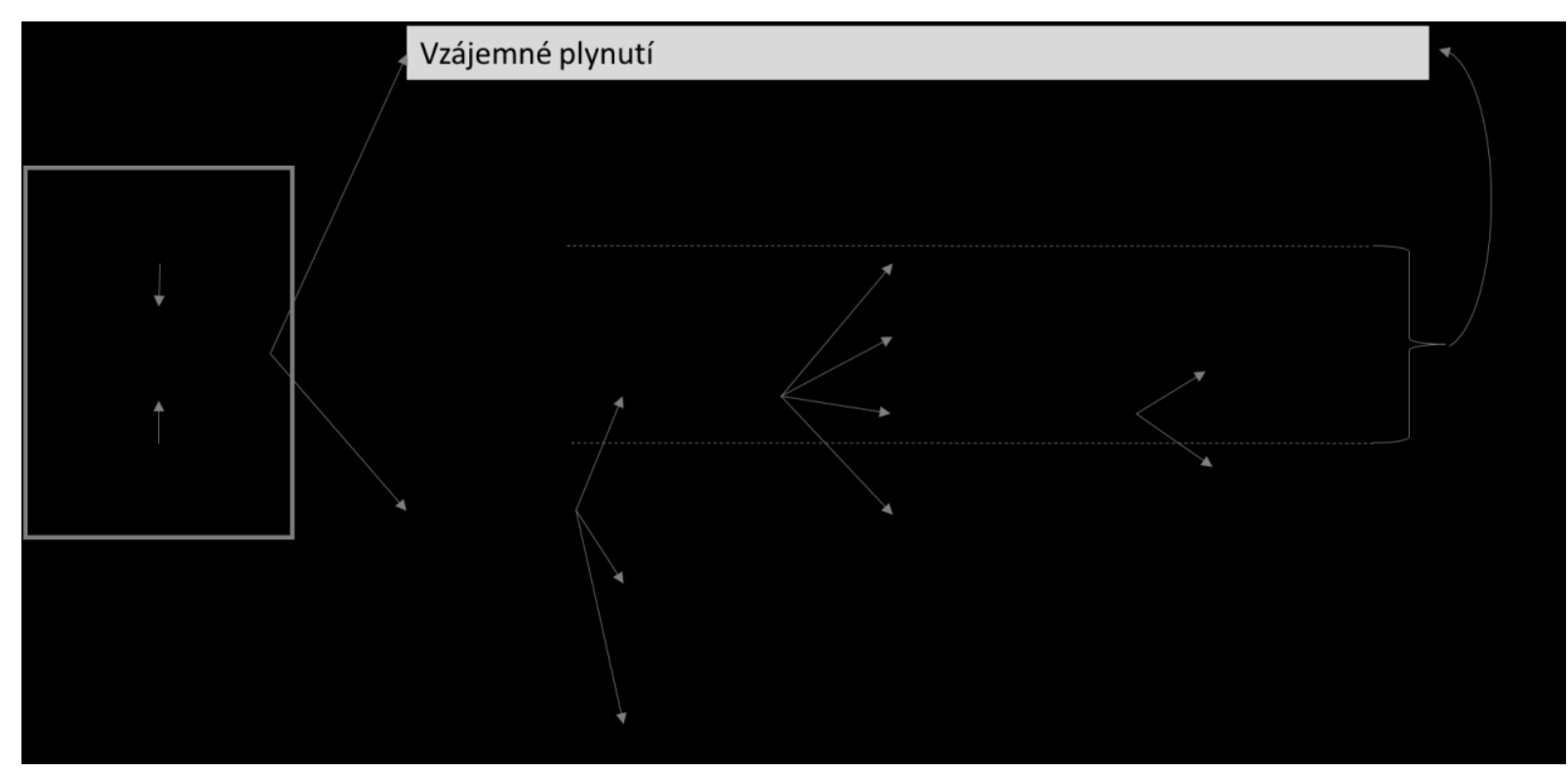

Obrázek 14. Obecný diagram řešení neočekávaných situací.

\subsection{Okolnosti vzniku neočekávané situace}

Může se zdát, že se často na vzniku neočekávané situace podílejí nějaké vnější nebo vnitřní podmínky, které student nečeká. Vnější podmínky mohou být spojené (a) s osobou: např́íklad tlak ze strany zástupce ředitele (Karel); žák vyhrožuje druhému žákovi (Jaroslava); agresivní žák (Jaroslava); (b) s materiálními podmínkami, kdy například chybí pomůcky (Cyril). Vedle toho jsou pro vznik neočekávané situace důležité vnitřni podmínky, které jsou např́íklad spojené s (a) očekáváním, jež se nenaplní: připravený plán selže (Františka), nebo se týká (b) 
obsahové neznalosti látky (vypadne nějaká znalost) či (c) neznalosti didaktické transformace obsahu, kdy student učitelství nezná určitý postup (Dana). Přesto nejsou neočekávané situace spuštěny jen vnitřním nebo vnějším podnětem, ale většinou jde o interakci vnějšího a vnitřniho nastavení, která teprve pak přivede studenta učitelství do neočekávané situace. Je pochopitelné, že může existovat různá míra zapojení těchto faktorů či nastavení. Nejzřetelněji je vidět, že neočekávaná situace nastává jako interakce, na př́ikladu, kdy informantka Jaroslava nezná odpověd’ na otázku. Teprve tím, že otázka (která je z tohoto pohledu metaforicky řečeno „klíčem” - viz kapitolu 1.2) „zapadne do zámku“ (tamtéž), kterým je zjištění (po prozkoumání toho, co si pamatuji), že neznám odpověd' na tuto otázku, to studentku přivádí do neočekávané situace.

Jedním z důležitých atributů neočekávaných situací je, že existuje určitá škála, do jaké míry je situace neočekávaná. Jak říká Alena: „Všechny situace jsou neočekávané“, ale liší se v miřre: ,je fakt rozdíl v tom, v té neočekávané situaci, že bude rozdíl, když mně nefunguje technika a vlastně nemůžu dělat to, co chci, anebo když nebudu zvládat žáky a třeba na mě bude mírit pistoli'“. (5. rozhovor)

Tyto okolnosti pak mají důležitý dopad na proces výuky, kdy bud’ dochází ke ztrátě rychlosti plynutí a následně $\mathrm{k}$ zaseknutí a zastavení výuky či ztrátě vzájemného vztahu student učitelství a žáci nebo se studentovi podaří navrátit se k vzájemnému plynutí vyučovacího žáka a studenta učitelství.

\subsection{Bezprostřední reakce na neočekávanou situaci}

Pokud je student učitelství vystaven neočekávané situaci, pak následuje bezprostřední reakce, která je často okamžitá a často automatická. Při neočekávané situaci se dostavuje reakce „Zaseknutí“, pokud situace není neočekávaná, tak situace dál plyne a informanti ji označují jako vzájemné plynutí (podrobněji viz podkapitolu 8.5.1).

\section{Vzájemné plynutí}

Pokud situace není závažná nebo není neočekávaná, tak pro tento proces informanti používají metaforu „plynutí“ či „plynulého pohybu“. Znamená to, „že to, že to, že se nestalo nic, nic zvláštního, nic, žádnej jako, nevím incident [...] nebo [...] prostě, žáci jenom, ehm, [...] 
pracovali v té hodině, co měli, a, a nic, ani““(Dana, 2. rozhovor). Téma plynulosti výuky se objevovalo i ve v neverbálních projevech studentů:

„ta klasická hodina, která jede takhle \{rukou ukazuje rychlý plynulý pohyb\}, jo, která třeba, neřeknu, jako když mám připravenou hodinu a odjede to prostě skvěle, že spolupracujou.“(Ema, 3. rozhovor).

Plynutí je tak spojené s tím, že vše jde tak, jak má a není v hodině žádný zádrhel, který by ji narušil at' po stránce kázeňské, obsahové nebo jakékoliv jiné. Studenti reflektují, že jde o nějaké kontinuum toho, jak moc je hodina plynulá nebo není, zda se „zpomaluje“, tím, že ji někdo narušuje: ,ale představovala bych si ten výklad aby \{úsměv\}, aby byl třeba trošičku plynulejší'“ (Dana, 4. rozhovor).

Cyril proces plynutí naznačuje na grafu, který nakreslil na základě své vlastní výpovědi. Jednotlivé čáry naznačují míru vyrušení a nejistoty u různých žáků.



Obrázek 15. Míra narušení a nejistoty (zdroj: Cyril - 2. rozhovor).

Zajímavý je na grafu i směr dolů a nahoru. Směr nahoru znázorňuje vzrůstající narušení hodiny a směr dolů odkazuje k zmírnění narušení hodiny a uklidnění. Stejně tak i Karel neverbálně naznačuje, že jistota je u země, kdy se z toho stává taková výuková situace, kterou 
si přeje a pojmenovává ji „dobrá cesta“ (5. rozhovor). Tyto „vtělené““ aspekty znalosti si však participanti neuvědomují a můžeme na ně nahlížet spíše jako na (pro jejich vnímání) skryté.

Pokud se situace komplikuje - je více neočekávaná, než jak ji student odhadl - pak kromě metafory „zpomalování“ používá i jinou metaforu, která je spojena se stoupající nebo klesající teplotou. Studenti naznačuji, že pokud se hodina „zpomaluje“, tak dochází k stoupání nebo klesání teploty, např́klad ve spojitosti s metaforou „,vření“:

Karel: Já se vždycky vystresuju v takové chvíli, protože ... já mám rád věci, které jsou naplánované ... když ne úplně tak aspoň z části, aby, a já si myslím, že ta výuka nejde naplánovat pro toho, pro toho, což mě taky trochu stresuje, ale, ale tak jako \{krčí rameny\} když, když, ale vřelo to ve mně, že jo? Věděl jsem, že tu první hodinu zvládnu tak jak tak, ale...

Výzkumník: Co to bylo za vření?

Karel: (pauza čtyři sekundy) Tak to souvisí s tím, že ... (pauza čtyři sekundy); \{gestikulace rukama\} a ted’ že jsem nevěděl, jestli tam přijde, nebo nepřijde, jestli ... se stihnem nějak domluvit, nestihnem se nějak domluvit ... pokrčí rameny\}. Já jsem učil poprvé, takže jsem jako neměl žádnou zkušenost ... ehm, což by docela dost často uklidnilo, protože, když někomu ukážu, že mám dobrou přípravu. (2. rozhovor)

Nebo naopak nejde o zvyšování teploty, ale o snižování teploty, když student zaživá neočekávanou situaci: ,je to takový to nepř́ijemně zamrznutí ... spirály [tím označuje své kognitivní a emoční schopnosti], že se jakoby možná trochu zpomalí a ta energie se zmenší, že jde jakoby směrem dovnitř a zase zpět” (Alena, 5. rozhovor).

Tyto metafory teploty odkazují například na tradiční konceptuální metaforu: „hněv je jako horko“ a „strach je jako zamrznutí“ (Aitchison, 2012). Gibbs a Berg (1999) poukazují na to, že stres je spojen s metaforou zahřátí a navrhují, že hněvu můžeme porozumět skrze kombinaci zadržení stresu a tedy zadržení teploty. Zadržení je tedy zpomalením procesu výuky a je asociováno s teplotou. U informantů se explicitně neobjevuje hněv, ale rozčílení, stejně tak zamrznutí není explicitně spojováno se strachem, ale maximálně s obavami. $Z$ toho je možné také vyvodit, že pokud hodina plyne, tak metaforicky řečeno má „optimální teplotu“, kdy nedochází k opaření ani k zamrznutí. Tento mechanismus je tak velmi podobný $\mathrm{i}$ mechanismu zobrazenému v obrázku 12. Pokud však je situace natolik neočekávaná nebo se postupně stane neočekávanou, natolik závažnou, že najednou tato závažnost překvapí (viz typ postupně vznikající typ neočekávané situace), pak dojde k tomu, že hodina neplyne a stane se bud' to, že se student zasekne (zamrznutí, opaření). 


\section{Zaseknutí}

„Zaseknutî“ je ústřední kategorie bezprostřední reakce na neočekávanou situaci. Ukazuje se, že je to důležitý invariant (ve smyslu neměnného základu neočekávané situace), který je spojený se všemi neočekávanými situacemi. Účastníci výzkumu o něm daleko více hovořili než např́íklad o kategorii „překvapeni““. Pokud tedy nastane neočekávaná situace, vždy u studenta učitelství dojde k ve větší či menší miřre k zaseknutí. Dochází k tomu při překročení určité míry intenzity neočekávané situace, se student dostává do stavu, který popisuje jako „zaseknutí“:

„Tak, hm, většinou jde hrozně dobře vidět, že se ten člověk nějak zasek, že ho něco rozhodilo a ti žáci se toho strašně rádi chytnou, když ... ten učitel znejistí nebo se dostane do nějaký trapný situace, že mají najednou proti němu nějakou zbraň. "(Cyril, 2. rozhovor)

Cyril tak přichází se svojí další metaforou - zbraň. To asociuje, že celá situace je vlastně ohrožující. Přitom Beáta spojuje tento proces se zpomalováním plynutí své výuky: „Protože třeba zbytek té skladby mám ráda a to je ten jediný moment (zesílí hlas a gestikuluje), kdy se tam zaseknu a jinak už bych ji třeba zahrála v pohodě a tady na tom se zbrzdím.“ (Beáta, 4. rozhovor) Zaseknutí tak dokonce odkazuje na proces ztráty pohybu v dané situaci. Zaseknutí může mít jiné metaforické podoby, jednou z nich je např́íklad ,zamrznutí‘“:

„Před tím zamrznutím, že to je vždycky nějakej stimul a potom dojde $\mathrm{k}$ tomu zamrznutí, prostě něco se stane, ten stimul může být jak facka, nevím, nevím, něco se stane, já zamrznu a ted'ka fakt člověk přemýšlí, nebo prostě pocitově vnímá, co se s ním děje a ted' jako: kam dál půjdu.“(Alena, 5. rozhovor)

Alena má metafory zamrznutí a zaseknutí na podobné úrovni: „potom, jak je člověk zamrznutej zaseknutej, tak asi spíš potom ta energie jde dovnitř nebo víc tak jako má tendenci se chránit nebo tak jako už už ti není taková jako otevřená náruč“ (Alena, 5. rozhovor). Stejně tak zaseknutí Alena spojuje i s druhou stranou teplotního extrému, kterou je metafora „opaření“.

Alena: V té neočekávané situaci, že bude rozdíl, když mně nefunguje technika, a vlastně nemůžu dělat to, co chci, anebo když nebudu zvládat žáky a třeba na mě bude míriit pistolí. A vlastně to se tak taky trošku projeví. Ale určitě nějakej podobný mechanismus tam máš vždycky, vždycky je tam nějaký to zaseknutí, opaření, nevím, nějakej šok a potom rychle teda jak reagovat na tu situaci. (5. rozhovor)

Obě metafory tak odkazují k bezprostřední reakci zaseknutí v reakci na neočekávanou situaci. Student učitelství se tak ocitne v náhlé situaci, kdy neví, co má dělat, je zmaten a jeho pozornost se postupně začne směrovat k nějakému řešení či zůstane paralyzován. 


\subsection{Strategie řešení neočekávané situace}

Různé strategie řešení se tak pohybují od plynutí až k zaseknutí. Obecně řečeno studenti rozlišují řešení neočekávané situace na škále od pasivního nicnedělání k aktivnímu jednání. Např́klad Alena (2. a 5. rozhovor) nejlépe popisuje tuto škálu možností, kdy aktivní stav asociuje s metaforou: „,vytěžit, nebo jestli se to fakt po tom nějak zmátoří, a vytěžím z toho to, co se má, z té situace“, přes zaplácnutí, kdy je snaha chytit se nějaké poslední možnosti, metaforicky to označuje „stéblem“ až po pasivní řešení, kterým je „nechat to volně plynout“. Na této škále jsme z dat identifikovali čtyři základní strategie, které studenti používají při zvládání neočekávané situace: 1) navrácení k plynuti; 2) útok jako způsob řešení zaseknutí; 3) ústup a opora $v$ autoritě jako strategie řešení zaseknutí; 4) přetrpění. V následující části podrobně popíšeme každou z nich.

\section{První strategie: navrácení se k plynutí}

Pokud situace nepřekročí určitou míru neočekávanosti (přesto ji studenti vidí jako neočekávanou) nebo je neočekávaná, ale student situaci zvládne, pak se navrací celý proces k ideálnímu plynutí (viz Dana, 2. rozhovor; Alena, 2. rozhovor). „Přenesu se přes neočekávanou situaci a v podstatě jakoby nic se neděje, nijak to nemá velkej dopad na, na, na tu hodinu... přenesu, jdu dál.“ (Alena, 5. rozhovor)

Nebo je hodina touto situací ovlivněna a jde ,jiným směrem“. Alena např́iklad redefinuje výukový cíl hodiny: „další možnost je, že teda zjistíš, že to teda nepůjde tím směrem, kterým si chtěl, ale jako furt to někam, má nějakou dynamiku, furt to někam směřuje“" (tamtéž). Snaží se pak nacházet další možnosti, kam situace může ústit „hledá“ je a zároveň ji „nechává volně plynout" (Františka, 2. rozhovor).

Přenesení přes situaci se děje například tím, že student ,jde směrem k žákům“ (Alena, 2. rozhovor). Má tendenci je znovu kontaktovat, aby zjistil, kde žáci momentálně jsou a co se děje. To nás přivádí $\mathrm{k}$ tomu, že se student učitelství díky přiblížení snaží o znovunavázání vzájemného plynutí vyučovacího procesu. Někdy je toho schopen okamžitě, a někdy musí neočekávanou situaci ,rozchodit“. $\mathrm{K}$ tomu nejčastěji používá různé somatické techniky jako je např́íklad rozdýchání a ulevení si hlasem. Rozdýchání znamená „sebeovládání,, což vede k uklidnění sebe sama: „To je uklidnění. To tak je, když člověk začne zhluboka dýchat, tak se 
uklidní, no, někdo dýchá, někdo potřebuje si zapálit a dýchat skrz tu cigaretu pomalu, anebo naopak, když se potřebuje vyhecovat, tak zase rychle prostě šlukuje, no tak.“ (Alena, 4. rozhovor)

Jde o typický př́íklad techniky při zvládání stresu. Nabízí se interpretace, že dojde-li k neočekávané situaci, která „opaři“‘, pak dochází k přerušení normálního cyklu dechu a po jeho vyřešení se opět skrze rozdýchání dostává do svého přrirozeného dechového cyklu. Nebo použije techniku, že si uleví hlasem: „No, já konkrétně si třeba v tu danou chvíli ulevím i hlasem jako jo, třeba.“ Což v případě Aleny znamená například zvýšení hlasu.

Alena (jak uvádí v 5. rozhovoru) má tyto techniky nejvíce propracované, ale přesto je zde podle ní určitý náznak (projev) tacitnosti. Techniky totiž používá na základě toho, že jí přijde určitý vnitřní ,impuls ze srdce“ (z kontextu jde o emoce) nebo z „hlavy“ (rozumová stránka osobnosti). V ideálním prrípadě se tak děje z obojího a jde o spojení ,jin jang, jak ten rozum, tak to srdce“. Což je pro ni „ideální energie, ideální prostě všechno, ideální stav bytí, vychování“. Aktuální strategie pro ni slouží k úlevě a k možnosti znovu směřovat svou „energii k žákům“. To, zda situaci dokáže řešit, nebo ne, závisí na tom, do jaké míry dokáže reflektovat $\mathrm{v}$ akci a jakou má zásobu možných řešení z minulosti (generativních modelů).

\section{Druhá strategie: útok jako způsob řešení zaseknutí}

Útok je reakce na neočekávanou situaci, která nastává v souhře podnětů od druhé osoby (žáků a/nebo kolegů) nebo i materiálních podmínek. Kdy se energie studenta učitelství obrátí bez seberegulačního mechanismu rovnou na žáka, to můžeme klasifikovat jako metaforicky řečeno „útok“. Jde o to, že studentova energie má př́liš velkou rychlost a směřuje přímo proti žákům nebo žákovi:

Jaroslava: Po dobrém to nejde, neudržím se ... žák v hodině vyhrožuje slabšímu, že ho napadne po škole. Zařvu, nic neplánuji, je to bezprostřední. Dítě zůstane v transu a já mám tak možnost to řešit ... Reaguji jako časovaná bomba. Valím do něj to svoje. Mám rudo, ve třídě je ticho, že by bylo slyšet špendlík. Chlapec má slzy $\mathrm{v}$ očích, už to nikdy neudělá, už nikdy nechce mít takový pocit. (2. rozhovor)

Jedná se taktéž o bezprostřední reakci „nic neplánuji“, je to spontánní. Podobně popisuje obdobnou situaci i Ema, která svou reakci spojuje přímo se svým tělem: „mluvilo za mě jenom tělo, protože z ničeho nic spolužák dal pěstí spolužákovi v hodině ... protože já jsem 
teda okamžitě zakřičela, že co to mělo znamenat“ (3. rozhovor). „Časovaná bomba“ u Jaroslavy odpovídá kontextu metafory „útoku“. Je zajímavé, že tímto př́stupem vytváŕí nečekanou situaci pro žáka, kdy ,zůstane v transu“, což bychom mohli klasifikovat jako žákovo ,zaseknutí“. Z kontextu úryvku můžeme vyvodit i rozčílení studentky učitelství směřující k žákovi, kdy je zajímavé, že toto rozčílení je i podle Cacciari, Massironi, \& Corradini (2004) často právě asociováno s červenou barvou - „rudo“.

Nejde jen o neočekávané situace, které jsou vyvolané interakcí mezi žáky, ale i v př́ípadě, kdy se cítí být ohrožený samotný student učitel, například položením otázek, na které neumí odpovědět, tak může zaútočit, protože nedokáže řešit situaci jiným způsobem a útok mu naskočí jako první možnost řešení (jde o generativní model, který má při ruce ze své zkušenosti):

Jaroslava: A ... ty děcka mi najednou začaly ř́ikat, že to nechápou a že před tím jsem říkala tohle, ted říkám tohle a já jsem na to reagovala tak, že, ehm, jo, to jsem vám říkala, ale ted'ka už mluvím o nějakých výjimkách to už máme v pokročilejší, a já jsem se do nich snažila jakoby navalit tolik informací a ted'ka oni tím, že se mě vyptávali, tak to ve mně spíš jako vzbudilo takovou tu nevoli, že \{chytne se za hlavu\} ... jaktože oni to nechápou, když já to tak perfektně vykládám a ... já jsem třeba měla, já jsem se rozčílila, ale jako ne až úplně nějak extrémně, v podstatě jsem jim vynadala za to, že oni nedávají pozor ... a až potom vlastně později při těch dalších a dalších hodinách jsem zjistila, že ta chyba byla opravdu na mé straně. (2. rozhovor)

\section{Třetí strategie: ústup a opora v autoritě jako řešení zaseknutí}

Ústupem se student učitelství stahuje do pozadí a nechá žáky nebo vnější podmínky, aby v daný moment udali směr výuky. Student učitelství tak s nimi nejde do momentálního konfliktu - útoku, ale jeho okamžitá reakce spočívá v ustoupení, necítí se být zmocněn k tomu situaci měnit. Jde tak o typ ústupu nikoli „,k někomu“, ale „před někým““.

Jaroslava: Učitel, ehm ... On s nimi měl první hodinu přírodopis, že jim řekl \{gestikuluje rukama\}, že s námi taky nic nedělal. A že-že se mnou budou moct třeba jít hrát fotbal. Tak jsem si říkala, no, tak jako nevím, co si tady teda domluvili, tak jsem říkala, kluci, tak vydržte chvilku. Já se zajdu ho zeptat, jak to teda je. A on mi ř́kal, no, oni-oni ř́kali, že chcou jít hrát fotbal, tak já se zajdu zeptat, ehm, k zástupkyni nebo do ředitelny jestli-jestli ehm, můžete jít ven. No, tak já jsem stála a říkám, no tak dobře. Tak přišel, že teda ven můžeme hrát jít ten fotbal, a že jim mám dělat dozor. \{gestikuluje rukama\} A já jsem tam stála na té chodbě a říkám, no, to je super, tak hlavně, že jsem si dělala přípravu. To jsem mu ještě hnedka ř́kala, že kdybych to věděla, tak že jsem si mohla ušetřit jako půlku neděle. \{gestikuluje rukama\} ... No. Protože já jsem fakt byla $z$ toho strašně jako zklamaná, že-že zbytečně se na něco připravuju a chystám. (3. rozhovor) 
Jiná podoba ústupu je i reálné opuštění prostoru třídy, ústup „,k někomu“. Situace se stala natolik neúnosnou, že ji napadalo jediné řešení, kterým je „ústup do ředitelny“. Studentka nemá již moc nad tím, co se děje ve tř́dě a její mysl přichází s jediným možným generativním modelem, který může tuto situaci vyřešit:

Alena: Oni ti [žáci] už byli tak jako rozjetí a úplně jako vopičáci skákali nahoru dolů a prostě řvali a ted' prostě já jsem tam byla takovej malej človíček mezi nima, mezi tím stádem prostě těch divokých zvírat, a tak jsem prostě fakt se snažila dvacet minut s tím něco dělat a když to prostě nešlo tak ... jsem prostě šla za panem ředitelem ... a tak bylo nějaký: bu bu bu, více méně se to už potom zklidnilo. (4. rozhovor)

Z pohledu kategorizace se jedná o postupně vznikající neočekávanou situaci „snažila jsem se dvacet minut s tím něco dělat“", která vrcholí opuštěním třídy a rezignací na řešení vlastními silami: ,jsem prostě šla za panem ředitelem“ (tamtéž). Použije to, co zná ze své osobní zkušenosti, kdy byla ještě žákem ve škole (odvolat se na ředitele).

\section{Čtvrtá strategie: přetrpění}

V podstatě se jedná o strategii, která nevede k navrácení se k vzájemnému plynutí v hodině, ale k jinému typu plynutí, které je charakteristické dominancí studenta učitelství a jeho kontrolou nad situací bez aktivního zapojení žáků:

Ale tady v podstatě, když už se zhroutí všechny plány, tak už, no, dobrý, tak to necháme volně plynout a uvidíme, co vznikne, ale tady, tady je to jiný, no. ... ono potom už nic jako nezbývá, ale spíš, že tady jsem měla jako daleko větší, jakoby pevnou strukturu toho, co jsem chtěla dělat. (Alena, 5. rozhovor)

Pro Alenu toto volné plynutí není příjemné a označuje jej slovem ,přetrpět“, protože z jejího pohledu žáci nemají zájem o vzájemné plynutí vyučovacího procesu: „to je ta poslední [možnost], že v podstatě už jenom, já nevím, jestli částečně zůstaneš jako - asi né opařenej už né, že prostě se to snažíš přetrpět“" (tamtéž). Směr dovnitř evokuje, že se její energie hromadí v ní a bud' ji dokáže zpracovat, nebo ne, a pak musí hodinu „dle svých slov „přetrpět“، Toto „opaření“ je počáteční (jiné označení pro zaseknutí), který v tomto způsobu reakce na neočekávanou situaci ústí do přetrpění a dlouho trvajícího zaseknutí: ,jsem se zasekla, řekla jsem si, že ne a celou hodinu jsem jim diktovala věty na překlad““.

$\mathrm{V}$ př́ípadě diktování vět na překlad jde o mechanickou, respektive tělesnou činnost, která nevyžaduje př́lišné zapojení kognice. Řešení je tak v oblasti automatizace, s níž nemá student učitelství žádný energetický výdaj, zatímco žáci ano, jedná se tak o „,volné plynutíc“. 


\subsection{Diskuze ke strategiím řešení neočekávaných situací}

Obecně by nás popis předchozích bezprostředních reakcí mohl přivést k mínění, že jsou velmi podobné jako základní strategie přežití u organismů, které popsal Cannon (1915): boj, útěk, zamrznutí (fight, flight, freeze response). Ale v tomto srovnání je potřeba být velmi obezřetní, protože stejně jako Cannon, tak i my používáme toto označení metaforicky. Například „Zamrznutí“ v Cannonově pojetí odpovídá tomu, čemu dle Bracha (2004) psychologové říkají hypervigilance. Z pohledu Porgese (2009) jsou tyto základní reakce organismu na nadměrný stres, hierarchicky uspořádané. Pokud vše v hodině „plyne“, daří se komunikace ve třídě a cítíme se bezpečně, pak je dle Porgese (2009) aktivní náš systém sociálního zapojení (social engagement system, SES), o který se stará parasympatikus. Pokud vycítíme ohrožení, organismus dle Porgese (tamtéž) reaguje mobilizací, za kterou je odpovědný náš sympatikus (boj a útěk). Pokud dochází k ohrožení života, tak přebírá funkci znovu parasympatikus a u jedince nastává tonická imobilita - to, co se nazývá právě zamrznutí. Systém reakcí studenta učitelství je podobný, ale musíme si být vědomi, že v obou př́padech jde o metaforický popis: systém sociálního zapojení je aktivní - návrat k plynutí nebo vzájemné plynutí; útok; útěk ústup; zásek - přetrpění.

Zaseknutí, které by mohlo být chápáno jako zamrznutí ve smyslu, jak jej předkládá Cannon, je ústřední kategorií neočekávané situace. Zaseknutí může poskytnout studentovi učitelství čas, kdy je možné, aby proběhla reflexe vakci, pokud však emoce zablokují př́ístup přemýšlení (viz metaforu vření) a nedojde k jejich ošetření, pak není možné, aby se spustila reflexe v akci. Kategorie řešení označená jako útok je v naší interpretaci spojena s nevyzrálým postojem učitele ke zvládání neočekávané situace, v které hrají roli i emoce. Kategorie řešení označená jako útěk je jednou z nejzazších možností, kterou učitel volí, když ztrácí moc nad tř́́dou a obrací se na vnější autoritu, jež mu má moc znovu zajistit. Dochází tak však k míchání typů moci (srov. Vlčková et al., 2015).

V rozhovorech jsme nenašli verbální náznak toho, že by si studenti byli explicitně vědomi celé struktury procesu řešení neočekávaných situací, což odkazuje k určité míře její tacitnosti. Spíše nacházíme zmínky o tom, že si některých částí procesu student nebyl vědom: ,jo jo, to je ale spíšs ten proces toho \{gestikulace rukama\}, že jsem si to nikdy, jako tak konkrétně neuvědomoval, jo“. Je nutné říci, že verbální klíče jako ,jsem si vědom“, „nad tím jsem takto neuvažoval“" nezaručují to, že student tento fenomén nemá zvědoměn jen ve své „,vnitřní řeči“. 
Stejně tak studenti sami reflektují i obtíž artikulovatelnosti některých myšlenek a znalostí: „Já nevím třeba ... nedokázala jsem moc říct jako ty ... věci, co dělám, nebo proč si myslím...“. Což obojí odkazuje $\mathrm{k}$ námi dvěma zvoleným kritériím tacitních znalostí, obtížné artikulovatelnosti a obtížnému uvědomování si znalostí o svém procesu řešení neočekávaných situací.

\subsection{Závěr}

$\mathrm{V}$ rámci této kapitoly jsme $\mathrm{v}$ teoretické části analyzovali důležité koncepty týkající se neočekávaných situací. Následně jsme podali vlastní teoretickou definici neočekávané situace založenou na momentu překvapení jako „pro první osobu překvapující smysluplným segmentem lidské zkušenosti“ a poukázali jsme na souvislost s moderní teoretickou neurovědou (konkrétně se schématem prediktivního kódování). Z této perspektivy jsme pak přistupovali k analýze sesbíraných dat a vytvořili typologii neočekávaných situací sestavenou na základě čtyř základních charakteristik (kritérií členění): libosti, impaktu, závažnosti a náhlosti či postupnosti jejich vzniku. V rámci mikroanalýzy procesu řešení neočekávaných situací jsme předložili tezi o interakčním vzniku neočekávaných situací, na němž se podílejí vnější a vnitřní faktory. Ty následně vedou ke ztrátě rychlosti nebo ke změně směru vzájemného plynutí vyučovacího procesu mezi žákem a studentem učitelství. Za důležitý invariant považujeme stav, který informanti metaforicky označují jako „zaseknutí“ a který je v neočekávané situaci vždy př́itomen. Dále jsme identifikovali čtyři obecné strategie řešení zaseknutí: navrácení se k plynutí, útok, pretrpěni a ústup. Celkově jsme tak podrobněji popsali různé variace a stěžejní invarianty prožitku neočekávaných situací. 


\section{Jak se utvářejí tacitní znalosti studentky učitelství Jaroslavy v průběhu její učitelské praxe?}

\section{Vlastimil Švec}

Studenti učitelství vstupují v 1. ročníku navazujícího magisterského studia do učitelské praxe, která je významnou etapou v rozvoji jejich pedagogických zkušeností a znalostí. Vstupují do ní se svými očekáváními, svým pojetím výuky, ale i s určitými tacitními znalostmi. V průběhu učitelské praxe u nich tacitní znalosti dále krystalizují a utvárejí se tacitní znalosti nové. Jak $\mathrm{k}$ tomu dochází, se pokusíme nastínit $\mathrm{v}$ této kapitole na př́kladu studentky, kterou označujeme jako Jaroslavu. V době výzkumu (podzim 2014 až jaro 2015) byla studentkou 1. ročníku navazujícího magisterského studia učitelství př́rodopisu a chemie. Jaroslava již disponovala pedagogickými zkušenostmi $\mathrm{z}$ vedení mladších žáků $\mathrm{v}$ př́rodovědném kroužku. V době zahájení našeho výzkumu udávala, že se této zájmové aktivitě dětí věnuje již třetím rokem.

V této empirické kapitole budeme chápat tacitní znalosti (dále TZ) takto:

a) TZ jsou znalosti, které se utvářejí $\mathrm{v}$ interakci studenta učitelství s prostředím (např. prostředím školy);

b) TZ jsou součástí dynamického znalostního pole, v němž z didaktického hlediska rozlišujeme čtyři roviny, které jsou vzájemně provázané (viz Šíp, kapitola 1):

- rovina interakcí (např. interakce studenta učitelství se žáky, cvičným učitelem, kolegy),

- rovina tělesnosti (znalosti jsou nejenom $\mathrm{v}$ hlavě, ale také $\mathrm{v}$ těle poznávajícího jedince),

- rovina vnějšího světa (v němž existujeme a interagujeme s jeho objekty),

- rovinu mysli (rovinu poznatků);

c) jsou méně uvědomované, a tedy obtižňne artikulovatelné (převoditelné do slov), ${ }^{104}$

\footnotetext{
${ }^{104}$ Tyto parametry TZ vzali v úvahu Nehyba a Svojanovský (2016), kteří při výzkumu projevů TZ vymezují tyto znalosti jako „obtížně artikulovatelný a/nebo méně uvědomovaný aspekt zkušenosti, který se může projevovat v explicitní rovině, jednak v myšlení (např. ve způsobu usuzování, soudech, rozhodování), ale také v jednání, prožívání a souvisejících tělesných projevech (např. gesta, mimika, spontánní reakce).“ (Nehyba \& Svojanovský,
} 
d) projevují se v jednání studenta.

TZ se utvářejí a uplatňují v interakci jedince ( $v$ našem př́ípadě studentky Jaroslavy) s prostředím, v mysli se ukládají jako poznatky. TZ vznikají ze zkušeností, lze je považovat za části, studentem zpracovaných, zkušeností, a to i s využitím podpůrných intervencí cvičného učitele. Proces vnitřního zpracování části zkušenosti studentem probíhá skrytě, tacitně. Jeho výsledkem jsou TZ.

\subsection{Cíle a design výzkumu}

Cílem výzkumné sondy bylo zjistit, jak se utvářejí TZ studentky učitelství Jaroslavy v průběhu její učitelské praxe. Tento cíl jsme konkretizovali výzkumnými otázkami: Jak se pojetí výuky Jaroslavy promitá do procesu utváření jejích TZ? Co vypovídá řešení neočekávaných pedagogických situací Jaroslavou o jejích TZ?

Zvolili jsme design kvalitativního výzkumu, založený na těchto metodách: (a) pozorování jednání studentky Jaroslavy ve vyučovacích hodinách, zaznamenávaná do archu zcela volným způsobem (dle uvážení výzkumníka); (b) hloubkové rozhovory se studentkou Jaroslavou; (c) stimulované vybavování situací Jaroslavou s využitím videozáznamu její vyučovací hodiny.

Výzkum probíhal se studentkou Jaroslavou v akademickém roce 2014/2015 na Pedagogické fakultě MU. Analyzovány byly čtyři rozhovory.

1. První rozhovor zjišt'oval studentčino pojetí výuky chemie (2014, podzimní semestr).

2. Druhý rozhovor byl zaměřen na to, jak studentka řeší pedagogické (zejména neočekávané) situace (2014, podzimní semestr).

3. Třetí rozhovor navazoval na pozorování dvou vyučovacích hodin - chemie a př́rodopisu (2015, jarní semestr).

4. Čtvrtý rozhovor byl realizován jako stimulované vybavování situací, zachycených na videozáznamu (2015, jarní semestr).

Rozhovory (každý v délce př̌ibližně 90 minut) byly natáčeny videokamerou. Takto vzniklé videozáznamy byly přepsány do textové podoby a následně analyzovány. Analýza zahrnovala:

2016, s. 62). V této souvislosti upozorňujeme na novější zajímavou studii, jejímiž autory jsou Adloff, Gerund a Kaldewey (2015), kteří se pokusili odlišit „různě silné“ TZ. Uvádějí tzv. slabou formu TZ (která může být přinejmenším artikulována slovy) a silnou formu TZ (která se stává viditelnou a tedy artikulovatelnou v tělesných aktech). 
- opakované pročítání textů rozhovorů, rozdělení textů do segmentů, z nichž každý vyjadřoval - v souladu s výzkumnými otázkami - určitý význam; ${ }^{105}$

- hledání souvislostí mezi označenými segmenty (z hlediska času - podzimní a jarní semestr) a obsahové podobnosti a návaznosti;

- interpretaci souvislostí. ${ }^{106}$

\subsection{Výsledky výzkumu}

\subsubsection{Pojetí výuky Jaroslavy v procesu utváření jejích TZ}

Podobně jako autorky 8. kapitoly i my se opíráme o Marešovo (2013, s. 455) vymezení učitelova pojetí výuky, který jím rozumí „komplex pedagogických názorů, pedagogických postojů a učitelových argumentů, které je zdůvodňují. Tento komplex vytváří kognitivní i emoční základnu pro učitelovo uvažování o edukaci, pro hodnocení edukace a učitelova jednání se všemi aktéry edukačního procesu.“ Mareš (2013, s. 456) uvádí, že učitelovo pojetí výuky je, mimo jiné, subjektivní, implicitní a relativně neuvědomované. Je zřejmé, že svými znaky je podobné některým charakteristikám TZ, které jsme uvedli. Upozorňujeme však na to, že pojetí výuky není zcela subjektivní, tj. není závislé pouze na jedinci, i když se utváří $\mathrm{v}$ jeho jedinečné zkušenosti. Jeho zkušenosti totiž vznikají v interakcích s druhými lidmi (např. žáky, kolegy apod.).

V našem výzkumu jsme zjišt’ovali studentčino pojetí výuky hloubkovým rozhovorem. Rozhovor byl zahájen úvodní otázkou: V tomto rozhovoru si ujasníme, jak se díváte na výuku chemie. Napište na papír všechno to, co se vám vybaví, když se řekne já a výuka chemie. Studentka měla k psaní pět minut. Potom začala nahlas číst to, co napsala. Po té se rozvinul první rozhovor.

Zjistili jsme, že jádrem pojetí výuky Jaroslavy je pojetí cílů výuky, pojetí učení žáků (orientace na žáky) a pojetí řešení pedagogických situací. Cílem výuky chemie je podle ní naučit děti spojovat znalosti se situacemi z běžného života ... učit děti nějakým zážitkem (1.

\footnotetext{
${ }^{105}$ Jde vlastně o specifickou formu otevreného kódování.

${ }^{106}$ Interpretace využívá kombinace induktivních i deduktivních postupů. Inspirovali jsme se prací, jejímž autorem je Jean-Claude Kaufmann (2010).
} 
rozhovor). Toto pojetí cílů rozvíjí studentčino pojetí učení žáků: ... aby si to každý tak nějak mohl osvojit jakoby po svém (1. rozhovor). Klade důraz na pokusy žáků (ve skupinách), jejichž výsledky u nich vyvolávají údiv, a vedou k novým poznatkům: žáky něco překvapilo ... začnou prahnout po těch informacích ... já nemusím vyvíjet až tolik aktivity, abych je nějak jakoby upoutala, ale oni sami jako chtěji (1. rozhovor).

Studentka se zamýšlí nad množstvím učiva, které žákům předkládá: ... ne do nich navalit kvantum informací ... i když já jsem měla takové tendence ze začátku, takové ty ambice říct jim úplně všechno, a potom zjistila po deseti minutách, že mě pưlka třídy neposlouchá ... tak jsem došla $k$ tomu, že takhle to dál asi nepůjde ... přesto potom jsem opakovala tu samou chybu, když jsem šla učit, aniž bych si to uvědomovala... (1. rozhovor). Studentčino přesvědčení, že není vhodné žáky zahlcovat informacemi lze považovat z didaktického hlediska za správné, avšak jeho realizace v reálné výuce není tak př́ímočará. Je v rozporu s její původní tendencí sdělit toho žákům co nejvíce. Není u ní ještě zcela vytvořena tacitní znalost a tedy ani poznatek o výběru a dávkování učiva.

V rozhovoru autor této kapitoly (výzkumník) položil studentce otázku: Kdy jste si to uvědomila?

Jaroslava: Hnedka na té první hodině ... ale ještě jsem to nechala běžet. Mně to trvalo půlku pololetí, než jsem si to sama v sobě nějak přeorganizovala, protože jsem pořád bojovala s tím, že toho těm dětem řikám přeci hrozně málo... (1. rozhovor).

Je zřejmé, že uvědomění si nesprávnosti určitého postupu studentkou někdy nestačí ke změně jejího jednání ve vyučovací hodině. Aby studentka po poměrně dlouhé době změnila své jednání, musela „sebe nastavit“ na tuto změnu (to sama v sobě preorganizovat). Zdá se, že přesvědčení či znalost studentky (v tomto případě o tom, jak by to nemělo v hodině probíhat) může tacitně přetrvávat. Uvědomění si toho, že to či ono není z pedagogického hlediska správné (zexplicitnění tacitního), ještě nemusí bezprostředně vést ke změně jednání. Pokud se ponoříme do výpovědí Jaroslavy hlouběji, můžeme její jednání popsat takto: Jaroslava hned v jedné z prvních vyučovacích hodin cítila, že není něco v pořádku. Nějakou dobu jí trvalo, než identifikovala to „něco“ (metaforicky vyjádřeno to nechala běžet). Tento „,běh“ trval půl roku, protože „bojovala“ (další metafora) s tím, že „toho dětem říká přeci hrozně málo“. V této době postupně „si to v sobě přeorganizovala“ (opět metafora). Tím ustoupila její 
myšlenka, že „toho říká hrozně málo“ a Jaroslava mohla přestat „bojovat“ a zahlédla to, co cítila již v první hodině své výuky: že „toho říká dětem hrozně moc“. Všimněme si, jak zde krystalizuje její TZ: Jaroslava zprvu cítila, že něco není v pořádku (potenciálně to věděla). Uchopovala tuto situaci pocitově, intuicí, ale zároveň ji nedovedla učinit přehlednou, tak, aby jí jasně porozuměla a mohla účinněji jednat. Její intuice ji nakonec vede k cíli a přeorganizování modelu jejího jednání.

Důležité místo ve studentčině pojetí výuky zaujímá přístup k pedagogickým, zejména náročnějším a neočekávaným pedagogickým situacím. Pojetí řešení pedagogických situací Jaroslavy zahrnuje kognitivní, ale i emocionální aspekt. Nad situacemi, které se objevily ve vyučovací hodině, se Jaroslava zamýšlí a snaží se jít víc do hloubky.

Výzkumník: Co to znamená jít do hloubky?

Jaroslava: ... ehm, vracet se zpátky do těch situací a přemýšlet o nich jinak ... Já si třeba často myslím, že si v hlavě rozpitvu tu danou situaci, ale není to tak. Já tak klouzám po tom povrchu ...

Výzkumník: Jak to rozpitvání v hlavě vypadá?

Jaroslava: $\mathrm{Hm}$, je to o tom si vybavit $\mathrm{v}$ podstatě ty detaily ... a hledání ... ehm, $\mathrm{v}$ tom nějakých těch př́čin ... nebo těch momentů, kdy třeba jako vzniklo to špatné v té situaci. (1. rozhovor).

Jaroslava ví, že něco nefunguje, snaží se zjistit proč, a tím změnit tuto neurčitou situaci v situaci určitou. Zatím většinou klouže po povrchu; avšak cíl „něco změnit““ (který si př́liš neuvědomuje) ji vede $\mathrm{k}$ návratu do situace, k jejímu rozpitvávání. Tyto, jen do určité míry uvědomované, momenty jednání Jaroslavy v neočekávané situaci mají tacitní charakter.

Jaroslava řekla, že to řešení [situace] mě někdy napadne, ale někdy třeba ne. ... Já jsem schopná najít řešení tam, kde už se mi to stalo, ale ne tam, kde se mi to stalo poprvé. ... Když se mi to sepne v hlavě, aha, toto už jsem řš̌ila, toto je ta situace. Předtím jsem to vyřešila takhle, tak zkusím to na to aplikovat znovu. Pak se třeba stane to, že ta aplikace na to nefunguje. Ale už to neberu tak tragicky ... (1. rozhovor).

\subsubsection{Utváření TZ Jaroslavy řešením neočekávaných situací v komunikaci se žáky}

Z rozhovorů jsme zjistili, že Jaroslava v řadě neočekávaných situací (např. při nekázni žáků, agresi) reaguje na základě svých pocitů: ... tak, jak to prostě cítím v ten daný moment, tak reaguju... Já myslím, že to je asi mojí povahou, protože já si hodně jako tak všímám, tak jako 
i celkově lidí kolem sebe, jakou mají náladu ... Přijde mi, že mám někdy až takový ten šestý smysl to prostě vycitit ... (2. rozhovor).

Zdá se, že způsob řešení neočekávaných situací se neopírá jenom o dřívější zkušenosti Jaroslavy z mezilidské komunikace a o tacitní znalosti, ale i o její další, hluboce uložené a neuvědomované dispozice a intuici.

Jaroslava: ... je to taková nějaká přirozená součást mě samotné ... prostě tak jako třeba dýchám a nepřemýšlím o tom, tak toto je situace, kdy prostě to udělám. ${ }^{107}$

V komunikaci ve tř́́dě se Jaroslava zaměřuje na žáky: ... já opravdu mám tendenci si v té třídě jakoby všímat těch dětí, jako dívat se jim do tvářre ... protože ona ta tvář leckdy vypoví o tom, jestli to děcko je unavené, nemá náladu, jestli ho to zajímá, nezajímá [toto všímání si tváří dětí a detekce jejich vnitřního rozpoložení probíhá tacitně], $k$ tomu jsem vlastně došla až ted', když se o tom tady bavíme [zexplicitnění tacitního]. Já toto nedělám jako úmyslně, spís neúmyslně, že já si fakt ty děti jako snažím prohližet, nějak to dělám asi podvědomě nebo ne vědomě, není to cílený. ... Já se dokážu jakoby nacítit na nějakou tu jejich úroveň [dětí]. (2. rozhovor).

Když se Jaroslava dívá do tváří dětí, zjišt’uje jejich vnitřní nastavení (tvář vypovídá o nitru) v dané situaci. To jí pomáhá nacitovat se na jejich úroveň (metafora). Dělá to intuitivně a teprve prri rozhovoru si to vybavuje (uvědomuje).

Domníváme se, že TZ se utvářejí na učitelské praxi pomalu. Jaroslava vstupuje do neobvyklých pedagogických situací s minimální poznatkovou výbavou, jejich řešení zpočátku vychází spíše z vnitřních determinant jednání, které nedovedeme ani úplně vyjmenovat. Zřjejmě mezi ně patří studentovo pojetí výuky, intuice a vrozené dispozice.

Nabízí se otázka, jakou úlohu hraje u Jaroslavy v řešení neočekávaných pedagogických situací teorie, zprostředkovávaná na fakultě. Jaroslava nad využitím pedagogické a psychologické teorie uvažuje a konstatuje: ... ted'ka se učím ty teoretické znalosti a najednou

\footnotetext{
107 Připomíná nám to Patočkovy úvahy o rozdílech mezi porozuměním a poznáním: „Možnost poznání tkví v porozumění, ale není s ním identická. Člověk rozumí tak, jako dýše. Když beru křídu do ruky, je v tom jistý akt porozumění, rozumím, $\mathrm{k}$ čemu to je. Není to věděni o nějakém účelu, nýbrž jen zařazení do určité vnitřní souvislosti, která ve mně funguje, která se toho chápe jako kř́ídy ke psaní. Tak rozumím prvotně sobě samému i tomu, co sám nejsem. Tak rozumím dříve, nežli znám.“(Patočka, 1995, s. 76).
} 
mám tendenci to analyzovat [situace]. ... Tak si řikám, že se má postupovat tak a tak [vypočítává na prstech] a ta situace mi prostě uniká. ... Ted'ka dostávám ty rady a nemůžu si přebrat v hlavě, jak mám reagovat-jestli podle nějakých pravidel, které jsou sepsány lidmi, kteři maji daleko více pedagogických zkušeností než já, anebo jestli mám reagovat nějak přirozeně.... Chtěla bych tu danou situaci vyřšsit jakoby i z toho pedagogického hlediska. A já jakoby beru poměrně vážně to, co se mi tady řiká na fakultě. (2. rozhovor)

Z úryvku je zřejmé, že jestliže je Jaroslava v určité situaci a přestane ji uchopovat jako celek, začne pak vědomě hledat a uplatňovat explicitní znalosti. Př́iliš silné zapojení vědomí však může způsobit, že celek situace „mizí”, svinuje se. Teoretické poznatky umožňují vyznat se lépe v situaci, pokud ji předtím studentka reflektuje. Předem připravené poznatky sice mohou, ale také nemusí, zapadat do kontextu dané situace. Jaroslava také uvádí, že jí teorie pomáhá spiš jakoby později, když už je to vyřešené a potřebuji si to jenom sama srovnat v hlavě, tak si to přriradím jakoby [zkušenosti z řešení situací] $k$ nějakým těm teoretickým poznatkům. Což mi pomáhá v tom učení, ale nepomáhá mi to v té konkrétni situaci. (2. rozhovor).

Za důležitou oporu utváření TZ lze považovat reflektivní semináře k učitelským praxím, o kterých jsme se již zmínili. Jaroslava říká, že v semináři se bavíme o těch věcech, které se dějí [na praxi], to rešení úplně tak nevychází z nějaké té teorie, ale z toho, co pak dáme dohromady těmi zkušenostmi [kolegů v semináři]... střetávají se tam ty zkušenosti a snažíme se přijít na nějaké ř ̌̌sení. Každý de facto navrhuje nějaké svoje řšsení nebo řiká nějaký svioj názor, který mě zase vede podívat se na to [na řešení situace] jinak ... ale podle mě to tomu člověku je k ničemu, dokud si sám nezažije tu situaci (2. rozhovor). Je zřejmé, že TZ se utvářejí v pedagogických situacích, jednáním a prožíáním studentky.

Reflektivní semináře vycházejí ze zkušeností studentů a z TZ spojených s řešením situací na učitelské praxi. Pomáhají tyto zkušenosti popsat, uvědomit si jejich klíčové momenty, a tím je také lépe strukturovat. To však, jak se zdá, nestačí. Nezastupitelný je v procesu utváření (a sdílení) TZ dialog s cvičným učitelem, který vidí vyučovací hodinu studenta a může s ním diskutovat o možnostech řešení neočekávaných pedagogických situací. Cvičný učitel chemie však Jaroslavě neposkytoval zpětnou vazbu o jejích vyučovacích hodinách: ... se mnou ty hodiny v podstatě nerozebírá. ... Řekl mi např́klad, že to, co jsem namalovala na tu tabuli, že to bylo jako perfektní, ale že dál by to vysvětloval jinak. (3. rozhovor) 
Ke konci prvního semestru učitelské praxe Jaroslava začala získávat odstup zejména od emocionálně náročných neočekávaných situací: ten odstup, to je právě to, co vědomě vytvář́m... řekla jsem si, že zkusím přistupovat [k situacím] s chladnějši hlavou... (2. rozhovor)

\subsubsection{Didaktické situace reflektované studentkou jako zdroj jejích TZ}

Tato část kapitoly vychází z pozorování dvou po sobě následujících vyučovacích hodin studentky Jaroslavy (chemie a přírodopisu v 8. ročníku) a z třetího rozhovoru, který na tyto hodiny navazoval.

a) Hodina chemie, 8. ročník, 5. vyučovací hodina, téma: vyčíslování chemických rovnic

\section{Ze záznamu pozorování hodiny výzkumníkem}

Frontální výuka, studentka promítá chemické rovnice, vyvolává žáky k tabuli, aby rovnice vyčíslili, tzn. doplnili koeficienty u látek vstupujících do reakce a látek vzniklých danou chemickou reakcí, např. $2 \mathrm{H}_{2}+\mathrm{O}_{2} \quad 2 \mathrm{H}_{2} \mathrm{O}$.

Studentka se opakovaně ptá žáků: Chápete to? ... Kdo to nechápe? ... Fakt to chápete všichni? ... Je to matematika děcka. Chápete to? Snaží se žáky aktivizovat také tím, že zadává úkoly na vyčíslení chemických rovnic, které řeší písemně do sešitů. Prochází mezi lavicemi a žákům podle potřeby pomáhá s vyčíslením rovnic.

Překvapuje mě, že žáci neznají názvosloví chemických sloučenin, neumí pojmenovat látky na levé i na pravé straně rovnice. Zdá se mi, že koeficienty rovnic doplňují mechanicky.

\section{Z rozhovoru po vyučovací hodině}

Výzkumník: Co tomuto učivu předcházelo? Názvosloví chemických sloučenin?

Jaroslava: Žáci ještě názvosloví neumí, umí napsat značku, ale to názvosloví se dělá až potom. ...V chemii dělají rovnice, jenom jejich vyčíslování, aniž by žáci znali názvosloví.

Výzkumník: Hm, a není to trochu mechanické?

Jaroslava: No, [žáci] poznají ty základní prvky. Ví, že Fe je železo. Ještě k tomu dělají chyby. Nemají to úplně zažité. ...

Výzkumník: Mně to připadá z didaktického hlediska nelogické.

Jaroslava: No, na této škole jedou úplně jinak ... mají to celé úplně jinak pomíchané. ... A já jsem z toho sama byla hrozně v rozpacích, protože už jsem chtěla najet na názvosloví. A vlastně pan učitel mi ř́kal: ne, my se musíme ted"ka vrátit $\mathrm{k}$ těm rovnicím. ... Myslím si, že by měli znát to názvosloví před těmi rovnicemi, nebo 
potom neví vůbec, o co tam jde a co tam vzniká...Já jsem ještě, po pravdě řečeno, hledala i cestu, jak z tohodle ven. Ale byl mi dán pokyn učitelem, že opravdu principem, ehm, lépe řečeno cílem toho má být naučit je jako vyčíslovat [chemické rovnice]. (3. rozhovor)

Jaroslava sama nalezla rozpor v didaktickém uspořádání učiva. Ví, jak by mělo být učivo uspořádáno, ale ve škole, kde praktikuje, na to má cvičný učitel jiný názor. Znalost uspořádání učiva lze pokládat za explicitní. Když učivo o vyčíslování chemických rovnic zprostřredkovávala žákům podle pojetí cvičného učitele, uvědomovala si, že by měla postupovat jinak. Ve skutečnosti však postupovala podle poměrně striktní explicitní instrukce cvičného učitele.

b) Hodina př́rodopisu, 8. ročník (stejná tř́ída jako v chemii), 6. vyučovací hodina, téma: mozek

\section{Ze záznamu pozorování hodiny výzkumníkem}

Frontální výuka. Je zde ale cítit jiná atmosféra (klima?) než v předcházející hodině chemie, a je to tatáž třída. Hodina začíná opakováním učiva o nervové soustavě. Studentka klade různě náročné otázky, např́klad: K čemu je nám nervová soustava? Co je centrem nervové soustavy? Co vidíte na tomto obrázku? Co se stane, když míchu mít nebudete? ... Žáci odpovídají sborově.

Nové učivo: mozek. Výklad s názornými promítanými obrázky, pokus o aktivizaci žáků, žáci doplňují do obrázku mozku v sešitech názvy jeho částí, studentka prochází třídou a dívá se do sešitů žáků (kontroluje jejich práci).

\section{Z rozhovoru po vyučovací hodině}

Výzkumník: V hodinách př́rodopisu má paní učitelka jinak nastavená pravidla...

Jaroslava: Ano, přesně tak. Právě, že paní učitelka je v tomdletom můj vzor. ... Je př́ísná a přesto strašně milá, vlídná. ... [Žáci] z ní nemají strach, ale respekt.

Výzkumník: Jaký jste měla záměr v této hodině?

Jaroslava: ... jsem s nimi chtěla dobrat tu nervovou soustavu, která končila tím mozkem. (3. rozhovor)

Takto široce formulovaný záměr mohl u Jaroslavy navodit dilema: nezahltit žáky informacemi a zároveň jim poskytnout řadu zajímavých poznatků.

Jaroslava: ... já jsem tu prezentaci měla nachystanou tak, že bych dokázala o tom jednom slajdu vykládat třeba 5, 10 minut, tak já jsem se to snažila co nejvíce zestručnit. Abych je prostě nezatěžovala ... vypíchnout jenom opravdu to nejdůležitější ... A chtěla jsem, aby si to zapsali sami ... 
Výzkumník: To bylo opisování z té prezentace?

Jaroslava: Ano ... když mám tak moc volnou ruku, tak potom nikdy nevím, jaký je to množství na psaní vhodný ... Jestli je to moc, nebo málo. ... A já si s tím pořád hraju.... Nemám ještě v tomhletom jasno. ... já ještě vždycky bojuju s tím, že já o tom vím tolik, že bych jim to všechno chtěla říct, že mi to všechno přijde strašně zajímavý ... (3. rozhovor)

Jaroslava již ví, že nesmí žáky přetěžovat informacemi. Tento cíl sleduje vědomě, přesto ještě odpovídající znalost není zcela ukotvena v jejím znalostním poli (já si s tím hraju).

Problém, jak vybírat klíčové a přitom zajímavé poznatky a jak je přiměřeném množství žákům předkládat (,dávkovat") si Jaroslava uvědomuje, dokonce jej explicitně formuluje. Pracovat s časovými odhady (co kdy a v jakém rozsahu žákům prezentovat) je pro Jaroslavu opakující se obtiž: Podařilo se mi to odvykládat, ale nepodařilo se mi to zopakovat. (3. rozhovor)

Strukturování vyučovací hodiny z didaktického i časového hlediska (o něm se Jaroslava dozvěděla $\mathrm{v}$ obecné didaktice) souvisí zrejejmě také s tím, jak Jaroslava usiluje o dodržení fází hodiny: ... snažím se dodržovat ty fáze hodiny a mně to v tom vždycky nadělá strašnou paseku. Já totiž nejsem s tím sžitá. Pak se začnu soustřed'ovat na to, co bych měla a úplně to domotám. ... Já z toho neméla vi̊bec dobrý pocit ... děcka na mne koukaly, takže mi jasně dávaly najevo, že to puisobí jako nějakým způsobem strojeně a nepřirozeně ...

I tady se Jaroslava snaží ř́́dit teoretickými poznatky. To ji vede $\mathrm{k}$ tomu, že přestává vidět situaci jako celek, a řešení situace tak není přrirozené. Žáci to dávají navenek najevo.

Jak se s tím Jaroslava pokusila vyrovnat? Tento týden jsem si dovolila trochu se vrátit k tomu, co jako mně nějak prišlo přirozené. Takže, já jsem to opakování prokládala s tou novou látkou. Že jsem prostě to tak nějak stř́dala. A neoddělila jsem si to od sebe, že bych jenom opakovala a pak bych probírala novou látku. ... Já to nemám ještě zažité ...

Výzkumník: Co to je, to zažité?

Jaroslava: Nemám to zautomatizované. ${ }^{108}$... To byla jedna hodina z těch devatenácti odučených. Takže, já ještě bych na to potřebovala čas ... já bych potřebovala tu praxi, nevím, čtrnáct dnů v kuse. ${ }^{109}$ (3. rozhovor)

\footnotetext{
${ }^{108}$ Rutinní, do určité míry zautomatizované postupy považujeme za jeden z předpokladů úspěšného utváření TZ při řešení náročnějších a neočekávaných situací.

109 Jaroslava bohužel po 1. ročníku přerušila studium a nemohla tedy ve 2. ročníku absolvovat souvislou učitelskou praxi. Nebylo tedy možné výzkumně sledovat její další cestu k učitelské profesi.
} 
Jaroslava si uvědomuje, že potřebuje více praxe, a to zejména souvislé, aby u ní došlo k zautomatizování některých postupů. V další části rozhovoru Jaroslava s určitým nadhledem i vhledem hodnotí svoji současnou didaktickou způsobilost.

Výzkumník: Jak byste tuto hodinu hodnotila? Celkově, zpětně, když o tom ted' přemýšlíte.

Jaroslava: No, [přemýšlí] ... Jako já to vnímám tak, že jsem došla tak někde do půli cesty. ... A byt’ pro mě to byla vlastně nejlepší hodina $\mathrm{z}$ těch, co jsem měla, tak zdaleka nebyla taková, jak si myslím, že by to mohlo jakoby fungovat. ... Já bych asi tu hodinu chtěla ještě víc postavit na tom, že ještě více oni pracují a ještě více oni se zapojují a přichází to jakoby od nich ... Ale ještě pořád nevím jak na to. Protože, ono je něco jiného, když jsem měla ten kroužek, který je postavený na tom, že ty děcka už od začátku tak pracují. A něco jiného je přijít do školy, kde je zažitý režim... (3. rozhovor).

V tomto sebehodnocení (sebereflexi) Jaroslava explicitně vyjadřuje, že by podobnou hodinu (v budoucnosti) chtěla založit na vyšší míře aktivity žáků. Realizace tohoto záměru však předpokládá, že si praktickým vedením hodiny osvojí další potřebné (nejenom) tacitní znalosti.

c) Výukové metody v didaktických situacích

Jaroslava uplatňovala hodinách, které na praxi vyučovala, často názorný výklad a vysvětlení, doplňované otázkami kladenými žákům. Snažila se nalézt takové metody a formy výuky, které by vyhovovaly více hlediskům, například cílům výuky, úrovni znalostí a zkušeností žáků, času, který měla k dispozici atd. Za náročné považuje období, kdy se poprvé na praxi dostávala do kontaktu se žáky v určité třídě: Oni ty prvni dvě hodiny fakt byli takoví, jakože nevěděli, co si můžou dovolit ... Je to pro mě hrozně krátká doba na to, abych s nima mohla nějak pracovat... (3. rozhovor)

Hledala metody, které by zabraly v daných situacích, jejími slovy hledala páky, zpưsoby, které by mohla opakovaně použit. Bud' jsem nenašla, nebo našla nějakou metodu, která mi zabere. Já [...] jsem ani jednu hodinu neměla stejnou, jakože jsem v každé hodině zkoušela něco nového. ... A nemůžu ani u jedné z těch metod, které jsem použila, ještě ted'ka v tuhletu chvilku říct, že by byla jako účinná. Já nevím, já bych tam musela prostě učit třeba dva měsice ... (3. rozhovor)

Jaroslava opět explicitně vyjadřuje potřebu souvislejší praxe. Pokusila se také o skupinovou práci žáků, přesto, že jí bylo „,doporučeno od obou učitelů, že se moc nemám jakoby pouštět do nějakých skupinek. Já jsem si to dovolila vyzkoušet, byla to druhá hodina chemie, co jsem měla. A dopadlo to úplně katastrofálně pro mě. Že my jsme za tu hodinu skoro nic nestihli, 
nebot' oni vytvořili, než si povykládali mezi sebou, co chtěli a než jsem je donutila dělat to, co chci já, tak ta hodina neméla moc velký efekt. (3. rozhovor)

Hledání účinné výukové metody probíhalo u Jaroslavy v průběhu učitelské praxe v rovině myšlenkové i v rovině jejího jednání. I když nemáme data o těchto jejích aktivitách, domníváme se, že si je Jaroslava uvědomovala.

\subsubsection{Odkrývání prvků TZ prostřednictvím stimulovaného vybavování}

Výzkumník: Budeme si povídat o vaší vyučovací hodině [př́rodopis]. Pustím videozáznam, budeme jej společně sledovat. Na váš signál záznam hodiny zastavím a vy se můžete vyjádřit $\mathrm{k}$ tomu, co pro vás $\mathrm{v}$ daném momentě bylo zajímavé, třeba i náročnější a co vás překvapilo.

Situace S1: Jaroslava stojí v přední části učebny, bokem k promítanému obrazu mozku, opakuje se žáky učivo, klade otázky, žáci odpovídají sborově.

Jaroslava: Já bych potřebovala dospět do té situace, že nebudu soustředěná na ten předek, ... potřebovala bych se dostat mezi ty děcka. Já si to uvědomuju i v těch hodinách předtím. Že jsem se víc fakt soustředila na to, co vykládám než na ty žáky. Kdybych mezi něma chodila, tak oni by byli daleko více pozorní ... (4. rozhovor)

Jaroslava explicitně formuluje nedostatek ve svém jednání a zároveň navrhuje, jak by mohla situaci řešit jinak: Ty jo, já jsem si to fakt ani neuvědomila, jak jsem se strašně chytala té prezentace. ... To mě úplně překvapilo. ... Já vždycky chci do té hodiny toho nacpat co nejvíc, a někdy je lepši méně. (4. rozhovor) Opakuje se pravidlo, které si Jaroslava uvědomuje: „méně může být více“. Vyjadřuje však zároveň moment překvapení: Ty jo, já jsem si to fakt neuvědomila.

Situace S2: frontální opakování versus pokus o samostatnou práci žáků

Jaroslava: Já jsem vlastně za celou tu praxi minimálně jednotlivě vyvolávala. ... Jakmile měl mluvit jenom jeden, tak pak stejně to za něj řekl někdo druhý na konci tř́́dy, aniž byl vyvolán. ... I na násleších jsem viděla, že je ti učitelé nevyvolávají jako jednotlivce vůbec. ... Já jsem ještě s nima zkoušela hned na té první hodině jim $\mathrm{v}$ podstatě zadat takový mini projektík, kdy oni měli $\mathrm{k}$ určité věci vymyslet další věci. Potom měli jako jednotlivě vystoupit za tu skupinku, nechtěli. (4. rozhovor)

Situace S3: při výkladu učiva Jaroslava uvedla určitý údaj (km za hod.) o rychlosti vzruchu u člověka a požadovala po žácích, aby jej převedli na jednodušší jednotku (cm za sekundu); šlo o to, aby si vybavili jednoduché matematické operace; žáci to nezvládali, Jaroslava je naváděla na řešení (převody jednotek)

Jaroslava: tady to byl pro mě moment překvapení ...Kdyby dostali ten př́iklad znova, tak si myslím, že by zase nevěděli. ... Já jsem se na jedné hodině prŕrodopisu a v té chemii taky snažila o podobný př́íklad. Oni ř́ikali, že je to pro ně moc těžký. (4. rozhovor) 
Situace S4: žák (muslim) má hlavu položenou na lavici, nesleduje dění ve tř́iě

Jaroslava: On má strašně problematickou povahu, já když jsem se ho snažila nějak zapojit, tak jsem s ním šla do konfliktu. ... Ani ti učitelé nemají na něho žádné páky, ani prostě neví, co s ním. ... On ještě bere v chemii třídního ... bylo mi řečeno, že on má problém s ženskou autoritou. (4. rozhovor)

Situace S5: skupinová práce, žáci vytvářejí na základě své volby skupinky po třech, řízení skupinové práce je pro Jaroslavu náročné, přestože je na hodinu velmi pečlivě připravena, včetně úkolů pro žáky (měli přiřadit částem těla člověka jejich názvy a napsat funkci těchto částí)

Jaroslava: ...to bylo jako fakt deset minut, než jsem je donutila, aby si nějak přesedali. ... Mě překvapilo, že oni najednou měli problém s tím přiřazováním názvi̊. Tato forma aktivity byla pro ně úplně jiná, toto s nima nedělala paní učitelka... (4. rozhovor)

Situace S6: Jaroslava se zamýšlí nad celou vyučovací hodinou

Jaroslava: Pro mě to je takový poučení, že bych třeba už příště celou hodinu postavila jenom na těch aktivitách [na skupinové práci] ... Já už jsem ř́kala, že já jsem v té tř̌́dě vyzkoušela úplně všechno a žádná hodina nebyla stejná. Akorát paní učitelka mi říkala, že jim toho říkám moc, že oni jsou na škole považováni za ty slabší. Ale já zas v tomhletom s ní úplně třeba nesouhlasím. ... Že třeba tady tím př́stupem [skupinovou výukou] je možný je $\mathrm{k}$ něčemu jako vyburcovat. (4. rozhovor)

V situaci S1 se u Jaroslavy utvářela TZ, kterou bychom mohli široce nazvat zprostředkováni učiva žákům. Projevil se v ní prvek, týkající se výběru učiva a jeho rozsahu pro danou vyučovací hodinu. Tento prvek však není zcela zvládnutý. Potvrzuje to také reflexe Jaroslavy, která si uvědomila, že se chytala prezentace a že má tendenci toho do hodiny co nejvíce nacpat.

Jaroslava se vyznačuje tím, že ve výuce ráda experimentuje, zkouší různé, často aktivizující výukové postupy, např́klad mini projekty žáků (S2) nebo skupinovou výuku (S5). Experimentování považujeme za aktivitu, která má tacitní charakter. Jaroslava takto získává zkušenosti s aplikací konkrétních metod výuky. Metoda skupinové výuky byla pro naši studentku náročná: neznala dobře třídu, žáci nebyli na tuto metodu navyklí a sama Jaroslava měla s metodou minimální zkušenosti. Domníváme se, že se u ní vytvářejí „obrysy” tacitní znalosti ř́dit skupinovou práci žáků. Metaforicky tento proces označujeme jako „krystalizaci TZ”. To znamená, že prvky této TZ se mohou v procesu získávání dalších zkušeností se skupinovou výukou měnit - růst a jinak strukturovat. 
Zajímavé je jednání Jaroslavy v situaci S4. Žák dává najevo nezájem, nespolupracuje. Jaroslava ho „,nechává být”, zřejmě se řídí zkušenostmi učitelů (s tímto žákem), kteří v dané trrídě vyučují. Tuto situaci však považujeme za otevřenou, vyžadující zřejmě hlubší sociologickou, psychologickou a pedagogickou analýzu (možná i konzilium se školním psychologem).

Jaroslava se dovede zpětně kriticky podívat na svoji komunikaci se žáky. Svoji činnost reflektuje a navrhuje možné alterace, tedy jiné výukové postupy, popřípadě změnu struktury analyzované vyučovací hodiny (S6). Domníváme se, že také tento proces probíhá tacitně.

\subsection{Závěr}

Pokusíme se nyní souhrnně odpovědět na položené výzkumné otázky.

\section{Jak se pojetí výuky Jaroslavy promítá do procesu utváření jejích TZ?}

Jak jsme již uvedli, pojetí výuky (studenta učitelství, učitele) má většinou implicitní (tacitní) charakter. Obecně se předpokládá, že změna pojetí výuky vede ke změně jednání. Neplatí to však zcela jednoznačně. V pojetí výuky u Jaroslavy jsme se zaměřili na výběr a strukturování učiva a na přístup $\mathrm{k}$ řešení neočekávaných pedagogických situací, které tvoří jádro jejího pojetí. Zpočátku při prrípravě, ale i při realizaci výuky byla téměř přesvědčena, že žákům musí „,ríci úplně všechno”. Na základě reálné výuky si poměrně brzy uvědomila, že předkládá žákům velké množství informací, což vedlo i k poklesu jejich zájmu. Změnila svoje pojetí, které vyjádřila v rozhovoru explicitně: „,nezahlcovat žáky informacemi”. Avšak tato změna, která proběhla na mentální úrovni, nezpůsobila - dle vyjádření samotné Jaroslavy - změnu jejího jednání ve vyučovacích hodinách. Teprve opakovaná reflexe (když se vzorec nepřiměřeného didaktického jednání opakoval) vedla k vnitřnímu přenastavení. Zdá se tedy, že změna pojetí výuky, která vede ke změně jednání, zahrnuje tři důležité kroky: (a) uvědomit si toto pojetí, (b) změnit jej, (c), „nastavit” se vnitřně na změnu jednání.

Pojetí řešení neobvyklých pedagogických situací se u Jaroslavy nevyvinulo z pedagogické teorie. Vznikalo tím, že Jaroslava byla do těchto situací postavena ve vyučovacích hodinách a musela bezprostředně reagovat. Jaroslava se pokoušela v těchto situacích vyznat, vracela se $\mathrm{k}$ nim po vyučovacích hodinách, „pitvala” je, snažila se proniknout do hloubky a postihnout významné momenty a příčiny vzniku těchto situací. Na základě uvedených výpovědí Jaroslavy (v hloubkových rozhovorech) se domníváme, že její „laborování” v neočekávaných 
situacích mělo převážně tacitní charakter. Uvědomovala si, že každá situace je jiná a že se nelze univerzálně připravit na jejich řešení, lze pouze některé situace předvídat.

\section{Co vypovídá řešení neočekávaných pedagogických situací Jaroslavou o jejích TZ?}

Z předcházející podkapitoly je zřejmé, že pojetí řešení neočekávaných pedagogických situací se u Jaroslavy teprve utvářelo tím, že se v těchto situacích ocitla a musela jednat. Její pojetí řešení situací je možno charakterizovat jako nevyhraněné a neúplné. Postupně u Jaroslavy krystalizovaly TZ i poznatky, jak v některých situacích jednat. Použití znalostí se však musí přizpůsobovat specifičnosti neočekávaných pedagogických situací. Přizpůsobení se děje ve spirále ,jednání - reflexe - změněné jednání”.

V neočekávaných pedagogických situacích Jaroslava experimentovala, tedy hledala a zkoušela různé pedagogické postupy. Některé „zabíraly” lépe, jiné méně. Na jejich účinnost usuzovala na základě odezvy žáků i na základě reflexe, která začínala často intuitivním zachycením situace. Musela však najít odstup od obecných pedagogických doporučení a poznatků, aby byla reflexe užitečná. Obecná doporučení a poznatky se staly součástí jejího experimentování až po určité době.

Reflektivní semináře $\mathrm{k}$ učitelské praxi považuje za zdroj inspirací k řešení podobných pedagogických situací. V diskusi s kolegy a vysokoškolskými učiteli, kteří se na vedení seminářů podíleli (obvykle pedagog a psycholog, popř. i/nebo oborový didaktik), vznikaly určité modely řešení, explicitně vyjádřené. Předpokladem utváření vlastních tacitních znalostí je však pedagogické situace ,zažít”.

Významnou úlohu při utváření TZ studentů má jejich sdílení s cvičným učitelem (o této problematice viz kapitolu 11 této monografie). Sdílení umožňuje facilitovat proces utváření TZ studentů učitelství. U Jaroslavy však k smysluplnému sdílení TZ, respektive jejich prvků (zejména ve výuce chemie) nedocházelo.

Souhrnně lze říci, že $\mathrm{v}$ průběhu učitelské praxe u studentky Jaroslavy tacitní znalosti krystalizovaly. Zdá se však, že to, co jsme pozorovali a slyšeli v rozhovorech s Jaroslavou, je „něco víc” než jen projevy TZ. Jakoby TZ byly namodulovány či vnořeny do „něčeho”, co tvoří jádro osobnosti, typické pro její myšlení a jednání. Výstižněji to vyjádřil Minkowski (2011, s. 105): „Všechny naše činy jsou jakoby neseny něčím neuchopitelnějším, méně určitým, celkovějším, co nelze rozebrat na izolované prvky. Jsou zaplaveny tím, co vyzařuje z 
osobnosti jako celku, a osobnost tento moment nedokáže odlišit, upřesnit ani si jej jasně uvědomit."

Každý empirický výzkum má obvykle své limity. V našem výzkumu za metodologický limit považujeme to, že jsme $\mathrm{v}$ rozhovorech neuplatňovali čistý jazyk, o němž je podrobněji pojednáno $\mathrm{v}$ řadě kapitol této monografie. I když popsané hloubkové rozhovory přinesly zajímavé výsledky, domníváme se, že jejich propojení s kladením otázek založených na čistém jazyce by umožnilo jít do větší hloubky při odhalování tacitních znalostí studentky Jaroslavy. 


\title{
11 Jak sdílí tacitní znalosti studentka učitelství Milada se svou cvičnou učitelkou
}

\begin{abstract}
Vlastimil Švec $\breve{~}^{110}$
Sdílení znalostí je v posledních letech opakovaně používaný pojem, a to zejména v oblasti znalostního managementu. Na tomto místě však nebudeme analyzovat studie, které se vztahují k této oblasti. Jen připomeneme, že sdílení se v manažerském pojetí často chápe jako přenos znalostí (přesněji řečeno - informací) od určitého jedince $\mathrm{k}$ jinému jedinci v rámci jedné organizace nebo $\mathrm{v}$ rámci různých organizací, popř́ípadě mezi organizacemi (např́íklad firmami). Do sdílení znalostí v tomto pojetí pronikají stále častěji informační a komunikační technologie, které přenos informací usnadňují, napřr. zrychlují a umožňují přenášet informace i z geografických oblastí od sebe velmi vzdálených.
\end{abstract}

Ve vzdělávacím kontextu je však sdílení znalostí procesem komplexním, který se vyznačuje určitými specifickými znaky. Patř́i k nim zejména (Švec, 2009a):

- konfrontace poznatků a informací mezi účastníky vzdělávacího procesu,

- společné vytváření nových poznatků,

- vzájemné učení se, například studentů učitelství, začínajícího a zkušeného učitele.

Úroveň a podoba sdílení znalostí závisí na úrovni zkušeností a znalostí jedinců, kteří do tohoto procesu vstupují. Kupř́ikladu učitelé-experti mezi sebou sdílejí pedagogické znalosti snadněji než student učitelství se zkušeným učitelem. Záleží však také na tom, do jaké míry si jedinci své znalosti uvědomují a do jaké míry jsou schopni je artikulovat. Explicitní znalosti, které si jedinci uvědomují a dovedou je vyjádřit, se sdílejí jednodušeji než znalosti tacitní, které si jedinci jen částečně uvědomují.

V této kapitole se budeme zabývat tacitními pedagogickými znalostmi, které sdílí studentka učitelství se svou cvičnou učitelkou v průběhu učitelské praxe na základní škole. Upozorníme

${ }^{110}$ Podklady pro empirickou část kapitoly (data z výzkumu) připravila K. Cásková. 
na některé teoretické a metodologické otázky sdílení tacitních znalostí cvičné učitelky se studentkou a následně se zaměříme na zkoumání tohoto procesu sdílení.

\subsection{Učňovství jako zpưsob sdílení tacitních znalostí}

Všimněme si nejdříve různých způsobů sdílení tacitních znalostí. Rintala \& Kuronen (2006) se pokusili podat prehled metod a forem sdílení tacitních znalostí. Vybereme z nich způsoby sdílení, které jsou využitelné ve vzdělávání učitelů (tabulka 10).

Tabulka 10

Možnosti sdíleni tacitnich znalostí v učitelském vzdělávání (Rintala \& Kuronen, 2006; upraveno, srov. Švec, 2012)

\begin{tabular}{|c|c|c|c|}
\hline $\begin{array}{l}\text { Typ } \\
\text { sdílení }\end{array}$ & $\begin{array}{l}\text { Způsob } \\
\text { sdílení }\end{array}$ & Počet sdílejících & Př́íklad \\
\hline 1. & $\begin{array}{l}\text { Klasické } \\
\text { učňovství }\end{array}$ & 2 & $\begin{array}{l}\text { Student učitelství pozoruje zkušeného } \\
\text { učitele, postupuje podle jeho } \\
\text { doporučení; potom zkušený učitel } \\
\text { pozoruje studenta a následně s ním vede } \\
\text { diskusi o jeho výuce. }\end{array}$ \\
\hline 2. & $\begin{array}{l}\text { Učňovství } \\
\text { v týmu }\end{array}$ & skupina & $\begin{array}{l}\text { Začínající a zkušení učitelé vzájemně } \\
\text { pozorují svou výuku a diskutují o } \\
\text { strukturaci učiva, metodách a formách } \\
\text { výuky apod. }\end{array}$ \\
\hline 3. & Mentoring & 2 & $\begin{array}{l}\text { Student učitelství a zkušený učitel } \\
\text { vyučují společně, společně plní cíle } \\
\text { výuky, učitel „koučuje” studenta. }\end{array}$ \\
\hline 4. & $\begin{array}{ll}\text { Diskuse } & \mathrm{v} \\
\text { týmu } & \end{array}$ & skupina & $\begin{array}{l}\text { Zkušení učitelé (experti) diskutují o } \\
\text { řešení konkrétních pedagogických } \\
\text { problémů (situací). }\end{array}$ \\
\hline 5. & $\begin{array}{l}\text { Vzájemné } \\
\text { učení }\end{array}$ & minimálně 2 & $\begin{array}{l}\text { Studenti učitelství se vzájemně učí - } \\
\text { pozorují postupně výuku toho druhého a } \\
\text { potom o svých postupech diskutují } \\
\text { (např. v reflektivním semináŕi). }\end{array}$ \\
\hline 6. & $\begin{array}{l}\text { Vyprávění } \\
\text { příběhů }\end{array}$ & minimálně 2 & $\begin{array}{l}\text { Zkušený učitel vypráví studentovi } \\
\text { učitelství nebo začínajícímu učiteli např. }\end{array}$ \\
\hline
\end{tabular}




\begin{tabular}{|l|l|l|}
\hline & & $\begin{array}{l}\text { o svých začátcích, způsobech } \\
\text { komunikace s problémovými žáky atd. }\end{array}$ \\
\hline
\end{tabular}

Všimneme si blíže prvního typu sdílení tacitních znalostí - učňovství. Je to vztah, do kterého vstupuje student učitelství (nebo začínající učitel) a cvičný učitel (mentor, zkušený učitel). Tento vztah předpokládá vzájemnou spolupráci aktérů sdílení a není jednostranný, to znamená, že v procesu sdílení se utvářejí tacitní znalosti studenta učitelství, ale zároveň se mohou upevňovat a rozvíjet tacitní znalosti cvičného učitele. Klasické (tradiční) učňovství je založeno na tom, že zkušený učitel předvádí méně zkušenému učiteli nebo studentovi učitelství plánované i neplánované vyučovací činnosti, ukazuje jak řešit pedagogické úlohy a situace. Model tradičního učňovství se opírá o čtyři základní aktivity učitele a studenta (srov. Collins, Holum, \& Brown, 1991):

- modelování činnosti učitelem, student učitele pozoruje,

- student se pokouší činnost simulovat, plní zadané úkoly, učitel mu poskytuje oporu,

- míra učitelovy opory se snižuje, za plnění úkolu přebírá větší odpovědnost student,

- učitel studenta vede prostřednictvím výběru vhodných úloh, doporučení a instrukcí, poskytování zpětné vazby, povzbuzování apod.

Tradiční učňovství, jehož ústřední místo zaujímá pozorování učitele, je vhodné spíše pro osvojování řemeslných dovedností. Pedagogické znalosti a dovednosti jsou však specifičtější. ${ }^{11}$ Collins, Holum, \& Brown (1991) nabídli model tzv. kognitivního učňovství, který vychází z požadavku, aby myšlení učitele i studenta bylo „viditelné“, aby došlo k odrytí tacitních procesů obou aktérů sdílení. Model kognitivního učňovství se opírá o řadu metod. Ačkoliv se některé z nich svým označením podobají aktivitám v tradičním učňovství, jejich podstata je poněkud jiná. Collins, Holum, \& Brown (1991) uvádějí tyto metody:

\footnotetext{
${ }^{111} \mathrm{Na}$ tento problém, v souvislosti s úlohou praxe $\mathrm{v}$ učitelském vzdělávání, jsme upozornili již dříve, a to na základě rozhovoru s I. Vyskočilem o hospitacích. Vyskočil upozornil na nesprávný př̌edpoklad, že student učitelství, který nemá učitelské zkušenosti, na praxi „něco“ uvidí a uslyší, pochopí, ,jak se co dělá“ a pak při vlastním výstupu napodobí, čímž získává určitou vlastní zkušenost. Ve skutečnosti však jde jen o nápodobu, reprodukci určitého výsledku, tedy něčeho „nevlastního“ (Švec, 2009b, s. 410-411).
} 
- modelování - student pozoruje zkušeného učitele a vytváří konceptuální model činností, které si má osvojit,

- koučování - učitel pozoruje studenta při plnění úkolu, poskytuje mu zpětnou vazbu, řídí jeho pozornost, volí další úlohy (,„šité“ studentovi na míru) atd.,

- poskytování „lešeni““ - učitel poskytuje studentovi doporučení k jeho řešení (činnosti), student je recipročně v roli učitele,

- artikulace - student se pokouší artikulovat svoje znalosti, zdůvodňuje řešení úloh apod.,

- reflexe - student srovnává svoje řešení (činnost) s řešením (činností) zkušeného učitele, popř. s řešením svého kolegy,

- zkoušení řšsení nové úlohy - učitel podněcuje studenta k samostatnému, vlastnímu řešení úlohy.

Modelem kognitivního učňovství se inspirujeme i v našem výzkumu; podrobněji jej v oblasti vzdělávání učitelů popsali van Velzen \& Volman (2009). Tento model byl rozšířen na model kolaborativního učňovství (Glazer \& Hannafin, 2006). Jeho základem jsou reciproční (vzájemné) interakce, v nichž jedinci pomáhají druhým maximalizovat jejich učební potenciál; je to určitá obdoba Vygotského zóny nejbližšího vývoje (Glazer \& Hannafin, 2006, s. 180-181). Využití modelu kolaborativního učení je poměrně široké: lze jej uplatnit při sdílení znalostí studenta učitelství s cvičným učitelem, ale i při spolupráci (sdílení) různě zkušených učitelů v učitelské komunitě ve škole.

Modelem kolaborativního učňovství se inspirovali van Velzen, Volman, Brekelmans, \& White (2012), kteří popisují tři fáze vedení vyučovací hodiny cvičným učitelem a studentem učitelství: 1. fáze - vyučovací hodinu vede cvičný učitel, 2. fáze - hodinu společně realizují cvičný učitel a student a 3. fáze - hodinu vede student samostatně.

McAdam, Mason, \& McCrory (2007) analyzovali četné studie zabývající se charakteristickými rysy a projevy tacitních znalostí. Dospěli mimo jiné k poznatku, že tacitní znalosti lze sdílet prostřednictvím interaktivní konverzace (s. 46). Podobně Torff (1999, s. 207) doporučuje, aby studenti učitelství poznali, že kooperativní učení (s cvičným učitelem) 
není pouze formou a metodou výuky, ale také procesem, ve kterém se mohou učit od druhých a společně s nimi konstruovat znalosti.

\subsection{Východiska výzkumu sdílení tacitních znalostí studentky s cvičnou učitelkou}

Pojem tacitní znalosti se obtížně vymezuje, protože jejich podstata zůstává skrytá vnějšímu pozorování. V pozorovaném jednání jedince se totiž projevuje až výsledek uplatnění tacitních znalostí, například to, jak student učitelství nebo zkušený učitel komunikují v určité hodině se žáky. Metaforicky řečeno, pozorujeme obal tacitních znalostí. Pokud bychom vycházeli z předpokladu, že tacitní znalosti studenta učitelství se utvářejí na základě jeho zkušeností z řešení pedagogických (zejména neočekávaných) situací, mohlo by nám to stačit. Zkušenostní učení se ve vzdělávání budoucích učitelů totiž již řadu let uplatňuje. Nás však zajímá, jak dochází ke sdílení tacitních znalostí cvičného učitele se studentem učitelství. Potřebujeme proto tacitní znalosti detekovat, což se neobejde bez vymezení tohoto klíčového pojmu.

Předpokládejme, že: (a) tacitní znalosti jsou znalosti, které se utvářejí interakcí studenta učitelství (učitele) s prostředím, ve kterém vyučuje; (b) tacitní znalosti lze do určité míry zexplicitnit, např́klad prostřednictvím sebereflexe či rozhovorem se studentem (nebo učitelem) o jeho vyučování, a to s využitím tzv. čistého jazyka. Velmi zjednodušeně můžeme říci, že tím určité tacitní znalosti dostávají podobu explicitních znalostí. Potom můžeme chápat explicitní znalosti a tacitní znalosti jako dva póly jednoho kontinua.

Nehyba \& Svojanovský (2016) vymezují tacitní znalosti v kontrastu k explicitním znalostem dvěma klíčovými atributy: (a) mírou uvědomovanosti znalosti; (b) mírou arikulovatelnosti znalosti.

Sdílením tacitních znalostí rozumíme proces spolupráce studentky učitelství s cvičnou učitelkou, ve kterém (Cásková, 2014, s. 104-105, upraveno): (a) si studentka uvědomuje svoje zkušenosti a tacitní znalosti, a to v konfrontaci s doporučeními cvičné učitelky, která vycházejí z pozorování studentčiny vyučovací hodiny; (b) cvičná učitelka posuzuje (tacitní i explicitní) znalosti studentky, které se projevují v jejím jednání a současně reflektuje její pozici na učitelské praxi; (c) studentka a cvičná učitelka se na sebe vzájemně vylad’ují (respektují názory i emoční naladění té druhé). 
Vycházíme z toho, že studentka učitelství a cvičný učitel disponují rozdílnou úrovní zkušeností a tacitních učitelských znalostí. Studentka učitelství má nedostatek pedagogických zkušeností a nové tacitní znalosti se u ní utvářejí. Lze předpokládat, že u zkušené cvičné učitelky jsou mnohé tacitní znalosti již vytvořeny a lze je pokládat za poměrně stabilizované.

\subsection{Metodologie výzkumu}

Cílem výzkumu bylo zjistit, jak probíhá sdílení tacitních znalostí mezi studentkou učitelství Miladou a její cvičnou učitelkou. Cíl jsme konkretizovali dvěma výzkumnými otázkami:

1) Jak probíhá sdílení tacitních znalostí Milady s cvičnou učitelkou?

2) Co a jak se sdillejí? Mění se něco v průběhu sdíleni??

Charakter výzkumných otázek vedl k volbě kvalitativního výzkumu. Základními metodami získávání dat byly: (a) rozhovory (diskuse) Milady s cvičnou učitelkou (ty byly zaznamenány videokamerou); rozhovor navazoval na pozorování Miladiny vyučovací hodiny (hodinu pozorovala cvičná učitelka i výzkumník); podle potřeby byla diskuse doplněna otázkami výzkumníka; (b) hloubkový rozhovor výzkumníka s Miladou.

Výzkum sdílení tacitních znalostí se uskutečnil na jedné brněnské základní škole v předmětu matematika v průběhu 2. a 3. semestru učitelské praxe v jarním semestru akademického roku 2013/2014 a v podzimním semestru akademického roku 2014/2015. ${ }^{112}$ Milada, studentka navazujícího magisterského studijního programu učitelství, i její cvičná učitelka se zúčastnily výzkumu na základě dobrovolného rozhodnutí. Cvičná učitelka vystudovala učitelství matematiky a biologie, vyučuje na druhém stupni základní školy matematiku a př́rodopis a má 27 let pedagogické praxe.

Kooperace studentky učitelství Milady s cvičnou učitelkou v průběhu učitelské praxe zahrnovala: vzájemná pozorování výuky (Milada hospitovala v hodinách cvičné učitelky a cvičná učitelka v hodinách Milady) a diskuse cvičné učitelky s Miladou o jejich výuce.

\footnotetext{
${ }^{112}$ Učitelská praxe je realizována ve třech semestrech: v prvním (praxe 1) a druhém (praxe 2) semestru se jedná o praxi průběžnou; ve třetím (praxe 3) semestru následuje praxe souvislá (4 týdny). V průběhu praxe student vykonává řadu činností, které jsou každodenní součástí práce učitele. Samostatně však vyučuje v rámci první praxe pouze 3 vyučovací hodiny $\mathrm{v}$ jednom předmětu, během druhé praxe 10 vyučovacích hodin $\mathrm{v}$ jednom předmětu. $\mathrm{V}$ rámci třetí praxe pak student vyučuje 20 hodin $\mathrm{v}$ jednom předmětu.
} 
Výzkumně jsme zachytili pouze jeden směr interakce cvičné učitelky a Milady: pozorování vyučovacích hodin Milady cvičnou učitelkou a navazující rozhovory (diskuse) obou aktérek sdílení. Celkem proběhly mezi studentkou a cvičnou učitelkou tři rozhovory (1. rozhovor květen 2014, 2. rozhovor - listopad 2014, 3. - listopad 2014). Tyto rozhovory byly orientovány na problematické situace, které cvičná učitelka identifikovala během pozorování studentčiny výuky. Dále vycházíme ze dvou dalších rozhovorů, které vedl výzkumník s Miladou. Jeden z nich (4. rozhovor - prosinec 2014) byl tematicky zaměřen na změnu subjektivního pojetí výuky, přičemž v samotné analýze jsou z tohoto rozhovoru využíány úryvky, které korespondují s tématy sdílenými mezi cvičnou učitelskou a Miladou. Druhý, realizovaný po ukončení praxe (5. rozhovor - květen 2015) rekapituloval učitelskou praxi Milady a tematicky byl zaměřen na vybraná místa z předchozích rozhovorů.

\subsection{Výsledky výzkumu}

Všechny rozhovory byly přepsány a získané texty rozděleny na úryvky (v souladu s výzkumnými otázkami), které byly označeny kategoriemi s využitím otevřeného kódování. $^{113}$ Výsledky výzkumu budeme prezentovat prostřednictvím vybraných situací, v nichž docházelo ke sdílení tacitních znalostí cvičné učitelky se studentkou Miladou a které se odehrály v průběhu učitelské praxe 2 a souvislé učitelské praxe 3 . Situace se vztahují ke třem následujícím tématům.

\section{První téma: nestejné pracovní tempo žáků ve vyučovací hodině}

Cvičná učitelka reagovala v rozhovoru na situaci v pozorované vyučovací hodině Milady: žáci dokončují v lavicích řešení úkolu, někteří již řešení dokončili, sedí a čekají. Milada je u tabule a vyvolá jednoho žáka, aby řešení úkolu napsal na tabuli. Zřejmě předpokládá, že žáci v lavicích kontrolují svá řešení současně s tím, jak žák píše řešení na tabuli. Žák v řešení udělal chybu. Milada vysvětluje žákovi, v čem udělal chybu.

Cvičná učitelka: ...byl to takový slabší okamžik, že ty děcka nebyly jakoby využity a vtažení do toho [do procesu vysvětlení př́činy chyby], pomohlo by určit si jako ty asistenty, ty seš rychlej, pojd', poradíš tomu a tomu. Navíc se cítí důležitý a řeknou si to možná způsobem míň odborným, než to říkáme my, ale těm děckám je 
to třeba někdy bližší a docela se to osvědčilo. Navíc ti šikovní mají pocit, že jsou užiteční a je to fajn i jako co se týká vztahů pro ty děcka. (2. rozhovor)

Cvičná učitelka (komentuje svou zpětnou vazbu): Já nevím, jestli to, co tady říkám Milada akceptuje, já to nevidím jako kritiku, ale spíš rady, které si člověk v praxi stejně hledá sám, ale možná je na to připravenější. (2. rozhovor)

Milada: Já si myslím, že mně nedochází spousta věcí, takže je dobré, když to zmíníte, protože to jsou fakt detaily si je uvědomovat, kdyby to paní učitelka neřekla, tak si to neuvědomuju, dokud se problém nevyskytne. (1. rozhovor)

Cvičná učitelka: [skočí do řeči] Mě to předtím nenapadlo to využití těch šikovných [v dřivějš̌́ době] a měla jsem pořád pocit, že teda budu dávat práci navíc [žákům, kteří skončili řešení úkolu dříve] a zase jsem se dostávala pořád do té situace, až už to bylo neudržitelné. Nakonec jsem viděla, s jakou chutí chodí po té třídě a pomáhají a že to má fakt $i$ ten dopad. ... A oni někdy, když jsem to dělala, tak oni si dokonce volali \{důraz\} toho člověka, že ani nestíhal běhat, e, jo, že byl fakt, jako že chtěli tu radu a ještě to s ním prodiskutovat takže, takže má to svoje plus. Samožrejmě se to zas nemůže dělat pořád, potřebujeme ty nadané trochu posunout, takže občas nějakej ten úkol navíc, nějaká zapeklitěǰ̌í úloha jakoby prémiová pro ně nachystaná, taky samozřejmě má smysl, ale je to jedna z možností. (1. rozhovor)

Milada: Mně přijdou, jakože některé děti, že mají problém s učitelem, že se ho jako bojí. (2. rozhovor)

Na konci tohoto rozhovoru cvičná učitelka zmíní situaci, která nastala v závěru hodiny a kterou hodnotí pozitivně: Milada vysvětlovala učivo, žáci vysvětlení neporozuměli. Jeden žák si spontánně stoupl před třídu a začal vysvětlovat spolužákům učivo.

Milada [vybavuje si své dř́ivěǰsí zkušenosti]: Mně se to líbí, když se to vysvětluje jakoby navzájem, mně to přijde takový přrirozeněǰsí, ale myslím, že jsou některé děti, které mají třeba problém s učitelem, že se ho bojí, takže si to raději vysvětlí mezi sebou. [Pokračuje, vrací se k situaci, kterou cvičná učitelka zmínila.]: ... což neplatí u sedmé cé, tam ostych neměli. Tak se mě líbilo právě, že jeden ten kluk jakoby přišel a fakt to začal vysvětlovat, že se vžil do té situace - že by vysvětloval. Tak jakoby úplně jasně, jednoduše začal: „Jste úplně blbí, a to nechápete." Mně to přišlo takový hezký, protože já jsem si říkala, jak jim to mám vysvětlit sama a ted'ka on spustí a řekne jim, co bych si asi nedovolila jim říct. Nedovolila bych si jim říci, když vysvětluju nové učivo, vy jste blbí. (3. rozhovor)

Po měsíci se výzkumník vrátil k tomuto tématu v rozhovoru s Miladou.

Výzkumník: Jak pracujete s různorodou tř́́dou?

Milada: To záleží, jestli je to opakování nebo vysvětlování učiva.

Výzkumník: Tak třeba vysvětlování učiva.

Milada: Já si myslím, že v tomhle př́ípadě můžeme využít jako by těch nadanějších, aby oni sami vysvětlili nové učivo těm dalším, a potom to shrnu třeba pro ostatní. (4. rozhovor, Milada).

Poslední rozhovor s Miladou proběhl po čtyřech měsících.

Výzkumník: S čím jsi souhlasila, co ti řekla všechno cvičná učitelka na praxi?

Milada: ... Tam asi bylo třeba takové to zapojování do výuky těch silnějších, aby pomáhali slabším žákům. (5. rozhovor)

Předpokládáme, že u cvičné učitelky pozorující Miladu v uvedené problematické situaci došlo k zexplicitnění jejích zkušeností a tacitních znalostí spojených s podobnými situacemi, a to ve 
formě doporučení, jak třídu lépe zaměstnat a využít „šikovnějších“ žáků k tomu, aby pomohli spolužákům, kteří jsou pomalejší v řešení. V komentáři cvičné učitelky se objevuje důležité upozornění na to, že v praxi bude Milada sama hledat, jak si poradit v neočekávané nebo obtížnější situaci, doporučení ji však může pomoci se v situaci zorientovat. Svoje doporučení pak podrobněji zdůvodňuje. Milada doporučení akceptuje, uvědomuje si, že jí pomáhá k nalézání alternativních řešení situací. Miladě se při tom vybavila dřívější zkušenost, kterou explicitně vyjádřila.

Cvičná učitelka pokračuje v komentáři k Miladině hodině a pozitivně hodnotí situaci, kdy jeden žák začal vysvětlovat učivo spolužákům. Milada se vrací ke své zkušenosti, že jsou děti, které se učitele „obávají“, bojí se ho například na něco zeptat. Pokud tomu tak není, líbí se jí, jak žák vysvětluje učivo ostatním. Toto téma zřejmě Milada považuje za závažné, nebot' se k němu vrací v rozhovorech s výzkumníkem.

\section{Druhé téma: zdi̊razňování důležitých poznatki̊ na tabuli}

Cvičná učitelka si všimla v pozorované hodině, že Milada ve svém zápise na tabuli graficky nezdůrazňuje nadpisy a důležitá fakta a nekontroluje, jak si žáci tyto informace zapisují do sešitů.

Cvičná učitelka: Takže tu definitivní odpověd' musíš jakoby zdůraznit, aby oni to v tom sešitě měli. Kdyby se pak učili doma, aby věděli, co se dělalo. Oni jsou to šestáci. At’ to má hlavu a patu.

Milada: Jo, ti k tomu ještě nedochází. (1. rozhovor)

Cvičná učitelka [jako by se obracela $\mathrm{k}$ žákům] ilustruje svoje doporučení názorně: Jo, to se vám krásně dařilo, ale nemusíte si to pamatovat vždycky, tak ted' to umíte. Pojd'me, zapíšeme si to a počkat a udělat $\mathrm{z}$ toho nadpisu a $\mathrm{z}$ toho rámečku udělat jakoby fakt. Vezměte si pastelky a jedem... [vrací se $\mathrm{k}$ hodnocení Milady] ... a to tam tak splynulo a pak se ti i stalo, že jsi tam ten vzoreček, napsalas, ten povrch, a vzoreček jsi pak možná doplnila $\mathrm{v}$ rámci př́kladu, ale měl by tam svítit.

Milada: No, ten zápis, mně to pořád nedochází. (2. rozhovor)

Téma je znovu evokováno ve třetím rozhovoru:

Výzkumník: Je ted' něco jinak?

Milada: Zdůrazňovat možná ty príklady, aby žáci měli přehled. To jsme se bavily předtím jakoby trošku mít ten pořádek na tabuli, možná systematičnost, důslednost. Napsat jasné konkrétní řešení, aby věděli, co se dělalo.

Cvičná učitelka [vstupuje do rozhovoru]: Jde jenom o to, že možná ty méně šikovní se nezorientují a z toho máte problém, že když tam dá učitel něco náročnějšího, a má tam moc těch čísel na tabuli, je to nepř́ijemné. ... Fakt to pohlídat, aby to děcka nepsaly nějak do mezer. Takže řeknu, máte všichni a smažem, ale to se stává i mně, jakoby vykládám, počmárám a ted’ si vzpomenu a vmačkám tam nějaký rožek. Jakoby šikovní to sledují, protože mě sledují pořád a někdo se nedívá a ted' zvedne oči a vůbec netuší, kde seš v kterém místě tabule. Stává se to, ale taky na to musím myslet, pak nějak zvýrazňuji a buším do tabule na místě, kde se mají koukat. 
I v tomto príípadě formulovala cvičná učitelka na základě pozorování Miladiny hodiny explicitní doporučení na základě svých zkušeností a zrrejmě i tacitních znalostí. Milada si uvědomuje obsah tohoto doporučení. Toto uvědomění si dané situace se později prohloubilo. Miladina výpověd' vyvolala u cvičné učitelky rozvinutí jejích dalších zkušeností a zřejmě i tacitních znalostí.

Po půl roce se téma znovu vynořuje ve čtvrtém rozhovoru výzkumníka s Miladou.

Výzkumník: Kterou situaci byste vybrala, ze které jste se poučila?

Milada: To jsem možná taky někde zmínila. Zápisy do sešitu, kontrolovat nadpisy, že to není samozřejmé, aby $\mathrm{v}$ tom měli trošku přehled.

V závěru souvislé praxe pořídila výzkumnice videozáznam Miladiny pokročilejší výuky. Ukázalo se, že doporučení cvičné učitelky se promítlo do jednání Milady. Potvrdila to svými slovy v posledním rozhovoru: Kontrolovala jsem zápisy i nadpisy, protože jsem měla čas, ale nevím, jestli to budu dělat př́ště, protože v hodině byl na to prostor a nebyl žádný jiný problém s žáky.

Milada se toto své tvrzení pokusila vysvětlit: To je můj problém, protože mně to nikdy nevadilo, protože jsem měla př́stup, co měli moji vyučující, že prostě byla popsaná celá tabule, hlavně ve fyzice a matice [Miladina zkušenost ze střední školy]. Prostě vždycky se to psalo do nějakého rožku. A došlo misto, tak se skočilo do jiného rožku a mně to přišlo kreativní a vtipné. Pokud žáci učitele sledují. ... Fakt jsem hodně narazila tady na pedagogické fakultě, že jsme byli nuceni psát úhledně. Mně to přšlo zbytečný, že žák pokud chce, tak jakoby to vnímá. Ale zároveň potom jsem si uvědomila, že když tohle budu dělat jako učitel, tak to prostě nejde, protože jsou to ještě malý děti ... Pokud ti žáci mají opravdu jako zájem, tak jsou schopni sledovat, prostě je rưzný složení třídy, někteři mají dyslexii, pro ně je to potřebné, aby měli ten text. A myslím, to jsem si uvědomila v těch hodinách, že to nejde, když vidím prázdný sešit, že nikdo nic nemá, to nejde. V další části rozhovoru Milada dodala: Je možné, že se může stát, že budu mít dalši hodiny a neudělám to, protože si to musím uvědomit, že ty dèti to potřebují. Může být i jiný problém s žáky nebo něco jiného a já nebudu mít čas. Nedojde mi to, dokud to nemám zažitý. 
Milada si uvědomila, že její zápis na tabuli by měl být přehledný a že je žádoucí kontrolovat zápisy žáků v sešitě. Stále však u ní přetrvává zkušenost ze střední školy, kde někteří učitelé psali na tabuli tam, kde bylo místo, přesto, že ví, že učitel by to neměl dělat. Paradoxně však připouští, že se jí to v některé z dalších hodin může stát.

\section{Třetí téma: udržení pozornosti žáků}

Milada: Klára a Sabina si psaly psaníčka a nevím, jak mám na to reagovat, jestli dávat př́ílady nebo vyvolávat $\mathrm{k}$ tabuli?

Cvičná učitelka [komentovala chování děvčat upozorněním, že procházejí pubertou. Potom pokračovala]: Nebo když neposlouchá [žák], tak se zeptám, řekni to ještě jednou a zase přitáhnu tu pozornost a udělám si křížek, ty jsi nevěděl, je to staré učivo.... Je to složité, protože když se zastavíme a řekneme, Františku, ty nedáváš zase pozor a víš, že nejsi úplně nejlepší a víš, že potom zase nebudeš vědět, a máte na to půl minuty. Když to tak ale uděláte třikrát, pak je to rozbourání vaší myšlenky o hodině, a je to ztráta jakoby pro všechny. (1. rozhovor)

Milada o slovech cvičné učitelky přemýšlí, což se projeví v následujícím rozhovoru.

Milada: Tak mě napadlo, a můžu jakoby říct že to neumí, že to nedokáže...?

Cvičná učitelka: Jakoby víš, můžeš, ale abys ho úplně neodrovnala. Třeba říct: dneska nemám dobrý pocit, čekala jsem, že to bude víc... jak jsme se bavily o tom klukovi z té šestky, ten to vyloženě potřebuje, třeba místo jedna mínus mu dát dva plus. On to těžko překusuje, ale je to pro něho výzva pro př́ššě, aby se zdokonalil. I potom vzhledem k postavení v tom kolektivu, pokud si myslí, že je perfektní, je strašně dobré ukázat, že to tak vždycky není, protože pro něho je to dobře a pro ostatní taky, protože oni si myslí, že to umí jenom on a my toho nedosáhneme jakoby. (2. rozhovor)

K této problematice se vrátila Milada i v závěrečném rozhovoru s výzkumníkem po souvislé učitelské praxi 3: Já jsem si vzpomněla, že paní učitelka řikala, že můžeme žákovi řict, že něco nedovede, pokud ty žáky zná a já si myslím, že s tím nemohu souhlasit. ... Já si myslím, že děti jsou vnímavé, protože neznám prostředí, odkud děti vychází, a myslím si, že je to jedna z věcí, která se jich může dotknout a může se to promítnout dál, ... setkala jsem se s tím... Mám třeba známého, který vystudoval s červeným diplomem [...] učitel na základní škole mu řekl $v$ určitém předmětu nějakou věc, která se ho dotkla a od té doby ho ten předmět přestal jakoby úplně bavit, a pritom by byl schopný to někam dotáhnout, měl k tomu jakoby buňky a všechno, takže z toho di̊vodu mám tento názor.

Milada položila - na základě své zkušenosti z hodiny - dotaz cvičné učitelce: jak zareagovat v situaci, když žáci nedávají pozor. Tato otázka vyvolala u cvičné učitelky doporučení, opět na základě jejích zkušeností. Doporučení Milada do určité míry akceptovala. Současně však u ní vyvolalo otázku, zda lze otevřeně žákovi říci, že něco nedovede. Miladina otázka byla pro cvičnou učitelku podnětem k doplňujícímu vysvětlení své odpovědi. Toto doplnění však 
vyvolalo u Milady nesouhlasný názor. Lze předpokládat, že toto doporučení cvičné učitelky Milada v nejbližším období ve své výuce neuplatní.

\subsection{Shrnutí výsledků a závěr}

V průběhu učitelské praxe sdílely Milada i zkušená cvičná učitelka tacitní i explicitní znalosti. Výzkumně jsme se zaměřovali na sdílení, které vycházelo z pozorování vyučovacích hodin Milady cvičnou učitelkou. Na pozorování Miladiny hodiny reagovala cvičná učitelka svým komentářem. V něm vyjadřovala explicitní doporučení k těm situacím (místům v hodině), které se jí jevily jako problematické. Tato doporučení, adresovaná Miladě, formulovala na základě svých dlouholetých zkušeností. Pokud vyjdeme z předpokladu, že ze zkušeností se vytvářejí tacitní znalosti, můžeme říci, že explicitně formulovaná doporučení cvičné učitelky představují její zexplicitněné tacitní znalosti. O doporučeních vedla cvičná učitelka s Miladou diskusi. V ní si Milada vyjasňovala svá stanoviska k daným tématům, a to na základě svých předchozích zkušeností, kdy byla žačkou na základní a zejména střední škole, a do určité míry i zkušeností z učitelské praxe. Tím zároveň vyjadřovala svá stanoviska k doporučením cvičné učitelky. Pokusme se nyní odpovědět na položené výzkumné otázky.

\section{Jak probíhá sdílení tacitních znalostí Milady s cvičnou učitelkou?}

Do procesu sdílení vstupovaly Milada i cvičná učitelka s rozdílnými tacitními znalostmi rozdílnými zejména svým rozsahem a mírou propojenosti a stability (tabulka 11).

Tabulka 11

Předpokládaná vstupní úroveň tacitních znalostí Milady a cvičné učitelky

\begin{tabular}{|l|l|l|l|}
\hline Tacitní znalosti & Rozsah & Míra propojenosti & Míra stability \\
\hline Milada & Malý & nízká & $\begin{array}{l}\text { nízká, TZ jsou } \\
\text { křehké }\end{array}$ \\
\hline Cvičná učitelka & Velký & vysoká & vysoká \\
\hline
\end{tabular}


Uvedená předpokládaná rozdílnost tacitních znalostí u Milady a cvičné učitelky nás vedla $\mathrm{k}$ volbě modelu sdílení, $\mathrm{v}$ němž můžeme rozlišit tyto fáze:

a) opakované pozorování Miladiny výuky cvičnou učitelkou; cílem pozorování bylo: poznat úroveň učitelských zkušeností a znalostí Milady a detekovat v Miladiných hodinách místa, která považovala cvičná učitelka za problémová, pro Miladu zatím náročná;

b) zexplicitnění tacitních znalostí cvičné učitelky, vyvolané detekovanými problémovými místy v Miladině hodině, a to ve formě metodických doporučení;

c) pochopení doporučení Miladou;

d) přijetí/nepřijetí doporučení Miladou;

e) eventuální vyzkoušení doporučení Miladou a začleňování takto utvářených získaných prvků tacitních znalostí do její znalostní báze.

Úrovně sdílení explicitně vyjádřených doporučení cvičné učitelky s Miladou podává tabulka 12.

\section{Tabulka 12}

Úrovně sdílení zexplicitněných tacitních znalostí cvičné učitelky Miladou

\begin{tabular}{|l|l|l|l|}
\hline Téma & \multicolumn{1}{|c|}{$\begin{array}{c}\text { Úroveň 1 } \\
\text { Pochopení principu } \\
\text { doporučení cvičné } \\
\text { učitelky Miladou }\end{array}$} & $\begin{array}{c}\text { Úroveň 2 } \\
\text { Uvědomění si } \\
\text { potřeby uplatnit } \\
\text { doporučení ve } \\
\text { výuce }\end{array}$ & $\begin{array}{c}\text { Úroveñ 2 } \\
\text { Uplatnění } \\
\text { doporučení } \\
\text { v Miladině výuce }\end{array}$ \\
\hline Téma 1 & ano & ano & ano \\
\hline Téma 2 & ano & ano & $\begin{array}{l}\text { ano, ale zřejmě ne } \\
\text { vždy }\end{array}$ \\
\hline Téma 3 & ano & ne & ne \\
\hline
\end{tabular}

Zexplicitnění tacitních znalostí cvičné učitelky bylo reakcí na to, co viděla ve vyučovací hodině Milady. K zexplicitnění vedly také Miladiny dotazy (v tématu 3). Metodická doporučení jsou zpětnou vazbou cvičné učitelky na Miladino jednání ve vyučovací hodině. Není to ani kritika, ani striktní instrukce, jak v dané situaci postupovat (viz 2. rozhovor, cvičná učitelka $\mathrm{v}$ 1. tématu).

Některé momenty svého jednání $\mathrm{v}$ pozorovaných vyučovacích hodinách si Milada neuvědomovala (viz 1. rozhovor v 1. tématu). Předpokládáme, že pokud by cvičná učitelka 
neupozornila Miladu na problematická místa v její vyučovací hodině, mohly by se u ní utvářet méně vhodné (či méně užitečné) tacitní znalosti. Sdílení tedy plní vedle funkce zpětnovazební také funkci preventivní.

\section{Co a jak se sdíli?? Mění se něco v průběhu sdílení?}

Z předcházející části kapitoly je zřejmé, že jsou sdíleny pedagogické, zejména didaktické tacitní znalosti. V procesu sdílení je startovacím bodem pozorování jednání Milady v její vyučovací hodině cvičnou učitelkou. Pokud objevila cvičná učitelka (v souladu se svými zkušenostmi) problematické místo v hodině, upozornila na něj v navazujícím rozhovoru Miladu a připojila metodické doporučení. Doporučení se stalo východiskem přemýšlení Milady o tom, co a jak v hodině dělala a jak by se to mohlo dělat jinak. Snažila se doporučení porozumět, popř́ipadě jej vyzkoušet a potom jej bud' přijmout, nebo nepřijmout.

Co se v průběhu sdílení měnilo? Na tuto otázku odpovíme jen částečně, protože nemáme $\mathrm{k}$ dispozici všechna potřebná data. Pozorovali jsme, že v průběhu učitelské praxe (a tedy i výzkumu) se na sebe Milada i cvičná učitelka vylad'ovaly. Vylad’ování bylo založeno na vzájemné důvěře a ochotě naslouchat jedna druhé. Docházelo k hlubšímu vzájemnému porozumění. V průběhu sdílení při pozorování a rozhovorech cvičná učitelka poznávala Miladu, a tím patrně citlivěji reagovala nejenom na problematická místa v její hodině, ale i na její utvářející se vyučovací styl.

Popsaný kvalitativní výzkum poodhalil pouze některé aspekty sdílení tacitních znalostí studentky učitelství Milady s cvičnou učitelkou. Ukázal na jednu stránku sdílení: na sdílení zexplicitněných tacitních znalostí cvičné učitelky, které byly reakcí na jednání Milady v pozorovaných vyučovacích hodinách. Nezkoumali jsme druhou, neméně zajímavou stránku sdílení, zahrnující vzájemná pozorování vyučovacích hodin Milady a cvičné učitelky a navazující diskuse o pozorované výuce. To považujeme za jeden z hlavních limitů našeho výzkumu. 


\section{Závěr Vlastimil Švec}

Monografie je výsledkem teoretického a empirického bádání směřujícího k vyjasnění pojmu tacitní znalosti (a to na kontinuu tacitní - explicitní) a k hledání odpovědi na otázku, jak se studenti učitelství pohybují na tomto kontinuu v průběhu reflexe své učitelské praxe. Je z ní zřejmé, že empirický výzkum bylo možné zahájit až po vyjasnění klíčového pojmu tacitní znalosti. To vyžadovalo hlubší studium nejenom pedagogických a psychologických, ale také filozofických pramenů a četné diskuse členů výzkumného týmu - autorů monografie. Toto teoretické bádání však pokračovalo i v průběhu přípravy, realizace a vyhodnocování výsledků empirických sond. Takto se, mimo jiné, dotvářela první kapitola a současně se zpřesňovala teoretická a metodologická východiska připravovaných výzkumů. Z první kapitoly čerpali autoři empirických kapitol také při analýze dat a jejich interpetaci. Užitečné bylo, že si navzájem četli a připomínkovali texty svých kapitol.

Jestliže jsme Úvod věnovali převážně teoretickým a filozofickým východiskům výzkumu tacitních znalostí, v Závěru se pokusíme alespoň nastínit některé možnosti využití výsledků (nejen) empirických kapitol v praxi, tedy ve vzdělávání studentů učitelství. Konec konců naše teoretické a empirické bádání se také orientovalo na požadavek zkvalitnit učitelské praxe studentů učitelství. ${ }^{114}$ Nepůjde však o konkrétní metodická doporučení, ale spíše o podněty k přemýšlení vzdělavatelů budoucích učitelů o tom, jak vytvářet v průběhu učitelských praxí podmínky pro kultivaci tacitních znalostí studentů učitelství.

Nejdříve k čistému dotazování a metaforám, jejichž problematika tvoří důležitou část monografie. Čisté dotazování je využitelné nejenom při výzkumech studentova (učitelova) myšlení a jednání, ale také v průběhu učitelských praxí. Umožňuje totiž vzdělavateli odhalit studentovy doposud skryté osobní předpoklady, jeho myšlení i okolnosti jeho jednání ve

\footnotetext{
${ }^{114}$ Podrobněji o této problematice (zejména o průběhu praxí a některých pohledech na faktory, které ovlivňují jejich účinnost) pojednává monografie - Švec, V., Svojanovský, P., \& Pravdová, B. (2016). Determinanty účinnosti učitelských praxí. Brno: Masarykova univerzita.
} 
vyučovacích hodinách. Technika čistého dotazování se zdá být poměrně jednoduchá, ale její tvořivá aplikace vyžaduje porozumění a zkušenosti (podrobněji viz kapitolu 3, případně kapitolu 5).

Metafory jsou „mostem“, který umožňuje propojení mezi tacitní a explicitní dimenzí znalostí. Vyskytují se často $\mathrm{v}$ (sebe)reflexích studentů a při sdílení jejich zkušeností $\mathrm{s}$ cvičným učitelem. Umožňují rozvíjet reflektivní myšlení studentů (Švec, 1999, s. 82). Lze je považovat za předstupeň utváření pedagogických pojmů. Pokud pozorně a empaticky nasloucháme studentovým metaforám, může se nám podařit usoudit, jak student rozumí svým zkušenostem, jak je interpretuje a označuje. Metaforické myšlení může doplňovat logické myšlení.

„Toto metaforické myšlení není tedy čistým logickým myšlením, ale myšlením, které je provázeno a obohacováno intuitivními vhledy, pohledy a objevy podobnosti, které přinášejí invenci, mají fantazii i kognitivní hodnotu. Jinak řečeno, metafora může mít klíč od dveří ,třinácté komnaty', kam př́isně logické myšlení nemůže vstoupit bez jejího doprovodu.“ (Stachová, 1993, s. 301)

Metafory mohou usnadnit zexplicitnění tacitních znalostí (viz kapitolu 7).

Jednou z významných proměnných, které vstupují do procesu utváření tacitních znalostí je studentovo pojetí výuky. Potvrzuje se, že samo toto pojetí má tacitní charakter. Studenti vstupují na učitelské praxe na škole s určitým, byt' obvykle nevyhraněným pojetím. Studentské pojetí se praxí postupně mění. K jeho změně dochází tehdy, jestliže si student na základě reflexe svých zkušeností uvědomí, že například jeho postup ve vyučovací hodině nezabírá. ${ }^{115}$ Zjistili jsme, že k nastartování postupné změny studentova pojetí výuky (respektive jeho složky) vede obvykle až opakovaná reflexe jeho určitého jednání. Považujeme proto za užitečné, aby v průběhu učitelské praxe vzdělavatel (cvičný učitel ve škole, pedagog, psycholog a oborový didaktik na fakultě) poznával studentovo pojetí výuky (např. rozhovory založenými na čistém dotazování) a aby také studenti učitelství prostřednictvím těchto rozhovorů a sebereflexe si svoje pojetí uvědomovali, a to v souvislosti se svým jednáním. Například při reflexi opakovaného způsobu svého jednání ve vyučovací hodině si student může položit otázku typu: „Co mne k tomuto opakovanému jednání vede?““

\footnotetext{
${ }^{115} \mathrm{~V}$ textu monografie se často objevují termíny reflexe a sebereflexe. Jde o termíny často používané v pedagogické teorii a praxi. Proto jejich teoretické pozadí nepřibližujeme v samostatné kapitole. Zájemce o tuto problematiku odkazujeme na novějš́ studii Svojanovského (2014).
} 
Studenti vstupují na učitelské praxe také s určitými pedagogickými, psychologickými a oborově didaktickými znalostmi. Tyto, většinou explicitní, znalosti představují pro studenty informační oporu zejména při plánování a realizaci vyučovacích hodin. Studenti se pomocí nich orientují především při projektování pedagogických situací, které plánují realizovat v připravované vyučovací hodině (např́iklad jak zahájí hodinu, jak se pokusí žáky motivovat, jak hodinu strukturovat a které výukové metody uplatnit apod.). Realizace projektovaných situací (které tvoří osu studentova plánování) závisí na řadě faktorů, mimo jiné na tom, jak student zná třídu, ve které má vyučovat, jakými pedagogickými zkušenostmi již disponuje, jak kvalitně probíhá komunikace s cvičným učitelem atd. V optimálním př́padě se plán jednání studenta (jeho představa) může $\mathrm{v}$ mnoha ohledech shodovat $\mathrm{s}$ jeho reálným uskutečněním $\mathrm{v}$ hodině. $\mathrm{V}$ řadě př́padů však musí student svi̊j plán modifikovat, popř́ípadě zcela změnit, a to zejména $\mathrm{v}$ neplánovaných, neočekávaných situacích (o nich podrobně v kapitole 9 ).

V průběhu učitelských praxí u studentů dochází k tacitnímu učení. Tacitní učení je učením, při němž se student učí méně uvědomovaně (nebo dokonce nevědomě) ze svého jednání v pedagogických situacích, které vznikají ve vyučovacích hodinách. Probíhá v dynamickém poli student učitelství - žáci ve třídě. Své jednání student (to, co dělal a jak reagovali žáci) prožívá $s$ různou intenzitou emocí, a to jak přímo v hodině, tak i po jejím skončení. Je žádoucí, aby toto své jednání student reflektoval bezprostředně po hodině (za podpory cvičného učitele) i s časovým odstupem (na fakultě se vzdělavatelem - pedagogem, psychologem - v semináŕích, které se k učitelské praxi vztahují, ale také s cvičným učitelem, který má možnost vidět studenta v různých hodinách a tak posoudit, jak se jeho tacitní znalosti vyvíjejí).

Tacitní učení není jednorázovou záležitostí (realizovanou např́klad v jedné vyučovací hodině), nýbrž probíhá opakovaně, i když v různé míře) na kontinuu tacitní - expliciní. Na př́kladu Jaroslavy (viz kapitolu 10) jsme viděli, jak se pomalu a postupně ve více hodinách utvářela (na základě jejích reflexí) jedna z klíčových didaktických dovedností - výběr, strukturování a „dávkování“ učiva v komunikaci se žáky.

V některých empirických sondách jsme dospěli k poznání, že studenti při řešení zejména náročnějších a neočekávaných situací experimentují. Při experimentování neuplatňují techniku „pokus - omyl“, ale zkoušejí různá řešení (často přímo v hodině) a zakoušejí jejich důsledky. Zkušenosti z řešení pedagogických situcí sdílejí studenti se cvičným učitelem. 
Sdílení tacitních i explicitních znalostí mezi cvičným učitelem a studentem lze považovat za jednu z hlavních aktivit realizovaných v průběhu učitelských praxí. $Z$ jedné naší výzkumné sondy (v prŕpadě Jaroslavy, viz kapitolu 10) vyplynulo, že nekvalitní (nedostatečné, povrchní) sdílení ze strany cvičného učitele znesnadňuje studentům př́ípravu na vyučovací hodiny a sebereflexi jejich jednání. Sdílí se obvykle to, co a jak se odehrává ve vyučovacích hodinách studenta a cvičného učitele. Tedy to, co pozoruje cvičný učitel ve studentově hodině, a to, co vidí student v hodině cvičného učitele. Rozdíl spočívá v tom, že učitelovy zkušenosti i tacitní znalosti jsou vyzrálejší než zkušenosti studenta na praxi. Proto smyslem sdílení není jen popsat to, co se v hodinách dělo, ale zejména porozumět tomu, co je za pozorovaným jednáním.

Ve výzkumné sondě (kapitola 11) je ukázána jedna z dimenzí sdílení - pozorování a komentování vyučovacích hodin studentky učitelství cvičnou učitelkou. Cvičná učitelka se pokusila analyzovat studentčinu činnost $\mathrm{v}$ hodině $\mathrm{z}$ její perspektivy, tedy $\mathrm{z}$ hlediska jejích dosavadních zkušeností i možností. Identifikovala v její činnosti důležité klíčové situace, které považovala za důležité pro její další pedagogickou činnost, např́íklad problematické zvládání organizace činnosti žáků, nedokonalé použití určitých postupů, neadekvátní volbu metody vzhledem k charakteru učiva apod. Popis a analýza těchto situací mohou vést k hlubší sebereflexi studenta a k jeho dokonalejšímu jednání. ${ }^{116}$

(Sebe)reflexe hraje významnou úlohu v procesu sdílení (nejen) tacitních znalostí. Doporučení cvičného učitele jsou jistě užitečná, avšak pro změnu studentova jednání je nutné vědomě a do hloubky toto jednání reflektovat. Tak si totiž student učitelství může uvědomit, jaké změny ve svém jednání by měl uskutečnit (Hrbáčková, 2005, s. 67).

\footnotetext{
${ }^{116}$ Hlubši sebereflexí rozumíme reflexi, při níž si student (postupně) uvědomuje stále více okolností, které mohly ovlivnit jeho jednání ve vyučovací hodině, v konkrétních pedagogických situacích.
} 


\section{Summary}

The book focuses on the issue of tacit knowledge, specifically in connection with student teachers. It summarizes the current view of (tacit) knowledge in philosophy, educational science, and research and challenges our understanding of this complex concept. Drawing on this, a series of research studies exploring the tacit dimension of student teachers' knowledge is presented. These studies tackle various aspects of the tacit dimension of knowledge and together provide a multifaceted view of this concept. The book aims at educational researchers in the field of teacher research as well as teacher educators who are interested in the content and process of creation of student teachers' tacit knowledge. We hope that the book will be of interest to a wider audience, too, as it discusses broader issues of the philosophy of knowledge and research on knowledge.

The theoretical part of the book opens with a detailed analysis of philosophical background of our understanding and study of (tacit) knowledge. (Early) modern paradigm is analysed and contrasted with current findings of neuroscience. Different understandings of the concept of knowledge are introduced, together with their origins and limitations. The first chapter leads us to conceptualizing knowledge not as isolated items in individual minds but as a dynamic interplay between the individual, other individuals and their whole environment (a unified field where perceived borders are no longer relevant or feasible).

Following this understanding of knowledge, the second chapter discusses the embodied nature of knowledge and language - and specifically metaphors. Metaphors are in this book understood as one of the ways of approaching the "tacit". This chapter thus provides a solid theoretical background to understanding metaphors and to their use in research. The third chapter ties to this and introduces a relatively new method of data collection that enables us to uncover people's understanding of the world around them, including their tacit knowledge. "Clean language" as an interview method aims to diminish the influence of the interviewer on the interviewee and helps explore their experience from their perspective - including exploring their metaphors (by avoiding “contamination" by the interviewer's metaphors).

Chapters four and five introduce the actual methodology of the presented research, focussing mainly on the research sample and the data collection that was common for all the 
studies presented later on. Clean language interview technique is described in detail together with an analysis of the actual interviews conducted as a part of our research, indicating their “cleanness" rating (i.e. how "clean" and (non)leading the interviews were).

The next part of the book opens with an overview of current empirical research on teachers' tacit knowledge. Chapter six reviews such research and summarizes the prevailing conceptualizations of tacit knowledge, research methods used and findings obtained.

Next, an example of the process of a concrete item of tacit knowledge becoming explicit is described. Phases of this process, namely metaphorisation-finding the literal meaning and reverse metaphorisation, are discussed. Following this, individual studies that were a part of the overall research project are introduced, each of them stating their aims and data analysis methods applied.

The first study focuses on student teachers' beliefs about pupils and educational content. Despite the fact that the research sample was homogenous in terms of the students' year of study and amount of compulsory teaching practice, the study shows that both the content of these student teachers' beliefs and their concreteness and explicitness/tacitness are highly individual. Their beliefs and tacit knowledge strongly influence how they behave during teaching practice, and especially in unexpected teaching situations. This is why this context is the focus of the next study. It provides a typology of unexpected situations and, based on our data, discusses how student teachers experience them and react to them. Being in unexpected situations and dealing with them helps student teachers create and develop their tacit knowledge. It is this process of tacit knowledge creation throughout teaching practice that is the main theme in chapter ten. In a case study, specific aspects of a student teacher's tacit knowledge are uncovered together with their origin. The last empirical chapter further develops this theme, this time focussing on the process of sharing tacit knowledge between a student teacher and her mentor during teaching practice. This case study explores both the content and the process of sharing.

The book closes with a synthesis of the theoretical considerations and concrete empirical findings of the research project. Practical implications for teacher education are discussed and critically analysed. 



\section{Seznam zkratek}

DNA deoxyribonukleová kyselina

GIM Grammar-targeted interview method (na gramatiku zacílená metoda vedení rozhovoru)

GPS globální polohový systém

fMRI funkční magnetická rezonance

IPA Interpretative phenomenological analysis (interpretativní fenomenologická analýza)

MK metaforická krajina

MCA Meaning constitution analysis (analýza konstituce významů)

PVC polyvinylchlorid

SES Social engagement systém (systém sociálního zapojení)

SPV studentovo pojetí výuky

TZ tacitní znalosti

ZN zrcadlové neurony 


\section{Literatura}

Adloff, F., Gerund, K., \& Kaldewey (2015). Locations, translations, and presentifications of tacit knowledge. In F. Adloff, K. Gerund, \& D. Kaldewey (Eds.), Revealing tacit knowledge (s. 7-17). Bielefeld: Transcript Verlag.

Aitchison, J. (1987). Words in the mind: An introduction to the mental lexicon. Oxford, UK: Blackwell.

Akbari, M. (2013). Metaphors about EFL teachers' roles: A case of Iranian Non-Englishmajor students. International Journal of English Language \& Translation Studies, 1(2).

Anderson, H., \& Gehart, D. R. (2007). Collaborative therapy and beyond: Bridging the gap between theory and practice. New York: Routledge.

Angelides, P. (2001). Using critical incidents to understand school cultures. Improving Schools, 4(1), 24-33.

Aristotelés. (1999). Rétorika / Poetika. Praha: Petr Rezek.

Axelsenová, D. (2012). Metafora v anglických pracích Erazima Koháka. In E. Kohák \& J. Trnka, J. (Eds.), Hledání české filosofie (s. 339-349). Praha: Filosofia.

Barbaras, R. (2005). Touha a odstup. Praha: Oikoymenh.

Barlow, H. B. (1961). Possible principles underlying the transformations of sensory messages. In W. A. Rosenblith (Ed.), Sensory communication (s. 217-234). Cambridge, MA: MIT Press.

Barner, R. (2008). The dark tower: Using visual metaphors to facilitate emotional expression during organizational change. Journal of Organizational Change Management, 21(1), 120137.

Barsalou, L. W. (1999). Perceptual symbol systems. Behavioral and Brain Sciences, 22(4), 577-660.

Berger, P. L., \& Luckmann, T. (1999). Sociální konstrukce reality: pojednání o sociologii vědění. Brno: Centrum pro studium demokracie a kultury.

Berliner, D. C. (1995). Teacher expertise. In L. W. Anderson (Ed.), International encyclopedia of teaching and teacher education (s. 46-52). Oxford: Elsevier Science Ltd.

Bernet, R., Kern, I., \& Marbach, E. (2004). Úvod do myšlení Edmunda Husserla. Praha: Oikoymenh.

Bestmann, S., Harrison, L. M., Blankenburg, F., Mars, R. B., Haggard, P., Friston, K. J., \& Rothwell, J. C. (2008). Influence of uncertainty and surprise on human corticospinal excitability during preparation for action. Current Biology, 18(10), 775-780. 
Blakemore, S. J., Goodbody, S. J., \& Wolpert, D. M. (1998). Predicting the consequences of our own actions: the role of sensorimotor context estimation. The Journal of Neuroscience, 18(18), 7511-7518.

Bohm, D. (1992). Rozvíjení významu. Praha: Unitaria.

Borg, S. (2003). Teacher cognition in language teaching: A review of research on what language teachers think, know, believe, and do. Language teaching, 36(02), 81-109.

Bracha, H. S. (2004). Freeze, flight, fight, fright, faint: Adaptationist perspectives on the acute stress response spectrum. CNS Spectrums: The International Journal of Neuropsychiatric Medicine, 9, 679-685.

Brevik, L. M. (2014). Making implicit practice explicit: How do upper secondary teachers describe their reading comprehension strategies instruction? International Journal of Educational Research, 67, 52-66.

Brookfield, S. D. (1990). The skillfull teacher: On technique, trust, and responsiveness in the classroom. San Francisco: Jossey-Bass.

Butterfield, L. D., Borgen, W. A., Amundson, N. E., \& Malio, A. S. T. (2005). Fifty years of the critical incident technique: 1954-2004 and beyond. Qualitative Research, 5(4), 475-497.

Cacciari, C., Massironi, M., \& Corradini, P. (2004). When color names are used metaforically: the role of linguistic and chromatic information. Metaphor and Symbol, 19(3), 169-190.

Cairns-Lee, H. (2015). Images of leadership development from the inside out, Advances in Developing Human Resources 7(3), 321-336.

Calderwood, J. (2011). Pervasive media arts: Participation, practice and well-being. Paper presented at Well-Being 2011: First International Conference Exploring the Multidimensions of Well-being, 18-19 July. Birmingham City University and the Royal Institute of British Architects (RIBA). Dostupné z cleanlanguage.co.uk/articles/attachments/CalderwoodPervasive_Media_Arts_Participation_Practice_Well-being.pdf.

Carpenter, S. (2011). Body of thought: How trivial sensations can influence reasoning. Scientific American Mind, 21(1/2), 38-45.

Casasanto, D., \& Gijssels, T. (2015). What makes a metaphor an embodied metaphor?. Linguistics Vanguard, 1(1), 327-337.

Casasanto, D. (2008). Similarity and proximity: When does close in space mean close in mind? Memory \& Cognition 36(6), 1047-1056.

Casasanto, D., \& Bottini, R. (2014). Mirror reading can reverse the flow of time. Journal of Experimental Psychology 143(2), 473-479.

Cásková, K. (2014). Sdílení tacitních znalostí mezi studenty učitelství a jejich vzdělavateli v průběhu pedagogické praxe. In V. Švec (Ed.), Znalostní báze učitelství (s. 97-115). Brno: Masarykova univerzita. 
Clark, A. (2001). Mindware. An Introduction to the philosophy of cognitive science. New York, Oxford: Oxford University Press.

Clarke, A. (2005). Situational analysis. Grounded theory after the postmodern turn. Thousand oaks, London \& New Dehli, Sage.

Clemente, M., \& Ramírez, E. (2008). How teachers express their knowledge through narrative. Teaching and Teacher Education, 24, 1244-1258.

Collins, A., Holum, A., \& Brown, J. S., (1991). Cognitive apprenticeship: Making thinking visible. American Educator, Winter. Dostupné z http:// www.21learn.org/arch/articles/brown_seely.html.

Connell, N. A., Klein, J. H., \& Powell, P. L. (2003). It's tacit knowledge but not as we know it: Redirecting the search for knowledge. The Journal of the Operational Research Society, 54(2), 140-152.

Damasio, A. (1994). Descartes' error: Emotion, reason and the human brain. London: Vintage.

Damasio, A. (2010). Self comes to mind. Constructing the conscious brain. New York: Pantheon Books.

Davidson, D. (1998). O samotné myšlence pojmového schématu. In J. Peregrin (Ed.). Obrat k jazyku druhé kolo. Postanalytická filosofie USA (s. 109 -125). Praha: Filosofia.

Davidson, D. (2004a). Koherenční teorie pravdy a poznání. Post scriptum. In D. Davidson, Subjektivita, intersubjektivta, objektivita (s. 159-183). Praha: Filosofia.

Davidson, D. (2004b). Epistemologie a pravda. In D. Davidson, Subjektivita, intersubjektivta, objektivita (s. 207-218). Praha: Filosofia.

Davidson, D. (2004c). Tř́i druhy poznání In D. Davidson, Subjektivita, intersubjektivta, objektivita (s. 233-249). Praha: Filosofia.

Davidson, D. (2006). What metaphors mean. In D. Davidson, The Essential Davidson. Oxford (s. 209-224). New York: Claredon Press.

Debreli, E. (2016). Pre-service teachers' belief sources about learning and teaching: An exploration with the consideration of the educational programme nature. Higher Education Studies, 6(1), 116-127.

Derrida, J. (1993). Bílá mytologie. Metafora ve filosofickém textu. In M. Petř́íek, jr. (Ed.), Texty k dekonstrukci (s. 196-276). Bratislava: Archa.

Descartes, R. (2003). Meditace o první filosofii. Praha: Oikoymenh.

Dewey, J. (1992). The Collected works of John Dewey. L. A. Hickman (Ed.). Charlottesville VA: InteLex Corporation.

Dewey, J. (2012). Unmodern philosophy and modern philosohy. Carbondale: Souther Illinois University Press. 
Dieker, L. A., \& Monda-Amaya, L. E. (1997). Using problem solving and effective teaching frameworks to promote reflective thinking in preservice special educators. Teacher Education and Special Education, 20, 22-36.

Doyle, N., Tosey, P., \& Walker, C. (2010). Systemic modelling: Installing coaching as a catalyst for organisational learning, The Association for Management Education and Development-e-Organisations \& People, 17(4), 13 -22.

Dreyfus, H. L., \& Wrathall, M. A. (2006). A companion to phenomenology and existentialism. Malden (MA), Oxford, Carlton: Blackwell Publishing Ltd.

Elliott, J. G., Stemler, S. E., Sternberg, R. J., Grigorenko, E. L., \& Hoffman, N. (2011). The socially skilled teacher and the development of tacit knowledge. British Educational Research Journal, 37(1), 83-103.

Englander, M. (2012), The interview: Data collection in descriptive phenomenological human scientific research, Journal of Phenomenological Psychology 43, 13-35.

Eraut, M. (2000). Non-formal learning and tacit knowledge in professional work. British Journal of Educational Psychology, 70(1), 113-136.

Evans, K., \& Kersh, N. (2004). Recognition of tacit skills and knowledge: Sustaining learning outcomes in workplace environments. Journal of Workplace Learning, 16(1/2), 63-74. Dostupné z http://www.emeraldinsight.com/doi/full/10.1108/13665620410521521.

Fauconnier, G., \& Turner, M. (2008). The way we think: Conceptual blending and the mind's hidden complexities. New York: Basic Books.

Feryok, A., \& Pryde, M. (2012). Images as orienting activity: Using theory to inform clasroom practices. Teachers and Teaching: theory and practice, 18(4), 441-454.

Feyerabend, P. K. (2001). Rozprava proti metodě. Praha: Aurora.

Fiorillo C. D., Tobler P. N., Schultz W. (2003). Discrete coding of reward probability and uncertainty by dopamine neurons. Science, 299, 1898-1902.

Flanagan, J. C. (1954). The critical incident technique. Psychological Bulletin, 51(4), 327358.

Flavell, J. H. (1979). Metacognition and cognitive monitoring: A new area of cognitivedevelopmental inquiry. American Psychologist, 34, 906-911.

Flick, U. (2009). An introduction to qualitative research. London: SAGE Publications.

Foster, C. (2015). Exploiting unexpected situations in the mathematics classroom. International Journal of Science and Mathematics Education, 13(5), 1065-1088.

Foucault, M. (2000). Slová a veci. Archeológia humanitních vied. Bratislava: Kalligram.

Foucault, M. (2002). Archeologie vědění. Praha: Hermann \& synové. 
Franklin, D. V., \& Wolpert, D. M. (2011). Computational mechanisms of sensorimotor control. Neuron, 72(3), 425-42. Dostupné z http://learning.eng.cam.ac.uk/pub/Public/Wolpert/Publications/Franklin_Neuron_2011.pdf.

Frensch, P. A., Haider, H., Rünger, D., Neugebauer, U., Voigt, S., \& Werg, J. (2003). The route from implicit learning to verbal expression of what has been learned: Verbal report of incidentally experienced environmental regularity. In L. Jiménez (Ed.), Attention and implicit learning (s. 335-366). Amsterdam: John Benjamins Publishing Company.

Friston, K. (2010). The free-energy principle: a unified brain theory?. Nature Reviews Neuroscience, 11(2), 127-138.

Friston, K., Kilner, J., \& Harrison, L. (2006). A free energy principle for the brain. Journal of Physiology-Paris, 100(1), 70-87.

Fuller, F., \& Brown, O. (1975). Becoming a teacher. In K. Ryan (Ed.), Teacher education. 74th yearbook of the national society for the study of education, Part 2 (s. 25-52). Chicago: University of Chicago Press.

Gallagher, S. (2015). A neurophenomenology of awe and wonder: Towards a non-reductionist cognitive science. Basingstoke, Hampshire: Palgrave Macmillan.

Gallese, V., \& Lakoff, G. (2005). The brain's concepts: The role of senso-motor system in conceptual knowledge. Cognitive neuropsychology, 22, s. 455-479.

Gardner, A., Gánem-Gutiérrez, A., Scott, J., Horan, B., \& Callaghan, V. (2011). Immersive education spaces using open wonderland: From pedagogy through to practice. In G. Vincenti, \& J. Braman, Multi-user virtual environments for the classroom: Practical approaches to teaching in virtual worlds (s. 190-205). Hershey: Information science reference (an imprint of IGI Global).

Gardner, M., Gánem-Gutiérrez, G. A., Scott, J., \& Fowler, C. (2009). Designing and building immersive education spaces using project Wonderland: From pedagogy through to practice. In Immersive education workshop, 19-20 October 2009, University of Oregon.

Gartmeier, M., Bauer, J., Gruber, H., \& Heid, H. (2008). Negative knowledge: Understanding professional learning and expertise. Vocations and Learning, 1(2), 87-103.

Gascoine, N., \& Thorton, T. (2013). Tacit Knowledge. New York: Acumen.

Geary, J. (2011). I is another: The secret life of metaphor and how it shapes the way we see the world. New York: Harper.

Gendlin, E. T. (1997). Experiencing and the creation of meaning: A philosophical and psychological approach to the subjective. Evanston: Northwestern University Press.

Gergen, K. J. (1999). An invitation to social construction. London: Sage.

Gerstner, G. E., \& Goldberg, J. L. (1994). Species-specific morphology of masticatory jaw movements. Behaviour, 128, 229-253. 
Gholami, K., \& Husu, J. (2010). How do teachers reason about their practice? Representing the epistemic nature of teachers'practical knowledge. Teaching and Teacher Education, 26, $1520-1529$.

Gibbs, R. W. (2005). Embodiment and cognitive science. Cambridge, New York, Melbourne etc.: Cambridge University Press.

Gibbs, R. W., \& Macedo, A. C. P. S. D. (2010). Metaphor and embodied cognition. DELTA: Documentação de Estudos em Lingüistica Teórica e Aplicada, 26(SPE), 679-700.

Gibbs, R. W., Lima, P. L. C., \& Francozo, E. (2004). Metaphor is grounded in embodied experience. Journal of pragmatics, 36(7), 1189-1210.

Gibbs, R., \& Berg, E. (1999). Embodied metaphor and perceptual symbols. Behavioral and Brain Sciences, 22, 617-618.

Giorgi, A. (2009). The descriptive phenomenological method in psychology: A modified Husserlian approach. Pittsburgh: Duquesne University Press.

Glazer, E. M., \& Hannafin, M. J. (2006). The collaborative apprenticeship model: Situated professional development within school settings. Teaching and Teacher Education, 22, 179193.

Gordon, D. C. (1978). Therapeutic metaphors: Helping others through the looking glass. Cupertino, CA: Meta Publications.

Grondin, J. (1997). Úvod do hermeneutiky. Praha: Oikoymenh.

Gröppel-Wegener, A. (2015). Design tasks beyond the studio. In R. Vande Zande, E. Bohemia, \& I. Digranes (Eds), Proceedings of the 3rd International conference for design education researchers, 1 (s. 93-108), Aalto University. Dostupné

$\mathrm{z}$ reserachgatenet/publication/279182704.

Grove, D. J., \& Panzer, B. I (1989). Resolving traumatic memories: Metaphors and symbols in psychotherapy. New York: Irvington.

Haider, H., \& Frensch, P. A. (2005). The generation of conscious awareness in an incidental learning situation. Psychological Research/Psychologische Forschung, 69, 399-411.

Harland, P. (2012a). Trust me, I'm the patient. London: Wayfinder Press.

Harland, P. (2012b). The power of six a six part guide to self knowledge. London: Wayfinder Press.

Haron, H., \& Alias, R. A. (2005). Conceptualization of tacit knowledge dimension. In Proceedings of the Postgraduate Annual Research Seminar 2005 (s. 12-17).

Harrer, S. (2014). From loss and grief to game design: Working with the experience of bereaved mothers. CHIPlay 2014: Participatory design for serious game design. Dostupné z participatoryseriousgamedesign.com/wp-content/uploads/2014/11/Harrer_V3.pdf. 
Havel, I. M. (1999). Přirozené a umělé myšlení jako filosofický problém. In V. Mařík, O. Štěpánková, \& J. Lažanský (Eds.), Umělá inteligence III. (s. 17-75). Praha: Academia.

Helmholtz, H. (1860/1962). Handbuch der physiologischen optik 3. New York: Dover.

Henry, C. (1999). The role of reflection in student teachers' perceptions of their professional development, Art Education, 52, 14-20.

Heracleous, L. T., \& Jacobs, C. D. (2008). Crafting strategy: The role of embodied metaphors. Long Range Planning, 41(3), 309-325.

Hrbáčková, K. (2005). Podněty k autoregulaci procesu rozvoje implicitních pedagogických znalostí. In V. Švec (Ed.), Od implicitních teorií výuky k implicitním pedagogickým znalostem (s. 65-69). Brno: Paido.

Hroch, J., Šíp, R., Madzia, R., \& Funda, O. (2010). Pragmatismus a dekonstrukce v angloamerické filozofii. Brno: Paido.

Hurlburt, R. T. (2009). Iteratively apprehending pristine experience. Journal of Consciousness Studies, 16, 156-188.

Hurlburt, R. T. (2011). Investigating pristine inner experience: Moments of truth. Cambridge: University Press.

Hurlburt, R. T., \& Schwitzgebel, E. (2007). Describing inner experience? Proponent meets skeptic. Cambridge, MA: Mit Press.

Husserl, E. (1996). Krize evropských věd a transcendentální fenomenologie. Praha: Akademia.

Husserl, E. (2004). Ideje k čisté fenomenologii a fenomenologické filosofii I. Praha: Oikoymenh.

Husserl, E. (2006). Ideje k čisté fenomenologii a fenomenologické filosofii II. Praha: Oikoymenh.

Cho, Y. (2014). Critiquing research interviews from a CA perspective: Treating interview as social practice. ARECLS 11, 35-54.

Chomsky, N. (1996). Perspektivy moci. Praha: Karolinum.

Ihde, D. (2012). Experimental phenomenology. Multistabilities. Albany: State University of New York Press.

Ijzerman, H., \& G. R. Semin (2009). The thermometer of social relations, Psychological Science, 20, 1214-1220.

Jakob, H. (2013). The predictive mind. Oxford: Oxford University Press.

Janík, T., Brebera, P., Dobrý, L., Kansanen, P., Píšová, M., Najvar, P., .. \& \& Trna, J. (2007). Pedagogical content knowledge nebo didaktická znalost obsahu? Brno: Paido. 
Janík, T. (2009). Didaktické znalosti obsahu a jejich význam pro oborové didaktiky, tvorbu kurikula a učitelské vzdělávání. Brno: Paido.

Janík, T., Slavík, J., Mužík, V., Trna, J., Janko, T., Lokajíčková, V., .. \& Zlatníček, P. (2013). Kvalita (ve) vzdělávání: obsahově zaměrený přistup ke zkoumáni a zlepšování výuky. Brno: Masarykova univerzita.

Janssen, S. K. H., Mol, A. P. J., van Tatenhove, J. P. M., \& Otter H. S. (2014). The role of knowledge in greening flood protection. Lessons from the Dutch case study future Afsluitdijk, Ocean \& Coastal Management, 95, 219-232.

Jarvis, P. (1992). Paradoxes of learning: On becoming an individual in society. San Francisco: Jossey-Bass.

Jarvis, P. (2004). Adult education and lifelong learning: Theory and practice. New York: Routledge.

Jarvis, P. (2009). Learning to be a person in society. Routledge: London.

Jarvis, P. (2010). Adult education and lifelong learning: theory and practice. New York: Routledge.

Johnson, M. (1987). The body in the mind: The bodily basis of meaning, reason and imagination. Chicago: University of Chicago.

Johnson, M. (2008). The meaning of the body. Chicago \& London: The Chicago University Press.

Joram, E., \& Gabriele, A. J. (1998). Preservice teachers' prior beliefs: Transforming obstacles into opportunities. Teaching and teacher education, 14(2), 175-191.

Jostmann, N. B., D. I. Lakens, \& T. W. Schubert (2009). Weight as an embodiment of importance, Psychological Science, 9, 1169-1174.

Jung, C. G. (1983). Memory, dreams, reflections. London: Fontana.

Kaufmann, J. C. (2010). Chápající rozhovor. Praha: Slon.

Kimmel, (2016). The microgenetic analysis of interaction - embodied skills for togetherness. [přednáška]. Brno: Společnost pro kognitivní vědu, 4. května 2016. Dostupné z https://slideslive.com/38896437.

King, N. (2004). Using interviews in qualitative research, In C. Cassell, \& G. Symon (Eds.), Essential guide to qualitative methods in organizational research (s. 11-22). London: Sage.

Kinsella, E. A. (2007). Embodied reflection and the epistemology of reflective practice. Journal of Philosophy of Education, 41(3), 395-409.

Kohák, E. (1984). The embers and the stars. A philosophical inquiry into the moral sense of nature. Chicago \& London: The Chicago University Press.

Kohák, E. (1993). Jan Patočka. Filosofickýživotopis. Praha: H\&H. 
Koláŕ, P. (2002). Pravda a fakt. Praha: Filosofia.

Korthagen, F. A. J. (1993). Two modes of reflection. Teaching and Teacher Education, 9(3), 317-326.

Korthagen, F. A. J. (2001). Linking practice and theory: The pedagogy of realistic teacher education. Hillsdale: N. J. L. Erlbaum.

Kövecses, Z. (2002). Metaphor: A practical introduction. Oxford, New York: Oxford University Press.

Kövecses, Z. (2010). Metaphor. A practical introduction. Oxford, New York: Oxford University Press.

Kövecses, Z. (2013). Recent development in metaphor theory. Are the new views rival ones? In F. González-García, M. P. Cervel, \& L. R. Hernández (Eds.) Metaphor and metonymy revisited beyond the contemporary theory of metaphor. Recent developments and applications Amsterdam (s. 11-25). Philadelphia: John Benjamines Publishing Company.

Kvasz, L. (2016). Princípy genetického konštruktivizmu. (rukopis přijat do recenzního řízení Orbis Scholae).

Lacey A., \& Luff, D. (2009). Qualitative research analysis. The NIHR RDS for the East Midlands / Yorkshire \& the Humber. Dostupné z https://www.rds-yh.nihr.ac.uk/wpcontent/uploads/2013/05/9_Qualitative_Data_Analysis_Revision_2009.pdf.

Lakoff, G., \& Núnez, R. (2000). Where mathematics comes from: How the embodied mind brings mathetmatics into being. New York: Basic Books.

Lakoff, G., \& Johnson, M. (1999). Philosophy in the flesh. The embodied mind and its chalange to western thought. New York: Basic Books.

Lakoff, G., \& Johnson, M. (2002). Metafory, kterými žijeme. Brno: Host.

Lakoff, G. (2006). Oheň, ženy a nebezpečné věci. Praha: Triáda.

Latour, B., \& Woolgar, S. (1986). Laboratory life. The contruction of scientific facts. Princeton \& New Jersey: Princeton University Press.

Latour, B. (1993). We have never been modern. Cambridge: Harvard University Press.

Latour, B. (2003). Nikdy sme neboli moderný. Bratislava: Kalligram.

Lawley, J., \& Linder-Pelz, S. (2016). Evidence of competency: exploring coach, coachee and expert evaluations of coaching. Coaching: An International Journal of Theory, Research and Practice, 9(2), 110-128.

Lawley, J. (2006). When where matters: How psychoactive space is created and utilised, The Model. Dostupné z cleanlanguage.co.uk/articles/articles/29/.

Lawley, J. (2010). Expert analysis report on using clean language to research 'Work-Life Balance' v4. Nepublikovaný rukopis. 
Lawley, J., \& Tompkins, P. (2000). Metaphors in mind: Transformation through symbolic modelling. London: The Developing Company Press.

Lawley, J., Meyer M., Meese R., Sullivan W., \& Tosey P. (2010). More than a balancing act? 'Clean language' as an innovative method for exploring work-life balance, University of Surrey and Clean Change Company.

Lejeune, M. (2011). Tacit knowledge: Revisiting the epistemology of knowledge. McGill Journal of Education, 46(1), 91-105.

Leung, A. K. Y., Kim, S., Polman, E., Ong, L. S., Qiu, L., Goncalo, J. A., \& Sanchez-Burks, J. (2012). Embodied metaphors and creative acts. Psychological Science, 23(5), 502-509.

Levin, B., \& He, Y. (2008). Investigating the content and sources of teacher candidates' personal practical theories (PPTS). Journal of Teacher Education, 59(1), 55-68.

Lifshitz, M., Cusumano, E. P., \& Raz, A. (2013). Hypnosis as neurophenomenology. Frontiers in human neuroscience, 7, 469.

Lincoln, Y. S., \& Guba, E. G. (1985). Naturalistic inquiry. Newbury Park, CA: Sage Publications.

Linder-Pelz, S., \& Lawley, J. (2015). Using clean language to explore the subjectivity of coachees' experience and outcomes. International Coaching Psychology Review, 10(2), 161174.

Lloyd, J. (2011). The Use of Metaphor in Counselling and Qualitative Research Interviews (Disertační práce). Manchester: University of Manchester. Dostupné z http://www.cleanlanguage.co.uk/articles/attachments/LloydMetaphor_in_Counselling_and_Qualitative_Research_Interviews.pdf.

Loftus, E. F., \& Palmer, J. C. (1974). Reconstruction of automobile destruction: An example of the interaction between language and memory. Journal of verbal learning and verbal behavior, 13(5), 585-589.

Loftus, E. F. (1975). Leading questions and the eyewitness report. Cognitive Psychology, 7, $560-572$.

Lortie, D. C. (1975). Schoolteacher: A sociological study. Chicago: University of Chicago Press.

Lutz, A., \& Thompson, E. (2003). Neurophenomenology integrating subjective experience and brain dynamics in the neuroscience of consciousness. Journal of Consciousness Studies, 10(9/10), 31-52.

Madzia, R. (2014). George Herbert Mead: Tělo, mysl, svět. Praha: Triton.

Mácha, J. (2009). Davidsonova kritika metaforického významu. Filosofický časopis:

Supplementum II. Studie k filosofii Donalda Davidsona. Praha: Filosofický ústav AV ČR. $139-150$ 
Mareš, J. (2013). Pedagogická psychologie. Praha: Portál.

Mareš, J., Slavík, J., Svatoš, T., \& Švec, V. (1996). Učitelovo pojetí výuky. Brno: Masarykova univerzita.

Martin J. N. T., \& Sullivan, W. (2007). ...and good systems practice is [pause] like [pause] what?: Clean language and metaphor landscapes as potential tools in systems practice. Systemist, 29(3).

Martin J. N. T. (1999). Imagery and metaphor, part of the Open university business and management postgraduate course B822: Creativity, innovation and change. The course included three videos related to David Grove's work featuring Caitlin Walker: Engaging the imagination; Group metaphor development; and clean language.

podcast.open.ac.uk/oulearn/business-and-management/podcast-b822-imagery-and-metaphor\#. Matošková, J. a kol. (2014). Úspěšný student vysoké školy a jeho tacitní znalosti. Žilina, Zlín: Georg, Univerzita Tomáše Bati ve Zlíně.

Maturana, H. R., \& Varela, F. J. (1992). The tree of knowledge: The biological roots of human understanding. Boston, MA: Shambhala.

Maxwell, J. A. (2013). Qualitative research design: An interactive approach. London: SAGE Publications.

McAdam, R., Mason, B., \& McCrory, J. (2007). Exploring the dichotomies within the tacit knowledge literature: Towards a proces of tacit knowing in organizations. Journal of knowledge management, 11(2), 43-59.

McCracken, J. (2016). Clean language in the classroom. Carmarthen, Wales: Crown House Publishing.

McNeill, D. (2008). Gesture and thought. Chicago: University of Chicago Press.

Meijer, P. C., Zanting, A., \& Verloop, N. (2002). How can student teachers elicit experienced teachers'practical knowledge? Journal of Teacher Education, 53(5), 406-419.

Melville, W., Campbell, T., Fazio, X., Stefanile, A., \& Tkaczyk, N. (2014). Problematizing the practicum to integrate practical knowlege. Res Sci Educ, 44, 751-775.

Merleau-Ponty, M. (2004). Viditelné a neviditelné. Praha: Oikoymenh.

Merleau-Ponty, M. (2010). Filosof a jeho stín. In K. Novotný (Ed.). Co je fenomén? Husserl a fenomenologie ve Francii (s. 85-110). Praha: Oikoymenh.

Merleau-Ponty, M. (2013). Fenomenologie vnímání. Praha: Oikoymenh.

Mezirow, J. (1990). Fostering critical reflection in adulthood: A guide to transformative and emancipatory learning. San Francisco: Jossey-Bass Publishers.

Minaříková, E., \& Janík, T. (2012). Profesní vidění učitelů: od hledání pojmu k možnostem jeho uchopení. Pedagogická orientace, 22(2), 181-204.

Minkowski, E. (2011). Vstřic kosmologii. Praha: Malvern. 
Moser, K. S. (2000). Metaphor analysis in psychology - method, theory, and fields of application. Forum: Qualitative Social Research, 1(2). Dostupné z http://www.qualitativeresearch.net/index.php/fqs/article/view/1090/2387.

Nagy, E. (2011). Sharing the moment: The duration of embraces in humans. Journal of ethology, 29(2), 389-393.

Nehyba, J. (2012). Tři inspirace od Petera Jarvise. Studia paedagogica, 17(1), 37-58.

Nehyba, J., \& Svojanovský, P. (2016). Tacitní znalosti v metaforách studentky učitelství. Studia paedagogica, 21(1), 57-85.

Nisbett, R., \& Wilson, T. (1977). Telling more than we can know: Verbal reports on mental processes. Psychological Review, 84(3), 231-259.

Nixon, S., \& Walker, C. (2009). Personal development planning - inspiring capability. In J. Buswell, \& N. Becket (Eds.), Enhancing student centred learning in business and management, hospitality, leisure, sport and tourism (s. 206-222). Newbury: Threshold Press.

Nixon, S. (2013). Using Metaphors to Aid Student Meta-Learning: When You're Learning at Your Best Your Like What? Creative Education, 4(7A2), 32-36.

Nixon, S., \& Walker, C. (2009). Modelling the curriculum through metaphors: One programme's approach, CETL (Centre for Excellence in Teaching and Learning) Journal: Innovations in Practice, 1(2), 3-6.

Nonaka, I. (1991). The knowledge-creating company. Harvard Business Review, 69(6), 96104.

Nonaka, I. (1994). A dynamic theory of organizational knowledge creation. Organization Science, 5(1), 14-37.

Nonaka, I., \& Krogh, G. (2009). Tacit knowledge and knowledge conversion: Controversy and advancement in organizational knowledge creation theory. Organization Science, 20(3), $635-652$.

Owen, I. R. (1996). Clean language: A linguistic-experiential phenomenology, In A. T. Tymieniecka (Ed.) Analecta Husserliana, 48 (s. 271-297). Dordrecht: Kluwer Academic.

Parkay, F. W. (2000) Restructuring a teacher education program: The psychological, social, and political dimensions of change. Action in Teacher Education, 22, 109-125.

Patočka, J. (1995). Tělo, společenství, jazyk, svět. Praha: Oikoymenh.

Peregrin, J. (1999). Význam a struktura. Praha: Oikoymenh.

Petitmengin, C. (1999). The intuitive experience. Journal of Consciousness Studies, 6(2/3), 43-47.

Petitmengin, C. (2006). Describing one's subjective experience in the second person: An interview method for the science of consciousness. Phenomenology and the Cognitive Sciences, 5(3/4), 229-269. 
Petitmengin, C., \& Bitbol, M. (2009). Listening from within. Journal of Consciousness Studies, 16(10/12), 363-404.

Petitmengin C. (2014). Researching the dynamics of intuitive experience. In M. Sinclair (Ed.), Handbook of research methods on intuition (s. 188-198). Boston: Edward Elgar Publishing.

Pickerden, A. M. (2013). How do older workers in the fire and rescue service deal with work life balance issues as they plan for, approach and transition through retirement? Thesis submitted for the degree of Doctor of Philosophy at the University of Leicester.

Pinker, S. (1998), How the mind works. London: The Softback Preview.

Píšová, M. (2005). Klinický rok: procesy profesního rozvoje studentů učitelství a jejich podpora. Pardubice: Univerzita Pardubice.

Píšová, M., Hanušová, S., Kostková, K., Janíková, V., Najvar, P., \& Tůma, F. (2013). Učitel expert: jeho charakteristiky a determinanty profesního rozvoje (na pozadí výuky cizích jazyků). Brno: Masarykova univerzita.

Podsakoff, P. M., MacKenzie, S. B., Lee, J. Y., \& Podsakoff, N. P. (2003). Common method biases in behavioral research: A critical review of the literature and recommended remedies. Journal of Applied Psychology. 88(5). 879-903.

Polanyi, M. (1958). Personal knowledge: Towards a post-critical philosophy. Chicago: The University of Chicago Press.

Polanyi, M. (1959). The study of man. London: Routledge \& Kegan Paul.

Polanyi, M. (1966). The tacit dimension. Chicago: The University of Chicago Press.

Polanyi, M. (1983). The tacit dimension. Gloucester: Peter Smith Publisher.

Polanyi, M. (1998). Personal knowledge. Chicago, IL: The University of Chicago Press.

Polanyi, M. (2009). The tacit dimension. Chicago: University of Chicago Press.

Popper, K. (2013). Knowledge and the body-mind problem: In defence of interaction.

Routledge.

Porges, S. W. (2009). The polyvagal theory: New insights into adaptive reactions of the autonomic nervous system. Cleveland Clinic Journal of Medicine, 76(2), 86-90.

Pravdová, B. (2014). Já jako učitel: profesní sebepojetí studenta učitelství. Brno: Muni-press.

Quine, W. O. V. (1998). Ontologická relativita. In J. Peregrin (Ed.). Obrat kjazyku druhé kolo. Postanalytická filosofie USA (s. 49-82). Praha: Filosofia.

Quine, W. O. V. (2002). Od stimulu k vědě. Praha: Filosofia.

Rämä, I., \& Kontu, E. (2012). Searching for pedagogical adaptations by exploring teacher's tacit knowlege and interactional co-regulation in the education of pupils with autism.

European Journal of Special Needs Education, 27(4), 417-431.

Ramachandran V. (2013). Neurony, které formovaly civilizaci [The Neurons that shaped 
civilization]. TEDx. [on-line] [ $\left.\begin{array}{lll}2016 & 03 & 21\end{array}\right]$ Dostupné z https://www.ted.com/talks/vs_ramachandran_the_neurons_that_shaped_civilization?language $=\mathrm{cs}$.

Ramscar, M., Matlock, T., \& Boroditsky, L. (2009). Time, motion and meaning: The experiential basis of abstract thought. In K. S. Mix, L. B. Smith, \& M. Gasser, The spatial foundations of language and cognition (s. 67-82). Oxford: University press.

Reber, A. S. (1989). Implicit learning and tacit knowledge. Journal of Experimental Psychology, 118(3), 219-235.

Ricoeur, P. (1976). Metaphore and symbol. In P. Ricoeur, Theory of interpretation: Discours and surplus of meaning (s. 45-69). Fort Worth: Texas Christian University Press.

Ricoeur, P. (1977). The rule of metaphor. The Creation of meaning in language. London \& New York: Routledge.

Ricoeur, P. (1997). Metafora a symbol. In P. Ricoeur, Teória interpretácie: diskurz a prebytok významu (s. 66-96). Bratislava: Archa.

Rimmele, R. (2002). Videograph. Multimedia-Player zur Kodierung von Videos. Kiel: IPN.

Rintala, N., \& Kuronen, T. (2006). How to share tacit nuclear knowledge? International Journal of Nuclear Knowledge Management, 2(2), 121-133.

Rockwell, W. T. (2005). Neither brain, nor ghost. A Nondualist alternative to the mind-brain identity theory. Cambridge, London: The MIT Press.

Rorty, R. (1991). Objectivity, relativism, and truth: Philosophical papers 1. Cambridge University Press.

Rorty, R. (2012). Filosofie a zrcadlo př́rody. Praha: Academia.

Roulston, K. (2010). Considering quality in qualitative interviewing. Qualitative Research, 10(2), 199-228.

Rowland, T., \& Zazkis, R. (2013). Contingency in the mathematics classroom: Opportunities taken and opportunities missed. Canadian Journal of Science, Mathematics and Technology Education, $\quad 13(2), \quad 137-153 . \quad$ Dostupné Z http://www.tandfonline.com/doi/abs/10.1080/14926156.2013.784825\#.V3Tp6biLTIU.

Sacks, O. (2010). The mind's eye. New York: Picador.

Sages, R. (2003). Truth as unveiling. In J. Lindénová, \& P. Szybek (Eds.) Validation of knowledge claims in human science. Lyon: 1'Interdisciplinaire.

Selinger, E. (Ed.). (2006). Postphenomenology. A critical companion to Ihde. Albany: State University of New York Press.

Seung, S. (2012). Connectome: How the brain's wiring makes us who we are. London: Allen Lane. 
Schein, E. H. (1985). Organisational culture and leadership: A dynamic view. San Francisco, CA: Jossey-Bass.

Schepens, A., Aelterman, A., \& Van Keer, H. (2007). Studying learning processes of student teachers with stimulated recall interviews through changes in interactive cognitions. Teaching and Teacher Education, 23, 457-472.

Schön, D. A. (1995). The reflective practitioner. Hampshire: Arena.

Schultz, W. (2010). Dopamine signals for reward value and risk: Basic and recent data. Behavioral and brain functions, 6(24). Dostupné z http://doi.org/10.1186/1744-9081-6-24.

Schultz, W., Dayan, P., \& Montague, P. R. (1997). A neural substrate of prediction and reward. Science, 275, 1593-1599.

Slavík, J., Chrz, V., Štech, S., Nohavová, A., Klumparová, Š., Hník, O., ...\& J. Valenta (2013). Tvorba jako způsob poznání. Praha: Karolinum.

Slavík, J., \& Janík, T. (2007). Fakty a fenomény v průniku didaktické teorie, výzkumu a praxe vzdělávání. Pedagogika, 57(3), 263-274.

Smith, J. A., Flowers, P., \& Larking, M. (2009). Interpretative phenomenological analysis. Theory, Method and research. Thousand Oaks: Sage.

Snoddon, M. (2005). Legacy of war: Experiences of members of the Ulster Defence Regiment. Belfast: Conflict trauma resource centre.

Stachová, J. (1993). Metafora, intuice, věda. In J. Stachová, \& J. Nosek (Eds.), Intuice ve vědě a filozofii (s. 299-308). Praha: Filozofický ústav AV ČR.

Sternberg, R. J. (1999). Epilogue: What do we know about tacit knowledge. In R. J.

Sternberg, \& J. A. Horwath (Eds.), Tacit knowledge in professional practice (s. 231-236).

London: Lawrence Erlbaum Associates.

Sternberg, R. J., Grigorenko, E. L., Gil, G., \& Hedlund, J. (2000). The ALL practical cognition framework. In T. S. Murray, Y. Clermont, \& M. Binkley (Eds.), Measuring adult literacy and life skills: New frameworks for assessment. Ottawa: Minister of Industry.

Sun, D. (2012). „Everything goes smoothly“: A case study of an immigrant Chinese language teacher's personal practical knowledge. Teaching and Teacher Education, 28, 760-767.

Svojanovský, P. (2014). Kvalita reflexe ve vzdělávání učitelů optikou jádrových kategorií reflexe. In V. Švec (Ed.) Znalostní báze učitelství (s. 145-163). Brno: Masarykova univerzita.

Šíp, R., \& Švec, V. (2013). Pojetí tacitních znalostí v paradigmatu sjednoceného pole. Pedagogická orientace, 23(5), 664-690.

Šíp, R. (2008). Richard Rorty. Pragmatismus mezi jazykem a zkušeností. Brno: Paido.

Šíp, R. (2015). Pedagogika a paradigmatický obrat v metodologii a teorii. Pedagogická orientace, 25(5), 671-699. 
Šusta, M., \& Kostroň, L. (2004). Úvod do systémové dynamiky pro sociální vědy. Dostupné z http://homen.vsb.cz/ let08/powersim/130uvodsysdyn.pdf.

Švaříček, R. (2011). Zlomové události při vytváření profesní identity učitele. Pedagogika.sk, $4,247-274$.

Švec, V. (1999). Pedagogická př́prava budoucích učitelů: problémy a inspirace. Brno:

Paido.

Švec, V. (2009a). Sdílení znalostí ve školním prostředí. Pedagogická orientace, 19(2), 22-37.

Švec, V. (2009b). Př́ípravné vzdělávání učitelů. In J. Průcha (Ed.), Pedagogická encyklopedie (s. 408-412). Praha: Portál.

Švec, V. (2011). Tacitní znalosti v činnosti profesionálů. In A. Gregar (Ed.), Tacitní znalosti a úspěšné řizení (s. 13-25). Martin: Alfa print.

Švec, V. (2012). Sdílení tacitních znalostí ve vzdělávání učitelů jako pohyb od praxe k teorii a zpět. In J. Kohnová (Ed.), Profesní rozvoj učitelů a cile školního vzdělávání (s. 103-113). Praha: PdF UK.

Švec, V. (Ed.).(2005). Od implicitních teorií výuky k implicitním pedagogickým znalostem. Brno: Paido.

Švec, V., Svojanovský, P., \& Pravdová, B. (Eds.). (2016). Determinanty účinnosti učitelských praxí. Brno: Masarykova univerzita.

Taylor, K., \& Marienau, C. (2016). Facilitating learning with the adult brain in mind: A conceptual and practical guide. San Francisco, CA Jossey-Bass.

Thelen, E., \& Smith, L. B. (1994). Dynamic system approach to the development of cognition and action. Cambridge: MIT Press.

Thibodeau, P. H., \& Boroditsky, L. (2011). Metaphors we think with: The role of metaphor in reasoning. PLoS ONE, 6(2), e16782. Dostupné z plosone.org/article/info:doi\%2F10.1371\%2Fjournal.pone.0016782.

Thompson, E., \& Varela, F. J. (2001). Radical embodiment: Neural dynamics and consciousness. Trends in cognitive sciences, 5(10), 418-425.

Tobin, K., \& Tippins, D. J. (1996). Metaphors as seeds for conceptual change and the improvement of science teaching. Science Education, 80(6), 711-730.

Tompkins, P., Sullivan, W., \& Lawley, J. (2005). „Tangled spaghetti in my head.” Therapy Today, 16(8), 32-36.

Torff, B. (1999). Tacit knowledge in teaching: Folk pedagogy and teacher education. In R. J. Sternberg, \& J. A. Horvath (Eds.), Tacit knowledge in professional practice (s. 195-213). London: Lawrence Erlbaum Associates.

Tosey, P. (2011). 'Symbolic Modelling' as an innovative phenomenological method in HRD research: The work-life balance project, presented at the 12th International Conference on 
HRD research and practice across Europe, University of Gloucestershire, 25th -27 th May 2011. Dostupné z http://epubs.surrey.ac.uk/7135/.

Tosey, P. (2015) 'And what kind of question is that? Thinking about the function of questions in qualitative interviewing'. In M. N. K. Saunders, \& P. Tosey (Eds.). Handbook of research methods on human resource development (s. 200-216). Cheltenham: Edward Elgar.

Tosey, P., \& Mathison, J. (2010). Exploring inner landscapes: NLP and psychophenomenology as innovations in researching first-person experience. Emerald Qualitative Research in Organizations and Management, 5(1), 63-82. Dostupné z http://epubs.surrey.ac.uk/7448/.

Tosey, P., Lawley, J., \& Meese, R. (2014). Eliciting metaphor through clean language: An innovation in qualitative research. British Journal of Management, 25(3), 629-646.

Tosey, P., Sullivan, W., \& Meyer, M. (2013). Clean Sources: Six metaphors a minute? Dostupné z https://core.ac.uk/display/30341478.

Trevarthen, C. (2011). What is it like to be a person who knows nothing? Defining the active intersubjective mind of a newborn human being. Infant and Child Development, 20(1), 119135.

Tripp, D. (1993). Critical incidents in teaching: Developing professional judgement. London: Routledge.

Trygestad, J. (1997). Chaos in the classroom: An apllication of chaos theory. Annual Meeting of the American Educational Research Association, Chicago, 1997.

Tulving, E., Schacter, D. L., \& Stark, H. A. (1982). Priming effects in word fragment completion are independent of recognition memory. Journal of Experimental Psychology: Learning, Memory and Cognition, 8(4), 336-342.

Turner, S. (2012). Making the tacit explicit. Journal for the Theory of Social Behaviour, 42(4), 385-402.

Tvrdý, F. (2014). Turingův test: filozofické aspekty umělé inteligence. Praha: Togga.

Urban, P. (2015). Fenomenologie a interdisciplinarita. In A. Novák (Ed.) Živá fenomenologie. (s. 31 -51). Praha: Togga.

Van de Cruys, S., \& Wagemans, J. (2011). Gestalts as predictions. Some reflections and an application to art. Gestalt Theory, 33(3), 325-344

Van Helsdingen, A., \& Lawley, J. (2012). Modelling shared reality: Avoiding unintended influence in qualitative research, Kwalon, 3, 1-7

Van Velzen, \& Volman, M. (2009). The activities of a school-based teacher educator: A theoretical and empirical exploration. European Journal of Teacher Education, 32(4), 345367. 
Van Velzen, C., Volman, M., Brekelmans, M., \& White, S. (2012). Guidedwork-based learning: Sharing practical teaching knowledge with student teachers. Teaching and Teacher Education, 28, 229-239.

Varela, F. J., \& Shear, J. (1999). First-person methodologies: What, why, how? Journal of Consciousness Studies, 6(2/3), 1-14.

Vlčková, K., Lojdová, K., Lukas, J., Mareš, J., Šalamounová, Z., \& Kohoutek, T. (2015). Z posluchárny za katedru: mocenské vztahy ve výuce studentů učitelství. Brno: Masarykova univerzita.

Vopěnka, P. (2012). Podivuhodná tvář baroka. Praha: Karolinum.

Cannon, W. B. (1915). Bodily changes in pain, hunger, fear and rage: An account of recent researches into the function of emotional excitement. New York: Appleton-Century-Crofts.

Wang, S. B., Zhou, Y., Chen, Y., \& Zhan, X. S. (2009). Chaotification of class teaching. In Education technology and computer science, 2009. ETCS'09. First International Workshop, 2. 346-349.

Weber, M. (2009). Metodologie, sociologie, politika. Praha: Oikoymenh.

Willems, R. M., Hagoort, P., \& Casasanto, D. (2010). Body-specific representations of action verbs, Psychological Science, 21, 67-74.

Wilson, N. L., \& Gibbs, R. W. (2007). Real and imagined body movement primes metaphor comprehension. Cognitive Science, 31(4), 721-731.

Wilton, N. (2010). An introduction to human resource management. London: Sage Publications.

Yolton, J. (1990). Mirrors and veils. Thoughts and things. In A. R. Malachowski (Ed.), Reading Rorty (s. 58-72). Cambridge: Basil Blackwell.

Yost, D. S., \& Sentner, S. M. (2000). An examination of the construct of the critical reflection: Implications for teacher education programming in the 21th century. Journal of Teacher Education, 51(1), 39-50.

Zanotto, M. S., \& Palma D. V. (2008). Oppening Pandora's box. Multiple readings of 'a metaphore'(s. 11-43). In M. S. Zanotto, L. Cameron, \& M. C. Cavalcantti (Eds.). Confronting metaphor in use. An applied linguistic approach. Amsterdam, Philadelphia: John Benjamins Publishing B. V.

Zappavigna, M. (2013). Tacit knowledge and spoken discourse. London: Bloomsbury.

\section{Věcný rejstř́́k}

abstraktní objekty

artikulovatelnost

artikulace

cílová oblast

čisté dotazování 
čisté otázky

čistota $\mathrm{v}$ rozhovoru

čistý jazyk

detekce (tacitních znalostí)

didaktická situace

dovednost

elitace tacitních znalostí

emoce

- primární emoce

- sekundární emoce

epizodická situace

explicitní znalosti

explikace

extenze

fenomenologická redukce

fenomenologie

figurativní jazyk

generický prostor

gestalt

implicitní znalosti

informace

intuice

jazyk

jednání

kategorizace otázek (v čistém

jazyce)

kognitivní vědy

konceptualizace

koncepty

kontext (situace)

kontinuum tacitní-explicitní

krystalizace (tacitních znalostí) kvalita

mentalizace

mentální objekty

metafora, metafory

- konceptuální metafory

- nekonvenční metafora

- vtělená metafora

metaforická krajina

metaforická strukturace

metaforické mapování

metaforické porozumění

metaforický jazyk

metakomentáře

mez akceptovatelnosti

model sdílení

moment překvapení

mysl

myšlení

nazírání

neočekávaná situace

- neprŕíjemná

- prríjemná

- typy

odezva

ostré pojmy

perspektiva první osoby

plynutí

pochopení

pojem, pojmy

- konkrétní pojmy

pojetí výuky studentů

- diagnostika 
- složky

pól inovace

pól reprodukce

pozadí

poznání

poznatek

- teoretické

- praktické

pragmatika

praktické znalosti

pravidla

praxe (učitelská)

proces metaforizace

propozice

prožitek

prožívání

předchozí zkušenosti

představy

předstírání

př́ípadová studie

reakce na neočekávanou situaci

reflektivní seminář

rekonceptualizace

reprezentace

rozhovor

- hloubkový rozhovor

rozšíření

rozštěpení reference

sdílení s cvičným učitelem

sdílení tacitních znalostí

sdílení znalostí

sdílený obsah sémantika

schéma, schémata

- abstraktní schémata

- představová schémata

situace

sjednocení znalostního pole

sjednocený celek

smíšená oblast

sociální konstruktivismus

společenství myslí

stimulované vybavování

struktura

struktura zkušenosti

strukturalismus

subjektivní pojetí výuky

symbol

tacitní dimenze znalosti

tacitní učení

tacitní znalosti

- $\quad$ rysy (znaky)

- vlastnosti

- zexplicitnění

tělo-mysl

teorie dynamických systémů

učňovství

- kognitivní

- kolaborativní

- tradiční

uchopení

uvědomovanost

vědění

vědomí 
verbalizace

vnímání

vnoření

vtělesnění

vyjednávání

výzkumy tacitních znalostí

významy

- vtělesněné významy

zaseknutí

zdrojová oblast

zexplicitněné tacitní znalosti zkušenost, zkušenosti

- asubjektivní zkušenost

zlomová událost

změna pojetí výuky

znalosti

znalostní pole

zpětná metaforizace

zrcadlové neurony

zvýznamňování 



\section{O autorech}

\section{James Lawley}

je nezávislý výzkumník a inovátor v oblasti čistého jazyka. Spolupracuje s celou řadou univerzit (např́klad University of Surrey, John Moores University, De Montfort University). Pochází z Londýna, kde se věnuje rozvíjení čistého jazyka napříč nejrůznějšími kontexty. Je spoluautorem knihy Metaphors in mind (2000).

\section{Mgr. Eva Minaříková, Ph.D.}

působí v Institutu výzkumu školního vzdělávání PdF MU. Předmětem jejího výzkumného zájmu jsou problémy pedeutologické, např. problematika využití videa $\mathrm{v}$ učitelském vzdělávání, profesní vidění a některé otázky didaktiky anglického jazyka.

\section{Mgr. Jan Nehyba, Ph.D.}

působí jako odborný asistent na katedře pedagogiky PdF MU. Zabývá se výzkumem tacitních znalostí studentů učitelství, opírá se v něm o techniku čistého jazyka a metafory. Má zkušenosti s reflektivní výukou dospělých, reflektivními semináři se studenty učitelství i zkušenosti psychoterapeutické.

\section{Mgr. Blanka Pravdová, Ph.D.}

působí jako odborná asistentka na katedře pedagogiky PdF MU. Věnuje se problematice učitelských praxí v pregraduální přípravě budoucích učitelů a profesnímu sebepojetí studentů učitelství. Je autorkou monografie Já jako učitel: profesni sebepojetí studenta učitelství (PdF MU, 2014). V předchozích letech působila jako středoškolská učitelka v Ostravě.

\section{Doc. PaedDr. Jan Slavík, CSc.}

vystudoval učitelství ruského jazyka a výtvarné výchovy pro 2. stupeň ZŠ. Habilitoval se v oboru pedagogika na PdF UK v Praze. Vyučuje na katedře výtvarné kultury a na katedře pedagogiky PdF ZČU v Plzni. Specializuje se na didaktiku a na expresivní obory ve všeobecném vzdělávání. 


\section{Mgr. Petr Svojanovský}

vystudoval učitelství občanské a tělesné výchovy na PdF MU a FSpS MU. V současnosti je doktorským studentem na PdF MU (školitel prof. V. Švec), působí jako asistent na katedře pedagogiky. Zabývá se zaváděním reflektivní praxe do vysokoškolské výuky, výzkumem tacitních znalostí a metafor.

\section{Mgr. Barbora Šimůnková}

vystudovala učitelství francouzského jazyka a dějepisu na PdF MU. Působí jako lektorka francouzštiny na jazykových školách a výzkumně se zabývá tématem zexplicitňování tacitních znalostí studentů učitelství prostřednictvím reflexe. Studuje doktorský program Pedagogika na katedře pedagogiky PdF MU (školitel prof. V. Švec).

\section{Doc. Mgr. Radim Š́́p, Ph.D.}

působí na katedře sociální pedagogiky a spolupracuje s katedrou pedagogiky PdF MU. Vedle pragmatismu a pragmatistické filozofie se věnuje filozofii a teorii vědy a proměnám moderního nacionalismu. Je autorem monografie Richard Rorty: pragmatismus mezi jazykem a zkušeností (Paido, 2008) a spolueditorem knihy Identity and social transformation (Rodopi, 2011).

\section{Prof. PhDr. Vlastimil Švec, CSc.}

působí na Institutu výzkumu školního vzdělávání PdF MU. Dvakrát zastával funkci vedoucího katedry pedagogiky PdF MU (1994-2001, 2012-2015). Je garantem doktorského studijního programu Pedagogika a školitelem doktorandů. Jeho dlouhodobým výzkumným tématem jsou pedagogické znalosti a dovednosti. V současné době je v popředí jeho zájmu problematika utváření tacitních znalostí studentů učitelství. 


\title{
Studenti učitelství mezi tacitními a explicitními znalostmi
}

\author{
Vlastimil Švec \\ James Lawley \\ Jan Nehyba \\ Petr Svojanovský \\ Radim Šíp \\ Eva Minaříková \\ Blanka Pravdová \\ Barbora Šimůnková \\ Jan Slavík
}

Vydala Masarykova univerzita roku 2016.

Překlady: Mgr. Eva Minaříková, Ph.D., Mgr. Petr Pecha

Návrh obálky: Mgr. art. Eva Šimonová, Mgr. Jan Nehyba, Ph.D.

Jazyková korektura: Mgr. Blanka Pravdová, Ph.D.

1. vydání, 2016, náklad 300 výtisků

Tisk MSD, spol. s. r. o., Lidická 23, 60200 Brno

ISBN doplnit 